\title{
minerals
}

Mineralogy and Geochemistry

of Ruby

Edited by

Frederick Lin Sutherland and Khin Zaw Printed Edition of the Special Issue Published in Minerals 
Mineralogy and Geochemistry of Ruby 



\section{Mineralogy and Geochemistry of Ruby}

Editors

Frederick Lin Sutherland

Khin Zaw

MDPI • Basel • Beijing • Wuhan $\bullet$ Barcelona $\bullet$ Belgrade $\bullet$ Manchester $\bullet$ Tokyo $\bullet$ Cluj $\bullet$ Tianjin

\section{MDPI}




\section{Editors}

Frederick Lin Sutherland

The Australian Museum

Australia
Khin Zaw

University of Tasmania

Australia

\section{Editorial Office}

MDPI

St. Alban-Anlage 66

4052 Basel, Switzerland

This is a reprint of articles from the Special Issue "Mineralogy and Geochemistry of Ruby" published online in the open access journal Minerals (ISSN 2075-163X).

For citation purposes, cite each article independently as indicated on the article page online and as indicated below:

LastName, A.A.; LastName, B.B.; LastName, C.C. Article Title. Journal Name Year, Article Number, Page Range.

ISBN 978-3-03943-615-6 (Hbk)

ISBN 978-3-03943-616-3 (PDF)

Cover image courtesy of Aaron Palke.

(C) 2020 by the authors. Articles in this book are Open Access and distributed under the Creative Commons Attribution (CC BY) license, which allows users to download, copy and build upon published articles, as long as the author and publisher are properly credited, which ensures maximum dissemination and a wider impact of our publications.

The book as a whole is distributed by MDPI under the terms and conditions of the Creative Commons license CC BY-NC-ND. 


\section{Contents}

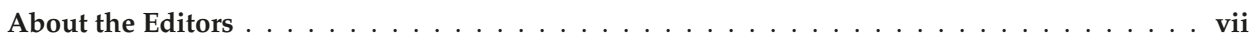

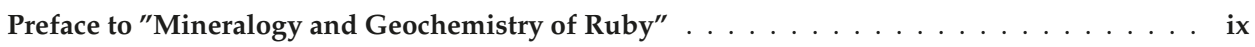

Frederick L. Sutherland and Khin Zaw

Editorial for Special Issue "Mineralogy and Geochemistry of Ruby"

Reprinted from: Minerals 2020, 10, 888, doi:10.3390/min10100888

Gaston Giuliani, Lee A. Groat, Anthony E. Fallick, Isabella Pignatelli and Vincent Pardieu Ruby Deposits: A Review and Geological Classification

Reprinted from: Minerals 2020, 10, 597, doi:10.3390/min10070597 . . . . . . . . . . . . . 11

Aleksander Kissin, Irina Gottman, Sergei Sustavov, Valery Murzin and Daria Kiseleva

The First Find of $\mathrm{Cr}_{2} \mathrm{O}_{3}$ Eskolaite Associated with Marble-Hosted Ruby in the Southern Urals and the Problem of $\mathrm{Al}$ and $\mathrm{Cr}$ Sources

Reprinted from: Minerals 2020, 10, 101, doi:10.3390/min10020101 _ . . . . . . . . . . . 95

Myint Myat Phyo, Hao A.O. Wang, Marcel Guillong, Alfons Berger, Leander Franz,

Walter A. Balmer and Michael S. Krzemnicki

U-Pb Dating of Zircon and Zirconolite Inclusions in Marble-Hosted Gem-Quality Ruby and Spinel from Mogok, Myanmar

Reprinted from: Minerals 2020, 10, 195, doi:10.3390/min10020195 . . . . . . . . . . . . . 107

Mandy Y. Krebs, Matthew F. Hardman, David G. Pearson, Yan Luo, Andrew J. Fagan and Chiranjeeb Sarkar

An Evaluation of the Potential for Determination of the Geographic Origin of Ruby and Sapphire Using an Expanded Trace Element Suite Plus Sr-Pb Isotope Compositions

Reprinted from: Minerals 2020, 10, 447, doi:10.3390/min10050447 . . . . . . . . . . . 125

Aaron C. Palke

Coexisting Rubies and Blue Sapphires from Major World Deposits: A Brief Review of Their Mineralogical Properties

Reprinted from: Minerals 2020, 10, 472, doi:10.3390/min10050472 _ . . . . . . . . . . 163

Andrey K. Litvinenko, Elena S. Sorokina, Tobias Häger, Yuri A. Kostitsyn,

Roman E. Botcharnikov, Alina V. Somsikova, Thomas Ludwig, Tatiana V. Romashova

and Wolfgang Hofmeister

Petrogenesis of the Snezhnoe Ruby Deposit, Central Pamir

Reprinted from: Minerals 2020, 10, 478, doi:10.3390/min10050478 . . . . . . . . . . . . . 183

Wim Vertriest and Aaron Palke

Identification of Opaque Sulfide Inclusions in Rubies from Mogok, Myanmar and

Montepuez, Mozambique

Reprinted from: Minerals 2020, 10, 492, doi:10.3390/min10060492 



\section{About the Editors}

Frederick Lin Sutherland is a Senior Fellow in Geosciences at The Australian Museum in Sydney, New South Wales. He graduated in geology at University of Tasmania and gained a MSc in Petrology in 1969. He was awarded a PhD in Geology at James Cook University of North Queensland in 1982. His research has focused on Australian and SE Asian minerals and gemstones, volcanic mineral associations, high pressure mantle and lower crustal xenocryst and xenolith suites, world class mineral collections and mass extinction events. He has served as Secretary and Chairman for the IMA Commission on Gem Materials. In his research he has authored and co-authored over 160 peer-reviewed papers and has written several well-received books that include Gemstones of the Southern Continents, The Volcanic Earth, Earthquakes and Volcanoes, and Gemstones and Minerals of Australia. Some 30 papers and book chapters have dealt with topics related to ruby. He is a present Associated Editor of The Journal of Gemmology.

Khin Zaw is Professor of Economic Geology at CODES (Centre of Ore Deposit and Earth Sciences), University of Tasmania, Hobart. He has a BSc from Yangon University, Myanmar, in 1968, an FGA Diploma (Fellowships of Gemmological Association of Great Britain) in 1969, a MSc (Economic Geology) from Queen's University, Canada, 1976 and a PhD from the University of Tasmania in 1990. He is a Fellow of the Australasian Institute of Mining and Metallurgy and a Fellow of Society of Economic Geologists. He was awarded a Geological Society of London (GSL) life Honorary Fellowship in 2019. He has over 35 years of experience working on genetic aspects of mineral deposits in Canada, Australia, New Zealand, China and many parts of SE Asia (Vietnam, Laos, Cambodia, Malaysia, Thailand, Indonesia, Myanmar and Malaysia), and has published a high number of papers relating to ore genesis and mineral exploration in the Australasian region. He works closely with his counterparts from the SE Asia region. He leads industry-CODES-funded projects on the Ore Deposits of SE Asia. He is currently associate editors of Journal of Asian Earth Sciences and Goescience Frontiers. 



\section{Preface to "Mineralogy and Geochemistry of Ruby"}

The studies in this volume specifically focus on ruby in its diverse connotations, which inevitably incorporate studies of allied minerals that accompany the presence of ruby in nature. This applies to the enclosing host rocks, mineral intergrowths with ruby, and the internal mineral inclusions within the ruby crystal structures. Some of these allied minerals provide radiometric elements for geochronological dating that helps constrain the ages of ruby growth, while others provide important clues to the geological and tectonic environments that formed ruby and affected its growth.

This Special Issue investigates one of the most sought after and valuable gem minerals within the annals of natural gemstone studies, namely ruby, the red-colored gem variety of corundum. The color results from a sufficiency of the trace element chromophore cation $\mathrm{Cr}^{3+}$, with modifications in color induced by other trace elements. Most of the contributions in this volume include invaluable data on the trace element variations that can be considered against color images of the studied rubies.

It also follows up on the publication of a preceding Minerals Special Issue on research advances that covered a wider spectrum of gemstones, "Mineralogy and Geochemistry of Gems" [1]. That volume included several studies on ruby. These are referenced here as useful supplementary studies for readers to consider [2-4], along with the studies presented in this Special Issue on ruby. During production of this Special Issue, other publications related to research topics on ruby continued to appear in the literature. One of special interest showed the extent that $\mathrm{Cr}$ can substitute into the ruby structure [5]. Ruby from secondary deposits from volcanic exposures at Mount Carmel, Israel, recorded contents up $32 \mathrm{wt} \% \mathrm{Cr}_{2} \mathrm{O}_{3}$. These high levels were attributed to exceptional reducing conditions of formation, although the precise source of the ruby remains for further study.

1. Voudouris, P.; Karampelas, S.; Melfos, V.; Graham, I. (eds.) Editorial for Special Issue "Mineralogy and Geochemistry of Gems". Minerals 2019, 9, 778, doi:10.3390/min 9120778.

2. Sutherland, F.L.; Zaw, K.; Meffre, S.; Thompson, J.; Goemann, K.; Thu, K.; Nu, T.T.; Zin, M.M.; Harris, S.J. Minerals 2019, 9, 28, doi: 10.3390/min 9010028.

3. Voudouris, P.; Mavrogonatos, C.; Graham, I.; Giuliani, G.; Karampelas, S.; Karantoni, V.; Wang, K.; Tarantola, A.; Zaw, K.; Meffre, S. Gem corundum deposits of Greece: Geology, Mineralogy and Genesis. Minerals 2019, 9, 49, doi:10.3390/min9010049.

4. Wang, K.K.; Graham, I.; Martin, L.; Voudouris, P.; Giuliani, G.; Lay, A.; Harris, S.J.; Fallick, A. Fingerprinting Paranesti Rubies. Minerals, 2019, 9, 91, doi:10.3390/min9020091.

5. Gain, S.E.M.; Griffin, W.L.; Saunders, M.; Toledo, V. Chromium in Corundum: Ultra-high Contents under Reducing Conditions. Microsc. Microanal. 2019, 25 (Suppl. 2), 2484-2485. doi:10.1017/S27619013151.

Frederick Lin Sutherland, Khin Zaw

Editors 



\title{
Editorial \\ Editorial for Special Issue "Mineralogy and Geochemistry of Ruby"
}

\author{
Frederick L. Sutherland ${ }^{1, *}$ and Khin Zaw ${ }^{2}$ \\ 1 Mineralogy and Petrology, Geosciences, Australian Museum, 1 William Street, Sydney, NSW 2010, Australia \\ 2 CODES-Centre of Ore Deposit and Earth Sciences, University of Tasmania, Hobart, TAS 7001, Australia; \\ khin.zaw@utas.edu.au \\ * Correspondence: linsutherland1@gmail.com
}

Received: 27 September 2020; Accepted: 2 October 2020; Published: 7 October 2020

\section{Introduction}

Ruby as a natural gemstone has an early history in which its colorful properties [1] were much valued in ornamental and symbolic jewelry by potentates and other persons of power and prestige [2,3]. This appreciation has extended into latter times and more so into the more general populace. It is an important gem for scientific study [4] and for exploration quests to find new ruby deposits $[5,6]$. This Special Issue brings together seven papers representing a diversity of scientific teams that have studied ruby and its allied mineral associates from a wide range of global deposits across various genetic settings. The papers cover a significant component of previous ruby literature within their pages, and with use of cutting-edge analytical results in most studies, the Special Issue offers a substantial advance towards a fuller understanding of ruby genesis. Not every aspect of ruby and known ruby deposit is referenced within the Special Issue contents due to the limited number of papers. It is hoped, however, that the Issue will stimulate further research into perceived gaps.

The seven separate papers represent 34 individual authors from 16 different institutions in 14 cities and 9 countries. The total number of countries that rubies were described or sourced from exceeded 33 and involved more than 70 separate areas.

\section{The Special Issue}

The centerpiece of the Special Issue is a major review of ruby and its range of genetic expressions in its deposits by Giuliani et al. [7]. This not only provides a solid foundation on the mineralogy and geochemistry involved in this gem varietal, but also presents an encompassing survey of its global deposits through historic and geological time. From this supporting synthesis, the satellite papers present their own particular points of interest that carry the ruby theme into new research territory [8-13]. Research into gem corundum, however, is a continuing process, and new aspects are already appearing since publication of the papers in the Special Issue. For example, a recent study into the chromophore trace elements that determine the spectrum of colors seen in gem corundum shows that their combined individual effects can now be quantified in their contributions to the observed final color [14]. In the case of ruby, not only do $\mathrm{Cr}^{3+}, \mathrm{Fe}^{3+}$ and $\mathrm{V}^{3+}$ substitutions in the structure give the characteristic colors, but the $\mathrm{Cr}^{3+}$ and $\mathrm{Fe}^{3+}$ can also introduce charge compensation by a trapped hole that can add subsidiary orange and yellow, respectively, into the resultant color.

\subsection{Ruby Review}

This large review by Giuliani et al. [7] runs to 83 printed pages, lists 270 cited references and includes 61 mostly color illustrative figures. The figures include many photos of rubies from different areas discussed throughout the text, field distribution maps of ruby deposits, field settings of ruby in deposits and a summary diagram of relative recorded ruby productions from different countries in 
the early 21st century. There are line drawings of ruby crystallographic features, graphs of different ruby spectra, photomicrographs of ruby-bearing host assemblages and internal fluid and mineral inclusions within rubies. A host of geochemical variation diagrams plot comparative ruby suites and their variously attempted classification boundaries. Other geochemical diagrams relate data to physical genetic parameters, such as pressure, temperature and oxidation states and associated mineral stability fields. Summary figures model ruby deposit genesis within lithospheric sections. One figure uses an innovative design to illustrate the geological history of economic ruby deposits. This spiral Earth-time diagram captures the irregular punctuated succession of the main ruby episodes, starting with Greenland deposits at around $2.7 \mathrm{Ga}$, then a major period of ruby formation linked to the Kuugan and East African orogenic events from $\sim 650$ to $500 \mathrm{Ma}$ and finishing with a profusion of Cenozoic deposits mostly associated with Himalayan orogenic events from 55 to $5 \mathrm{Ma}$.

The review surveys a great variety of ruby deposits across the continents and includes newer exploration regions, such as Greenland. Ruby deposits in India, however, lack direct description and need further examples, such as a recent study on a rare peraluminous ensemble in which ruby and sapphire associate with spinel and sapphirine in a highly calcic anorthosite-layered complex in Tamil Nadu, India [15]. Overall, a feature of the review is an application of an enhanced ruby classification based on the surveyed deposits. A simplified outline of the classification is given in a final figure in the Conclusions. Three environments of host rocks for rubies are categorized. Magmatic-metamorphic assemblages (Type I) are subdivided into alkali basalts (IA) and kimberlite (IB) hosts. Metamorphic rocks (Type II) are subdivided into Metamorphic, sensu stricto, hosts (Type IIA), which subdivide into mafic-ultramafic (IIA1) and marble (IIA2) types, and Metasomatic hosts (Type IIB), which then subdivide into plumasite-metasomatic (IIB1) and shear zone, fault and fold structural metasomatic (IIB2) types. A Sedimentary, detrital, category (Type III) includes alkali basalt and kimberlite sources (IIIA) and metamorphic (IIIB) sources [7].

Three tables are included in the review [7]. Table 1 presents selected representative major/minor electron microprobe analyses (EMPA) of the rubies used in the classification of the global deposits. Table 2 provides laser ablation-inductively coupled plasma-mass spectrometry (LA-ICP-MS) analyses of trace element contents in selected rubies related to the classification of their deposits. Table 3 sets out representative typological ruby localities that exemplify the different categories established for the new and enhanced classification for global ruby deposits.

Finally, photographic images scattered through the text depict hands cupping ruby crystals, fingers indicating ruby within outcrops, miners working at mine sites and locals selling gemstones at source. These visuals remind readers of the human interactions involved in extracting ruby from its natural environment [7].

\subsection{Myanmar Ruby Studies}

Two studies focus on ruby from Myanmar, in particular from the Mogok area, a historic and still-active venue for top quality ruby [16]. The Mogok gem tract includes marbles that commonly host these ruby deposits, while suites of igneous intrusive rocks in the area [17] also formed some contact zone ruby-bearing skarn deposits.

A Swiss-based research team, Myint Myat Phyo et al. [9], presented new detailed U-Pb dating on gem-quality ruby (and spinel) by using zircon and zirconolite inclusions in these rubies and within the host and adjacent lithological units within the Mogok gemstone-tract. The use of zirconolite is a first for such dating in ruby. Besides the age-dating results, accompanying rare earth elements (REE) data on the mineral inclusions help to characterize the genetic origin of the ruby and assist its profiling for geographic typing of Mogok area rubies. Two variants of laser ablation-inductively coupled mass spectrometry (LA-ICP-MS) methods were used in the analytical determinations. One [18] was the 'Time of Flight' method (LA-ICP-TOF-MS) and the other was a 'Sector Field' method (LA-ICP-SF-MS). The single detector ' $\mathrm{SF}^{\prime}$ method has $15 \times$ higher sensitivity than the 'TOF' method and was more adapt at analyzing between transitions in highly zoned zircons. The 'TOF' method was ideal for monitoring 
elemental variations when switching between grains and was used for detailed elemental and isotopic determinations in small and more complex zircons and zirconolite crystals.

In the study, 109 zircon and 14 zirconolite grains were analyzed from ruby and spinel crystals. Analyses were made of core and rim zones where well defined. Zircon cores ranged from 94 to $26 \mathrm{Ma}$ and rims from 30 to $22 \mathrm{Ma}$. The youngest ages were concordant for both ruby at $22.3 \pm 0.4 \mathrm{Ma}$ and spinel at $22.9 \pm 0.7 \mathrm{Ma}$. Accessory zircon and zirconolite grains in the host marble gave similar age spreads from 95 to $17 \mathrm{Ma}$ to the inclusion range, but the youngest concordant rim ages at $17.01 \pm 0.4 \mathrm{Ma}$ were slightly younger. Accessory zircon in ruby-bearing garnet-orthopyroxene gneiss gave Jurassic to Cretaceous core values and a young concordant rim age of $32.0 \pm 0.03 \mathrm{Ma}$, while zircon in a biotite-garnet gneiss gave core ages up to $\sim 985 \mathrm{Ma}$, with young rims giving concordant ages at $26.1 \pm 1.2 \mathrm{Ma}$. All the age ranges related to this study are plotted up in a summary figure along with the age data available from previous Mogok gem tract studies. This shows the substantive increase in dating now available from the present study for ruby inheritance and growth recorded for the Mogok tract than in previous age dating within the 200-15 Ma age range [9].

The REE data on zircons and zirconolite in this study were analyzed from core zones. The zircons in the rubies show enrichments in HREE, associated with very low to below detection LREE, and show subdued to absent $\mathrm{Ce}$ and $\mathrm{Eu}$ anomalies. The accessory zircon grains in the marble host and proximal gneissic rocks show more pronounced REE contents and Ce and Eu anomalies. The new data form a firmer base to specify inclusion signatures in Mogok tract ruby and allied rock suites. These low LREE/higher REE profiles reported for the included zircon in ruby in this study find reinforcement in a previous study [19]. Those zircon inclusions showed similar notably low LREE and more enriched HREE but were recorded in Mogok ruby with a different locality and ruby age.

A further Mogok ruby study by Vertriest and Palke [13] targeted the identity and genetic implications of opaque sulfide inclusions in the marble-hosted rubies. The authors then compared the Mogok inclusion features against those of opaque sulfide inclusions in Mozambique rubies, which formed in a very different host lithology and genetic growth processes. The aim of the study was to identify the mineralogy of the two inclusion suites and to consider any potential effects on ruby chromophore coloration and fluorescence and any signaled differences in their genetic formation. The Mogok rubies formed in carbonate platforms contaminated with organic materials and evaporated salt deposits which underwent metamorphic events and fluid interchanges. The Montepuez rubies formed in less clearly understood peak metamorphic processes associated with amphibole formation. These differences were expected to show up in the opaque sulphide suites.

The studied rubies came from the documented field collections in the Gemological Institute of America and were prepared for photomicrography in the Bangkok laboratory. Back-scattered electron (BSE) images and electron microprobe analyses (EMPA) on the inclusions were gathered at the Analytical Facility at CalTech, Pasadena, California. Sulfide inclusions were found in 85\% of Mogok samples and $40 \%$ of Montepuez rubies. Two figures each of Mogok and Montepuez photomicrographs and BSE images of the inclusions provide instructive viewing of the opaque sulphide inclusion phases. Mogok inclusions are mostly single phases, whereas Montepuez inclusions have more complex phases and show exsolution features. The tabled EMPA data identified pyrrhotite, sphalerite and one pyrrhotite-pyrite composite among Mogok inclusions, while complex Montpuez inclusions contained chalcopyrite, pentlandite and pyrrhotite with some exsolved Fe-Ni sulfides. An important outcome in this new study over previous studies is better identifications. An earlier suggested predominance of pyrite for Mogok sulfide inclusions had misidentified the phase, which is now identified as pyrrhotite. Similarly, claimed chalcopyrite in Montepuez rubies has proved to be largely $\mathrm{Fe}-\mathrm{Ni}-\mathrm{Cu}$ sulfides [13].

In a wide-ranging discussion, the authors debate the complexities involved in unravelling the precise geneses of these sulfide inclusions within the two contrasting ruby-bearing regions. A high $\mathrm{T}$ stability for pyrrhotite, the main Mogok sulfide, at $>743{ }^{\circ} \mathrm{C}$ suggested a protogenetic origin, based on a marble-related peak metamorphic T range of $620-670{ }^{\circ} \mathrm{C}$. The Mogok rubies were generated during a lower $\mathrm{T}$ retrograde event. The binding of Fe by $\mathrm{S}$ before ruby formation may explain its low-Fe ruby 
nature and consequent undamped fluorescence effect. The rarer sphalerite inclusion within Mogok rubies was linked to low grade metamorphism of the host marble platform. In contrast, the more complex Montepeluez sulfide inclusions are accompanied by greater ranges in Fe contents within the rubies, giving less noticeable fluorescence effects [13].

\subsection{Geographic Typing of Rubies}

Locality determination for quality gemstones has become an important issue for tracing and confirming their sources and values, with an array of analytical techniques now marshalled to guide their scientific validation [20]. For ruby, its geographic origin can be determined with a high degree of confidence; with application of suitable statistical treatments, rubies from different deposits can be distinguished in up to $96 \%$ of cases [21]. In typing rubies from Appaluttoq deposits in SW Greenland, Krebs et al. [22] used sophisticated trace element and $\mathrm{Sr}-\mathrm{Pb}$ isotope methods to distinguish two sets of rubies derived from two hosts of different host lithologies. They also, for the first time, age-dated ruby growth histories directly from the ruby compositions. Off-line laser ablation was combined with thermal ionizing mass spectrometry (TIMS) in analyzing the radiogenic isotopic compositions. These novel techniques are used in a wider study presented in this current Special Issue [10].

In terms of the wider study, Krebs et al. [10] examine the usefulness of trace element and radiogenic isotopes for geographic typing for gem corundum. They stress that distinction of host lithology is more reliable than in determining a precise geographic provenance, particularly for marble-type ruby. Studied samples came from three gem corundum deposit types. Amphibole-metamorphic ruby types included deposits from Montepeluez, Mozambique; Winza, Tanzania; Andilamena/Zahmena and Ampanihy/Toliara, Madagascar. Marble-ruby types included various deposits within the Mogok Gem Tract and Nama, Kachin State, Myanmar; Luc Yen, Vietnam; Jegdalek, Afghanistan; Morogoro, Tanzania. Metamorphic blue sapphire deposits included Andilamena and Andrebabe, Madagascar; various Mogo Gem Tract sites, Myanmar; Elahera, Sri Lanka.

Novel methodology developed to cater for low trace element abundances of the previous SW Greenland study [22] was employed again here, and the Greenland results were added in for comparison in the discussion section. The ppm data for 26 elements in the trace element array are provided in a Supplementary table, while a table in the text lists results for eight elements considered relevant or useful for geographic typing, viz. $\mathrm{Mg}$, Ti, $\mathrm{Cr}, \mathrm{Fe}, \mathrm{Ni}, \mathrm{Zn}$ and $\mathrm{Ga}$. The analyzed values are plotted in several figures that include primitive mantle plots as comparative multi-element arrays, and box plots of $\mathrm{Eu}, \mathrm{Ce}$ and $\mathrm{Sr}$ vs. $\mathrm{Eu} / \mathrm{Eu}^{*}, \mathrm{Ce} / \mathrm{Ce}^{*}$ and $\mathrm{Sr} / \mathrm{Sr}{ }^{*} ; \mathrm{Ta}$ vs. $(\mathrm{Ta} / \mathrm{Nb})_{\mathrm{N}} ; \mathrm{Pb}$ vs. $(\mathrm{U} / \mathrm{Pb})_{\mathrm{N}} ; \mathrm{Th}$ vs. $(\mathrm{Th} / \mathrm{U})_{\mathrm{N}} ; \mathrm{Hf}$ vs. $(\mathrm{Zr} / \mathrm{Hf})_{\mathrm{N}}$.

Radiogenic isotope analyses are listed in a text table, shown as ranges in ratios of ${ }^{87} \mathrm{Sr} /{ }^{86} \mathrm{Sr}$ and ${ }^{206} \mathrm{~Pb} /{ }^{204} \mathrm{~Pb},{ }^{207} \mathrm{~Pb} /{ }^{204} \mathrm{~Pb},{ }^{207} \mathrm{~Pb} /{ }^{204} \mathrm{~Pb}$ and ${ }^{208} \mathrm{~Pb} /{ }^{206} \mathrm{~Pb}$ for samples from each types of corundum deposits. Bow and whisker diagrams in three figures plot the comparative ranges for these isotopes for each of the corundum types, while a further figure plots the isotopic values as ${ }^{87} \mathrm{Sr} /{ }^{86} \mathrm{Sr}$ vs. ${ }^{207} \mathrm{~Pb} /{ }^{206} \mathrm{~Pb}$ for the three corundum types, which showed no close correlation between these three suites.

In the Discussion, the authors plot their data on several typical diagrams previously used for corundum provenance studies. They use only LA-ICP-MS data for the comparisons in binary diagrams for $\mathrm{Cr} / \mathrm{Ga}$ vs. $\mathrm{Fe} / \mathrm{Ti}$ and $\mathrm{Fe}$ vs. $\mathrm{Ga} / \mathrm{Mg}$ and for triangular diagrams for $\mathrm{Fe}-\mathrm{Ti} \times 10-\mathrm{Mg} \times 100 ; \mathrm{Fe}-\mathrm{V}-\mathrm{Ga}$; $\mathrm{Fe} / 20-\mathrm{V} \times 3-\mathrm{Ga} \times 3$. In the $\mathrm{Cr} / \mathrm{Ga}$ vs. Fe/Ti diagram, high-Fe metamorphic ruby, marble-type ruby and blue sapphire fall into discrete fields with only minor overlaps. Different localities within these fields, however, significantly overlap. Among marble-type rubies, those from Mong Hsu are distinctive [19,22], though in general, none of the typical discrimination schemes are very effective in separating localities of the same deposit type.

Using broader trace element data, the authors evaluated other elements as discriminators, such as $\mathrm{Ni}, \mathrm{Zn}$ and $\mathrm{Pb}$, with $\mathrm{Ni}$ showing good discrimination among amphibole-ruby deposits. Combined in an $\mathrm{Ni} \times 100-\mathrm{Ti}-\mathrm{V} \times 10$ triangular figure, it separated fields from Winza, Tanzania, Namehaca, Mozambique and Ampanihy and Zahmena, Madagascar. In contrast, Appaluttoq ruby, Greenland, 
showed a wide range and overlapped with the Namehaca and Zahmena fields. The Greenland field overlap was partly resolved in a Ga vs. V plot, but incompletely. None of the added elements proved useful for marble-ruby deposits. Instead, binary figures for $\mathrm{V}$ vs. Cr and Fe vs. V could roughly divide Myanmar and Morogoro area rubies, while ternary diagrams for $\mathrm{Fe} / \mathrm{Mg} \times 2-\mathrm{Cr} / \mathrm{Ti}-\mathrm{V} \times 10$ and $\mathrm{V}-\mathrm{Cr} / 10-\mathrm{Ti}$ achieved passable separations of Myanmar, Morogoro, Tanzania and Afghanistan rubies. For metamorphic blue sapphires, a figure using three binary plots, $\mathrm{Mg}$ v.s V, V vs. $\mathrm{Cr} \times \mathrm{Ti}$ and $\mathrm{V}-\mathrm{Cr} / 10-\mathrm{Ti}$, was employed to examine distributions of Myanmar, Andrebabe and Sri Lankan fields.

Multivariant statistical analysis, both Principal Component and Linear Discriminant, were applied by the authors to increase reliability of origin determination and detect elements of potential discriminatory use. Linear discriminant solutions are shown in a summary figure of element arrays for the main ruby and sapphire groups, and On-Line and Off-Line solutions were compared. Similarly, the most useful combinations of isotopic ratios and trace elements were also compared in a final figure.

In the Conclusions, the authors considered that geographic differentiation of amphibolite-type rubies is fairly simple but is more challenging for marble-type rubies and metamorphic blue sapphires. They emphasize the promise of using combined isotopic and trace element fingerprints, but for precise geographic origin, more powerful discriminating tools need development [10].

\subsection{Gem Corundum Spectrum}

In the paper by Palke [11], the author brings together the two main gem varieties of corundum. They have similar properties, although ruby differs in a relative excess of the chromophore ion $\mathrm{Cr}^{3+}$ that introduces a red color in comparison to the other colored variety sapphire. The two varieties, however, can occur together in the same gem deposit, and this theme is developed in the survey.

The Introduction indicates that changes in host rock chemistry and physical conditions during formation can enable $\mathrm{Cr}$ to enter the corundum structure. Many rubies form in platform carbonates, although the precise process is not well understood. In its outline, the study aims to focus on some important regions where deposits yield both ruby and sapphire suites. The studied samples were selected from the Gemological Institution of America (GIA) Colored Stones Collection and also gained from contacts associated with the Montana Bureau of Mines, mineral dealers and miners from MT, USA, sapphire fields. The sample sets included rubies largely from South East Asia: Thailand/Cambodia, Sri Lanka, Mogok and Myanmar, but also from more limited sources in Montana, USA. Transitional pink sapphires from Sri Lanka and Montana were also present, while the main blue sapphires were sourced from the Thailand/Cambodia, Sri Lanka, Mogok, Myanmar and Montana fields. The gemstones were largely recoveries from eluvial and alluvial deposits, with some Yogo, Montana, stones related to a primary deposit [11].

Analytical methods used for trace element data on the ruby-sapphire spectrum relied on LA-ICP-MS methodology adopted at the GIA Lab. The runs used ${ }^{27} \mathrm{Al}$, NIST 610 and NIST612 glass as standards, for accuracies within 5-20\%. Only main trace elements were run for the surveyed deposits and, with detection limits in ppm, were Mg (1.2-4.7), Ti (0.1-0.5), V (0.1-0.5), Cr (1.3-5.1), $\mathrm{Fe}(13.7-54.8)$ and $\mathrm{Ga}(0.1-0.2)$. Mineral inclusions in the rubies and sapphires were identified with a Renishaw, Raman microscope system. It had the capacity to analyze many inclusions beneath the exterior surface as well as others exposed on polished surfaces.

Each deposit was successively described in context of the host geological setting, trace element results and inclusion suites within the color groups. The trace element results for each constituent color group were accompanied by correlation matrices that brought out positive and negative trends. The listed data for each locality are placed within 11 text tables for their discussion. Plots of the trace element data from each deposit use specific trace element parameters that illustrate the relationships within color groups and occupy five figures within the text. Photo micrographs of typical inclusions in rubies and sapphires within suites occupy a further five figures within the text.

Thailand/Cambodia suites, studied from the important Chanthanburi and Pailin gem fields, suggest that this large region of ruby and sapphire deposits overlapping the border between the two 
countries differs from other deposits farther afield. Trace element contents, their correlation trends and inclusion characteristics mark significant separations between the color suites. The origin of the ruby sources remains in debate, either being in highly mafic metamorphosed rocks sampled by later alkali basalts or related to peritectic melting reactions caused by basalt magmas.

Mogok, Myanmar, suites include rubies associated with high-grade folded marble beds, where $\mathrm{Cr}$ and $\mathrm{Al}$ were introduced from mobilized molten-evaporate beds, while blue sapphires were generated where pegmatitic syenites intruded into gneisses and other metamorphic hosts. These source differences are reflected in trace element separations in several discrimination diagrams, but are less obvious in some plots, such as Ga vs. Mg which shows notable overlap. The correlation matrices bring out some unexpected features, where both rubies and sapphires both show significant positive correlation between $\mathrm{Cr}$ and $\mathrm{V}$. The V-rich nature of Mogok rubies and sapphires are consistent with previous LA-ICP-MS imaging and analyses [23]. Differences between rubies and sapphires show up in their inclusions with carbonate, apatite and sulfide, dominant in ruby, and feldspars, zircon and polysynthetic twinning, common in sapphires.

Montana, USA, sapphire and ruby suites cover a number of spaced deposits across a wide region. The secondary suites are largely alluvial and are derived from rhyolitic and rare mafic hosts. They show a range of pastel colors mostly blue, green and lavender that pass into yellow, orange and ruby. $\mathrm{Cr}$ values vary by three orders of magnitude, above the two orders of magnitude for $\mathrm{Mg}$, $\mathrm{Ti}, \mathrm{Fe}$ and $\mathrm{Ga}$. In Fe vs. Cr plots, good separation is achieved between blue sapphires, pink sapphires and rubies, whereas $\mathrm{Ga}$ vs. Mg plots only show large overlaps. Correlation matrices reveal a strong positive $\mathrm{Ti}$, $\mathrm{Mg}$ trend. Inclusion suites across the color range show only minor differences.

Montana Yogo Primary suite is derived from a deep-seated lamprophyre intrusion and includes blue and violet sapphires and ruby. It is easily distinguished from the other Montana suites by trace element plots, correlation matrices and inclusion suites. Plots of Fe vs. Cr diagrams show good separations between the sapphire and ruby colors. Melt inclusions, however, show generally similar compositions across the color range.

Sri Lankan sapphire and ruby suites are mostly recovered from alluvial deposits. Host rocks are not well sourced. They probably represent amphibolitic and granulitic metamorphic rocks formed during Neoarchean-late Ordovician collision of $\mathrm{E}$ and W parts of continental Gondwana. The gem fields produced blue and pink sapphires and rubies among other colors. The sapphire to ruby range shows some separation with increasing $\mathrm{Cr}$ in a Ga vs. Cr plot, whereas a Ga vs. Fe plot shows much overlap. A similarity in inclusions is seen through the suite, mostly biotite, rutile silks and negative crystals.

In his discussion, the author considered the roles of inclusion suites and geochemistry within the studied gem corundum deposits. The inclusions are important direct clues to origins, although they have limits, while the path of geochemistry suggests controls related to the crystallizing environment but is not always fully understood and leads to breakdown in some assignments. The present survey shows two types of coexisting ruby and sapphire deposits, polygenetic and monogenetic. Polygenetic examples include the Thailand/Cambodia and Mogok, Myanmar deposits, although they may have overly common links, such as both being related to the Himalayan orogeny. Clear differences exist in $\mathrm{Cr}$ and Fe contents, though other elements such as $\mathrm{Mg}$, Ti and Ga overlap in contents. Monogenetic examples include Montana and Sri Lanka deposits. A surprising observation is that $\mathrm{Cr}$ contents can range through extreme levels, with little other variation in other elements or within inclusion suites [11].

In conclusion, this study, though limited to several producing deposits, can be amplified through further studies in deposits elsewhere, such as in Australia, Colombia, Myanmar, Vietnam and Tajikistan. The present study suggests that rubies and sapphires within joint deposits do not necessarily reflect clear-cut tectonic or geological host controls in their formation [11]. 


\subsection{Allied Mineral Assemblages}

Ruby largely forms in metamorphosed/metasomatised ultramafic/mafic hosts and carbonate platform beds in fold belt sequences where $\mathrm{Cr}$ and $\mathrm{Al}$ enrichments are present, so that the presence of allied Cr-bearing minerals in host assemblages and in the ruby as inclusions are likely. In their paper, Kissin et al. [8] report the presence of a $\mathrm{Cr}$ mineral previously unrecorded as a genetic phase associated with ruby. In their Introduction, the authors identify the new allied mineral as eskolaite, a chromium oxide, $\mathrm{Cr}_{2} \mathrm{O}_{3}$, and give its location at the Kuchinsko ruby marble deposits in the southern Urals area, Russia. They suggest it is a useful find for discussion on the sources of $\mathrm{Al}$ and $\mathrm{Cr}$ in ruby-bearing marbles. The Introduction also provided preliminary surveys on ideas and references relating to formation of marble-hosted rubies and known types of global geological environments that record eskolaite.

In the geological setting, the authors describe the surroundings of the ruby deposit located in the Kochkar Anticlinorium, bounded by thrusts that dip below adjacent synclinorium belts. Granite gneissic domes form centers produced by dynamothermal metamorphism within the anticlinorium, framed by schists, amphibolites and marbles, intruded by granite and pegmatite dykes. Carboniferous prograde metamorphism that formed two types of marble was followed by Permian-Triassic retrograde metamorphism that formed a third marble type. The granite/pegmatite dykes were related to anatectic granites in the gneissic domes. Later Paleogene-Neogene karst deposits were formed that include eluvial rubies, showing no alluvial transport attrition. A geological map of the location and broad regional structural features accompanies the section [8].

The Materials and Methods outline sampling of ruby from the Kuchniskoe area where crystals were garnered from the karst deposits. Three different types of ruby were found, each related to the underlying marble type. Ruby grains with surface aggregates of a co-existing dark mineral phase were recorded by scanning electron microscopy (SEM) and identified using X-ray diffraction (XRD) at the State Mining University, Ekaterinburg. The eskolaite and ruby surface matrices were then subjected to electron microprobe analysis (EMPA) at the Russian Academy of Science laboratory, Ekaterinburg. Samples were run from both prograde and retrograde metamorphic ruby types. The XRD and EMPA results are listed separately in two text tables and the photomicrography and SEM imaging are illustrated in three composite text figures.

Discussion of the analytical results detailing the eskolaite-ruby association firstly considered the T-P conditions of its formation in relation to the regional geological events. The peak prograde metamorphism for the ruby-hosted marble, calculated by calcite-dolomite thermo-barometry, was $660{ }^{\circ} \mathrm{C}$ at 1.9-2.6 kbar. This was compared with slightly lower T-P for Type 3 ruby from the retrograde phase of metamorphism, estimated at $\mathrm{T} 550-600{ }^{\circ} \mathrm{C}, \mathrm{P} 1.9-2.2 \mathrm{kbar}$, with $\mathrm{P}_{\mathrm{CO} 2}$ 0.4-1.4 kbar. The T-P for the inter dome region of the Kochlar Anticlinorium, where the ruby deposits lie, was based on mineral paragenesis of the assemblage; garnet + biotite + plagioclase + quartz \pm staurolite \pm sillimanite \pm cordierite. This gave T $500-620^{\circ} \mathrm{C}, \mathrm{P} 3.0-4.0 \mathrm{kbar}$, and may reflect an estimate for ruby Type 1 prograde metamorphic formation conditions. Eskolaite in the marble deposit intergrowths is associated with high-Cr ruby, a relationship that was used to formulate an eskolaite-ruby geo-thermometer. This gave a $\mathrm{T}$ of $700-850^{\circ} \mathrm{C}$, higher than that known for the metamorphism in the Kochlar Anticlinorium, which lies between $670-800{ }^{\circ} \mathrm{C}$. The cause of this discrepancy was unclear but may involve factors such as oxygen fugacity and $\mathrm{pH}$ conditions.

An extensive section was devoted to the $\mathrm{Al}$ and $\mathrm{Cr}$ sources for combined ruby and eskolaite formation by the authors. Several modes of potential formation were considered and thought unlikely on available evidence. Although redistribution of $\mathrm{Al}$ and $\mathrm{Cr}$ through metamorphism of sedimentary limestones with evaporate lenses fit some of the criteria, it did not fit the evidence of both the prograde and retrograde formational phases. The authors instead proposed that the dual ruby and eskolaite formation resulted from a hydro-metasomatism process where a high temperature fluid was generated during domal 'granitization'. This provided $\mathrm{SiO}_{2}, \mathrm{Na}, \mathrm{K}$ and $\mathrm{H}_{2} \mathrm{O}$ and removed $\mathrm{Mg}, \mathrm{Fe}, \mathrm{Ca}$ and other components. The eskolaite formed in the final stages of each ruby growth, with maximum 
$\mathrm{Cr}$ availability during prograde metamorphism and then after a transition $\mathrm{Cr}$ replenishment during retrograde metamorphism. In their Conclusion, the authors considered that the find of eskolaite in tandem with ruby in the Kuchinskoe marbles illustrated a new process of introducing $\mathrm{Al}$ and $\mathrm{Cr}$ into a mineral zone [8].

\subsection{Multiple Ruby Assemblages}

In a detailed study of the Snezhnoe ruby deposit, Central Palmir Mountains, Tajikistan, Litvenoko et al. [12] describe four ruby-bearing host assemblages intercalated within ruby-free assemblages. An introduction sets out the mineralogy of ruby as a corundum variety, aspects of ruby mineralization and the tectonic processes that make reconstructions of ruby formation a challenge. Features of the Snezhnoe marble-hosted ruby deposit, its earlier studies and comparisons with other similar ruby deposits of the Alpine-Himalayan fold belt followed. The Snezhnoe deposit, however, was considered understudied prior to the present project.

In the geologic setting, the ruby deposit site is pin-pointed in a figure of the large-scale geological map of the Palmir Mountains structures, where it lies within the Mazkul-Rangakul Anticlinorium. Two further figures show details of the Snezhnoe deposit in relation to other ruby deposits in a map of the marble layers in the southwestern limb of the Shatput Anticline and in a closer scale cross section. In this, the ruby deposit lies in steep-dipping en echelon lenses within a sequence of marbles intercalated with amphibole-pyroxene and scapolite calciphyres, gneisses and crystallized schists. The ruby lenses are cut by numerous late hydrothermal veins.

The Snezhnoe ruby-bearing rocks were sampled during field explorations from 2010 to 2017. A large array of instrumental methods at different institutions were employed for a multi-tasked gathering of data on the nature of the ruby deposit and its genetic formation. Selected mineral extractions were studied using XRF spectrometry at the Vernadsky Institute, Russian Academy of Sciences, Moscow, with mineral identifications made in XRD runs at the Russian State Geological Prospecting Museum, Moscow. Mineral composition data were collected by EMPA techniques at the Vernadsky Institute, with most elements being analyzed within detection limits of $<0.01 \mathrm{wt} \%$. LA-ICP-MS methodology was used on ruby samples for studying trace element values within internal zoning, at the Institut für Geowissenschaften, Johannes Gutenberg Universität, Mainz. Trace element and $\mathrm{U}-\mathrm{Pb}$ isotopic compositions were analyzed using an ICP-MS unit coupled with an Analyte G2 excimer laser at the Westfälische Wilhelms Universität Münster. For rutile dating, ${ }^{206} \mathrm{~Pb},{ }^{207} \mathrm{~Pb},{ }^{232} \mathrm{Th}$ and ${ }^{238} \mathrm{U}$ isotope data allowed Concordia and age calculations at the Berkeley Geochronology Centre, USA. Minimum entrapment pressures for rutiles in rubies were estimated by shifts in $\mathrm{Cr}^{3+} \mathrm{R}$-lines, seen using a confocal Raman spectrometer coupled with an Olympus microscope and automatic XYZ-stage. Oxygen isotopic compositions of ruby grains were determined using a high-resolution ion probe at Heidelberg, Germany, after DSE imaging to avoid areas of inclusions. Ruby-bearing rocks were powdered for $\mathrm{Rb}-\mathrm{Sr}$ and $\mathrm{Sm}-\mathrm{Nd}$ isotope analyses, while mineral fractions of plagioclase and phlogopite were processed for $\mathrm{Rb}-\mathrm{Sr}$ geochronology. Measurements were made using a multi-collector TIMS facility at the Russian Academy of Science facility, Moscow.

Results on one-mineral, three-mineral (2) and four-mineral ruby-bearing assemblages included: calcite; plagioclase + muscovite + margarite; muscovite + phlogopite + margarite; scapolite group + phlogopite + muscovite + margarite. Ruby-free assemblage results mostly included plagioclase + scapolite + phlogopite + muscovite. The micas were commonly enriched in $\mathrm{Cr}$ and $\mathrm{V}$, with the greener varieties being indicators of ruby. Visible accessory mineral grains analyzed included graphite, corundophyllite, rutile and dravite-elbaite series, while a range of other minerals were identified under high magnifications. A table lists the major, minor and accessory minerals in assemblages in the text. Text figures illustrate macrophotography, photomicrography and a diagram of random ruby crystals in host rock illustrate the ruby-bearing assemblages. Results on pink to bright red and purple-hued ruby showed ranges in $\mathrm{Cr}$ up to $0.55 \mathrm{wt} \%$, $\mathrm{Fe}_{\text {total }}$ up to $0.2 \mathrm{wt} \%$ (EMPA) and $\mathrm{Ga}$ analyses showed a significant range from 68-98 ug/g (LA-ICP-MS). Mineral element values and ratios of analyzed rubies 
in figure diagrams shear clear metamorphic association for ruby in marble in some diagrams, although in others, transitional overlapping towards magmatic trends is seen. The $\delta^{18} \mathrm{O}$ isotopic compositions fall into a narrow range from +15.1-15.3, typical of crustal associations.

Compositional results on the ruby-bearing rocks showed variations between 38-98 wt \% $\mathrm{Al}_{2} \mathrm{O}_{3}$, up to $12 \mathrm{wt} \%$ alkalis $\left(\mathrm{Na}_{2} \mathrm{O}_{3}+\mathrm{K}_{2} \mathrm{O}\right)$ and 3-10 wt \% CaO. Crustal-normalized multi-element arrays of ruby-associated micaceous lenses and marbles were depicted in a figure diagram. Minor elements, mostly enriched in $3^{+}$and $4^{+}$and less so for $1^{+}, 2^{+}$and $5^{+}$charged lithophile elements, overall exceeded Earth's crust average values, particularly Ce $(\times 248)$. F contents up to 4.6 wt $\%$ indicate significant inputs into mineral-forming activity of fluids. Using LA-ICP-MS U-Pb results on rutiles, a figure of their plots in a Concordia diagram showed a lower intercept at $12.0 \pm 1.5 \mathrm{Ma}$ and a potential upper intercept at $\sim 4.9 \mathrm{Ma}$. Rutile grains inter-grown with zircon enabled thermometry and indicated a $\mathrm{T}$ range of $\sim 830 \pm 60^{\circ} \mathrm{C}$. $\mathrm{Rb}-\mathrm{Sr}$ isotope results on ruby-bearing rocks plotted in a ${ }^{87} \mathrm{Sr} /{ }^{86} \mathrm{Sr}$ plotted in a figure indicated two error isochrones, one at $12 \pm 3.0 \mathrm{Ma}$ and another at 23 $\pm 1-2 \mathrm{Ma}$, the latter likely linked to alteration opening up the $\mathrm{Rb}-\mathrm{Sr}$ system in phlogopite. An Nd isotopic result gave a bulk rock $\varepsilon \mathrm{Nd}_{(20 \mathrm{ma})}$ value of -9.6 [12].

Discussion was opened up with the authors reviewing different hypotheses on the origin of the ruby-bearing rocks, which included metasomatic, hydrothermal, and sedimentary-metamorphic scenarios, although all of these were previously controversial. The authors considered these using a figure in which two Ternary diagrams plotted element oxides against $\mathrm{SiO}_{2}$ and $\mathrm{Al}_{2} \mathrm{O}_{3}$, plotting data from the present study. A sedimentary origin was discerned in both diagrams but had different overlaps, one that invoked Precambrian illitic clays and bauxitic ores while the other suggested illitic and kaolinitic clay sources and proximal lateritic bauxites. Considering the ruby geochemistry using trace element ratios, plotted oxide sums and $\mathrm{O}$ isotope data, the authors confirmed an earlier hypothesis-the ruby-bearing rocks were once an Al-enriched protolith, reworked during iso-chemical metamorphism [12].

Thermometry from zircon in rutile results and barometry from Raman mapping of rubies was plotted in a $\mathrm{T}\left({ }^{\circ} \mathrm{C}\right)-\mathrm{P}$ (kbar) figure showing previous modelling of T-P fields, a peak metamorphism point, alumino-silicate stability fields and schematic Greenschist, Amphibolite and Granulite fields. The $\mathrm{Rb}-\mathrm{Sr}$ isotope, $\mathrm{U}-\mathrm{Pb}$ rutile Concordia and $\mathrm{K}-\mathrm{Ar}$ muscovite age plots were linked to cooling and relaxing stages after peak metamorphism during the Alpine-Himalayan Orogeny, while the T/DM model age confirmed the hypothesis of a Proterozoic protolith for the ruby-bearing rocks. The ages of Snezhnoe and other ruby deposits in the orogenic region were compared in a figured map.

In their Conclusions, the authors summarize the outcomes related to the tectono-metamorphic development of the Snezyhnoe ruby deposit, the likely T-P formation conditions, the chromophore and genetic trace elements and inclusions in the rubies, and the nature of the ruby-bearing petrological assemblages, which confirm a crustal origin and offer prospecting indicators. The authors present a robust updated characterization and interpretation of the Snezhnoe ruby [12].

Funding: This research received no external funding.

Acknowledgments: The Guest Editors both wish to transmit special thanks to all the contributing authors, the Minerals editorial team, especially Francis Wu, Assistant Editor, and Sweater Shi, Section Managing Editor, and the many reviewers for their ready responses and critical commentaries that honed the quality of the published papers, prior to their compilation in the Minerals Special Issue on the Mineralogy and Geochemistry of Ruby.

Conflicts of Interest: The authors declare no conflict of interest.

\section{References}

1. Hughes, R.W. Ruby Connoisseurship. Seeing Red. Guide 2001, 20, 7-16.

2. Samuels, S.K. Burma Ruby: A History of Mogok's Rubies from Antiquity to the Present; SK Enterprises: Tucson, AZ, USA, 2003; p. 254.

3. Hardy, J. Ruby: King of Gems; Thames and Hudson: London, UK, 2017; p. 320. 
4. Hughes, R.W.; Manorotkul, W.; Hughes, E.B. Ruby \& Sapphire: A Gemologist's Guide; RWH Publishing/Lotus Publishing: Bangkok, Thailand, 2017; p. 707.

5. Levitsky, A.G.; Sims, D.H.R. Surface geochemical techniques in gemstone exploration at the Rockland Ruby Mine, Mangare area, S.E. Kenya. J. Geochem. Expl. 1997, 59, 87-89. [CrossRef]

6. Yakymchuk, C.; Szilas, K. Corundum formation by metasomatic reactions in Archaen metapelites, SW Greenland: Exploration vectors for ruby deposits within high-grade greenstone belts. J. Geosci. Front. 2018, 9, 727-749. [CrossRef]

7. Giuliani, G.; Groat, L.A.; Fallick, A.E.; Pignatelli, I.; Pardieux, V. Ruby Deposits: A Review and Geological Classification. Minerals 2020, 10, 597. [CrossRef]

8. Kissin, A.; Gottman, I.; Murzin, V.; Kiseleva, D. The first find of $\mathrm{Cr}_{2} \mathrm{O}_{3}$ eskolaite associated with marble-hosted ruby in the Southern Urals and the problem of the $\mathrm{Al}$ and $\mathrm{Cr}$ sources. Minerals 2020, 10, 101. [CrossRef]

9. Phyo, M.M.; Wang, H.A.; Guillong, M.; Berger, A.; Franz, L.; Balmer, W.A.; Krzemnicki, S. U-Pb Dating of Zircon and Zirconolite Inclusions in Marble-Hosted Gem-Quality Ruby and Spinel from Mogok, Myanmar. Minerals 2020, 10, 195. [CrossRef]

10. Krebs, M.Y.; Hardman, M.F.; Pearson, D.G.; Luo, Y.; Fagan, A.J.; Sarkar, C. An evaluation of the potential for determination of the geographic origin of ruby and sapphire using an expanded trace element suite plus $\mathrm{Sr}-\mathrm{Pb}$ isotope compositions. Minerals 2020, 10, 447. [CrossRef]

11. Palke, A.C. Coexisting Rubies and Blue Sapphires from Major World Deposits: A brief review of their mineralogical properties. Minerals 2020, 10, 472. [CrossRef]

12. Litvinenko, A.K.; Sorokina, E.S.; Häger, T.; Yuri, A.; Kostitsyn, R.E.; Botcharnikov, E.; Samsickova, A.V.; Ludwig, T.; Tatiana, V.; Romaskova, V.; et al. Petrogenesis of the Snezhnoe Ruby Deposit, Central Pamir. Minerals 2020, 10, 478. [CrossRef]

13. Vertriest, W.; Palke, A.C. Identification of Opaque Sulfide Inclusions in Rubies from Mogok, Myanmar and Montepuez, Mozambique. Minerals 2020, 10, 492. [CrossRef]

14. Dubinsky, E.V.; Stone-Sunderberg, J.; Emmett, J.L. A quantitative description of the causes of color in Corundum. Gem. Gemol. 2020, 56, 2-28. [CrossRef]

15. Karmaker, S.; Mukherjee, S.; Sanyal, S.; Sengupta, P. Origin of peraluminous minerals (corundum, spinel, and sapphirine) in a highly calcic anorthosite from the Sittampundi Layered Complex, Tamil, Nadu, India. Contrib. Mineral. Petrol. 2020, 172, 1-23. [CrossRef]

16. Thu, K.; Zaw, K. Chapter 23: Gem Deposits of Myanmar. In Myanmar: Geology, Resources \& Tectonics; Barber, A.J., Zaw, K., Crow, M.J., Eds.; Geological Society of London: London, UK, 2017; Volume 48, pp. 497-529.

17. Thu, K. The Igneous Rocks of the Mogok Stone Tract: Their Distributions, Petrography, Petrochemistry, Sequence, Geochronology and Economic Geology. Ph.D. Thesis, University of Yangon, Yangon, Myanmar, 2007.

18. Wang, H.A.; Krzemnicki, M.S.; Braun, J.; Chalain, J.P.; Lefèvre, P.; Zhou, W.; Cartier, L.E. Simultaneous high sensitivity trace-element and isotopic analyses of gemstones, using laser-ablation-inductively coupled plasma-mass spectrometry (LA-ICP-MS). J. Gemmol. 2016, 35, 212-223. [CrossRef]

19. Sutherland, F.L.; Zaw, K.; Meffre, S.; Thompson, J.; Goemann, K.; Thu, K.; Nu, T.T.; Zin, M.M.; Harris, S.J. Diversity in Ruby Geochemistry and its inclusions: Intra- and inter-Continental Comparisons from Myanmar and Australia. Minerals 2019, 9, 28. [CrossRef]

20. Groat, L.A.; Giuliani, G.; Stone-Sundberg, J.; Sun, Z.; Renfro, N.D.; Palke, A.C. A Review of Analytical Methods Used in Geographic Origin of Determination of Gemstones. Gems Gemol. 2019, 55, 4-512. [CrossRef]

21. Kochelek, K.; McMillan, N.J.; McManus, C.; Daniel, D.L. Provenance determination of sapphires and rubies using laser-induced break down spectroscopy and multivariant analysis. Am. Mineral. 2015, 100, 1921-1931. [CrossRef]

22. Krebs, M.Y.; Pearson, D.G.; Fagan, A.J.; Bussweiler, Y.; Sarker, C. The application of trace elements and Sr-Pb isotopes to dating and tracing of ruby formation: The Aappaluttoq deposit, SW Greenland. Chem. Geol. 2019, 253, 42-58. [CrossRef]

23. Zaw, K.; Sutherland, L.; Yui, T.-F.; Meffre, S.; Thu, K. Vanadium-rich ruby and sapphire within Mogok Gemfield, Myanmar: Implications for gem color and genesis. Miner. Depos. 2014, 50, 25-39. [CrossRef]

(C) 2020 by the authors. Licensee MDPI, Basel, Switzerland. This article is an open access article distributed under the terms and conditions of the Creative Commons Attribution (CC BY) license (http://creativecommons.org/licenses/by/4.0/). 


\title{
Ruby Deposits: A Review and Geological Classification
}

\author{
Gaston Giuliani ${ }^{1, *}$, Lee A. Groat ${ }^{2}$, Anthony E. Fallick ${ }^{3}$, Isabella Pignatelli ${ }^{4}$ and \\ Vincent Pardieu ${ }^{5}$
}

1 Géosciences Environnement, Université Paul Sabatier, GET/IRD et Université de Lorraine, C.R.P.G./C.N.R.S., 15 rue Notre-Dame-des-Pauvres, BP 20, 54501 Vandœuvre, France

2 Earth, Ocean and Atmospheric Sciences, University of British Columbia, Vancouver, BC V6T 1Z4, Canada; groat@mail.ubc.ca

3 Isotope Geosciences Unit, Scottish Universities Environmental Research Centre (S.U.E.R.C.), Rankine

Avenue, East Kilbride, Glasgow G75 0QF, UK; anthony.fallick@glasgow.ac.uk

4 Georessources, Université de Lorraine, UMR 7539 CNRS-UL, BP 70239 Vandœuvre, France; isabella.pignatelli@univ-lorraine.fr

5 Field gemmologist \& Consultant at VP Consulting, Manama, Bahrain; vince@fieldgemology.org

* Correspondence: giuliani@crpg.cnrs-nancy.fr; Tel.: +33-3-83594238

Received: 30 March 2020; Accepted: 23 June 2020; Published: 30 June 2020

\begin{abstract}
Corundum is not uncommon on Earth but the gem varieties of ruby and sapphire are relatively rare. Gem corundum deposits are classified as primary and secondary deposits. Primary deposits contain corundum either in the rocks where it crystallized or as xenocrysts and xenoliths carried by magmas to the Earth's surface. Classification systems for corundum deposits are based on different mineralogical and geological features. An up-to-date classification scheme for ruby deposits is described in the present paper. Ruby forms in mafic or felsic geological environments, or in metamorphosed carbonate platforms but it is always associated with rocks depleted in silica and enriched in alumina. Two major geological environments are favorable for the presence of ruby: (1) amphibolite to medium pressure granulite facies metamorphic belts and (2) alkaline basaltic volcanism in continental rifting environments. Primary ruby deposits formed from the Archean (2.71 Ga) in Greenland to the Pliocene (5 Ma) in Nepal. Secondary ruby deposits have formed at various times from the erosion of metamorphic belts (since the Precambrian) and alkali basalts (from the Cenozoic to the Quaternary). Primary ruby deposits are subdivided into two types based on their geological environment of formation: (Type I) magmatic-related and (Type II) metamorphic-related. Type I is characterized by two sub-types, specifically Type IA where xenocrysts or xenoliths of gem ruby of metamorphic (sometimes magmatic) origin are hosted by alkali basalts (Madagascar and others), and Type IB corresponding to xenocrysts of ruby in kimberlite (Democratic Republic of Congo). Type II also has two sub-types; metamorphic deposits sensu stricto (Type IIA) that formed in amphibolite to granulite facies environments, and metamorphic-metasomatic deposits (Type IIB) formed via high fluid-rock interaction and metasomatism. Secondary ruby deposits, i.e., placers are termed sedimentary-related (Type III). These placers are hosted in sedimentary rocks (soil, rudite, arenite, and silt) that formed via erosion, gravity effect, mechanical transport, and sedimentation along slopes or basins related to neotectonic motions and deformation.
\end{abstract}

Keywords: ruby deposits; classification; typology; magmatism; metamorphism; sedimentary; metasomatism; fluids; stable and radiogenic isotopes; genetic models; exploration

\section{Introduction}

Ruby is the red gem variety of the mineral corundum. The name corundum was introduced in the early 19th century by French mineralogist De Bournon when gemmological terminology was transformed from a rather confusing system mainly based on color and origin into a system based on a new science: 
mineralogy. The term "corundum" likely originated from the Sanskrit kurunvinda meaning "hard stone", which became kurund in vernacular. It was the name used by the native people met during the field expedition sent by De Bournon to describe the stones they were mining in Southern India.

If the name "corundum" originates from Sanskrit, in Sanskrit rubies were called ratnaraj, queen of precious stones and symbol of permanent internal fire. In Greco-Roman times, the reference to fire was also common; in 400 before Christ Theophrastus [1] related ruby to anthrax (coal). Two thousand years ago Pliny [2] called all red stones carbunculus (diminutive of carbo), which became escarboucle in old French. In the 11th century, the Arab scholar Al Biruni separated different types of rubies based on specific gravity and hardness, but his work remained unknown in Europe for centuries except possibly for a few scholars like French bishop Marbode [3] who, a few years later, also separated carbuncles into three different types.

The term "ruby" appeared in European languages during the Middles Ages. How and why it was introduced is not clear but it was used by [4]. It is derived from the Latin ruber, meaning red. It became popular and then, until the introduction of the word corundum in the 19th century, most red stones were just called rubies. Experts and authors commonly separated different types based on their origin: "Oriental Ruby" was used for stones mined from Burma or Ceylon (ruby), "Balas Ruby" for gems mined from the modern-day Tajikistan (spinel), and "Bohemian ruby" was used for gems coming traditionally from the modern-day Czech Republic ("red garnet", either pyrope, almandine, and/or spessartite). However, as rubies, spinels, and garnets are often found in association and as new deposits were discovered, the system became very confusing. Ironically, the majority of the most famous rubies (like the "Black Prince Ruby" and the "Timur Ruby" of the British Crown Jewels or the "Cote de Bretagne Ruby" of the French Crown Jewels) that contributed significantly to the public recognition of the word "ruby" would actually, according to the new terminology based on mineralogy, be spinels. As gemmology is not simply about science, but also about history, art, and trade, these gems are still called by their historic "ruby" name, maintaining the taste for either curiosity, controversy, or confusion among many authors, particularly those with a non-scientific and/or historical background.

Currently we know that ruby is the chromium ( $\mathrm{Cr}$ )-rich variety of corundum, but other chromophores such as vanadium $(\mathrm{V})$ and iron $(\mathrm{Fe})$ may be present in the structure of the mineral. The ideal formula of corundum is $\mathrm{Al}_{2} \mathrm{O}_{3}$ and it crystallizes in the trigonal system, with a hardness of 9 on the Mohs scale (while spinel and garnets crystallize in the cubic system and are softer with a hardness of 8). Unlike spinel and garnet, ruby is a dichroic mineral, which will show a different color (either purplish- or orangey-red) depending on which direction light travels inside the gem. In gemmology this is of critical importance because lapidaries, wishing to optimize the color from a rough stone by cutting it, can produce a red, a pinkish red, a purplish red, or an orangey-red stone, depending on how they decide to orientate and cut the gem.

The ruby industry is very lucrative [5] but it is far more complex than many ore industries such as iron, silver, or gold because the values of ruby do not depend only on weight or purity. The value depends on a much more complex quality, with grading systems including many artistic, subjective, and cultural aspects. In addition to the well-known and rather comprehensive system established by the diamond trade based on the 4Cs (i.e., color, clarity, cut, and carat weight of the gem) in the middle of the 20th century, with colored stones such as rubies additional factors have a critical importance for market value.

First, it has to be established that the gem was actually mined and was not produced from a factory. Synthetic rubies created either by flux, flame fusion, or some hydrothermal process appeared at the end of the 19th century. If the arrival of synthetics created some initial scandals and panic, the trade answered by establishing gemmological laboratories that were able to identify natural gems versus synthetics and thus re-establish the necessary confidence for the trade to grow.

Second, enhancements and treatments are also of importance to the final evaluation. To satisfy the strong demand for large clean rubies, some very efficient heat treatment techniques were developed in the 1990s in Thailand. These were different from the traditional blow-pipe technique used in Sri Lanka for centuries and described by many travellers beginning with Al Burini in the 10-11th centuries. 
Whilst the blow pipe was used to remove the purplish aspect in some rubies, the new technique went further: using borax as a flux additive it could heal fractures in rubies and thus enable the cutting of larger stones. Due to this new treatment technique and the ones that followed, new deposits, such as Mong Hsu in eastern Myanmar, started to dominate the ruby trade in the early 1990s and Thailand increased its importance as the World's main ruby trading centre [6]. In the early 1990s, in Bangkok, it was very rare to find gem corundum that had not been heat-treated [7]. Drucker in [8], at the end of 1990, explained that the average price of ruby fell after controversy over its treatments. However, if the average price for rubies fell, prices for fine untreated rubies have exploded, particularly since the early 2000s (as observed in the reports from auction houses, many available online).

As the auction results show, not only did the prices for unheated rubies increase, but also the prices for unheated Myanmar rubies. Geographic origin is the last important factor to consider in establishing the value of a fine ruby (Figure 1). At this point it is critical to understand that, as fine rubies are both very rare but also very durable products, they usually survive for centuries after being mined, passing from one owner to another. As a consequence, the few very fine gems coming from existing mines are actually in competition with all the fine gems mined in the past, which are mainly from Myanmar (formerly known as Burma). Due to this, modern ruby traders are actually acting more like antique dealers than exploration geologists or Indiana Jones [9]. Public recognition and romance are very important factors contributing to demand for fine gemstones [10].

The assignment of a commercial value to ruby and other gems is carried out by gem merchants with the help of a few specialized gemmological laboratories providing independent third-party opinions. These labs provide answers for the following key questions [11]: (1) Is the gem the ruby variety of corundum? (2) Is it natural or synthetic ruby? (3) Has it been enhanced? (4) Where is it from (geographic origin)? If for most of these laboratories the answer to the first question is more or less routine work, the question about origin determination remains a great challenge [11]. The geographic origin is often controversial as in many cases it is based on expert opinion more than on provable facts [12-15]. Origin determination was introduced by Eduard Gübelin who worked on inclusions in gems using mainly microscopy [16,17], but also Raman and infrared spectroscopy. Such techniques are usually suitable for high value large rubies (that are usually never really free of mineral inclusions) but find their limits in the case of small clean stones or for heated stones (with inclusions that have been altered or even melted by heat treatment). Currently, these techniques are combined with the analysis of trace elements using energy dispersive X-ray fluorescence (EDXRF) and more especially since the early 2000s laser ablation-inductively coupled plasma-mass spectroscopy (LA-ICP-MS). To be able to produce origin reports, gemmological laboratories require sophisticated instrumentation, an experienced and qualified team, and a solid and very reliable reference collection.

The pricing of natural ruby is unique in terms of color and weight in carats. Currently if factory-grown synthetic rubies are cheap, if carving- or bead-grade treated rubies of low transparency and either dark or light color can be worth only a few dollars per kilo, a natural untreated ruby is still perhaps the world's most expensive gemstone. The best Myanmar rubies are more highly valued than an equivalent-sized flawless colorless diamond. The world record price for a single ruby sold at auction currently belongs to the Sunrise ruby, sold in 2015 for US $\$ 32.42$ million (US\$1.27 million per carat at 25.59 ct) [18]. In December 2015, the 15.04 ct Crimson Flame ruby was sold for UU $\$ 18.3$ million (US\$1.21 million per ct). Another notable ruby is the 10.05 ct Ratnaraj, sold for US $\$ 10.2$ million (just over US\$1 million per ct) in November 2017. Fine-quality unheated rubies from the recently discovered Didy mine in Madagascar also command high prices [19]. A set of eight faceted rubies, ranging from seven to more than 14 cts in weight, had an estimated market value of US\$10 million [20]. The discovery of the Montepuez ruby deposits in Mozambique in May 2009 [21-23] and their exploitation by various companies including Gemfields Group Ltd. [24,25] changed the international ruby market $[6,26]$. A recent Competent Persons Report by SRK Consulting forecast production of 432 million carats from Montepuez over 21 years [27]. The resource at Montepuez is divided into primary reserves of 253 million cts (projection of 115 cts per ton) and secondary (mainly 
colluvial) reserves of 179 million cts (projection of 7.07 cts per ton). Twelve Montepuez auctions held since June 2014 have generated US\$512 million in aggregate revenue (see Gemfields website). The auction by Gemfields Group Ltd. in June 2018 yielded a record sale of US\$71.8 million with an average price of US\$122 per ct. The success of the Gemfields ruby auctions are due to product from the Mugloto colluvial deposit, which provided clean and very high-quality red stones with typical sizes between one and 10 cts, and occasionally larger crystals [24].
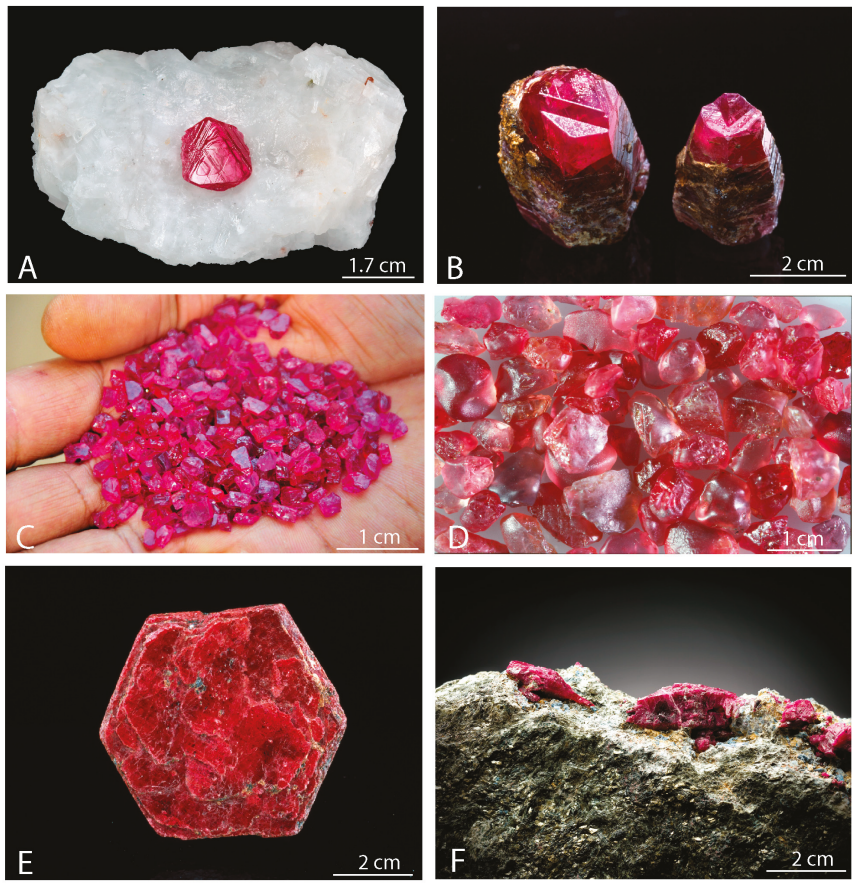

Figure 1. Rubies worldwide. (A) Ruby crystal $(1.7 \mathrm{~cm} \times 1.7 \mathrm{~cm} \times 0.5 \mathrm{~cm})$ in marble from Bawpadan, Mogok, Myanmar. Photo: Louis-Dominique Bayle @ le Règne Minéral; $(\mathbf{B})$ rubies (from left to right: $2.1 \mathrm{~cm} \times 1.3$ $\mathrm{cm} \times 1.3 \mathrm{~cm}$ and $1.7 \mathrm{~cm} \times 1 \mathrm{~cm} \times 1 \mathrm{~cm}$ ) from Ambohimandrosoa, Antsirabe area, Madagascar. Collection: L. Thomas; Photo: Louis-Dominique Bayle (C) le Règne Minéral; (C) rubies from the Montepuez mine, Mozambique. Vincent Pardieu (C Gemmological Institute of America; (D) Barrington Tops alluvial ruby concentrate, crystals up to $9 \mathrm{~mm}$ in size, New South Wales, Australia. Photo: Australian Museum Collection, courtesy Gayle Webb; (E) ruby crystal $(6 \mathrm{~cm} \times 4.8 \mathrm{~cm} \times 1 \mathrm{~cm})$ extracted from amphibolite rocks at Ampanihy, Southern Madagascar. Collection: J. Béhier. Photo: Louis-Dominique Bayle (C) le Règne Minéral; (F) rubies in phlogopite matrix with plagioclase (white) and minor kyanite (blue) hosted in between leucogabbro and meta-ultramafic rocks affected by fluid circulation and metamorphic metasomatism, Aappaluttoq deposit, southwest Greenland. Photo: Courtesy True North Gems Inc. (Vancouver, BC, Canada).

Over the last decade, knowledge on the formation of ruby deposits has improved significantly as their origin determination using a variety of new methods and analytical procedures. The present article synthesizes the state of knowledge on the geology and genesis of ruby deposits. The different issues focused on their location on the planet, their physical and chemical properties, pressure-temperature conditions of crystallization, the source of the constituent elements (viz. aluminum, chromium, vanadium, and iron), their age of formation, and finally the different proposed genetic models. 
In this review we propose a geological classification scheme for ruby based on scientific works and own experience. The classification typology should open a new framework for mineral exploration guidelines and geographic determination for gemmological laboratories.

\section{Worldwide Ruby Deposits}

The distribution of major and minor commercial, industrial, scientific, and historical world sources of ruby is shown in Figure 2.

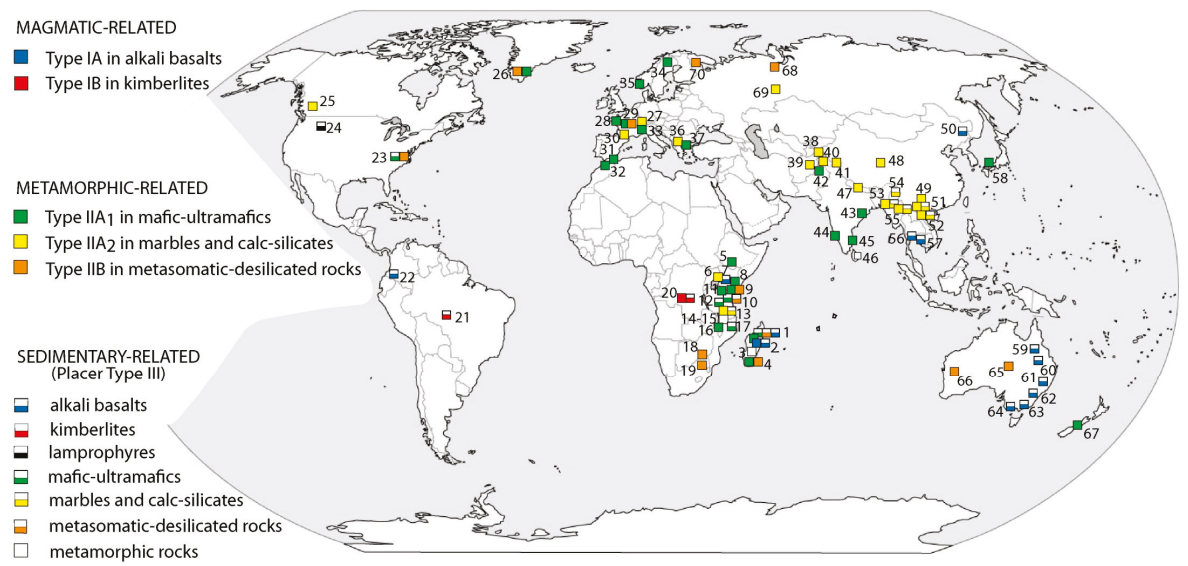

Figure 2. Main major and minor world sources of ruby plotted according to their geological types. Madagascar: (1) Andilamena, Ambodivoangy-Zahamena, Didy, Vatomandry; (2) Andriba; Ankaratra (Antsirabe-Antanifotsy region, Soamiakatra-Ambohimandroso; Ambohibary); (3) Zazafotsy; Ilakaka-Sakaraha; (4) Bekily-Vohibory area (Ambatomena; Ianapera; Fotadrevo; Anavoha; Maniry; Gogogogo; Vohitany; Ejeda). Ethiopia: (5) Kibre mengist, Dilla. Kenya: (6) West Pokot; (7) Baringo; (8) Kitui; (9) Mangare (Rockland-formerly John Saul mine; Penny Lane; Aqua, Hard Rock). Tanzania: (10) Umba valley; (11) Longido, Lossogonoi; (12) Winza; Loolera (Kibuko); (13) Morogoro (Mwalazi; Visakazi; Nyama, Kibuko, etc.); Mahenge (Lukande; Mayote; Kitwaro; Ipanko; (14) Songea; (15) Tunduru. Malawi: (16) Chimwadzulu. Mozambique: (17) Montepuez (Namahumbire/Namahaca), M'sawize, Ruambeze. Zimbabwe: (18) O'Briens (verdites). South Africa: (19) Barberton (verdites). Democratic Republic of Congo: (20) Mbuji-Mayi. Brazil: (21) São Luis-Juina River. Colombia: (22) Mercaderes-Rio Mayo. United States: (23) North Carolina (Corundum Hill; Cowee Valley; Buck Creek); (24) Montana (Rock Creek). Canada: (25) Revelstoke. Greenland: (26) South of Nuuk region (Fiskenæsset district-Aappaluttoq); North of Nuuk (Storø; Kangerdluarssuk). Switzerland: (27) Campo Lungo. France: (28) Brittany (Champtoceaux); (29) French Massif Central (Haut-Allier-Chantel; Peygerolles; Lozère-Aveyron-Marvejols; Vialat-du-Tarn); (30) Pyrenées (Arignac). Spain: (31) Alboran sea; Marrocos: (32) Beni Bousera. It aly: (33) Piedmont. Norway: (34) Froland. Finland: (35) Kittilä. Macedonia: (36) Prilep. Greece: (37) Gorgona-Xanthi; Paranesti-Drama. Tajikistan: (38) Snezhnoe, Turakuloma, Badakhshan. Afghanistan: (39) Jegdalek, Kash. Pakistan: (40) Hunza valley; (41) Batakundi, Nangimali; (42) Dir. India: (43) Orissa, Kalahandi; (44) Karnakata (Mysore); (45) Andhra Pradesh (Salem district). Sri Lanka: (46) Ratnapura, Polonnaruwa; Elahera. Nepal: (47) Chumar, Ruyil. China: (48) Qinghai; (49) Yuan Jiang. (50) Muling. Vietnam: (51) Luc Yen-Yen Bai; (52) Quy Chau. Myanmar: (53) Mogok, (54) Namya; (55) Mong Hsu. Thailand: (56) Chanthaburi-Trat (Bo Waen, Bo Na Wong, Wat Tok Phrom, Bo Rai, Nong Bon). Cambodia: (57) Pailin, Samlaut. Japan: (58) Ida. Australia: (59) Lava Plains; (60) Anakie fields-Rubyvale; (61) New England fields (Inverell); (62) Macquarie-Cudgegong, Barrington Tops-Yarrowitch; (63) Tumbarumba; (64) Western Melbourne fields; (65) Harts range; (66) Poona. New Zealand: (67) Westland (Hokitika). Russia: (68) Polar Urals (Hit Island); (69) Ural mountains (Kuchin-Chuksin-Kootchinskoye); (70) Karelia. 
High-value rubies are important mineral resources that contribute significantly to the gross domestic product of many countries. In 2005, Africa was officially (statistics are rare on the production of most ruby deposits) responsible for around $90 \%$ of world ruby production (in weight, not in quality; 8000 tons [28]; Figure 3) and this was before 2009 when the Montepuez ruby deposits were discovered in Mozambique [21-23].

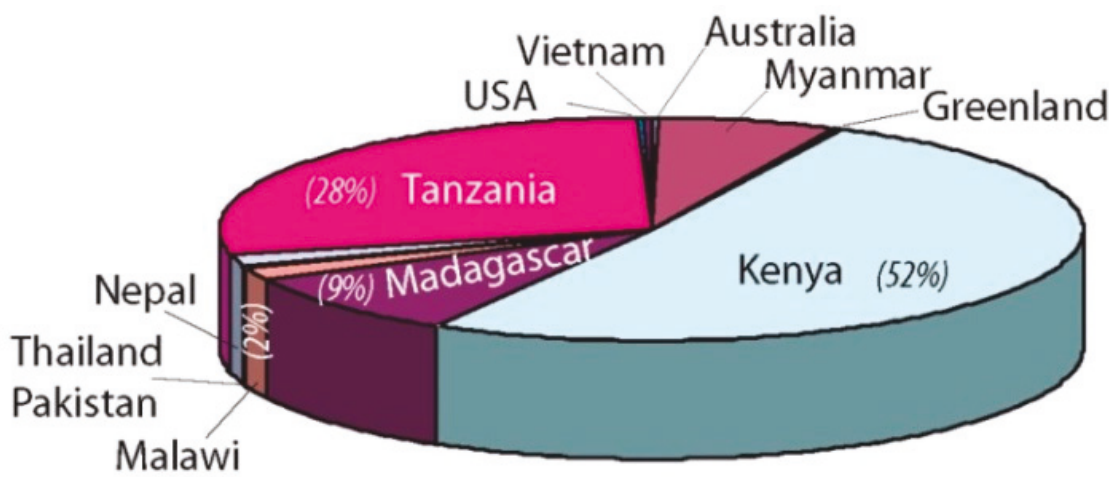

Figure 3. Ruby production worldwide in 2005 showing the production (in \%) of some African countries, and others; modified from [28].

The highest-quality ruby crystals come from Central and South-East Asia and Eastern Africa ([27]; see Figure 1C). Myanmar, with the Mogok Stone Tract (see Figure 1A), is famous for having produced rubies of the finest quality since 600 CE $[5,29,30]$. These are often called "pigeon blood", a term of Myanmar origin popularized by English traders in the 19th century [31]. Other Asian producers including Thailand (Chanthaburi-Trat mines) and Cambodia (Pailin and Samlaut) emerged as serious players in the 1970s, but their production has declined dramatically over the past 20 years [6]. Ruby deposits in Vietnam (Luc Yen, Yen Bai, and Quy Chau areas), Afghanistan (Jegdalek), Pakistan (Hunza valley), Azad-Kashmir (Batakundi and Nangimali), and Tajikistan (Kukurt, Turakoluma, and Badakshan) have become significant producers since the end of the 1980s, but their production remains limited. In the early 1990s Mong Hsu in Eastern Myanmar emerged as a major deposit but its production has declined since the early 2000s [6].

Today the high production and quality of rubies from Mozambique (and to a lesser extend Madagascar) has changed the way rubies are traded and with the arrival of these new players, the production of many other deposits collapsed [6]. Production from the Winza deposit diminished to the point of essentially disappearing, and the Rockland (former John Saul) mine in Kenya stopped producing. In Africa (Figure 4) gem rubies are mined in Kenya (Mangare and Baringo), Tanzania (Umba-Kalalani, Morogoro, Mahenge, and Loolera), Malawi (Chimwadzulu), Madagascar (Vatomandry, Andilamena, Didy, Zahamena, and Ilakaka), and Mozambique (Montepuez, Ruambeze, and M'sawize). The Montepuez mine is the most highly mechanized ruby mine worldwide [6,26]. In Southern Greenland True North Gems Inc. started working on the Aappaluttoq deposit near Fiskenæsset in 2005 (see Figure 1F) [32-37] and a mine (operated by "Greenland Ruby") entered into production in 2017. 


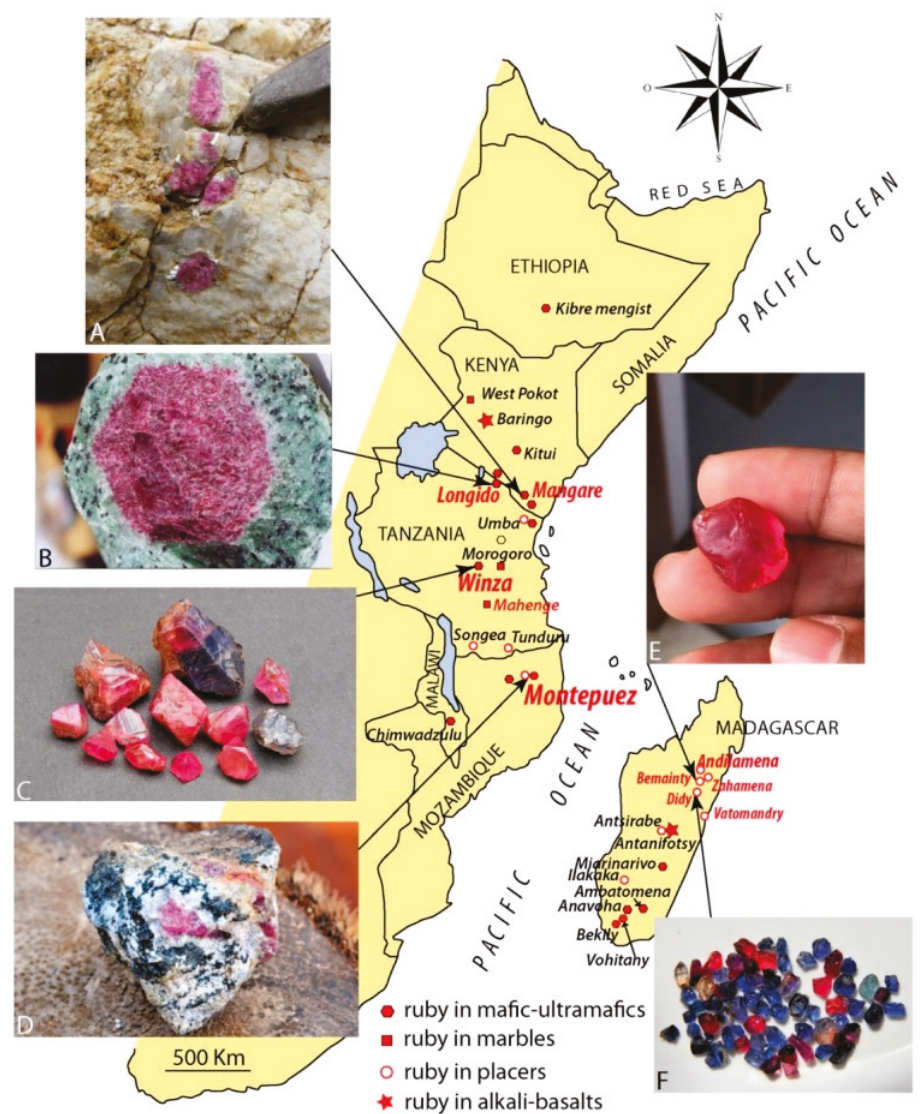

Figure 4. In East Africa and Madagascar rubies have been and are produced from both primary and secondary deposits. The most important deposits are those located in the Neoproterozoic Metamorphic Mozambique Belt. Of much lesser importance are deposits in which the ruby is entrained as xenocrysts in Cenozoic alkali basalts; these are the Baringo and Antanifotsy (Soamiakatra) deposits in Kenya and Madagascar, respectively. (A) Desilicated pegmatite in ultramafic rocks of the Rockland (ex-John Saul) mine in the Mangare area. Photo width $7 \mathrm{~cm}$. Photo: Gaston Giuliani; (B) a ruby hexagonal prism ( $5 \mathrm{~cm}$ across) in anyolite rock (with green zoisite and black amphibole) from Longido, Tanzania. Photo: Gaston Giuliani; (C) rubies and two colored sapphires ( $3 \mathrm{~cm}$ across) from the Winza deposit in Tanzania, which occurs in metamorphosed leucogabbro and amphibolite. Photo: Vincent Pardieu; (D) ruby (5 cm long) in metasomatized amphibolite at M'sawize. Photo: Vincent Pardieu (C) GIA; (E) pink corundum (1 cm across) from placer at Bemainty, Madagascar. Photo: Vincent Pardieu (C) GIA; and (F) ruby and sapphires recovered from placer at Didy, Madagascar. Photo: Vincent Pardieu.

\section{The Mineralogical, Physical, and Chemical Properties of Ruby}

\subsection{Mineralogical and Physical Properties}

Corundum $\left(\alpha-\mathrm{Al}_{2} \mathrm{O}_{3}\right)$ is trigonal and crystallizes in space group $R \overline{3} c$ with approximate unit-cell parameters $a=4.76 \AA$ and $c=12.99 \AA$ [38]. In corundum the oxygen atoms are in a hexagonal close packing arrangement corresponding to an ABAB stacking of alternate anion layers (Figure 5). This arrangement creates octahedral sites of which 2/3 are occupied by $\mathrm{Al}$ as suggested by the cation-anion ratio in the formula. Each $\mathrm{Al}$ atom is coordinated by three oxygen atoms from layer $\mathrm{A}$ and 
three from layer B. The structure is thus based on pairs of edge-sharing octahedra in sheets parallel to $\{0001\}$. In each pair, one octahedron shares a face with an octahedron in the sheet below, while the other octahedron has a shared face with an octahedron in the sheet above [39].
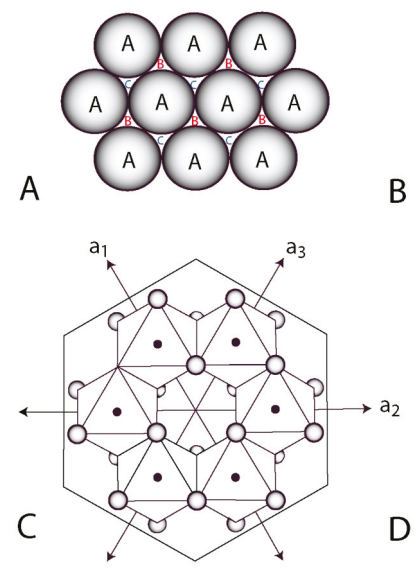

B

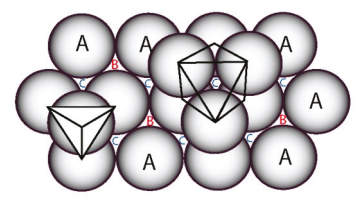

D

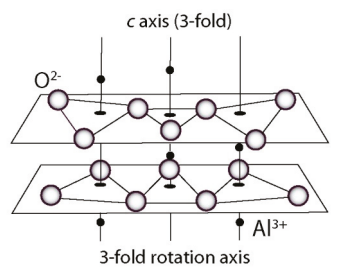

Figure 5. The crystal structure of corundum. (A) A single layer of spheres representing oxygen atoms in hexagonal close packed coordination. In a second layer the spheres would be oriented over the B locations, and a third layer would be over the first (A locations); (B) six oxygen atoms coordinate $\mathrm{Al}$ atoms at the $\mathrm{C}$ positions forming an octahedron (the tetrahedral coordinated site is vacant). Only two out of every three $\mathrm{Al}$ sites are occupied in the $\mathrm{Al}$ layers; $(\mathbf{C})$ the crystal structure of corundum looking down $c$; and (D) perspective view of the crystal structure of corundum $[5,40]$.

If there are no cation substitutions in the structure, corundum is colorless. However when chromophorous elements replace aluminum in the octahedral site, the crystal is colored. The substitution of $\mathrm{Al}^{3+}$ by $\mathrm{Cr}^{3+}$ results in pink to red colors, depending on the $\mathrm{Cr}$ content. The pink corundum variety is called "pink sapphire" or "pink ruby", and the red variety, with higher $\mathrm{Cr}$ contents $\left(0.1<\mathrm{Cr}_{2} \mathrm{O}_{3}<3.0\right.$ wt \%; [5]), is called "ruby". However, the distinction between these two varieties is not yet well defined and is debated by gem dealers and laboratories. As such, in the present work, pink corundum crystals that are associated with deep red ruby in some deposits worldwide will be considered rubies from here onward. Concentrations of $9.4 \mathrm{wt} \% \mathrm{Cr}_{2} \mathrm{O}_{3}$ were measured in ruby from Karelia in Russia [41] and up to 13 and $13.4 \mathrm{wt} \%$ respectively, in ruby from Westland in New Zealand [42], and in ruby inclusions in diamond from placers associated with the Juina kimberlite [43].

The optical absorption spectrum of ruby shows two large absorption bands (Figure 6) with transmission windows at $480 \mathrm{~nm}$ (blue visible light) and at $610 \mathrm{~nm}$ (red visible light).

The most desired color for rubies is known in the trade as "pigeon's blood". While there is no globally accepted definition for it, it is usually used for stones with a vivid red color with sometimes a small amount of blue (just enough to balance the yellow from the gold on which the stone might be set). The presence of $\mathrm{Cr}$ at the octahedral site also gives rise to strong fluorescence when the stone is exposed to ultraviolet light $(365 \mathrm{~nm})$. The intensity of fluorescence is a function of $\mathrm{Cr}$ concentration and the $\mathrm{Cr} / \mathrm{Fe}$ ratio [43], because the presence of $\mathrm{Fe}$ or an excess of $\mathrm{Cr}$ tends to eliminate or quench the fluorescence in ruby. In some stones, the fluorescence can even be seen when exposed to the ultraviolet component in sunlight, and this makes the ruby's color more intense, increasing its value. This fluorescence is sometimes observed in small pinkish rubies, from marble deposits, that contain little to no iron, including those traditionally from Myanmar (Mogok, Mong Hsu, and Namya), and recently from Vietnam and Afghanistan [44]. Some rubies from amphibolite (Mozambique) and alkali-basalts (Thailand) have also been described as "pigeon's blood" in laboratory reports but this is controversial because most reputable laboratories limit their use of the term to strongly fluorescent 
rubies (which means the low-iron type, which is typically from marble-type deposits). The intensity of fluorescence is a function of the Fe content of ruby and three categories are distinguished: Burma Pigeon's Blood Strong Fluorescent, Mozambique Type I Pigeon's Blood Fluorescent, and Mozambique Type II Pigeon's Blood Fluorescent [44] (Figure 7).

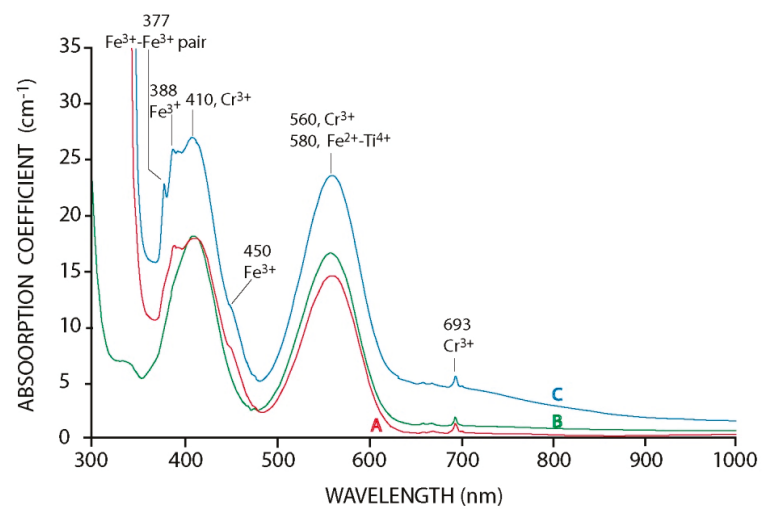

Figure 6. Ultraviolet, visible, and near infrared (UV-Vis-NIR) spectra of rubies from the Maninge Nice and Mugloto deposits, Mozambique; modified from [26]. The three spectra show the $\mathrm{Cr}^{3+}$ absorption bands at 410 and $560 \mathrm{~nm}$, and the $\mathrm{Cr}^{3+}$ "doublet" at $694 \mathrm{~nm}$. Spectrum (A) of a ruby from Mugloto also shows the shoulder at $330 \mathrm{~nm}$ but in addition a single $\mathrm{Fe}^{3+}$ feature at 377, 388, and $450 \mathrm{~nm}$ that reflects a higher Fe content in this ruby. Spectrum (B) of a ruby from Maninge Nice shows a shoulder at $330 \mathrm{~nm}$ caused by $\mathrm{Fe}^{3+}$ pairs. Spectrum (C) of a ruby from Mugloto differs from the others mainly by a $\mathrm{Fe}^{2+} \rightarrow \mathrm{Ti}^{4+}$ charge transfer band centered at $580 \mathrm{~nm}$ and increasing absorption above $600 \mathrm{~nm}$.
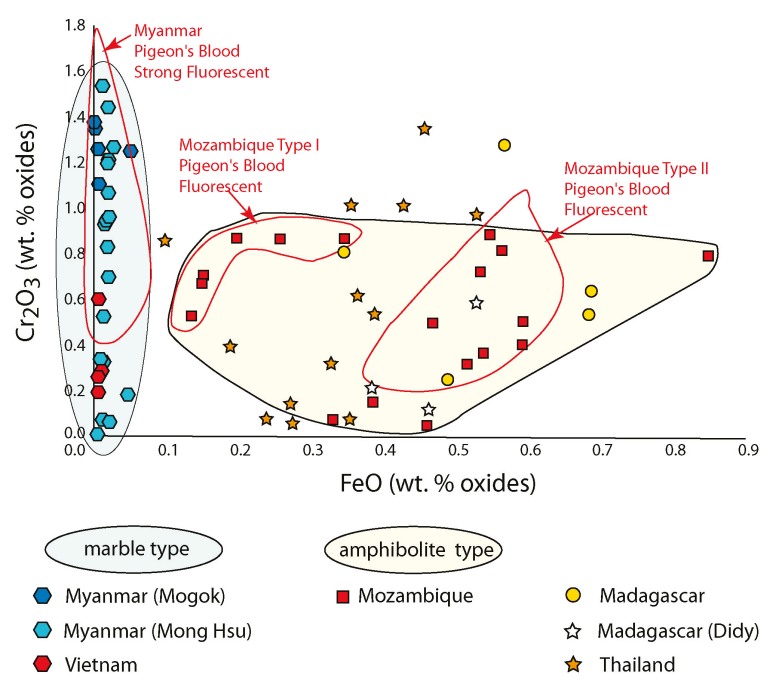

Figure 7. FeO versus $\mathrm{Cr}_{2} \mathrm{O}_{3}$ diagram of different pigeon's blood color of rubies worldwide (modified from [44]. The color of the gem is defined as vivid with high intensity and low tone. The distinction of rubies between Myanmar Pigeon's Blood Strong Fluorescent (in marble from Myanmar and Vietnam), Mozambique Type I Pigeon's Blood Fluorescent, and Mozambique II Pigeon's Blood Fluorescent (both in amphibolite) is correlated with the amount of Fe in the ruby, respectively $\mathrm{FeO}<0.1 \mathrm{wt} \%$; $0.1<\mathrm{FeO}<0.35 \mathrm{wt} \%$; and $0.35<\mathrm{FeO}<0.6 \mathrm{wt} \%$ (data from [44]). 
Euhedral crystals of ruby can exhibit several faces (Figure 8) that correspond to the following crystalline forms [38]: pinacoid $\{0001\}$, first-order hexagonal prism $\{10 \overline{1} 0\}$, second-order hexagonal prism $\{11 \overline{2} 0\}$, hexagonal dipyramid $\{h h \overline{2} h l\}$, rhombohedron $\{h 0 \overline{h l}\}$, and ditrigonal scalenohedron $\{h k i l\}$.

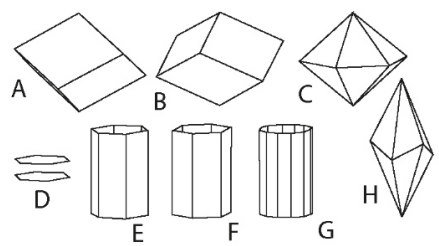

Figure 8. Crystalline forms of the $\overline{3} 2 / \mathrm{m}$ class of the rhombohedral system, after [38]. (A) positive rhombohedron; (B) negative rhombohedron; (C) hexagonal dipyramid; (D) pinacoid; (E) first-order hexagonal prism; (F) second-order hexagonal prism; (G) dihexagonal prism; and (H) ditrigonal scalenohedron.

Rubies from Mong Hsu in Myanmar show a number of different habits (Figure 9) [30,45] and are bounded by pinacoidal $\{0001\}$ faces and hexagonal dipyramidal faces $\{h h \overline{2} h l\}$, sometimes associated with small rhombohedral $\{10 \overline{1} 1\}$ faces. Second-order prism $\{10 \overline{2} 0\}$ faces are also observed in some rubies. The smaller dipyramidal faces are $\{22 \overline{4} 3\}$, whereas the larger dipyramidal ones are often reported as $\{44 \overline{8} 1\}$ or $\{1414 \overline{28} 3\}$, or less commonly $\{22 \overline{4} 1\}$ or $\{11 \overline{2} 1\}$. The $\{1414 \overline{28} 3\}$ indices are too high for smooth faces, and it could be possible that they consist of alternating microsteps between $\{11 \overline{2} 0\}$ and $\{0001\}$ faces [46,47]. Rubies from Mogok are generally tabular with predominant pinacoids and rhombohedral $\{10 \overline{1} 1\}$ and dipyramidal $\{11 \overline{2} 1\}$ faces. Other habits (Figure 9) have been reported for marble-hosted rubies from Morogoro in Tanzania as flattened to tabular pseudo-cubes, pseudocubes according to the relative size of the six rhombohedral faces and six additional prism faces $\{10 \overline{2} 1\}$ with a lath-like form [48], and Jegdalek in Afghanistan [5]. Rubies in alkali basalt from Thailand and Cambodia are tabular and have combinations of rhombohedral $\{10 \overline{1} 1\}$ and pinacoid $\{0001\}$ faces (Figure 9).

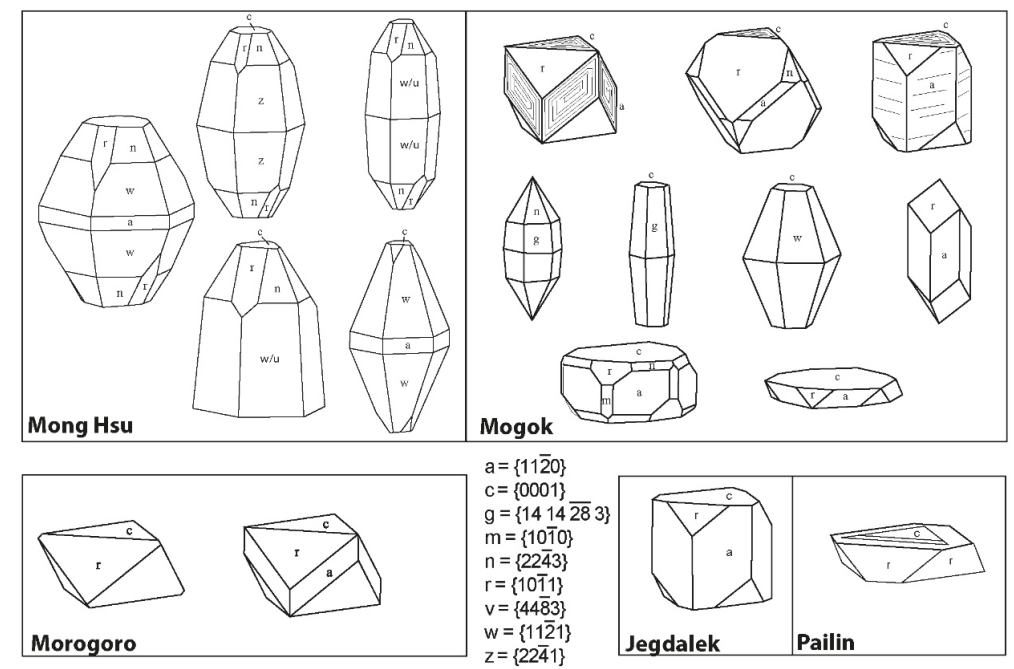

Figure 9. Main habits of ruby from different marble-hosted deposits: Mong Hsu and Mogok in Myanmar, Morogoro in Tanzania, and Jegdalek in Afghanistan. The rubies from the Pailin deposit (Cambodia) are from alkali-basalt placer deposits. From [5,30,45,48]. 
To explain these morphological differences, Sorokina et al. [49] introduced the concept of crystal "ontogeny" that encompasses nucleation, growth, and alteration of single crystals. According to their data, the variations of crystal habits in rubies from deposits in Africa and South-East Asia can be directly correlated with $\mathrm{Cr}$ and $\mathrm{Fe}$ contents and changes in $\mathrm{P}-\mathrm{T}$ conditions during crystal growth.

\subsection{The Trapiche Texture of Ruby}

The conditions under which the ruby grows can give rise to a particular texture called 'trapiche' (Figure 10A). This texture was first described by [50] for an unusual Colombian emerald that resembles the spokes of a milling wheel used to process sugar cane. The term "trapiche" was used exclusively for emeralds until the 1990s, when trapiche rubies appeared in the Thai and Burmese gem markets [47,51,52].

The trapiche texture is composed of growth sectors separated by more or less sharp boundaries of inclusions [53,54], known as "sector boundaries". These boundaries separate a central "core" (corresponding to the pinacoidal growth sectors) from the surrounding growth sectors. The boundaries are generally inclined with respect to the $c$ axis. This texture should not be confused with that seen in purple-pink and blue sapphires (Figure 10B) and resulting from the distribution of different inclusions in alternating portions of the crystal and called "trapiche-like" [55,56].

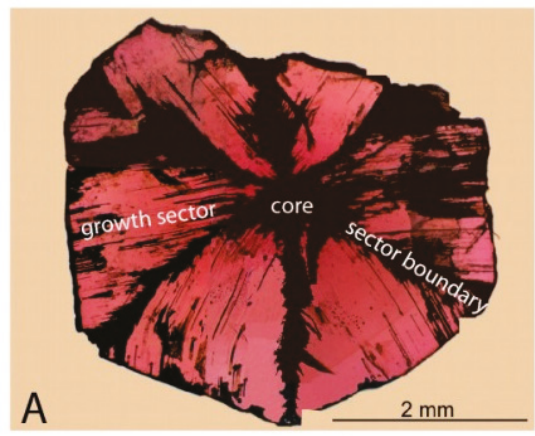

B

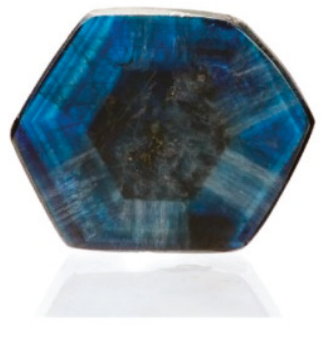

Figure 10. The trapiche texture of corundum. (A) Photomicrograph in transmitted light of a trapiche ruby from Mong Hsu, Myanmar (Photo: Virginie Garnier) and (B) aspect of a "trapiche-like" sapphire from southern Africa $(2 \mathrm{~cm} \times 1.8 \mathrm{~cm} \times 0.2 \mathrm{~cm}, 13.46 \mathrm{cts})$. Photo: Louis-Dominique Bayle C le Règne Minéral.

The trapiche texture is best seen in cross-sections perpendicular to the $c$ axis. The presence and size of the core depends on the orientation of the cross-section in the crystal [57] (Figure 11A). Thus, two cross-section appearances are possible: (1) the core is present and the sector boundaries surround it and develop from its edges to the rim of the crystal, separating six trapezoidal growth sectors (Figure 11B) and (2) the core is absent and the sector boundaries intersect at a central point, giving rise to triangular growth sectors (Figure 11C).

Variable contents of chromophores, in particular $\mathrm{Cr}$ but also Ti and $\mathrm{V}$ have been detected in different rubies as well as within the same samples $[52,58,59]$. This can explain why the core can be red $(\mathrm{Cr}>\mathrm{Ti})$ or black $(\mathrm{Ti}>\mathrm{Cr}$ ) [60], although the core is sometimes yellowish/white-to-brown like the sector boundaries. For both core and sector boundaries, the yellowish/white-to brown color is due to the presence of calcite, dolomite, corundum, unidentified silicate inclusions containing $\mathrm{K}-\mathrm{Al}-\mathrm{Fe}-\mathrm{Ti}$, and Fe-bearing minerals. Iron oxides/hydroxides formed during late weathering that was favored by the high porosity of the sector boundaries (Figure 12) [52,57]. The sector boundaries develop along the ‘110> directions and can contain other solid inclusions such as plagioclase, rutile, titanite, margarite, zircon, etc. [57-59], but they do not contain matrix material from the host rock. This absence is an important feature differentiating trapiche rubies from trapiche emeralds [61]. 

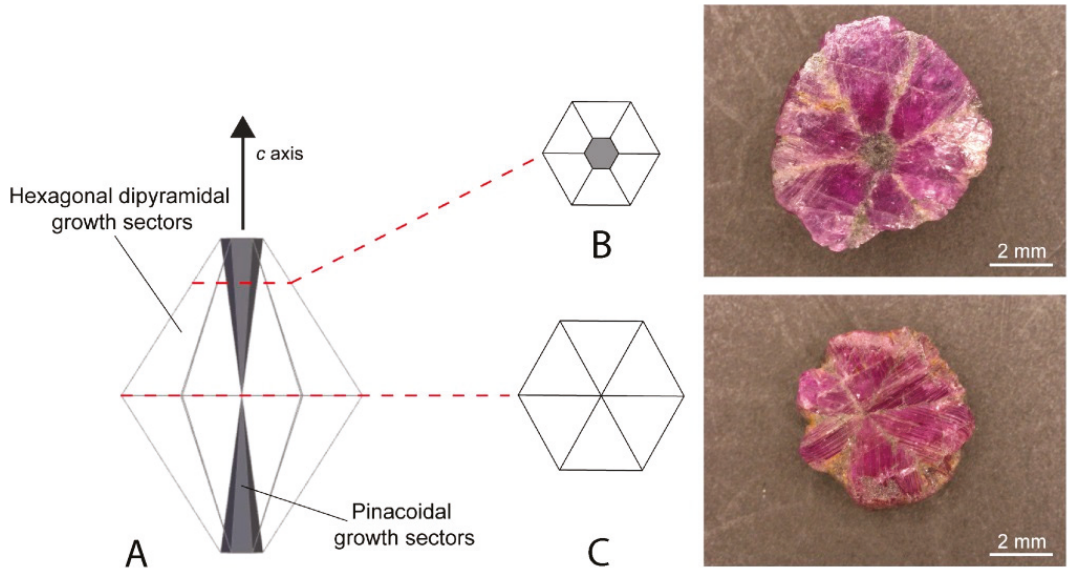

Figure 11. Variations of the ruby trapiche texture. (A) Variation of the core, which corresponds to the pinacoidal growth sectors (in grey). These sectors have a tapered shape and the core size varies as a function of the orientation of the cross-section; (B) aspect of the section near the vertex of the pyramid; and (C) aspect of the section if cut in the vertex plane. Photos by Isabella Pignatelli of two trapiche rubies from Mong Hsu, Myanmar.

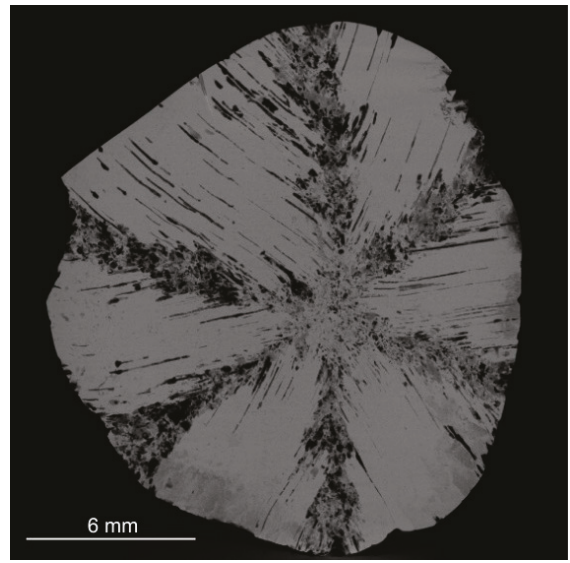

Figure 12. X-ray computed tomography image showing the high porosity (in black) of a trapiche ruby from Luc Yen, North Vietnam [57]. The porosity corresponds to $0.6 \%$ of the ruby volume and is developed in the sector boundaries. Photo: Christophe Morlot.

Tube-like voids filled with carbonates, liquid, and/or gas may be observed in the growth sectors (Figure 13) $[51,57,62]$. These can develop from the core or sector boundaries and extend into the growth sectors, running perpendicular to the sectors with an inclination of $5^{\circ}$ relative to the $\{0001\}$ ruby faces. Sometimes the tube-like voids can be parallel to the c axis.

Garnier et al. [58,59] found single-phase (liquid), two-phase (liquid + gas), and three-phase (liquid + gas + solid) inclusions between the tube-like voids and/or their extensions into the sector boundaries. Microthermometry and Raman spectrometry indicate that these inclusions correspond to the trapping of two immiscible fluids during the ruby formation: a carbonic fluid in the $\mathrm{CO}_{2}-\mathrm{H}_{2} \mathrm{~S}-\mathrm{COS}-\mathrm{S}_{8}-\mathrm{AlO}(\mathrm{OH})$ system and molten salts [62-64]. These fluids are considered the product of metamorphism of evaporites during the devolatization of carbonates and thermochemical-sulfate reduction. 
Trapiche rubies are found in Myanmar, Vietnam, Tajikistan, Pakistan, and Nepal, but have never been described by geologists in situ in primary deposits. The trace element contents of the Myanmar and Vietnamese trapiche rubies prove that they originated from marble-type deposits [57-59]. Moreover, similar mineralogical and chemical features have been observed for trapiche and non-trapiche rubies from Mong Hsu in Myanmar and Luc Yen in Vietnam, confirming that they formed in the same geological context, i.e., marble-hosted ruby deposits $[57,58,62,65]$. The rubies formed in the amphibolite facies, during retrograde metamorphism at $620<\mathrm{T}<670{ }^{\circ} \mathrm{C}$ and $2.6<\mathrm{P}<3.3 \mathrm{kbar}[65,66]$.
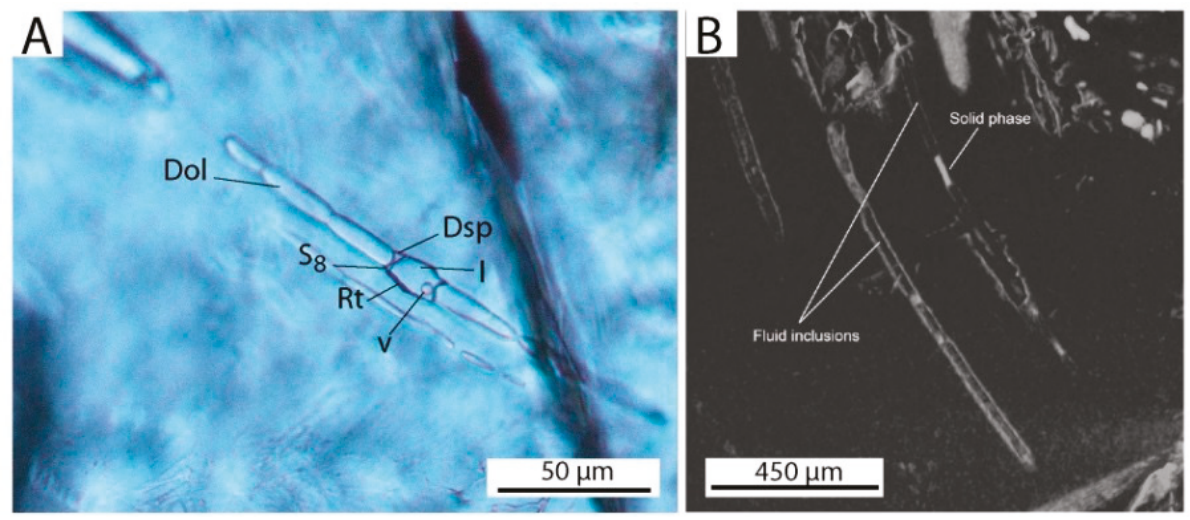

Figure 13. Solid and fluid inclusions trapped by trapiche rubies. (A) Primary fluid inclusions trapped along the sector boundary of a trapiche ruby from Mong Hsu, Myanmar. The fluid inclusion was trapped within tube-like structures formed by dolomite (Dol). It is a multi-phase fluid inclusion containing a two-phase (liquid + vapor) $\mathrm{CO}_{2}-\mathrm{H}_{2} \mathrm{~S}-\mathrm{S}_{8}$-bearing fluid and minerals including diaspore (Dsp) and rutile (Rt). V = vapor phase, 1 = liquid phase; from [62]. Photo: Gaston Giuliani; (B) X-ray computed tomography image of a trapiche ruby from Luc Yen, north Vietnam, showing tube-like voids that contain solid and fluid inclusion cavities; from [57]. Photo: Christophe Morlot.

In this geological context, the trapiche texture developed very quickly, as witnessed by the trapping of several solid and fluid inclusions and the formation of tube-like voids. The growth episodes in minerals are due to changes in the driving-force conditions [47]. In solution growth, mass transfer plays a key role. The driving force is defined by the difference in concentration between the bulk and subsurface supersaturation, i.e., the concentration gradient within the boundary layer [46]. Three growth episodes due to changes in driving force conditions were identified by [47] (Figure 14). Firstly, the core formed under low driving-force conditions via layer-by-layer growth (Step 1). It s development was hindered by the rapid formation of sector boundaries, which enveloped it and constitute the "skeleton" of the trapiche ruby (Step 2). These boundaries formed when the driving-force conditions increased and adhesive-type growth took place. Finally, a decrease in the driving-force conditions allowed the formation of growth sectors and the corresponding crystal faces through ordinary layer-by-layer growth (Step 3). The growth sectors filled the interstices left by the sector boundary, completing the trapiche texture.

\subsection{Chemical Composition and Geographic Origin of Ruby}

Currently, the accurate chemical composition of rubies can be determined by several analytical techniques, such as X-ray fluorescence (XRF), electron microprobe analysis (EMPA), laser ablation-inductively coupled plasma-mass spectrometry (LA-ICP-MS), and secondary ion mass spectrometry (SIMS). Chemical data facilitate the differentiation between natural and synthetic rubies [67] (Figure 15) and help to determine their geological origin worldwide [11,68-72]. 


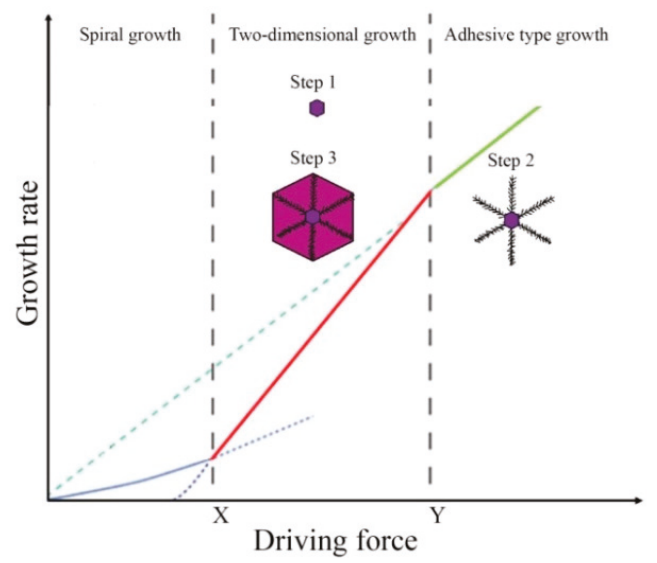

Figure 14. Schematic diagram showing growth rate versus driving force of the three development stages of trapiche ruby. The diagram shows the different types of crystal growth mechanisms, modified from [47]: spiral growth, two-dimensional growth, and adhesive-type growth. The increasing intensity of the driving force is presented between the critical points $X$ and $Y$, where nucleation occurred. The curves represent growth rate versus driving force relations for the three mechanisms. The curve (in blue) shows the spiral growth mechanism; the curve (in red) represents the two-dimensional nucleation growth mechanism; the curve (in green) denotes the adhesive-type mechanism. A rough interface is expected above point $\mathrm{Y}$ and it corresponds to the dendritic stage of trapiche-ruby formation. The nucleation occurred between $X$ and $Y$ domains where the growth sectors formed in trapiche texture. Finally, a smooth interface is expected below $\mathrm{X}$ where nucleation by dislocation occurred either for non-trapiche ruby or in overgrowth zone in trapiche ruby.

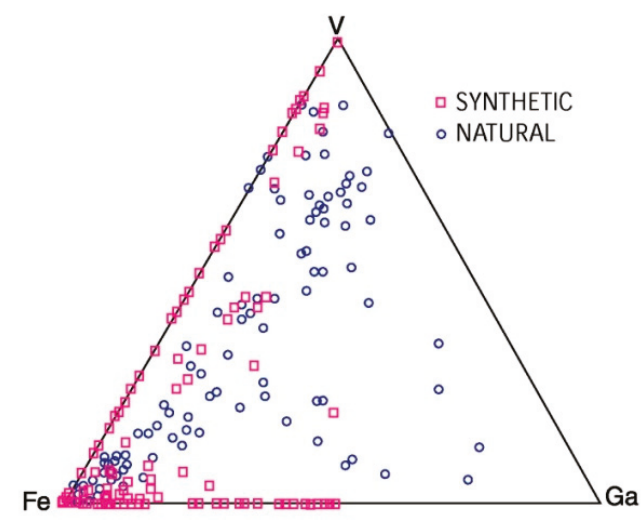

Figure 15. Gallium (Ga)-vanadium (V)-iron (Fe) ternary showing the distinction between natural and synthetic rubies, modified from [67].

Sutherland et al. [73-75] used a $\mathrm{Fe}_{2} \mathrm{O}_{3} / \mathrm{TiO}_{2}$ versus $\mathrm{Cr}_{2} \mathrm{O}_{3} / \mathrm{Ga}_{2} \mathrm{O}_{3}$ diagram to decipher the metamorphic versus magmatic origin of corundum. This diagram is commonly used for the separation of blue sapphires from several deposits worldwide [76]. The corundum crystals termed "metamorphic" have pastel (blue, pink, and orange) to red colors, and are rich in chromium and poor in gallium $\left(\mathrm{Cr}_{2} \mathrm{O}_{3} / \mathrm{Ga}_{2} \mathrm{O}_{3}\right.$ ratio > 3). The corundum crystals defined as "magmatic" are xenocrysts of blue-green-yellow (BGY) sapphires with a $\mathrm{Cr}_{2} \mathrm{O}_{3} / \mathrm{Ga}_{2} \mathrm{O}_{3}$ ratio $<1$. The diagram was applied to rubies and sapphires related to alkali basalt from the provinces of Antananarivo (the Soamiakatra, Kianjanakanga, and Ambatomainty deposits) and 
Toamasina (the Vatomandry and Andilamena deposits) in Madagascar [77,78] (Figure 16). Note that all of the points related to rubies plot in the metamorphic field. They overlap data for rubies from Andilamena, which is located in the north of the Vatomandry area, and where the corundum is hosted in different types of rocks (viz. metamorphosed mafic and ultramafic rocks (M-UMR) and plumasites in M-UMR). The majority of the sapphires plot in the magmatic domain. The distribution of sapphires from the Vatomandry area is heterogeneous, and while most are located in the magmatic domain yet others are in the metamorphic one. The latter corresponds to colorless, light to dark green, and light to purplish blue sapphires with significant $\mathrm{Cr}_{2} \mathrm{O}_{3}$ contents (150 ppm $<\mathrm{Cr}_{2} \mathrm{O}_{3}<2100$ ppm).

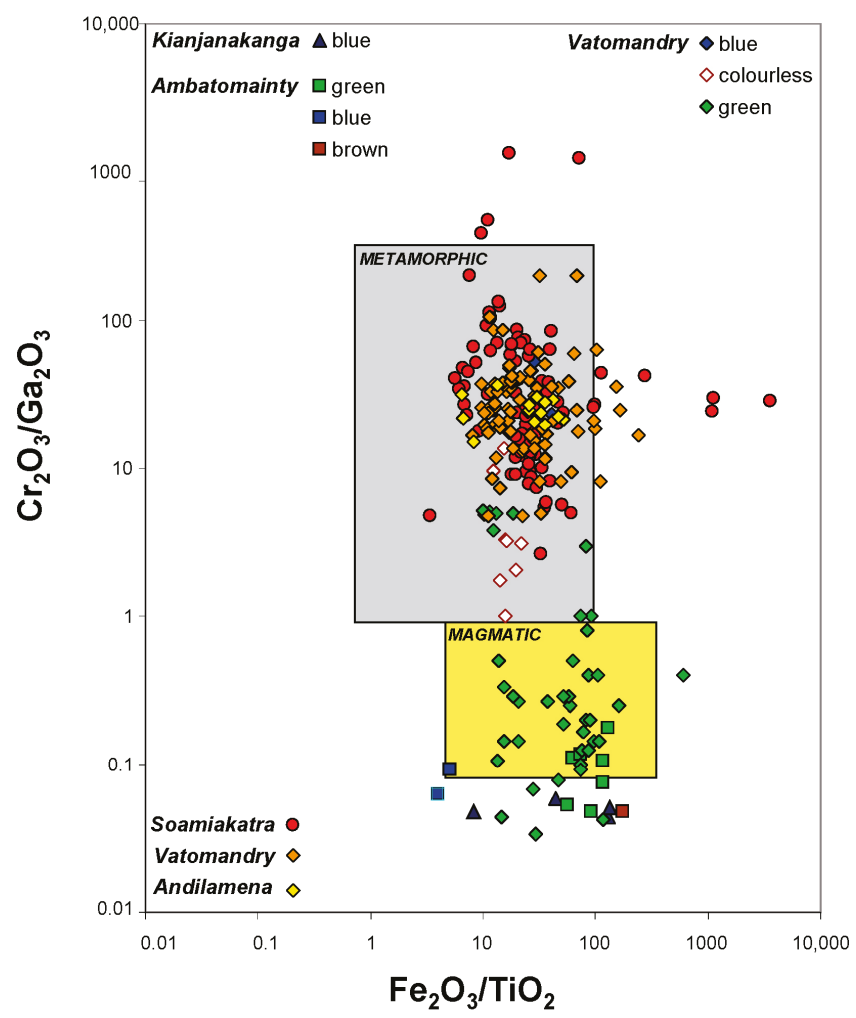

Figure 16. $\mathrm{Cr}_{2} \mathrm{O}_{3} / \mathrm{Ga}_{2} \mathrm{O}_{3}$ versus $\mathrm{Fe}_{2} \mathrm{O}_{3} / \mathrm{TiO}_{2}$ diagram for rubies and sapphires associated with alkali basalts from the Antananarivo and Toamasina Provinces in Madagascar. The metamorphic and magmatic boxes defined for Australian sapphires are from [68,75].

Giuliani et al. [72] and Uher et al. [79] proposed a new chemical classification diagram for gem corundum based on the different types of primary corundum deposits worldwide (see $[40,80])$. It used a database of 2000 EMPA analyses of ruby and sapphire that were obtained under the same analytical conditions. The $\mathrm{FeO}+\mathrm{TiO}_{2}+\mathrm{Ga}_{2} \mathrm{O}_{3}$ versus $\mathrm{FeO}-\mathrm{Cr}_{2} \mathrm{O}_{3}-\mathrm{MgO}-\mathrm{V}_{2} \mathrm{O}_{3}$ diagram in Figure 17 uses: (1) the $\mathrm{FeO}$ content to discriminate between iron-poor rubies in marbles and iron-rich rubies in M-UMR and (2) the second discriminator between ruby and sapphire is the addition to (Y-axis parameter) or subtraction from (X-axis parameter) $\mathrm{FeO}$ of trace elements associated preferentially with sapphire $\left(\mathrm{TiO}_{2}\right.$ and $\left.\mathrm{Ga}_{2} \mathrm{O}_{3}\right)$ or ruby $\left(\mathrm{Cr}_{2} \mathrm{O}_{3}, \mathrm{~V}_{2} \mathrm{O}_{3}\right.$, and $\left.\mathrm{MgO}\right)$. The fields of the different gem corundum deposits are: for rubies, (R1) marble; (R2) John Saul mine-type; (R3) M-UMR; (R4) metasomatites; for sapphires, (S1) syenitic rocks; (S2) metasomatites; and (S3) alkali-basalt and lamprophyre. Finally, the chemical diagram permits a clear separation with limited overlap of the main types of deposit found worldwide. 


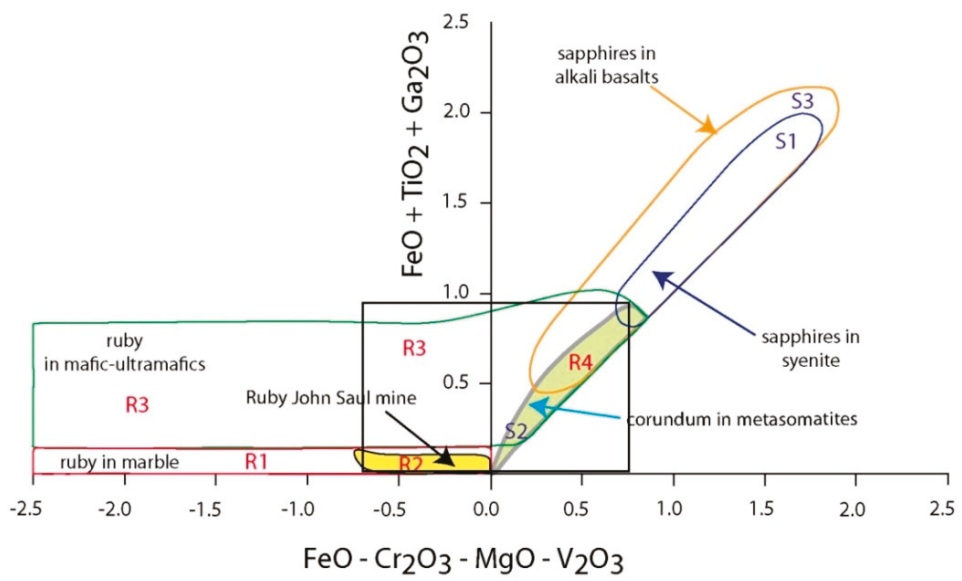

Figure 17. $\mathrm{FeO}-\mathrm{Cr}_{2} \mathrm{O}_{3}-\mathrm{MgO}-\mathrm{V}_{2} \mathrm{O}_{3}$ versus $\mathrm{FeO}+\mathrm{TiO}_{2}+\mathrm{Ga}_{2} \mathrm{O}_{3}$ diagram based on a database of 2000 electron microprobe analysis (EMPA) analyses (in wt \% oxides) showing the main chemical fields defined for different types of corundum deposits worldwide [72]. Different geochemical domains are defined (see text).

The chemical diagram provides sufficient discrimination to distinguish between the different types of corundum deposits for the following reasons: (1) the database contains more than 2000 EMPA analysis representative of all of the types of primary deposits and (2) the magmatic sapphire domain (S1) is defined by the geology and chemistry of corundum. The sapphires are hosted in syenitic rocks or occur as megacrysts in syenitic xenoliths carried by alkali basalts. Most of the sapphires in placers linked to the erosion of alkali basalts (domain S2) overlap the domain S1. The main superposition of geological domains is for ruby of metasomatic (-metamorphic) origin that overlaps the domain of ruby associated with M-UMR (strictly metamorphic); (3) the diagram uses Ga and Mg despite their high detection limits, and the two elements are opposed: Ga is added to Ti while $\mathrm{Mg}$ is added to $\mathrm{Cr}$ and $\mathrm{V}$. This choice corresponds with the fact that $\mathrm{Ga}$ and $\mathrm{Ti}$ are concentrated in magmatic sapphires (syenitic rocks) while $\mathrm{Mg}, \mathrm{Cr}$, and $\mathrm{V}$ are concentrated in metamorphic rubies hosted in $\mathrm{Mg}-\mathrm{Cr}-(\mathrm{V})$-rich protoliths.

A statistical classification by discriminant factors analysis using oxide concentrations ( $\mathrm{Ti}, \mathrm{Mg}, \mathrm{V}$, $\mathrm{Cr}, \mathrm{Fe}$, and $\mathrm{Ga}$ ) of more than 900 corundum crystals from the main primary deposits worldwide was proposed by [72]. The deposits were classified into different types: (1) for ruby as marble, M-UMR, and metasomatites and (2) for sapphires as syenitic rocks, metasomatites, plumasites, and skarns.

The discriminating factors F1 and F2 calculated for the different types of ruby deposits (known classes) with their respective centroid for each class are as follows:

Factor $1=0.271691 \times\left(\mathrm{Cr}_{2} \mathrm{O}_{3}-0.294456\right) / 0.376245+0.796762 \times(\mathrm{FeO}-0.26294) / 0.224015$

$+0.0206904 \times\left(\mathrm{Ga}_{2} \mathrm{O}_{3}-0.0112047\right) / 0.0124095+0.136135 \times(\mathrm{MgO}-$

$0.00545581) / 0.00526035-0.124367 \times\left(\mathrm{TiO}_{2}-0.0274651\right) / 0.0539087-0.108332 \times\left(\mathrm{V}_{2} \mathrm{O}_{3}\right.$

$-0.0102233) / 0.0111099$

Factor $2=0.124957 \times\left(\mathrm{Cr}_{2} \mathrm{O}_{3}-0.294456\right) / 0.376245-0.121871 \times(\mathrm{FeO}-0.26294) / 0.224015$

$-0.287007 \times\left(\mathrm{Ga}_{2} \mathrm{O}_{3}-0.0112047\right) / 0.0124095-0.0527783 \times(\mathrm{MgO}-$

$0.00545581) / 0.00526035+0.0584802 \times\left(\mathrm{TiO}_{2}-0.0274651\right) / 0.0539087-0.439517 \times\left(\mathrm{V}_{2} \mathrm{O}_{3}\right.$

$-0.0102233) / 0.0111099$ 
The discriminating factors F1 and F2 calculated for the different types of sapphire deposits (known classes) with their respective centroid for each class are as follows:

$$
\begin{aligned}
& \text { Factor } 1=0.23095 \times\left(\mathrm{Cr}_{2} \mathrm{O}_{3}-0.0613814\right) / 0.0596296-0.723839 \times(\mathrm{FeO}- \\
& 0.489593) / 0.372367-0.0403934 \times\left(\mathrm{Ga}_{2} \mathrm{O}_{3}-0.0159195\right) / 0.00946033+0.0767757 \times \\
& (\mathrm{MgO}-0.00613983) / 0.0040002-0.00901195 \times\left(\mathrm{TiO}_{2}-0.0236271\right) / 0.0567399+ \\
& 0.0791335 \times\left(\mathrm{V}_{2} \mathrm{O}_{3}-0.00402119\right) / 0.00329669
\end{aligned}
$$

$$
\begin{aligned}
& \text { Factor } 2=-0.530426 \times\left(\mathrm{Cr}_{2} \mathrm{O}_{3}-0.0613814\right) / 0.0596296-0.638704 \times(\mathrm{FeO}- \\
& 0.489593) / 0.372367-0.00893226 \times\left(\mathrm{Ga}_{2} \mathrm{O}_{3}-0.0159195\right) / 0.00946033-0.200622 \times(\mathrm{MgO} \\
& -0.00613983) / 0.0040002+0.296868 \times\left(\mathrm{TiO}_{2}-0.0236271\right) / 0.0567399-0.165072 \times\left(\mathrm{V}_{2} \mathrm{O}_{3}-\right. \\
& 0.00402119) / 0.00329669
\end{aligned}
$$

Finally, prediction diagrams were proposed for the different types of deposits and applied to placers of alkali basalt-related deposits [72]. Figure 18 shows how such a diagram can be used to determine the most probable deposit type for ruby from the Soamiakatra deposit in Madagascar.
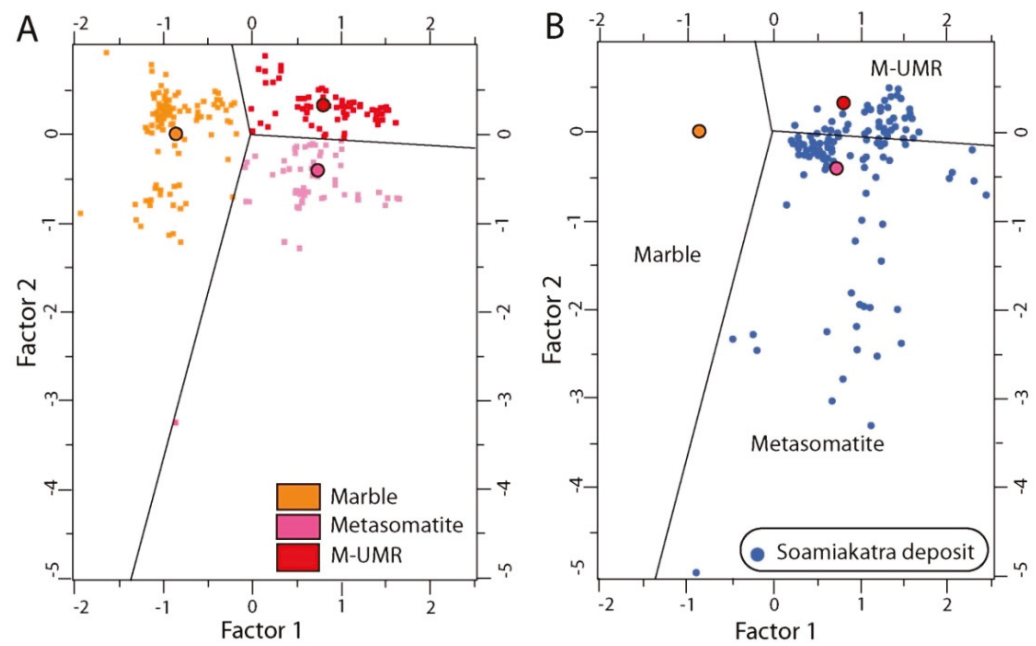

- 0 centroid of each known class of deposit types

Figure 18. Discriminant factors analysis using oxide concentrations in ruby; modified from [72]. (A) Diagram used to distinguish between the different types of ruby deposit (marble, metamorphosed mafic and ultramafic rocks (M-UMR), and metasomatite) with the centroids of the known deposit classes and (B) prediction of the geologic origin of rubies from the Soamiakatra deposit in the Antanarivo province of Madagascar.

Peucat et al. [70] obtained LA-ICP-MS analyses of corundum from different geological settings and suggested using their $\mathrm{Fe}, \mathrm{Ti}, \mathrm{Cr}, \mathrm{Ga}$, and $\mathrm{Mg}$ contents and chemical ratios such as $\mathrm{Ga} / \mathrm{Mg}, \mathrm{Fe} / \mathrm{Ti}, \mathrm{Fe} / \mathrm{Mg}$, and $\mathrm{Cr} / \mathrm{Ga}$ to determine their geological origins. The $\mathrm{Ga} / \mathrm{Mg}$ ratio versus the Fe content has proven to be an efficient tool for discriminating between some metamorphic and magmatic blue sapphires, even if some localities overlap and are difficult to discriminate. Natural rubies have normally limited Ga $(<200 \mathrm{ppm})$ and low $\mathrm{Ga} / \mathrm{Mg}$ ratios $(<10)$ and in some cases their trace-element contents are unusual and they plot in the field for sapphire [81].

The use of Fe versus $\mathrm{Ga} / \mathrm{Mg}$ for ruby is presented here for different types of deposits (Figure 19). The main types of deposits are discriminated as a function of the Fe content of the ruby: (1) range 10,000-1000 (ppm) for ruby in M-UMR (metamorphism sensu stricto and metamorphic metasomatic) with 
the example of different ruby deposits in Southern Madagascar (Vohitany, Anavoha, and Andriba), Greenland (Aappaluttoq), Mozambique (Maninge Nice at Montepuez), ruby as xenocrysts in alkali basalts (examples include Pailin, Macquarie River, New England, and Chanthaburi-Trat) and kimberlite (Mbuji-Mayi) or alluvial from kimberlites (Juina, Brazil); (2) range 1000-10 ppm for ruby in marbles (Lu Yen-Yen Bai and Quy Chau in Vietnam, Mogok and Mong Hsu in Myanmar); and (3) less than 10 ppm for metasomatites as plumasites (John Saul mine, Kenya).

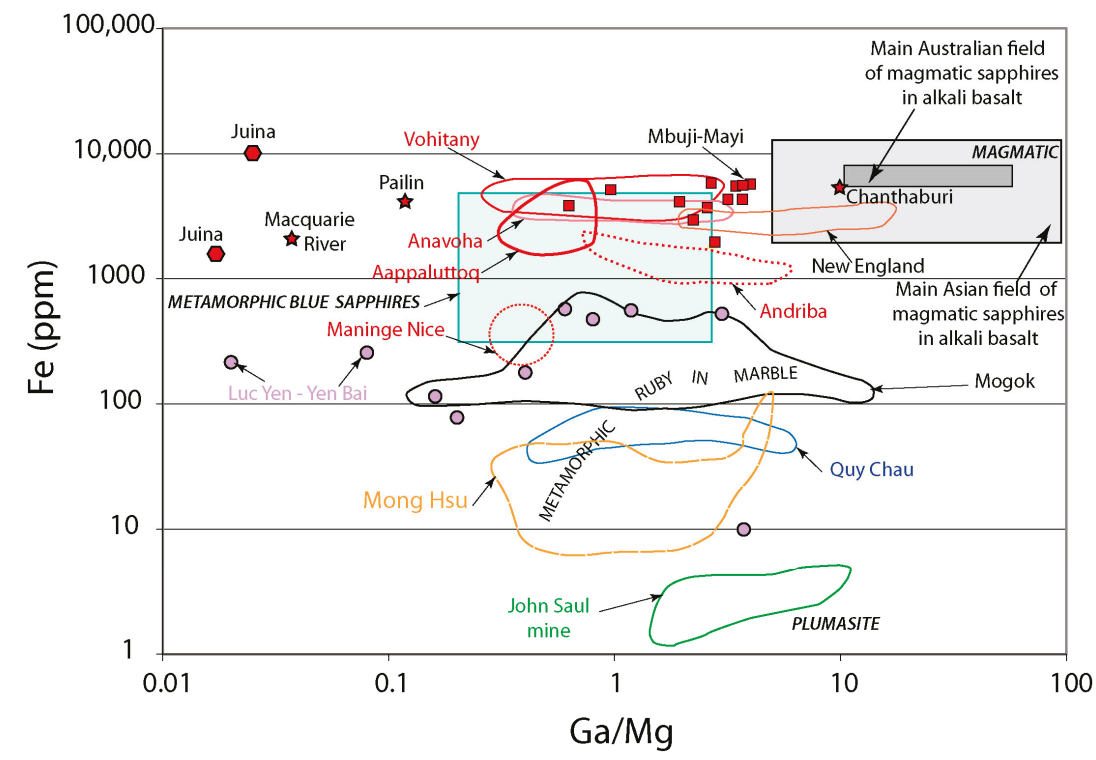

Figure 19. Fe (ppm) versus $\mathrm{Ga} / \mathrm{Mg}$ discrimination diagram for ruby (this work; modified from [69]), showing the variation of Fe content for some rubies relative to their geological environments. The boxes for magmatic sapphire related to alkali basalts are reported for comparison with the plot of Pailin sapphire in Cambodia (data from [72,82]) as well as the box of metamorphic sapphires (drawn with the range of values defined in the tables of [70]). The following different types of ruby and/or their chemical fields are shown: (1) the chemical domain of rubies associated with M-UMR (red domains) from (i) Madagascar [72] with the occurrences of Vohitany (analysis, $n=25$ ), Anavoha $(n=6)$, and Andriba $(n=6)$; (ii) Greenland and the chemical domain of Aappaluttoq ruby deposit ( $n=24$, data from [83]); (iii) Mozambique (Montepuez mining district) with the colluvial deposit of Maninge Nice from (Pardieu, unpublished data); (2) inclusions of ruby in diamonds from Juina in Brazil (red hexagon) [43]; (3) xenocrysts of ruby from the Mbuji-Mayi kimberlite in the Democratic Republic of Congo (red square) [84]; (4) xenocrysts of rubies in alluvial of alkali basalts such as Pailin, Chantaburi-Trat, and Macquarie River and New England in Australia (red star) [82,85,86]; (5) rubies in marble from Luc Yen-Yen Bai represented by single measurements (violet circle) and Quy Chau (blue domain) in Vietnam [57,66], Mogok (black domain) [87], and Mong Hsu (orange domain) [88]; and (6) rubies from the former John Saul (now Rockland) mine in Kenya (green domain) from desilicated pegmatites (Giuliani et al., unpublished data). These rubies show high variations in Fe, which permits discrimination of their geological type; this is characterized by a decrease of Fe from rubies in M-UMR to marble and metasomatic rocks (plumasite and shear-zones). The $\mathrm{Ga} / \mathrm{Mg}$ ratio of rubies from M-UMR is different from magmatic sapphires but is within the range of values of metamorphic sapphires as defined by [69]. The domains represent the distribution of several spot analyses. The others analyses are the average values of punctual measurements. 
The $\mathrm{Ga} / \mathrm{Mg}$ ratio is highly variable, between 0.1 and 10 , and some rubies such as those occurring as xenocrysts in alkali basalt (Chanthaburi-Trat and New England) and M-UMR (Madagascar) plot in the magmatic field of sapphire (right side of Figure 19). Such an overlap opens the question of the significance of such geochemical signatures and will be discussed elsewhere.

Geographic origin determination of ruby has become a great challenge during recent decades [72]. The sampling of rubies from reliable sources worldwide $[20,36,89]$ has facilitated the assembly of reliable reference collections in the gem laboratories [90]. The mineral assemblages and inclusions combined with trace element chemistry sometimes make it possible to decipher the geographic origin of rubies. Trace elements are used by most of the laboratories and the data are collected with several analytical techniques [91] mainly LA-ICP-MS.

Representative analyses of rubies originating from deposits of different geological types are presented in Tables 1 and 2. The quantification of the various trace elements is done using commercially available calibration standards such as those provided by the National Institutes of Standards and Technology (NIST) or the United States Geological Survey (USGS). The difference in composition between the standards and the analyzed corundum has led to some uncertainties in the data generated by the different laboratories. The Gemmological Institute of America laboratory developed matrix-matched corundum standards of ruby and sapphire and the standard deviation of the analyzed ruby became negligible and therefore can be compared with a database of stones with known provenance [92]. The application of this analytical protocol to ruby made it possible to confirm the geological classification of gem corundum (ruby and pink corundum) for (1) Fe-poor ruby hosted in marble and (2) Fe-rich ruby in M-UMR (Figure 20). The geographic determination is not based on the $\mathrm{Cr}$ content of ruby because it appears by experience that it is not useful for origin certification [11]. The discrimination for Fe-rich rubies in M-UMR is based on the contents of V-Mg-Fe as shown in Figure 20 for deposits in Mozambique, Madagascar, and Thailand/Cambodia.

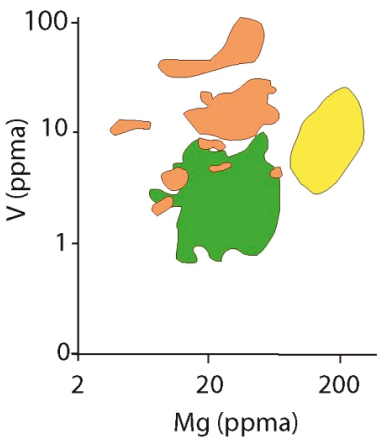

Mozambique

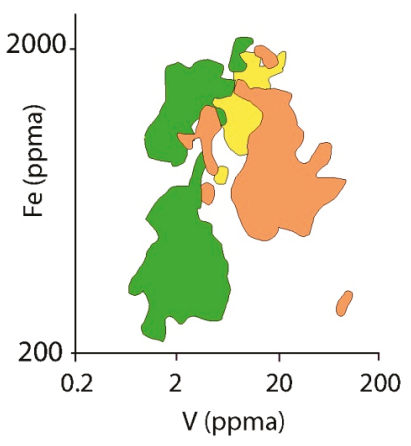

Madagascar

\section{Thailand/Cambodia}

Figure 20. The geographic origin of rubies from Mozambique, Madagascar, and Thailand/Cambodia using $\mathrm{V}$ versus $\mathrm{Mg}$ and Fe versus $\mathrm{V}$ diagrams, modified from [11]. The limits of detection of the analyses by laser ablation-inductively coupled plasma-mass spectroscopy (LA-ICP-MS) are for $\mathrm{Mg}, \mathrm{V}$, and Fe respectively, 0.1-0.3, 0.03-0.2, and 5-20 ppm.

The geographic origin of ruby can usually be achieved based on inclusions in association with trace element chemistry despite some overlaps [11-14]. The oxygen isotopic compositions of these rubies overlap strongly and are not useful for geographic origin determination [93]. 


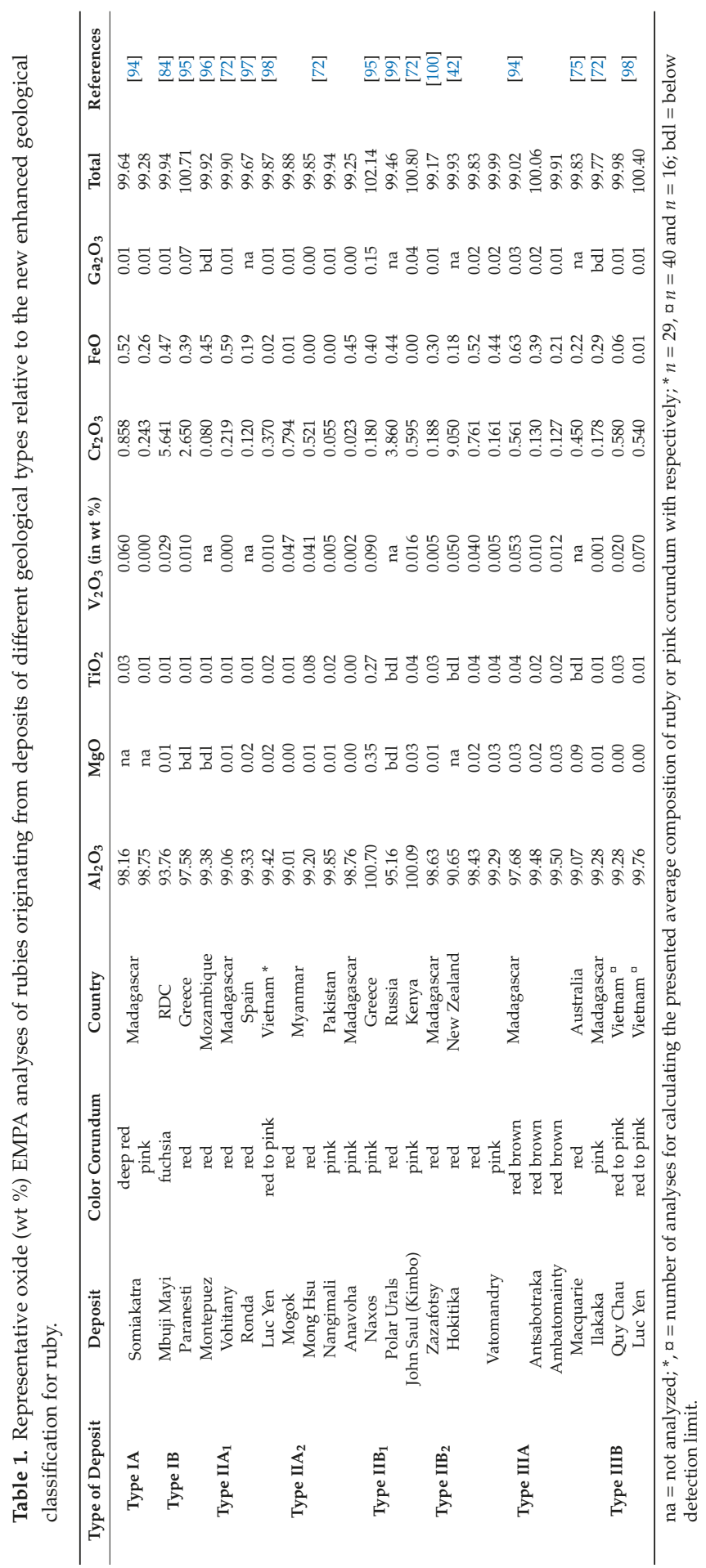




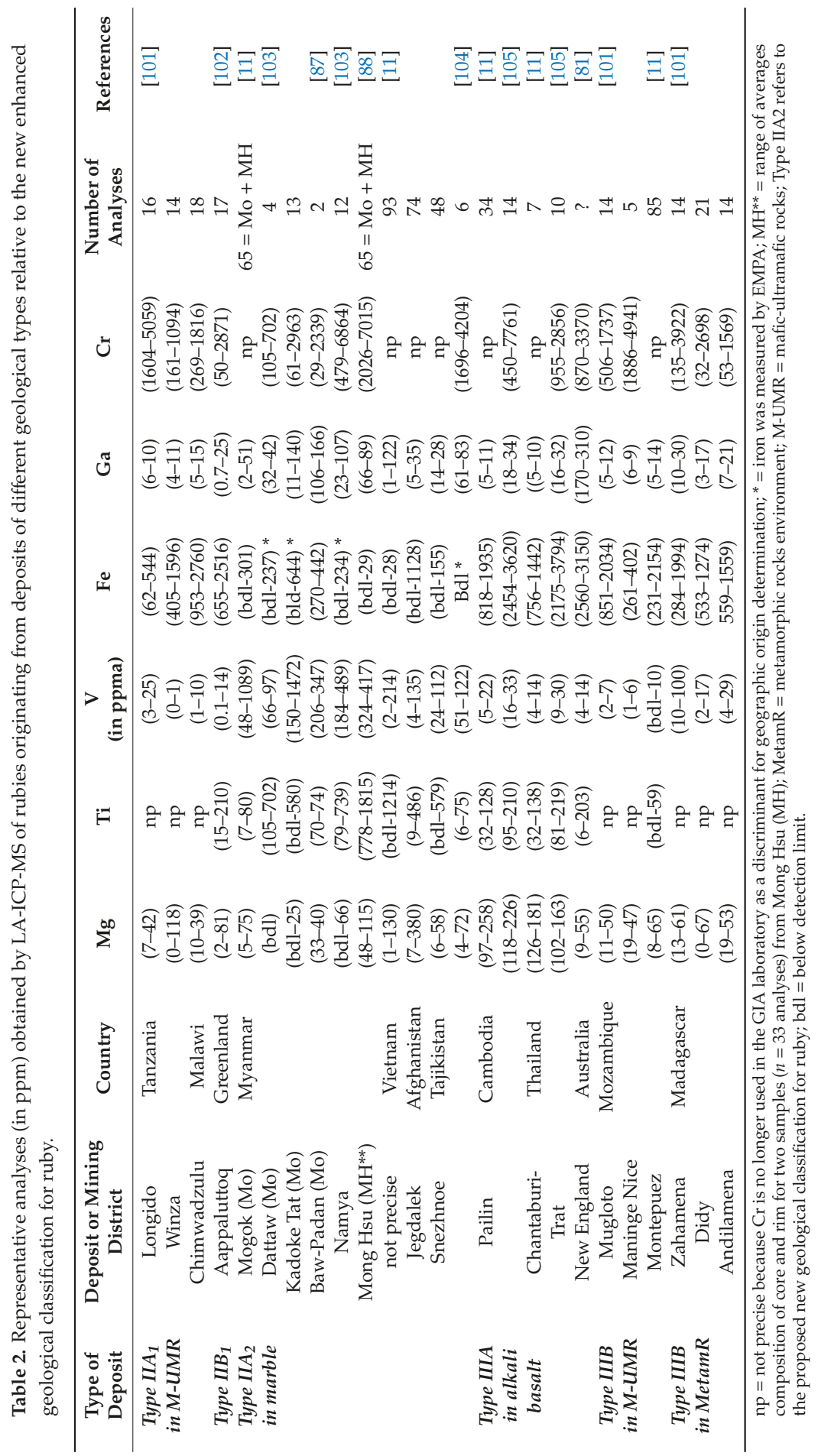




\section{Geological Environment and Age of Primary Ruby Deposits}

The global distribution of ruby deposits is closely linked to the Wilson cycle, i.e., collision, rift and subduction geodynamics $[80,106,107]$. Ruby forms in mafic, felsic, and metamorphosed carbonate platform geological environments, but it is always associated with rocks depleted in silica and enriched in alumina. In the presence of silica, $\mathrm{Al}$ is preferentially incorporated into Al-Si-bearing minerals such as feldspars and micas. The mineral association of corundum commonly consists of plagioclase, sapphirine, biotite, phlogopite, amphibole, pyroxene, and carbonates [108].

Two major geological environments are favorable for the presence of ruby, specifically amphibolite to medium-pressure granulite facies metamorphic belts, and alkaline basaltic volcanism in continental rifting environments. Three questions arise concerning ruby in metamorphic environments, which formed primarily via changes in temperature and pressure and fluid-rock interaction such as diffusion or percolation (metasomatism): (1) the origin and role of the parental fluids; (2) the nature and importance of the protolith; and (3) the characteristics of the paleogeography of the depositional sedimentary environment (in the case of carbonate platforms).

Gem ruby is rare because it requires the existence of several conditions: (1) an environment containing aluminum or the circulation of an Al-bearing metasomatic fluid; (2) a parental fluid issued either from the gem host-rock environment or exotic fluid circulations at medium to high temperatures ( $\mathrm{T}>500{ }^{\circ} \mathrm{C}$ ); (3) a seed surface and sufficient space for the growth of the crystal; (4) the incorporation of trace elements especially $\mathrm{Cr}, \mathrm{Fe}$, and $\mathrm{V}$ from the parental fluid in the unit cell of the mineral; and (5) the absence of internal crystalline deformation during and after growth.

In the amphibolite to medium-pressure granulite facies metamorphic belts, the gem corundum pressure-temperature field corresponds to a pressure domain above $2 \mathrm{kbar}$, and temperatures between 500 and $850^{\circ} \mathrm{C}$ (Figure 21).

The host lithologies are alumina-rich and/or silica-poor rocks such as marble, aluminous gneiss, metamorphosed M-UMR, or juxtaposed meta-felsic and silica-poor rocks affected by the circulation of fluids at their contact and altered by metasomatism (metasomatites such as desilicated pegmatite called plumasite, skarn, etc.). Marble is a silica- and alumina-depleted rock, and under these conditions the transport of alumina by a fluid phase seems necessary for the crystallization of corundum; however, $\mathrm{Al}$ is usually considered to be an immobile element but investigations on different ruby deposits associated with fluid circulation and metasomatism have shown that $\mathrm{Al}$ was mobile [83].

Ruby-bearing skarns have not been clearly identified but the presence of silica enrichments in certain rubies from Mogok [87,103] led some authors to suspect the influence of thermal anomalies accompanying the different Si-rich intrusions affecting the mining district. This opens debate on the accuracy of determination of $\mathrm{Si}$ content in ruby, and the use of accurate ruby standards is necessary to decrease the detection limit of $\mathrm{Si}$ as done by $[87,92]$. Stone-Sundberg et al. [92] measured by LA-ICP-MS analysis Si ranging from 70 to $305 \mathrm{ppm}$ in rubies from Mogok as well as other elements such as B (11-82 ppm), Ga (280-800 ppm), and Sn (2-35 ppm) that recorded potential skarn trace-element enrichments [88]. Emmett et al. [109] focused on the low mass resolution of quadrupole ICP-MS as the cause of that technique inability to measure accurately $\mathrm{Si}$ in corundum. Another problem is that ICP-MS occurs in a silica glass torch, which causes large variations in the Si background leading to high detection limits [109]. The results published up to now for different rubies [91,104] remain questionable. Measurements of Si by SIMS could be a more accurate method as explained by [109].

In alkali basalt volcanism, rubies are xenocrysts carried to the surface by the magmas. The corundum is found either as xenocrysts or crystal within xenoliths in lava flows and plugs of subalkaline olivine basalts, high alumina alkali basalt, and basanite. These magmas occur in crustal extensional environments impacted by the rise of upwelling mantle plumes. Ruby-bearing xenoliths are very rare because the mother rocks generally melt or disintegrate during storage in the magma chamber or during the magma transport. In Madagascar, xenoliths of ruby-bearing clinopyroxenite and metagabbro have been found in the Soamiakatra deposit. The metamorphic ruby formed in the lower crust at a temperature around $1100{ }^{\circ} \mathrm{C}$ and a pressure of about $20 \mathrm{kbar}[77,94]$. 


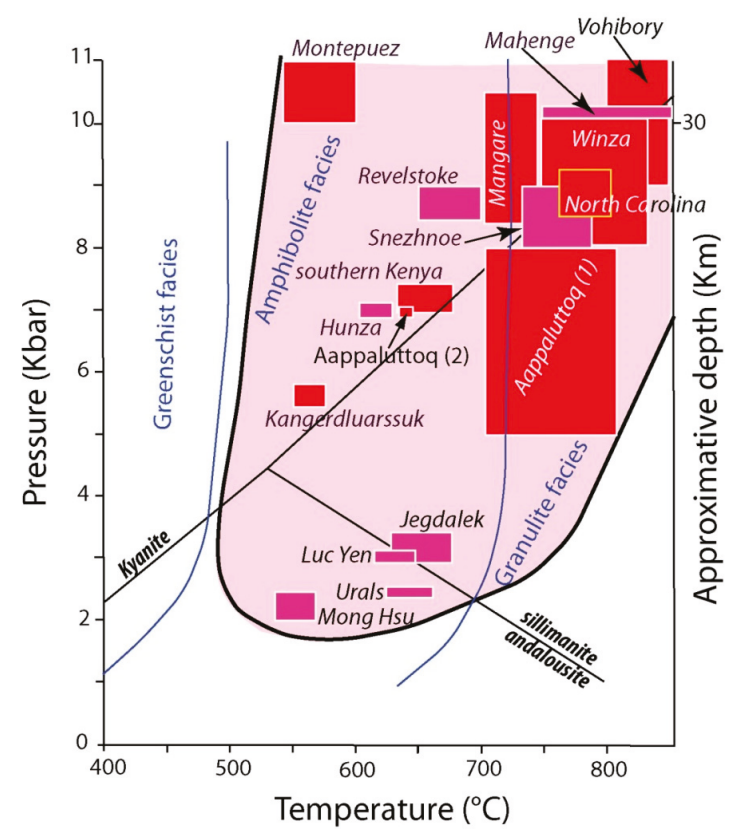

Figure 21. Pressure-temperature (P-T) formation conditions of metamorphic gem ruby (modified from [40,110]). The P-T fields of: (1) the marble type deposits from Mong Hsu [60], Urals [111], Luc Yen and Jegdalek [65], Hunza [112], Revelstoke [113], Mahenge [114], and Snezhnoe [115] are represented by violet rectangles and (2) the M-UMR deposits, metamorphic sensu stricto or associated with metasomatic metamorphism are represented by red rectangles: Greenland-Kangerdluarssuk [116], Aappaluttoq 1 [34] and 2 [83]; Southern Kenya [117,118]; Montepuez [96]; Mangare [119]; Winza [120]; North Carolina [121]; and Vohibory [122]. The P-T fields of ruby and pink corundum in clinopyroxenites and metagabbro xenoliths associated with alkali basalts are not shown. The schematic fields of Greenschist, Amphibolite, and Granulite facies are reported.

The ages of corundum formation are defined by indirect dating of a series of minerals (zircon, monazite, rutile, titanite, and micas) present either in the host rocks or as syngenetic inclusions in the corundum. These minerals have different blocking temperatures for closure to isotopic migration that make it possible to establish a cooling history for the corundum. Four main periods of gem corundum formation that include ruby and sapphire and encompass the main economic production worldwide, are presented in Figure $22[80,106,107]$. The others primary ruby occurrences known worldwide as in Australia, Norway, Finland, United-States, and other countries (see Figure 2) were not considered in the main periods of gem ruby formation. They are either uneconomical or without determination of ages.

The oldest deposits were formed in the Archean (2.97-2.6 Ga). An example is the Aappaluttoq ruby deposit in the 2.97 Ga Fiskenæsset anorthosite complex, Greenland (Figure 2). The deposit occurs at the contact between two types of rocks, i.e., ultramafic rocks (meta-peridotite or dunite) and an anorthite-rich rock (anorthosite and leucogabbro) [34,83]. Ruby is hosted in phlogopite-calcic amphibole metasomatic rocks formed by fluid-rock interaction at the contact of the two lithologies. The metasomatic fluids were triggered by the intrusion of pegmatites dated between 2.72 and $2.70 \mathrm{Ga}$ with $\mathrm{U}-\mathrm{Pb}$ zircon geochronology by LA-ICP-MS [83]. U/Pb dating of monazite gave age at $2.64 \mathrm{Ga}$ [34] and a direct $\mathrm{Pb}-\mathrm{Pb}$ isochron age of $2.68 \mathrm{Ga}$ was obtained on ruby by Thermal Ionisation Mass Spectrometry [103]. The age of ruby is correlated to the age of the pegmatites intrusion; consequently an average age at $2.71 \mathrm{Ga}$ is considered for ruby formation [83]. 


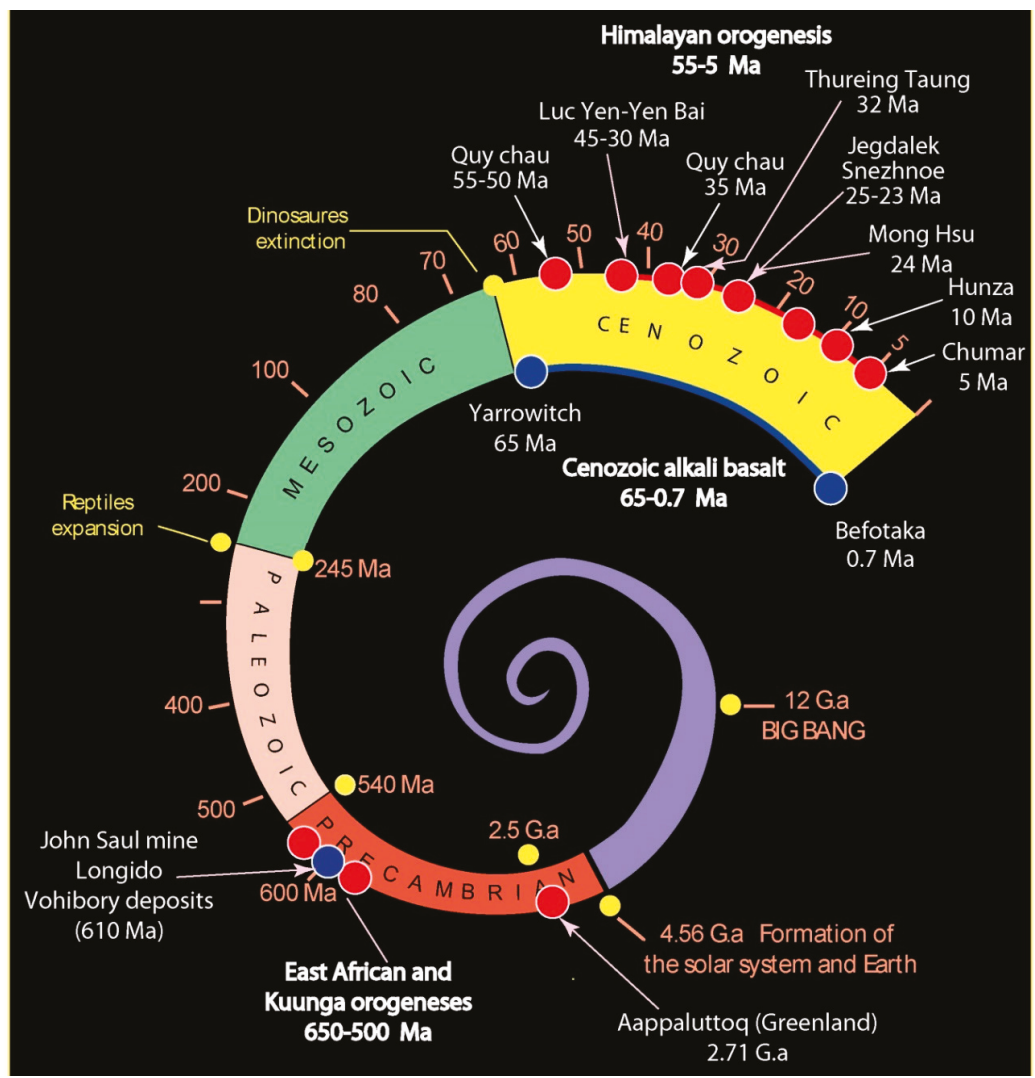

Figure 22. The spiral time diagram of corundum formation that includes economic ruby (and sapphire) deposits. Four main economic corundum periods have been defined worldwide by different methods of indirect dating of corundum. The oldest deposit is Aappaluttoq in Greenland where the ruby formed during the Archean at $2.71 \mathrm{Ga}$. The main period of gem rubies formation was the Pan-African orogeny (750-450 Ma). This includes primary ruby deposits in the Pan-African tectonic-metamorphic belt such as the John Saul mine in Kenya, Longido in Tanzania, and the deposits of Southern Madagascar, all formed at around $610 \mathrm{Ma}$. The third period corresponds to the Cenozoic Himalayan orogeny (55 Ma to the Quaternary) with the famous marble-hosted ruby deposits in Central and South-East Asia as in the deposits of Thureing Taung at Mogok and Mong Hsu in Myanmar [88]. The fourth period is dominated by the extrusion of alkali basalts in the Cenozoic (65 Ma to Quaternary) where ruby (and sapphire) were transported as xenocrysts or in xenoliths by the magmas. The age of the parental rocks of the ruby is unknown but a metamorphic origin is preferentially evidenced. Most of the ages are minimum cooling ages except those obtained on zircon by the $\mathrm{U} / \mathrm{Pb}$ method.

The second period of corundum formation was the Pan-African orogeny (750-450 Ma). This includes primary ruby and sapphire deposits in the gemstone belt of eastern Africa, Madagascar, India, and Sri Lanka that are linked to collisional processes between Eastern and Western Gondwana during Pan-African tectonic-metamorphic events [123]. The metamorphic ruby and sapphire deposits in Southern Madagascar have numerous geological similarities with those in Eastern Africa, Sri Lanka, and Southern India (see [40]). U/Pb dating of zircon from the John Saul mine in Kenya (612 $\pm 6 \mathrm{Ma}$; [118]), Longido in Tanzania (610 $\pm 6 \mathrm{Ma}$; [124]), and the Vohibory deposits in Madagascar (612 $\pm 5 \mathrm{Ma}$; [125]) reveal similar periods of formation related to the East African orogeny. The precise 
age of formation for the ruby deposit of Montepuez in Mozambique is unknown but a Pan-African age is probable [126]. Moreover, the $\mathrm{U} / \mathrm{Pb}$ ages of zircon coeval with sapphire in the Andronandambo skarn deposit in Southern Madagascar range between 523 and $510 \mathrm{Ma}$ [127], and the ${ }^{40} \mathrm{Ar} /{ }^{39} \mathrm{Ar}$ ages of biotite-phlogopite syngenetic with sapphire and ruby from the Ambatomena, Sahambano, and Zazafotsy deposits in Madagascar are between 494 and 487 Ma [128]. LA-ICP-MS dating of rutile inclusions in ruby from the John Saul and Aqua mines in the Mangare area gave ages of 533 and $526 \mathrm{Ma}$, respectively [129]. These cooling ages, lower that those obtained by the U/Pb method, must be considered as minimum ages but as confirming the existence of a metamorphic corundum episode during the late Pan-African orogenic cycle (Cambrian) and corresponding to the Kuunga orogeny [130].

The third period corresponds to the Cenozoic Alpine orogeny with tectonics events registered in the Alps; Rhodopes and Himalayas (55 Ma to the Quaternary). Examples include the marble-hosted ruby deposits in Campo Lungo (Switzerland) and Xanthi (Greece), and in Central and South-East Asia. In the Himalayas, the ruby deposits in marble occur in metamorphic blocks that were affected by major tectonic events during the collision of the Indian and Asian plates [131-134]. The ruby has been indirectly dated by ${ }^{40} \mathrm{Ar} /{ }^{39} \mathrm{Ar}$ stepwise heating experiments performed on single grains of coeval phlogopite, and by ion-probe U-Pb analyses of zircon included in the corundum $[40,88,106,135]$. Other indirect dating for the Snezhnoe deposits in Central Pamir was realized on bulk rock (ruby-bearing phlogopite-plagioclase rocks) by the $\mathrm{Rb}-\mathrm{Sr}$ method [134]. The $\mathrm{Rb}-\mathrm{Sr}$ errorchron age yielded $23 \pm 1.6 \mathrm{Ma}$, which had to be considered as a minimum age for ruby formation. All of the Eocene to Pliocene ages (55-5 Ma) are consistent with extensional tectonic events that were active from Afghanistan to Vietnam in the ruby-bearing metamorphic belt.

The fourth main period of gem economic ruby is dominated by the extrusion of alkali basalts in the Cenozoic (65 Ma to Quaternary). Gem corundum occurs worldwide as xenocrysts or megacrysts in xenoliths or enclaves incorporated in basaltic magmas during their ascent. Such sapphire and ruby deposits occur from Tasmania through Eastern Australia, South-East Asia, and Eastern China to far Eastern Russia $[68,85,88,106]$. They are also found in Nigeria and Cameroon in the Airr and Hoggar regions, the French Massif Central in the Limagne rift, and in Northern, Central, and Eastern Madagascar [39]. In the Australian West Pacific margins intraplate basaltic fields, the U/Pb ages on zircons are widespread between 60 and $1 \mathrm{Ma}[69,73,85,86,106]$. Nevertheless, $\mathrm{U} / \mathrm{Pb}$ dating of zircons xenocrysts in the Barrington Tops deposits in New South Wales indicated multiple episodes of corundum formation and eruptive discharges between 60 and $3 \mathrm{Ma}$ [136]. Few U/Pb data gave ages of 150 and $180 \mathrm{Ma}$ for zircons from the deposit of Cudgegong [136], and $400 \mathrm{Ma}$ for those from Tumbarumba [137]. These oldest ages signify that the Australian West Pacific margins has been essentially a passive margin in a couple hundred million years until the Cenozic basalts related to continental rifting brought corundum to the surface.

\section{Classification of Ruby Deposits}

\subsection{Genetic Classifications}

Gem corundum deposits are classified as either primary or secondary deposits. The primary deposits contain corundum either in the rock where it crystallized or as xenocrysts and in xenoliths in the rock that carried it from the zone of crystallization in the crust or mantle to the Earth's surface [39]. The secondary deposits, i.e., present-day placers, are of three types [138]: (1) eluvial concentrations derived by in situ weathering, or weathering plus gravitational movement, or accumulation; (2) colluvial deposits corresponding to decomposed primary deposits which have moved vertically and laterally down-slope as the hillside eroded; and (3) alluvial deposits resulting from erosion of the host rock and transport of corundum by streams and rivers. Concentration occurs where water velocity drops at a slope change in the hydrographical profile of the river, e.g., at the base of a waterfall, broad gullies, debris cones, meanders, and inflowing streams. Sometimes the corundum placers are mined in beach sands $[139,140]$. 
Classification systems for corundum deposits have evolved over time and are based on different mineralogical and geological features including: (1) the morphology of the corundum [141]; (2) the geological context of the deposits [5]; (3) the lithology of the host rocks [142]; (4) the genetic processes responsible for corundum formation [110]; (5) the genetic type of the deposit [143], (6) the geological environment and nature of the corundum host-rock $[40,80,108,140]$; (7) the oxygen isotopic composition of the corundum [144], and (8) discriminant factors developed using oxide concentrations in 900 corundum samples from the main primary deposits [72]. Classification systems for ruby deposits have not been previously proposed.

\subsection{An Enhanced Classification for Ruby Deposits}

In this work we proposed classifying ruby from primary and secondary deposits into three main types (Table 3 ).

Primary ruby deposits were subdivided into two types based on their geological environment of formation: (Type I) magmatic and (Type II) metamorphic.

(Type I) Magmatic-related with two sub-types:

(1) Sub-Type IA: Rubies either as xenocrysts or in xenoliths hosted by magmatic rocks such as alkali basalts (Madagascar, and others; see Figure 2);

(2) Sub-Type IB: Xenocrysts of ruby in kimberlite (Democratic Republic of Congo).

(Type II) Metamorphic-related with two sub-types:

(1) Sub-Type IIA: Metamorphic deposits sensu stricto in metamorphosed mafic and ultramafic

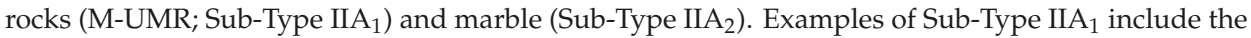
ruby deposits in M-UMR from Montepuez (Mozambique), Bekily-Vohibory region (Madagascar), and others, examples of Sub-Type IIA ${ }_{2}$ concern the ruby deposits in marble from the Mogok Stone Track, and others.

(2) Sub-Type IIB: Metamorphic-metasomatic deposits characterized by high fluid-rock interaction and metasomatism (Sub-Type $\mathrm{IIB}_{1}$ ), i.e., plumasite or desilicated pegmatites as at the former John Saul mine in Kenya, and metasomatites in M-UMR as at Aappaluttoq (Greenland), and marble, and shear zone-related or fold-controlled metasomatic-metamorphic deposits in different substrata, corundum-bearing $\mathrm{Mg}$-Cr-biotite schist and gneiss or marble (Sub-Type $\left.\mathrm{IIB}_{2}\right)$. Examples are respectively the ruby occurrences at Sahambano, Zazafotsy, and Ambatomena in Madagascar, and Mahenge and the Uluguru Mountains in Tanzania.

Secondary ruby deposits are defined as Type III, i.e., sedimentary-related. They are divided into three sub-types hosted in sedimentary rocks:

(1) Sub-Type IIIA: Gem placers in alkali basalt environments (Eastern Australia, Central Madagascar, South-East Asia, and others).

(2) Sub-Type IIIB: Gem placers in metamorphic environments (Montepuez in Mozambique and the Mogok Stone Track in Myanmar, and others).

(3) Sub-Type IIIC: Gem placers with ruby originating from multiple and unknown sources, such as Ilakaka in Madagascar, Tunduru and Songea in Tanzania, and others. 


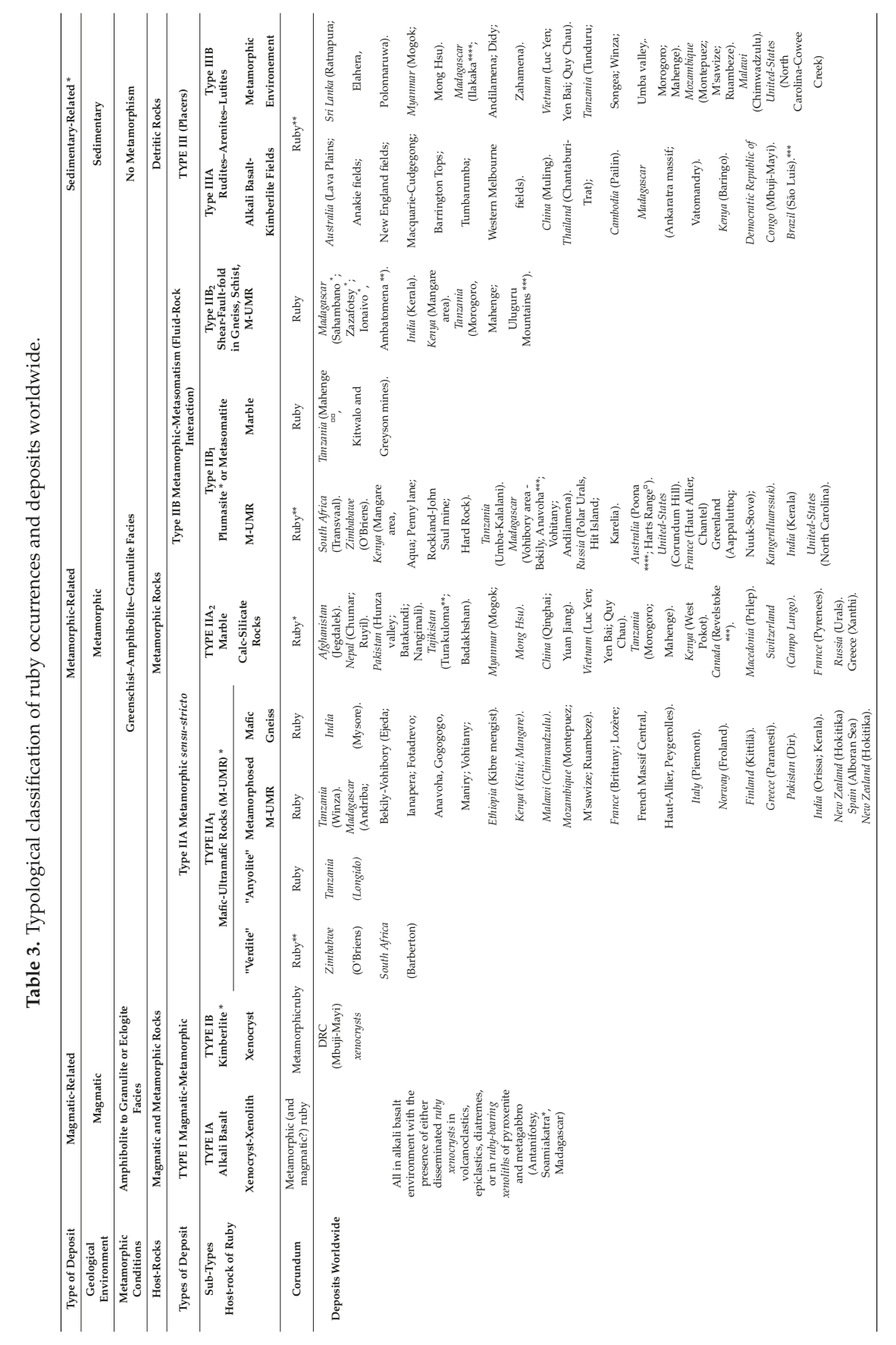




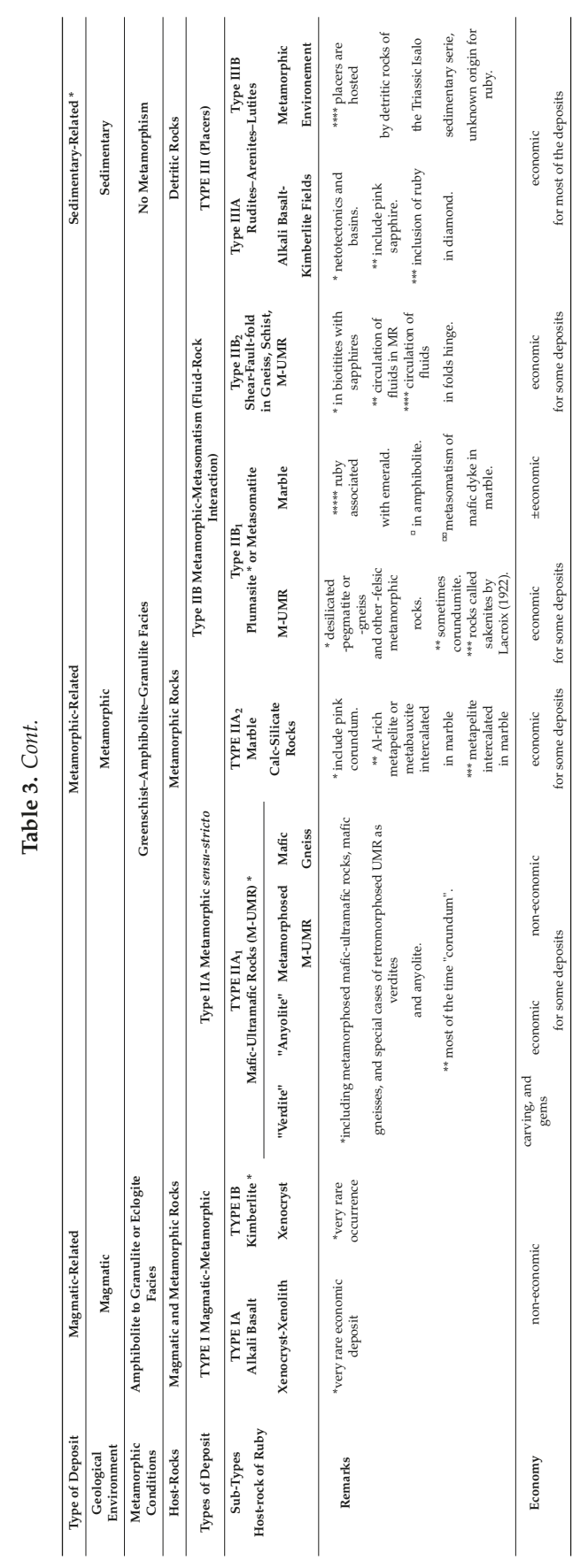




\section{The Different Types of Ruby Deposits}

We will now examine the main ruby deposits worldwide using the above classification.

\subsection{Magmatic-Related (Type I)}

6.1.1. Sub-Type IA: Metamorphic Rubies either as Xenocrysts or Xenoliths in Magmatic Rocks such as Alkali Basalts (See Table 3)

During recent decades, studies of sapphire and ruby xenocrysts in alkali basalts focused on the nature of solid and fluid inclusions [11,75,85,145-150], trace element chemistry $[70,72-74,81,150]$, oxygen isotopes $[40,144,151-153]$, and the nature of their parental xenoliths $[75,77,81,145,154]$ to show that gem corundum may have different magmatic and metamorphic origins. Whatever their origin, these rubies are classified in the Type I category because the classification is based on their geological environment and not on their genetic origin.

The origin of ruby has long been debated but its metamorphic origin was accepted based on the work done by Australian researchers on different deposits from eastern Australia $[68,106]$, work that focused on trace element diagrams, mineral inclusions, and oxygen isotopes [155]. A metamorphic origin has been questioned once more by recent studies showing melt inclusions in ruby from the Chanthaburi-Trat region of Thailand and Pailin in Cambodia [105].

The metamorphic origin of xenocrystic rubies as in Eastern Australia, the Kanchanaburi-Bo Rai and Nam Yuen deposits in Thailand, and Pailin in Cambodia, and Central and Eastern Madagascar is characterized by their trace element distributions and inclusions. The classical $\mathrm{Fe} / \mathrm{Ti}$ versus $\mathrm{Cr} / \mathrm{Ga}$ chemical variation diagram proposed by [74] permits characterization of "metamorphic" ruby and pink corundum, which are rich in $\mathrm{Cr}$ and poor in $\mathrm{Ga}\left(\mathrm{Cr}_{2} \mathrm{O}_{3} / \mathrm{Ga}_{2} \mathrm{O}_{3}\right.$ ratio $\left.>3\right)$, and contain inclusions of chromiferous spinel, pleonaste, Al-rich diopside, and sapphirine. Recently, [81] characterized rubies (up to $3370 \mathrm{ppm} \mathrm{Cr}$ ) and pink corundum (up to $1520 \mathrm{ppm} \mathrm{Cr}$ ) from New England placers, which have distinctive trace element features compared to those found elsewhere in Eastern Australia. In particular they exhibit very high contents of Ga (up to $310 \mathrm{ppm}$ ) and $\mathrm{Si}$ (up to $1820 \mathrm{ppm}$ ). High Ga and Ga/Mg values are unusual in ruby, and the trace elements suggest a magmatic-metasomatic influence for the genesis of New England rubies. The oxygen isotopes $\left(\delta^{18} \mathrm{O}=4.4 \pm 0.4 \%, n=22\right)$ fit within the range of $\delta^{18} \mathrm{O}$ values defined for ruby hosted in M-UMR. Zoned ruby and pink corundum (Figure 23A) have high $\mathrm{Mg}$, $\mathrm{Ga}$, and $\mathrm{Cr}$ and the $\mathrm{Fe}$ versus $\mathrm{Ga} / \mathrm{Mg}$ diagram suggests magmatic affinity (Figure 23B).

The geological origin of New England rubies before their transport by alkali basalts remains a great mystery. Sutherland et al. [81] proposed for their formation either the interaction of intrusive fractionated I-type granitoid magmas, during the New England orogeny, with Cr-bearing ophiolites, or ruby-bearing eclogites and -cliopyroxenites in metamorphosed M-UMR. It is important to note that the different chemical parameters (such as $\mathrm{Ga} / \mathrm{Mg}$, $\mathrm{Fe} / \mathrm{Ti}, \mathrm{Fe} / \mathrm{Mg}$, and $\mathrm{Cr} / \mathrm{Ga}$ ) proposed by [70] were designed only for origin determination of blue sapphires. In some cases, the use of these chemical diagrams is not useful for discriminating geologic or geographic origin of corundum. In the case of Australian rubies, the majority of the data are scattered in the field of metamorphic sapphires, but those of New England overlap the field of magmatic ones. The New England case, and other as for Chanthaburi-Trat and Pailin rubies illustrate the complexity and ambiguity of the use of trace element chemistry [11].

These chemical domains have no genetic significance for some cases and they illustrate only the variation of metals in the parental fluids before their incorporation in the structure during crystal growth, i.e., a kind of chemical color signature. On the contrary, the $\mathrm{Fe}(\mathrm{ppm})$ versus $\mathrm{Ga} / \mathrm{Mg}$ discrimination diagram applied to ruby (see Figure 19) shows that the high variation of Fe in ruby correlates with the geological classification of ruby deposits characterized by decreasing Fe in ruby from M-UMR to marble and plumasite. The overlap is not extensive, as it is for sapphires and the diagram can apparently be used for deciphering the geological origins of ruby. 


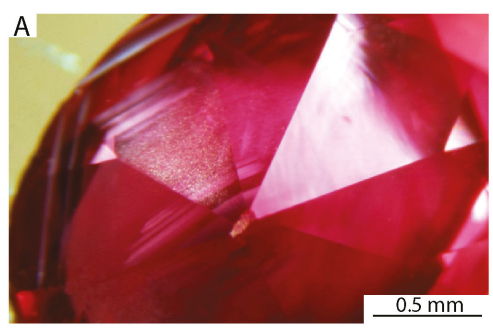

B

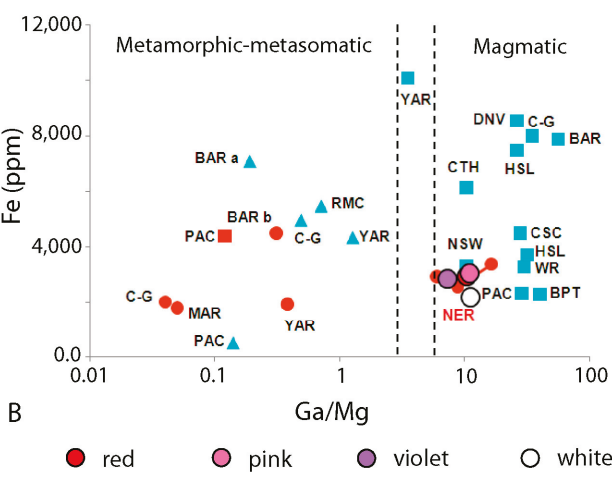

Figure 23. Rubies from the New England locality of Eastern Australia. (A) Apex culet view of an oval-cut 2.31 carats zoned ruby showing alternating growth zones passing through violet to white and pink bands and to ruby on the extreme margin of the top table, Collection Australian Museum. Photo: Gayle Webb; (B) Fe (ppm) versus Ga/Mg diagram for ruby and pink, violet, and white corundum from New England ruby (NER) and other Eastern Australian localities; chemical data from [86]. The red symbols indicate ruby, the blue triangles metamorphic sapphire suites, and the blue squares magmatic-transitional sapphire suites. The different localities are: NSW = New South Wales; BAR = Barrington Tops; YAR = Yarrowitch; $\mathrm{C}-\mathrm{G}=$ Cudgegong-Gulgong; MAR = Macquarie River; $\mathrm{WR}=$ Weld River, NE Tasmania; PAC = Pailin, Cambodia; BPT = Bo Phloi, Thailand; HSL = Huai Sai, Laos; CSC = Changle, Shandong, China; DNV = Dak Nong, Vietnam; CTH = Chanthaburi-Trat, Thailand; RMC $=$ Rio Mayo, Colombia.

Mineral inclusions are also key features in the debate about metamorphic versus magmatic origin of rubies. The most common solids are clinopyroxene (Al-rich diopside), plagioclase (bytownite to andesine), K-feldspar-spinel association [148,149], garnet (pyrope, \pm almandine), sapphirine, scapolite, Cr-spinel, meionite, phlogopite, anatase, apatite, sillimanite, and sulphides [5,68,77,105,145,146,154,156]. All of these minerals are described in rubies found in metamorphic environment, although some of them are also found in magmatic assemblages. The discovery of melt inclusions in ruby reopened the debate about their possible magmatic origin [105,148,149]. Glassy melt inclusions are described frequently for sapphires in alkali basalts [157] and lamprophyres [147,158] but not commonly in rubies. Melt inclusions in rubies from Thailand and Cambodia were reported by [16], recognized by [156], and confirmed by $[148,149]$. Two types of melt inclusions were observed in the Thai and Cambodian rubies [106]: (1) glassy melt inclusions with negative crystal morphology, generally 25-100 $\mu \mathrm{m}$ in size, and with a contraction bubble; (2) polycrystalline aggregates, 200-500 $\mu \mathrm{m}$ across, considered to be recrystallized melt inclusions. The EMPA analyses of two melt inclusions in ruby from Thailand and Cambodia gave similar chemical compositions in wt \% oxides: 53.4. $<\mathrm{SiO}_{2}<55 ; 23.6<\mathrm{Al}_{2} \mathrm{O}_{3}<24 ; 4.9<\mathrm{CaO}<6.2$; $4.4<\mathrm{Na}_{2} \mathrm{O}<5.2 ; 0.1<\mathrm{K}_{2} \mathrm{O}<3.1 ; 1.2<\mathrm{FeO}<1.6 ; 1.4<\mathrm{MgO}<1.9 ; 0.1<\mathrm{TiO}_{2}<0.2$, and $6.3<$ volatiles $<7.5$. These chemical data are comparable to those found for melt inclusions in Yogo Gulch sapphires from Montana. Palke et al. [105] suggested that corundum formed during partial melting of hydrated and carbonated lower crustal anorthosites or troctolites by local intrusion of the lamprophyres or alkali basalts (for the Thai and Cambodian deposits) that eventually carried the corundum to the surface. The genetic model proposed by [105] for the Thai and Cambodian rubies is an anorthosite that was converted at higher pressure to a garnet-clinopyroxenite. In this scenario, Palke et al. [105] argued that ruby is not an "accidental xenocryst" transported by the alkali basalt but rather an "in situ" xenocryst enclave in the alkali basalt itself before its transport to the surface. To the contrary and despite the presence of melt inclusions in ruby from Bo Rai, Promwongan et al. [148,149] and Sutthirat et al. [154] considered that the assemblage Al-rich pyroxene, plagioclase, pyrope, and spinel closely resembles the mineralogy of mafic granulite xenoliths in alkali basalt associated with the Bo Rai gem field. 
The main discussion that arises from this genetic scenario is that the proposed anorthosite protolith for ruby formation has been affected by deformation and consequent metamorphism at high temperature. Under these conditions, how can we define the exact nomenclature and the genesis of ruby, i.e., magmatic origin (anorthosite) or metamorphic (clinopyroxenite or metagabbro in the eclogite facies), or both? The following studies are examples of the ongoing debate:

(1) Sutthirat et al. [145] reported ruby $\left(0.27 \mathrm{wt} \% \mathrm{Cr}_{2} \mathrm{O}_{3}\right)$ included in a clinopyroxene $(0.22 \mathrm{wt} \%$ $\mathrm{Cr}_{2} \mathrm{O}_{3} ; 16.7 \mathrm{wt} \% \mathrm{Al}_{2} \mathrm{O}_{3}$; and $1.8 \mathrm{wt} \% \mathrm{Na}_{2} \mathrm{O}$ ) xenocryst in the Nong Bon alkali basalt, one of the Cenozoic Chantaburi-Trat basalts of Eastern Thailand. Ruby from the alluvial deposits contains inclusions of garnet (pyrope), sapphirine, and Al-Na-clinopyroxene. Thermodynamic calculation constrained the temperatures of ruby + clinopyroxene crystallization to between 800 and $1150 \pm 100{ }^{\circ} \mathrm{C}$ and pressures of between 10 and $25 \mathrm{kbar}$, corresponding to depths of $35-90 \mathrm{~km}$. The pyrope + ruby assemblages formed at depths greater than $60 \mathrm{~km}$ and the source rock proposed was a mafic ruby-pyrope-pyroclasite or ruby-pyrope-clinopyroxenite. Sutthirat et al. [145] rejected a magmatic crystallization for the ruby and this was confirmed by later studies of Thai ruby $[148,149,154]$.

(2) Sutherland et al. [75] studied a suite of alluvial-sourced pink corundum and ruby (up to $0.6 \mathrm{wt} \% \mathrm{Cr}_{2} \mathrm{O}_{3}$ ) from the paleodrainage deposits along the Cudgegong-Macquarie River in New South Wales, Australia. The ruby contained inclusions of clinopyroxene $\left(0.1 \mathrm{wt} \% \mathrm{Cr}_{2} \mathrm{O}_{3} ; 20.3 \mathrm{wt} \%\right.$ $\mathrm{Al}_{2} \mathrm{O}_{3}$; and $1.0 \mathrm{wt} \% \mathrm{Na}_{2} \mathrm{O}$ ), meionite, and anatase. Primary fluid inclusions are either two-phase (liquid + gas) or three-phase (liquid + gas + daughter phases), but melt inclusions were not reported. The comparison of clinopyroxene-ruby thermometry at Cudgegong-Macquarie suggested ruby formation at temperatures between 1000 and $1300{ }^{\circ} \mathrm{C}$. The $\mathrm{P}-\mathrm{T}$ diagram showing thermometric paths for Al-rich diopside-ruby pairs from different ruby deposits in Thailand and Australia represented in Figure 24 [75,81]. Saminpanya et al. [146] confirmed the presence of inclusions of garnet (pyrope), Al-rich diopside, and sapphirine in Thai rubies. They proposed that the rubies crystallized in high-pressure metamorphic rocks of UMR composition in the upper mantle.

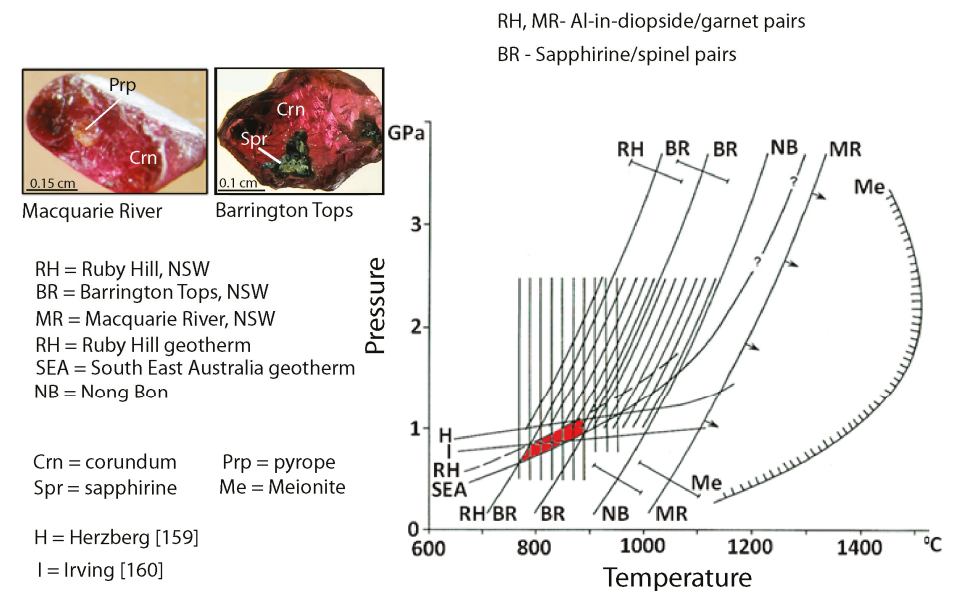

Figure 24. Thermometric traces for mineral inclusion pairs for rubies from Australia (Ruby Hill, Barrington Tops, and Macquarie River) and Thailand (Nong Bon), modified from [81]. The P (GPa)-T $\left({ }^{\circ} \mathrm{C}\right)$ diagram is based on $\mathrm{Al}$ - in diopside/garnet and sapphirine/spinel pairs, after $[75,136]$. The traces intersect the $\mathrm{T}$ range for Barrington Tops rubies (vertical lines), the East Australian ruby-bearing xenolith-derived Mesozoic garnet granulite (RH) and late Cenozoic (SEA) geotherms, the garnet to spinel pyroxenite transition of [159] (H), and the garnet-clinopyroxene-plagioclase transition of [160] (I). The red area represents P 6-8 kbar for the Barrington Tops ruby suite. The extreme Al-rich diopside and meionite-bearing Macquarie River ruby suggests a P-T crystallization between thermometric trace (MR) and the meionite stability boundary (Me). 
(3) Sutthirat et al. [154] studied different types of xenoliths contained in basalts from Bo Rai viz. (1) peridotites; (2) clinopyroxenites; and (3) ruby-bearing mafic granulites with plagioclase-clinopyroxenespinel-garnet. Peridotitic xenoliths have characteristics of depleted mantle (lherzolite to harzburgite and dunite) and the P-T estimates yielded approximately $1000-1300{ }^{\circ} \mathrm{C}$ at 1.6-1.9 GPa. Clinopyroxenite and mafic granulites xenoliths are mantelic cumulates formed at P-T, respectively, between 950 and $1200{ }^{\circ} \mathrm{C}$ and 1.6 and $2.2 \mathrm{GPa}$, and 700 and $1000{ }^{\circ} \mathrm{C}$ and 0.95 and $1.3 \mathrm{GPa}$. The xenoliths suffered a few metamorphic events and the authors argued that ruby formation is clearly related to mafic granulite xenoliths (which appear to have formed at about $30-50 \mathrm{~km}$ depths before transport by basaltic eruption).

(4) The Soamiakatra ruby deposit in the Antsirabe area, Antananarivo province, was an economic in situ mining site such as at Pailin, Cambodia, where ruby was found either as xenocrysts in alkali basalt or in xenoliths brought to the surface by the Cenozoic Ankaratra volcanism [77]. The deposit at Morarano known as Soamiakatra [95,161-163] was discovered in 1997. Ruby has been extracted by panning from alluvial and soils, but prospecting and mechanization of operations exposed the weathered primary deposit at the top of the basaltic plug (Figure 25A). The ruby-bearing clay and phyllitic material of whitish color (20 m thick) was exploited for two years before bedrock was reached (Figure 25B). The secondary deposit assured an easy and effective ruby production of high quality.
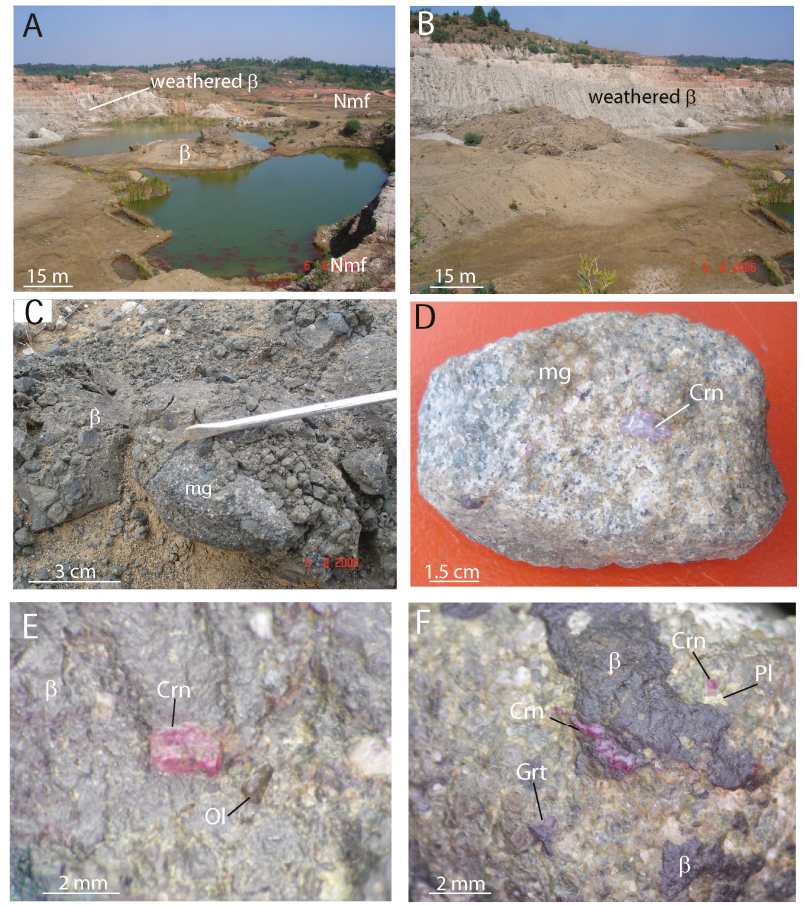

Figure 25. The Soamiakatra ruby deposit (Madagascar). (A) View of the quarry showing the contact of the alkali basalt $(\beta)$ plug with the Neoproterozoic metamorphic formations (Nmf). The economic weathered upper zone of the alkali basalt $(\beta)$ was mined in the past up to the non-weathered basalt; (B) aspect of the ruby-bearing weathered basaltic zone, around $20 \mathrm{~m}$ thick, mined in benches; (C) ruby-bearing metagabbro xenolith $(\mathrm{mg})$ carried by the alkali basalt $(\beta)$; (D) macroscopic aspect of a ruby (Crn)-bearing metagabbro xenolith $(\mathrm{mg})$; (E) xenocryst of ruby with an olivine (Ol) crystal in the alkali basalt $(\beta)$; and $(\mathrm{F})$ ruby-garnet $(\mathrm{Grt})$-plagioclase $(\mathrm{Pl})$-bearing metagabbro crosscut by the alkali basalt $(\beta)$ flow. Photos: Gaston Giuliani and Saholy Rakotosamizanany. 
The alkali basalt dyke intruded graphitic gneisses, khondalites, and migmatites of the Neoproterozoic Ambatolampy and Tolongoina series. The alkali basalt hosts numerous enclaves and xenoliths (Figure 25C), 2-20 cm across, of crustal (gneiss, migmatite, and granitoid) and mafic (peridotite, clinopyroxenite, gabbro, and garnetite) origin. Ruby was found: (1) as xenocrysts up to $2 \mathrm{~cm}$ across in the alkali basalt (Figure 25E); (2) in clinopyroxenite xenoliths composed of plagioclase (labradorite and bytownite), scapolite (meionite), garnet (pyrope), clinopyroxene (Al-diopside), orthopyroxene $(85 \mathrm{~mol} \% \mathrm{En}$ ), and pargasite; and (3) in banded metagabbro (Figure 25D,F) composed of alternating dark and greyish ruby-bearing bands. The dark bands contain pyrope (Figure 26A,C), plagioclase (labradorite-bytownite), $\mathrm{Mg}( \pm \mathrm{Cr}$ )-spinel, scapolite (meionite), Al-diopside, and orthopyroxene (85 $\mathrm{mol} \% \mathrm{En}$ ). The greyish band is made up of labradorite-bytownite, diopside, magnesian spinel, sapphirine (Figure 26D), some calcite, and pyrope. Diopside formed as a clean and clearly visible corona around both corundum and $\mathrm{Mg}( \pm \mathrm{Cr}$ )-spinel (Figure 26D). Two generations of clinopyroxene are discriminated (Figure 26A,B): (1) early Al-rich crystals (13-17.5 wt \% $\mathrm{Al}_{2} \mathrm{O}_{3}$ ), 1-2 mm across, associated with plagioclase, garnet, and scapolite (Cpx1), and (2) late and less Al-rich crystals (5-8.8 wt \% $\mathrm{Al}_{2} \mathrm{O}_{3}$, Cpx2), 10-40 $\mu \mathrm{m}$ across, formed around Cpx1 (Figure 26B) or as inclusions in ruby.
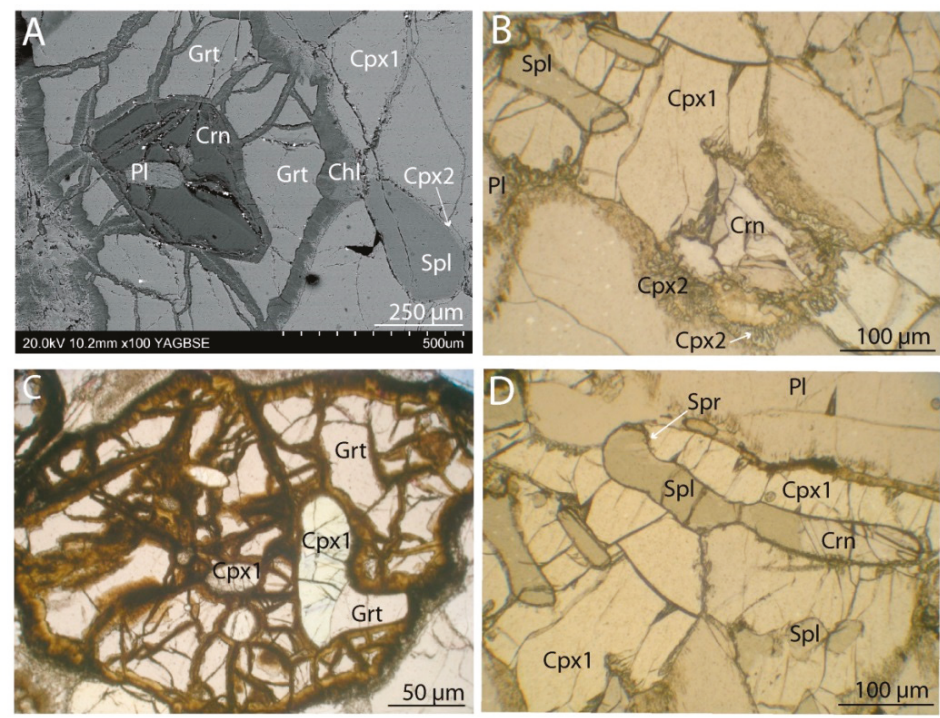

Figure 26. Petrographic aspects of the metagabbroic xenoliths in the Soamiakatra ruby deposit. (A) Plagioclase (Pl)-bearing ruby (Crn) within garnet (Grt). Garnet (pyrope) associated with an Al-rich clinopyroxene (Cpx1) and showing a keliphitic texture. The keliphitic halo is composed of small grains of chlorite (Chl). The spinel ( $\mathrm{Spl}$ ) and $\mathrm{Cpx} 1$ are bordered by a second generation of clinopyroxene (Cpx2); (B) association ruby-Cpx1-plagioclase (Pl)-spinel. The ruby formed upon Cpx1 while small crystals of Cpx2 formed later; (C) inclusions of Cpx1 in pyrope (Grt); and (D) association spinel-ruby with Cpx1 with plagioclase. Spinel is bordered by sapphirine (Spr). Photos: Saholy Rakotosamizanany.

Mineral inclusions in the ruby consist of phlogopite, rutile with some lamellar exolutions of ilmenite, zircon, albite, Al-pyroxene, garnet (pyrope), and $\mathrm{Mg}$-spinel. The trace element chemistry of the ruby is characterized by low $\mathrm{Ga}_{2} \mathrm{O}_{3}$ (between 70 and $110 \mathrm{ppm}$ ) and high $\mathrm{Cr}_{2} \mathrm{O}_{3} / \mathrm{Ga}_{2} \mathrm{O}_{3}$ ratios (see Figure 16). Vanadium varies from less than 22 to $860 \mathrm{ppm}$. Titanium ranges between 60 and $940 \mathrm{ppm}$, and $\mathrm{Cr}$ between 350 and $3830 \mathrm{ppm}$. The Soamiakatra rubies fall into the metamorphic domain defined by [68] when plotted on the $\mathrm{Fe}_{2} \mathrm{O}_{3} / \mathrm{TiO}_{2}$ versus $\mathrm{Cr}_{2} \mathrm{O}_{3} / \mathrm{Ga}_{2} \mathrm{O}_{3}$ diagram (see Figure 16).

Petrographic examinations showed two main stages for the mineral assemblages: (1) the first stage is typified by the association Cpx + garnet + scapolite + ruby, and spinel + ruby + garnet. The spinel 
is always surrounded by a ring of ruby, clinopyroxene, and sapphirine, and the mineral association is in turn haloed by coronitic garnet. Thermodynamic calculations constrained the P-T estimates of the assemblages to around $1100{ }^{\circ} \mathrm{C}$ and $2 \mathrm{GPa}$; (2) the second stage results in the destabilization of scapolite to anorthite + calcite with the destabilization of some Al-diopside in pargasite, and also the reaction spinel + ruby to sapphirine $\left(\mathrm{T} 1100{ }^{\circ} \mathrm{C}\right.$ and $\left.\mathrm{P} 15 \mathrm{GPa}\right)$

The P-T conditions of around $1100^{\circ} \mathrm{C}$ and $2 \mathrm{GPa}$ clearly show that the xenoliths originated from the upper mantle and that the metagabbros experienced the eclogite facies. During decompression the mineral assemblage was marked by the destabilization of Cpx1 and the formation of Cpx2 (in the granulite facies). Rakotosamizanany et al. [77] hypothesized that the ruby formed in M-UMR at the base of the lower crust-upper mantle and was later transported to the surface by the alkali basalt. The oxygen isotopic composition of the rubies $\left(1.25 \% \circ<\delta^{18} \mathrm{O}<5 \%, n=5\right)$ is within the range of values defined for ruby in basaltic environments $\left(1.25 \%\right.$ o $<\delta^{18} \mathrm{O}<5.9 \%$ o, $n=4$; mean $\delta^{18} \mathrm{O}=3.1 \pm 1.1 \%$ o, $\left.n=80\right)$ and in metamorphosed M-UMR $\left(0.25 \%\right.$ o $<\delta^{18} \mathrm{O}<6.8 \%, n=19$; [163]. Rubies from Chantaburi-Trat volcanics have similar O-isotopic ranges $\left(1.3 \%\right.$ o $<\delta^{18} \mathrm{O}<4.2 \%$; [152]) and the $\mathrm{P}-\mathrm{T}$ conditions are identical to those proposed for the Soamiakatra rubies.

(5) Occurrences of ruby in the Neoproterozoic Vohibory formation from Southern Madagascar (see Figure 1E) are found in M-UMR complexes of meta-peridotite, -gabbro, and -troctolite transformed into amphibolites and serpentinites with anorthositic dykes [116]. The ruby occurrences include Anavoha, Gogogogo, Maniri, Vohitany, Ianapera, and Marolinta [164]. The ruby frequently occurs in sapphirine or gedrite and locally garnet (pyrope-almandine)-bearing amphibolites and locally anorthosite [122]. These rocks are associated with garnet-bearing granulites (salite + almandine + hornblende + andesine). At Anavoha, ruby occurs with (1) sapphirine or gedrite + garnet, and (2) anorthosite with ruby + garnet + anorthite. These ruby-bearing rocks are associated with a coronitic metatroctolite.

The transition is sharp between the metatroctolite and the sapphirine or gedrite amphibolites and gradual between the garnet ( $50 \%$ almandine-35\% pyrope)-ruby-bearing anorthosite and amphibolites. The ruby is surrounded by a corona of green spinel and anorthite and the mineralogical association is gedrite + anorthite + garnet $(60 \%$ pyrope $)+$ ruby \pm spinel. Sometimes the ruby is totally replaced by spinel. The $\mathrm{P}-\mathrm{T}$ conditions of ruby formation during the Neoproterozoic metamorphism was estimated at $\mathrm{P}=0.9-1.15 \mathrm{GPa}$ and $750-800{ }^{\circ} \mathrm{C}$ [116], similar to those reported by [75] for the ruby-bearing xenolith of Ruby Hill in Australia.

At Vohitany and Anavoha, ruby is also found in desilicated pegmatites at the contact of amphibolites.

We previously examined the origin of ruby transported to the surface by basaltic volcanism by studying examples from Thailand, Australia [81], and Madagascar. Mafic cumulate xenoliths are rare worldwide and [154] showed that mantle and deep crustal xenoliths from the Bo Rai ruby deposit were the probable source of "basaltic rubies" mined in placers from Thailand and Cambodia. The Cpx-Spl-Grt $\pm(\mathrm{Ol}) \pm(\mathrm{Opx})$ and $\mathrm{Pl}-\mathrm{Cpx}-\mathrm{Spl} \pm(\mathrm{Grt}) \pm(\mathrm{Crn})$ assemblages were considered to be two different types of mafic cumulates with high $\mathrm{Al}_{2} \mathrm{O}_{3}$ contents that suffered metamorphic overprints [154]. P-T constraints based on textural observations gave estimated depths of formation between 30 and $80 \mathrm{~km}$. These xenoliths are similar to those reported for ruby-related alkali basalts from Madagascar [77]. At Soamiakatra, the estimated temperature $1100{ }^{\circ} \mathrm{C}$ and pressure $2 \mathrm{GPa}$ of ruby formation are comparable to those proposed for mafic cumulates from Bo Rai. Al-rich clinopyroxene-pyrope-anorthite is the main assemblage of these ruby-bearing metagabbros and clinopyroxenites. Spinel and ruby are associated but ruby also formed at the expense of clinopyroxene.

The probable original source of the ruby in the mafic cumulates carried by Cenozoic alkali basalt plugs in the Ankaratra massif is visible in the Neoproterozoic metamorphic rocks of the Vohibory formation in Southern Madagascar. The ruby-bearing amphibolites and anorthosites are the fruit of the metamorphic transformation of a magmatic cumulate complex.

The presence of melt inclusions as described by $[105,148,149]$ opened the debate about the possibility of "magmatic" ruby. The genetic model proposed by [105], i.e., an anorthosite 
converted at higher pressure to a garnet-clinopyroxenite, is debatable but not applicable for ruby in Madagascar. The melt inclusions can result either from an incongruent melting of plagioclase during metamorphism [165] or directly through a peritectic melting reaction involving plagioclase or other al-rich minerals. In consequence, most rubies in alkali basalts can be considered actually as metamorphic in origin but the presence of primary melt inclusions in ruby [105] indicates that a free magma phase existed during ruby growth. Additional studies characterizing carefully the inclusions in more basalt-related rubies would be helpful to shed more light on the two possible origins, i.e., metamorphic versus magmatic. The ruby-bearing mineral assemblages described in M-UMR, metamorphosed and recrystallized at depth within the mantle, at Beni Bousera, Morocco [166,167] and Ronda, Spain [97], and considered of metamorphic origin, can be described as a potential restitic component of a partially melted mafic M-UMR protolith?

The $\delta^{18} \mathrm{O}$ values of ruby from the Soamiakatra, Bo Rai, Pailin, Barrington, Anavoha, and Beni Bousera occurrences fit within the worldwide range defined for ruby in basaltic environments $\left(1.25 \%\right.$ o $<\delta^{18} \mathrm{O}<5.9 \%$, mean $\delta^{18} \mathrm{O}=3.5 \pm 1.3 \%$, $\left.n=57\right)$ and ruby associated with M-UMR $\left(1.25 \%\right.$ o $<\delta^{18} \mathrm{O}<7.0 \%$, mean $\delta^{18} \mathrm{O}=5.0 \pm 1.2 \%$ o, $n=32 ;$ [84], Figure 27). Both ranges of $\delta^{18} \mathrm{O}$ values overlap and are closed to the $\delta^{18} \mathrm{O}$ mantle value of $5.5 \pm 0.4 \%$ [168]. Nevertheless, the genetic source of ruby, i.e., strictly metamorphic or magmatic cannot be specified as the oxygen isotopic composition of ruby is largely buffered by that of its protolith, whether metamorphic or magmatic [92].

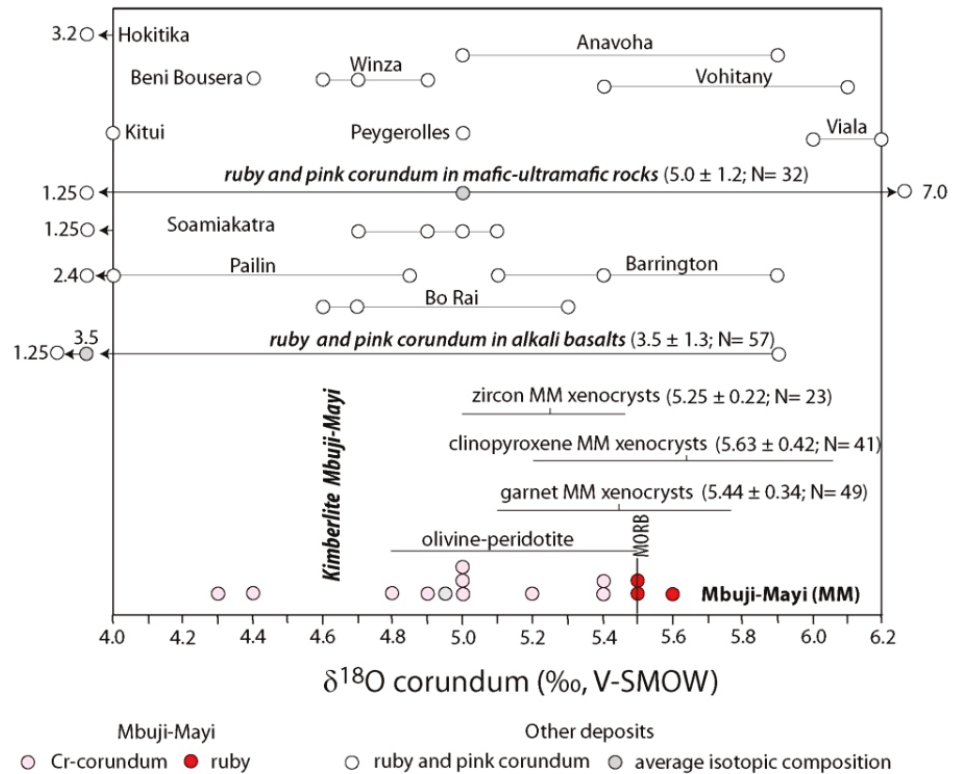

Figure 27. Oxygen isotope ranges defined for different ruby and pink corundum deposits and occurrences related to metamorphosed mafic-ultramafics and alkali basalts worldwide as well as the kimberlite at Mbuji-Mayi, modified from [84]. The data are reported in the conventional delta notation relative to V-SMOW (Vienna Standard Mean Ocean Water). The $\delta^{18} \mathrm{O}$ values for zircon, clinopyroxene, and garnet megacrysts from the Mbuji-Mayi kimberlites are from [163]. The deposits that occur in amphibolites are Anavoha and Vohitany (Madagascar), Viala and Peygerolles (France), Kitui (Kenya), and Winza (Tanzania). The Hokitika (New Zealand) and Beni Bousera (Morocco) occurrences are linked to metamorphosed M-UMR. 
6.1.2. Sub-Type IB: Metamorphic Rubies as Xenocrysts in the Mbuji-Mayi Kimberlite (Democratic Republic of Congo; See Figure 2, Table 3)

Ruby has been described as micrometric crystal inclusions in diamond at Juina in Brazil [43,169-171]. Crystals of ruby and Cr-bearing corundum (up to $2 \mathrm{~cm}$ ) xenocrysts have been found in the Mbuji-Mayi kimberlite in the Democratic Republic of Congo [84]. The kimberlite contains megacrysts of garnet and diopside [172], zircon and baddeleyite, and also Mg-rich ilmenite, $\mathrm{Nb}$ - or Cr-rich rutile, corundum, kyanite, Mg-rich chlorite, and rutile-silicate intergrowths [173]. The $0.5-2 \mathrm{~cm}$-sized corundum megacrysts are:

(1) Gem rubies from red to fuchsia and flashy-pink deep pink rubies $(n=3)$ that contain Cr-bearing spinel (with $\mathrm{Cr}_{2} \mathrm{O}_{3}$ up to $1.5 \mathrm{wt} \%$ ), chromite, and rutile. The rubies have very high contents of $\mathrm{Cr}_{2} \mathrm{O}_{3}$ (0.71-4.59 wt \%) and FeO (0.22-0.66 wt \%). Vanadium is between 986 and 1867 ppm, and Ti less than $68 \mathrm{ppm}$. The contents of $\mathrm{MgO}(31-100 \mathrm{ppm})$ and $\mathrm{Ga}_{2} \mathrm{O}_{3}(50-193 \mathrm{ppm})$ range to moderate levels with a low $\mathrm{Ga} / \mathrm{Mg}$ ratio (0.6-2.6, see Figure 19).

In the diagram FeO- $\mathrm{Cr}_{2} \mathrm{O}_{3}-\mathrm{MgO}-\mathrm{V}_{2} \mathrm{O}_{3}$ versus $\mathrm{FeO}+\mathrm{TiO}_{2}+\mathrm{Ga}_{2} \mathrm{O}_{3}$ [84], the three rubies plot in the domain R3 of M-UMR (Figure 28):
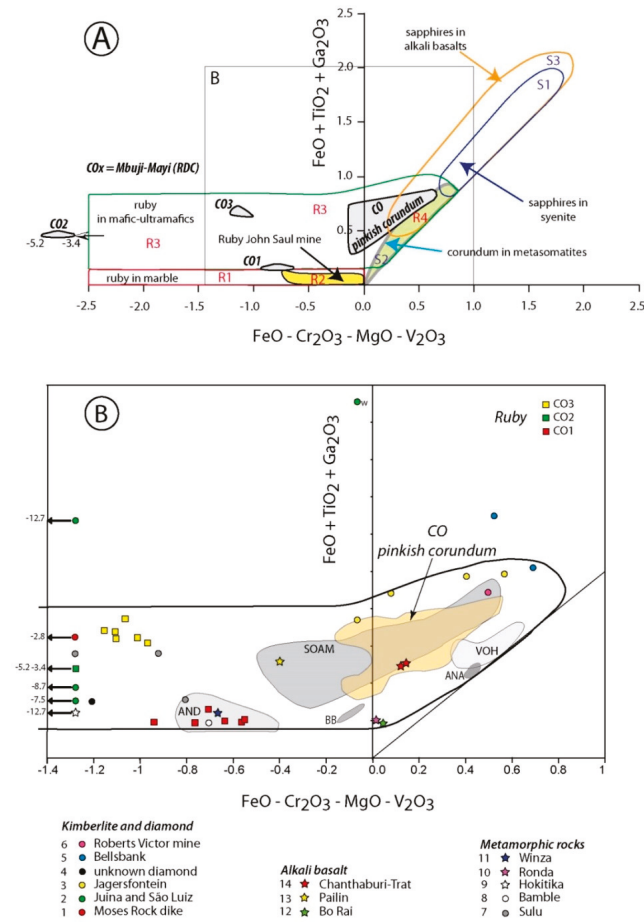

Figure 28. Chemical variation of ruby and pinkish corundum from the Mbuji-Mayi kimberlite in the Democratic Republic of Congo. (A) The FeO- $\mathrm{Cr}_{2} \mathrm{O}_{3}-\mathrm{MgO}-\mathrm{V}_{2} \mathrm{O}_{3}$ versus $\mathrm{FeO}+\mathrm{TiO}_{2}+\mathrm{Ga}_{2} \mathrm{O}_{3}$ (analysis in wt \%) classification diagram, modified from [84]. The different chemical fields of the studied corundum are reported with respectively those for ruby (samples CO1, CO2, and CO3) and pinkish corundum (CO, yellowish field); (B) Field of chemical compositions of the ruby and pink sapphires from Mbuji-Mayi. Different chemical fields are reported for ruby from Beni Bousera in Morocco (BB), Soamiakatra (SOAM), Anavoha (ANA), Vohitany (VOH), and Andriba (AND) from Madagascar. Other representative compositions of ruby from occurrences in kimberlite and diamond, alkali basalt, and metamorphic rocks are also shown; modified from [84,164]. 
(a) The field of sample $\mathrm{CO} 1$ overlaps the plots of rubies from Andriba in Madagascar hosted in ultramafics [174], the Winza deposit in Tanzania located in amphibolite and metagabbro [120], high-grade Proterozoic orthoamphibolites of the Bamble area in Norway [43], and ultrahigh pressure ruby-rich garnetite layers in garnet lherzolite in the Sulu terrane of China [175].

(b) The field of sample $\mathrm{CO} 2$ is defined by the very high $\mathrm{Cr}_{2} \mathrm{O}_{3}$ content of ruby up to $4.6 \mathrm{wt} \%$. Chromium-rich ruby is rare and found in the Brazilian São Luiz alluvial deposit and in the Juina kimberlite [43,170], the Moses Rock Dyke kimberlite in Utah [176], the metagabbros at Karelia in Russia [41], and in the serpentinite at Hokitika in New Zealand [42].

(c) The field of sample CO3 is comparable to the chemical composition of ruby-bearing garnetite xenolith in garnet peridotite from the Sulu terrane in China [175].

The rubies have a restricted range of $\delta^{18} \mathrm{O}$ values from $5.5 \%$ o to $5.6 \%$ o $(n=3$; Figure 27$)$. They fit within the worldwide O-isotopic range of rubies associated with metamorphosed M-UMR.

(2) Cloudy pinkish to greyish corundum $(n=10)$, which are host to inclusions of Mn-rich ilmenite, margarite, and rutile. They are richer in $\mathrm{FeO}(0.38-0.75 \mathrm{wt} \%)$ than rubies and they always contain some $\mathrm{Cr}_{2} \mathrm{O}_{3}(0.08-0.58 \mathrm{wt} \%)$ and $\mathrm{V}(318-1128 \mathrm{ppm})$. The $\mathrm{Ga} / \mathrm{Mg}$ ratio (1.95-3.95) is in the range of, or above, the $\mathrm{Ga} / \mathrm{Mg}$ ratio of ruby. They have $\delta^{18} \mathrm{O}$ values in the range $4.3-5.4 \%$ with a mean $\delta^{18} \mathrm{O}$ value of $4.9 \pm 0.4 \%$ o $(n=10$; Figure 27), within the accepted range of mantle values [168]. These oxygen isotope values are within the range of values defined for ruby xenocrysts or megacrysts carried to the surface by alkali basalts [84]. They are also similar to those found for ruby in eclogites derived from oceanic crust [166] and hosted by clinopyroxene xenocrysts from Bo Rai alkali basalt alluvials as well as those from the Soamiakatra metagabbros.

Kimberlites, like alkali basalts, are conveyors of gems (respectively diamond and corundum) from the asthenosphere and/or lithosphere to the upper crust [86,177]. Ruby and sapphire inclusions in diamond are rare and corundum xenocrysts or megacrysts in kimberlites are exceptional. On the contrary, diamond has never been found as inclusions in corundum or within xenocrysts in alkali basalts. The chemistry and oxygen isotope composition of ruby from Mbuji Mayi allow for different possible origins:

(1) An upper mantle-derived material (garnet lherzolite, garnetite and pyroxenite) that could have been infiltrated and metasomatized by the kimberlite melt, or a high-pressure orogenic peridotite; or (2) eclogite-type xenoliths (omphacitic clinopyroxene-bearing metagabbro and/or clinopyroxenite) affected by a retrograde metamorphic stage in the granulite facies at the base of the continental crust (Figure 29).

The pinkish to greyish corundum could also have different probable origins: either as subducted oceanic crust transformed into eclogite, or as clinopyroxenite layers/horizons in peridotite.

\subsection{Metamorphic-Related (Type II)}

6.2.1. Sub-Type IIA: Metamorphic Deposits Sensu Stricto with Two Different Types Formed in Amphibolite to Granulite Facies (See Table 3)

Sub-Type IIA $\mathrm{A}_{1}$ includes ruby in metamorphosed mafic and ultramafic rocks (M-UMR) as found at Montepuez in Mozambique (see Table 3).

Ruby and pink corundum in metamorphosed M-UMR called "ruby in amphibolite" by some gemmologists originate from the metamorphism of gabbroic and dunitic rocks from ophiolites or volcano-sedimentary sequences. These deposits are the main sources of pink and red corundum but generally not of gem quality material. 


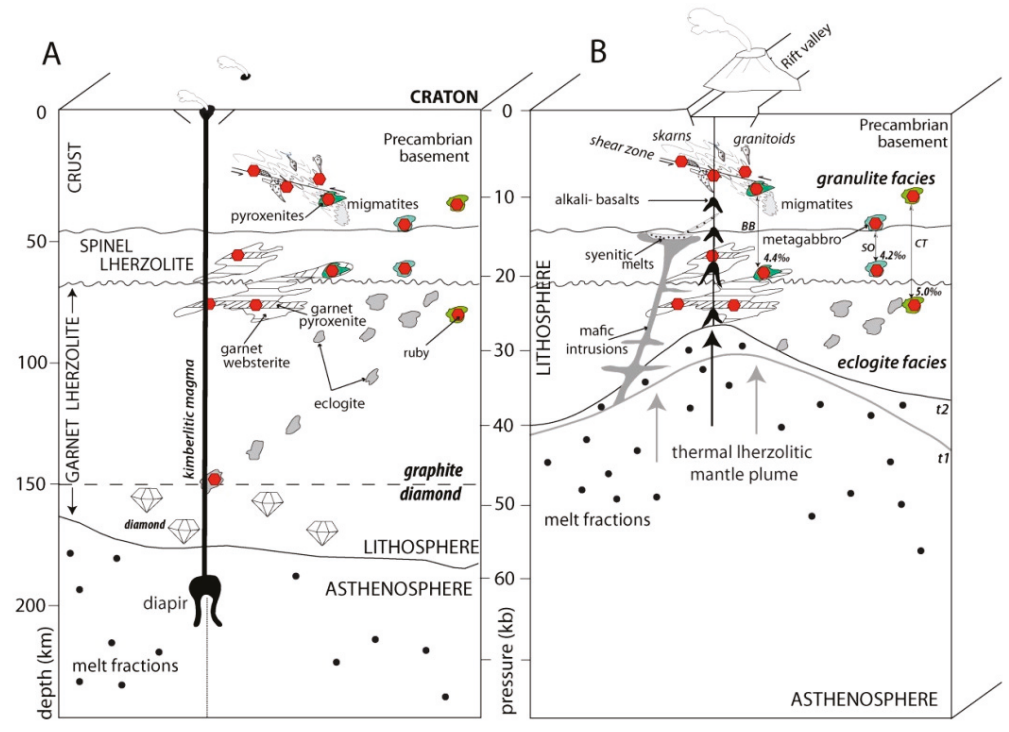

Figure 29. Schematic genetic models for gem corundum related to kimberlite (A) and alkali basalt (B) environments, modified from [178-180]. The drawings show the different types of corundum occurrences hosted in Precambrian basements in the crust, and lherzolites in the lithosphere. Selected ruby occurrences are indicated (with their corresponding $\delta^{18} \mathrm{O}$ composition, in \%o) including the Beni Bousera (BB) garnet clinopyroxenite, the Soamiakatra (SO) garnet metagabbro and -clinopyroxenite, and the Chanthaburi-Trat (CT) pyroxene inclusion in ruby, with their retrograde metamorphic location in the granulite facies. Panel (B) shows ruby deposits associated with alkali basalt in continental extension domains characterized by thermal anomalies linked to mantle plumes and rift valley fracturing and volcanism in the upper part of the crust. $\mathrm{t} 1$ and $\mathrm{t} 2$ are two successive ascent stages of the alkali basalt magmatism.

The crystals are used for cabochon cut and ornamental artifacts such as the famous 'anyolite' from Longido in Tanzania [181-183] (see Figure 4B). Such ruby deposits in amphibolite and gabbro are known (see Figure 2) from Kittilä in Finland [184], Sittampundi in India [185], Chantel in France [186], Paranesti in Greece [95,187], Lossogonoi in Tanzania [181], Kitui in Kenya [188], Chimwadzulu in Mozambique [189,190], the Vohibory formations in Madagascar [119,122,164] (see Figure 1E), the Harts Range in Australia [191,192], Dir in Pakistan [193], Hokkaido in Japan [194], and some of the deposits in North Carolina in the USA $[5,121,195]$. In Africa, the ruby deposits discovered in the last decade are highly economic for their color, clarity, and quantity; these are Winza in Tanzania $[120,196,197]$ (see Figure 4C), and at Montepuez, Ruambeze, and M'sawize in Mozambique [21-23,25,26,96,198] (see Figure 1C).

The common mineral assemblage of the ruby-bearing amphibolite includes corundum, anorthite, amphibole (gedrite, pargasite), and margarite [21,22,121,122]. Others minerals including sapphirine, pyrope-almandine garnet, spinel, kornerupine, plagioclase, phlogopite, and zoisite may be present. The initial basic composition of the protolith includes gabbro, dunite, and troctolite [121,122,194,199].

(1) The ruby deposits at Longido and Lossogonoi in Northeastern Tanzania are hosted in amphibolite dykes that crosscut metamorphosed M-UMR (Figure 30). At Longido, the ruby is located in amphibolite dykes up to $1 \mathrm{~m}$ thick that are oriented parallel to the metamorphic foliation [118]. The dykes crosscut a serpentinite with relics of olivine and orthopyroxene. They are retromorphosed to a rock composed of zoisite and ruby called "anyolite" (green stone in Massai language). The contact of the dyke with the serpentinite is outlined by the presence of phlogopite and Mg-amphibole schist. 
The mineral assemblage in the amphibolite is anorthite + corundum + amphibole + green spinel while the anyolite contains zoisite + corundum \pm tschermakite. The age of formation of the ruby obtained on zircon by the $\mathrm{U} / \mathrm{Pb}$ method is $610 \mathrm{Ma}$ [124].

(2) At the Winza deposit in central Tanzania, high-quality ruby and sapphires have been recovered from an eluvial deposit. Mining revealed that the gem corundum crystals are embedded in dark amphibolite $[120,196,197]$. The corundum is locally associated with areas of brown to orangey garnet \pm feldspar, with accessory Cr-spinel, mica, kyanite, and allanite. The ruby and sapphire crystals are closely associated with dykes of a garnet- and pargasite-bearing rock crosscutting amphibolite (Figure 31A). The central part of the dyke is composed of garnet (pyrope-almandine) + pargasite \pm plagioclase \pm corundum \pm spinel \pm apatite. Metamorphic conditions estimated from the garnet-amphibole-corundum equilibrium assemblage are T $800 \pm 50{ }^{\circ} \mathrm{C}$ and $\mathrm{P}$ 8-10 kbar [120]. The rubies and pink corundum are zoned with rhombohedral twin planes. The rubies exhibit a suite of inclusions with amphibole, garnet, apatite, and opaque minerals (chalcocite). Medium and vivid red rubies have orange-brown hair-like inclusions of unknown composition [120]. The chemical compositions of the Winza ruby and pink sapphires (Figure 31B) include moderate contents of $\mathrm{Cr}\left(0.1-0.8\right.$ wt \% $\left.\mathrm{Cr}_{2} \mathrm{O}_{3}\right)$ and $\mathrm{Fe}\left(0.2-0.8\right.$ wt \% $\left.\mathrm{Fe}_{2} \mathrm{O}_{3}\right)$, very low to low amounts of $\mathrm{Ti}$ (55-192 ppm $\mathrm{TiO}_{2}$ ) and $\mathrm{V}$ (up to $164 \mathrm{ppm} \mathrm{V}_{2} \mathrm{O}_{3}$ ), and low to moderate $\mathrm{Ga}$ (64-146 ppm $\mathrm{Ga}_{2} \mathrm{O}_{3}$ ).
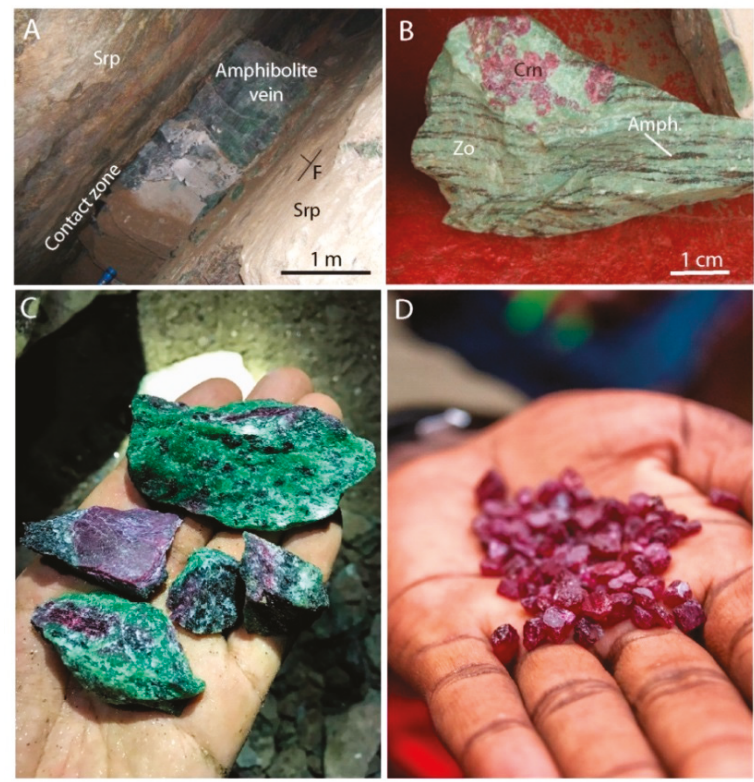

Figure 30. The ruby-bearing amphibolite from Longido, Northern Tanzania. (A) The amphibolite dyke, which is up to $1 \mathrm{~m}$ thick and parallel to the metamorphic foliation, crosscuts a serpentinite. The contact zone between the two rocks is marked by the presence of a phlogopite and amphibole-bearing schist. Photo: Elisabeth Le Goff; (B) anyolite with patches of ruby (Crn) and retrograde zoisite (Zo). Remnants of the amphibolite (Amph) highlight the metamorphic foliation. Photo: Elisabeth Le Goff; (C) representative samples of anyolite with ruby and black amphibole (tschermakite). Photo: Vincent Pardieu; (D) ruby crystals extracted from new veins that are very different to the classical massive ruby of Longido. Photo: Vincent Pardieu.

(3) The majority of gem-quality rubies from Africa are from deposits located in metamorphosed M-UMR from the Neoproterozoic Metamorphic Mozambique Belt (NMMB). The Rockland mine was the main producer of cabochon-grade ruby until the discovery of the Winza deposit in 2007. Then, 
the confirmed presence of ruby in the Niassa National Reserve in Mozambique in 2008 opened the economic reign of Mozambique over the production of very high quality rubies worldwide as in the Montepuez mining district (Figure 32) $[21,22,198,200,201]$. A review and summary of the history, geology, and gemmological properties of ruby from Mozambique was recently published by [26].

The NMMB is subdivided into several complexes grouped in four geological entities, which are from west to east [202-204]: (1) the Ponta Messula complex; (2) the Unango and Maruppa complexes; (3) the Nampula complex; and (4) the east-west Pan-African overthrusts (e.g., Nairoto, Meluco, Muaquia, M'sawize, Xixano, Lalamo, and Montepuez), which form the Cabo Delgado complex overlying the Marrupa complex (see Figures 2-42 from [40]). The ruby deposits are within the Cabo Delgado complex:

(a) The Ruambeze (or Luambeze) deposit, in Niassa province, is located between Marrupa and Meculo along the Luambeze River. It was apparently discovered in 1992 [21] and it has produced dark red to brown cabochon grade material.

(b) The M'sawize deposit, in Niassa province, is located in the Niassa National Reserve, about $43 \mathrm{~km}$ southeast of M'sawize village [21]. The M'sawize complex is composed of orthogneiss and paragneiss. The M'sawize ruby deposit is hosted by metagabbro and gabbroic gneiss [22]. The ruby is associated with actinolite, anorthite, scapolite, epidote, and diopside, as well as with eluvial ruby-rich soil [22]. Ruby has Fe and Cr oxide contents between 0.28 and 0.33 and 0.12 and $0.48 \mathrm{wt} \%$, respectively, which fall in the range of the Winza ruby from Tanzania [23].
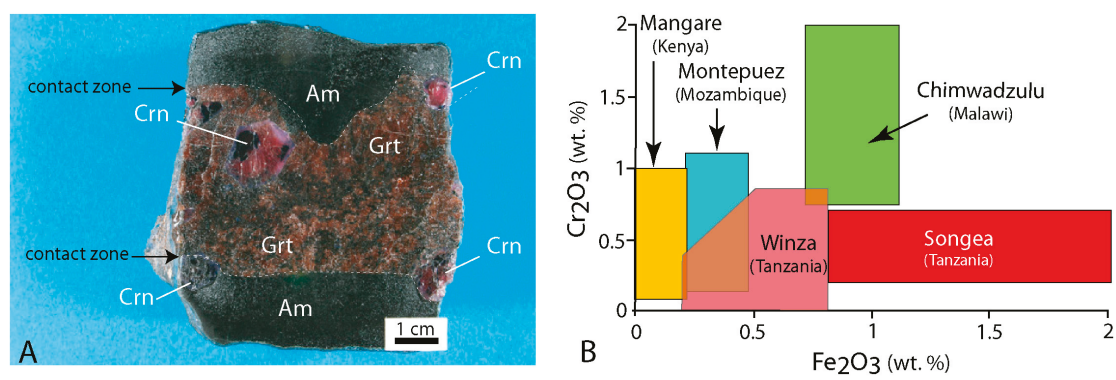

Figure 31. The Winza ruby deposit in Tanzania. (A) The primary ruby and sapphire (Crn) mineralization is hosted by an orangey brown garnet-rich rock (Grt) intercalated in a fine-grained amphibolite (Am). Photo: Patrick Lagrange; (B) the $\mathrm{Cr}_{2} \mathrm{O}_{3}$ versus $\mathrm{Fe}_{2} \mathrm{O}_{3}$ diagram showing the chemical composition of the Winza rubies compared with those from other ruby deposits hosted in metamorphosed M-UMR in the Neoproterozoic Metamorphic Mozambique Belt: Chimwadzulu (Malawi), Mangare (Kenya), Montepuez (Mozambique), and the placers at Songea (Tanzania).

(c) The Namahumbire and Namahaca deposits in Delgado province are together called the Montepuez deposits. The Cabo Delgado nappe complex represents the remnant of Neoproterozoic volcanic arcs and a microcontinent after $596 \pm 11 \mathrm{Ma}$ [205]. The lithological succession is very complex due to intense deformation but structural trends can be drawn from satellite images (Figure 32; [25]). The ruby area includes high-grade metamorphic rocks such as gneisses, migmatites, marbles, and amphibolites [96]. At the end of 2018, mining was being done by companies such as Fura Gems, Beleza Ruby, Gemfields, Mustang, and Redstone [25], and by numerous small-scale miners working either in community areas such as at Nacaca or illegally inside other company concessions.

Two types of deposits are known: (1) extensive secondary deposits, i.e., colluvials, which are the main source of faceted-grade material [25] (also see Chapter 6.3.2. Sub-Type IIIB) and (2) primary deposits in amphibolite $[96,198,200]$.

The primary deposit is made up of ruby- and pink corundum-bearing lenses of amphibolites in migmatitic gneiss. They contain amphibole (pargasite), anorthite, and mica $[22,96,200]$ (Figure 33). 


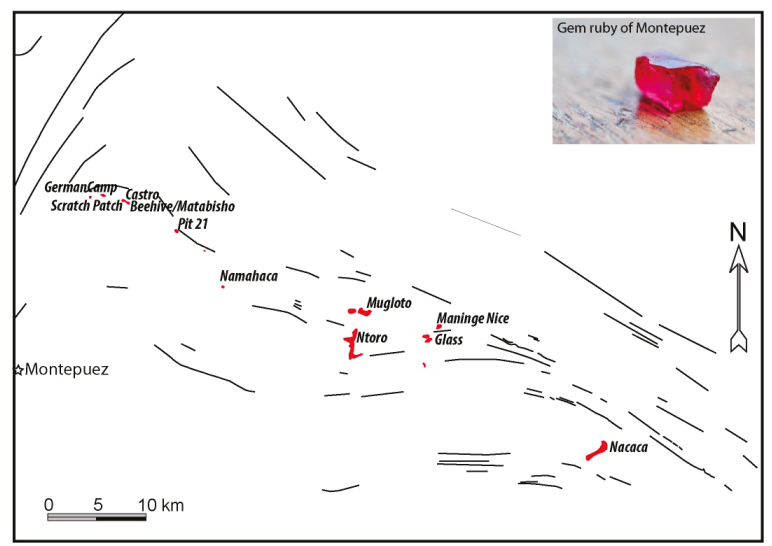

Figure 32. The Montepuez mining district with the different ruby mines of primary and mostly secondary deposits (drawn as red spots). The structural trends observed from both satellite imagery and field works are shown. The ruby mineralization defines a $\mathrm{N} 110^{\circ} \mathrm{E}$ trending zone that extends for $40 \mathrm{~km}$; modified from [25]. Crystal of ruby (size $1 \mathrm{~cm}$ long). Photo: Vincent Pardieu (C) GIA.
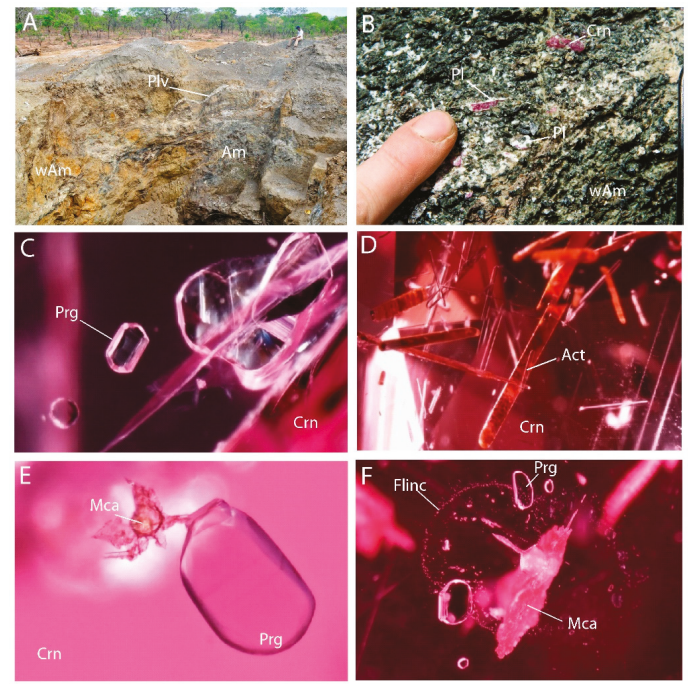

Figure 33. The Mozambican ruby deposits. (A) Ruby-bearing amphibolite (Am) at the M'sawize deposit, Niassa Province, 2009. The weathered amphibolite (wAm) is crosscut by whitish plagioclase veins (Plv); (B) the Maninge Nice deposit, Concession Gemfields, Montepuez, 2012. The ruby (Crn) is surrounded by a plagioclase corona ( $\mathrm{Pl}$, anorthite) in a weathered amphibolite (wAm); (C) euhedral pargasite (Prg) in ruby. Field of view $1.5 \mathrm{~mm}$; (D) inclusions of actinolite (Act) in ruby. Field of view $2.5 \mathrm{~mm}$; (E) crystal of pargasite associated with mica (Mca) in ruby. Field of view $1.1 \mathrm{~mm}$; (F) a melted mica (Mca) surrounded by a halo of fluid inclusions (Flinc) arranged in a "butterfly wing" indicative of decrepitation and recrystallization phenomena. The pargasite is euhedral and devoid of deformation. Field of view 1.7 mm. Photos A and B: Vincent Pardieu (C) GIA. Photos C to F: Jonathan Muyal (C) GIA.

The texture is granoblastic with $120^{\circ}$ triple junctions between amphibole and anorthite. The mineral assemblage formed during prograde metamorphism. The ruby often shows a corona 
of spinel + anorthite formed during the retrograde stage [96]. The ruby porphyroblasts have sizes between $1 \mathrm{~mm}$ and $1 \mathrm{~cm}$. The $\mathrm{P}-\mathrm{T}$ conditions of ruby formation $\left(\mathrm{P}=10-11.5 \mathrm{kbar}\right.$ and $\left.\mathrm{T}=450-600^{\circ} \mathrm{C}\right)$, calculated from $\mathrm{P}-\mathrm{T}$ pseudosections, show the lowest temperature of formation compared to similar ruby-bearing amphibolites (see Figure 21) such as at Mangare [119], Winza [120], North Carolina [121], and Vohibory [122]. These calculated P-T conditions obtained by pseudo-sections [97] for the formation of ruby of Montepuez is somewhat questionable because clinochlore (and quartz) is a retrograde mineral in M-UMR and not in equilibrium with ruby. Geochemical analyses of amphibolites indicated that the protolith was basaltic and associated with subduction-related arc magmatism [96], following the model proposed by [206] for the arc assembly and continental collision in the Neoproterozoic East African Orogen.

Sub-Type IIA $\mathrm{A}_{2}$ includes rubies in marble such as those of the Mogok Stone Track (Myanmar), and others from central and eastern Asia, Canada, and Tanzania, (see Table 3).

Ruby and pink corundum deposits hosted in marbles are known from Asia [5,30,65,103,112,115,134,207-210], North America [113,211], Europe [95,110], and Africa [48,110,114,182] (see Figure 2). These ruby deposits are hosted by meta-pure or impure limestone of carbonate platforms and are of two types: (1) in marble where the gem corundum crystallized as a result of prograde and retrograde isochemical metamorphic reactions, mainly in a closed system, and where the ruby occurs as disseminated crystals in marble, in Central and Southeast Asia and other places worldwide [65]; and (2) in impure marble containing gneiss and silicate layers where the ruby crystallized at the peak of prograde metamorphism, such as at Revelstoke in Canada [113,212], Snezhnoe in Tadjikistan [115,134], and Morogoro in Tanzania $[114,163]$.

(1) Ruby mines in marble in Central and South-East Asia.

These are one of the main worldwide sources of high-quality ruby with intense color and high transparency [5]. There is extensive literature on the geology and gemmology of these deposits; see $[5,29,40,65,80,87,88,110,133,143,156]$. Below we will present a short overview of the geology of these ruby deposits and focus on the significance of the mineral associations and geochemistry of the paleofluids in order to discuss the genesis of the corundum.

These deposits occur from Afghanistan to Southern China (see Figure 2) in marbles that are intercalated with garnet biotite-sillimanite- or biotite-kyanite-bearing gneisses, amphibolites, and quartzites (Figure 34A), which are sometimes intruded by granitoids, as in the Mogok district $[87,88,213]$. The marble units consist of discontinuous horizons up to $300 \mathrm{~m}$ in thickness, oriented parallel to the main regional foliations, thrusts, or shear zones related to the Cenozoic Himalayan orogenesis between 45 and $5 \mathrm{Ma}[88,133]$. The ruby mineralization is restricted to impure marble horizons. The protolith of the ruby-bearing metamorphic rocks comprises of carbonates enriched in detrital clays and organic matter, and intercalated evaporitic layers (Figure 34B). Ruby crystals occur: (1) disseminated within marbles and associated with phlogopite, muscovite, scapolite, margarite, spinel, titanite, pyrite, and graphite, as at Jegdalek, Afghanistan; Chumar and Ruyil, Nepal; Hunza and Nangimali, Pakistan; Mogok and Mong Hsu, Myanmar; Luc Yen, Vietnam; and Yuan Jiang in China; (2) in veinlets or gash veins, as in some occurrences in Northern Vietnam, and associated with phlogopite, margarite, titanite, graphite, and pyrite, and sometimes related to micro-shear zones, as at Nangimali in Pakistan (Figure 34C); and (3) in pockets associated with K-feldspar, phlogopite, margarite, graphite, and pyrite in some occurrences in Northern Vietnam.

The thermobarometric conditions of mineral equilibrium have shown that ruby could have grown during both prograde and retrograde metamorphic events. The most common reaction is the formation of ruby by the destabilization of spinel (Figure 35A):

$$
\text { spinel }+ \text { calcite }+\mathrm{CO}_{2} \leftrightarrow \text { corundum }+ \text { dolomite }
$$

Ruby formed during the retrograde metamorphism stage at T $620-670{ }^{\circ} \mathrm{C}$ and P 2.6-3.3 kbar [65]. The aluminum and the chromophorous elements in the ruby originated from marbles ( $\mathrm{Al}$ up to 1000 ppm, $\mathrm{V}$ and $\mathrm{Cr}$ between 5 and 30 ppm for the Nangimali deposit). 
The variations of local chemistry of the marbles along several decimeters are due to lateral facies variations of the protoliths which resulted in a succession of different $\mathrm{F}-\mathrm{Na}-\mathrm{SO}_{4}{ }^{2-}$-rich mineral associations: (1) F-aspidolite ( $\mathrm{Na}_{2} \mathrm{O}$-rich phlogopite; Figure 34D) associated with F-phlogopite and F-paragonite in the different mineralized zones, as seen in the Nangimali deposit in Pakistan [214]; (2) anhydrite either associated with F-tremolite, F-edenite, F-pargasite, and carbonates in samples from the Hunza Valley, Pakistan and Luc Yen, Vietnam, or included in ruby with relics of spinel (Figure 35A,B); (3) anhydrite and salt crystals $\left(\mathrm{CaCl}_{2}, \mathrm{NaCl}\right.$, and $\left.\mathrm{KCl}\right)$ as solids in the Nangimali, Luc Yen, and Mogok deposits; and (4) F-bearing dravite-uvite tourmaline and apatite, indicating a low activity of water in the fluid.

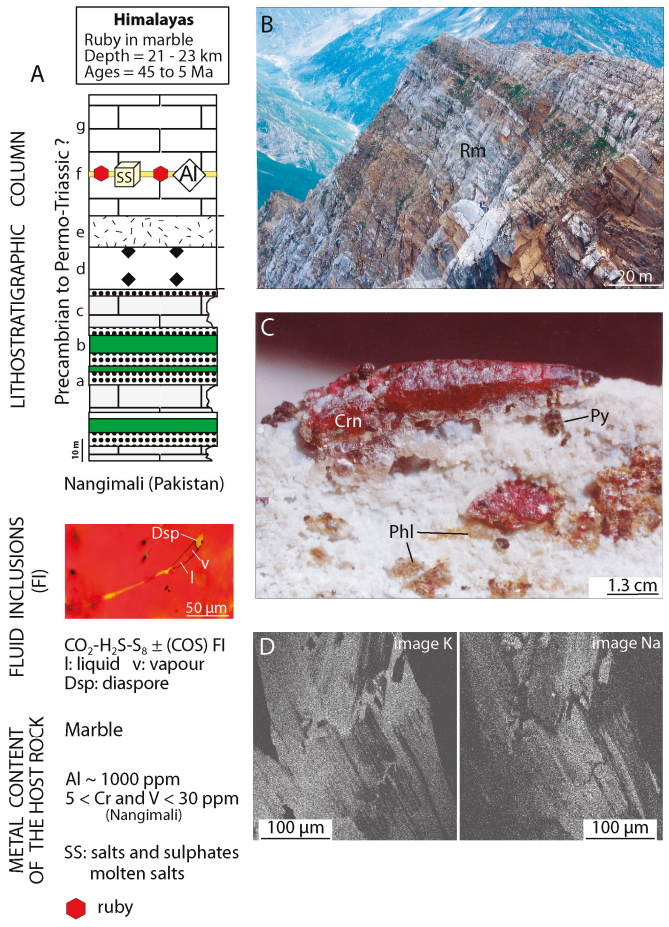

Figure 34. Ruby in metamorphosed carbonate platforms from Central and South-East Asia. (A) The Nangimali formation, Pakistan, showing the location of the ruby deposit in the metamorphic pile. Abbreviations: a: quartzite; b: amphibolite; c: mica-bearing marble; d: pyrite-bearing marble; e: calc-schist and garnet-biotite micaschist; f: ruby-anhydrite-bearing yellow Mg-marble; g: white dolomite and/or calcite marble; (B) the succession of marble (white) and garnet-sillimanite-bearing calc-schist and micaschist (brown); the unique ruby-bearing marble is reported as Rm; (C) gem ruby-bearing gash vein: (Crn), phlogopite (Phl) and pyrite (Py) in marble; and (D) back-scattered electron images of coexisting phlogopite and aspidolite with their X-ray images for potassium (K) and sodium (Na) [214]. Photos: Gaston Giuliani.

Paleo-fluids trapped as primary fluid inclusions in the minerals during their growth allow access to the composition of the mineralizing fluids. The combination of these data with those obtained for the stable isotope ratios of elements such as oxygen, hydrogen, sulphur, and boron on minerals coeval with the gems allows for characterization of the origin and source of the different chemical elements. Microthermometry studies combined with Raman spectroscopy of primary fluid inclusions in ruby revealed the coeval trapping of two types of carbonic fluid inclusions [62,63]: mono- to two-phase fluid inclusions (Figure 35D) in the system $\mathrm{CO}_{2}-\mathrm{H}_{2} \mathrm{~S} \pm \mathrm{COS} \pm \mathrm{S}_{8} \pm\left(1<\mathrm{H}_{2} \mathrm{O}<10 \mathrm{~mol} \%\right.$ ), and polycrystalline 
fluid inclusions (Figure 35C) in the system Na-K-Ca- $\mathrm{CO}_{3}-\mathrm{SO}_{4}-\mathrm{NO}_{3}-\mathrm{Cl}-\mathrm{F} \pm \mathrm{CO}_{2}-\mathrm{H}_{2} \mathrm{~S} \pm \mathrm{H}_{2} \mathrm{O}$. The different solids in the polycrystalline fluid inclusions are mixtures of carbonates with $\mathrm{Ca}-\mathrm{Na}-\mathrm{Al}$ cations, such as shortite and dawsonite, sulphates (mainly anhydrite and barite), phosphates (F-apatite), nitrates, fluorides (fluorite), and chlorides (halite, $\mathrm{Ca}$ and $\mathrm{K}$ chlorides). These solids are daughter minerals of ionic liquids formed during the metamorphism of evaporites and limestones [65]. In ruby, these polycrystalline fluid inclusions are rare because if the salts are not immediately trapped by the crystals, and they dissolve because of their high solubility in water-rich fluids.
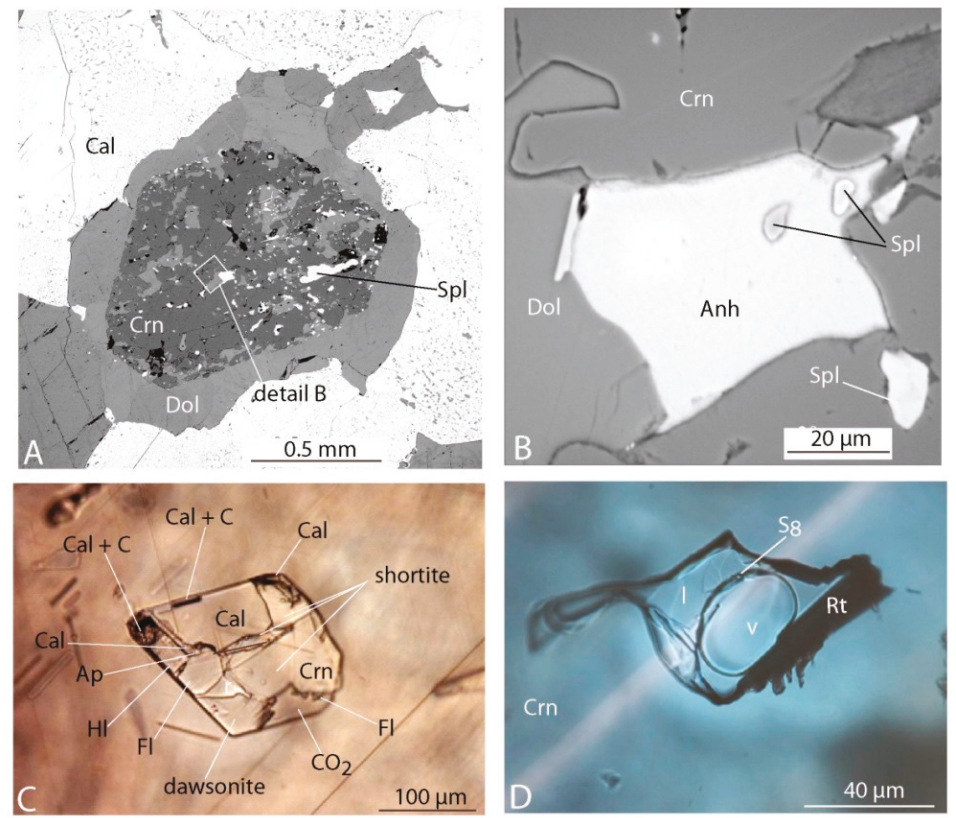

Figure 35. Mineral assemblage and fluid inclusions in ruby-bearing marble deposits from Central and South-East Asia. (A) Association ruby (Crn), dolomite (Dol), calcite (Cal), and spinel (Spl) illustrating the formation of ruby by the chemical reaction: spinel + calcite $+\mathrm{CO}_{2} \leftrightarrow$ corundum + dolomite, Hunza valley (Pakistan); (B) inset of Figure 35A (detail B) showing the presence of anhydrite (Anh) with spinel inclusions (Spl). Spinel is a pre-ruby phase that has high $\mathrm{Cr}$ (up to $19 \mathrm{wt} \% \mathrm{Cr}_{2} \mathrm{O}_{3}$ ) and $\mathrm{Zn}$ (up to 10 wt \% $\mathrm{ZnO}$ ) contents; (C) primary polycrystalline fluid inclusion cavity in ruby containing different solids (molten salts), which are mixtures of carbonates, with Ca-Na-Al cations such as calcite (Cal), dawsonite (Dw), shortite, and apatite (Ap), fluorite $(\mathrm{Fl})$, halite $(\mathrm{Hl})$, graphite $(\mathrm{C})$, and a $\mathrm{CO}_{2}-\mathrm{H}_{2} \mathrm{~S}$-bearing fluid phase $\left(\mathrm{CO}_{2}\right)$, Mogok, Myanmar; and (D) three phase fluid inclusions with $\mathrm{CO}_{2}$ and $\mathrm{H}_{2} \mathrm{~S}$ liquid (l) + vapor $(\mathrm{V})$ phases and native sulphur $\left(\mathrm{S}_{8}\right)$ trapped by ruby in a rutile (Rt)-bearing cavity, Mong Hsu deposit Myanmar. Photos A and B: Virginie Garnier, [65]; Photos C and D: Gaston Giuliani, [62,63].

Crushing and leaching of rubies [62] showed that chloride is the dominant anion (25 to $53 \mathrm{~mol}$ $\%$ ) with sulphate (2 to $36 \mathrm{~mol} \%$ ), nitrate (2 to $17 \mathrm{~mol} \%$ ), and fluoride (0 to $25 \mathrm{~mol} \%$ ). Sodium is the dominant cation (16 to $42 \mathrm{~mol} \%$ ). The presence of nitrate is a strong argument for a continental input to the original sediment as, generally, nitrate salts precipitate in closed basin playas or salars. In addition, the isotopic variation of sulphur in anhydrite included in ruby and marble defines two sets of $\delta^{34} \mathrm{~S}$ (V-CDT) values: the first, between $27 \%$ ond $23 \%$, for a marine anhydrite; the second, between $4.8 \%$ and $1.6 \%$, for a continental source [65].

The presence of sulphate-carbonate-fluorine mixtures decreased the melting temperature of halite and other salts, and allowed the formation of chlorine- and fluorine-bearing ionic liquids. Fluorine of 
continental origin probably played an important role in the extraction of the Al present in impurities (clays) from the impure limestone. The existence of an ionic liquid trapped in the form of polycrystalline solids in ruby explains the color and clarity of the ruby by (1) the mobilization of $\mathrm{Al}, \mathrm{Cr}$, and $\mathrm{V}$ contained in the meta-limestone, and (2) their incorporation in an isotropic environment allowing crystalline growth with a minimum of defects.

The presence of evaporites of either continental or marine origin in the Ca-Mg protoliths is the key feature in the metamorphic model for ruby in marble. Ruby formed during the metamorphism, in the amphibolite facies, of carbonates interbedded with mudstones and containing intercalations of sulphates-chlorides-nitrates-borates of impure evaporites. The lithological control of the mineralization is a function of the paleogeography of the carbonate platform environment. The original sedimentary landscape converges to an epeiric carbonate platform succession with a combination of salt and evaporite mudflats of gypsum and anhydrite [62].

(2) Ruby and pink corundum in marble with intercalated silicate and gneiss layers.

(i) The Revelstoke occurrence is in the Monashee Complex of the Omineca belt of the Canadian Cordillera, British Columbia [113,212]. Ruby $\left(\mathrm{Cr}_{2} \mathrm{O}_{3} \leq 0.21\right.$ wt \%) occurs in folded and stretched layers associated with green Cr-V-Ti-Ba-rich muscovite + Ba-bearing K-feldspar + anorthite \pm phlogopite \pm Na-poor scapolite. Other silicate layers within the marble are: (1) diopside + tremolite \pm quartz and (2) almandine-rich garnet + Na-rich scapolite + diopside + tremolite $+(\mathrm{Na}, \mathrm{K})$-amphiboles. Corundum formed at the peak of metamorphism $\left(\mathrm{T} 650-700{ }^{\circ} \mathrm{C}\right.$ and at $\mathrm{P}$ 8.5-9 kbar) and the sources of the $\mathrm{Cr}$ are the silicate layers and gneiss.

(ii) The Snezhnoe deposit in Tadjikistan $[115,134]$ is localized in the Muzkol-Rangkul anticlinorium within the Cimmerian zone of the Central Pamir. The Muzkol metamorphic series consists of calcitic marbles present as layers intercalated with amphibole-pyroxene and scapolite calciphyres, gneisses, Ti-Ba-rich muscovite schists, and quartzites. These calcitic marbles host the Snezhnoe deposit, formed by micaceous ruby-bearing lenses arranged as discrete en echelon lenses along the marble foliation. Ruby is found in four mineral assemblages as (i) scapolite + phlogopite + muscovite + margarite; (ii) plagioclase + muscovite + margarite; (iii) muscovite + phlogopite + margarite; and (iv) calcite. The main economic paragenesis is associated with ruby + calcite. The temperature of the metamorphic processes was estimated at $760 \pm 30^{\circ} \mathrm{C}$ using Zr-in-rutile geothermometry [134]. Ancient Al-enriched sediments such as metapelite or meta-bauxite intercalated in the marbles are suggested to be the possible protolith for the ruby-parent rocks.

(iii) At the Ngong'Oro mine, Morogoro district in Tanzania [182], ruby is located in metasomatic zones concordant to the metamorphic foliation, and formed at the contact between marble and biotite gneiss layers. The ruby is associated with spinel and sapphirine.

6.2.2. Sub-Type IIB: Metamorphic-Metasomatic Deposits Formed by Fluid-Rock Interaction and Metasomatism (See Table 3)

1. Sub-Type IIB $_{1}$ corresponds to desilicated pegmatites (plumasite) and associated metasomatites in M-UMR such as at the Rockland mine (Kenya) or Polar Urals and Karelia (Russia), and others (see Table 3). This sub-type also concerns deposits associated with M-UMR intercalated with Si-Al rocks (gneiss, leuco-gabbro, or anorthosite), which have suffered fluid percolation and consequent metasomatism such as at the Aappaluttoq ruby deposit in Greenland.

These deposits formed at medium to high temperatures during hydrothermal-metamorphic fluid circulation and bi-metasomatism that developed at the contact of two contrasting lithologies, i.e., either granitoid or pegmatite or gneiss adjoining different rocks, such as metamorphosed M-UMR or marble $[83,110]$. The metasomatic reactions are related to the infiltration of post- or magmatic or metamorphic solutions, which originated from the same granite or from other magmatic or metamorphic events. The geochemical mechanism of dissolution of quartz (desilication) by a loss of a $\mathrm{SiO}_{2}$-bearing rock, involves diffusion of $\mathrm{Si}$ from a pegmatite vein to a M-UMR for example (which plays the role of $\mathrm{SiO}_{2}$ sink) at a rate more rapid than the diffusion of $\mathrm{Al}$. The Al:Si ratio increases in the 
pegmatite vein, and a metasomatic plagioclase-corundum association in which the mass of alumina per unit volume is much greater than in the initial rock may develop if the volume of rock decreases at the same time and is underlain by a zone of quartz dissolution. These desilicated pegmatite or granitoidic veins are called plumasite following the definition of [215] that where formerly described as an oligoclase-corundum rock [216] forming a dyke in a serpentinized peridotite at Plumas, California. Gordon [215] noted that they were described from several countries (United-States, South Africa, and Russia) as "an abnormal group of granitic pegmatites, composed either of plagioclase, usually albite, alone (albitite), of plagioclase and corundum or largely corundum, all of which occcuring exclusively in peridotites or their altered equivalents". Gordon [215] indicated that the desilication occurred by fluid-rock interaction along the contact between the pegmatite and the intruded M-UMR. The mineralogical composition of the desilicated pegmatite and contact rocks depends of the degree of desilication. Some desilicated pegmatites present metasomatic zoning characterized by different mineral assemblages from the centre to the periphery of the dyke as described by [195] at the ruby Corundum Hill mine, in Macon County (United-States).

World-class gem corundum samples, including tabular ruby in desilicated pegmatites, have been described from the Umba and Kalalani deposits, which are located in serpentinite bodies [217] in Tanzania. World-class rubies were mined in the Mangare area in southern Kenya, including from the well-known (and formerly) John Saul mine [118,119]; and the Polar Urals in Russia [218] and Karelia [41]. Another unusual case of bi-metasomatism that is not a desilicated pegmatite, is related to the intrusion of ultramafic dykes in marble as observed at the Kitwalo ruby occurrence in the Mahenge district (Tanzania). At Kitwalo the ruby is hosted by phlogopite schists and formed via fluid-rock interaction at the contact between marble and an ultramafic dyke (Figure 36) [182].

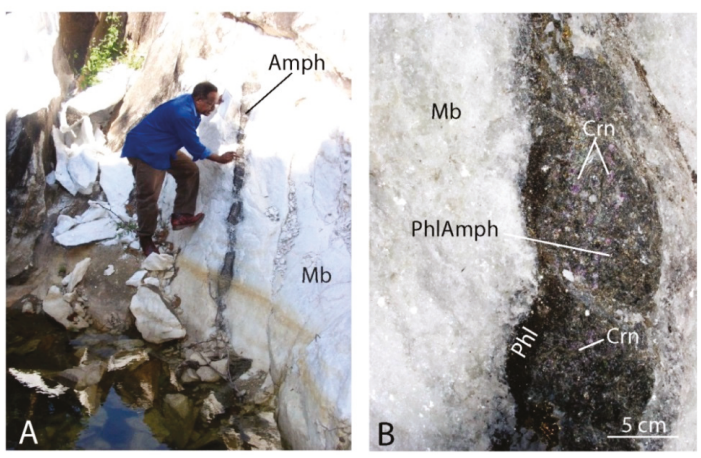

Figure 36. The ruby occurrence at Kitwalo, Mahenge district, Tanzania. (A) Amphibolite vein (Amph) crosscutting a dolomitic marble $(\mathrm{Mb})$ and $(\mathbf{B})$ detail of the contact between the two rocks showing a phlogopitite $(\mathrm{Phl})$, a result of fluid-rock interaction. The amphibolite exhibits a high degree of phlogopitization (PhlAmph) associated with the ruby deposition (Crn). Photos: Elisabeth Le Goff.

We proposed to examine different deposit cases in order to characterize the infiltrational fluid metasomatism of M-UMR during medium to high grade metamorphism:

(1) In the United-States, these deposits are associated with M-UMR intercalated with Si-Al rocks metamorphosed in the amphibolite to granulite facies. The contact between meta-dunite and amphibolite with gneisses at different scales is underlined by metamorphic-metasomatic zones. The Corundum Hill mine at Macon County in North Carolina presents different types of contacts and distributions of ruby [195]:

(a) A gradual transition between ruby accumulations and meta-dunite with some remnants of M-UMR in the ruby zone (Figure 37A). 
(b) The contact zone is characterized by a metasomatic column, of 6-7.5 m width, symmetrical from the periphery to the centre (Figure 37B) with dunite, talc schist, fibrous enstatite, green chloritite, chloritite-bearing ruby, and spinel (1.8-2.4 m wide). At Hunters mine, the amphibolite presents a plagioclase vein with symmetrical metasomatic zoning, $0.9-1.2 \mathrm{~m}$ wide, from the outer to inner zones the following mineral assemblage: amphibolite, actinolitite, ruby-bearing margarite-vermiculite, and ruby-bearing feldspar vein altered into kaolin (Figure 37C). These different types of contact indicate the circulation of metamorphic-metasomatic fluids between two rocks of different competency and chemistry. The considerable width of some metasomatic columns, up to $7.5 \mathrm{~m}$, indicates a clear infiltrational metasomatic process as described for the Polar Urals [99].
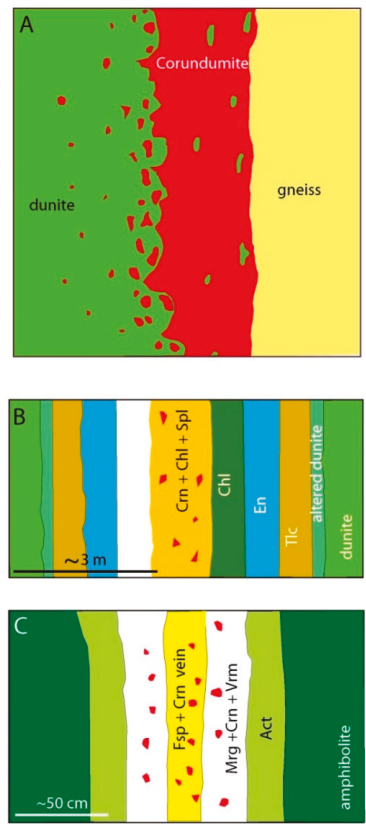

Figure 37. Metasomatic zoning in ruby-bearing metamorphosed dunites and amphibolites in the deposits of North Carolina, USA, modified from [195]. (A) The contact between dunite and gneiss is outlined by corundumite, Corundum Hill mine, Macon County. The scale is not qualitative; (B) ruby-bearing metasomatic zones in dunite at the Corundum Hill mine. The central part contains green chlorite $(\mathrm{Chl})+$ ruby $(\mathrm{Crn})+$ spinel $(\mathrm{Spl})$ and the other zones are symmetrically disposed from this centre part. En = enstatite; Tlc = talcose rock; $(\mathbf{C})$ ruby-bearing feldspar vein in amphibolite at Hunters, Iredell County. A metasomatic-metamorphic symmetrical zoning is developed around the vein. From the centre to the periphery: (1) a zone composed of vermiculite (Vrm)-bearing ruby with some margarite (Mrg) and (2) an actinolite (Act) zone at the contact with the amphibolite.

(2) In Kenya, rubies were discovered in the Mangare area, Voi mining district, in 1973 by John Saul [183]. Mining in the John Saul mine (recently renamed the Rockland mine) provided a regular supply of either facet grade or cabochon rubies from 1993 to 2012. The John Saul, Penny Lane, and Hard Rock deposits occur in lenses of serpentinized ultramafic rock (UMR) bound by shear zones in a metasedimentary series composed of graphitic gneiss and felsic gneiss (Figure 38) [118]. Fe-poor ruby $(\mathrm{FeO}<0.06 \mathrm{wt} \%)$ and pink corundum is located in (i) micaceous lenses and pockets along the contact of a shear zone with the metasomatized UMR. The ruby is associated with \pm spinel \pm sapphirine + mica or in some cases with phlogopite $+\mathrm{Mg}$-chlorite; (ii) in plumasitic veins that crosscut the serpentinites 
where the ruby is associated with zoisite and anorthite \pm muscovite [119]. The P-T conditions for ruby formation are between 700 and $750{ }^{\circ} \mathrm{C}$ and 8 and $10 \mathrm{kbar}$ in the metamorphic granulite facies.

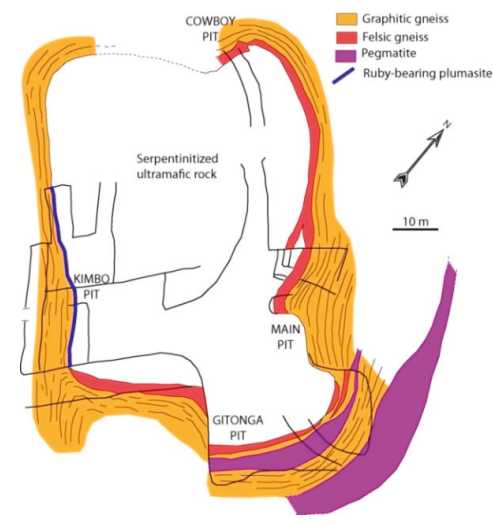

Figure 38. Geological map of the John Saul (now Rockland) mine and its serpentinized ultramafic rock body located in the metamorphic formations of Mgama-Taita, modified after [118]. The Kimbo Pit extension follows the structural direction of the desilicated pegmatite vein, i.e., a ruby-bearing plumasite, which formed at the contact between the graphitic gneisses and the ultramafic body.

As seen in the Kimbo Pit at the John Saul mine (Figure 38), the ruby-bearing-plagioclasite vein is always present at a depth of $40 \mathrm{~m}$ and has a longitudinal extent of $100 \mathrm{~m}$. The contact of the vein with the UMR is outlined by a phlogopite schist with apatite and Mg-chlorite [118]. The plagioclasite is coarse-grained and is composed of oligoclase-andesine (Figure 39A). Locally, a huge concentration of ruby (around $70 \%$ in volume), green tourmaline (uvite-dravite), and blue apatite with some phlogopite is observed (Figure 39B). In other places, the ruby exhibited zoned scalenohedron crystals (Figure 39C) or "mushroom" (so-called by John Saul) habits up to $3 \mathrm{~cm}$ across (Figure 39D). The production of ruby from July 1995 to April 1997 was estimated to have been $36 \mathrm{~kg} / \mathrm{m}^{3}$ [219]. The U/Pb age obtained on zircons from the plumasite was $612 \pm 0.6 \mathrm{Ma}$ and the $\mathrm{P}-\mathrm{T}$ conditions for ruby formation were estimated to have been $500{ }^{\circ} \mathrm{C}$ and $5 \mathrm{kbar}$ [118].

(3) The ruby occurrences in Northwestern Karelia in Russia, located between the Kola and Karelia Archean blocks, is another case of desilication of pegmatite and gneisses due to the fluid-rock interaction $[143,220]$. The deposits, which are located in a 3.0-2.5 Ga polymetamorphic Archean complex, are in ruby-bearing paragneisses, amphibolites, and amphibole schists. Several collisional episodes occurred but at 1.9-1.8 Ga metamorphism and regional intrusions with pegmatites were responsible for the ruby formation through metasomatic processes. The ruby-bearing plumasite veins crosscut biotite-hornblende gneiss and amphibolite. The veins range from several $\mathrm{cm}$ to $10 \mathrm{~m}$ thick and up to $60 \mathrm{~m}$ long, and are parallel to the metamorphic foliation. The plumasite is composed of plagioclase (oligoclase-andesine), phlogopite, tourmaline, zoisite, epidote, and chlorite. The corundum crystals have prismatic and bladed shapes, $5 \mathrm{~cm}$ long and up to $3 \mathrm{~cm}$ in diameter. The ruby contains up to $9.4 \mathrm{wt} \% \mathrm{Cr}_{2} \mathrm{O}_{3}$. Ruby and pink corundum from the Proterozoic gneisses have the lowest-known $\delta^{18} \mathrm{O}$ compositions $(-1.5 \%$ o to $-27 \%$ o) for terrestrial corundum [221], while the corundum in the amphibolite has $\delta^{18} \mathrm{O}$ contents between $-2.3 \%$ and $7 \%$ o [1] (Figure 40). The plagioclase and amphibole have similar O-isotope values as the ruby. The highly depleted $\delta^{18} \mathrm{O}$ values are due to the circulation of meteoric glacial subwaters in a rift zone at around $2.4 \mathrm{Ga}$, which affected the initial isotopic composition of the protolith prior to ruby formation $[41,222]$. 

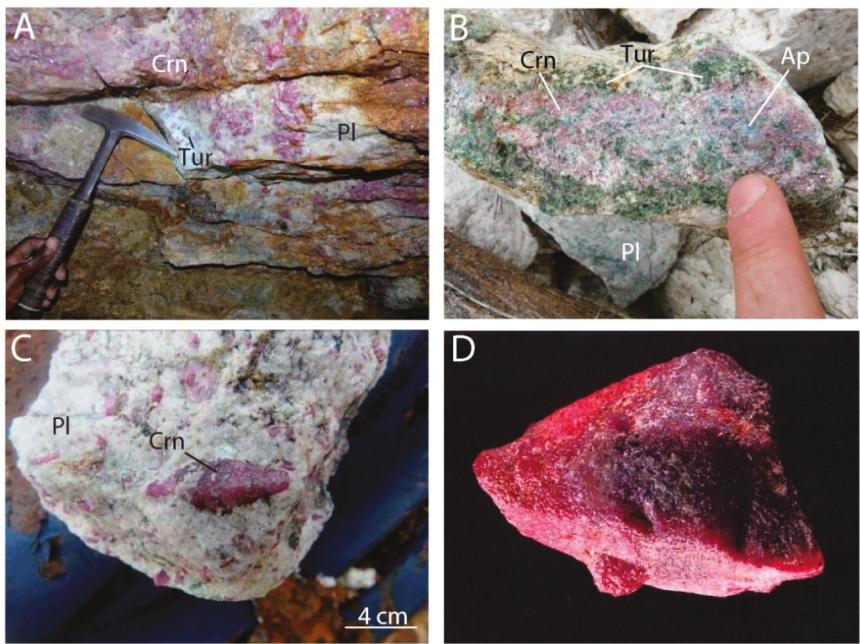

Figure 39. The ruby-bearing rocks of the John Saul mine, Voi area, Kenya [118,163]. (A) The Kimbo Pit and its ruby-bearing plumasite showing the mineral assemblage ruby $(\mathrm{Crn})$, plagioclase $(\mathrm{Pl})$, and some tourmaline (Tur); (B) concentration of ruby, green tourmaline, and blue apatite (Ap) in the plagioclase vein of the Kimbo Pit; (C) ruby showing the scalenohedron habit in the plagioclase matrix of the plumasite, Kimbo Pit; and (D) mushroom habit of a ruby, $3 \mathrm{~cm}$ across, from the John Saul mine. Photos A-C: Gaston Giuliani; Photo D: Courtesy John Saul.
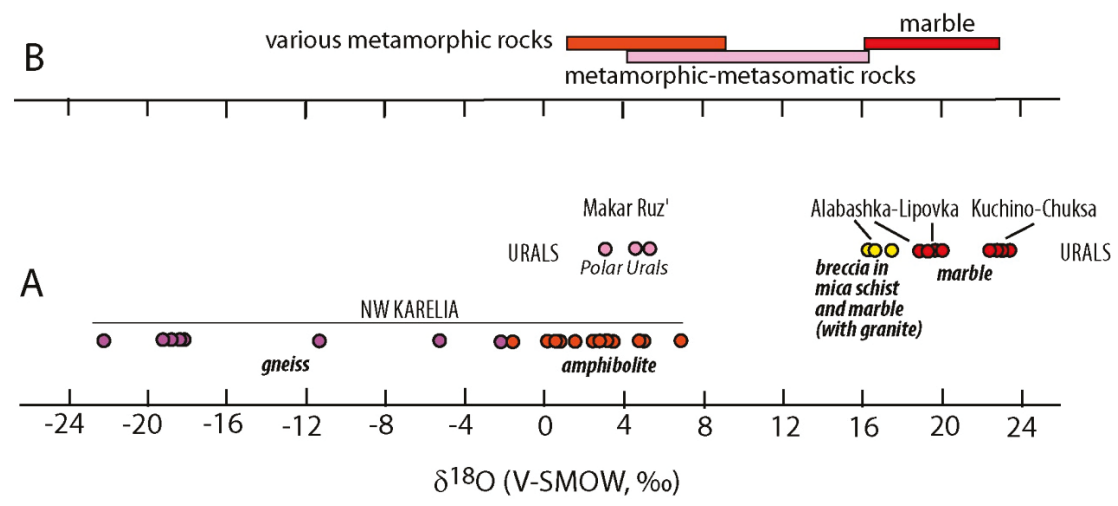

Figure 40. Oxygen isotopic composition of ruby from various Russian occurrences. (A) Oxygen isotopic composition of ruby in marble, breccia in mica schist and marble, and plagioclase-dominated metasomatic rocks from the Urals, and gneisses and amphibolites from northwest Karelia, Russia, modified from [153] and (B) the oxygen isotopic range of values for ruby worldwide associated with primary deposits $[40,41,93,163]$.

(4) Ruby-bearing plagioclasite vein at Makar Ruz' in the Ray-Iz ophiolitic belt of Polar Urals, Russia (see Figure 2) $[143,223]$. The Paleozoic ophiolitic massif consists mainly of dunite and harzburgite that underwent polyphase metamorphism with a high degree of serpentinization. Chromitite in dunite yielded an Ordovician Re-Os age of $470 \mathrm{Ma}$ [224] while zircon from the ruby-bearing plagioclasite gave a Silurian U/Pb between 380 [218] and $398 \mathrm{Ma}$ [225]. The vein was completely mined out and is no longer visible. Scherbakova (1975, in [99]) recognized two types of plagioclasite: (i) plagioclase-rich and phlogopite-rich. The plagioclasite vein, 10-12 m thick, presented a clear symmetric metasomatic 
zoning as also observed in emerald-bearing plagioclasite hosted in metamorphosed M-UMR [226]. From the centre to the outer metasomatic zones (Figure 41) this is: (i) plagioclasite (andesine to oligoclase), 1.5-2.5 m wide, with amphibole (actinolite-tremolite, pargasite) and without ruby; (ii) a ruby $\left(0.3<\mathrm{Cr}_{2} \mathrm{O}_{3}<7.5 \mathrm{wt} \%\right.$ )-bearing phlogopite-rich zone (with Na-rich phlogopite, i.e., aspidolite in Cr-spinel; [99]), $0.3-1 \mathrm{~m}$ thick, with plagioclase, Cr-spinel $(0.46<\mathrm{Cr} \#<0.86)$. The phlogopite is Ba-rich $(0.8<\mathrm{BaO}<2.7 \mathrm{wt} \%$, [218]). Paragonite $(0.8<\mathrm{Sr}<2.3 \mathrm{wt} \%)$, margarite, and zoisite always occur between the ruby and plagioclase, and are probably retromorphic phases. The mean modal composition is plagioclase (32-67 vol \%), paragonite (7-31 vol \%), phlogopite (10-22 vol \%), and Cr-spinel (5-7 vol \%); (iii) plagioclase, amphibole (pargasite), clinochlore, Cr-spinel, talc, and augite in a 7-8 $\mathrm{m}$ thick zone; (iv) finally the dunite, which exhibited three sub-zones, from the inner to the outer, respectively: (a) chlorite + talc $+\mathrm{Cr}$-spinel; (b) chlorite + talc + carbonate + serpentine + olivine; and (c) amphibole (actinolite-tremolite) + chlorite + Cr-spinel + talc + serpentine + olivine.

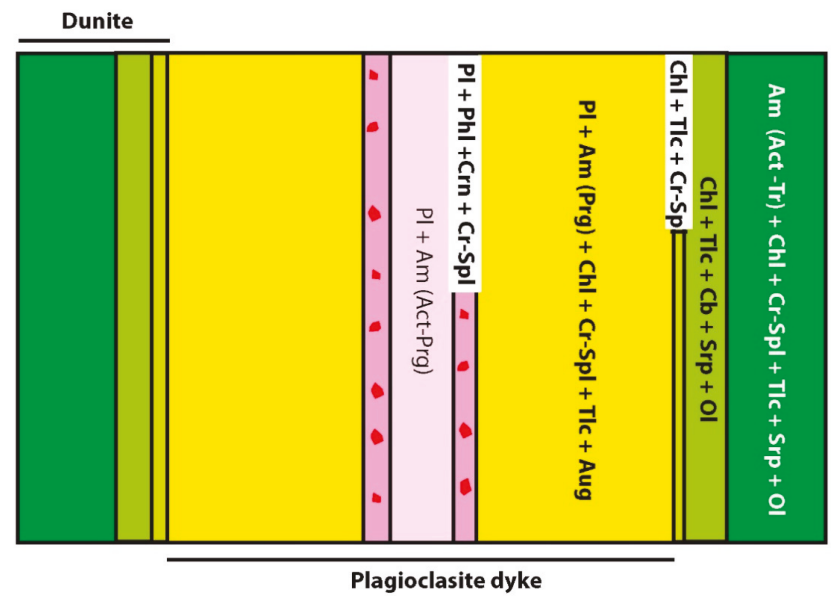

Figure 41. The ruby-bearing plagioclasite dyke in a serpentinized dunite from the Makar Ruz' deposit in the Ray-Iz ophiolitic belt of Polar Urals, Russia, modified from [99]. The plagioclasite shows a symmetrical metasomatic zoning with sharp contact zones characteristic of metasomatic zoning and percolation of fluids. Ruby ( $\mathrm{Crn}$ ) is hosted in the plagioclase (anorthite)-phlogopite (Phl)-Cr-spinel (Cr-Spl) inner zone of the metasomatic column. Abbreviations: Am = amphibole, Act = actinolite, $\mathrm{Tr}=$ tremolite, $\mathrm{Prg}=$ pargasite, $\mathrm{Tl} c=$ talc, $\mathrm{Srp}=$ serpentinite, $\mathrm{Ol}=$ olivine, $\mathrm{Pl}=$ plagioclase, $\mathrm{Chl}=$ chlorite, Aug $=$ augite, and $\mathrm{Cb}=$ carbonate

Aqueous fluid inclusions in the plagioclase are rich in $\mathrm{HCO}_{3}{ }^{-}, \mathrm{SO}_{4}{ }^{2-}$, and $\mathrm{Cl}^{-}$. Zircon $\varepsilon \mathrm{Hf}$ values are between -11 and +13 ; the calculated $\varepsilon N d(380 \mathrm{Ma})$ value is +3.3 for the whole-rock plagioclasite [227] and the $\varepsilon \mathrm{Nd}(400 \mathrm{Ma})$ values are +6.4 and +6.6 , respectively for dunite and harzburgite (Ronkin, 2000 in [99]).

Based on these considerations, different authors agree that (i) the vein minerals resulted from the fluid-rock interaction with the dunite and not from the fractional crystallization of ultramafic magma as proposed by [228]; (ii) the source of $\mathrm{Cr}$ is the chromitite in the dunite; and (iii) the metasomatic columns are due to fluid circulation, which is considered subduction-zone-derived and from metasomatism in the mantle wedge. The association plagioclase-corundum gave $\mathrm{P}-\mathrm{T}$ estimates at 1.0-1.1 GPa and between 600 and $700{ }^{\circ} \mathrm{C}$ [99]. The formation of ruby and pink corundum is attributed to desilication of the dunite by the Na-Al-Si fluid circulation [218] rather than derivation from precursor pegmatite [100]. Such metasomatic zones that display clear zonation with very sharp metasomatic fronts, i.e., metasomatic columns (see Figure 37C), formed by infiltrational processes following the 
rules of [229], are also seen in the Haut-Allier, France [40,186], at Corundum Hill mine in North Carolina [195], and in the Vohibory unit in Southern Madagascar [164].

(5) In Southern Madagascar, desilicated rocks called "sakenites" by [230] occur at Sakeny, northwest of Ihosy. Sakenite is a whitish to greenish rock composed of anorthite \pm corundum (mostly sapphire and sometimes ruby) \pm spinel \pm sapphirine \pm phlogopite \pm amphibole (edenite) \pm clinopyroxene \pm zircon, and is found in boudinaged bands or benches in the Precambrian high-grade granulitic domain of Southern Madagascar. The "sakenites" are intercalated with Al-rich paragneisses, amphibolites, and clinopyroxenites. The benches can attain $10 \mathrm{~m}$ width and display petrographic variations within a single bench, with local predominance of one mineral species. [230] distinguished sapphirine, spinel, spinel + sapphirine-bearing "sakenites", and sometimes "anorthitic corundumite" (anorthite + corundum or \pm spinel) and "corundumite" occurring as pebbles and rounded blocks in rivers [231] (Figure 42A). Raith et al. [232] revisited the occurrence and described sakenites associated with phlogopitites, calc-silicate rocks, and marbles. The P-T conditions of formation of the intercalated Al-rich paragneisses were estimated at $800{ }^{\circ} \mathrm{C}$ and 6-7 kbar [232].
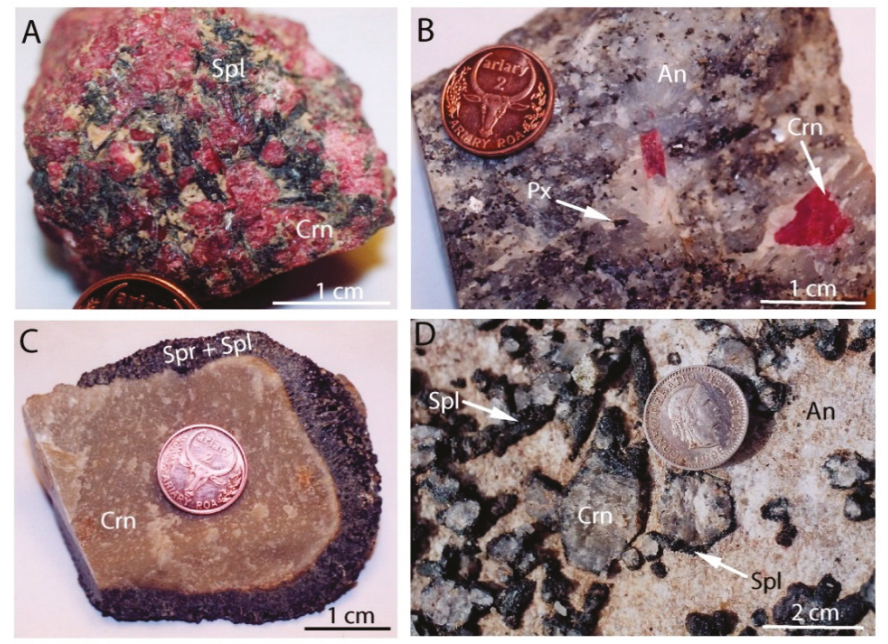

Figure 42. The sakenites from Sakeny and other sites in Southern Madagascar. (A) Corundumite composed of ruby (Crn) and spinel (Spl). Collection Lacroix, MNHN, Muséum National d'Histoire Naturelle de Paris; (B) sakenite, i.e., plumasite from the Anavoha occurrence. The ruby crystals are disseminated in a matrix of anorthite (An) and pyroxene (Px). Collection Lacroix, MNHN Paris; (C) the corundumite from Sakeny. A corona of sapphirine (Spr) and spinel is present around the whitish sapphire (Crn). Collection Lacroix, MNHN Paris; (D) sakenite vein with anorthite, corundum + spinel at Bekinana (Tranomaro area). The corundum generally shows a corona of black spinel. Photos: Gaston Giuliani.

At lower P-T conditions $\left(750-700{ }^{\circ} \mathrm{C}\right.$ and $\left.6 \mathrm{Kbar}\right)$ the sakenite was affected by the circulation of potassic fluids. The corundum + anorthite assemblage was transformed into phlogopite and Mg-Al minerals producing corundum-spinel-sapphirine-bearing phlogopitites. Subsequently the corundum was replaced by spinel, spinel-sapphirine, or sapphirine at lower temperatures and pressures [232].

Other occurrences in southern Madagascar include Vohidava, Anavoha (Figure 42B), and Bekinana [164]. These rocks are anorthitites showing corona textures due to the partial or complete replacement of corundum porphyroblasts by spinel and sapphirine (Figure 42C,D), or spinel + hibonite, spinel + sapphirine, K-feldspar + spinel, and anorthite + sapphirine. Lacroix considered "sakenites" to be a product of high-grade metamorphism of clay-rich marls. [233] favored metamorphism/metasomatism of clay-rich limestones. Raith et al. [232] suggested kaolinite-rich sediments or calcareous bauxites as a 
protolith. The chemical composition of the "anorthitic corundumite" [230], i.e., $12.3 \mathrm{wt} \% \mathrm{SiO}_{2}$ and 73.6 wt \% $\mathrm{Al}_{2} \mathrm{O}_{3}$, implies a loss of silica with drastic enrichment of alumina, with mafic rocks (amphibolites and clinopyroxenites) or marble and calc-silicate rocks playing the role of $\mathrm{SiO}_{2}$ sink at a rate more rapid than the diffusion of Al.

(6) In Southwest Greenland, numerous ruby occurrences have been discovered and mapped in the Fiskenæsset Anorthosite Complex [33,34,83,234,235]. Fagan [34] stated that there are at least 534 individual corundum occurrences in the area and an open-pit ruby mine recently opened at the Aappaluttoq locality (Figure 43A). The deposit has defined minable reserves of 59.2 million grams of pink corundum and ruby [35].

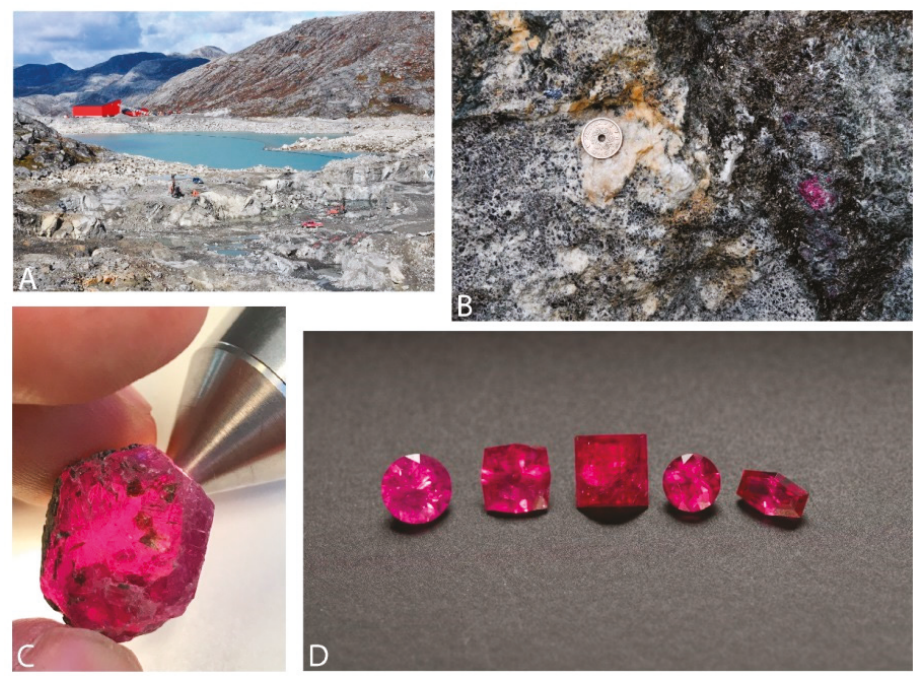

Figure 43. (A) The ruby mine at Aappaluttoq. Photo: Vincent Pardieu; (B) gem corundum in outcrop. Photo: Vincent Pardieu; (C) ruby rough. Photo: Vincent Pardieu; (D) a selection of cut gems $(0.5-0.75 \mathrm{ct})$ from the Greenland deposits [34], courtesy of True North Gem Inc.

The 2.97 Ma Fiskenæsset Complex is one of the best preserved layered Archean intrusions in the world ([236] and references therein). It consists of a ca. 550-m-thick association of anorthosite, leucogabbro, gabbro, and metamorphosed UMR (dunite, peridotite, pyroxenite, and hornblendite), which are found in the mining area at Aappaluttoq (Figure 44). Despite amphibolite to granulite facies metamorphism (that peaked at $2.80 \mathrm{Ga}$ ([235] and references therein)) and polyphase deformation, primary cumulate textures and igneous layering are well-preserved [236].

The rubies occur in a reaction metasomatic zone (Figure 43B) formed at the contact between an anorthite-rich rock, such as anorthosite or leucogabbro, and an UMR, such as a metamorphosed dunite or peridotite. The metasomatic zones resulting from fluid percolation are typically $0.5-5 \mathrm{~m}$ wide and contain ruby, phlogopite, cordierite, spinel, sapphirine, calcic amphibole, sillimanite, and kornerupine [83]. The ruby reaction zone consists of three main groups: (i) phlogopitite with $80 \%$ mica (eastonite-phlogopite) and up to $20 \%$ corundum; (ii) sapphirine-gedrite rocks, and (iii) anthophyllite-cummingtonite (-pargasite) rocks. The rubies formed at approximately $640{ }^{\circ} \mathrm{C}$ and 7 kbar, when pegmatites intruded, at $2.71 \mathrm{Ga}$, the anorthite-rich rock and juxtaposed UMR [83,235]. This caused the anorthite to alter to calcic amphibole, releasing $\mathrm{Al}$, and $\mathrm{Cr}$ from the UMR to be mobilized by the pegmatitic fluids. The ruby-forming reaction occurred at upper amphibolite facies conditions and under high fluid flux interaction between two rocks of contrasting chemistry.

Keulen et al. [83] proposed to name this kind of deposit as ruby-bearing ultramafic complexes. The description of the deposit confirms that it formed through an intense fluid-rock interaction 
that resulted in large amounts of K-metasomatism (ruby-phlogopitite zone). In consequence, the Aappaluttoq deposit might be classified in the Sub-type $\mathrm{IIB}_{1}$ proposed by the enhanced classification for ruby deposits (see Table 3). The nature of the protoliths can vary worldwide from mafic to ultramafic rocks for low $\mathrm{Si}$ and $\mathrm{Cr}$-bearing rocks, and from gneiss, granitoid to anorthosite rocks for Si-Al-K-rich rocks.
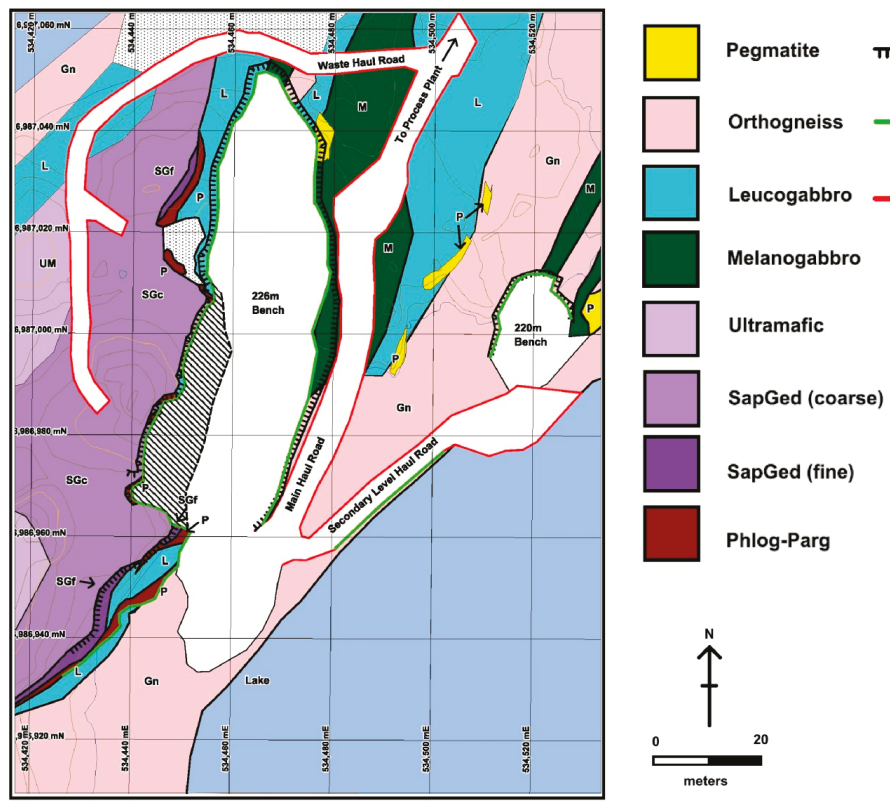

Figure 44. Geological map of the Aappaluttoq ruby mine [34]. SapGed: sapphirine-gedrite; Phlog-Parg: phlogopite-pargasite; Gn: orthogneiss; SGc and SGf: coarse (c) and fine (f) sapphirine-gedrite; L: leucogabbro; M: melanogabbro; UM: ultramafic rock; and P: pegmatite (yellow) or phlogopitite (marron).

According to [83] rubies from the Fiskenæsset Complex (Figure 43C) are distinguished by their high $\mathrm{Cr}$, intermediate $\mathrm{Fe}$, low $\mathrm{V}, \mathrm{Ga}$, and $\mathrm{Ti}$, low $\mathrm{O}$ isotope values $(1.6-4.2 \%$ ), and rare mineral inclusions (e.g., anthophyllite + biotite) and growth features. Numerous faceted pink corundum to ruby more than 1 carat have been cut (Figure 43D) and the largest piece of $\mathrm{Cr}$-corundum recovered to date is the carved opaque 440 ct Kitaa Ruby [35].

There are also a number of occurrences in Greenland north of the Fiskenæsset Complex. Keulen et al. [83] listed (approximately from north to south): Ujarassuit Nunaat, Maniitsoq NW, Kangerluarsuk, several occurrences on the island of Storø, and Kapisillit.

At Kangerluarsuk, ruby occurs in schist with plagioclase, both surrounded by biotite, with minor orthopyroxene, amphibole, and olivine ([237] and references therein). The ruby formed by a metamorphic reaction between a metaperidotite and a kyanite-quartz-garnet schist (with minor plagioclase, spinel, and mica) at amphibolite-facies conditions.

At Ujarassuit Nunaat, an ultramafic enclave experienced amphibolite-grade metamorphism resulting in gabbro anorthosite with amphibole-calcite plagioclase and a small amount of red corundum overgrowing the latter [238].

On Storø Island, similar to Kangerluarsuk, the ruby occurs in a mica schist layer up to $3 \mathrm{~m}$ thick and formed by a metamorphic reaction between a metaperidotite and a sillimanite-biotite-garnet schist (with minor plagioclase) at amphibolite-facies conditions [237]. 
At both Kangerluarsuk and Storø Island, the ruby is thought to have resulted from the breakdown of kyanite and sillmanite at elevated temperatures due to the removal of $\mathrm{SiO}_{2}$. The reaction was facilitated by a chemical potential gradient between the relatively $\mathrm{Si}$ - and Al-rich metasedimentary rocks and the low-Si ultramafic rocks. According to [237], the additional required $\mathrm{Al}_{2} \mathrm{O}_{3}$ was supplied via metasomatism, with the $\mathrm{Al}$ mobilized by complexation with hydroxide at alkaline conditions or transported as K-Al-Si-O polymers at deep crustal levels.

Poulsen et al. [239] described several occurrences of pink corundum near Nattivit in Southeast Greenland. The corundum occurs where late-stage felsic pegmatites crosscut and interact with metamorphosed ultramafic rocks. The source of $\mathrm{Al}$ is the plagioclase in the pegmatite with removal of Si by interaction with the UMR [239].

2. Sub-Type IIB $_{2}$ is characterized by ruby and pink corundum in shear zone-related or fold-controlled deposits in different substrata (M-UMR, gneiss, schist, and marble) with fluid circulation and metasomatism.

These deposits formed at medium to high temperatures during metasomatic-metamorphic fluid circulation. They include ruby or pink corundum-bearing metamorphosed and metasomatized M-UMR and marble (see Table 3) such as those from the Neoproterozoic occurrences of Zazafotsy, Sahambano, and Ambatomena (Southern Madagascar), Kerala (southern India), and Mahenge and the Uluguru Mountains (Tanzania).

(1) For Madagascar, the geology and genesis of these types of deposits was described by [40,164]. These studies focused on the Sahambano and Zazafotsy deposits that produced sapphires (rather than rubies) from feldspar-rich mafic gneisses. Fractures and tension gashes associated with shear zones favored fluid circulation and biotitization of the host rocks. At Sahambano, sapphires and pink to reddish corundum $\left(1000<\mathrm{Cr}_{2} \mathrm{O}_{3}<2000 \mathrm{ppm}\right)$ occur in biotitites with sillimanite and spinel, and also in gneisses with sapphirine, K-feldspar, biotite, sillimanite, spinel, garnet, and albite. The corundum formed at $\mathrm{T} 650^{\circ} \mathrm{C}$ and P $5 \mathrm{kbar}[240,241]$. At Zazafotsy, the corundum deposit lies in the Zazafotsy shear zone system [242]. The corundum occurs in lenses with different mineral assemblages:

(i) Almandine garnet, biotite, plagioclase, and sillimanite, with a corona of spinel and K-feldspar formed around corundum (Figure 45A). The resulting mineral assemblage can be described by the following reaction:

$$
\text { biotite }+ \text { corundum } \rightarrow \text { spinel }+ \text { K-feldspar }+\mathrm{H}_{2} \mathrm{O}
$$

The association of corundum, garnet, spinel, and sillimanite in some samples results from the reaction:

$$
\text { garnet }+ \text { corundum } \rightarrow \text { spinel }+ \text { sillimanite }
$$

(ii) In biotite schist with biotite, corundum, spinel, and minor grandidierite (Figure 45B).
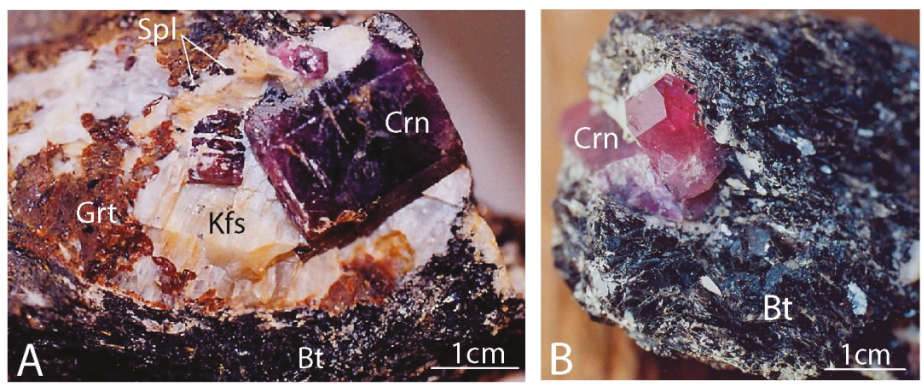

Figure 45. The Zazafotsy ruby and sapphire deposit, northeast of Ihosy, Southern Madagascar. (A) Purple sapphires (Crn) in a garnet (Grt)-bearing biotite schist (Bt). The crystals are embedded in a corona of K-feldspar (Kfs) and spinel (Spl) and (B) pink corundum hosted by a biotitite (Bt). Photo: Gaston Giuliani. 
The Ambatomena ruby deposit was exploited by a private mining company between 2000 and 2001. The production was of very good quality with euhedral crystals up to $2 \mathrm{~cm}$ across and $3 \mathrm{~cm}$ long. The ruby deposit is located in the Androyan granulitic metamorphic series, which is composed of para-and orthogneisses, marble, granite, clinopyroxenite, and quartzite. The four ruby deposits (called D1 to D4) formed lenses of clinopyroxenite (D1 and D2), sapphirinite (D3), and plagioclasite (D4) intercalated with garnet-bearing granofels [243] (Figure 46). The formation of ruby is linked to the percolation of fluids at the contact between the lenses and the granofels. The ruby $\left(2180<\mathrm{Cr}_{2} \mathrm{O}_{3}<6670 \mathrm{ppm}\right)$ is found in phlogopitized clinopyroxenites (G2), sapphirinites (G3 and G4; Figure 47A), and plagioclasites (G4; Figure 47B). The mineral assemblage of the ruby is spinel, K-feldspar, plagioclase, clinopyroxene, sapphirine, phlogopite, sillimanite, cordierite, titanite, rutile, and hibonite (Figure 47C,D). The retrograde metamorphic stage is characterized by the destablization of ruby into spinel in the plagioclasites and sapphirine in the clinopyroxenites, each mineral forming a corona around ruby crystals.

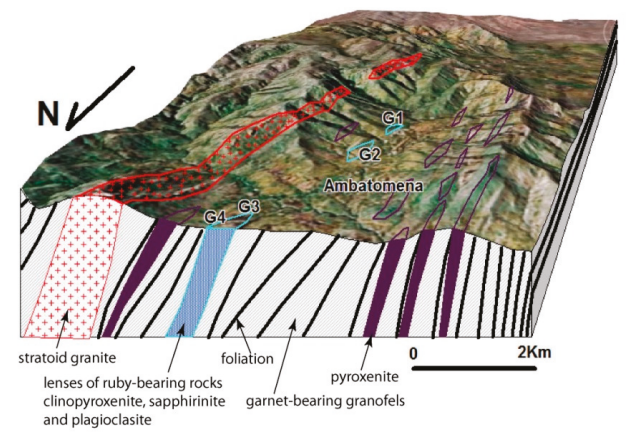

Figure 46. Panoramic view and geological cross-section of the Ambatomena ruby deposit, Betroka region, Southern Madagascar, modified from [243]. The correlation between the ruby-bearing occurrences (G1-G4) and the garnet-bearing hornfels and pyroxenites can be seen in the cross-section.
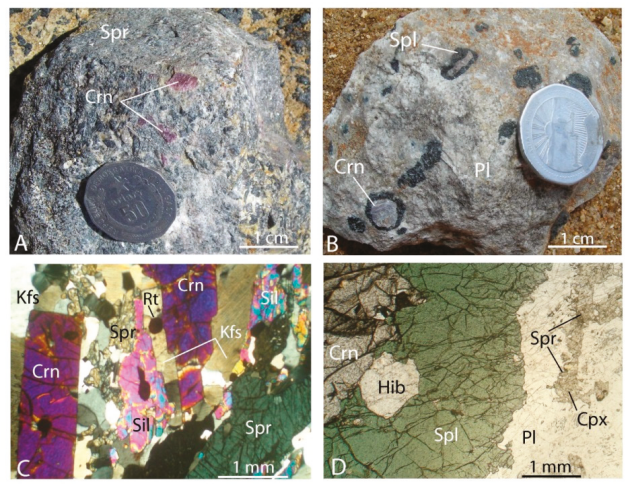

Figure 47. The Ambatomena ruby deposit, south of Betroka, Southern Madagascar. (A) Ruby (Crn)-bearing sapphirinite (Spr); (B) plagioclasite (Pl) with whitish corundum (Crn) showing a corona of spinel (Spl); (C) microscopic image of ruby-bearing sapphirinite with a granoblastic texture of K-feldspar (Kfs), sapphirine (Spr), sillimanite (Sil), and rutile (Rt). The ruby sometimes has a corona of sapphirine and K-feldspar; (D) microscopic image of the corundum-bearing plagioclasite. The texture is granoblastic decussate with plagioclase $(\mathrm{Pl})$ and corundum. The plagioclase is associated with some sapphirine and clinopyroxene (Cpx). The corundum is embedded in a corona of green spinel with some hibonite (Hib). Photos: Alfred Andriamamonjy. 
(2) For Tanzania, the ruby deposits in the Uluguru and Mahenge Mountains are located, respectively, in dolomite- and calcite-dominated marbles but deformation controlled the mineralization, which is located in saddle reef structures within fold hinges [114] (Figure 48A). The ruby is metamorphic and formed between 620 and $580 \mathrm{Ma}$. At Mahenge the deposits are Kitwalo, Ipango, Matote, and Lukande. The Morogoro mining district consists of the Kibuko, Mwalazi, Nyama Nyama, Visaki, and Msonge deposits. The marbles belong to the Neoproterozoic cover sequence that was thrust onto the gneissic basement of the Eastern Granulites. At Uluguru, the mineral assemblage is dolomite, phlogopite \pm spinel, pargasite, scapolite, plagioclase, margarite, chlorite, and tourmaline.

At Mahenge, the paragenesis is calcite, plagioclase, phlogopite \pm dolomite, pargasite, sapphirine, titanite, and tourmaline. Two episodes of ruby formation were defined by [114]:

(i) Ruby formed during the prograde metamorphic stage at T $750{ }^{\circ} \mathrm{C}$ and P $1.0 \mathrm{GPa}$ by the breakdown of either diaspore or via the chemical reaction:

$$
\text { margarite } \leftrightarrow \text { anorthite }+ \text { corundum }+\mathrm{H}_{2} \mathrm{O}
$$

The metamorphic mineralizing fluids circulated along the zones of higher permeability at granulite facies conditions.
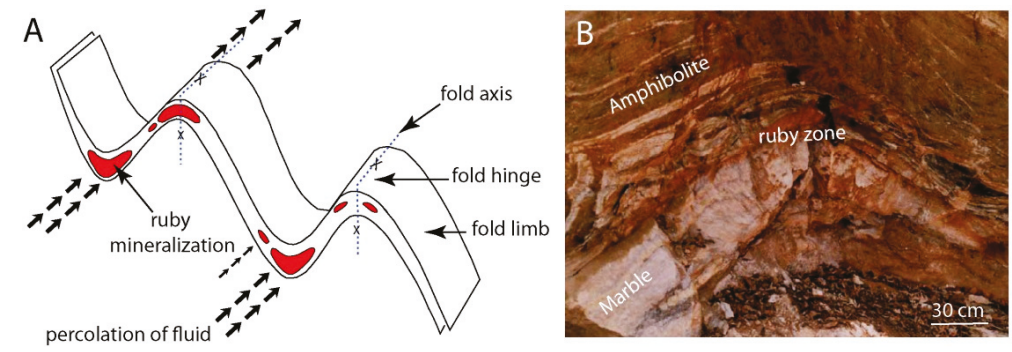

Figure 48. (A) The schematic structural control of ruby mineralization in the Uluguru and Mahenge mountains, Southern Tanzania, modified from [114]. Ruby formed in zones of higher permeability near fold hinges; (B) the structural control of ruby formation by folding and opening of fractures is also observed at the Lukande ruby deposit in the Mahenge Mountains. The ruby mineralization is located in the hinge of a fold that affected both marble and amphibolite. The contact between the two contrasting rocks hosts a metasomatic zone composed of carbonates, phlogopite, and Mg-amphibole. Photo: Gaston Giuliani.

(ii) Changes in the $\mathrm{T}-\mathrm{XCO}_{2}$ conditions of the metamorphic fluid triggered the ruby deposition through two main reactions:

$$
\begin{gathered}
\text { spinel }+ \text { calcite }+\mathrm{CO}_{2} \leftrightarrow \text { corundum }+ \text { dolomite } \\
\text { margarite }+ \text { calcite } \leftrightarrow \text { corundum }+ \text { scapolite }+\mathrm{H}_{2} \mathrm{O}
\end{gathered}
$$

The sources of Cr (and V) were not discussed by [114] but two possibilities can be proposed: (i) a sedimentary source, i.e., limestone or Mg-limestone (muds or clays interbedded with impure carbonates) from the carbonate platform of the Neoproterozoic Mozambican ocean. Such a source was also proposed for the tsavorite mineralization in Northern Tanzania [244]. Both tsavorite at Merelani and ruby in the Mahenge and Uluguru Mountains formed in a similar geological setting and during the East African orogeny; (ii) a mafic source such as amphibolite that was infiltrated by the fluids circulating along zones of higher permeability during folding and the formation of saddle reef structures.

At the Lukande deposit, the marbles are intercalated with Cr-bearing amphibolites that were folded and fractured (Figure 48B). Both types of rocks have suffered fluid percolation and 
ruby-bearing metasomatic zones formed at the marble-amphibolite contact. The mineral assemblage is ruby-carbonate-phlogopite-magnesian amphibole. The style of deformation and the nature of the protoliths are similar to those proposed for the formation of tsavorite vein deposits from the Merelani area [244]. The metamorphic formations were affected by tight ductile isoclinal folding and shearing, and the tsavorite occurs at the hinges of sheared isoclinal folds within saddle-reef structures.

\subsection{Sedimentary-Related (Type III): Placer Deposits}

Placers are hosted in sedimentary rocks (soil, rudite, arenite, and silt) that formed via erosion, gravity effect, mechanical transport, and sedimentation along slopes or basins related to neotectonics. Climate is a major factor in the formation of secondary deposits. In tropical areas, rocks are exposed to meteoric alteration, resulting in an assemblage of clay minerals, Fe and Mn oxides, and other supergene phases. Corundum and zircon are resistant minerals found in soils, laterites, and gravelly levels overlying bedrock. In high-altitude areas such as in Nepal, Pakistan, and Azad-Kashmir the alteration is mechanical and ruby is found in boulders accumulated on the lower part of the slopes as for the Nangimali deposit [245]. Present-day placers are illustrated in Figure 49, which follows the classification proposed by [138]:

(i) Eluvial concentrations derived by in situ weathering or weathering plus gravitational movement or accumulation. Eluvial-deluvial deposits are on slopes and in karst cavities (marble type). Colluvial deposits correspond to decomposed primary deposits, which have moved vertically and laterally down-slope as the hillside eroded.

(ii) Alluvial deposits resulting from the erosion of the corundum-bearing host rock and transport by streams and rivers. Concentration occurs where water velocity drops at a slope change in the hydrographical profile of the river, e.g., at the base of a waterfall, broad gullies, debris cones, meanders, and inflowing streams. Terminal placers [138] formed by deltaic, aeolian, and marine accumulations are unknown for ruby deposits.

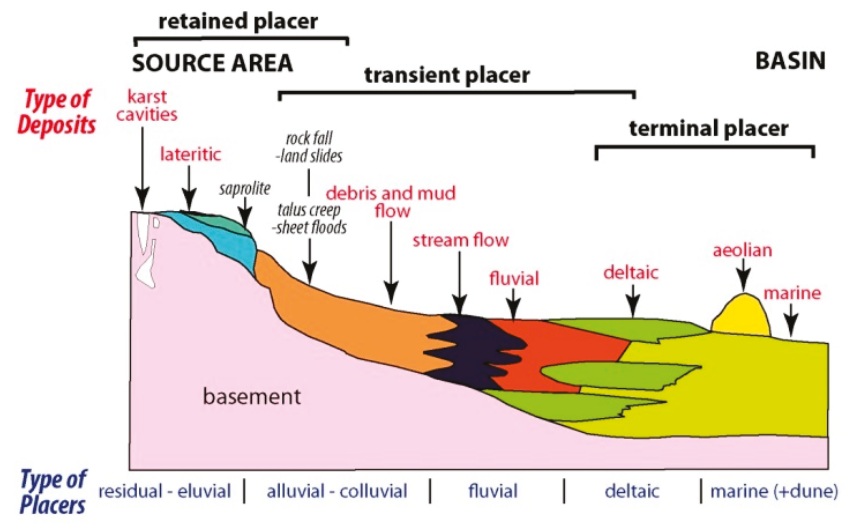

Figure 49. The different types of placer deposits formed on the continental surface and deltaic or marine basins, modified from [138]. The majority of these types of placer, except for aeolian and marine placers, occur for gem corundum deposits worldwide.

The placer deposits are divided in three main sub-types (Table 3).

6.3.1. Sub-Type IIIA: Gem Placers in an Alkali Basalt Environment (Eastern Australia, Pailin-Chanthaburi-Trat, Eastern and Central Madagascar, and Others)

Ruby-bearing placers linked to volcanic rocks are found in continental alkali basalt extrusions [68] (Figure 2). These deposits are sporadic and economically quite rare when compared to sapphire deposits of the same type, except for the ruby deposits at Pailin and Chanthaburi-Trat [145]. In Australia, Ray et al. [246] 
showed that within the New South Wales deposits, in 420 listed gem corundum occurrences, $10 \%$ had ruby. However, the production realized on the short-term depended on worldwide demand.

Ruby placers in alkali basalt environments include the deposits in eastern Australia [81,106,247-250]; Asia, with deposits at Pailin, Cambodia $[5,74,82,248]$ and the provinces of Chanthaburi-Trat and Kanchanaburi [145,146,148,149,154,251]; China with the Muling deposit in Shandong province [252]; Eastern Africa, in Kenya with the Baringo deposit, which is linked to the volcanism of the East African rift [118]; and in Madagascar at Antsirabe in Antananarivo province [95,161,231] and Vatomandry in Toamasina province [77,78].

(1) In Eastern Australia, ruby placers linked to volcanic rocks are found in continental alkali basalt extrusions [68] (Figure 2). They occur as scattered deposits that are subordinate to sapphires [81,85] (Figure 50). Rubies are found in alluvial placers shed from Cenozic lava fields within an eruptive zone extending from Northeast Queensland to Southeast Tasmania. The main deposits are located in New South Wales, i.e., Barrington Tops, Macquarie-Cudgegong Rivers, and New England (Figure 50A). Occurrences are also found in South Australia at Adelaide, Victoria around Melbourne, and Tasmania.

In New South Wales the deposits are found [81,85,86]:

(i) At Barrington Tops, erosion and transport by drainages of the eroded Barrington Tops volcano gave rise to the formation of mineable placers in the river. Ruby was found in 1851 and alluvial prospecting was done over a long period between the 1960s and 1990s. The geology of the Barrington Tops Plateau was described in the early 2000s [253] and mining at Upper Manning River took place from early 2005 until 2008 (Figure 50B). The ruby is associated with other pink, purple, and pastel blue corundum used for jewelry (Figure 50C).
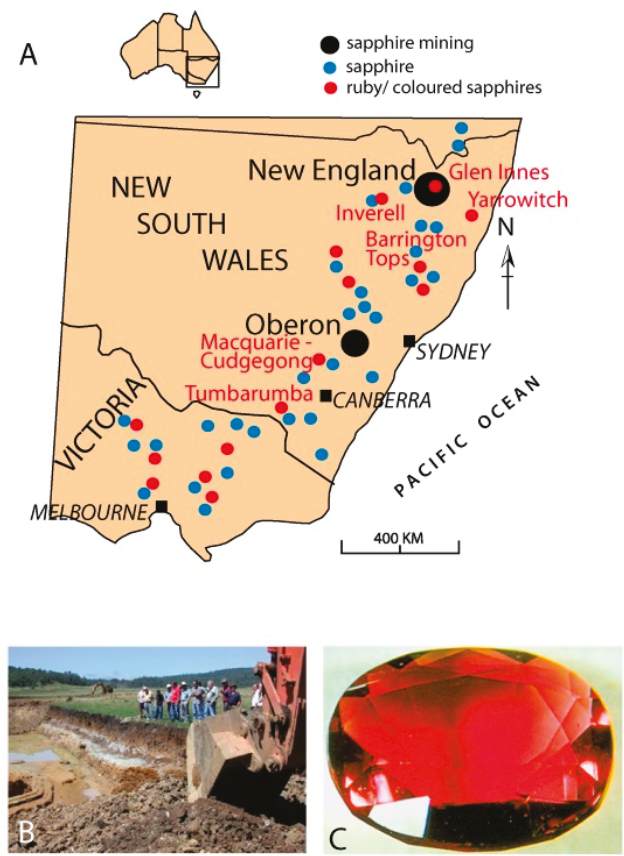

Figure 50. (A) Location of ruby deposits in New South Wales, modified after [81,86]; (B) opening of the Barrington Tops mine, March 2005, upper Manning flats. Photo: Cluff Resources Pacific M/L, Courtesy Lin Sutherland; (C) faceted 1 carat ruby, $6 \mathrm{~mm} \times 4 \mathrm{~mm}$ across, Gloucester Tops, SE Barington Tops plateau. Photo. Gayle Webb. 
(ii) At Yarrowitch, the alluvial gem field is more restricted than at Barrington Tops and the ruby is associated with sapphires, red zircon, and spinel. The alluvial occurrences have not been mined.

(iii) At Macquarie-Cudgegong Rivers, extensive alluvial exploitation took place in the rivers from 1851 to 1941 . The placers contain ruby, sapphires, zircon, gold, and diamond; their original source is unknown, despite the presence of numerous basaltic vents in the area.

(iv) At Tumbarumba, ruby is minor and the placers contain blue to green sapphires, which are corroded and worn.

(v) At New England, the Inverell-Glen Innes area is known for its sapphire placers. Ruby is scarce but is recovered from all the rivers. The crystals grade from red into pink and purple corundum [86]. Sometimes, the crystals are zoned with red to pink cores, a white peripheral zone, and a violet rim. Several large gem crystals have been cut, such as the 48 carat "Aurora" zoned stone found near Glen Innes in 1988, which was cut into a 17 carats red, a 9 carats blue, and a 2 carats pink stones [249]. Other stones have been faceted, such as a 2.13 carats purple red oval cut, a 0.31 carats light red baguette cut, and a 0.22 carats red marquise cut [81].

In Queensland, rubies are very rare and the deposits are mainly composed of sapphires. In Victoria and Tasmania, pink to red corundum are rare and the high content of Fe turns the color to brown [254].

(2) The presence of corundum in alluvial placers from Madagascar has been known since the beginning of the 20th century [231]. The deposits formed by the erosion of corundum-bearing Cenozic lava fields within eruptive zones extending from the centre of the island, in the Ankaratra massif, Antananarivo province, to the north in the Montagne d'Ambre, Antsiranana province (Figure 51). The production of ruby in Madagascar became significant after the discovery in 2000 of two ruby deposits in the province of Toamasina named Andilamena [164] and Vatomandry [255].

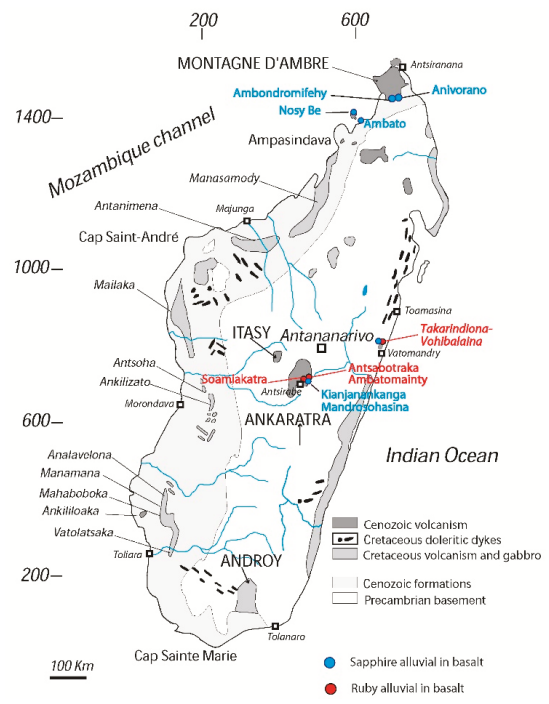

Figure 51. The volcanic provinces of Madagascar, modified from [256] with the localities of the basaltic corundum deposits related to the Cenozoic basalts in the provinces of Antsiranana, Antananarivo, and Toamasina [161,162]. The deposits of gem corundum: north in Antsiranana Province, the mining districts of Ambondromifehy and Anivorano in the Montagne d'Ambre, Ambato peninsula and Befotaka in Nosy Be island; Central Madagascar in Antananarivo Province, the mines of Soamiakatra, Mandrosohasina-Kianjanakanga (Antsirabe area) in the volcanic Ankaratra massif; and east in Toamasina Province, with the deposits of Vatomandry in the Takarindiona and Vohibalaina basaltic areas. The geographic coordinates are related to the Laborde projection. 
In 2005 Madagascar was the third largest ruby-exporting country after Kenya and Tanzania (see Figure 3). The secondary deposits, i.e., alluvial placers and paleoplacers are located (i) to the north and east of Antsirabe city in Antananarivo province (Ambatomainty, Antsabotraka, and Soamiakatra deposits) and (ii) to the north of Vatomandry in Toamasina province. In this last province the alluvial and paleoplacer deposits border the Takarindiona and Vohibalaina basaltic massifs (Figure 51). The mining sites are Amfao, Sahanonoka, and Antsidikana near the commune of Amboditavolo. They are located in a number of watersheds and major river systems downstream of the Vohibalaina volcanic massif, and those of Antanambao, Mahatsara, and Ankazombanga on the southern and eastern borders of the Takarindiona massif [94].

At Vatomandry, the ruby is associated with crystals of sapphire and red zircon in some paleoplacers but mostly in alluvials. Generally, the gem gravels consist of $0.5-2 \mathrm{~m}$ thick sediments overlying bedrock in the riverbeds. The ruby crystals are $5 \mathrm{~mm}$ to $3 \mathrm{~cm}$ across, rounded and with different colors (red, red purple, red brown, and pink), but a red-purple color is dominant [77].

The most common inclusions in ruby from the Sahanonoka deposit are rutile and zircon (Figure 52A), which are cogenetic and arranged in clusters [161,162,255]. Ilmenite, rutile, and Al-silicates also occur as inclusions (Figure 52B). The other solids are talc (Figure 52C), phlogopite (Figure 52D), pentlandite, plagioclase, titanite, ilmenorutile, hematite, and Al-silicates. Apatite was observed by [78]. Rutile crystals were identified as a daughter phase in the cavities of fluid inclusions trapped by the ruby. The fractures in the rubies are filled by limonite and kaolinite [78].
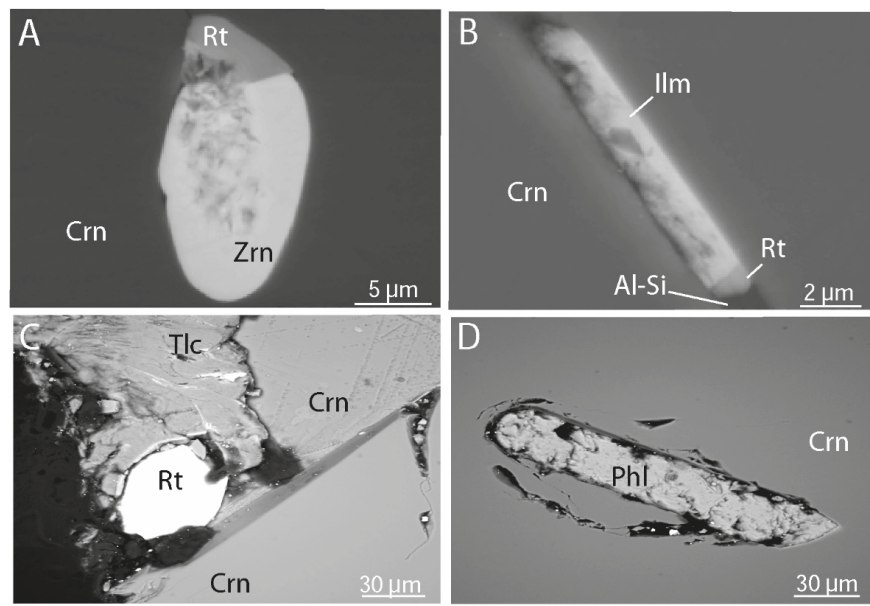

Figure 52. Inclusions in ruby from the Sahanonoka deposit in the Vatomandry area [94]. (A) Zircon (Zrn) associated with rutile (Rt); (B) rutile, ilmenite (Ilm), and Al-silicate (Al-Si); in ruby (Crn);

(C) association of rutile and talc (Tlc) in ruby; and (D) phlogopite (Phl) crystal included in a ruby.

The original source of these rubies is unknown neither xenocrysts nor corundum xenoliths have ever been observed in the basalts. The placers that are proximal and downstream of the different basaltic volcanics, ruby crystals associated with fragments of basalt, and red to orangey zircon and sapphires leave a high probability that the rubies were connected to the different basaltic flows of the Takarindiona and Vohibalaina basaltic massifs.

The Fe contents of the rubies (1500-8460 ppm) are always higher than $\mathrm{Cr}$ and $\mathrm{V}$. The $\mathrm{Cr}_{2} \mathrm{O}_{3}$ contents differ with color: (i) red brown (4760-6670 ppm), (ii) red (3500-3800 ppm), (iii) pink (1390-11,670 ppm), and (iv) red to purple (720-2000 ppm). The chemical diagram for classification of corundum deposits (Figure 53) shows a distinctive bimodal chemical distribution for the rubies from Vatomandry, which plot in the metamorphosed M-UMR (R3) and metasomatic (R4) domains. The first field in the R3 
domain (M-UMR signature) contains red and red brownish rubies; the second field in the R4 domain (metasomatic such as plumasite or metasomatite in M-UMR) contains red to purple and pink stones. The bimodal distribution is also present for the rubies from Soamiakatra in Ankaratra and Andimalena, while the rubies from Antsabotraka and Ambatomainty plot in the metasomatic domain.

The $\delta^{18} \mathrm{O}$ values for rubies from the Vatomandry mining district span the range $2.7-6.7 \%$ o $(n=8)$ with a mean value of $\delta^{18} \mathrm{O}=5.1 \pm 1.4 \%$. They fit within the worldwide range defined for ruby in basaltic environments $\left(1.3 \%\right.$ o $<\delta^{18} \mathrm{O}<5.9 \%$, mean $\delta^{18} \mathrm{O}=3.1 \pm 1.1 \%$ o, $n=57$; [80] $)$ and ruby associated with M-UMR $\left(0.25 \%\right.$ o $<\delta^{18} \mathrm{O}<6.8 \%$ o, $\left.n=19\right)$. Solid inclusions, chemical composition, and oxygen isotopes are compatible with a metamorphic origin for the Vatomandry rubies.
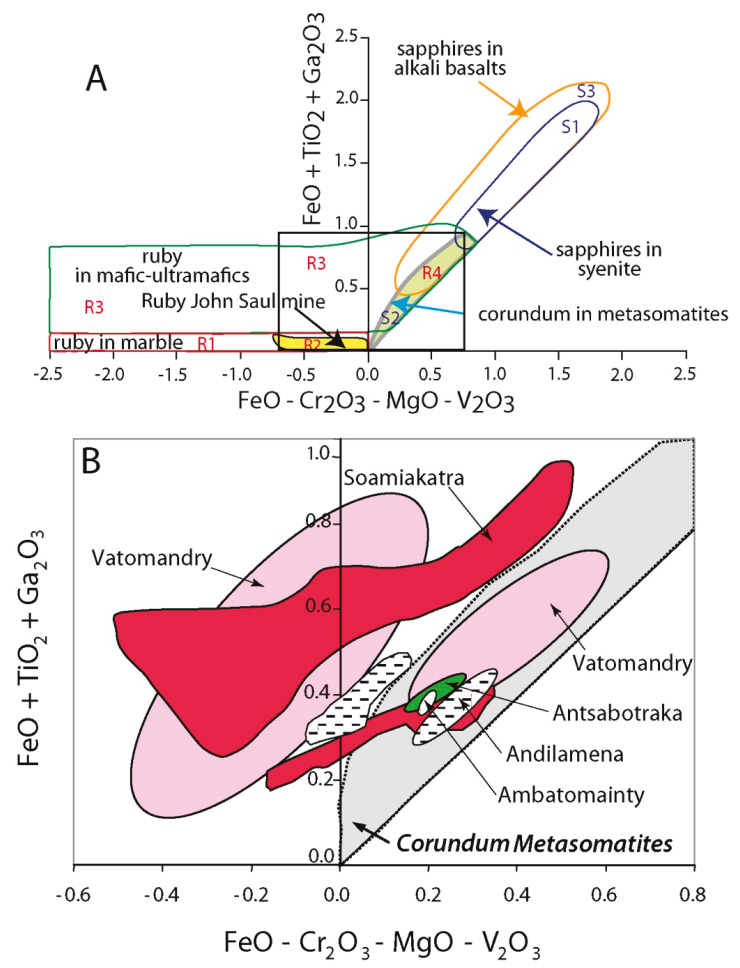

Figure 53. (A) Chemical diagram $\mathrm{FeO}-\mathrm{Cr}_{2} \mathrm{O}_{3}-\mathrm{MgO}-\mathrm{V}_{2} \mathrm{O}_{3}$ versus $\mathrm{FeO}+\mathrm{TiO}_{2}+\mathrm{Ga}_{2} \mathrm{O}_{3}$ showing the main chemical fields defined for different types of corundum deposits worldwide [72,77]; (B) field of chemical compositions of ruby from the Vatomandry deposits (Toamasina Province) compared with the primary deposit at Soamiakatra, and the placer deposits of Antsabotraka and Ambatomainty (Antananarivo Province). The Vatomandry and Soamiakatra deposits show a distinct bimodal chemical distribution in the M-UMR (R3) and metasomatite (R4) domains, respectively. The deposit at Andilamena in Toamasina Province is apparently not related to alkali basalts but is likely derived from plumasite in M-UMR because field work has shown the presence of in situ highly altered mafic rocks, biotite schists, and kaolinite-bearing rocks.

6.3.2. Sub-Type IIIB: Gem Placers in Metamorphic Environment in M-UMR (Montepuez, Mozambique) and Marble (Mogok Stone Track, Myanmar, and Others)

(1) At Montepuez in Mozambique, the main source of facet-grade material in the Gemfields Group Ltd. properties is secondary deposits in M-UMR environments [25,26] (see Figures 32 and 54). The placer deposits were previously interpreted as alluvial and related to a flood event in the river 
systems [27,200,257,258]. However, Simonet [25] concluded that the deposits were not alluvial since there was no evidence of systematic rounded pebbles, variations in the grain sizes and graded bedding in the sediments.

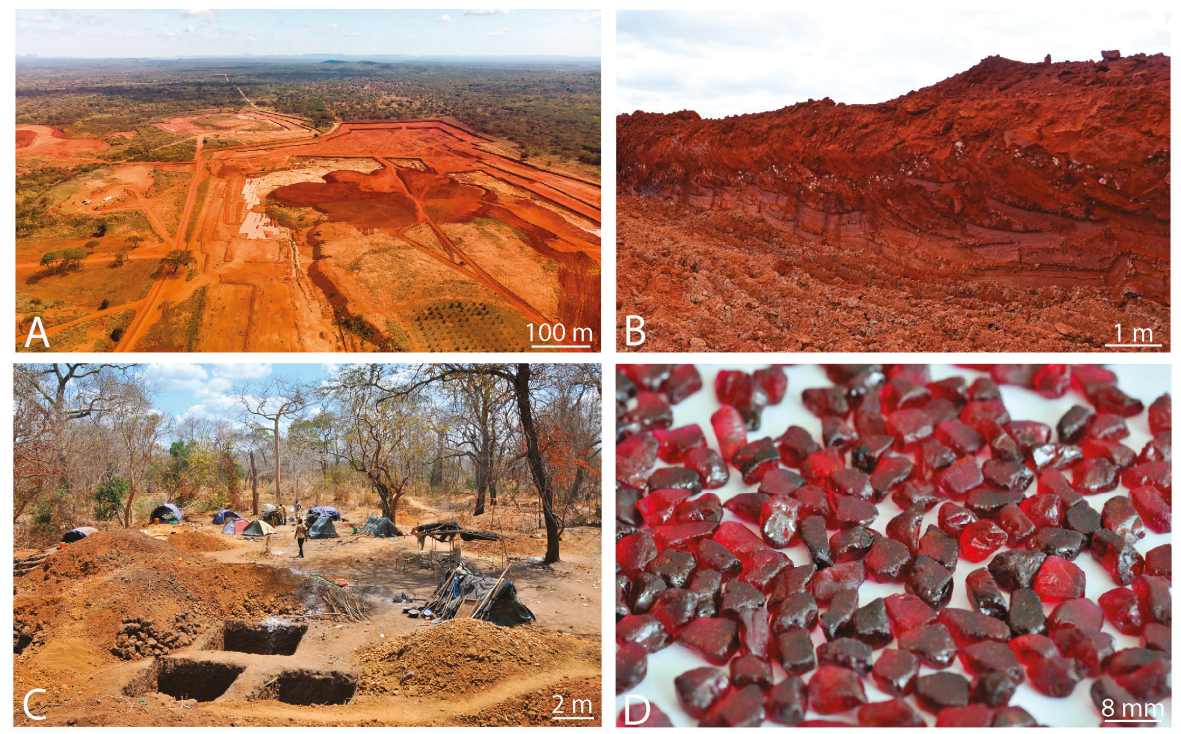

Figure 54. The placer deposits in the Montepuez mining district in Mozambique. (A) Aerial view of the Mugloto Pit operated by the Gemfields Group Ltd. The miners are using a back-filling technique (top) and using tree plantations for rehabilitation (bottom); (B) the ruby-rich gravel layer at Mugloto in the Montepuez mining district. The detritic levels contain sub-angular quartz and clay pebbles located between 4 and $10 \mathrm{~m}$ under the surface. Gemfields removes the overburden and uses an excavator to collect this gravel layer, that is then sent to the wash plant to extract rubies; (C) small scale miners near Nacaca village, an area reserved for locals outside the southeast border of the Gemfields concession, where a few thousand people have worked since 2012. At this location small rubies are found in gravels under to 2-5 $\mathrm{m}$ of overburden. The Nacaca stones are usually smaller and contain more inclusions than those from Mugloto and their iron content is similar to that of the material from Maninge Nice; (D) parcel of rough rubies from Mugloto Pit near Montepuez (about $0.5 \mathrm{~g}$ per stone) at a Gemfields rough ruby auction in Singapore. The rubies coming from a gravel layer range from bright to dark red (depending on their iron contents), and present some abrasion features. The area was discovered in early 2014 and probably more than $90 \%$ of Gemfields income since then has been extracted from this deposit. Photo: Vincent Pardieu (C) GIA.

The secondary deposits are mainly colluvial with limited horizontal transport (more sub-angular fragments) and a few alluvial pebbles (smooth and round appearance). Most of the mineralized horizons are stone lines, i.e., weathering-resistant rock fragments formed over millions of years of erosion [25]. The stone lines, which are composed of angular fragments of quartz and pegmatite, are excellent traps for smaller grains of high-density minerals such as ruby. The colluvial deposits (Figure 54) are either associated with the proximal primary deposits (as at the Maninge Nice/glass mines) or disconnected (as at the Mugloto mine). Simonet [25] proposed an exploration scheme for the colluvial deposits in the Montepuez area based on detailed mapping of the primary deposits (stressing the importance of the strike and dip of the mineralized structures) and erosion through time (Figure 55). The distance between the primary deposit in outcrop and the edge of the colluvial accumulation increases during the erosion process. Mapping of the stone lines and outcrops of ruby-bearing rocks could be an important tool for future ruby placer exploration in the Montepuez mining area. 


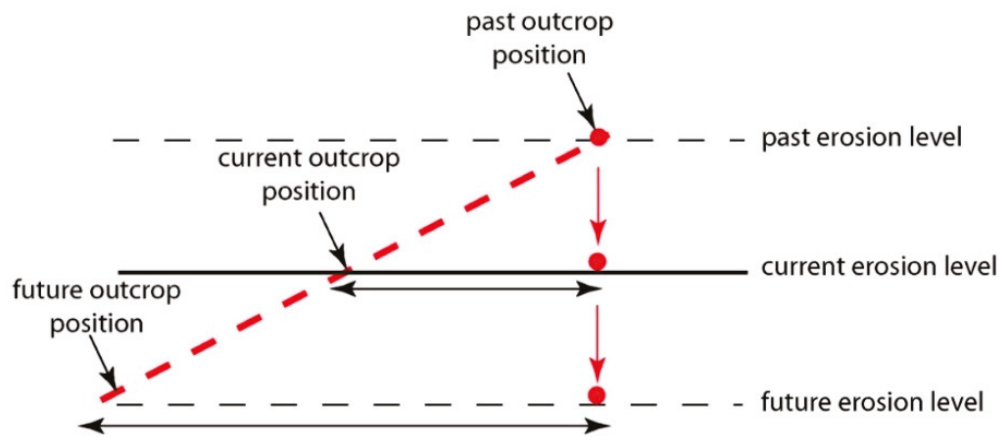

Figure 55. Schematic time-relationship of the formation and position of a colluvial placer through erosion of an angle-dipping primary deposit [25].

(2) Economic ruby placer deposits in marble environments of South-Eastern Asia (Figure 2).

In the Mogok Stone Track in Myanmar (Figure 56A), gem-bearing levels enriched in pebbles, sand, silt, clay, and iron oxides are called 'byon' [259,260] (Figure 56B,C).
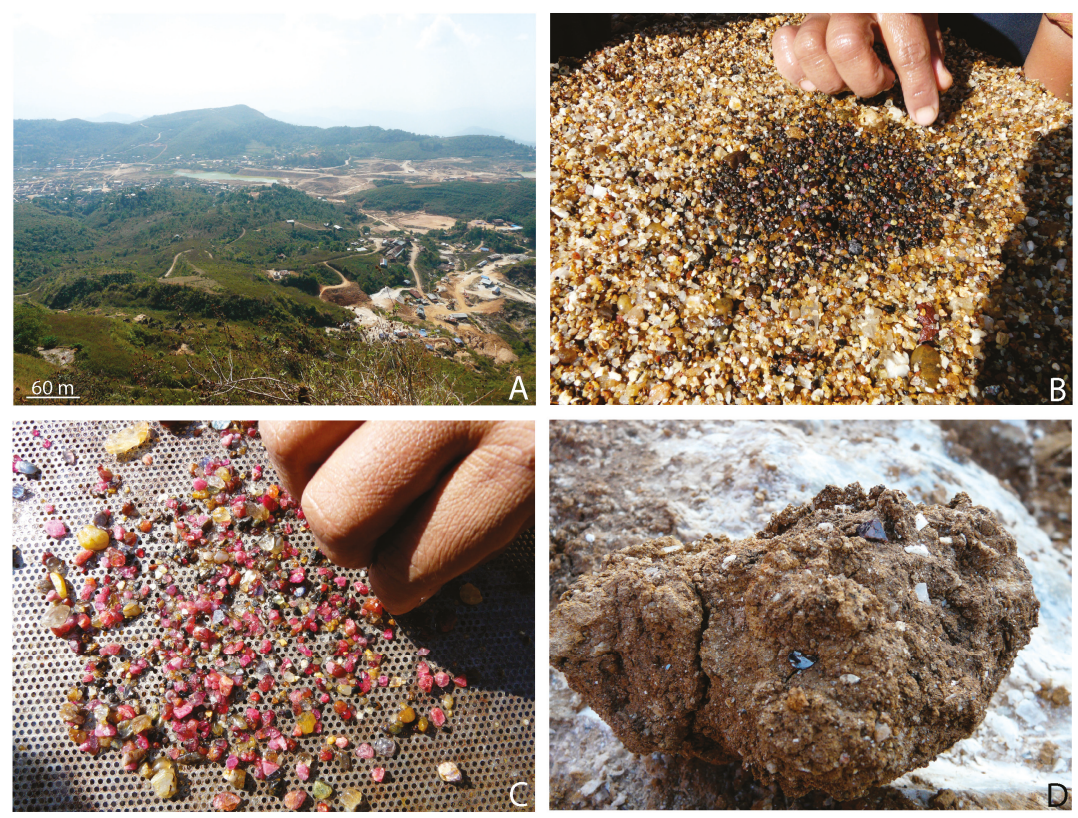

Figure 56. Different aspects of the gem placers in the Mogok Stone Track, Myanmar (in January 2015). (A) Panoramic view of the primary deposits mined in marble on the flank of the hills (foreground view) and secondary deposits, i.e., placers, mined in the valley (background); (B) image of the gem-bearing material called 'byon' enriched in gravels and sand. The concentration of heavy minerals is visible and is composed of iron oxides, corundum, quartz, and pieces of marble; (C) concentration of gem minerals (ruby, spinel, and sapphire) in the pan of a miner; and (D) sedimentary breccia formed in a cave placer karst. The breccia formed from an argillite containing crystals of spinel, plates of graphite, and fragments of marble and quartz. Size of the breccia sample around $15 \mathrm{~cm}$ long. Photo: Gaston Giuliani. 
Similar deposits are found at Namya in the northern part of the country where the monsoon is an effective erosion mechanism in low-altitude environments [5,108,261]. The gem concentration is closely related to the formation of karst and chemical weathering of marble and associated rocks, i.e., schists, gneisses, and granitoids (Figure 56D). The cave placers in karst contain sedimentary breccias formed by argillites with ruby, sapphire, spinel, graphite, and fragments of marble and quartz. The ruby and other gems (sapphire and spinel) are trapped in eluvial, colluvial, alluvial, fracture-filling, and cave deposits (Figure 57) [29].

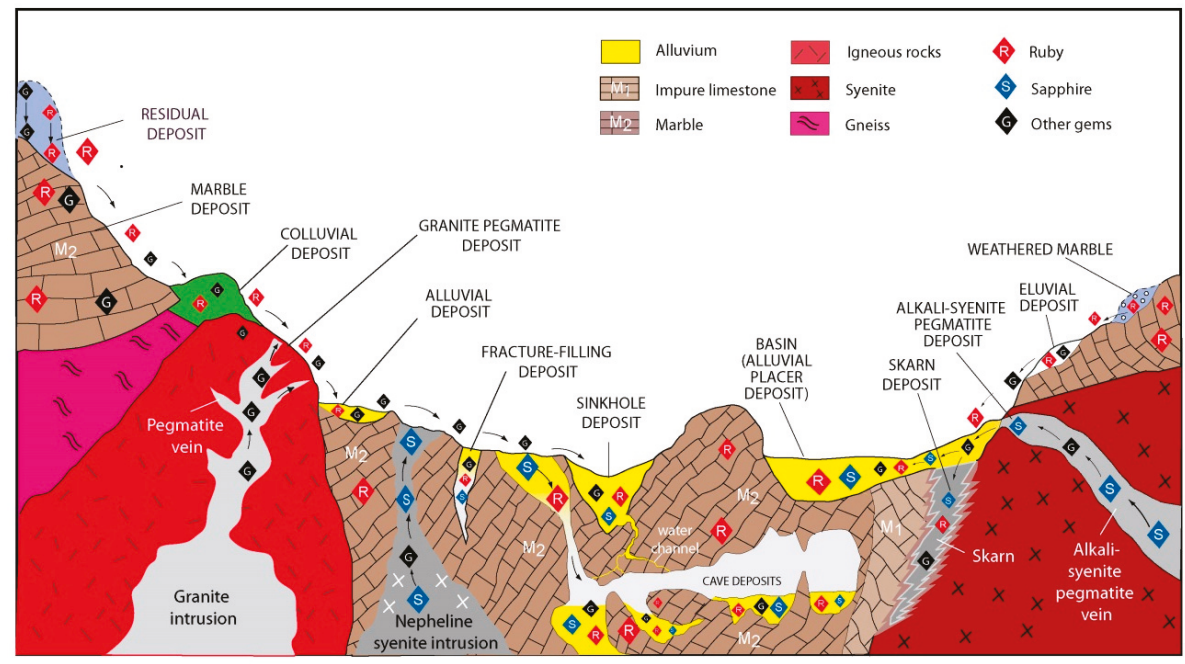

Figure 57. The main types of ruby-bearing placers in the Mogok Stone Track, Myanmar; modified from [29]. The primary ruby deposits are located in marble and the secondary deposits are residual, colluvial, alluvial, fracture-filling, and cave placers in karst morphologies. The figure represents the ruby deposit of Dattaw in marble (on the left) and the sapphire deposit of Thurein-taung (on the right). At Mogok, the different types of primary deposits of ruby and sapphires resulted in the mingling of gems from different sources in single secondary accumulations.

In Vietnam, the placers are proximal to the main primary deposits of ruby and colored sapphires in marble. They are located in the Luc Yen and Yen Bai provinces in the Red River shear zone area and in the Quy Chau ruby deposit (Nghe An province) in the Bu Kang metamorphic zone in Central Vietnam [98,210]. The placers are exploited at Luc Yen, An Phu, Khoang Thong, and Nuoc Ngap (Luc Yen district); at Truc Lau, Yen Thai, Tan Huong, Tan Dong, Hoa Cuong, and Tran Yen (Yen Bai district); and at Quy Hop and Quy Chau (Nghe An district). The paleoplacer at Truc Lau consists of $10 \mathrm{~m}$ of sediments overlying bedrock. The rubies and blue sapphires are contained in $5 \mathrm{~m}$ thick gravel layer overlain by a $3.5 \mathrm{~m}$ thick bed of Quaternary sediments and 1-1.5 m of soil. In 2002, up to two boulders $(1-2 \mathrm{~kg})$ of pink sapphire and star ruby were recovered every month in the paleoplacer. The placer deposits consist of gravel concentrations in karst pockets (Figure 58A) and alluvial fans (Figure 58B) found all over the Luc Yen region [261,262]. The gem-bearing valleys are often narrow and correspond to small depressions, which typically range in area from 2 to $3 \mathrm{~km}^{2}$ (Figure 58D). These placers furnish a variety of gem-quality materials for a market, which has been open daily in Luc Yen city since 1987 (Figure 58C). The rubies in the placers have a proximal origin as confirmed by the oxygen isotopic values of the crystals: $\delta^{18} \mathrm{O}$ ranges between $15.5 \%$ ond $22.3 \%$, which overlaps the worldwide oxygen isotopic range (16-23\%o) defined for ruby hosted in marble [40,93].

Mining is conducted on a small scale, from Bai Lai in the northeast of Luc Yen to the Na Ha area in the south, near the banks of Thac Ba Lake. The most active sites are along the streams of Cong Troi, 
in Nuoc Ngap (An Phu area). Material is also removed from old mines in areas such as Minh Tien, Khoan Thong, and Bai Chuoi, where big companies mined the most accessible and profitable material, often missing areas between marble pinnacles (Figure 58E) that excavators could not easily reach. As a result, some gem-rich ground was left behind; this is now collected by locals with shovels and buckets.

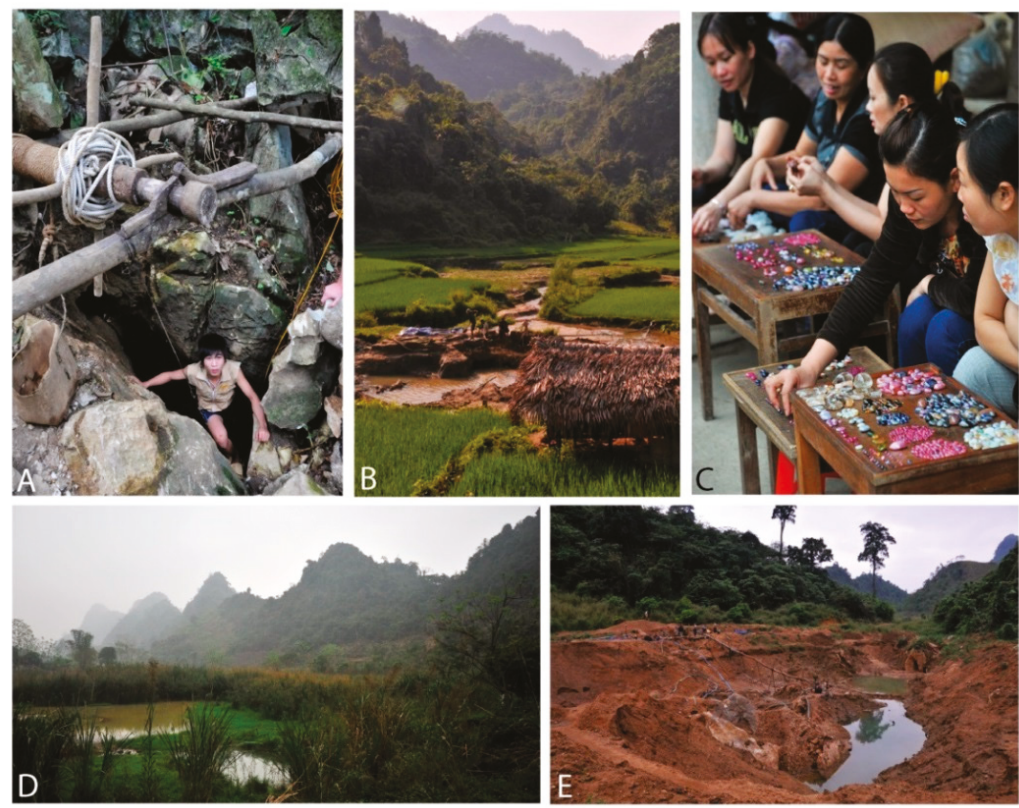

Figure 58. Ruby-bearing placers hosted in marble from northern Vietnam (Luc Yen area; 2009). (A) Exploitation by locals of ruby-bearing gravel concentration in karst pockets; (B) artisanal exploitation of ruby-bearing alluvial fans concentrated in narrow valleys bordered by rice fields; $(\mathbf{C})$ the famous gem market at Luc Yen city; authorization for the photograph of the Luc Yen market by filed gemmologist M. Shuan, and (D) the gem-bearing valleys are often narrow and correspond to small depressions, which typically range in area from 2 to $3 \mathrm{~km}^{2}$. These valleys are defined by shear zones and faults that crosscut the marble units. The karst geomorphology is characterized by an alignment of marble domes forming cones and lines of karst hills; (E) excavation of ruby-bearing areas continued up to the marble pinnacles, but the missed gem areas between the pinnacles is exploited by locals with shovels, picks and buckets. Photos: Vincent Pardieu (C) GIA.

\subsubsection{Sub-Type IIIC: Gem Placers with Ruby Originating from Multiple and Unknown Sources}

Gem placers of economic interest are also found in Madagascar (Ilakaka, Andilamena, Bemainty, Didy, and Zahamena) and Tanzania (Tunduru, Songea, and Umba). The historical, geological, and mineralogical features of these deposits are described in different publications; see $[5,19,20,108,161,164,263-266]$. These placers contain ruby, sapphires, and other minerals (garnets, alexandrite, topaz, zircon, spinel, and tourmaline) that originate from multiple unknown sources. We can note that at Songea and Andilamena, corundum is found both in placers and in situ in highly weathered rocks.

In the Ilakaka area (see Figure 4), gem corundum is found at three gravel levels in two main alluvial terraces deposited on the Triassic Isalo sandstone [108]. The terraces are weakly consolidated, but correspond to paleoplacers. The terraces are the result of the erosion and stripping of the sandstones. The deposit is not well consolidated and is composed of quartz-rich sands containing pebbles of ferruginous laterite, rounded blocks of Isalo sandstone and quartz, and quartzite and schist pebbles. 
The Ilakaka deposits produce very fine blue, blue-violet, violet, purple, orange, yellow, and translucent sapphire crystals along with pink corundum and rare rubies, zircon, alexandrite, topaz, garnet, spinel, andalusite, and tourmaline. In 2002, test mining by Gem Mining Resources Company over 38 days resulted in approximately 43 kilos of gems, comprising of $4 \%$ semi-precious stones, volcanic glasses, and ruby, and $96 \%$ sapphire comprising $58 \%$ pink gem corundum, 30\% sapphire, and $8 \%$ other colors of sapphire (e.g., yellow, orange, padparadscha, and green). Microscopic examination of respectively 30 ruby and 58 blue sapphire crystals showed that all of the rubies have the same gemmological features, i.e., growth, twinning, color bands, and solid inclusions, but that the blue sapphires define two different mineralogical groups [40].

The ruby crystals have $\delta^{18} \mathrm{O}$ values between $2.6 \%$ ond $3.8 \%$ o $\left(\delta^{18} \mathrm{O}_{\text {mean }}=3.5 \pm 0.5 \%\right.$ o, $\left.n=4\right)$ that are within the isotopic range defined for primary ruby deposits in metamorphosed M-UMR from Southern Madagascar $\left(2.5 \%\right.$ o $<\delta^{18} \mathrm{O}<6.8 \%$; [128]). The Phanerozoic sedimentary sequences and the Isalo Group cover the northern part of the Vohibory unit, where intercalations or complexes of M-UMR hosting ruby and pink corundum are common [164]. Erosion of the Vohibory unit during the Late Carboniferous to Middle Jurassic contributed to the concentration of ruby in the basin. A proximal source for ruby in Ilakaka from the Vohibory region is likely. Quaternary erosion remobilized paleoplacers.

In the eastern part of Madagascar, several ruby-bearing placers have been discovered over the last 20 years as the Vatomandry deposit [255] (see Figure 4). The ensuing rush of locals and immigrants opened up several mining zones in the areas of Andilamena (2000-2004), Andrebabe (2002), Moramanga (2010), Didy (2012), Zahamena (2015), and Bemainty (2016). The deposits are generally exploited by either unlicensed miners when working outside of protected areas or illegal miners when working inside the areas (Figure 59). The miners operate in quagmires with shovels and buckets, washing gravels in pans and removing the stones from the sieves by hand.
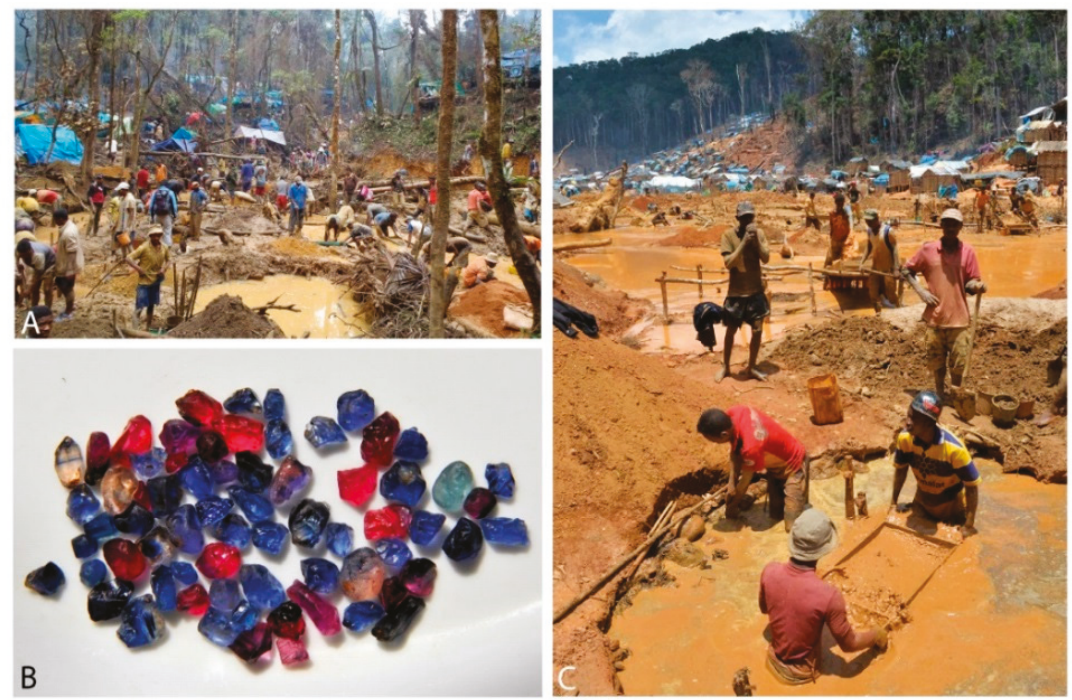

Figure 59. Placer deposits in the eastern part of Madagascar. (A) General view of the ruby and sapphire deposit in the jungle of Didy. Photo: Nirina Rakotosaona; (B) crystals of ruby and sapphires from the Didy deposit. The crystals are around $8 \mathrm{~mm}$ in size; photo: Vincent Pardieu (C) GIA; and (C) sapphire and pink corundum placer deposits in the jungle near Bemainty. Photo: Vincent Pardieu.

Ruby is generally associated with sapphires at Vatomandry [77,78], Didy [265] (Figure 59), and Bemainty [265] but is exploited as a main gem mineral from the Andilamena and Zahamena 
deposits [266]. Up until the present, geological information is lacking, but visits to the mining district of Andilamena by V. Pardieu allowed him to observe the corundum host rocks, which were highly weathered. They comprised fuchsite-bearing altered mafic rocks, biotite schists, and kaolinite-bearing rocks. The rubies are found in mafic rocks and/or biotite schists. Sapphires are restricted to veins of quartz-free kaolinite-bearing rocks that crosscut the mafic rocks.

Debate on the geologic and geographic origins of rubies from Andilamena and Vatomandry involved:

(i) The chemistry of these rubies in the diagram $\mathrm{FeO}-\mathrm{Cr}_{2} \mathrm{O}_{3}-\mathrm{MgO}-\mathrm{V}_{2} \mathrm{O}_{3}$ versus $\mathrm{FeO}+\mathrm{TiO}_{2}$ $+\mathrm{Ga}_{2} \mathrm{O}_{3}$ is similar and characterized by an overlap of two chemical domains (bimodal distribution; see Figure 53). On the contrary, the diagram V versus Fe (Figure 60) shows a clear difference in the $\mathrm{V}$ contents of ruby for both deposits that allows the allocation of the geographic origin of the Vatomandry rubies relative to Andilamena and also the main ruby deposits worldwide;

(ii) The $\delta^{18} \mathrm{O}$ values for rubies from the Vatomandry mining district span the range $2.7-6.7 \%$ o $(n=8)$ with a mean value of $\delta^{18} \mathrm{O}=5.1 \pm 1.4 \%$ o $(n=5)$. Those for rubies from the Andilamena deposit are between $0.5 \%$ and $4 \%$ o with a mean value of $\delta^{18} \mathrm{O}=2.9 \pm 1.5 \%$ o [128]. Both ranges of $\delta^{18} \mathrm{O}$ values overlap and fit within the worldwide range defined for ruby in basaltic environments $\left(1.3 \%\right.$ o $<\delta^{18} \mathrm{O}<5.9 \%$, mean $\delta^{18} \mathrm{O}=3.1 \pm 1.1 \%$ o, $\left.n=57\right)$; [80]) and ruby associated with metamorphosed M-UMR $\left(0.25 \%\right.$ o $<\delta^{18} \mathrm{O}<6.8 \%$ o, $\left.n=19\right)$. Both rubies are compatible with a metamorphic origin.

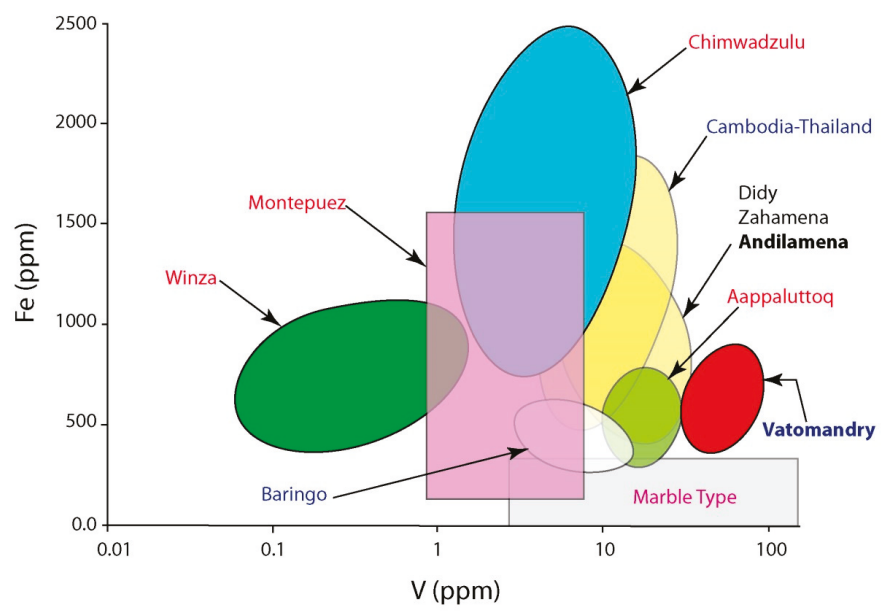

Figure 60. V versus Fe (in ppm) for the main ruby deposits of Madagascar (Vatomandry, Andilamena, Didy, Zahamena) and other deposits worldwide (Kenya, Baringo; Greenland, Aappaluttoq; Tanzania, Winza; Mozambique, Montepuez; Malawi, Chimwadzulu; Cambodia and Thailand; and finally deposits of marble type from Central and Southeastern Asia). Chemical data from [200,267] and Pardieu unpublished data. The chemical domain of ruby from Vatomandry is clearly separated from all the other ones and this parameter permits to precise its geographic origin. The name of ruby deposits related respectively, to $\mathrm{M}$-UMR is written in red (Types $\mathrm{IIA}_{1}, \mathrm{IIB}_{1}$ ), to marble deposits in violet (Type $\mathrm{IIB}_{2}$ ), to alkali-basalt in blue (Type IIIA), and to metamorphic environment in black (Type IIIB).

\section{Conclusions and Perspectives}

In the present paper, the ruby occurrences and deposits were classified into three main types: (Type I) magmatic-related, (Type II) metamorphic-related, and (Type III) sedimentary-related (Figure 61).

The economic ruby deposits, in terms of volume and quality, are the placers that in the new ruby deposits classification are called "Sedimentary-related (Type III)". The hardness and density of ruby are the main physical parameters that enable it to survive the erosion of primary deposits, mechanical transport, and accumulation along slopes or sedimentation in basins. Today Africa is the 
top gem ruby producer in the world, via secondary deposits in metamorphic environments (Sub-Type IIIB) resulting from the erosion of primary deposits in metamorphosed mafic and ultramafic rocks (M-UMR; Sub-Types IIA $\mathrm{I}_{1}$ and $\mathrm{IIB}_{1}$ ).

Over the last decade the main discoveries of ruby have been in Mozambique and Madagascar. It is not the end but the beginning of a new era for understanding the formation of such primary deposits and prospecting their associated placers. At the Montepuez mining district, the colluvial deposits are highly economic and characterized by limited transport. Most of the mineralized horizons are stone lines but the placers are proximal to the primary deposits. The exploration scheme proposed by [25] for the colluvial deposits based on detailed mapping of the primary deposits and erosion through time is of high importance. It includes the study of the paleogeography of eroded areas (plateaux and basins) in Eastern Africa where ruby occurrences are known, and the geology of mineralized structures in metamorphic belts.

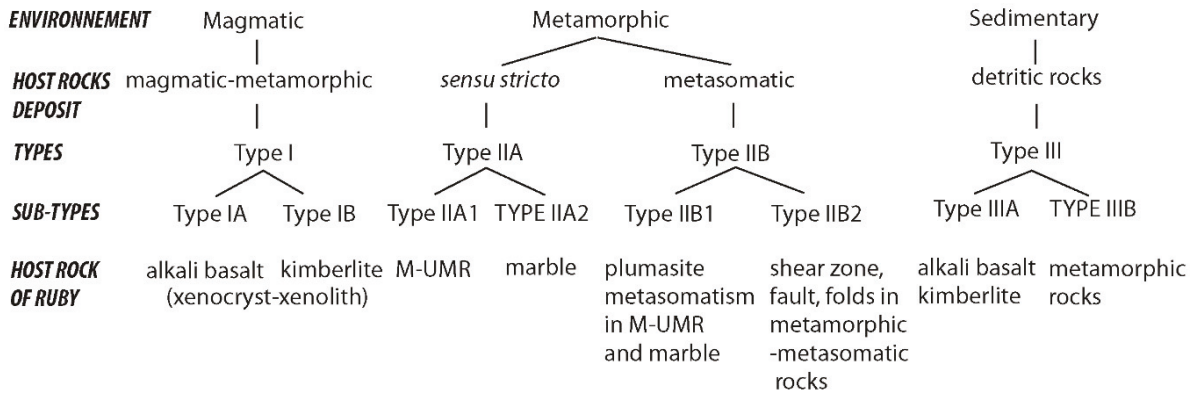

Figure 61. New typological classification for ruby occurrences and deposits worldwide. M-UMR = metamorphosed mafic-ultramafic rocks.

The extent of erosion through time can be assessed by dating the colluvial or alluvial material by measuring ${ }^{10} \mathrm{Be}$ (cosmogenic isotope) in recent quartz-rich sediments or in pebbles of quartz (alluvial or not), which allows the quantification of mean denudation rates, in alluvial terraces and abrasion, across a watershed or an ancient basin. Cosmogenic isotopes are produced on the Earth's surface by the interaction of cosmic rays and their products with matter $\left({ }^{10} \mathrm{Be}, \mathrm{T} 1 / 21.5 \mathrm{Ma}\right)$. Such isotopes accumulate progressively in rocks near the surface, depending on altitude and erosion rates. The cosmogenic isotopic concentration of the sediment provides access to the average erosion rate of the watershed at its source. Fission track studies on zircon (and apatite) may be used in sediment provenance determination and in terms of the time of cooling below $300^{\circ} \mathrm{C}$ in the zircon-bearing protolith before erosion.

The new and major discoveries of ruby and sapphire placers in Eastern Madagascar at Didy, Zahamena, and Bemainty, located in tropical forests, are economic. They were found by local people in areas, which are crosscut by numerous NE-SW faults separating small alluvial and diluvial basins. These zones are difficult to access and are protected forest areas; therefore prospecting has not been done but the combination of photosatellite images with geological maps, looking for metamorphic M-UMR formations, will help in the discovery of new placers.

Other ruby-bearing Neoproterozoic metamorphic M-UMR in East Africa have been productive and some of them still produce a few rubies as in Tanzania (Winza, Longido), Kenya (Mangare area, Kitui), Malawi (Chimwadzulu), and Southern Madagascar (Vohibory region). In 2005 these countries assumed most of the worldwide production. These primary deposits in M-UMR can be found in all metamorphosed volcano-sedimentary sequences from the Archean to the Cenozoic. The discovery and production of ruby at the Aappaluttoq deposit (south of Nuuk; Fiskenæsset district) and the presence of new occurrences north of Nuuk (Kangerdluarssuk) is an excellent example that must encourage a better understanding of their formation and their prospecting as a function of the latitude of the different countries (tropical versus glacial and temperate climates). 
The second important type of ruby deposit includes those located in marble (Sub-Type IIA I $_{2}$ in Central and Southeastern Asia. These Cenozoic deposits are always one of the main worldwide sources of high quality ruby with intense color and high transparency, such as the famous Mogok pigeon blood rubies. The mining district of Mogok is rich in different types of gems including red spinel and ruby in marble. Genetic models are proposed for their genesis. They formed during the metamorphism, in the amphibolite facies, of carbonates interbedded with mudstone and evaporitic (salts and sulfates) intercalations. Lithological control of the mineralization is a function of the paleogeography of the carbonate platform environment before metamorphism. The role of evaporites is proposed as key for the genesis of ruby in marble but Al-enriched sediments such as metapelite or meta-bauxite intercalated in the marbles are in some cases also possible protolith for the ruby-parent rocks (Revelstoke and Snezhnoe deposits). The Mogok mining district remains a suitable site for developing further geological research considering the complexity of the relationships between the metamorphic rocks and granitoid intrusions. The formation of ruby-bearing skarns is possible, given the recrystallization of some carbonates, with crystals up to $10 \mathrm{~cm}$ across, present in the Dattaw mine. Multi-stage mineralization and telescoped episodes of thermal anomalies related to regional or contact metamorphism are highly probable. Future efforts will move towards developing more effective exploration guidelines that consider new geological factors responsible for the formation of ruby at Mogok and the timing of formation of these multi-stage gem deposits.

The timing between deformation, metamorphism, and ruby formation in these marble deposits is of importance, as shown in some deposits from Tanzania that are associated with folding, saddle-reef structure, and fluid circulation in zones of higher permeability. This scheme is applicable for all deposits, whatever their ages, but must be prospected in the Neoproterozoic Metamorphic Belt.

The classification proposed for ruby occurrences and deposits is a necessary step to build a new scheme for understanding ruby-mineralization from the field to the laboratory. The determination of the different sub-types based on the host rock of ruby and the knowledge on the genesis of most of the deposits will help us to understand the mineral associations and the chemistry of rubies. The combination of all these data linked to a specific type of deposit will serve as a basis for the determination of the geographical origin of rubies.

The diversification of known ruby sources in the world during these last two decades has increased considerably the challenge of gem ruby geographic origin determination [11-15]. The gemmological laboratories amassed rubies with samples obtained by professional field gemmologists $[9,21,37,90,200]$. The precise gem localization combined with accurate chemical analysis obtained by LA-ICP-MS calibrated by natural standards [92], enriched the collections of standard stones for different types of ruby deposits worldwide. The combination of inclusions and trace element chemistry makes the geographic origin determination more reliable currently, although it can remain inconclusive [11]. The case of ruby and sapphire in placers from basaltic environments is illustrative and the geographic origin is always matter of debate; the geologic origin is often confronted to different possible possibilities, i.e., metamorphic sensu stricto, metamorphic-metasomatic, and magmatic for gem material $[11,268]$. The $\mathrm{V}$ versus Fe diagram of ruby from several economic deposit (see Figure 60) confirms clearly the separation of the two main types of primary ruby deposits worldwide, i.e., those hosted in M-UMR (Types $\mathrm{IIA}_{1}$ and $\mathrm{IIB}_{1}$ ) and in marble $\left(\mathrm{IIB}_{2}\right)$, which are typically metamorphic. The origin of ruby from secondary deposits, i.e., placers in the alkali basalt environment (Type IIIA) is debatable because melt inclusions are present in some rubies from Thailand, Cambodia, and Montana. A magmatic origin is probable but the $V$ versus Fe diagram shows that their chemical domain overlaps that of rubies from metamorphic origin. The discussion presented here provides a basis for further investigations into the origin of these rubies keeping in mind that they were incorporated by ascending basaltic magmas as xenocrysts from possible different geological sources.

Rubies are classified by most of the gemmological laboratories into two groups based on their trace element chemistry [11]: (i) low (below $200 \mathrm{pm}$ ) and high iron (above $400 \mathrm{ppm}$ ) rubies. The marble-hosted metamorphic rubies (Type IIA $\mathrm{I}_{2}$ ) have a very low Fe content when compared to all the other types 
of rubies except those from the former John Saul mine (see Figure 19, e.g., plumasite of Type $\mathrm{IIB}_{1}$ ). Nevertheless rubies in marble deposits have similar inclusion characteristics and their chemical domain overlap as well as their oxygen isotopic values. This remark opens the debate about the reality of determining the geographic origin of a gem when disconnected from its geological environment. Some stones and sometimes of top-quality are mingled with other ones and finally whenever the ruby is Fe-poor, the geographic determination is inconclusive. Myanmar stones are always highly prized on the market for their color and transparency. The Mogok and Mong Hsu rubies are identified based on their internal features and trace element profiles [11]. High-iron rubies (Thailand, Cambodia, Madagascar, Mozambique, Kenya, and Greenland) are usually basically identified by their inclusions and trace element profiles (V, $\mathrm{Mg}$, and Fe but not $\mathrm{Cr}$, see Figure 20; $[11,82,83])$. The main question of geographic attribution remains for rubies between these two ranges of Fe contents.

The new geological classification of ruby based on the geological environment and the gem host-rock proposed three main types and eight sub-types of deposits. The classification system reflects the interplay between tectonic with magmatic and metamorphic events during the history of the Earth, and through continental plate tectonics within Wilson cycles, over circa 150 millions of years. The final point concerns the basic erosion of ruby-bearing rocks at the surface, and the transport and sedimentation of the detrital material in basins. The different sub-types for primary deposits are based on the gem host-rock of ruby, which is different from place to place in the crust, the final petrographic product depending on the nature of the fluids, the timing of their circulation and the intensity of fluid-rock interaction. Desilication and/or metasomatism phenomena are effective processes able to extract not only the chromophores $\mathrm{Cr}, \mathrm{V}$, and Fe but also Al from M-UMR for the formation of ruby. The different sub-types of deposits will help either the geologist to understand the genesis of new deposits and to define zones of interest for exploration or the gemmologist for geographic origin determination.

Fingerprinting of ruby used by gemmologists is a tool derived from geological and mineralogical investigations: (i) Trace elements $(\mathrm{V}, \mathrm{Fe}, \mathrm{Ga}$, and $\mathrm{Mg}$ ) are used as previously reported. Ti is also an interesting element that can be used for determining the geological history of the gem-bearing sample as shown by [269] for corundum. The combination of different ratio such as $\mathrm{Mg} / \mathrm{Mg}+\mathrm{Fe}$ versus $\mathrm{Cr} / \mathrm{Cr}+\mathrm{V}$ will permit to trace the source of these elements, i.e., ultramafic versus mafic rocks as done for emerald by [270]; (ii) the combination of $\mathrm{Fe}, \mathrm{Ti}, \mathrm{Ga}, \mathrm{Cr}, \mathrm{V}$, and $\mathrm{Mg}$ with oxygen isotope ratios of ruby provide a powerful tool for the determination of geologic origin $[40,82,87,93,144,151,152]$. The oxygen isotopes separate clearly three types of ruby deposits: (a) marble, (b) the John Saul mine type, and (c) metamorphosed M-UMR. The analysis of oxygen isotopes by SIMS is semi-destructive as is LA-ICP-MS for trace elements analysis but can be applied on cut and polished rubies; and (iii) inclusions are helpful in origin determination but similar geologic environments can produce gems of similar inclusion suites [269]. Determining the geological origin of corundum mingled in huge metamorphic placers remains a very difficult task, as for the Ilakaka deposit in Madagascar.

The objective geological criteria synthesized in the present review through scientific works and experience open a new framework for mineral exploration guidelines. The final conclusion is that the main economic ruby deposits are the result of continental plate tectonics. Ruby deposits are found where continental plate collision formed mountain ranges, as was the case in the Neoproterozoic with the Metamorphic Mozambican Belt, or with the Himalayas. Continental collision increases the thickness of the continental lithosphere, which is accompanied by an increase of pressure and temperature producing a zone of higher grade metamorphism (amphibolite to granulite facies), and sometimes melting rocks to form felsic magmas. Extensive deformation at high temperature with kilometer-scaled migration of material and fluids along shear zones (e.g., in the case either of the Red River shear zone in Southern China and Northern Vietnam or the Mogok Metamorphic Belt, where ruby is found in placers defining the trace of shear zones in Northern Vietnam) and faults results in the remobilization and precipitation of elements, and tectonic melange zones. These processes are heterogeneous, and proceed by dissolution and precipitation, as well as by fusion and crystallization, 
where elements (such as chromium) are unusually concentrated in the crust. The return to isostatic equilibrium ( $30 \mathrm{~km}$ thick for the continental crust) and erosion processes through time brings to the surface the metamorphic roots (belts) of these ancient mountain chains. This is currently the case with the Mozambican metamorphic belt where high-temperature gems such as ruby, spinel, tsavorite, and other garnets are found.

The main production of gem ruby is provided by this Pan-African metamorphic belt. All ruby deposits are of metamorphic origin in the broad sense. These mineral deposits are associated either with regional metamorphism sensu stricto or through fluid-rock interactions accompanied by metasomatism, contemporary with, or slightly later than, metamorphism. Their dismantling by current erosion creates important reserves and the exploration of continental placers in tropical landscapes where regoliths have been present for several thousand years should be studied with new approaches.

Author Contributions: All the authors contributed with their field and laboratory work and experience, and the works of worldwide researchers for over one century with the first detailed description, at the beginning of the 20th century, of the Malagasy deposits by A. Lacroix (MNHN Paris), to the realization of this description of the state-of-the-art of the geology and genesis of ruby deposits worldwide. G.G., L.A.G. and V.P. collected the studied samples in the field as well as realized photographs on specific geological and gemmological cases. G.G. conducted geological mapping in several areas worldwide and G.G., L.A.G., I.P. and V.P. obtained and evaluated part of the mineralogical and geochemical data. I.P. conducted cristallography on corundum crytals as well as the study on trapiche rubies from differents deposits. A.E.F. and G.G. obtained and evaluated the oxygen isotope data. V.P. obtained and evaluated part of the gemmological data. Investigations in the different specific domains were realized by the authors in their own laboratory. G.G. realized some software for corundum chemical analysis as well as the original draft preparation and the supervision of the paper project with approval of the co-authors. The writing was realized by all the autors in their area of competence with the supervision by G.G and language corrections by A.E.F. Review and editing was done by G.G. All authors have read and agreed to the published version of the manuscript.

Funding: The present paper was realized without any direct funding. The work is based on the knowledge and funding obtained in the course of more than 30 years work on the geology of gems.

Acknowledgments: The authors want to thank the Editor of Minerals and Guest Editors, Frederick Lin Sutherland and Khin Zaw, for invitation to contribute in a special issue on "Mineralogy and Geochemistry of Ruby", and for their valuable suggestions. We are also thankful to four anonymous reviewers for improving the text by pertinent and constructive comments on the article. The authors want also to thank D. Schwarz, E. Le Goff, C. Simonet for their discussion and collaborations on the scientific topic. G.G. wants to thank the Institut de Recherche pour le Développement (IRD, France) and the French CNRS and the Unversities of Lorraine and Paul Sabatier (CRPG/CNRS-Université de Lorraine and GET/IRD-Université Paul Sabatier) for academic and financial support for research on the geology of gems over the past 30 years.

Conflicts of Interest: The authors declare no conflict of interest.

\section{References}

1. Eichholz, D.E. Theophrastus, De Lapidibus; Oxford Clarendon Press: Oxford, UK, 1965.

2. Littré, E. Tome Second. In Histoire Naturelle de Pline; Chez Firmin-Didot et Cie: Paris, France, 1877.

3. Ernault, L. Marbode, Évêque de Rennes, Sa Vie et Ses Oeuvres; Hte Cailleres: Rennes, France, 1890; pp. $1035-1123$.

4. Albertus Magnus Liber Mineralium; Jacob Köbel: Oppenheim, Germany, 1518.

5. Hughes, R.W. Ruby and Sapphire; RWH Publishing: Boulder, CO, USA, 1997.

6. Pardieu, V. Thailand, the undisputed ruby kingdom: A brief history. InColor 2019, 42, 14-22.

7. Themelis, T. The Heat Treatment of Ruby and Sapphire; Gemlab Inc.: New York, NY, USA, 1992.

8. Shigley, J.E.; Dirlam, D.M.; Laurs, B.M.; Boehm, E.W.; Bosshart, G.; Larson, W.F. Gem localities of the 1990s. Gems Gemol. 2000, 36, 292-335. [CrossRef]

9. Dussart, S. The version of field gemologist Vincent Pardieu. IGR It alian Gemol. Rev. 2019, 7, 58-64.

10. Raden, A. Stoned: Jewelry, Obsession, and How Desire Shapes the World; Ecco: Manhattan, NY, USA, 2015.

11. Palke, A.C.; Saeseaw, S.; Renfro, N.D.; Sun, Z.; McClure, S.F. Geographic origin determination of ruby. Gems Gemol. 2019, 55, 580-612. [CrossRef]

12. Gübelin Gem Laboratory: The roots of origin determination. Jewel. News Asia 2006, 52-62.

13. Gübelin Gem Laboratory: The limits of orgin determination. Jewel. News Asia 2006, 66-71.

14. Gübelin Gem Laboratory: A hoolistic method to determining gem origin. Jewel. News Asia 2006, 118-126.

15. McClure, S.F.; Moses, T.M.; Shigley, J.E. The geographic origin dilemma. Gems Gemol. 2019, 55, 457-462. 
16. Gübelin, E.J.; Koivula, J.I. Photoatlas of Inclusions in Gemstones; ABC Edition: Zurich, Switzerland, 1986.

17. Gübelin, E.J.; Koivula, J.I. Photoatlas of Inclusions in Gemstones; Opinio Publishers: Basel, Switzerland, 1985; Volume 3.

18. Sotheby's Magnificient Jewels and Noble Jewels, Auction 502. 2005. Available online: http://www.sothebys. com (accessed on 20 June 2020).

19. Pardieu, V. Ruby and Sapphire Rush near Didy, Madagascar. April-June 2012. Available online: https: //www.gia.edu/doc/Ruby-and-Sapphire-Rush-Near-Didy-Madagascar.pdf (accessed on 20 June 2020).

20. Peretti, A.; Hahn, L. Record-breaking discovery of ruby and sapphire at the Didy mine in Madagascar: Investigating the source. In Color 2013, 21, 22-35.

21. Pardieu, V.; Jacquat, S.; Senoble, J.B.; Bryl, L.P.; Hughes, R.W.; Smith, M. Expedition Report to the Ruby Mining Sites in Northern Mozambique (Niassa and Cabo Delgado Provinces), Bangkok, GIA Laboratory. 2009. Available online: https:/www.gia.edu/doc/Expedition-report-Ruby-mining-sites-Northern-Mozambique (accessed on 20 June 2020).

22. Pardieu, V.; Jacquat, S.; Bryl, L.P.; Senoble, J.B. Rubies from northern Mozambique. InColor 2009, 12, 32-36.

23. Pardieu, V.; Thanachakaphad, J.; Jacquat, S.; Senoble, J.B.; Bryl, L.P. Rubies from the Niassa and Cabo Delgado Regions of Northern Mozambique. A Preliminary Examination with an Updated Field Report Annex. Bangkok, GIA Laboratory. Available online: https://www.gia.edu/doc/Niassa_Mozambique_Ruby_ September13_2009.pdf (accessed on 20 June 2020).

24. Pardieu, V. Gemfields' November 2017 ruby auction yields record results. InColor 2018, 37, 62-63.

25. Simonet, C. The Montepuez ruby deposits, what's next? InColor 2018, 37, 32-40.

26. Vertriest, W.; Saeseaw, S. A decade of ruby from Mozambique: A review. Gems Gemol. 2019, 55, 162-183. [CrossRef]

27. A Competent Persons Report on the Montepuez Ruby Project, Mozambique; SRK Consulting (UK) Limited: Cardiff, UK, 2015; 195p.

28. Yager, Y.G.; Menzie, W.D.; Olson, D.W. Weight of Production of Emeralds, Rubies, Sapphires, and Tanzanite from 1995 through 2005. Open file Report 2008-1013; USGS: Reston, VA, USA, 2008.

29. Themelis, T. Gems and Mines of Mogok; Ted Themelis: Bangkok, Thailand, 2008; ISBN 0940965-30-5.

30. Peretti, A.; Schmetzer, K.; Bernhardt, H.J.; Mouawad, F. Rubies from Mong Hsu. Gems Gemol. 1995, 31, 2-26. [CrossRef]

31. Streeter, E.W. Precious Stones and Gems, Their History Sources and Characteristics; George Bell \& Son: London, UK, 1892.

32. Rohtert, W.; Ritchie, M. Three parageneses of ruby and pink sapphire discovered at Fiskenæsset, Greenland. Gems Gemol. 2006, 42, 149-150.

33. Fagan, A.J. True North Gems Greenland mining-The final lap. InColor 2015, 29, 36-49.

34. Fagan, A.J. The Ruby and Pink Sapphire Deposits of SW Greenland: Geological Setting, Genesis, and Exploration Techniques. Ph.D. Thesis, University of British Columbia, Vancouver, BC, Canada, 2018.

35. Smith, C.P.; Fagan, A.J.; Bryan, C. Ruby and pink sapphire from Aappaluttoq, Greenland. J. Gemmol. 2016, 35, 294-306. [CrossRef]

36. Lucas, A.; Palke, A.; Vertriest, W. Mining rubies in Greenland. The Aappaluttoq ruby mine. InColor 2018, 37, $42-52$.

37. Vertriest, W.; Palke, A.C.; Renfro, N.D. Field gemology: Building a research collection and understanding the development of gem deposits. Gems Gemol. 2019, 55, 490-511. [CrossRef]

38. Cesbron, F.; Lebrun, P.; Le Cléac'h, J.M.; Notari, F.; Grobon, C.; Deville, J. Corindons et spinelles. In Minéraux et Fossiles 15; Editions CEDIM: Paris, France, 2002.

39. Bowles, J.F.W.; Howie, R.A.; Vaughan, D.J.; Zussman, J. Rock-Forming Minerals. Non-Silicates: Oxides, Hydroxides and Sulphides; The Geological Society: London, UK, 2011; Volume 5A.

40. Giuliani, G.; Ohnenstetter, D.; Fallick, A.E.; Groat, L.; Fagan, J. The geology and genesis of gem corundum deposits. In Geology of Gem Deposits; Groat, L.A., Ed.; Mineralogical Association of Canada: Tucson, AZ, USA, 2014; Short Course Series; Volume 44, pp. 29-112.

41. Bindeman, I.N.; Serebryakov, N.S. Geology, petrology and $\mathrm{O}$ and $\mathrm{H}$ isotope geochemistry of remarkably ${ }^{18} \mathrm{O}$ depleted Paleoproterozoic rocks of the Belmorian belt, Karelia, Russia, attributed to global glaciation 2.4 Ga. Earth Planet. Sci. Lett. 2011, 306, 163-174. [CrossRef] 
42. Grapes, R.; Palmer, K. (Ruby-sapphire)-chromian mica-tourmaline rocks from Westland, New Zealand. J. Petrol. 1996, 37, 293-315. [CrossRef]

43. Hutchinson, M.T.; Nixon, P.H.; Harley, S.L. Corundum inclusions in diamonds-discriminatory criteria and a corundum composition dataset. Lithos 2004, 77, 273-286. [CrossRef]

44. Perretti, A. The Making of an International Color Standard by GRS: "Pigeon's Blood" and "Royal Blue". Definitions, Retroperspective and Future. 2015. Available online: http://www.pigeonsblood.com (accessed on 23 November 2019).

45. Smith, C.P.; Surdez, N. The Mong Hsu ruby: A new type of Burmese ruby. Jewelsiam 1994, 5, 82-98.

46. Sunagawa, I. Crystals: Growth, Morphology and Perfection; Cambridge University Press: Cambridge, UK, 2005.

47. Sunagawa, I.; Bernhardt, H.-J.; Schmetzer, K. Texture formation and element partitioning in trapiche ruby. J. Cryst. Growth 1999, 206, 322-330. [CrossRef]

48. Hänni, H.A.; Schmetzer, K. New rubies from the Morogoro Area, Tanzania. Gems Gemol. 1991, 27, $156-167$. [CrossRef]

49. Sorokina, E.S.; Hofmeister, W.; Häger, T.; Mertz-Kraus, R.; Buhre, S.; Saul, J. Morphological and chemical evolution of corundum (ruby and sapphire): Crystal ontogeny reconstructed by EMPA, LA-ICPMS, and $\mathrm{Cr}^{3+}$ Raman mapping. Am. Mineral. 2016, 101, 2716-2722. [CrossRef]

50. McKague, H.L. Trapiche emeralds from Colombia. Gems Gemol. 1964, 11, 210-213.

51. Schmetzer, K.; Hänni, H.A.; Bernhard, H.J.; Schwarz, D. Trapiche rubies. Gems Gemol. 1996, 32, $242-250$. [CrossRef]

52. Schmetzer, K.; Beili, Z.; Yan, G.; Bernhard, H.J.; Hänni, H.A. Element mapping of trapiche rubies. J. Gemmol. 1999, 26, 289-301. [CrossRef]

53. Win, K.K. Trapiche of Myanmar. Austr. Gemmol. 2005, 22, 269-270.

54. Schmetzer, K.; Bernhardt, H.J.; Hainschwang, T. Chemical and growth zoning in trapiche tourmaline from Zambia-A re-evaluation. J. Gemmol. 2011, 32, 151-173. [CrossRef]

55. Koivula, J.I.; Kammerling, R.C.; Fritsch, E. Gem News: “Trapiche” purple-pink sapphire. Gems Gemol. 1994, 30, 197.

56. Kiefert, L. Unusual trapiche sapphire. Gems Gemol. 2012, 48, 229.

57. Pignatelli, I.; Giuliani, G.; Morlot, C.; Pham, V.L. The texture and chemical composition of trapiche ruby from Khoan Thong, Luc Yen mining district, northern Vietnam. J. Gemmol. 2019, 36, 726-745. [CrossRef]

58. Garnier, V.; Ohnenstetter, D.; Giuliani, G.; Schwarz, D. Rubis trapiches de Mong Hsu, Myanmar. Rev. Ass. Fr. Gemmol. AFG 2002, 144, 5-12.

59. Garnier, V.; Ohnenstetter, D.; Giuliani, G.; Blanc, P.; Schwarz, D. Trace-element contents and cathodoluminescence of "Trapiche" rubies from Mong Hsu (Myanmar): Geological significance. Miner. Petrol. 2002, 76, 179-193. [CrossRef]

60. Peretti, A.; Mullis, J.; Mouawad, F. The role of fluoride in the formation of color zoning in rubies from Mong Hsu (Myanmar, Burma). J. Gemmol. 1996, 25, 3-19. [CrossRef]

61. Pignatelli, I.; Giuliani, G.; Ohnenstetter, D.; Agrosi, G.; Mathieu, S.; Morlot, C.; Branquet, Y. Colombian trapiche emeralds: Recent advances in understanding their formation. Gems Gemol. 2015, 51, $222-259$. [CrossRef]

62. Giuliani, G.; Dubessy, J.; Pignatelli, I.; Schwarz, D. Fluid inclusions study of trapiche and non-trapiche rubies from Mong Hsu deposit, Myanmar. Can. Mineral. 2018, 56, 1-13. [CrossRef]

63. Giuliani, G.; Dubessy, J.; Banks, D.; Lhomme, T.; Ohnenstetter, D. Fluid inclusions in ruby from Asian marble deposits: Genetic implications. Eur. J. Mineral. 2015, 27, 393-404. [CrossRef]

64. Giuliani, G.; Dubessy, J.; Ohnenstetter, D.; Banks, D.; Branquet, Y.; Feneyrol, J.; Fallick, A.E.; Martelat, J.-E. The role of evaporites in the formation of gems during metamorphism of carbonate platforms: A review. Mineral. Depos. 2018, 53, 1-20. [CrossRef]

65. Garnier, V.; Giuliani, G.; Ohnenstetter, D.; Fallick, A.E.; Dubessy, J.; Banks, D.; Hoàng, Q.V.; Lhomme, T.; Maluski, H.; Pêcher, A.; et al. Marble-hosted ruby deposits from central and southeast Asia: Towards a new genetic model. Ore Geol. Rev. 2008, 34, 169-191. [CrossRef]

66. Garnier, V. Les Gisements de Rubis Associés aux Marbres de l'Asie Centrale et du Sud-est: Genèse et Caractérisation Isotopique. Ph.D. Thesis, University of Nancy, Nancy, France, 2003.

67. Muhlmeister, S.; Fritsch, E.; Shigley, J.E.; Devouard, B.; Laurs, B.M. Separating natural and synthetic rubies on the basis of trace-element chemistry. Gems Gemol. 1998, 34, 80-101. [CrossRef] 
68. Sutherland, F.L.; Schwarz, D.; Jobbins, E.A.; Coenraads, R.R.; Webb, G. Distinctive gem corundum suites from discrete basalt fields: A comparative study of Barrington, Australia, and West Pailin, Cambodia, gemfields. J. Gemmol. 1998, 26, 65-85. [CrossRef]

69. Sutherland, F.L.; Coenraads, R.R.; Abduriyim, A.; Meffre, S.; Hoskin, P.W.O.; Giuliani, G.; Beattie, R.; Wuhrer, R.; Sutherland, G.B. Corundum (sapphire) and zircon relationships, Lava Plains gem fields, NE Australia: Integrated mineralogy, geochemistry, age determination, genesis and geographic typing. Mineral. Mag. 2015, 79, 545-581. [CrossRef]

70. Peucat, J.J.; Ruffault, P.; Fritsch, E.; Bouhnik-Le Coz, M.; Simonet, C.; Lasnier, B. Ga/Mg ratios as a new geochemical tool to differentiate magmatic from metamorphic blue sapphires. Lithos 2007, 98, 261-274. [CrossRef]

71. Sutherland, F.L.; Abduriyim, A. Geographic typing of gem corundum: A text case from Australia. J. Gemmol. 2009, 31, 203-210. [CrossRef]

72. Giuliani, G.; Caumon, G.; Rakotosamizanany, S.; Ohnenstetter, D.; Rakotondrazafy, A.F.M. Classification chimique des corindons par analyse factorielle discriminante: Application à la typologie des gisements de rubis et saphirs. Rev. Ass. Fr. Gemmol. AFG 2014, 188, 14-22.

73. Sutherland, F.L.; Schwarz, D. Origin of gem corundums from basaltic fields. Austr. Gemmol. 2001, 21, 30-33.

74. Sutherland, F.L.; Hoskin, P.W.O.; Fanning, C.M.; Coenraads, R.R. Models of corundum origin from alkali basaltic terrains: A reappraisal. Contrib. Mineral. Petrol. 1998, 133, 356-372. [CrossRef]

75. Sutherland, F.L.; Coenraads, R.R.; Schwarz, D.; Raynor, L.R.; Barron, B.J.; Webb, G.B. Al-rich diopside in alluvial ruby and corundum-bearing xenoliths, Australian and SE Asian basalt field. Mineral. Mag. 2003, 67, 717-732. [CrossRef]

76. Abduriyim, A.; Kitawaki, H. Applications of laser ablation-inductively coupled plasma-mass spectrometry (LA-ICP-MS) to gemology. Gems Gemol. 2006, 42, 98-118. [CrossRef]

77. Rakotosamizanany, S.; Giuliani, G.; Ohnenstetter, D.; Rakotondrazafy, A.F.M.; Fallick, A.E.; Paquette, J.-L.; Tiepolo, M. Chemical and oxygen isotopic compositions, age and origin of gem corundums in Madagascar alkali basalts. J. S. Afr. Earth Sci. 2014, 94, 156-170. [CrossRef]

78. Arlabosse, J.-M.; Delaunay, A.; Lenne, N. Les rubis de Vatomandry-Madagascar. Rev. Ass. Fr. Gemmol. AFG 2018, 203, 6-15.

79. Uher, P.; Giuliani, G.; Szakall, S.; Fallick, A.E.; Strunga, V.; Vaculovic, D.; Ozdin; Greganova, M. Sapphires related to alkali basalts from the Cerová Highlands, Western Carpathians (southern Slovakia): Composition and origin. Geol. Carpathica 2012, 63, 71-82. [CrossRef]

80. Giuliani, G.; Ohnenstetter, D.; Garnier, V.; Fallick, A.E.; Rakotondrazafy, A.F.M.; Schwarz, D. The geology and genesis of gem corundum deposits. In Geology of Gem Deposits; Groat, L.A., Ed.; Mineralogical Association of Canada: Yellowknife, NT, Canada, 2007; Short Course Series; Volume 37, pp. 27-78.

81. Sutherland, F.L.; Graham, I.T.; Harris, S.J.; Coldham, T.; Powell, W.; Belousova, E.A.; Martin, L. Unusual ruby-sapphire transition in alluvial megacrysts, Cenozoic basaltic gem field, New England, New South Wales, Australia. Lithos 2017, 278-281, 347-360. [CrossRef]

82. Sutherland, F.L.; Giuliani, G.; Fallick, A.E.; Garland, M.; Webb, G.B. Sapphire-ruby characteristics, West Pailin, Cambodia: Clues to their origin based on trace element and $\mathrm{O}$ isotope analysis. Austr. Gemmol. 2009, 23, 373-432.

83. Keulen, N.; Thomsen, T.B.; Schumacher, J.C.; Poulsen, M.D.; Kalvig, P.; Vennemann, T.; Salimi, R. Formation, origin and geographic typing of corundum (ruby and pink sapphire) from the Fiskenaæsset complex, Greenland. Lithos 2020, 366-367. [CrossRef]

84. Giuliani, G.; Pivin, M.; Fallick, A.E.; Ohnenstetter, D.; Song, Y.; Demaiffe, D. Geochemical and oxygen isotope signatures of mantle corundum megacrysts from the Mbuji-Mayi kimberlite, Democratic Republic of Congo, and the Changle alkali basalt, China. C.R. Geosciences 2015, 347, 24-34. [CrossRef]

85. Sutherland, F.L.; Khin, Z.; Meffre, S.; Giuliani, G.; Fallick, A.E.; Webb, G.B. Gem-corundum megacrysts from east Australian basalt fields: Trace elements, oxygen isotopes and origins. Austr. J. Earth Sci. 2009, 56, 1003-1022. [CrossRef]

86. Sutherland, L.; Graham, I.; Harris, S.; Khin, Z.; Meffre, S.; Coldham, T.; Coenraads, R.; Sutherland, G. Rubis australasiens. Rev. Ass. Fr. Gemmol. AFG 2016, 197, 13-20.

87. Khin, Z.; Sutherland, F.L.; Yui, T.F.; Meffre, S.; Thu, K. Vanadium-rich ruby and sapphire within Mogok gemfield, Myanmar: Implications for gem color and genesis. Mineral. Depos. 2015, 50, 25-39. [CrossRef] 
88. Sutherland, F.L.; Khin, Z.; Meffre, F.; Thompson, J.; Goemann, K.; Kyaw, T.; Than, T.N.; Mhod, Z.M.; Harris, S.I. Diversity in ruby chemistry and its inclusions: Intra and inter-continental comparisonsfrom Myanmar and Eastern Australia. Minerals 2019, 9, 28. [CrossRef]

89. Pardieu, V. Concise field report Volume 1: Pailin, Cambodia, Dec 2008-Feb 2009, Bangkok, GIA Laboratory. 2009. Available online: https://www.gia.edu/doc/Field-ReportPailin,pdf (accessed on 25 June 2020).

90. Pardieu, V. Field gemology. The evolution of data collection. InColor 2020, 46, 100-106.

91. Groat, L.A.; Giuliani, G.; Stone-Sundberg, J.; Sun, Z.; Renfro, N.D.; Palke, A.C. A review of analytical methods used in geographic origin determination of gemstones. Gems Gemol. 2019, 55, 512-535. [CrossRef]

92. Stone-Sundberg, J.; Thomas, T.; Sun, Z.; Guan, Y.; Cole, Z.; Equall, R.; Emmett, J.L. Accurate reporting of key trace elements in ruby and sapphire using matrix-matched standards. Gems Gemol. 2017, 53, 438-451. [CrossRef]

93. Giuliani, G.; Fallick, A.E.; Garnier, V.; France-Lanord, C.; Ohnenstetter, D.; Schwarz, D. Oxygen isotope composition as a tracer for the origins of rubies and sapphires. Geology 2005, 33, 249-252. [CrossRef]

94. Rakotosamizanany, S. Les Corindons Gemmes Dans Les Basaltes Alcalins et Leurs Enclaves à Madagascar: Significations Pétrologique et Métallogénique. Ph.D. Thesis, Université Henri Poincaré, Nancy, France, 2009.

95. Voudouris, P.; Mavrogonatos, C.; Graham, I.; Giuliani, G.; Melfos, V.; Karampelas, S.; Karantoni, V.; Wang, K.; Tarantola, A.; Khin, Z.; et al. Gem Corundum deposits of Greece: Geology, mineralogy and genesis. Minerals 2019, 9, 49. [CrossRef]

96. Fanka, A.; Sutthirat, C. Petrochemistry, mineral chemistry, and pressure-temperature model of corundum-bearing amphibolite from Montepuez, Mozambique. Arab. J. Sci. Eng. 2018, 43, 3751-3767. [CrossRef]

97. Morishita, T.; Arai, S.; Gervilla, F. High pressure aluminous mafic rocks from the Ronda peridotite massif, southern Spain: Significance of sapphirine- and corundum-bearing assemblages. Lithos 2001, 57, 143-161. [CrossRef]

98. Pham, V.L.; Hoàng, Q.V.; Garnier, V.; Giuliani, G.; Ohnenstetter, D. Marble-hosted ruby from Vietnam. Can. Gemmol. 2004, 25, 83-95.

99. Ishimaru, S.; Arai, S.; Miura, M.; Shmelev, V.; Pushkarev, E. Ruby-bearing feldspathic dyke in peridotite from Ray-Iz ophiolite, the Polar Urals: Implications for mantle metasomatism and origin of ruby. J. Mineral. Petrol. Sci. 2015, 110, 76-81. [CrossRef]

100. Andriamamonjy, S.A. Les corindons associés aux roches métamorphiques du Sud ouest de Madagascar: Le gisement de saphir de Zazafotsy. Master Thesis, Université d'Antananarivo, Tananarive, Madagascar, 2006.

101. Kongsomart, B.; Vertriest, W.; Weeramonkhonlert, V. Preliminary observations on facet-grade ruby from Longido, Tanazania. Gems Gemol. 2017, 53, 472-473.

102. Krebs, M.Y.; Pearson, D.G.; Fagan, A.J.; Bussweiler, Y.; Sarkar, C. The application of trace elements and Sr-Pb isotopes to dating and tracing ruby formation: The Aappaluttoq deposit, SW Greenland. Chem. Geol. 2019, 523, 42-58. [CrossRef]

103. Harlow, G.E.; Bender, W. A study of ruby (corundum) compositions from the Mogok Belt, Myanmar: Searching for chemical fingerprints. Am. Mineral. 2013, 98, 1120-1132. [CrossRef]

104. Sorokina, E.S.; Litvinenko, A.K.; Hofmeister, W.; Häger, T.; Jacob, D.E.; Nasriddinov, Z.Z. Rubies and sapphires from Snezhnoe, Tajikistan. Gems Gemol. 2015, 51, 160-175. [CrossRef]

105. Palke, A.C.; Wong, J.; Verdel, C.; Avila, J.N. A common origin for Thai/Cambodian rubies and blue and violet sapphires from Yogo Gulch, Montana, USA? Am. Mineral. 2018, 103, 469-479. [CrossRef]

106. Graham, I.; Sutherland, L.; Khin, Z.; Nechaev, V.; Khanchuk, A. Advances in our understanding of the gem corundum deposits of the West Pacific continental margins intraplate basaltic fields. Ore Geol. Rev 2008, 34, 200-215. [CrossRef]

107. Stern, R.J.; Tsujimori, T.; Harlow, G.; Groat, L. Plate tectonic gemstones. Geology 2013, 41, 723-726. [CrossRef]

108. Garnier, V.; Giuliani, G.; Ohnenstetter, D.; Schwarz, D. Saphirs et rubis. Classification des gisements de corindon. Le Règne Minéral 2004, 55, 4-47.

109. Emmett, J.L.; Stone-Sundberg, J.; Guan, Y.; Sun, Z. The role of silicon in the color of gem corundum. Gems Gemol. 2017, 53, 42-47. [CrossRef]

110. Simonet, C.; Fritsch, E.; Lasnier, B. A classification of gem corundum deposits aimed towards gem exploration. Ore Geol. Rev. 2008, 34, 127-133. [CrossRef] 
111. Kissin, A.J. Ruby and sapphire from the southern Ural Mountains, Russia. Gems Gemol. 1994, 30, $243-252$. [CrossRef]

112. Okrusch, M.; Bunch, T.E.; Bank, H. Paragenesis and petrogenesis of a corundum-bearing marble at Hunza (Kashmir). Mineral. Depos. 1976, 11, 278-297. [CrossRef]

113. Dzikowski, T.J.; Cempirek, J.; Groat, L.A.; Dipple, G.M.; Giuliani, G. Origin of gem corundum in calcite marble: The Revelstoke occurrence in the Canadian Cordillera of British Columbia. Lithos 2014, 198-199, 281-297. [CrossRef]

114. Balmer, W.A.; Hauzenberger, C.A.; Fritz, H.; Sutthirat, C. Marble-hosted ruby deposits of the Morogoro region, Tanzania. J. Afr. Earth. Sci. 2017, 134, 626-643. [CrossRef]

115. Litvinenko, A.K. Nuristan-South Pamir province of Precambrian gems. Geol. Ore Depos. 2004, 46, $263-268$.

116. Garde, A.; Marker, M. Corundum crystals with blue-red color zoning near Kangerdluarssuk, Sukkertoppen district, West Greenland. Rep. Gronl. Geol. Unders. 1988, 140, 46-49.

117. Key, R.M.; Ochieng, J.O. The growth of rubies in south-east Kenya. J. Gemmol. 1991, 22, 484-496. [CrossRef]

118. Simonet, C. Géologie des Gisements de Saphir et de Rubis. L'exemple de la John Saul Mine, Mangari, Kenya. Ph.D. Thesis, Université de Nantes, Nantes, France, 2000.

119. Mercier, A.; Debat, P.; Saul, J.M. Exotic origin of the ruby deposits of the Mangari area in SE Kenya. Ore Geol. Rev. 1999, 14, 83-104. [CrossRef]

120. Schwarz, D.; Pardieu, V.; Saul, J.M.; Schmetzer, K.; Laurs, B.M.; Giuliani, G.; Klemm, L.; Malsy, A.K.; Hauzenberger, C.; Du Toit, G.; et al. Ruby and sapphires from Winza (Central Tanzania). Gems Gemol. 2008, 44, 322-347. [CrossRef]

121. Tenthorey, E.A.; Ryan, J.G.; Snow, E.A. Petrogenesis of sapphirine-bearing metatroctolites from the Buck Creek ultramafic body, southern Appalachians. J. Metam. Geol. 1996, 14, 103-114.

122. Nicollet, C. Saphirine et staurotide riche en magnésium et chrome dans les amphibolites et anorthosites à corindon du Vohibory Sud, Madagascar. Bull. Minéral. 1986, 109, 599-612. [CrossRef]

123. Kröner, A. Late Precambrian plate tectonics and orogeny: A need to redefine the term Pan-African. In African Geology; Klerkx, J., Michot, J., Eds.; Tervuren, Musée Royal de l'Afrique Centrale: Tervuren, Belgium, 1984; pp. 23-28.

124. Le Goff, E.; Deschamps, Y.; Guerrot, C. Tectonic implications of new single zircon Pb-Pb evaporation data in the Lossogonoi and Longido ruby-districts, Mozambican metamorphic Belt of north-eastern Tanzania. Comptes Rendus Geosci. 2010, 342, 36-45. [CrossRef]

125. Jöns, N.; Schenk, V. Relics of the Mozambique Ocean in the central East African Orogen: Evidence from the Vohibory Block of Southern Madagascar. J. Metam. Geol. 2008, 26, 17-28. [CrossRef]

126. Bingen, B.; Jacobs, J.; Viola, G.; Henderson, I.H.C.; Skår, Ø.; Boyd, R.; Thomas, R.J.; Solli, A.; Key, R.M.; Daudi, E.X.F. Geochronology of the Precambrian crust in the Mozambique belt in NE Mozambique, and implications for Gondwana assembly. Precambrian Res. 2009, 170, 231-255. [CrossRef]

127. Paquette, J.L.; Nédelec, A.; Moine, B.; Rakotondrazafy, A.F.M. U-Pb single zircon Pb-evaporation and Sm-Nd isotopic study of a granulite domain in SE Madagascar. J. Geol. 1994, 102, 523-538. [CrossRef]

128. Giuliani, G.; Fallick, A.E.; Rakotondrazafy, A.F.M.; Ohnenstetter, D.; Andriamamonjy, A.; Rakotosamizanany, S.; Ralantoarison, T.; Razanatseheno, M.M.; Dunaigre, C.; Schwarz, D. Oxygen isotope systematics of gem corundum deposits in Madagascar: Relevance for their geological origin. Mineral. Depos. 2007, 42, 251-270. [CrossRef]

129. Sorokina, E.S.; Rošel, D.; Häger, T.; Mertz-Kraus, R.; Saul, J.M. LA-ICP-MS U-Pb dating of rutile inclusions within corundum (ruby and sapphire): New constraints on the formation of corundum deposits along the Mozambique belt. Mineral. Depos. 2017, 52, 641-649. [CrossRef]

130. Meert, J.G.; Van Der Voo, R.; Ayub, S. Paleomagnetic investigation of the Neoproterozoic Gagwe lavas and Mbozi complex, Tanzania and the assembly of Gondwana. Precambrian Res. 1995, 74, 225-244. [CrossRef]

131. Garnier, V.; Giuliani, G.; Maluski, H.; Ohnenstetter, D.; Phan, T.T.; Hoàng, Q.V.; Pham, V.L.; Vu, V.T.; Schwarz, D. Ar-Ar ages in phlogopites from marble-hosted ruby deposits in northern Vietnam: Evidence for Cenozoic ruby formation. Chem. Geol. 2002, 188, 33-49. [CrossRef]

132. Garnier, V.; Ohnenstetter, D.; Giuliani, G.; Maluski, H.; Deloule, E.; Phan, T.T.; Pham, V.L.; Hoang, Q.V. Age and significance of ruby-bearing marbles from the Red River shear zone, northern Vietnam. Can. Mineral. 2004, 43, 1315-1329. [CrossRef] 
133. Garnier, V.; Maluski, H.; Giuliani, G.; Ohnenstetter, D.; Schwarz, D. Ar-Ar and U-Pb ages of marble hosted ruby deposits from central and south East Asia. Can. J. Earth Sci. 2006, 43, 1-23. [CrossRef]

134. Litvinenko, A.K.; Sorokina, E.S.; Häger, T.; Kostitsyn, Z.A.; Botcharnikov, R.E.; Somsikova, T.; Romashova, T.V.; Hofmeister, W. Petrogenesis of the Snezhnoe ruby deposit, Central Pamir. Minerals 2020, 10, 478. [CrossRef]

135. Khin, Z.; Sutherland, F.L.; Graham, I.; McGee, B. Dating zircon inclusions in gem corundums from placer deposits, as a guide to their origin. In Proceedings of the 33rd International Geological Congress (IGC), Oslo, Norway, 6-14 August 2008.

136. Sutherland, F.L.; Fanning, C.M. Gem-bearing basaltic volcanism, Barrington, New South Wales: Cenozoic evolution, based on basalt K-Ar ages and zircon fission track and $\mathrm{U} / \mathrm{Pb}$ isotope dating. Austral. J. Earth Sci. 2001, 48, 221-237. [CrossRef]

137. Graham, I.T.; Sutherland, F.L.; Webb, G.B.; Fanning, C.M. Polygenetic corundums from New South Wales gemfields. In Metallogeny of the Pacific Northwest: Tectonics, Magmatism and Metallogeny of Active Continental Margins; Khanchuk, A.I., Gonevchuk, A.N., Mitrokhin, I.F., Simanenko, N.J., Cook, Seltmann, R., Eds.; Falnulka: Vladivostok, Russia, 2004; pp. 336-339.

138. Dill, H.G. Gems and placers-A genetic relationship par excellence. Minerals 2018, 8, 470-513.

139. Rhamdohr, R.; Milisenda, C.C. Neue Vorkommen von Saphir-Seifenlagerstätten auf Nosy-Bé, Madagaskar. Z Dt. Gemmol. Ges. 2004, 53, 143-158.

140. Giuliani, G.; Groat, L. Geology of corundum and emerald gem deposits: A review. Gems Gemol. 2019, 55, 464-489. [CrossRef]

141. Ozerov, K. Form of corundum crystals as dependent upon chemical composition of medium. Dolk. Akad. Nauk SSSR 1945, XLVII, 49-52.

142. Schwarz, D. Aus Basalten, Marmoren und Pegmatiten. Spezielle Ursachen formten in der Erdkruste edle Rubine und Saphire. In Rubin, Saphir, Korund: Schön, Hart, Selten, Kostbar; Weise, C., Ed.; ExtraLapis: München, Germany, 1998; Volume 15, pp. 5-9.

143. Kievlenko, E.Y. Geology of Gems; Ocean Pictures Ltd.: Littleton, CO, USA, 2003.

144. Giuliani, G.; Ohnenstetter, D.; Fallick, A.E.; Groat, L.; Feneyrol, J. Geographic origin of gems linked to their geographical history. InColor 2012, 19, 16-27.

145. Sutthirat, C.; Saminpanya, S.; Droop, G.T.R.; Henderson, C.M.B.; Manning, D.A.C. Clinopyroxene-corundum assemblages from alkali-basalt and alluvium, eastern Thailand: Constraints on the origin of Thai rubies. Mineral. Mag. 2001, 65, 277-295. [CrossRef]

146. Saminpanya, S.; Sutherland, F.L. Different origins of Thai area sapphire and ruby, derived from mineral inclusions and co-existing minerals. Eur. J. Mineral. 2001, 23, 683-694. [CrossRef]

147. Baldwin, L.C.; Tomaschek, F.; Ballhaus, C.; Gerdes, A.; Fonseca, R.O.C.; Wirth, R.; Geisler, T.; Nagel, T. Petrogenesis of alkaline basalt-hosted sapphire megacrysts. Petrological and geochemical investigations of in situ sapphire occurrences from the Siebengebirge volcanic field, Germany. Contrib. Mineral. Petrol. 2017, 172. [CrossRef]

148. Promwongan, S.; Sutthirat, C. Mineral inclusions in ruby and sapphire from the Bo Welu gem deposit in Chanthaburi, Thailand. Gems Gemol. 2019, 55, 354-369.

149. Promwongan, S.; Sutthirat, C. An update on mineral inclusions and their composition in ruby from the Bo Rai gem field in Trat Province, eastern Thailand. J. Gemmol. 2019, 36, 634-645. [CrossRef]

150. Palke, A.C.; Hapeman, J.R. Rubies from Rock Creek, Montana. Gems Gemol. 2019, 55, $286-288$.

151. Yui, T.F.; Khin, Z.; Limkatrun, P. Oxygen isotope composition of the Denchai sapphire, Thailand; a clue to its enigmatic origin. Lithos 2003, 67, 153-161. [CrossRef]

152. Yui, T.F.; Wu, C.-M.; Limkatrun, P.; Sricharn, W.; Boonsoong, A. Oxygen isotope studies on placer sapphire and ruby in the Chanthaburi-Trat alkali basaltic gemfield, Thailand. Lithos 2006, 86, 197-211. [CrossRef]

153. Vysotskiy, S.V.; Nechaev, V.P.; Kissin, A.Y.; Yakovenko, V.V.; Ignat'ev, A.V.; Velivetskaya, T.A.; Sutherland, F.L.; Agoshkov, A.I. Oxygen isotopic composition as an indicator of ruby and sapphire origin: A review of Russian occurrences. Ore Geol. Rev. 2015, 68, 164-170. [CrossRef]

154. Sutthirat, C.; Hauzenberger, C.; Chualaowanich, T.; Assawincharoenkij, T. Mantle and deep crustal xenoliths in basalts from the Bo Rai ruby deposit, eastern Thailand: Original source of basaltic ruby. J. Asian Earth Sci. 2018, 164, 366-379. [CrossRef] 
155. Khin, Z.; Sutherland, F.L.; Dellapasqua, F.; Ryan, C.G.; Yui, T.Z.; Mernagh, T.P.; Duncan, D. Contrasts in gem corundum characteristics, eastern Australian basaltic fields: Trace elements, fluid/melt inclusions and oxygen isotopes. Mineral. Mag. 2006, 70, 669-687.

156. Vertriest, W.; Palke, A. Identification of opaque sulphide inclusions in rubies from Mogok, Myanmar and Montepuez, Mozambique. Minerals 2020, 10, 492. [CrossRef]

157. Limkatrun, P.; Khin, Z.; Ryan, C.G.; Mernagh, T.P. Formation of the Denchai gem sapphires, northern Thailand: Evidence from mineral chemistry and fluid/melt inclusion characteristics. Mineral. Mag. 2001, 65, 725-735.

158. Palke, A.C.; Renfro, N.D.; Berg, R.B. Melt inclusions in alluvial sapphires from Montana, USA: Formation of sapphires as restitic component of lower crustal melting? Lithos 2017, 278-281, 43-53. [CrossRef]

159. Herzberg, C.T. Pyroxene geothermometry and geobarometry: Experimental and thermodynamic evaluation of some subsolidus phase relations involving pyroxenes in the system $\mathrm{CaO}-\mathrm{MgO}-\mathrm{Al}_{2} \mathrm{O}_{3}-\mathrm{SiO}_{2}$. Geochim. Cosmochim. Acta 1978, 42, 945-957. [CrossRef]

160. Irvin, A.J. Geochemical and high pressure experimental studies of garnet pyroxenite and pyroxene granulite xenoliths from the Delegate basaltic pipes, Australia. J. Petrol. 1974, 15, 1-40. [CrossRef]

161. Rakotosamizanany, S.; Giuliani, G.; Ohnenstetter, D.; Rakotondrazafy, A.F.M.; Fallick, A.E. Les gisements de saphirs et de rubis associés aux basaltes alcalins de Madagascar: Caractéristiques géologiques et minéralogiques. 1ère partie: Caractéristiques géologiques des gisements. Rev. Assoc. Fr. Gemmol. AFG 2009, 169, 13-21.

162. Rakotosamizanany, S.; Giuliani, G.; Ohnenstetter, D.; Rakotondrazafy, A.F.M.; Fallick, A.E. Les gisements de saphirs et de rubis associés aux basaltes alcalins de Madagascar: Caractéristiques géologiques et minéralogiques. 2ème partie: Caractéristiques minéralogiques. Rev. Assoc. Fr. Gemmol. AFG 2009, 170, 9-18.

163. Rakotosamizanany, S. Les corindons gemmes associés au magmatisme basaltique de Madagascar. In Rapport Final du Projet de Gouvernance des Ressources Minérales (PGRM) de Madagascar; PGRM: Antananarivo, Madagascar, 2008.

164. Rakotondrazafy, A.F.M.; Giuliani, G.; Fallick, A.E.; Ohnenstetter, D.; Andriamamonjy, A.; Rakotosamizanany, S.; Ralantoarison, T.; Razanatseheno, M.; Offant, Y.; Garnier, V.; et al. Gem corundum deposits in Madagascar: A review. Ore Geol. Rev. 2008, 34, 134-154. [CrossRef]

165. Promprated, P.; Taylor, L.A.; Neal, C. R Petrochemistry of mafic granulite xenoliths from the Chantaburi basaltic field: Implications for the nature of the lower crust beneath Thailand. Int. Geol. Rev. 2003, 45, 383-406. [CrossRef]

166. Kornprobst, J.; Piboule, M.; Roden, M.; Tabit, A. Corundum-bearing garnet clinopyroxenites at Beni Bousera (Morocco): Original plagioclase-rich gabbros recrystallized at depth within the mantle? J. Petrol. 1990, 31, 717-745. [CrossRef]

167. Chetouani, K.; Bodinier, J.-L.; Garrido, C.J.; Marchesi, C.; Amri, I.; Targuisti, K. Spatial variability of pyroxenite layers in the Beni Bousera orogenic peridotite (Morocco) and implications for their origin. Comptes Rendus Geoscience 2016, 348, 619-629. [CrossRef]

168. Mattey, D.; Lowry, D.; Macpherson, C.G. Oxygen isotope composition of mantle peridotite. Earth Planet. Sci. Lett. 1994, 128, 231-241. [CrossRef]

169. Watt, G.; Harris, J.W.; Harte, B.; Boyd, S.R. A high-chromium corundum (ruby) inclusion in diamond from the São Luiz alluvial mine, Brazil. Mineral. Mag. 1994, 58, 490-493. [CrossRef]

170. Hutchinson, M.T.; Hursthouse, M.B.; Light, M.E. Mineral inclusions in diamonds: Associations and chemical distinctions around the $670 \mathrm{~km}$ discontinuity. Contrib. Mineral. Petrol. 2001, 142, 119-126. [CrossRef]

171. Hutchinson, M.T. Constitution of the Deep Transition Zone and Lower Mantle shown by Diamonds and their Inclusions. Ph.D. Thesis, University of Edinburgh, Edinburgh, UK.

172. Pivin, M.; Femenias, O.; Demaiffe, D. Metasomatic mantle origin for Mbuji-Mayi and Kundelungu garnet and clinopyroxene megacrysts (Democratic Republic of Congo). Lithos 2009, 112S, 951-960. [CrossRef]

173. Pivin, M. La Suite Complexe des Mégacristaux des Kimberlites de Mbuji-Mayi en République Démocratique du Congo: Témoins du Métasomatisme dans le Manteau Lithosphérique Sous-Continental Archéen du Craton du Congo-Kasaii. Ph.D. Thesis, Université Libre de Bruxelles, Bruxelles, Belgique, 2012.

174. Ratrimo, V. Les indices à corindons gemmes du socle précambrien de Madagascar. In Rapport Final du Projet de Gouvernance des Ressources Minérales (PGRM) de Madagascar; PGRM: Antananarivo, Madagascar, 2008. 
175. Zhang, R.Y.; Liou, J.G.; Zheng, J.P. Ultrahigh pressure corundum rich-garnetite in garnet peridotite, Sulu terrane, China. Contrib. Mineral. Petrol. 2004, 147, 21-31. [CrossRef]

176. Padovani, E.R.; Tracey, R. A pyrope-spinel (alkremite) xenolith from Moses Rock Dyke: First known North American occurrence. Am. Mineral. 1981, 66, 741-745.

177. Shirey, S.B.; Cartigny, P.; Frost, D.J.; Keshav, S.; Nestola, F.; Nimis, P.; Pearson, D.G.; Sobolev, N.V.; Walter, M.J. Diamonds and the geology of mantle carbon. Rev. Mineral. Geochem. 2013, 75, 355-421. [CrossRef]

178. Eggler, D.H.; McCallum, M.E.; Smith, C.B. Megacryst assemblage in kimberlite from Northern Colorado and Southern Wyoming: Petrology, geothermometry-barometry and areal distribution. In The Mantle Sample: Inclusion in Kimberlites and other Volcanics; Boyd, F.R., Meyer, H.O.A., Eds.; Books Series Special Publication; American Geophysical Union: Washington, DC, USA, 1979; pp. 213-226. ISBN 9780875902135. Online ISBN 9781118664858. [CrossRef]

179. Stachel, T.; Harris, J.W. The origin of cratonic diamonds-Constraints from mineral inclusions. Ore Geol. Rev. 2008, 34, 5-32. [CrossRef]

180. Giuliani, G.; Fallick, A.E.; Ohnenstetter, D.; Pégère, G. Oxygen isotopes of sapphire from the French Massif Central: Implications for the origin of gem corundum in basaltic fields. Mineral. Depos. 2009, 44, 221-231. [CrossRef]

181. Dirlam, D.M.; Misiorowski, E.B.; Tozer, R.; Stark, K.B.; Bassett, A.M. Gem wealth of Tanzania. Gems Gemol. 1992, 28, 80-102. [CrossRef]

182. Le Goff, E.; Deschamps, Y.; Cocherie, A.; Guerrot, C.; Ketto, D. Structural, petrological and geochronological constraints of the Tanzanian ruby belt. In Proceedings of the 22ème RST Meeting Nancy. University of Nancy, Nancy, France, 21-24 April 2008.

183. Saul, J. Chronique de la découverte de trois mines historiques de gemmes en Afrique de l'Est. Le Règne Minéral 2013, 2, 89-92.

184. Haapala, I.; Siivola, J.; Ojanperä, P.; Yletyunen, V. Red corundum, sapphirine and kornerupine from Kittilä, Finnish Lapland. Bull. Geol. Soc. Finland 1971, 43, 221-231. [CrossRef]

185. Janardhanan, A.; Leake, B.E. Sapphirine in the Sittampundi complex, India. Mineral. Mag. 1974, 39, $901-902$. [CrossRef]

186. Forestier, F.; Lasnier, B. Découverte de niveaux d'amphibolites à pargasite, anorthite, corindon et saphirine dans les schistes cristallins du Haut-Allier. Contrib. Mineral. Petrol. 1969, 23, 194-235. [CrossRef]

187. Wang, K.; Graham, I.; Martin, L.; Voudouris, P.; Giuliani, G.; Lay, A.; Harris, J.H.; Fallick, A.E. Fingerprinting Paranesti rubies through oxygen isotopes. Minerals 2019, 9, 91. [CrossRef]

188. Barot, N.; Harding, R.R. Pink corundum from Kitui, Kenya. J. Gemmol. 1994, 24, 165-172. [CrossRef]

189. Andreoli, M.A.G. Petrochemistry, tectonic evolution and metasomatic mineralizations of Mozambique belt granulites from Malawi and Tete (Mozambique). Precambrian Res. 1994, 25, 161-186.

190. Henn, U.; Bank, H.; Bank, F.H. Red and orange corundum (ruby and padparadscha) from Malawi. J. Gemmol. 1990, 22, 83-89. [CrossRef]

191. McColl, D.; Warren, R.G. The first discovery of ruby in Australia. Aust. Mineral. 1979, 26, 121-125.

192. Mortimer, G.E.; Cooper, J.A.; James, P.R. U-Pb and Rb-Sr geochronology and geological evolution of the Harts Range ruby mine area of the Arunta Inlier, central Australia. Lithos 1987, 20, 445-467. [CrossRef]

193. Aboosally, S. Update on production in Pakistan, Afghanistan. Jew. News Asia 1999, 1, 60-64.

194. Morishita, T.; Kodera, T. Finding of corundum-bearing gabbro boulder possibly derived from the Horoman peridotite complex, Hokkaido, northern Japan. J. Mineral. Petrol. 1998, 93, 52-63. [CrossRef]

195. Pratt, J.H. The occurrence and distribution of corundum in the United States. Geol. Surv. Bull. 1901, 180, 98.

196. Senoble, J.B. An expedition to Tanzania's new ruby deposit in Winza. InColor 2008, 44-45. Available online: https:www.gemstone.org/incolor/Incolor07/index.html\#44 (accessed on 27 June 2020).

197. Peretti, A.; Peretti, F.; Kanpraphai, A.; Bieri, W.; Hametner, C.; Günther, D. Winza rubies identified. Contrib. Gemol. 2008, 7, 1-97.

198. Pardieu, V.; Chauviré, B. Les rubis du Mozambique. Le Règne Minéral 2013, 2, 101-108.

199. Nicollet, C. Crustal evolution of the granulites of Madagascar. In Granulites and Crustal Evolution; Vielzeuf, D., Vidal, P., Eds.; Springer: Berlin, Germany, 1990; pp. 291-310.

200. Pardieu, V.; Sangsawong, S.; Chauviré, B.; Massi, L.; Sturman, N. Rubies from the Montepuez area (Mozambique), Bangkok, GIA Laboratory. 2013. Available online: https://www.gia.edu/doc/GIA_Ruby_ Montepuez_Mozambique.pdf (accessed on 25 June 2020). 
201. Vertriest, W.; Pardieu, V. Update on gemstone mining in northern Mozambique. Gems Gemol. 2016, 52, 404-409. [CrossRef]

202. Norconsult Consortium Mineral Resources Managemant Capacity Building Project, Republic of Mozambique; Component 2: Geological Infrastructure Development Project, Geological Mapping Lot 1; Geophysical Interpretation; Report no. B4; National Directorate of Geology: Maputo, Republic of Mozambique, 2007.

203. Norconsult Consortium Mineral Resources Managemant Capacity Building Project, Republic of Mozambique; Component 2: Geological Infrastructure Development Project, Geological Mapping Lot 1; Sheet Explanation: 32 sheets; Scale: 1: 250000; Report no. B6.f; National Directorate of Geology: Maputo, Republic of Mozambique, 2007.

204. Boyd, R.; Nordgulen, O.; Thomas, R.J.; Bingen, B.; Bjerkgard, T.; Grenne, T.; Henderson, I.; Melezhik, V.A.; Often, M.; Sandstad, J.S.; et al. The geology and geochemistry of the East African Orogen in Northeastern Mozambique. S. Afr. J. Geol. 2010, 113, 87-129. [CrossRef]

205. Viola, G.; Henderson, I.H.C.; Bingen, B.; Thomas, R.J.; Somethurst, M.A.; de Azavedo, S. Growth and collapse of a deeply eroded orogen: Insights from structural, geological and geochronological constraints on the Pan-African evolution of NE Mozambique. Tectonics 2008, 27, 1-31. [CrossRef]

206. Stern, R.J. Arc assembly and continental collision in the Neoproterozoic East African Orogen: Implications for the consolidation of Gondwanaland. Annual Rev. Earth Planet. Sci. 1994, 22, 319-351. [CrossRef]

207. Smith, C.P.; Gübelin, E.J.; Bassett, A.M.; Manandhar, M.N. Rubies and fancy-color sapphires from Nepal. Gems Gemol. 1997, 33, 24-41. [CrossRef]

208. Bowersox, G.W.; Foord, E.E.; Laurs, B.M.; Shigley, J.E.; Smith, C.P. Ruby and sapphire from Jegdalek, Afghanistan. Gems Gemol. 2000, 36, 110-126. [CrossRef]

209. Pêcher, A.; Giuliani, G.; Garnier, V.; Maluski, H.; Kausar, A.B.; Malik, R.M.; Muntaz, H.R. Geology and Geochemistry of the Nangimali ruby deposit area, Nanga-Parbat Himalaya (Azad Kashmir, Pakistan). J. Asian Earth Sci. 2002, 21, 265-282. [CrossRef]

210. Pham, V.L.; Pardieu, V.; Giuliani, G. Update on gemstone mining in Luc Yen, Vietnam. Gems Gemol. 2014, 49, 233-245.

211. Dunn, P.; Frondel, C. An uncommon margarite/corundum assemblage from Sterling Hill, New Jersey. Mineral. Rec. 1990, 21, 425-427.

212. Dzikowski, T.J.; Groat, L.A.; Dipple, G.M.; Marshall, D. Origin of the Revelstoke carbonate-hosted gem corundum occurrence, British Columbia, Canada. In Proceedings of the International Mineralogical Association Conference, Budapest, Hungaria, 21-27 August 2010.

213. Kyaw, T. The Igneous Rocks of the Mogok Stone Tract: Their Distributions, Petrography, Petrochemistry, Sequence, Geochronology and Economic Geology. Ph.D. Thesis, University of Yangon, Yangon, Myanmar, 2007.

214. Garnier, V.; Ohnenstetter, D.; Giuliani, G. L'aspidolite fluorée: Rôle des évaporites dans la genèse du rubis des marbres de Nangimali (Azad-Kashmir, Pakistan). Comptes Rendus Geoscience 2004, 336, 1245-1253. [CrossRef]

215. Gordon, S.G. Desilicated pegmatites. Proc. Acad. of Nat. Sci. Phila. 1921, 73, 169-192. Available online: https://www.jstor.org/stable/4063801 (accessed on 17 May 2020).

216. Lawson, A.C. Plumasite, an oligoclase corundum rock, near Spanish Peak, California University of California. Pub. Geol. Sci. 1903, 3, 219-229.

217. Seifert, A.V.; Hyrsl, J. Sapphire and garnet from Kalalani, Tanga Province, Tanzania. Gems Gemol. 1999, 35, 108-120. [CrossRef]

218. Meng, F.; Shmelev, V.R.; Kulikova, K.V.; Ren, Y. A red-corundum-bearing vein in the Rai-Iz ultramafic rocks, Polar Urals, Russia: The product of fluid activity in a subduction zone. Lithos 2018, 320-321, 302-314. [CrossRef]

219. Simonet, C. Geology of the Yellow Mine (Taita-Taveta District, Kenya) and other yellow tourmaline deposits in East Africa. J. Gemmol. 2000, 27, 11-29. [CrossRef]

220. Terekhov, E.N. REE distribution in corundum-bearing and other metasomatic rocks during the exhumation of metamorphic rocks of the belmorian belt of the Baltic Shield. Geochem. Int. 2007, 45, 364-380. [CrossRef]

221. Bindeman, I.N.; Schmitt, A.K.; Evans, D.A.D. Origin of the lowest-known $\delta^{18} \mathrm{O}$ silicate rock on Earth in Paleoproterozoic Karelian rift. Geology 2010, 38, 631-634. [CrossRef]

222. Vysotskiy, S.V.; Ignat'ev, A.V.; Levitskii, V.I.; Nechaev, V.P.; Velivetskaya, T.A.; Yakovenko, V.V. Geochemistry of stable oxygen and hydrogen isotopes in minerals and corundum-bearing rocks in northern Karelia as an indicator of their unsual genesis. Geochem. Int. 2014, 52, 773-782. [CrossRef] 
223. Spiridonov, E.M. Gemstone deposits of the former Soviet Union. J. Gemmol. 1998, 26, 111-124. [CrossRef]

224. Walker, R.J.; Prichard, H.M.; Ishiwatari, A.; Pimentel, M. The osmium isotopic composition of convecting upper mantle deduced from ophiolite chromites. Geochim. Cosmochim. Acta 2002, 66, 329-345. [CrossRef]

225. Vakhrusheva, N.V.; Ivanov, K.S. The nature and age of plagioclasites in the ultrabasic Rai-Iz massif (Polar Urals). Dokl. Earth Sci. 2018, 480, 587-590. [CrossRef]

226. Giuliani, G.; Groat, L.; Marshall, D.; Branquet, Y. Emerald deposits: A review and enhanced classification. Minerals 2019, 9, 105. [CrossRef]

227. Glodny, J.; Austrheim, H.; Molina, J.F.; Rusin, A.; Seard, D. Rb/Sr record of fluid-rock interaction in eclogites: The Marun-Keu complex, Polar Urals, Russia. Geochim. Cosmochim. Acta 2003, 67, 4353-4373. [CrossRef]

228. Bryanchaninova, N.I.; Makeev, A.B.; Zubkova, N.V.; Filipov, N.V. Sodium-strontium mica $\mathrm{Na}_{0.50} \mathrm{Sr}_{0.25} \mathrm{Al}_{2}$ $\left(\mathrm{Na}_{0.25}{ }_{0.75}\right) \mathrm{Al}_{1.25} \mathrm{Si}_{2.75} \mathrm{O}_{10}(\mathrm{OH})_{2}$ from Rubinovyi Log. Dokl. Earth Sci. 2004, 395, 260-265.

229. Korzhinskii, D.S. Theory of Metasomatic Zoning; Clarendon Press: Oxford, UK, 1970.

230. Lacroix, A. Les Gisements de Phlogopites de Madagascar et les Pyroxénites qui les Renferment: Ann. Géol. Serv. Min.; Imprimerie officielle: Tananarive, Madagascar, 1941.

231. Lacroix, A. Minéralogie de Madagascar, tome 1; Challamel A.: Paris, France, 1922.

232. Raith, M.M.; Rakotondrazafy, R.; Sengupta, P. Petrology of corundum-spinel-sapphirine-anorthite rocks (sakenites) from the type locality in Southern Madagascar. J. Metam. Geol. 2008, 26, 647-667. [CrossRef]

233. Devouard, D.; Raith, M.M.; Rakotondrazafy, R.; El-Ghozzi, M.; Nicollet, C. Occurrence of musgravite in anorthite-corundum-spinel-sapphirine rocks (sakenites) from south Madagascar: Evidence for a high-grade metasomatic event. In Proceedings of the 18th General Meeting of the International Mineralogical Association, Edinburgh, Scotland, 1-6 September 2002.

234. Keulen, N.; Kokfelt, T.F. The Homogenization Team. A Seamless, Digital, Internet-Based Geological Map of South-West and Southern West Geenland, 1:100.000, 61. Geological Survey of Danemark and Greenland. 2011, pp. 300-364. Available online: http://geuskort.geus.dk/gisfarm/svgrl.jsp (accessed on 5 September 2018).

235. Keulen, N.; Schumacher, J.C.; Næraa, T.; Kokfelt, T.F.; Scherstén, A.; Szilas, K.; van Hinsberg, V.J.; Schlatter, D.M.; Windley, B.F. Meso- and Neoarchaean geological history of the Bjørnesund and Ravns Storø Supracrustal Belts, southern West Greenland: Settings for gold enrichment and corundum formation. Precambrian Res. 2014, 254, 36-58. [CrossRef]

236. Polat, A.; Fryer, B.J.; Appel, P.W.U.; Kalvig, P.; Kerrich, R.; Dilek, Y.; Yang, Z. Geochemistry of anorthositic differentiated sills in the Archean ( 2970 Ma) Fiskenæsset Complex, SW Greenland: Implications for parental magma compositions, geodynamic setting, and secular heat flow in arcs. Lithos 2011, 123, 50-72. [CrossRef]

237. Yakymchuk, C.; Szilas, K. Corundum formation by metasomatic reactions in Archean metapelite, southern West Greenland-Identification of exploration vectors for ruby deposits within high-grade greenstone belts. Geosci. Front. 2018, 9, 727-749. [CrossRef]

238. Appel, C.C.; Appel, P.W.U.; Rollinson, H.R. Complex chromite textures reveal the history of an early Archaean layered ultramafic body in West Greenland. Mineral. Mag. 2002, 66, 1029-1041. [CrossRef]

239. Poulsen, M.D.; Paulick, H.; Rosa, D.; van Hinsberg, V.J.; Petersen, J.; Thomsen, L.L. Follow-up on Ujarassiorit mineral hunt finds and outreach activities, South-East Greenland. In Review of Survey Activities 2014; Bennike, O., Garde, A.A., Watt, W.S., Eds.; Geological Survey of Denmark and Greenland Bulletin: Greenland, Danemark, 2015; Volume 33, pp. 53-56. Available online: www.geus.dk/publications/bull (accessed on 25 June 2020).

240. Ralantoarison, L.T. Les Corindons Associés aux Roches Métamorphiques du Sud de Madagascar: Le Gisement de Saphirs de Sahambano (Sud-Est d'Ihosy). Master's Thesis/Mémoire de DEA, Université d'Antananarivo, Antananarivo, Madagascar, 2006.

241. Ralantoarison, T.; Offant, Y.; Andriamamonjy, A.; Giuliani, G.; Rakotondrazafy, A.F.M.; Ohnenstetter, D.; Schwarz, D.; Fallick, A.E.; Razanatseheno, M.; Rakotosamizanany, S.; et al. Les saphirs multicolores de Sahambano et Zazafotsy, région granulitique d'Ihosy, Madagascar. Rev. Assoc. Fr. Gemmol. AFG 2006, 158, 4-13.

242. Andriamamonjy, S.A. Importance des fluides sur la métallogénie des gisements de saphirs et de rubis dans le domaine granulitique de haute température du Sud de Madagascar: Cas de Zazafotsy et d'Ambatomena. Ph.D. Thesis, Université d'Antananarivo, Antananarivo, Madagascar, 2010. 
243. Andriamamonjy, A.; Giuliani, G.; Ohnenstetter, D.; Rakotondrazafy, A.F.M.; Ralantoarison, T.; Ranatsenho, M.M.; Rakotosamizanany, S.; Fallick, A.E. Les corindons d'âge néoprotérozoïque de Madagascar. Le Règne Minéral 2013, 2, 109-117.

244. Feneyrol, J.; Giuliani, G.; Ohnenstetter, D.; Fallick, A.E.; Martelat, J.-M.; Monié, P.; Dubessy, C.; Rollion-Bard, C.; Le Goff, E.; Malisa, E.; et al. Worldwide tsavorite deposits: New aspects and perspectives. Ore Geol. Rev. 2013, 53, 1-25. [CrossRef]

245. Malik, R.H. Geology and Ressource Potential of Kashmir Ruby Deposits; Unpublished Report; Azad-Kashmir Mineral and Industrial Development Corporation: Muzaffarabad (Azad-Kashmir), Pakistan, 1994.

246. Ray, H.N.; MacRae, G.P.; Cain, L.J.; Malloch, K.R. New South Wales Industrial Minerals Data Base, 2nd ed.; Geological Survey of New South Wales: Sydney, Australia, 2013.

247. Oakes, G.; Barron, L.M.; Lishmund, S.R. Alkali basalts and associated volcanoclastic rocks as a source of sapphire in Eastern Australia. Aust. J. Earth Sci. 1996, 43, 289-298. [CrossRef]

248. Sutherland, F.L.; Coenraads, R.R. An unusual ruby-sapphire-sapphirine-spinel assemblage from the Tertiary Barrington volcanic province, New South Wales. Austr. Mineral. Mag. 1996, 60, 623-638. [CrossRef]

249. Webb, G.; Sutherland, F.L. Gemstones of New England. Austr. J. Mineral. 1998, 4, 115-121.

250. Abduryiyim, A.; Sutherland, F.L.; Coldham, T. Past, present and future of Australian gem corundum. Austr. Gemmol. 2012, 24, 234-242.

251. Vichit, P.; Vudhichativanich, S.; Hansawek, R. The distribution and some characteristics of corundum-bearing basalts in Thaïland. J. Geol. Soc. Thailand 1978, M4, 1-27.

252. Liu, Y.; Lu, R. Ruby and sapphire from Muling, China. Gems Gemol. 2016, 52, 98-100.

253. Sutherland, F.L.; Graham, I. Geology of the Barrington Tops Plateau; It s Rocks, Minerals and Gemstones, New South Wales, Australia; The Australian Museum Society: Sydney, Australia, 2003; p. 56.

254. Birch, W.D. Gem corundum from the St Arnaud district, western Victoria, Australia. Austr. J. Mineral. 2008, 14, 73-78.

255. Schwarz, D.; Schmetzer, K. Rubies from the Vatomandry area, eastern Madagascar. J. Gemmol. 2001, 27, 409-416. [CrossRef]

256. Rasimanana, G. Caractérisations Géochimiques et Géochronologiques de Trois Épisodes Magmatiques (Crétacé, Miocène Terminal et Quaternaire) à Madagascar Liés aux Phénomènes de Rifting. Ph.D. Thesis, Université d'Orsay, Paris, France, 1996.

257. Chapin, M.; Pardieu, V.; Lucas, A. Mozambique: A ruby discovery for the 21st century. Gems Gemol. 2015, 51, 44-54. [CrossRef]

258. Hsu, T.; Lucas, A.; Pardieu, V. Mozambique: A Ruby Discovery for the 21st Century. GIA Research News. 2014. Available online: https://www.gia.edu/gia-news-research-mozambique-expedition-ruby-discoverynew-millennium (accessed on 25 June 2020).

259. Kane, R.E.; Kammerling, R.C. Status of ruby and sapphire mining in the Mogok Stone Tract. Gems Gemol. 1992, 28, 152-174. [CrossRef]

260. Kammerling, R.C.; Scarratt, K.; Bosshart, G.; Jobbins, E.A.; Kane, R.E.; Gübelin, E.J.; Levinson, A.A. Myanmar and its gems-an update. J. Gemmol. 1994, 24,3-40. [CrossRef]

261. Garnier, V.; Giuliani, G.; Ohnenstetter, D.; Schwarz, D.; Kausar, A.B. Les gisements de rubis associés aux marbres de l'Asie centrale et du Sud-est. Le Règne Minéral 2006, 67, 17-48.

262. Kane, R.E.; McClure, S.F.; Kammerling, R.C.; Khoa, N.D.; Mora, C.; Repetto, S.; Khai, N.D.; Koivula, J.I. Rubies and fancy sapphires from Vietnam. Gems Gemol. 1991, 27, 136-155. [CrossRef]

263. Keller, P. Gemstones of East Africa; Geoscience Press: Phoenix, AZ, USA, 1992.

264. Henn, U.; Milisenda, C.C. Neue Edelsteinvorkommen in Tansania: Die region Tunduru-Zongea. Z Deut. Gemmol. Gesell. 1997, 46, 29-43.

265. Pardieu, V.; Vertriest, W.; Weeramonkhonlert, V.; Raynaud, V.; Atikarnsakul, U.; Perkins, R. Sapphires from the Gem Rush Bemainty Area, Ambatondrazaka (Madagascar). GIA Research News. 2017. Available online: https:/www.gia.edu/gia-news-research/sapphires-gem-rushbemainty-ambatondrazakaMadagascar (accessed on 20 June 2020).

266. Pardieu, V.; Sangsawong, S.; Detroyat, S. Gem News International: Rubies from a new deposit in Zahamena National Park, Madagascar. Gems Gemol. 2015, 51, 454-456. 
267. Thirangoon, K. Ruby and Pink Sapphire from Aappaluttoq, Greenland: Status of Ongoing Research, GIA, Bangkok, Thailand. 2009. Available online: https://www.gia.edu/gia-news-research-nr32309 (accessed on 20 June 2020).

268. Palke, A.C. Coexisting rubies and blue sapphires from major world deposits: A brief review of their mineralogical properties. Minerals 2020, 10, 472. [CrossRef]

269. Palke, A.C.; Breeding, C.M. The origin of needle-like inclusions in natural gem corundum: A combined EPMA, LA-ICP-MS, and nanoSIMS investigation. Am. Mineral. 2017, 102, 1451-1461. [CrossRef]

270. Franz, G.; Vyshnevskyi, O.; Taran, M.; Khomenko, V.; Wiedenbeck, M.; Schiperski, F.; Nissen, J. A new emerald occurrence from Kruta Balka, Western Peri-Azovian region, Ukraine: Implications for understanding the crystal chemistry of emerald. Am. Mineral. 2020, 105, 162-181. [CrossRef]

(C) 2020 by the authors. Licensee MDPI, Basel, Switzerland. This article is an open access article distributed under the terms and conditions of the Creative Commons Attribution (CC BY) license (http://creativecommons.org/licenses/by/4.0/). 

Article

\title{
The First Find of $\mathrm{Cr}_{2} \mathrm{O}_{3}$ Eskolaite Associated with Marble-Hosted Ruby in the Southern Urals and the Problem of Al and Cr Sources
}

\author{
Aleksander Kissin ${ }^{1,2, *}$, Irina Gottman ${ }^{1,2}$, Sergei Sustavov ${ }^{2}$, Valery Murzin ${ }^{1}$ and Daria Kiseleva ${ }^{1}$ \\ 1 A.N. Zavaritsky Institute of Geology and Geochemistry, Ural Branch of Russian Academy of Sciences, \\ Vonsovskogo str., 15, 620016 Ekaterinburg, Russia; gottman@igg.uran.ru (I.G.); murzin@igg.uran.ru (V.M.); \\ Kiseleva@igg.uran.ru (D.K.) \\ 2 Department of Mineralogy, Petrology and Geochemistry, Ural State Mining University, Kuybysheva str.,30, \\ 620144 Ekaterinburg, Russia; sustavov.s@ursmu.ru \\ * Correspondence: kissin@igg.uran.ru
}

Received: 16 November 2019; Accepted: 22 January 2020; Published: 24 January 2020

\begin{abstract}
The results of the study of eskolaite associated with marble-hosted ruby found for the first time in the Kuchinskoe occurrence (Southern Urals) are presented. Here, eskolaite was located on the surface and near-surface regions of ruby crystals. Eskolaite diagnostics was confirmed by powder X-ray diffraction (URS-55). The morphology and chemical composition of eskolaite and associated ruby was studied using a JSM-6390LV scanning electron microscope and a Cameca SX 100 electron probe microanalyzer. The eskolaite crystals were hexagonal and tabular, up to $0.2 \mathrm{~mm}$ in size. Ruby mineralization was formed during prograde and retrograde dynamothermal metamorphism. The eskolaite associated with the prograde stage ruby contained $\mathrm{Al}_{2} \mathrm{O}_{3}\left(9.1-23.62 \mathrm{wt} \%\right.$ ), $\mathrm{TiO}_{2}$ (0.52-9.66 wt \%), $\mathrm{V}_{2} \mathrm{O}_{3}\left(0.53-1.54\right.$ wt \%), $\mathrm{FeO}\left(0.03-0.1\right.$ wt \%), $\mathrm{MgO}\left(0.05-0.24\right.$ wt \%), and $\mathrm{SiO}_{2}$ $(0.1-0.21 \mathrm{wt} \%)$. The eskolaite associated with the retrograde stage ruby was distinguished by a sharp depletion in Ti and contained $\mathrm{Al}_{2} \mathrm{O}_{3}(12.25-21.2 \mathrm{wt} \%), \mathrm{TiO}_{2}(0.01-0.07 \mathrm{wt} \%), \mathrm{V}_{2} \mathrm{O}_{3}(0.32-1.62 \mathrm{wt}$ $\%), \mathrm{FeO}(0.01-0.08 \mathrm{wt} \%), \mathrm{MgO}(0.0-0.48 \mathrm{wt} \%)$, and $\mathrm{SiO}_{2}(0.01-0.1 \mathrm{wt} \%)$. The associated rubies contained almost equal amounts of $\mathrm{Cr}_{2} \mathrm{O}_{3}(2.36-2.69 \mathrm{wt} \%)$ and were almost free from admixtures. The identification of the eskolaite associated with the marble-hosted rubies from the Kuchinskoe occurrence is a new argument in favor of introduction of $\mathrm{Al}$ and $\mathrm{Cr}$ into the mineral formation zone. The mineralization was localized in the metamorphic frame of the granite gneiss domes and was formed synchronously with them.
\end{abstract}

Keywords: gems; ruby; marble; eskolaite; Southern Urals

\section{Introduction}

The issue of $\mathrm{Al}$ and $\mathrm{Cr}$ sources in ruby (a corundum containing a chromium isomorphic impurity) deposits in calcite (dolomite) marbles is actively discussed in the scientific literature. Various ideas have been studied on this issue: (1) the lateritic weathering of an impure limestone [1-4]; (2) the lenses of bauxite-like sediments in limestones [5]; (3) the desilication of primary sedimentary rocks during regional alkali metasomatism [6]; (4) the introduction of $\mathrm{Al}$ and $\mathrm{Cr}$ by metamorphogenic fluids during rock granitization and dynamothermal metamorphism $[7,8] ;(5)$ the introduction of $\mathrm{Al}$ using the gas phase of deep fluids during alkaline magmatism [9]; (6) the introduction of $\mathrm{Al}$ as a result of decompression during deep tectonic erosion [10]; and (7) the redistribution of $\mathrm{Al}$ and $\mathrm{Cr}$ during the metamorphism of sedimentary limestones with evaporitic lenses [11,12]. A review of the views on this issue was given by Giluani et al. [13]. All researchers noted the presence of $\mathrm{Cr}$-containing minerals in ruby-bearing marble, such as muscovite (fuchsite), phlogopite, margarite, pargasite, diopside, 
tourmaline, diaspore, rutile, sphene, and red spinel. In the Middle Ural Mountains (Urals, Russia), uvarovite with a grossular admixture $\left(\mathrm{Cr}_{2} \mathrm{O}_{3}\right.$ up to $\left.18.60 \mathrm{wt} \%\right)$ is found in ruby-bearing marbles [14]. The article reports on the discovery of chromium oxide in the intergrowth with ruby, which can be used in discussions about the sources of $\mathrm{Al}$ and $\mathrm{Cr}$ in ruby-bearing marbles.

Natural chromium oxide $\left(\mathrm{Cr}_{2} \mathrm{O}_{3}\right)$ of supposedly hydrothermal-metasomatic genesis was discovered in the middle of the last century in the Outokumpu Cu-Co-Zn skarn deposit in Finland and was called eskolaite [15]. Hydrothermal-metasomatic eskolaite was also described in the chromitites of the Mariinsky and Bazhenovsky ophiolite massifs in the Middle Urals. In the Mariinsky emerald deposit, eskolaite formed inclusions in mariinskite (a chromium analogue of chrysoberyl) associated with fluorophlogopite, Cr-containing muscovite, and tourmaline [16]. In the Bazhenovsky massif, eskolaite was found in alumina chromitites [17] as well as in the form of inclusions in mariinskite [18].

The eskolaite of magmatic origin was found in the chromite ores of the Rai-Iz and Voikar-Syninsky hyperbasite massifs in the Polar Urals [19]. It formed as a result of fractionation of sulfide and chromospinelide ores from a silicate melt at temperatures $900-1100{ }^{\circ} \mathrm{C}$ The magmatic eskolaite was also described in magnetite-ilmenite ores of the Kusa gabbro intrusion (Southern Urals) [20].

Eskolaite was found in kimberlites [21-23]. The eskolaite intergrown with diamond and with picrochromite inclusions was reported for the Udachnaya kimberlite pipe (Yakutia) [24].

In the Cis-Baikal region, the eskolaite and karelianite $\left(\mathrm{V}_{2} \mathrm{O}_{3}\right)$ of metamorphic genesis were revealed in the thin layers of graphite-enriched sillimanite-cordierite quartzite schists of the Olkhon series [25]. The grain size was 5-20 $\mu \mathrm{m}$ in intergrowth with rutile, $(\mathrm{Cr}, \mathrm{V})_{2} \mathrm{Ti}_{3} \mathrm{O}_{9}$ olkhonskite, and $\mathrm{V}_{2} \mathrm{Ti}_{3} \mathrm{O}_{9}$ schreyerite. In the metacarbonate rocks of the Slyudyanka series (Southern Cis-Baikal), the eskolaite was described in calcite-quartz-diopside rocks [26]. The eskolaite was accompanied by magnesiochromite and $(\mathrm{Cr}, \mathrm{V})_{2} \mathrm{O}_{3}$ karelianite-eskolaite. The authors of [26] believe that $\mathrm{Cr}$ and $\mathrm{V}$ were introduced into paleo-sediments by chemical deposition. Then, during prograde granulite facies metamorphism, $\mathrm{Cr}$ and $\mathrm{V}$ participated in the formation of magnesiochromite, eskolaite, and karelianite. The formation of eskolaite in metamorphic rocks is possible even at low chromium concentrations in the substrate, but under the conditions of isochemical metamorphism, $\mathrm{Cr}$ inertness, and the absence of its isomorphic incorporation into co-crystallizing minerals.

This article presents the results of the studies of eskolaite from the Kuchinskoe marble-hosted ruby occurrence in the Southern Urals, a mineral phase that has not been previously described in association with marble-hosted ruby.

\section{Geological Setting}

The Kuchinskoe marble-hosted ruby occurrence is located in the Kochkar anticlinorium (Southern Urals) (Figure 1). The anticlinorium runs in the submeridional direction for $140 \mathrm{~km}$, with a width up to $28 \mathrm{~km}$ [27]. The tectonic boundaries are represented by thrusts dipping under the adjacent synclinorium structures. The anticlinorium is characterized by the presence of granite gneiss domes, which form the centres of dynamothermal metamorphism [28-30]. Crystalline schists, amphibolites, and marbles intruded by the dikes of granites and pegmatites occur in the metamorphic frame of the domes [31]. The metamorphism is syntectonic: prograde in the Carboniferous period and retrograde in the Permian-Triassic period. The level of metamorphism in the dome structures reached the conditions of the amphibolite facies and in the inter-dome structures reached the epidote-amphibolite facies (according to mineral paragenesis) [28,29].

The geology of the Kuchinskoe marble-hosted ruby occurrence was studied by one of the authors (A.K.) from 1979 to 1988 as a field geologist performing geological explorations. The ruby-bearing marbles of the Kuchinskoe occurrence are localized in the inter-dome structure. The marbles are banded, cleaved, and repeatedly recrystallized [32]. At the deposit: (1) coarse-grained calcite marble is the most prevalent, while (2) Mg-calcite marble (which can be schisted) is found locally, among which the bodies of (3) dolomite-calcite/calcite-dolomite marble are found. The marbles are split by dikes of granite and pegmatite. Type 1 and 2 marbles existed at the time of the dike introduction. The dike 
was not tectonically disturbed in the time intervals of its contact with these marbles. Consequently, the cleaving and schisting of these marbles took place before the dike introduction. There are no quenching zones in the dike and no marble recrystallization at the contact. This is explained by the similar temperatures of the embedded granite solution-melt and the host rocks. At the contacts with the massive two-carbonate marble, dikes are disturbed by low-amplitude shears and a zone of forsterite skarn 1.5-3.0 cm wide is formed along the marble. Consequently, two-carbonate marble was formed after the introduction of the dike. The dikes are genetically related to anatectic granites in the apical part of the granite gneiss domes. The time of their massive introduction records the time of stress relief and the drop in all-round pressure. Thus, 1 and 2 type marbles were formed during prograde metamorphism, while type 3 marble was formed during retrograde metamorphism [7,8,33,34].
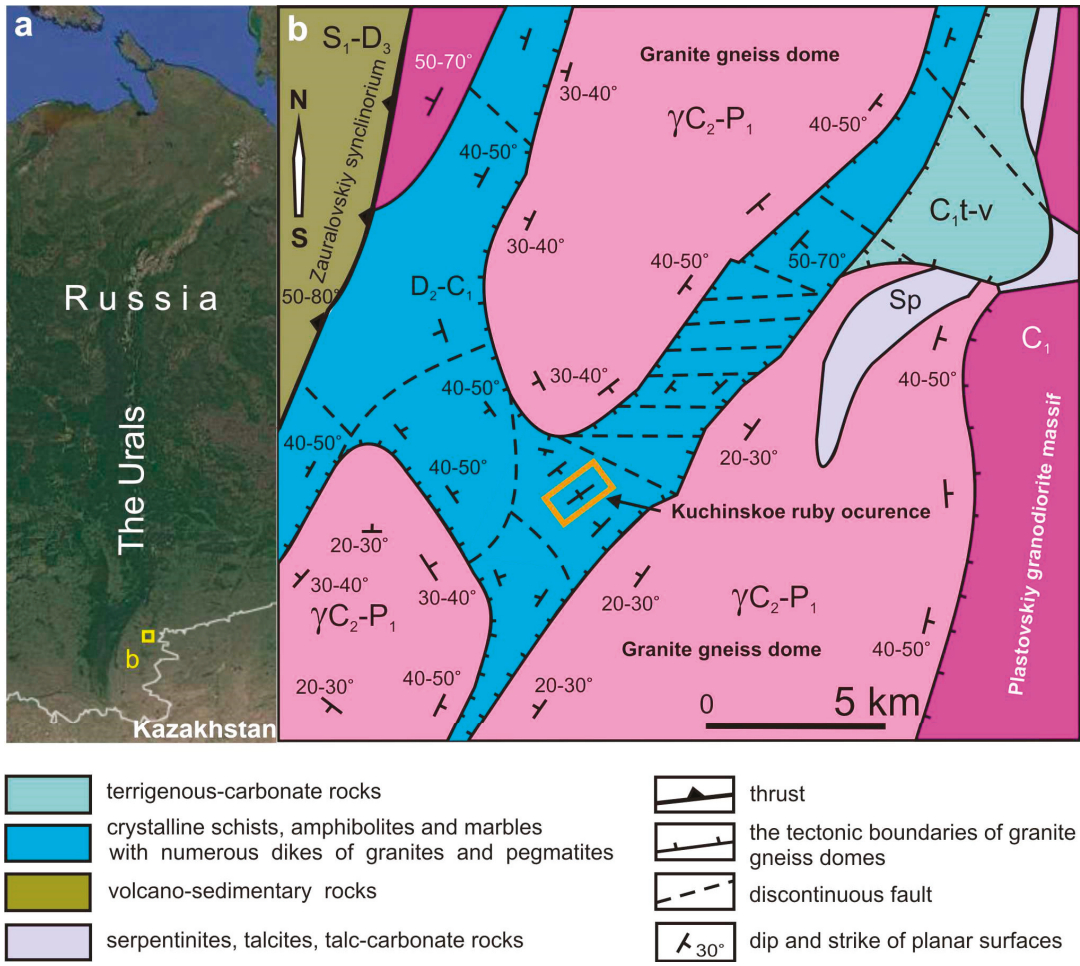

$$
\begin{aligned}
& \text { terrigenous-carbonate rocks } \\
& \text { crystalline schists, amphibolites and marbles } \\
& \text { with numerous dikes of granites and pegmatites } \\
& \text { volcano-sedimentary rocks } \\
& \text { serpentinites, talcites, talc-carbonate rocks }
\end{aligned}
$$

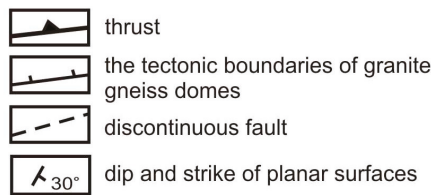

Figure 1. (a) The localization of the Kuchinskoe marble-hosted ruby occurrence and (b) a schematic geological map of the site.

Type 1 rubies are dark red crystals of tabular shape with the highest $\mathrm{Cr}_{2} \mathrm{O}_{3}$ content (1.22-2.91 wt $\%$ ). They are found in the form of disseminated impregnation in $\mathrm{Mg}$-calcite marble and are replaced by spinel in dolomite marble. They are accompanied by pyrite, anhydrite, and apatite. Type 2 rubies are pink, short-columnar, rounded crystals with the lowest $\mathrm{Cr}_{2} \mathrm{O}_{3}$ content $(0.11-0.51 \mathrm{wt} \%)$. They are found in the form of disseminated impregnation in dolomite-calcite/calcite-dolomite marble and accompanied by rutile and pyrite, often replaced with pink spinel associated with graphite, forsterite, and norbergite. Type 3 rubies (more correctly called corundum) are represented by long-prismatic crystals and irregular-shaped grains of red, blue, violet, and white color, and are often polychromatic; the red corundum is close to type 1 rubies in terms of $\mathrm{Cr}_{2} \mathrm{O}_{3}$ contents (0.03-2.97 wt \%). These corundums are confined to cleavage cracks in marbles and are accompanied by colorless phlogopite, pyrite, pyrrhotite, sphalerite, and other minerals. They are replaced by spinel associated with fluorite $[7,8]$. 
Karst formations filled with Paleogene-Neogene kaolin-montmorillonite clays mixed with quartz sand are widely developed in the area of marble distribution in the Kochkar anticlinorium. All formations were studied by drilling and tested during ruby prospecting. In karst sediments, ruby and related minerals (fuchsite, phlogopite, Cr-pargasite, red spinel, and others) are found only if ruby-bearing marbles are present under the karst. There are no signs of abrasion on the surfaces of ruby crystals and associated minerals, which indicates the absence of their transportation by water flows.

\section{Materials and Methods}

The authors had at their disposal several kilograms of crystals and the grains of red corundum (ruby and pink sapphire) of non-jewellery quality, 2-20 $\mathrm{mm}$ in size. The investigated rubies were extracted from karst formations in marbles. Corundum crystals from the Kuchinskoe marble quarries did not exceed $9 \mathrm{~mm}$ in size. While the largest crystal from karst formations reaches $5 \mathrm{~cm}$, crystals up to $4 \mathrm{~mm}$ prevail. The types of corundum (see geological setting) from karst are easily diagnosed and correspond to the types of corundum from the underlying marbles. Their colors, transparency, inclusions, chemical composition, as well as the mineralogy of the intergrowths were also identical. Sometimes corundum mineralization of marbles can also be traced in the karst clays lying on the surface of the mines. In the surroundings of the Kuchinskoe occurrence, other primary sources of corundum are not known. The studied rubies are genetically associated with marbles, as is evidenced by the studies of oxygen isotopes [35].

Ruby grains with the largest aggregates of an unknown mineral were studied by scanning electron microscopy (SEM) and electron probe microanalysis (EPMA) at the Geoanalitik Collective Use Center of the Institute of Geology and Geochemistry of the Ural Branch of the Russian Academy of Sciences (Ekaterinburg). The X-ray powder diffraction analysis of the eskolaite structure was performed at the Ural State Mining University (Ekaterinburg).

Powder X-ray diffraction studies were performed on an URS-55 X-Ray powder diffraction spectrometer using the following operational conditions: RKD chamber, $\mathrm{Fe}_{\mathrm{K} \alpha+\beta}$ radiation, voltage $30 \mathrm{kV}$, current $10 \mathrm{~mA}$. Eskolaite powder was mixed with rubber glue. A cylinder was made from this mixture, which was fixed in the sample holder. The analysis was carried out using a photo method. The results are shown in Table 1.

The chemical composition of the minerals was studied on a CAMECA SX 100 electron probe microanalyzer (Cameca, Gennevilliers, France). The analyses were carried out with an accelerating voltage of $15 \mathrm{kV}$, a current of $10 \mathrm{nA}$ for $\mathrm{Al}, 20 \mathrm{nA}$ for $\mathrm{Cr}$, and $150 \mathrm{nA}$ for $\mathrm{Fe}, \mathrm{Ti}, \mathrm{Mg}$, Si, and $\mathrm{V}$, with an electron beam diameter of $1-3 \mu \mathrm{m}$ on the sample. The following standard samples were used: $\mathrm{Cr}_{2} \mathrm{O}_{3}, \mathrm{Al}_{2} \mathrm{O}_{3}, \mathrm{Fe}_{2} \mathrm{O}_{3}, \mathrm{MgO}, \mathrm{TiO}_{2}, \mathrm{~V}_{2} \mathrm{O}_{5}$, and $\mathrm{SiO}_{2}$. To identify all the peaks, the most intense $\mathrm{K} \alpha$ lines were used. The superposition of the $\mathrm{V} \mathrm{K} \alpha$ line on Ti $\mathrm{K} \beta$ was taken into account. $\mathrm{Al}, \mathrm{Mg}$, Ga were measured using TAP crystals, chromium-LPET, titanium and vanadium-PET, and iron-LLIF crystal. The duration of the intensity measurement at the peaks of the analytical lines and the background on each side of the peak were: for the major elements- $\mathrm{Al}$ and $\mathrm{Cr}-10$ and $5 \mathrm{~s}$, respectively; for $\mathrm{Fe}, \mathrm{Ti}, \mathrm{Mg}$, $\mathrm{Si}, \mathrm{Al}, \mathrm{Cr} 30$ and $15 \mathrm{~s}$; and for $\mathrm{V} 60$ and $30 \mathrm{~s}$. Standard deviation of the elemental content (wt \% ) was less than 0.5 for $\mathrm{Cr}$, less than 0.6 for $\mathrm{Al}$, less than 0.01 for $\mathrm{Fe}, \mathrm{Ti}, \mathrm{Mg}$, Si, and V, 0.02 for $\mathrm{Ga}$, less than 0.06 for $\mathrm{Al}$ (in eskolaite), and 0.05 for $\mathrm{Cr}$ (in corundum). Three polished sections of ruby with eskolaite were studied (Table 2). Sample 1 was a type 1 ruby (analyses 1 and 2) with 3 inclusions (analyses 3-5). Sample 2 was a type 3 ruby (analyses 6-9) with 6 inclusions (analyses 10-15). Sample 3 was a type 3 ruby (analyses 16-18) with 5 inclusions (analyses 19-23). 
Table 1. Eskolaite X-Ray diffraction data.

\begin{tabular}{|c|c|c|c|c|}
\hline \multicolumn{3}{|c|}{ Eskolaite JCPDS } & \multicolumn{2}{|c|}{ Eskolaite with Ruby } \\
\hline$d(\AA)$ & $I / I_{1}$ & $h k l$ & $I$ & $d_{\alpha / n}$ \\
\hline 3.633 & 74 & 012 & 6 & 3.64 \\
\hline 2.666 & 100 & 104 & 10 & 2.67 \\
\hline 2.480 & 96 & 110 & 10 & 2.48 \\
\hline 2.264 & 12 & 006 & 1 & 2.26 \\
\hline 2.176 & 38 & 113 & 3 & 2.16 \\
\hline 2.048 & 9 & 202 & - & - \\
\hline 1.816 & 39 & 024 & 4 & 1.811 \\
\hline 1.672 & 90 & 116 & 10 & $1.663 *$ \\
\hline 1.579 & 13 & 122 & 2 & 1.565 \\
\hline 1.465 & 25 & 214 & 3 & 1.462 \\
\hline 1.4314 & 60 & 300 & 7 & 1.426 * \\
\hline 1.2961 & 20 & 1.0 .10 & 1 & 1.286 \\
\hline 1.2398 & 17 & 220 & 1 & 1.233 \\
\hline 1.2101 & 7 & 306 & - & - \\
\hline 1.1731 & 14 & 128,312 & - & - \\
\hline 1.1488 & 10 & 0.210 & 3 & 1.144 \\
\hline 1.1239 & 10 & 134 & - & - \\
\hline 1.0874 & 17 & 226 & 10 & 1.083 \\
\hline 1.0422 & 16 & 2.1 .10 & 8 & 1.038 \\
\hline \multicolumn{5}{|c|}{ X-Ray diffraction pattern contains 9 lines not included in the Table } \\
\hline \multicolumn{3}{|c|}{$\begin{array}{c}\mathrm{a}_{\mathrm{o}}=4.954 \\
\mathrm{c}_{\mathrm{O}}=13.584\end{array}$} & \multicolumn{2}{|c|}{$\begin{array}{c}\mathrm{a}_{\mathrm{o}}=4.94 \\
\mathrm{c}_{\mathrm{o}}=13.51\end{array}$} \\
\hline
\end{tabular}

* Reflections used for unit cell parameters calculation.

Table 2. The chemical composition of eskolaite and associated ruby of the prograde and retrograde metamorphism according to X-ray microanalysis.

\begin{tabular}{|c|c|c|c|c|c|c|c|c|c|c|}
\hline \multirow{2}{*}{ No } & \multirow{2}{*}{ Object } & \multicolumn{8}{|c|}{ Oxide (wt \%) } & \multirow{2}{*}{$\begin{array}{c}\text { Crystal Chemical } \\
\text { Formula }\end{array}$} \\
\hline & & $\mathrm{TiO}_{2}$ & $\mathrm{FeO}$ & $\mathrm{V}_{2} \mathrm{O}_{3}$ & $\mathrm{MgO}$ & $\mathrm{Al}_{2} \mathrm{O}_{3}$ & $\mathrm{SiO}_{2}$ & $\mathrm{Cr}_{2} \mathrm{O}_{3}$ & Total & \\
\hline \multicolumn{11}{|c|}{ Prograde Metamorphism } \\
\hline 1 & Ruby 1 & bdl & bdl & bdl & bdl & 95.95 & 0.07 & 2.91 & 98.93 & $\mathrm{Cr}_{0.04} \mathrm{Al}_{1.96} \mathrm{O}_{3}$ \\
\hline 2 & Ruby 1 & bdl & bdl & bdl & bdl & 97.51 & bdl & 2.47 & 99.98 & $\mathrm{Cr}_{0.03} \mathrm{Al}_{1.97} \mathrm{O}_{3}$ \\
\hline 3 & Esk & 9.66 & bdl & 1.54 & 0.24 & 9.1 & 0.1 & 78.21 & 98.9 & $\mathrm{Cr}_{1.52} \mathrm{Al}_{0.26} \mathrm{~V}_{0.03} \mathrm{Ti}_{0.18} \mathrm{Mg}_{0.01} \mathrm{O}_{3}$ \\
\hline 4 & Esk & 0.52 & & 0.53 & 0.15 & 23.62 & 0.14 & 73.3 & 98.37 & $\mathrm{Cr}_{1.34} \mathrm{Al}_{0.64} \mathrm{~V}_{0.01} \mathrm{Mg}_{0.01} \mathrm{O}_{3}$ \\
\hline \multicolumn{11}{|c|}{ Retrograde Metamorphism } \\
\hline 5 & Ruby 3 & bdl & bdl & 0.04 & bdl & 97.12 & 0.04 & 2.16 & 99.36 & $\mathrm{Cr}_{0.03} \mathrm{Al}_{1.97} \mathrm{O}_{3}$ \\
\hline 6 & Ruby 3 & bdl & bdl & 0.11 & bdl & 97.39 & 0.07 & 1.78 & 99.35 & $\mathrm{Cr}_{0.02} \mathrm{Al}_{1.98} \mathrm{O}_{3}$ \\
\hline 7 & Ruby 3 & bdl & bdl & bdl & bdl & 96.2 & 0.03 & 2.97 & 99.20 & $\mathrm{Cr}_{0.04} \mathrm{Al}_{1.96} \mathrm{O}_{3}$ \\
\hline 8 & Ruby 3 & bdl & bdl & bdl & bdl & 95.79 & 0.03 & 2.67 & 98.49 & $\mathrm{Cr}_{0.04} \mathrm{Al}_{1.96} \mathrm{O}_{3}$ \\
\hline 9 & Esk & bdl & 0.08 & 1.37 & 0.16 & 12.25 & bdl & 83.76 & 97.64 & $\mathrm{Cr}_{1.62} \mathrm{Al}_{0.35} \mathrm{~V}_{0.03} \mathrm{O}_{3}$ \\
\hline 10 & Esk & bdl & 0.08 & 0.32 & 0.08 & 16.15 & 0.1 & 82.08 & 98.82 & $\mathrm{Cr}_{1.54} \mathrm{Al}_{0.45} \mathrm{~V}_{0.01} \mathrm{O}_{3}$ \\
\hline 11 & Esk & bdl & bdl & 0.62 & bdl & 17.81 & bdl & 80.34 & 98.8 & $\mathrm{Cr}_{1.49} \mathrm{Al}_{0.49} \mathrm{~V}_{0.02} \mathrm{O}_{3}$ \\
\hline 12 & Esk & bdl & bdl & 0.56 & 0.08 & 18.5 & bdl & 80.23 & 99.41 & $\mathrm{Cr}_{1.48} \mathrm{Al}_{0.51} \mathrm{~V}_{0.01} \mathrm{O}_{3}$ \\
\hline 13 & Esk & 0.07 & bdl & 1.62 & bdl & 19.11 & bdl & 78.69 & 99.52 & $\mathrm{Cr}_{1.45} \mathrm{Al}_{0.52} \mathrm{~V}_{0.03} \mathrm{O}_{3}$ \\
\hline 14 & Esk & bdl & 0.06 & 0.93 & 0.12 & 21.2 & bdl & 77.6 & 99.96 & $\mathrm{Cr}_{1.41} \mathrm{Al}_{0.57} \mathrm{~V}_{0.02} \mathrm{O}_{3}$ \\
\hline 15 & Ruby 3 & bdl & bdl & bdl & bdl & 97.13 & 0.03 & 2.64 & 99.80 & $\mathrm{Cr}_{0.04} \mathrm{Al}_{1.96} \mathrm{O}_{3}$ \\
\hline 16 & Ruby 3 & bdl & bdl & bdl & bdl & 97.48 & 0.07 & 2.40 & 99.95 & $\mathrm{Cr}_{0.03} \mathrm{Al}_{1.97} \mathrm{O}_{3}$ \\
\hline 17 & Ruby 3 & bdl & bdl & bdl & bdl & 96.97 & 0.03 & 2.40 & 99.40 & $\mathrm{Cr}_{0.03} \mathrm{Al}_{1.97} \mathrm{O}_{3}$ \\
\hline 18 & Esk & 0.02 & 0.09 & 0.73 & 0.17 & 18.0 & bdl & 79.4 & 98.41 & $\mathrm{Cr}_{1.48} \mathrm{Al}_{0.50} \mathrm{~V}_{0.01} \mathrm{Mg}_{0.01} \mathrm{O}_{3}$ \\
\hline 19 & Esk & & 0.02 & 0.39 & 0.12 & 26.02 & bdl & 73.74 & 100.3 & $\mathrm{Cr}_{1.30} \mathrm{Al}_{0.69} \mathrm{~V}_{0.01} \mathrm{O}_{3}$ \\
\hline 20 & Esk & bdl & 0.02 & 1.5 & 0.14 & 24.59 & bdl & 72.95 & 99.2 & $\mathrm{Cr}_{1.31} \mathrm{Al}_{0.66} \mathrm{~V}_{0.03} \mathrm{O}_{3}$ \\
\hline 21 & Esk & bdl & 0.02 & 1.94 & 0.26 & 13.39 & bdl & 82.08 & 97.69 & $\mathrm{Cr}_{1.57} \mathrm{Al}_{0.38} \mathrm{~V}_{0.04} \mathrm{Mg}_{0.01} \mathrm{O}_{3}$ \\
\hline 22 & Esk & & bdl & 0.6 & 0.21 & 25.61 & bdl & 73.75 & 100.18 & $\mathrm{Cr}_{1.30} \mathrm{Al}_{0.68} \mathrm{~V}_{0.01} \mathrm{Mg}_{0.01} \mathrm{O}_{3}$ \\
\hline
\end{tabular}


The sections of ruby grains with eskolaite as well as ruby grain surface morphology were studied using scanning electron microscopy (SEM). Back scattered electron images were obtained by a JSM-6390LV electronic scanning microscope (JEOL, Akishima, Tokyo, Japan) with an INCA Energy 450 X-Max 80 energy dispersive spectrometer (Oxford Instruments, Abingdon, Great Britain). Operating conditions were an acceleration voltage of $20 \mathrm{kV}$ and an exposure time of $5 \mathrm{~ms}$ per pixel.

\section{Results}

SEM indicated that the dark colored crusts on a ruby were represented by $\mathrm{Cr}_{2} \mathrm{O}_{3}$ eskolaite with $\mathrm{Al}, \mathrm{Fe}, \mathrm{Ti}$, and $\mathrm{V}$ admixtures. The eskolaite was represented by an aggregate of small tabular crystals (Figures 2-4) up to 10 microns in size, rarely up to $0.2 \mathrm{~mm}$. More often, crystals of diaspore, spinel, rutile, and green tourmaline were observed on the surface of ruby crystals. The growth of eskolaite crystals on corundum is chaotic and tends to develop along and within surface imperfections on the ruby crystal faces and on their near-surface part. X-ray diffraction studies confirmed the diagnosis of the mineral (Table 1). The results of the $\mathrm{X}$-ray microanalysis of eskolaite and associated ruby are given in Table 2. The admixtures of $\mathrm{Al}, \mathrm{Ti}, \mathrm{V}$, and sometimes Fe, widely varying in content, are common for eskolaite.

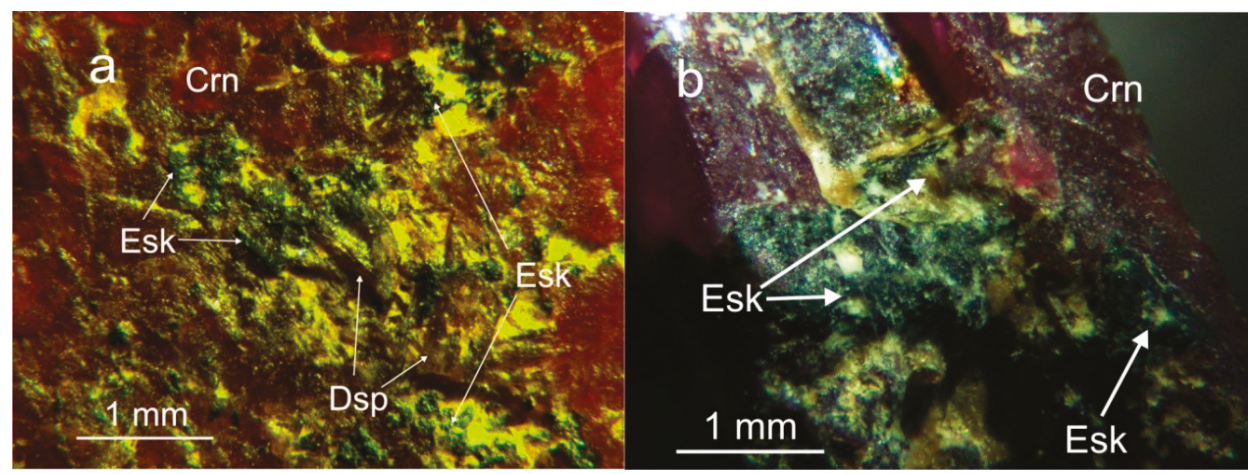

Figure 2. Eskolaite (Esk) and diaspore (Dsp) on the (a) pinacoidal and (b) rhombohedral crystal faces of the prograde stage ruby (Crn).

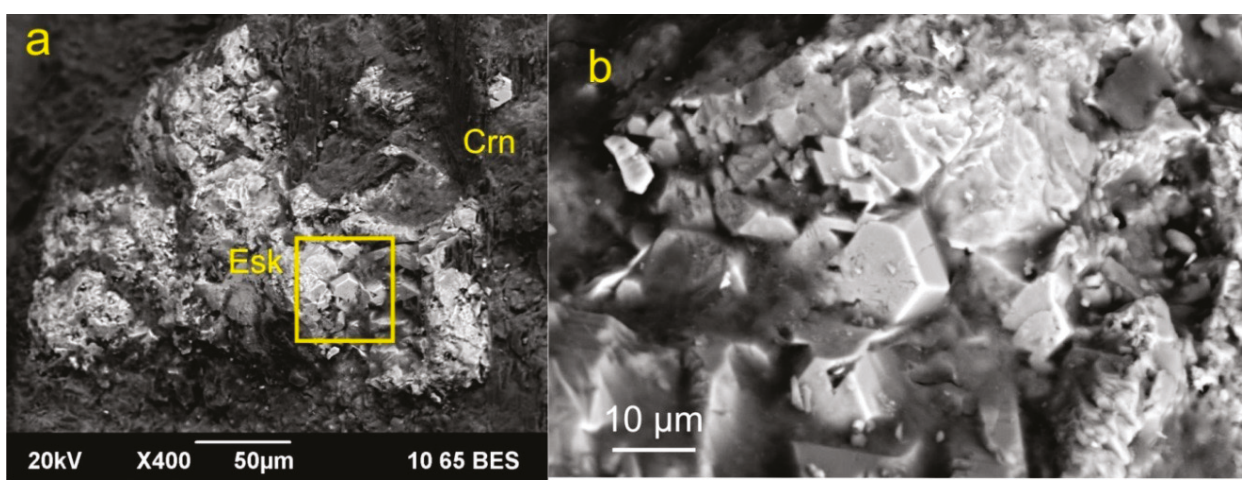

Figure 3. The aggregation of eskolaite crystals (Esk) on the surface of a ruby (Crn) crystal: (a) general view and (b) a close-up of the yellow fragment depicted in Figure 3a. 

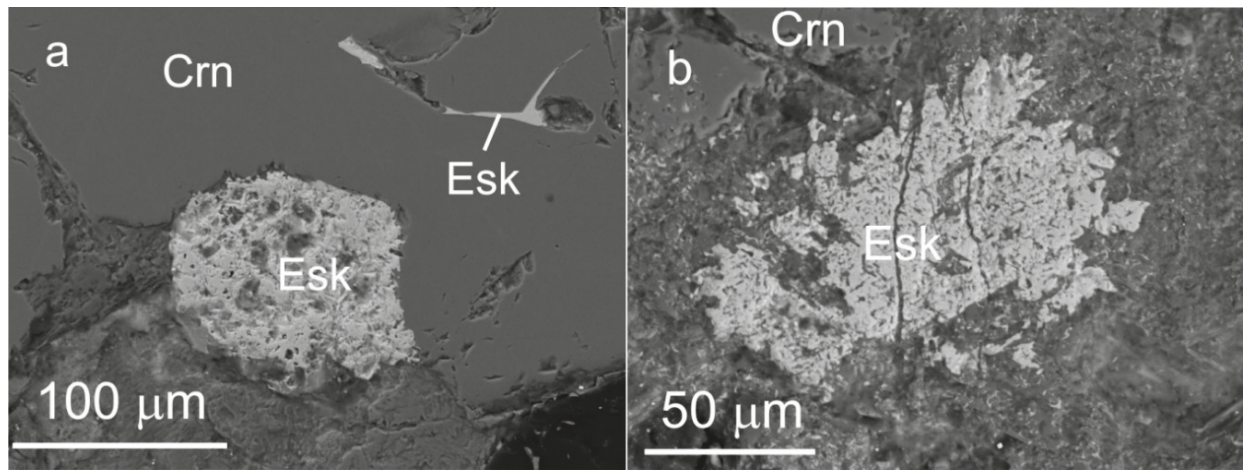

Figure 4. Back-scattered electron (BES) image of the eskolaite (Esk) (a) on type 1 ruby and (b) on type 3 ruby.

\section{Discussion}

\subsection{PT-Conditions for the Formation of Ruby and Eskolaite Association in the Kuchinskoe Occurrence}

At the peak of the regional metamorphism of carbonate rocks in the Kuchinskoe marble-hosted ruby occurrence, the temperature reached $660{ }^{\circ} \mathrm{C}$ (calcite-dolomite geothermobarometer [36]) at a pressure of $2.6-1.2 \mathrm{kbar}$ [7]. The temperature of type 3 ruby formation is estimated as $600-550{ }^{\circ} \mathrm{C}$, $\mathrm{p}=2.2-1.9 \mathrm{kbar}$, and $\mathrm{p}_{\mathrm{CO}_{2}}=1.4-0.4 \mathrm{kbar}$. PT conditions for the formation of type 1 ruby have not yet been evaluated. However, the temperature was probably in the range of $550-600{ }^{\circ} \mathrm{C}$ and the pressure could reach 3-4 kbar. These PT conditions for the formation of ruby-bearing marbles of the Kuchinskoe occurrence are in good agreement with the results of the studies of regional metamorphism in the Kochkar anticlinorium using mineral paragenesis (Garnet + Biotite + Plagioclase + Quartz \pm Staurolite \pm Sillimanite \pm Cordierite): $570-640^{\circ} \mathrm{C}, 3-5 \mathrm{kbar}$ [28]; 590-620 ${ }^{\circ} \mathrm{C}, 2.5-3.0 \mathrm{kbar}$ [29]; and 500-620 ${ }^{\circ} \mathrm{C}$, 3.0-4.0 kbar (in inter-dome structures) and $620-700{ }^{\circ} \mathrm{C}$ (in domes) [30]. The pressure during the retrograde metamorphism is estimated by the depth of formation of the Kochkar anticlinorium, which is $4.0-4.5 \mathrm{~km}$ (about $1.5 \mathrm{kbar}$ ) [28]. At the Kuchinskoe occurrence, the eskolaite is only associated with high-chromium rubies, which possibly indicates the genetic relationship between these minerals. To estimate the temperature of eskolaite formation, a geothermometer was proposed based on the experimental data on the stability of corundum-eskolaite solid solution at various PT parameters [37]. The molar fractions of $\mathrm{Cr}_{2} \mathrm{O}_{3}$ eskolaite crystals $\left(\mathrm{X}_{\mathrm{Cr} 2 \mathrm{O} 3}\right)$ on the rubies of prograde and retrograde stages, according to their crystal-chemical formulas, are 0.65-0.8 (see Table 2). Such $\mathrm{X}_{\mathrm{Cr} 2 \mathrm{O} 3}$ values for eskolaite, subject to their homogeneity, make it possible to estimate the formation temperature of this mineral by the corundum-eskolaite geothermometer as $700-850{ }^{\circ} \mathrm{C}$ Such a high temperature excludes the formation of eskolaite in karst conditions. At the same time, it is higher than the estimate of the temperatures of metamorphism in the Kochkar anticlinorium $\left(500-670{ }^{\circ} \mathrm{C}\right)$. The mismatch in the temperature parameter of the ruby and eskolaite formation is still difficult to explain. This discrepancy may be due to the influence of oxygen fugacity, $\mathrm{pH}$, or other factors.

\subsection{Aluminum and Chromium Sources in the Formation of Ruby and Eskolaite in Marbles}

1. The following geological data dispute the sedimentary origin of $\mathrm{Al}$ and $\mathrm{Cr}$ in ruby-containing marbles [1-5]:

(i) there is no evidence of sedimentary lamination in ruby-containing marbles;

(ii) in the Kochkar anticlinorium, the length of a strip of carbonate rocks is measured in the tens of kilometers, with a width of up to $2.7 \mathrm{~km}$. The marbles of this strip contain an admixture of $\mathrm{Al}$ and $\mathrm{Cr}$ and are in the same zone of metamorphism, but ruby mineralization occurs very locally; 
(iii) the length of the areas of ruby mineralization in marbles rarely exceeds $250-300 \mathrm{~m}$ along the flow cleavage and their width does not exceed $80 \mathrm{~m}$. The vertical scale of mineralization has not been established, but is the greatest in small bodies. Thus, ruby mineralization forms flattened lenticular columnar bodies and this form of ruby-bearing marbles contradicts the concept of stratified sediments;

(iv) the formation of rubies in marble occurred both at the prograde and retrograde metamorphism, and was not one-act (see geological setting): 2-3 types of ruby can be seen in one marble sample, which requires the changes of conditions during their formation.

But we did not exclude the participation of $\mathrm{Al}$ and $\mathrm{Cr}$ of sedimentary origin in the formation of rubies, provided that they were dissolved by metamorphogenic fluids.

2. Desilication of sedimentary terrigenous-carbonate rocks during regional alkaline metasomatism [6] could take place. But there are no signs of marble desilication in the Kuchinskoe occurrence. In addition, the formation of rubies occurred during the prograde and retrograde metamorphism.

3. The introduction of deep fluids into Al marbles by the gas phase during alkaline magmatism [9] or decompression during deep tectonic erosion of the Earth's crust [9] cannot be applied for the Kuchinskoe marble-hosted ruby occurrence since there is no alkaline magmatism and deep tectonic erosion here.

4. The redistribution of $\mathrm{Al}$ and $\mathrm{Cr}$ during metamorphism of sedimentary limestones with evaporate lenses $[10,11]$ does not contradict facts (i-iii), but does not explain fact (iv). Mg-metasomatism in the marbles of the Kochkar anticlinorium manifested twice: (1) through organogenic limestones at an early prograde metamorphism with the formation of fine-grained dolomites and (2) through Mg-calcite and calcite marbles at an early retrograde metamorphism, with the formation of medium-grained dolomite-calcite marbles. $\mathrm{Mg}$ metasomatism of the prograde metamorphism is probably caused by the destruction of evaporites where metasomatic dolomites of this stage are enriched in $\mathrm{Al}, \mathrm{Cr}, \mathrm{V}, \mathrm{Cu}, \mathrm{Co}$, and REE. By contrast, two-carbonate marbles are depleted in these elements.

5. The introduction of $\mathrm{Al}$ and $\mathrm{Cr}$ by metamorphogenic fluids during rock granitization $[7,8]$ does not contradict the facts (i-iv). By "granitization" we mean a high temperature metasomatic process that brings the initial rock closer to granite in chemical composition through the introduction of $\mathrm{SiO}_{2}, \mathrm{Na}, \mathrm{K}, \mathrm{H}_{2} \mathrm{O}$, and the removal of $\mathrm{Mg}, \mathrm{Fe}, \mathrm{Ca}$ and other femic components. As a possible cause of granitization, we considered the deformation of the continental crust during Late Paleozoic collision $[30,34,38]$, the times of tectonic deformations, dome formation, and metamorphism in the Kochkar anticlinorium coincide [28-30]. They culminated in the introduction of anatectic granites and pegmatites. The rocks of the dome structures are enriched with fluorophilic elements $(\mathrm{Be}, \mathrm{Li}, \mathrm{Sn}$, $\mathrm{Ta}, \mathrm{Nb}$, and others) and the rocks of the inter-dome structures are rich in $\mathrm{Fe}, \mathrm{Mg}, \mathrm{Ca}, \mathrm{Ti}$, and others. The substrate was volcanic-sedimentary rocks, distributed around the Kochkar anticlinorium [27].

6. The solution for the problem of the $\mathrm{Cr}$ and $\mathrm{Al}$ sources for the formation of red corundum in the hyperbasite Rai-Iz massif (the Polar Urals) was recently considered [39]. The authors [39] believe that the vein was the product of the interaction between a subduction-zone-derived fluid and mantle wedge peridotite. The $\mathrm{Cr}$ content of the red corundum was potentially derived from accessory chromian spinel in the peridotite. Popov et al. [40] considered that the chromium-bearing spinels of the Bazhenovsky ophiolite complex are the main chromium sources for the coloring of emeralds and alexandrites of the Mariinsky deposit (Middle Urals), located $15 \mathrm{~km}$ west. We did not comment on these statements, since only ruby-containing marbles were considered in this article.

7. In Mg-calcite (ruby-bearing) marble, the content of $\mathrm{Al}$ and $\mathrm{Cr}$ is low at $0.11-0.13 \mathrm{wt} \% \mathrm{Al}_{2} \mathrm{O}_{3}$ and $0.00096-0.0014 \mathrm{wt} \% \mathrm{Cr}_{2} \mathrm{O}_{3}$ [8]. Marbleized bituminous organogenic limestones in the marginal parts of the anticlinorium (about $5 \mathrm{~km}$ from the Kuchinskoe occurrence) contain 3-times greater the amount of $\mathrm{Al}$ and $\mathrm{Cr}$. The primary chemical composition of limestones changed significantly during the prograde and initial retrograde metamorphism $[8,32,34]$. Evaporitic lenses, if present in limestone (as suggested in [11,12]), could also undergo these processes.

We believe that ruby and eskolaite in the Kuchinskoe occurrence were formed by the hydrothermal-metasomatic process. Eskolaite was observed only on the surface of ruby crystals or in 
their near-surface region. This is probably due to the formation of eskolaite only at the final stage of the ruby crystal growth. Chromium zonal distribution in ruby crystals was not observed. Corundum enrichment (or depletion) in chromium in the contact zone with eskolaite was sometimes present, but is not a rule. The reason for this has not yet been established. Probably, the chromium content in corundum is limited by crystallization conditions rather than by chromium activity. This corresponds to the observed facts: the spinel and ruby have maximum $\mathrm{Cr}$ contents at the prograde stage, minimal $\mathrm{Cr}$ concentration at transitional stage, and again enriched in $\mathrm{Cr}$ at the retrograde stage. Sazonov [41] noted that $\mathrm{Al}^{3+}$ and $\mathrm{Cr}^{3+}$ have amphoteric properties and migrate under the similar conditions in hydrothermal metasomatic processes. In this case, we can assume that $\mathrm{Al}$ and $\mathrm{Cr}$ were introduced into the marble by high-temperature fluid. The metamorphism of sedimentary carbonate rocks in the Kochkar anticlinorium was not isochemical $[7,8]$ and $\mathrm{Cr}$ was a component of many accessory minerals in marbles. Consequently, eskolaite could not form under the conditions of isochemical metamorphism. Due to the evolution of metamorphic conditions, the introduction of $\mathrm{Al}$ into the system ceased, but $\mathrm{Cr}$ still entered, forming crystalline crusts on the ruby.

\section{Conclusions}

The identification of eskolaite in association with rubies in the marbles of the Kuchinskoe occurrence is a new argument in favor of the introduction of $\mathrm{Al}$ and $\mathrm{Cr}$ into the mineral formation zone. Here, eskolaite was associated only with high-chromium rubies of the prograde and retrograde metamorphism, which confirms the migration of these elements in similar conditions. The formation of eskolaite occurs at the final stage of the ruby crystal growth and later. The eskolaite of prograde stage contains an admixture of titanium, which is explained by its low activity and inability to form its own minerals. The occurrence of rutile and sphene at the retrograde stage explains the low titanium content in the recent eskolaite. The parameters and morphology of the mineralized zones also indicate the introduction of $\mathrm{Al}$ and $\mathrm{Cr}$ by metamorphogenic fluids.

Author Contributions: Conceptualization, investigation and writing-original draft preparation, A.K.; writing-review and "Results" and "Discussion" section editing, supervision, V.M.; Powder X-Ray diffraction analysis and structure solution, S.S.; SEM and EMPA analyses, I.G.; writing-review, "Materials and Methods" section editing and translation, D.K. All authors have read and agreed to the published version of the manuscript.

Funding: The work was performed within the framework of topic No. AAAA-A18-118052590028-9 of the IGG UB RAS state assignment; SEM and EMPA analyses were carried out at the Geoanalitik UB RAS Collective Use Center within the framework of topic No. AAAA-A18-118053090045-8 of the IGG UB RAS state assignment.

Acknowledgments: The Editor of Minerals and Guest Editors are thanked for organizing the Special Issue on "Mineralogy and Geochemistry of Ruby and Allied Assemblages" and extending an invitation to submit a contribution for consideration. This particularly includes Frederick Lin Sutherland and Khin Zaw. We thank the Reviewers for the important comments and constructive suggestions, which helped us to improve the quality of the manuscript.

Conflicts of Interest: The authors declare no conflict of interest. The funders had no role in the design of the study; in the collection, analyses, or interpretation of data; in the writing of the manuscript, or in the decision to publish the results.

\section{References}

1. Bank, H.; Okrusch, M. Über Rubin-Vorkommen in Marmoren von Hunza (Pakistan). Z. Dt. Gemmol. Ges. 1976, 25, 67-85.

2. Harlow, G.E.; Bender, W. A study of ruby (corundum) compositions from the Mogok Belt, Myanmar: Searching for chemical fingerprints. Am. Mineral. 2013, 98, 1120-1132. [CrossRef]

3. Okrusch, M.; Bunch, T.E.; Bank, H. Paragenesis and petrogenesis of a corundum bearing marble at Hunza (Kashmir). Miner. Depos. 1976, 11, 278-297. [CrossRef]

4. Rossovskiy, L.N.; Konovalenko, S.I.; Ananjev, S.A. Conditions of ruby formation in marbles. Geologiya Rudnyh Mestorozhdeniy 1982, 24, 57-66. (In Russian) 
5. Litvinenko, A.K. The reconstruction of bauxite-like sediments in the Early Proterozoic metamorphites of the Central Pamir. In Proceedings of the Materials of the 5th All-Russian Lithologic Conference "The Types of Sedimentogenesis and Lithogenesis and Their Evolution in the History of the Earth", Ekaterinburg, Russia, 14-16 October 2008; pp. 428-430. (In Russian).

6. Dufour, M.S.; Kol'tsov, A.B.; Zolotarev, A.A.; Kuznetsov, A.B. Corundum-containing metasomatites of the Central Pamir. Petrologiya 2007, 15, 160-177. (In Russian) [CrossRef]

7. Kissin, A.Y. Marble-hosted Ruby Deposits (by the Example of Urals); UB RAS Publishing House: Sverdlovsk, Russia, 1991. (In Russian)

8. Kissin, A.Y.; Murzin, V.V.; Tomilina, A.A.; Pritchin, M.E. Ruby-sapphire-spinel mineralization in the marbles of the Middle and Southern Urals: Geology, mineralogy, genesis. Geol. Ore Depos. 2016, 58, 385-402. [CrossRef]

9. Terekhov, E.N.; Kruglov, V.A.; Levitsky, V.I. Rare earth elements in corundum bearing metasomatites and associated rocks of the Eastern Pamir. Geochimiya 1999, 3, 238-250. (In Russian)

10. Terekhov, E.N.; Akimov, A.P. Tectonic position and genesis of jewelry corundum deposits in High Asia. Litosfera 2013, 5, 122-140. (In Russian)

11. Spiridonov, E.M. Gemstone deposits of the former Soviet Union. J. Gemmol. 1998, 26, 111-124. [CrossRef]

12. Garnier, V.; Giuliani, G.; Ohnenstetter, D.; Fallick, A.E.; Dubessy, J.; Banks, D.; Vinh, H.Q.; Lhomme, T.; Maluski, H.; Pêcher, A.; et al. Marble-hosted ruby deposits from Central and Southeast Asia: Towards a new genetic model. Ore Geol. Rev. 2008, 34, 169-191. [CrossRef]

13. Giuliani, G.; Ohnenstetter, D.; Fallick, A.E.; Groat, L.; Fagan, J. The geology and genesis of gem corundum deposits. In Geology of Gem Deposits; (Short Course Series); Raeside, E.R., Ed.; Mineralogical Association of Canada: Québec, QC, Canada, 2014; pp. 29-112.

14. Kisin, A.Y.; Murzin, V.V.; Batalina, A.A.; Tomilina, A.V. Green garnet from the Alabashka and Lipovka ruby occurrences (Middle Urals). Vestnik UrO RMO 2014, 11, 52-59. (In Russian)

15. Kuova, O.; Vuorelainen, Y. Eskolaite, a new chromium mineral. Am. Mineral. 1958, 43, 1098-1105.

16. Pautov, L.A.; Popov, M.P.; Erokhin, Y.V.; Khiller, V.V.; Karpenko, V.Y. Mariinskit $\mathrm{BeCr}_{2} \mathrm{O}_{4}-\mathrm{A}$ new mineral, chrysoberyl analog. Zap. RMO 2012, 6, 43-62. (In Russian)

17. Erokhin, Y.V. Chromite mineralization of the Bazhenovsky ophiolite complex (Middle Urals). Litosfera 2006, 3, 160-165. (In Russian)

18. Erokhin, Y.V.; Khiller, V.V.; Zoloev, K.K.; Popov, M.P.; Grigoryev, V.V. Mariinskit from the Bazhenovsky ophiolite complex-The second find in the world. Dokl. Earth Sci. 2014, 455, 441-443. (In Russian)

19. Moloshag, V.P.; Alimov, V.Y.; Anikina, E.V.; Gulyaeva, T.Y.; Vakhrusheva, N.V.; Smirnov, S.V. Accessory mineralization of chromitites of alpinotype hyperbasites of the Urals. Zap. VMO. 1999, 2, 71-83. (In Russian)

20. Bocharnikova, T.D.; Voronina, L.K. The first find of eskolaite in the magnetite-ilmenite ores of the Kusa gabbro intrusion. Ezhegodnik-2007 Proc. IGG UB RAS. 2008, 155, 226-229. (In Russian)

21. Sobolev, N.V. Deep Inclusions in Kimberlites and the Problem of the Upper Mantle Composition; Nauka (Siberian Branch): Novosibirsk, Russia, 1974; 264p. (In Russian)

22. Sobolev, V.K.; Zherdev, P.Y.; Kolodko, A.A. Eskolaite-The first find in kimberlites. Mineral. Zhurnal 1993, 15, 83-85. (In Russian)

23. Schulze, D.J.; Flemming, R.L.; Shepherd, P.H.M.; Helmstaedt, H. Mantle-derived guyanaite in a Cr-omphacitite xenolith from Moses Rock diatreme, Utah. Amer. Miner. 2014, 99, 1277-1283. [CrossRef]

24. Logvinova, A.M.; Wirth, R.; Sobolev, N.V.; Seryotkin, Y.V.; Yefimova, E.S.; Floss, C.; Taylor, L.A. Eskolaite associated with diamond from the Udachnaya kimberlite pipe, Yakutia, Russia. Amer. Miner. 2008, 93, 685-690. [CrossRef]

25. Koneva, A.A.; Suvorova, L.F. Rare chromium and vanadium oxides in the metamorphic rocks of the Priolkhonye (Western Baikal region). Zap. VMO. 1995, 124, 52-61. (In Russian)

26. Reznitsky, L.Z.; Sklyarov, E.V.; Karmanov, N.S. Eskolaite in the metacarbonate rocks of the Slyudyanka series (Southern Baikal). Dokl. Earth Sci. 1998, 362, 657-661. (In Russian)

27. Geology of the USSR. T. XII. Perm, Sverdlovsk, Chelyabinsk and Kurgan regions. Part I. Geological description. Book 2; Nedra: Moscow, Russia, 1969; 304p. (In Russian)

28. Keilman, G.A. Migmatite Complexes of Mobile Belts; Nedra: Moscow, Russia, 1974; 200p. (In Russian) 
29. Boltyrov, V.B.; Pystin, A.M.; Ogorodnikov, V.N. Regional metamorphism of rocks in the northern framing of the Sanarsky granitoid massif on the South Urals. In Geologiya Metamorficheskikh Kompleksov Urala (Geology of Metamorphic Complexes of the Urals); SGI: Sverdlovsk, Russia, 1973; pp. 53-66. (In Russian)

30. Ogorodnikov, V.N.; Sazonov, V.N.; Polenov, Y.A. Kochkarsky ore district (Southern Urals). In Minerageny of Suture Zones of the Urals; UGGGA: Ekaterinburg, Russia, 2004; 216p. (In Russian)

31. Talantsev, A.S. Pocket Pegmatites of the Urals; Nauka: Moscow, Russia, 1988; 144p. (In Russian)

32. Kisin, A.Y. Deformation macrostructures in carbonate rocks of granite-gneiss complexes of Urals. Lithosfera 2007, 1, 90-108. (In Russian)

33. Kissin, A.J. Ruby and Sapphire from the Southern Ural Mountains, Russia. Gems Gemol. 1994, 30, $243-252$. [CrossRef]

34. Kisin, A.Y.; Koroteev, V.A. Block Folding and Ore Genesis; IGG UrO RAN: Ekaterinburug, Russia, 2017; 349p.

35. Vysotskiy, S.V.; Nechaev, V.P.; Kissin, A.Y.; Yakovenko, V.V.; Ignat'ev, A.V.; Velivetskaya, T.A.; Sutherland, F.L.; Agoshkov, A.I. Oxygen isotopic composition as an indicator of ruby and sapphire origin: A review of Russian occurrences. Ore Geol. Rev. 2015, 68, 164-170. [CrossRef]

36. Talantsev, A.S. Geothermobarometry according to Dolomite-Calcite Paragenesis; Science: Moscow, Russia, 1981; 136p. (In Russian)

37. Chatterjee, N.D.; Leistner, H.; Terhart, L.; Abraham, K.; Klaska, R. Thermodynamic mixing properties of corundum-eskolaite, $\alpha-\left(\mathrm{Al}, \mathrm{Cr}^{3+}\right)_{2} \mathrm{O}_{3}$, crystalline solid solutions at high temperatures and pressures. Amer. Miner. 1982, 67, 725-735.

38. Kissin, A.Y.; Koroteev, V.A. Stress Gradients as the Driving Force of Mass Movement in General Crustal Folding. Dokl. Earth Sci. 2009, 424, 7-10. [CrossRef]

39. Meng, F.; Shmelev, V.R.; Kulikova, K.V.; Ren, Y. A red-corundum-bearing vein in the Rai-Iz ultramafic rocks, Polar Urals, Russia: The product of fluid activity in a subduction zone. Lithos 2018, 320-321, 302-314. [CrossRef]

40. Popov, M.P.; Sorokina, E.S.; Kononkova, N.N.; Nikolaev, A.G.; Karampelas, S. New Data on the Genetic Linkage of the Beryl and Chrysoberyl Chromophores of the Ural's Emerald Mines with Chromium-Bearing Spinels of the Bazhenov Ophiolite Complex. Dokl. Earth Sci. 2019, 486, 630-633. [CrossRef]

41. Sazonov, V.N. Chromium in the Hydrothermal Process (on the Example of the Urals); Nauka: Moscow, Russia, 1978; 287p. (In Russian) 



\title{
$\mathrm{U}-\mathrm{Pb}$ Dating of Zircon and Zirconolite Inclusions in Marble-Hosted Gem-Quality Ruby and Spinel from Mogok, Myanmar
}

\author{
Myint Myat Phyo ${ }^{1,2}$, Hao A.O. Wang ${ }^{2, *}$, Marcel Guillong ${ }^{3}$, Alfons Berger ${ }^{4}$, Leander Franz ${ }^{1, *}$, \\ Walter A. Balmer ${ }^{2}$ and Michael S. Krzemnicki ${ }^{2}$ \\ 1 Department of Environmental Sciences, Mineralogy and Petrology, University of Basel, Bernoullistrasse 30, \\ 4056 Basel, Switzerland; myint.myatphyo@ssef.ch \\ 2 Swiss Gemmological Institute SSEF, Aeschengraben 26, 4051 Basel, Switzerland; \\ info@collectionbalmer.com (W.A.B.); director@ssef.ch (M.S.K.) \\ 3 Institute of Geochemistry and Petrology, ETH Zurich, Clausiusstrasse 25, 8092 Zürich, Switzerland; \\ marcel.guillong@erdw.ethz.ch \\ 4 Institute of Geological Sciences, University of Bern, Baltzerstrasse 1+3, 3012 Bern, Switzerland; \\ alfons.berger@geo.unibe.ch \\ * Correspondence: hao.wang@ssef.ch (H.A.O.W.); leander.franz@unibas.ch (L.F.); \\ Tel.: +41-61-262-06-40 (H.A.O.W.)
}

Received: 15 November 2019; Accepted: 15 February 2020; Published: 21 February 2020

\begin{abstract}
The Mogok area in Myanmar (Burma) is known since historic times as a source for some of the finest rubies and spinels in the world. In this study, we focus on in-situ U-Pb geochronological analyses of zircon and zirconolite, either present as inclusions in gem-quality ruby and spinel or as accessory minerals in ruby- and spinel-bearing marble and adjacent granulite facies gneisses. The age determination was carried out using both laser ablation inductively coupled plasma time-of-flight mass spectrometry (LA-ICP-TOF-MS) and sector-field mass spectrometry (LA-ICP-SF-MS). In addition, we present multi-element data (REE) of zircon and zirconolite collected with LA-ICP-TOF-MS to further characterize these inclusions. Most of the studied zircon grains display growth zoning (core/rim) regardless if as inclusion in gemstones, or as accessory mineral in host rock samples. U-Pb dating was conducted on both core and rim of zircon grains and revealed most ages ranging from $200 \mathrm{Ma}$ in the core to $\sim 17 \mathrm{Ma}$ in the rim. The youngest $\mathrm{U}-\mathrm{Pb}$ ages determined from the rim of zircon inclusions in gem-quality ruby and spinel are $22.26 \pm 0.36 \mathrm{Ma}$ and $22.88 \pm 0.72 \mathrm{Ma}$, respectively. This agreement in $\mathrm{U}-\mathrm{Pb}$ ages is interpreted to indicate a simultaneous formation of ruby and spinel in the Mogok area. In ruby- and spinel-bearing marble from Bawlongyi, the youngest zircon age was determined as $17.11 \pm 0.22 \mathrm{Ma}$. Furthermore, $\mathrm{U}-\mathrm{Pb}$ age measured on the rim of zircon grains in a biotite-garnet gneiss reveals a Late Oligocene age $(26.13 \pm 1.24 \mathrm{Ma})$, however older ages up to Precambrian age were also recorded in the cores of zircon as accessory minerals from this gneiss. These old ages point to a detrital origin of the analysed zircon cores. Although non-matrix matched standard was applied, zirconolite $\mathrm{U}-\mathrm{Pb}$ age results are narrower in distribution from $\sim 35 \mathrm{Ma}$ to $\sim 17 \mathrm{Ma}$, falling within the range of zircon ages. Based on results which are well in accordance with previous geochronological data from the Mogok Metamorphic Belt (MMB), we deduce that gem-quality ruby and spinel from Mogok probably formed during a granulite-facies regional metamorphic event in Oligocene to Early Miocene, related to post collision tectonics of the Eurasian and Indian plates. Our data not only provide key information to understand the formation of gem-quality ruby and spinel in the so-called Mogok Stone Tract, but also provide assisting evidence when determining the country of origin of gemstones in gemmological laboratories.
\end{abstract}

Keywords: ruby; spinel; Mogok; geochronology; U-Pb dating; zircon; zirconolite 


\section{Introduction}

Ruby, the chromium-bearing red variety of corundum $\left(\mathrm{Al}_{2} \mathrm{O}_{3}\right)$ and chromium-bearing red spinel $\left(\mathrm{MgAl}_{2} \mathrm{O}_{4}\right)$ are among the world's most valued gemstones. In the gem trade, the price of a ruby and spinel is not only defined by their size and quality, but also to a large part by their geographic (country of) origin, notably when they are from a historically important and famed gem deposit. Ruby and spinel of gem-quality from marble-hosted deposits are known from a number of localities, such as the Mogok area (Figure 1) and Mong Hsu in Myanmar, the Hunza Valley in Pakistan, Jegdalek in Afghanistan, Murgab in Tajikistan, Luc Yen in Vietnam and the Morogoro region in Tanzania. From these deposits, the Mogok area is considered by far the most important and historically reputed source for ruby and spinel in the trade. This explains, why in literature corundum (ruby and sapphire) and to a lesser extent spinel from Mogok have been extensively studied, either gemmologically and in general [1-4], or focusing specifically on trace elements [5,6], stable isotopes [7-10], solid inclusions [11] and fluid inclusions [12]. In geochronology, a number of studies were published about the Mogok area or further gem deposits worldwide, either investigating minerals related to gemstone formation or inclusions in rough and faceted gemstones [13-21].

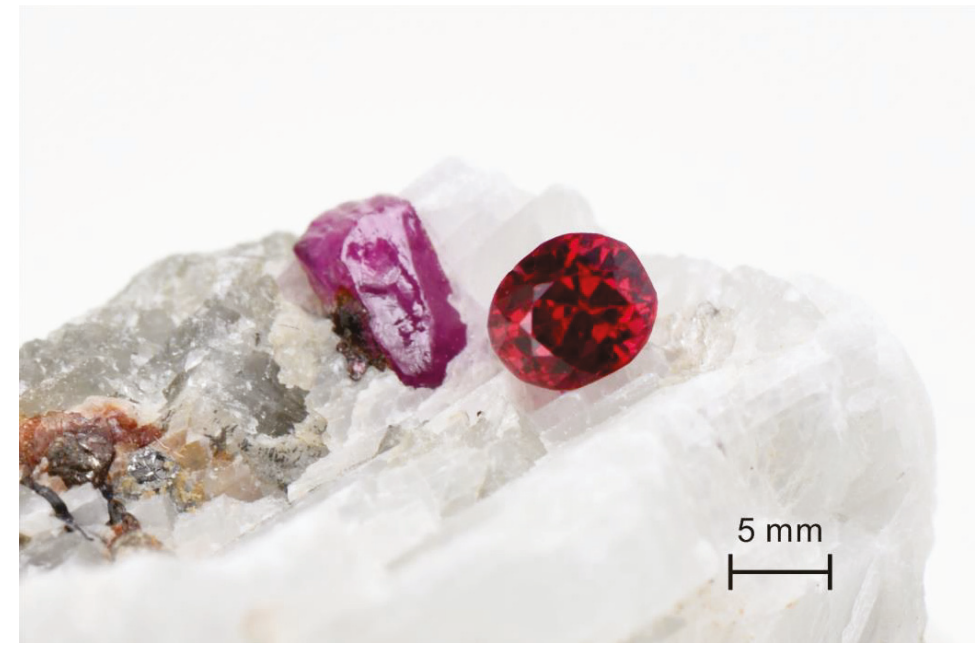

Figure 1. Faceted gem-quality ruby $(0.369 \mathrm{ct})$ and rough ruby crystal within marble from Mogok area, Myanmar. Photo: M.M.P.

In recent years, $\mathrm{U}-\mathrm{Pb}$ dating of inclusions (e.g., zircon, titanite, etc.) in gemstones using laser ablation inductively coupled plasma mass spectrometry (LA-ICP-MS) has become more popular due to easier access to instrumentation, minimum sample preparation, smaller laser crater size and improved instrument sensitivity $[22,23]$. The $\mathrm{U}-\mathrm{Pb}$ ages of inclusions found in a gemstone indicate the maximum possible formation age of that gemstone. As such, these radiometric ages may provide gemmological laboratories with additional evidence when carrying out country of origin determination as a commercial service to the gem trade. This is especially helpful when separating ruby, sapphire and spinel related to the Himalayan orogenesis (e.g., Mogok area in Myanmar) from those related to the much older Pan-African orogeny (e.g., Morogoro area in Tanzania) [17,19,24-26].

For the Mogok area, only a limited amount of geochronological data from inclusions in gemstones and from accessory minerals in host rocks have been published so far: zircon inclusion in ruby $\sim 32$ Ma [16], titanite in ruby $\sim 32 \mathrm{Ma}$ [14], zircon in sapphire $\sim 27 \mathrm{Ma}$ [24], zircon in granitic host rocks $\sim 16.8 \mathrm{Ma}$ [26]. More geochronological data from this gem-rich area is thus still essential in order to 
get a better understanding of its complex geology and to be able to compile a genetic model for the formation of gemstones in the Mogok area.

In this paper, we present new $\mathrm{U}-\mathrm{Pb}$ ages of zircon and zirconolite, found as inclusions in gem-quality ruby and spinel or as accessory minerals in host rock samples from the Mogok area. In addition, we present rare earth element data (REE) of selected zircon and zirconolite grains for further characterization. Our data contributes to a better understanding of the complex geological processes resulting in the formation of gem-quality ruby and spinel in the studied area. Furthermore, our data may assist gemmological laboratories specifically in country of origin determination.

\section{Regional Geological Setting}

The Mogok Metamorphic Belt (MMB), further described in early studies [27,28], is a large sickle-shaped belt of regionally metamorphosed rocks stretching N-S from central to upper Myanmar as the southern continuation of the Himalayan syntaxis [29]. It forms the western margin of the Shan-Thai Block (Sibumasu Block) and is adjacent to the north-south trending right-lateral strike-slip Sagaing Fault, related to the youngest Cenozoic metamorphic events [30]. The Mogok-Mandalay-Mergui Belt extends to the Mergui area in the southern part of Myanmar [31,32]. In the so-called Mogok Stone Tract [27], located at the northeastern end of the MMB, there is an accumulation of world-renowned gem deposits, namely of rubies, sapphires and spinels [3,28]. The formation of those gemstones is related to late-stage Cenozoic metamorphic events within this geological unit [30,33,34]. The Mogok area mainly consists of upper amphibolite to granulite facies marbles, schists and gneisses [35]. Amongst these, the Mogok gneisses [27] in the southern part of the Mogok area are considered to be the oldest rock units in this area of Myanmar [36]. Gem-quality ruby and spinel are found in the Mogok area in both primary deposits in marbles and secondary deposits in alluvial and eluvial placers, as well as accumulated placers in karstic sinkholes and caverns [37].

The MMB has been extensively studied with a main focus on regional geology, geochemistry and geochronology $[30,33,38-40]$. In terms of geochronology, the ruby- and spinel-bearing marbles from the Mogok area are stratigraphically interpreted in previous studies $[27,28]$ as being metamorphosed limestones of Precambrian age. Searle and Haq considered the Mogok metasediments to be originally Precambrian to Jurassic rocks of the Shan Plateau [41], whereas Clegg described them as mid-Cretaceous limestones and Jurassic sediments [42]. From the Precambrian to Cenozoic, the MMB experienced several magmatic and metamorphic events, which are commonly summarized as: Precambrian to Palaeozoic regional metamorphism and magmatism indicated by Ordovician age on zircon from foliated leucogranite [2] and Late Cambrian age on biotite gneiss [21] as well as Jurassic magmatism on biotite augen gneiss [40]. The latest, high-grade regional metamorphic event in the MMB occurred in Paleogene to Early Neogene due to the collision of the Sibumasu Block with the West Burma Block subsequent to the collision of the Indian and the Asian plates $[43,44]$ and was followed by an intense episode of post-tectonic magmatism [2,26,45].

\section{Materials and Methods}

\subsection{Zircon and Zirconolite}

Prior to analyses, all gemstone samples (ruby and spinel) were polished to expose zircon and zirconolite inclusions. For host rocks, samples were first embedded in epoxy, before being polished.

The zircon and zirconolite inclusions were identified using a standard gemmological microscope (StereoZoom7, Cambridge Instruments, Cambridge, UK) and a polarization microscope (Leica DMLS, Wetzlar, Germany), two Raman micro-spectrometers (Renishaw inVia equipped with an argon-ion laser at $514.5 \mathrm{~nm}$; Swiss Gemmological Institute SSEF, Basel, Switzerland; Bruker Senterra with a Nd-YAG laser at 532 nm; Department of Environmental Sciences, Mineralogy and Petrology, University of Basel, Basel, Switzerland), and a scanning electron microscope (FEI Nova Nano SEM 230, Nano Imaging Lab, University of Basel, Basel, Switzerland) equipped with an energy-dispersive spectrometer (EDS) 
and a back-scattered electron detector (BSE). In order to avoid any contamination, the samples were not coated. More details about the analytical conditions applied for Raman and SEM analyses are described in our previous publication on spinel inclusions from Mogok [11].

Zircon $\left(\mathrm{ZrSiO}_{4}\right)$ is found as inclusion in gem-quality ruby and spinel and as accessory mineral in three host rock samples (ruby- and spinel-bearing marble from Bawlongyi area, granulite-facies gneiss from Aunglan Taung area in central Mogok and granulite-facies gneiss from Kinn area in western Mogok, see Table 1).

Table 1. List of samples from Mogok investigated for this study. The scale bars represent $5 \mathrm{~mm}$ length for gemstones and $5 \mathrm{~cm}$ for host rocks.

\begin{tabular}{|c|c|c|c|c|c|}
\hline Sample Name & Locality & Host Material & Analysed Grain & Weight (ct) & Sample Photo \\
\hline SSEF96663_A & Mansin & & $\begin{array}{l}4 \text { Zircons and } \\
5 \text { Zirconolites }\end{array}$ & 2.411 & - \\
\hline SSEF96666_A & & & 1 Zircon & 2.431 & - \\
\hline SSEF96666_B & & Ruby & 1 Zircon & 1.270 & \\
\hline SSEF96667_A & Kyatpyin & & 1 Zircon & 1.615 & \\
\hline SSEF96668_A & Kyaukpoke & & 1 Zircon & 0.268 & \\
\hline SSEF92720_D & Kyauksaung & & 2 Zircons & 0.405 & 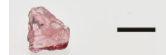 \\
\hline SSEF92725_D & & Spinel & 2 Zircons & 0.673 & \\
\hline SSEF92725_E & & & 1 Zircon & 0.940 & - \\
\hline BLG_12 & Bawlongyi & $\begin{array}{c}\text { Ruby- and } \\
\text { Spinel-bearing } \\
\text { Marble }\end{array}$ & $\begin{array}{c}32 \text { Zircons and } 9 \\
\text { Zirconolites }\end{array}$ & & \\
\hline ALT_03 & $\begin{array}{l}\text { Aunglan } \\
\text { Taung }\end{array}$ & & 40 Zircons & & \\
\hline K_01 & Kinn & & 24 Zircons & & \\
\hline
\end{tabular}


Only 5 from a total of 85 ruby samples as well as 3 from 100 spinels contained zircon inclusions suitable for dating in terms of size and proximity to the sample's surface. Most of the observed zircon inclusions in the examined gemstone samples however were either too small $(<10 \mu \mathrm{m})$ or located too deep inside the sample to be reached by laser ablation and therefore could not be considered for $\mathrm{U}-\mathrm{Pb}$ dating in this study. In total, 8 zircon inclusions from ruby and 5 zircon inclusions from spinel were analysed for this study. The size of the analysed zircon grains in ruby range from 50 to $300 \mu \mathrm{m}$ in diameter. In contrast to this, the zircon grains in spinel are smaller with a maximum diameter of $50 \mu \mathrm{m}$, with some inclusions being as small as $10 \mu \mathrm{m}$. In addition to the zircon inclusions from gemstones, we have studied zircon present as accessory mineral in host-rocks. In the ruby- and spinel-bearing marble from Bawlongyi area (Figure 2), we analysed a total of 32 zircons, occurring either as individual grains or intergrown with zirconolite. Furthermore, we analysed 40 zircons found as accessory mineral in a garnet-orthopyroxene gneiss from Aunglan Taung and 24 zircon grains in biotite-garnet gneiss from the Kinn area (Figure 2). The size of the accessory zircons in the Aunglan Taung gneiss is $35 \mu \mathrm{m}$ to $50 \mu \mathrm{m}$, while those from Kinn gneiss are even smaller with a size of $10 \mu \mathrm{m}$ to maximum $35 \mu \mathrm{m}$ [46].

Zirconolite, ideally $\mathrm{CaZrTi}_{2} \mathrm{O}_{7}$, is known in several polytypoids, such as zirconolite-3O (orthorhombic), zirconolite-3T (trigonal), zirconolite-2M (monoclinic) and non-crystalline (metamict) or undetermined polytypoid [47]. This latter option explains why we were not able to identify zirconolite in our study using Raman spectroscopy. In fact, they all revealed featureless (amorphous) Raman spectra. However, by analysing the major and minor elemental composition using SEM equipped with an EDS detector, we were able to positively identify the zirconolite grains present in our samples. We observed two types of zirconolite: (1) individual inclusion of $40 \mu \mathrm{m}$ to $100 \mu \mathrm{m}$ size in ruby from Mansin, and (2) intergrown with zircon in Bawlongyi marble (see Table 1). Here, zirconolite forms either a 10-50 $\mu \mathrm{m}$ thick rim around zircon or occurs as small (maximum $5 \mu \mathrm{m}$ ) amoeboid inclusions within zircon.

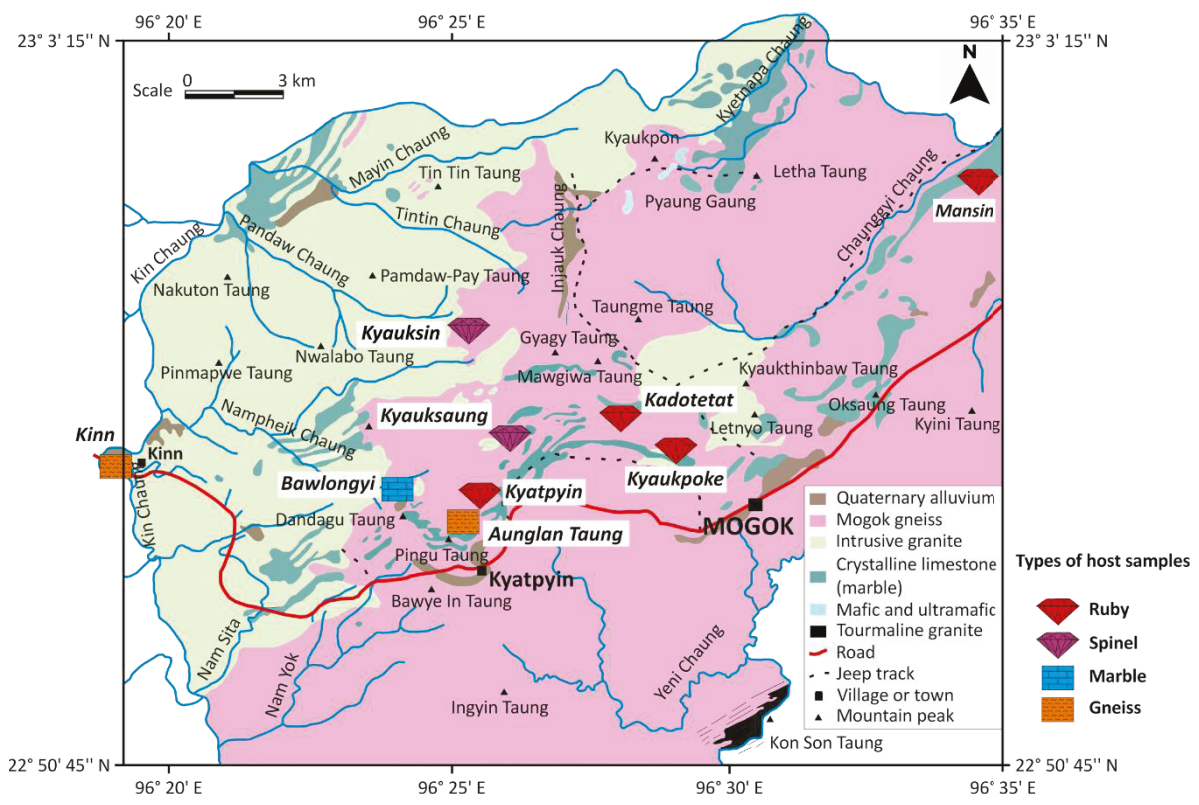

Figure 2. Sample locations plotted on the geological map of the Mogok area (modified after [28] and [48] with permission). 
To our knowledge, this study provides the first detailed characterization of zirconolite from the Mogok area. A detailed list of the zircon and zirconolite analysed and their occurrences are given in Table 1 and Supplementary Data.

\subsection{Growth Zonation of Zircon and Zirconolite}

Zircon often shows complex growth zonation patterns. This may strongly influence radiometric dating if an analysis is conducted across growth zones of different ages [49]. In order to visualize such zoning in our zircon (and zirconolite) grains (Figure 3a,b) and to determine the appropriate position to carry out U-Pb dating, we additionally collected variable pressure secondary electron (VPSE) images using a ZEISS EVO 50 SEM (Institute of Geological Sciences, University of Bern, Bern, Switzerland). These images reveal three different types of patterns: (a) zircon with a characteristic core/rim growth zonation, (b) zircon showing an irregular zoning pattern and (c) zircon with no zonation detectable by VPSE imaging.
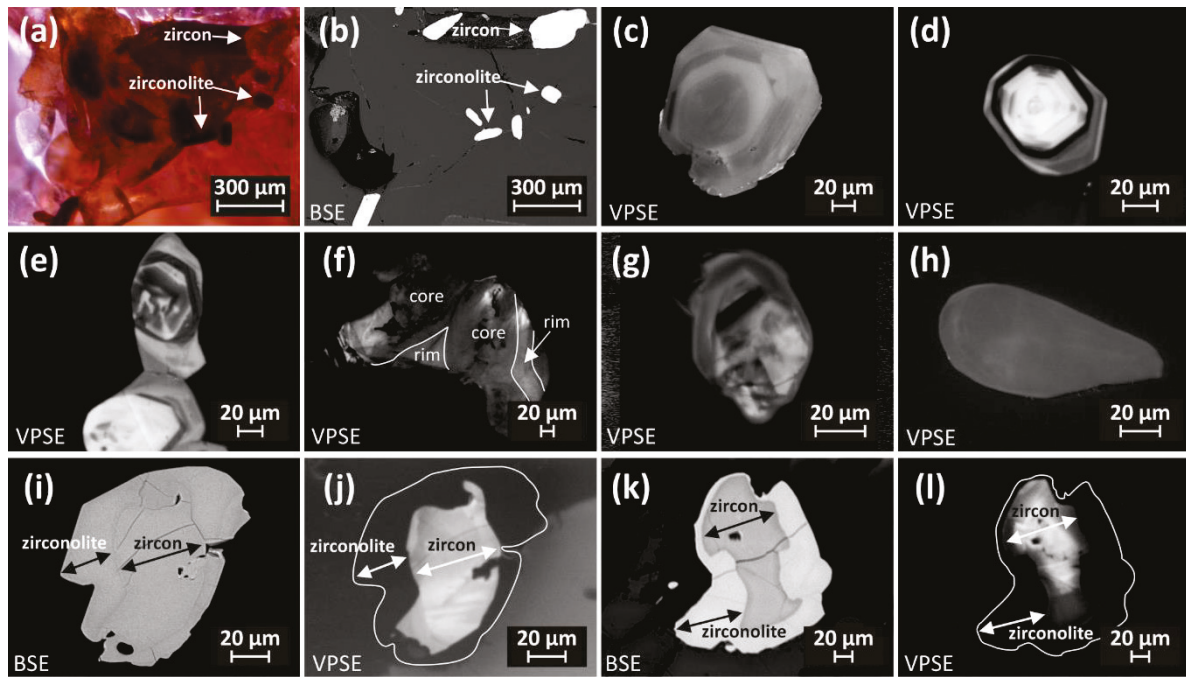

Figure 3. (a) Photomicrograph of zircon and zirconolite inclusion in ruby from Mansin, and (b) corresponding back-scattered electron (BSE) image. (c) Variable pressure secondary electron (VPSE) image of zircon inclusion in ruby from Kyatpyin with distinct core/rim zonation. (d,e) Similar core/rim zonation in VPSE images of accessory zircon from Aunglan Taung gneiss. (f) VPSE image of zircon inclusion in ruby from Mansin showing irregular zoning with an aggregated core and a homogeneous rim. (g) VPSE image of accessory zircon from Kinn gneiss showing irregular zoning. (h) VPSE image of zircon inclusion in spinel from Kyauksin revealing nearly no zoning. (i) BSE image of zircon and zirconolite intergrown in Bawlongyi marble (zirconolite occurs as a rim around zircon inclusion), and (j) their corresponding VPSE image. (k) BSE image of another zircon and zirconolite intergrowth in Bawlongyi marble and (l) their corresponding VPSE image.

Distinct core/rim growth zonation is found in some zircon grains included in rubies from Kyatpyin (Figure 3c), but also in accessory zircons from gneisses (Figure 3d,e). The distinct core/rim growth zonation may indicate a magmatic origin of the core surrounded by a metamorphic rim. Such a zonation pattern is often observed, specifically in accessory zircon from gneiss [50]. Irregular zoning is found in zircon inclusions in ruby from the Mansin area (Figure 3f) revealing aggregated textures in the core and more homogeneous rim sections, but also in zircons present as accessory minerals in the studied gneisses (Figure 3g). BSE and VSPE images showing no (significant) growth zoning patterns are observed for zircon inclusions in spinel (Figure 3h), but also for the accessory zircons in 
Bawlongyi marble (Figure 3i-1). This is also true for all investigated zirconolite grains. They show a homogeneous VPSE reaction and no zoning features, regardless if present as individual inclusion in ruby from Mansin or intergrown with zircon in Bawlongyi marble (Figure 3j,1).

\subsection{LA-ICP-MS Instrumentations}

For in-situ radiometric $\mathrm{U}-\mathrm{Pb}$ dating and the multi-element characterization (specifically $\mathrm{REE}$ ) of the zircon and zirconolite grains, a combined approach of two different mass spectrometer setups was applied to benefit from the advantages of each of these systems: (1) LA-ICP time-of-flight MS (LA-ICP-TOF-MS, Swiss Gemmological Institute SSEF, Basel, Switzerland) and (2) sector-field MS (LA-ICP-SF-MS, Institute of Geochemistry and Petrology, ETH Zurich, Zurich, Switzerland). Single detector SF-MS has about 15 times higher sensitivity compared to TOF-MS [51], hence a distinctly smaller laser spot can be used for analysis, minimizing potential overlaps of age zones, especially when analysing zoned zircon. Since the SF-MS data acquisition is sequential, only a limited number of masses can be collected. In contrast to this, TOF-MS allows simultaneous acquisition of the full mass spectrum, hence it is ideal for constant monitoring of elemental variations (e.g., when passing from one mineral to another), especially when the laser ablates into small mineral intergrowth. The drawback of this second method is its relatively lower sensitivity, thus requiring a larger laser ablation spot (e.g., $35 \mu \mathrm{m}$ ). Obviously, this last condition (laser spot size) of LA-ICP-TOF-MS is challenging, especially when analysing small zircon and zirconolite with narrow and/or complex growth zoning. Therefore, we applied LA-ICP-SF-MS for small and complex zoned zircon and for zirconolite, using a small spot size of only 13 to $19 \mu \mathrm{m}$ and integration times of $10 \mathrm{~ms}\left({ }^{202} \mathrm{Hg},{ }^{208} \mathrm{~Pb},{ }^{232} \mathrm{Th},{ }^{235} \mathrm{U},{ }^{238} \mathrm{U}\right), 20 \mathrm{~ms}\left({ }^{204} \mathrm{~Pb}\right)$, $75 \mathrm{~ms}\left({ }^{207} \mathrm{~Pb}\right)$ and $90 \mathrm{~ms}\left({ }^{206} \mathrm{~Pb}\right)$, resulting in a total sweep time of $0.243 \mathrm{~s}$ (including MS settling time) for these eight selected isotopes of interest. In doing so, we were able to determine the different ages of the core and the rim of zoned zircon separately. The LA-ICP-TOF-MS system was then used for a detailed elemental and isotopic characterization of selected zircon and zirconolite grains, allowing the simultaneous acquisition of the full mass spectrum $\left({ }^{7} \mathrm{Li}^{+}\right.$to $\left.{ }^{238} \mathrm{U}^{+}\right)$every $30 \mu$ s. For our analyses, 5000 full TOF-mass spectra were averaged and reported in one output data point (integration time $0.151 \mathrm{~s}$ ). Data reduction of the TOF spectrum includes gas black correction, baseline correction based on two anchor points on both sides of the mass peak, as well as signal integration over a mass window $(0.25$ atomic mass unit), centred at the mass peak, in order to obtain the peak intensity (unit in $\mathrm{mV}$ ) [52]. Further TOF- and SF-MS instrument parameters are listed in Supplementary Table S1.

For LA-ICP-SF-MS, we used the zircon standard GJ-1 $\left(601.86 \pm 0.37 \mathrm{Ma}\right.$, from ${ }^{206} \mathrm{~Pb} /{ }^{238} \mathrm{U}$ age results) $[53,54]$ as a primary dating standard, with additional zircon secondary standards Plešovice $\left(337.13 \pm 0.37 \mathrm{Ma},{ }^{206} \mathrm{~Pb} /{ }^{238} \mathrm{U}\right.$ age) [55], Temora $1\left(416.8 \pm 1.1 \mathrm{Ma},{ }^{206} \mathrm{~Pb} /{ }^{238} \mathrm{U}\right.$ age) [56], Zircon 91500 $\left(1063.51 \pm 0.39 \mathrm{Ma},{ }^{206} \mathrm{~Pb} /{ }^{238} \mathrm{U}\right)$ [57]. The secondary reference zircon ages from measurements in this study are in accordance with published results. Data processing was carried out using software packages Iolite (version 2.5) [58] and VizualAge (version 2013-02) [59] for age calculation and uncertainty propagation. Laser induced element fractionation (LIEF) was corrected based on the primary reference material analysed with identical conditions as the sample. Unless otherwise mentioned, calculated ages are quoted as two times the standard error (2SE) and propagation of uncertainty is by quadratic addition. Reproducibility and age uncertainty of reference material are propagated where appropriate.

For TOF-MS, we employed an in-house zircon single crystal SSEF87244 with an age of $523 \pm 5 \mathrm{Ma}$, as primary standard for U-Pb dating. This crystal was characterized by ICP-SF-MS to have a high uranium concentration (approximately $\mathrm{U} 2000 \mathrm{mg} / \mathrm{kg}$ ) and having no detectable amount of common lead $\left({ }^{204} \mathrm{~Pb}\right)$. The ages obtained from secondary standard Zircon $91500\left(1059.62 \pm 8.70 \mathrm{Ma},{ }^{206} \mathrm{~Pb} /{ }^{238} \mathrm{U}\right.$ age) are in accordance with the published result within the uncertainty. For dating analyses of zirconolite, we applied the same set of zircon standards, due to the lack of a matrix-matched zirconolite standards. For data processing, we used an in-house developed calculation script based on MATLAB (R2018b, The MathWorks, Inc., Natick, MA, USA). Benefiting from the full mass spectrum analysis in TOF-MS, it was possible to recheck if the whole measurements were done on targeted inclusions 
or if the ablation moved into host materials (ruby, spinel, etc.) by monitoring transient signals of various isotopes in TofDaq software (V1.2.97, TOFWERK AG, Thun, Switzerland). Furthermore, raw transient signals were carefully checked for common $\mathrm{Pb}$ interference based on isotope ${ }^{204} \mathrm{~Pb}$. In most of our samples, the ${ }^{204} \mathrm{~Pb}$ signal was below the detection limit. Therefore, no correction for common $\mathrm{Pb}$ was applied. However, there may be still a small amount of common $\mathrm{Pb}$ present in our samples due to the low natural abundance of ${ }^{204} \mathrm{~Pb}$ isotope, as shown in some discordant results in Wetherill and Tera-Wasserburg plots, and these discordant ages are omitted in the reported ages. The intensity ratios of $\mathrm{U}-\mathrm{Pb}$ isotopes were monitored with TofDaq software to select appropriate sections in the transient signal that could be used for dating calculation. The radiometric ages based on ${ }^{206} \mathrm{~Pb} /{ }^{238} \mathrm{U}$ and ${ }^{207} \mathrm{~Pb} /{ }^{235} \mathrm{U}$ ratios are calculated using gas blank corrected signals. The radiometric ages are calculated as a ratio of the mean method and errors (2SE) are propagated following the procedures suggested by [60]. The age uncertainty of reference materials is propagated afterwards and other uncertainties are not included. All dating results are plotted using IsoplotR (V3.0) [61]. Analysis is accepted only when its age with 2SE overlaps the concordia curve [62]. For TOF-MS, the REEs were quantified using a non-matrix matched NIST610 SRM glass as external standard, due to its nearly full coverage of the periodic table of the elements. Additionally, Ca was used as internal standard and a total mass normalization procedure was applied [63].

\section{Results}

In total, we analysed 109 zircon grains and 14 zirconolite grains for this study. For the detailed U-Pb data and trace element data of all samples we refer the interested reader to the Supplementary Data.

\subsection{U-Pb Dating of Zircons}

For zircon inclusions in gem-quality ruby and spinel showing growth zoning patterns in VPSE imaging (e.g., Figure 3c), we analysed both core and rim separately. Individual spots from zircon core reveal a wide range of ages, from $\sim 94 \mathrm{Ma}$ to $\sim 26 \mathrm{Ma}$ (Figure $4 \mathrm{a}$ ). The zircon rim displays ages between $\sim 30 \mathrm{Ma}$ to $\sim 22 \mathrm{Ma}$ (Figure 4a). The youngest ages are concordant at 22.26 $\pm 0.36 \mathrm{Ma}$ for zircon in ruby (Figure 5a) and 22.88 $\pm 0.72 \mathrm{Ma}$ for zircon in spinel (Figure 5b).

In the ruby- and spinel-bearing Bawlongyi marble, we observed both zircon and zirconolite as accessory mineral phases. The $\mathrm{U}-\mathrm{Pb}$ ages of zircon grains cover a wide range from Cretaceous $(\sim 95 \mathrm{Ma})$ to Early Miocene ( 17 Ma, Figure $4 \mathrm{~b})$. This is similar to the zircon inclusions in gemstones. The youngest age of zircon is concordant at $17.11 \pm 0.22 \mathrm{Ma}$ (Figure $5 \mathrm{c}$ ) which is younger than that from our investigated rubies and spinels. The core ages from accessory zircon intergrown with zirconolite reveal ages ranging from $\sim 65 \mathrm{Ma}$ to $\sim 55 \mathrm{Ma}$. These ages are within the range as the age of zircon cores found in gemstones (ruby and spinel).

Analysed zircon core results in garnet-orthopyroxene gneiss from Aunglan Taung yield groups of Jurassic ( $180 \mathrm{Ma}$ to $\sim 140 \mathrm{Ma}$ ) and Cretaceous ( 110 Ma to $70 \mathrm{Ma}$ ) ages (Figure 6$)$. The U-Pb ages of zircon rims were found to be concordant at $31.98 \pm 0.30 \mathrm{Ma}$, as is shown in Figure $5 \mathrm{~d}$.

$\mathrm{U}-\mathrm{Pb}$ ages of accessory zircon in biotite-garnet gneiss from Kinn reveal mainly discordant ages (Supplementary Figure S2). Two zircon rim measurements give a concordant age of $26.13 \pm 1.24 \mathrm{Ma}$ (Figure 5e). These rim ages are also consistent with ages of zircon rims in gemstones from the present study. The discordia may correspond to a mixture with different overgrowth ages, or $\mathrm{Pb}$ loss. The oldest zircon core age is $\sim 985 \mathrm{Ma}$, and a VPSE image of this zircon is shown in Supplementary Figure S3. 

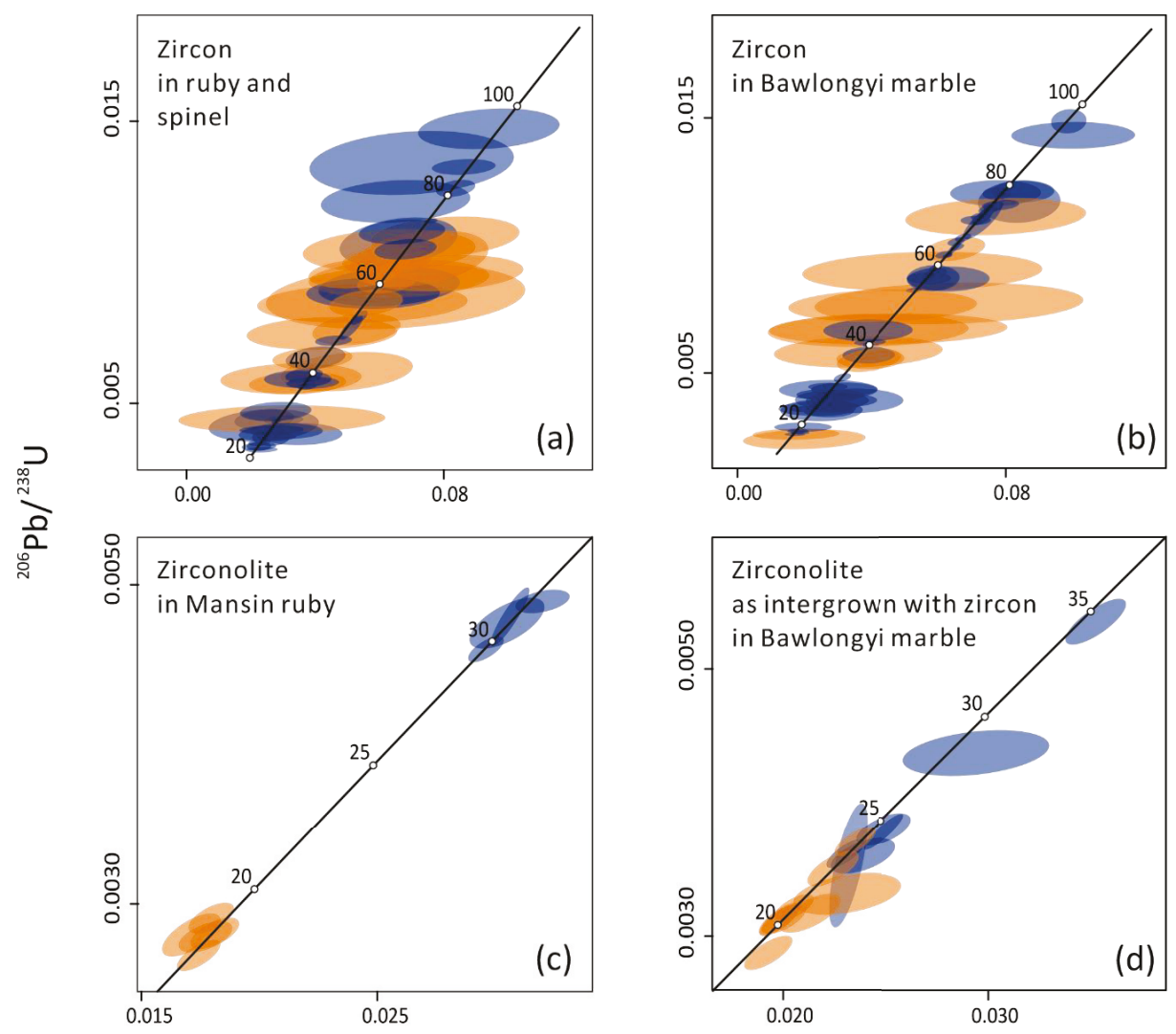

$$
{ }^{207} \mathrm{~Pb} /{ }^{235} \mathrm{U}
$$

Figure 4. Wetherill diagrams showing wide range of $\mathrm{U}-\mathrm{Pb}$ age of (a) zircon inclusion in gem-quality ruby and spinel, (b) accessory zircon in Bawlongyi marble, (c) zirconolite inclusion in ruby from Mansin and (d) zirconolite intergrown with zircon in Bawlongyi marble. Ellipses indicate two standard error (2SE) uncertainty of measurements. Blue is by sector-field (SF)-MS and orange is by time-of-flight (TOF)-MS.

\section{2. $\mathrm{U}-\mathrm{Pb}$ Dating of Zirconolite}

Zirconolite grains from Mansin ruby and from ruby- and spinel-bearing marble (Bawlongyi) were analysed by TOF-MS and SF-MS, as shown in Figure 4c,d. Zirconolite from Mansin ruby reveals a concordia age of $29.78 \pm 0.38 \mathrm{Ma}$ (Figure $5 \mathrm{f}$ ) analysed by SF-MS, whereas TOF-MS analysis adjacent to the SF-MS measurements reveals an age of $18.06 \pm 0.36 \mathrm{Ma}$ (Figure 5g). Furthermore, zirconolites observed as intergrowth of zircons in ruby- and spinel-bearing marble yield apparent concordia ages at 23.61 $\pm 0.36 \mathrm{Ma}$ using the SF-MS setup (Figure 5h) and 20.30 \pm 0.30 Ma using the TOF-MS (Figure 5i). These different results for zirconolite may be due to different growth zonings in the inclusions, which could not be identified by VPSE imaging. The discrepancy may also be due to the application of a non-matrix matched standard (zircon), which induces various fractionation effects with different instrument operating parameters and corrections $[53,64]$. Since both measurements have revealed secondary reference zircon (Zircon91500) in accordance with the published ages within uncertainty, the two instrumental setups were operated normally. Therefore, the reported zirconolite ages may lack of accuracy and 2SE of uncertainty is related to measurement precision. Due to lack of a zirconolite 
reference material, it is important to mention that the zirconolite ages obtained here may be only indicative and can be improved further.
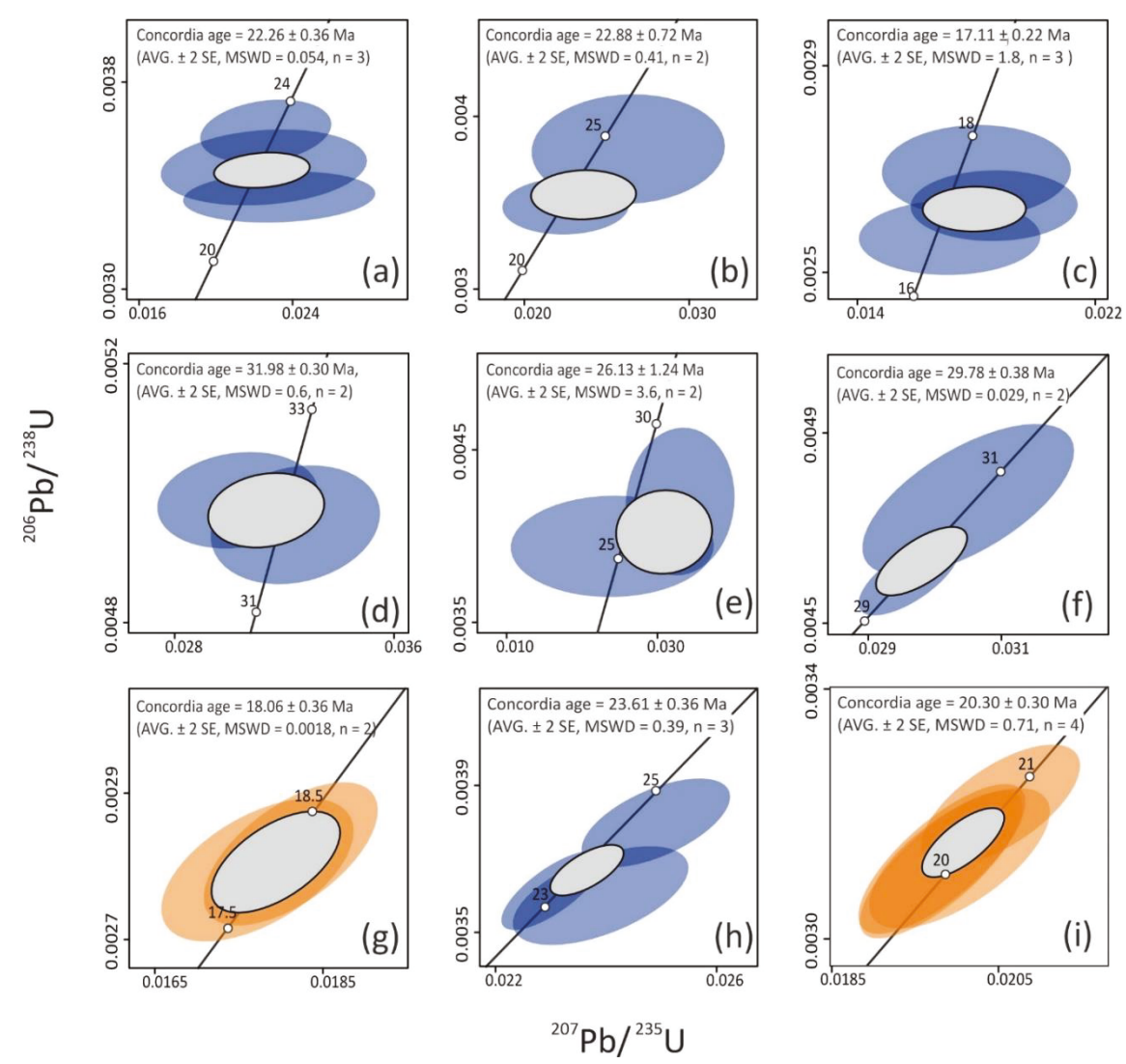

Figure 5. Concordia ages analysed on the rim of zircon inclusion in (a) Mansin and Kyatpyin ruby $(22.26 \pm 0.36 \mathrm{Ma}),(\mathbf{b})$ Kyauksin spinel $(22.88 \pm 0.72 \mathrm{Ma})$ and accessory zircon in (c) Bawlongyi marble $(17.11 \pm 0.22 \mathrm{Ma})$, (d) Aunglan Taung gneiss (31.98 $\pm 0.30 \mathrm{Ma})$ and (e) Kinn gneiss (26.13 $\pm 1.24 \mathrm{Ma})$. Concordia age of zirconolite inclusion from Mansin ruby showing (f) $29.78 \pm 0.38$ Ma by SF-MS, and (g) $18.06 \pm 0.36 \mathrm{Ma}$ by TOF-MS as well as of zirconolite intergrown with zircon in Bawlongyi marble showing (h) $23.61 \pm 0.36$ Ma by SF-MS, (i) $20.30 \pm 0.30$ Ma by TOF-MS. Reported ages are concordia ages with two standard error (2SE) of uncertainty of measurements. Blue ellipses are by SF-MS and orange ellipses are by TOF-MS with 2SE of uncertainty. Gray ellipses indicate concordia age with 1SE of uncertainty.

\subsection{REE Composition of Zircon and Zirconolite}

Using TOF-MS, we collected multi-element data, specifically of the rare earth elements (REE), simultaneously to the U-Pb measurements. For a detailed list of the REE concentrations of selected zircon and zirconolite samples present as inclusions in ruby and spinel and as accessory minerals in host rock (Bawlongyi marble) and adjacent gneisses (Aunglan Taung gneiss and Kinn gneiss) the reader is referred to Supplementary Data. Most of the zircon REE data are from the core of the inclusions/accessory minerals, whereas in the zirconolite no zoning was observed by VPSE imaging.

The chondrite-normalized Coryell-Masuda diagrams of our samples reveal for zircon a distinct enrichment in heavy REE (HREE) in all samples [50]. Zircon inclusions from gem-quality ruby 
(Figure 7a) vary quite largely in their REE concentrations, thus resulting in a rather broad REE pattern in the chondrite-normalized plot. Still, all investigated zircon inclusions in ruby show a very similar trend with part of light REE (LREE) at or even below detection limit. In addition, they show only a weak negative Eu anomaly and no positive Ce anomaly. The REE pattern of zircon in spinel (blue traces in Figure 7a) follows the same trend, but in addition these inclusions contain even less LREE, mostly below detection limit.

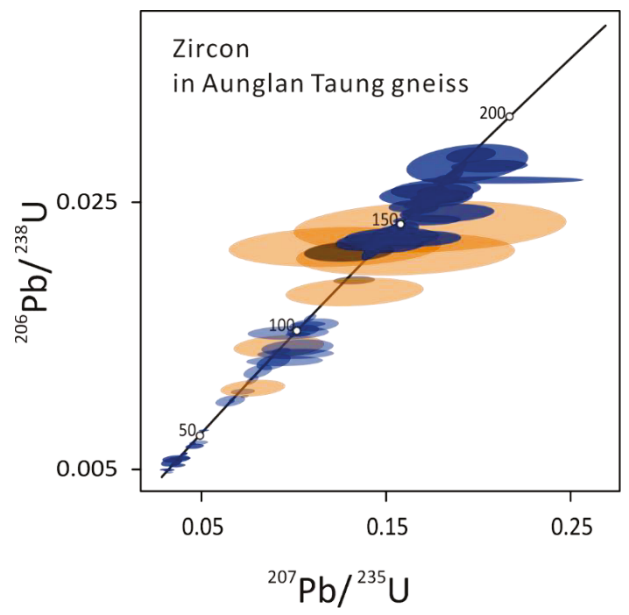

Figure 6. Wetherill diagram of accessory zircon in Aunglan Taung gneiss. Ages of accessory zircon in Kinn gneiss show discordia ages and are reported in Supplementary Figure S2. Ellipses indicate two standard error (2SE) uncertainty of measurements. Blue is by SF-MS and orange is by TOF-MS.
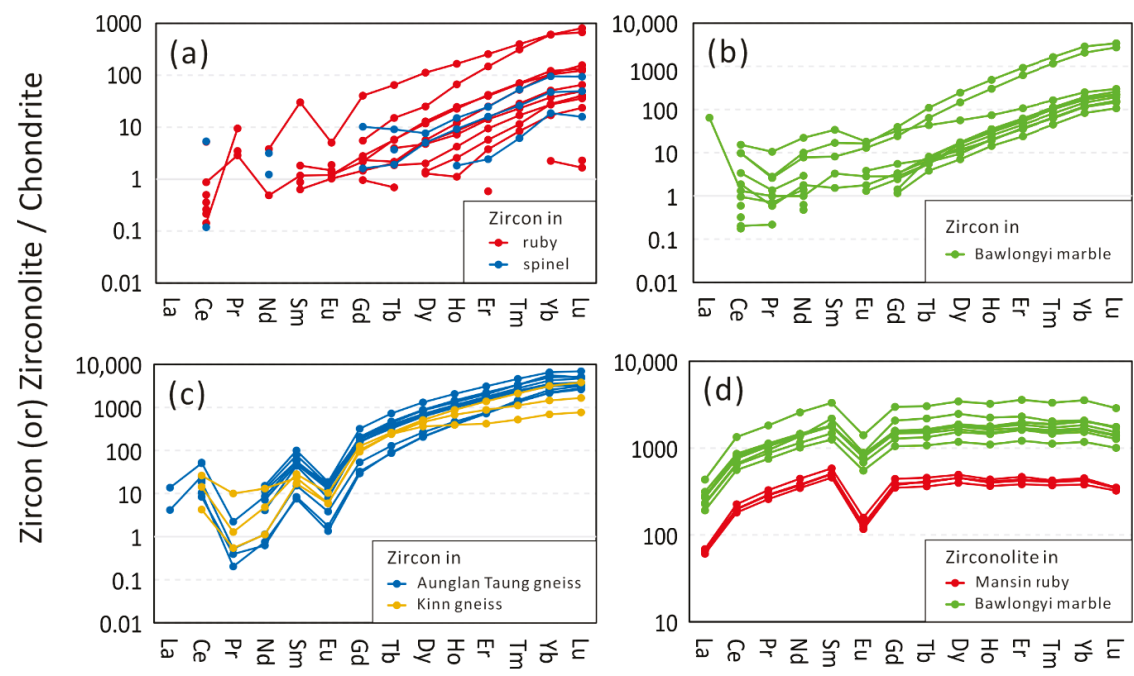

Figure 7. Chondrite normalized Coryell-Masuda rare earth element (REE) diagrams of (a) zircon inclusion in gem-quality ruby and spinel (b) marble (c) gneiss and (d) zirconolite from ruby and marble. (Chondrite REE values from [65]). 
Zircon as accessory mineral in Bawlongyi marble (Figure $7 \mathrm{~b}$ ) shows a very similar pattern as the zircon inclusions in ruby, again with only a weak negative Eu anomaly, but in contrast to the zircon inclusions in ruby with a (weak) positive Ce anomaly. In general, the concentrations of REE in zircons from the marble are higher than from zircon inclusions in ruby (and spinel), as can also be seen in the chondrite-normalized plot. The most pronounced enrichment in HREE is observed in zircons from the gneiss samples (Aunglan Taung and Kinn) (Figure 7c). In addition, these zircons show also distinct negative Eu and positive Ce anomalies.

Compared to zircon, the analysed zirconolites show a distinctly different REE pattern in their chondrite-normalized plot (Figure 7d). Both, zirconolite as inclusions in ruby (from Mansin) and as accessory minerals in marble host rock (Bawlongyi) reveal a rather flat REE pattern, dominated by a distinct negative $\mathrm{Eu}$ anomaly and a general relative depletion in LREE. Similar to the zircon inclusions in ruby (and spinel), the concentration of REE is lower in the zirconolite inclusions in gem-quality ruby than in the host-rock (Bawlongyi marble).

\section{Discussion and Conclusions}

The zircons from gemstone samples and ruby- and spinel-bearing marble from Mogok area reveal consistent radiometric $\mathrm{U}-\mathrm{Pb}$ ages over a wide time range from Cretaceous to Early Miocene. The youngest ages (Late Oligocene to Early Miocene) are found in the rim of accessory zircon in the Bawlongyi marble. They are in good agreement with previously reported $\mathrm{U}-\mathrm{Pb}$ ages on zircon inclusions [16], as well as on a titanite inclusion in ruby from Thurein Taung (western Mogok) [14]. Similar U-Pb ages are also known from analyses carried out by commercial gemmological laboratories on faceted gem-quality ruby and sapphire from Mogok [17-19].

The $\mathrm{U}-\mathrm{Pb}$ ages calculated in the rim of zircon indicate a late regional metamorphic event and are interpreted to be related to the formation of the marble-hosted ruby and spinel in the Mogok area. The youngest concordia ages recorded from the rim of zircon inclusions in our studied gemstones are $22.26 \pm 0.36 \mathrm{Ma}$ (ruby) and $22.88 \pm 0.72 \mathrm{Ma}$ (spinel). Based on the evident similarity of ages of the zircon rims in both, ruby and spinel, we presume that ruby and spinel both formed during Oligocene to Early Miocene and under similar granulite-facies regional metamorphic conditions as recorded in the surrounding Mogok area $[4,35,66,67]$. Interestingly, the youngest age of zircon grains in Bawlongyi marble is even younger with $17.11 \pm 0.22 \mathrm{Ma}$. This is interpreted to be related to post-regional metamorphic contact metamorphism $[2,26,45,68]$ caused by the late intrusion of Kabaing granite nearby (Figure 2). This youngest zircon age is in accordance with dating results on zircons from Kabaing granite (16.8 $\pm 0.5 \mathrm{Ma})$ [26]. A comparison of geochronological data from this study with previously reported data from literature is presented in Figure 8.

Moreover, we observe two age groups in the core of accessory zircon in the garnet-orthopyroxene gneiss from Aunglan Taung (central Mogok): (1) Jurassic and (2) Cretaceous (Figure 6). Jurassic zircon ages were previously recorded in granite from the Mogok area [2] and in orthogneiss of Kyanigan Hills close to the Mogok area [39]. According to Mitchell [69] and references therein, the Mogok belt was considered as a former northward continuation of the Sumatra-western Myanmar Late Cretaceous magmatic arc, as suggested by several age results on granodioritic to tonalitic plutons and batholiths from Banmauk area. The youngest rim ages of zircon grains in Aunglan Taung gneiss reveal a concordia age at $31.98 \pm 0.30 \mathrm{Ma}$, similar ages have been reported in other studies [16,70]. Accessory zircon in the biotite-garnet gneiss from Kinn area shows discordant ages. The oldest $\mathrm{U}-\mathrm{Pb}$ ages (Precambrian) are found in the core of a zircon grain, which we interpreted as a detrital zircon based on its growth zoning pattern (see Supplementary Figure S3).

These old age results are in accordance with former studies which attribute the metasediments of Mogok a Precambrian age $[27,28,41]$. The Late Oligocene ages (e.g., $26.39 \pm 1.24 \mathrm{Ma}$ ) from zircon rims in Kinn gneiss are interpreted to represent the most recent regional metamorphic event. 


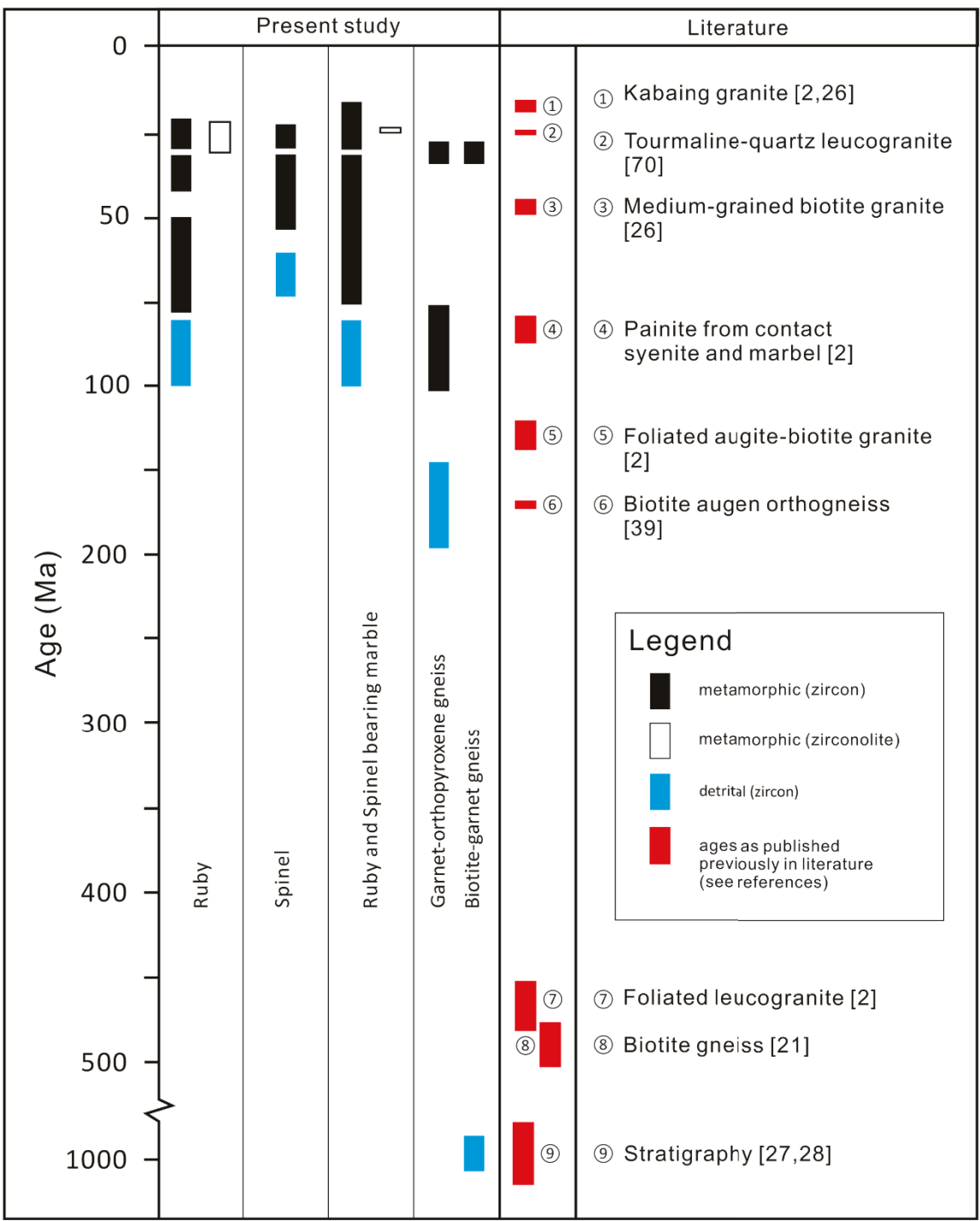

Figure 8. U-Pb ages reported in this study compared to previously published ages from the Mogok Stone Tract.

Zirconolite in ruby from Mansin reveals a U-Pb age of 18.06 $\pm 0.36 \mathrm{Ma}$ using TOF-MS and 29.78 \pm 0.38 Ma using SF-MS. A difference is also observed with zirconolite intergrown with zircon in ruby- and spinel-bearing marble (20.30 \pm 0.30 Ma with TOF-MS and 23.61 \pm 0.36 Ma with SF-MS). This discrepancy is discussed in previous section. Despite these differences, the U-Pb ages are still within the range of those previously reported in literature $[2,20,21,28]$. Further research is ongoing to understand the cause of this discrepancy and to find a method to eliminate it in order to obtain more accurate $\mathrm{U}-\mathrm{Pb}$ ages on zirconolite.

To summarize, our $\mathrm{U}-\mathrm{Pb}$ ages on zircon and zirconolite found as inclusions in gem-quality ruby and spinel and as accessory minerals in ruby- and spinel-bearing marble and in adjacent granulite-facies gneisses are well in agreement with data from the wider Mogok area reported 
previously in literature [14,21,38-40,68,71]. To visualize this larger context, Figure 9 presents a summary of $\mathrm{U}-\mathrm{Pb}$ ages from this study together with $\mathrm{U}-\mathrm{Pb}$ data of the wider Mogok area [72]. Based on the results of this study and in accordance with previous investigations, we conclude that the Mogok area and its surroundings experienced a Paleogene granulite-facies regional metamorphic overprint, influenced by post-collisional tectonics of the Eurasian and Indian plates [70,73]. We further assume that the marble-hosted gem-quality ruby and spinel of the Mogok Stone Tract formed during this regional metamorphic event between $30 \mathrm{Ma}$ and $22 \mathrm{Ma}$, i.e., from Oligocene to Early Miocene.

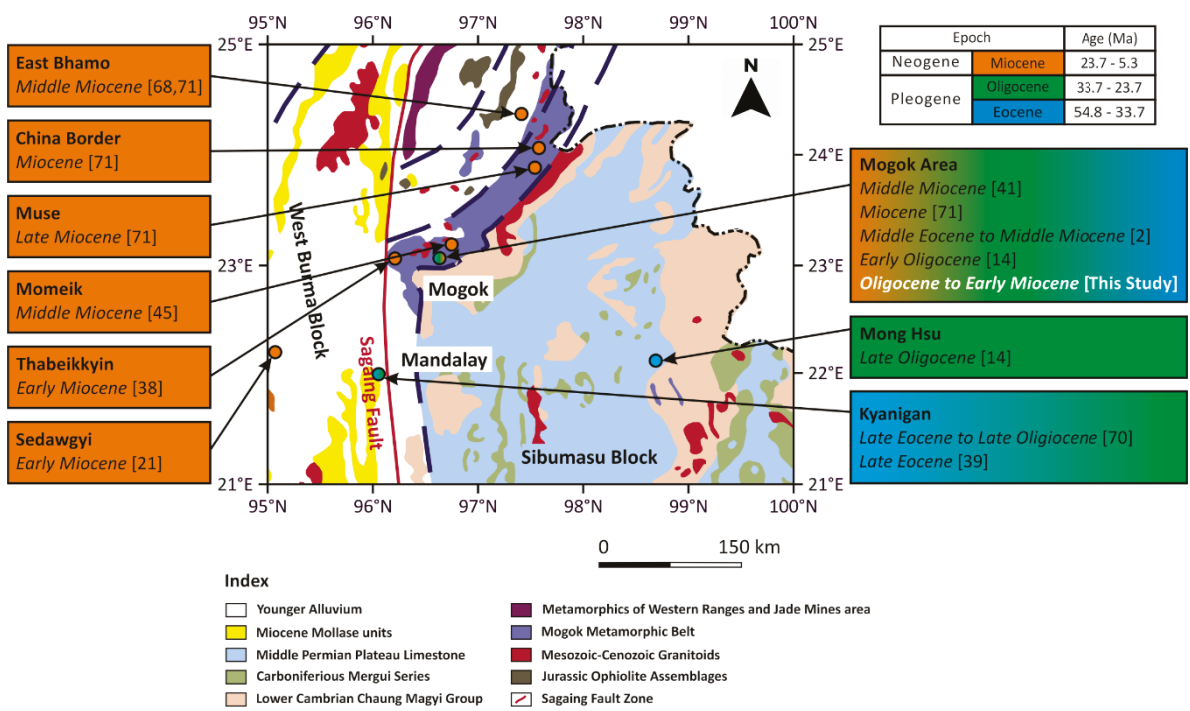

Figure 9. Map showing current research of Mogok combined with previous geochronological studies in its surrounding area (modified after [74] with permission).

Simultaneously to U-Pb dating measurements, REE concentrations in zircon and zirconolite were measured by LA-ICP-TOF-MS and chondrite-normalized REE diagrams were plotted in Figure 7a-d. A positive $\mathrm{Ce}$ anomaly and a negative Eu anomaly such as observed in the investigated accessory zircons in Aunglan Taung and Kinn gneisses (Figure 7c) are common in zircon [75,76] and generally related to magmatic fractionation processes (e.g., by feldspar crystallizations and/or a function of the oxygen fugacity and the Eu anomaly of the melt) [77]. Our focus is to characterize the studied zircon and zirconolite inclusions and accessory minerals from Mogok (Myanmar). Specifically, as to our knowledge, it is the first time that the full range of REEs in zirconolite from Mogok is reported. The zircon and zirconolite REE concentrations (see Supplementary Data) and REE plots may aid in country of origin determination for gem-quality ruby and spinels in commercial gemmological laboratories, similar to a study on apatite inclusions in gem-quality corundum and spinel from Mogok and other deposits [78].

The present study adds considerable new geochronological (U-Pb) and geochemical (REE) data to previous research about the Mogok area in Myanmar. With a special focus on zircon and zirconolite present as inclusions in gem-quality ruby and spinel and as accessory minerals in their marble host rock and adjacent gneisses, our data provides a better understanding of ruby and spinel formation within the Mogok Stone Tract, one of the finest ruby and spinel sources in the world.

Supplementary Materials: The following are available online at http://www.mdpi.com/2075-163X/10/2/195/s1, Figure S1: Typical laser ablation spot position on zircon and zirconolite grains as drawn overlapping with Figure 4, Figure S2: Wetherill diagram of accessory zircon in Kinn gneiss, Figure S3: VPSE image of the zircon as accessory 
mineral in Kinn gneiss, where an oldest age was found in this study, Table S1: LA-ICP-MS instrument operating parameters. Supplementary Data: $\mathrm{U}-\mathrm{Pb}$ age result and REE concentration in zircon and zirconolite.

Author Contributions: All authors were involved in designing the experiments. M.M.P., L.F., W.A.B., M.S.K. collected and prepared the samples. A.B., M.M.P. conducted VPSE imaging. H.A.O.W., M.M.P. conducted measurements using TOF-MS. M.G., M.M.P., H.A.O.W. conducted measurements using SF-MS. M.M.P., M.G., H.A.O.W. performed data analysis. M.M.P. prepared manuscript. All authors contributed in figures and in the manuscript. M.S.K. and H.A.O.W. conceived of and supervised the project. All authors have read and agreed to the published version of the manuscript.

Funding: This research was funded by grants from Canton Basel, Freiwillige Akademische Gesellschaft Basel and SSEF in Switzerland.

Acknowledgments: The authors would like to thank Ma Mie (Silken East Co. Ltd., Thailand), Ko Chu (Kyauksaung mine, Mogok) and local mine owners in Mogok area for their generous support and for the donation of gem-quality samples for this study. We appreciate the kind help of Ko Kyaw Swar, Ko Nay, Sebastian Hänsel, U Aung Kyaw Htun, Ko Ja Mu, Ah Ba and Anty Phyu during the field trip to Mogok in 2016. We thank Pascal Tschudin at University of Basel for the preparation of thin sections and Evi Bieler from the Nano Imaging Lab of the University Basel for numerous SEM-EDS and BSE images. Thanks also to the academic editors of this special issue, four anonymous reviewers and Laurent E. Cartier for detailed suggestions and comments on the manuscript.

Conflicts of Interest: The authors declare no conflict of interest.

\section{References}

1. Gordon, R. On the Ruby Mines near Mogok, Burma. Proc. R. Geogr. Soc. Mon. Rec. Geogr. 1888, 10, 261-275. [CrossRef]

2. Thu, K. The Igneous Rocks of the Mogok Stone Tract: Their Distribution, Petrography, Petrochemistry, Sequence, Geochronology and Economic Geology. Ph.D. Thesis, University of Yangon, Yangon, Myanmar, 2007.

3. Themelis, T. Gems and Mines of Mogok; A\&T Pub.: Los Angeles, CA, USA, 2008.

4. Phyo, M.M. Mineralogical, Gemmological and Petrological Study of the Mogok Stone Tract in Myanmar with a Special Focus on Gem-Quality Ruby and Spinel. Ph.D. Thesis, Universität Basel, Basel, Switzerland, 2019.

5. Harlow, G.E.; Bender, W. A study of ruby (corundum) compositions from the Mogok Belt, Myanmar: Searching for chemical fingerprints. Am. Mineral. 2013, 98, 1120-1132. [CrossRef]

6. Sutherland, F.L.; Zaw, K.; Meffre, S.; Yui, T.-F.F.; Thu, K. Advances in trace element "fingerprinting" of gem corundum, ruby and sapphire, Mogok area, Myanmar. Minerals 2014, 5, 61-79. [CrossRef]

7. Giuliani, G.; Fallick, A.E.; Garnier, V.; France-Lanord, C.; Ohnenstetter, D.; Schwarz, D. Oxygen isotope composition as a tracer for the origins of rubies and sapphires. Geology 2005, 33, 249-252. [CrossRef]

8. Yui, T.F.; Zaw, K.; Wu, C.M. A preliminary stable isotope study on Mogok Ruby, Myanmar. Ore Geol. Rev. 2008, 34, 192-199. [CrossRef]

9. Zaw, K.; Sutherland, L.; Yui, T.-F.; Meffre, S.; Thu, K. Vanadium-rich ruby and sapphire within Mogok Gemfield, Myanmar: Implications for gem color and genesis. Miner. Depos. 2015, 50, 25-39. [CrossRef]

10. Giuliani, G.; Fallick, A.E.; Boyce, A.J.; Pardieu, V.; Pham, V.L. Pink and red spinels in marble: Trace elements, oxygen isotopes, and sources. Can. Mineral. 2017, 55, 743-761. [CrossRef]

11. Phyo, M.M.; Franz, L.; Bieler, E.; Balmer, W.; Krzemnicki, M.S. Spinel from Mogok, Myanmar-A detailed inclusion study by raman microspectroscopy and scanning electron microscopy. J. Gemmol. 2019, 36, 418-435. [CrossRef]

12. Giuliani, G.; Dubessy, J.; Banks, D.A.; Lhomme, T.; Ohnenstetter, D. Fluid inclusions in ruby from Asian marble deposits: Genetic implications. Eur. J. Mineral. 2015, 27, 393-404. [CrossRef]

13. Sutherland, F.L.; Piilonen, P.C.; Zaw, K.; Meffre, S.; Thompson, J. Sapphire within zircon-rich gem deposits, Bo Loei, Ratanakiri Province, Cambodia: Trace elements, inclusions, U-Pb dating and genesis. Aust. J. Earth Sci. 2015, 62, 761-773.

14. Sutherland, F.; Zaw, K.; Meffre, S.; Thompson, J.; Goemann, K.; Thu, K.; Nu, T.; Zin, M.; Harris, S. Diversity in ruby geochemistry and its inclusions: Intra- and inter-continental comparisons from Myanmar and Eastern Australia. Minerals 2019, 9, 28. [CrossRef]

15. Coenraads, R.R.; Lin Sutherland, F.; Kinny, P.D. The origin of sapphires: U-Pb dating of zircon inclusions sheds new light. Mineral. Mag. 1990, 54, 113-122. [CrossRef] 
16. Zaw, K.; Sutherland, F.L.; Graham, I.; Meffre, S.; Thu, K. Dating zircon inclusions in gem corundum deposits and genetic implications. In Proceedings of the 13th Quardrennial IAGOD Symposium, Adelaide, Australia, 6-9 April 2010.

17. Elmaleh, E.; Schmidt, S.T.; Karampelas, S.; Link, K.; Kiefert, L.; Süssenberger, A.; Paul, A. U-Pb ages of zircon inclusions in sapphires from Ratnapura and Balangoda (Sri Lanka) and implications for geographic origin. GEMS Gemol. 2019, 55, 18-28.

18. Krzemnicki, M.S.; Wang, H.A.O.; Phyo, M.M. Age dating applied as a testing procedure to gemstones and biogenic gem materials. In Proceedings of the 36th IGC Conference, Nante, France, 27-31 August 2019; pp. $48-50$.

19. Link, K. Age Determination of zircon inclusions in faceted sapphires. J. Gemmol. 2016, 34, 692-700. [CrossRef]

20. Garnier, V.; Maluski, H.; Giuliani, G.; Ohnenstetter, D.; Schwarz, D. Ar-Ar and U-Pb ages of marble-hosted ruby deposits from central and southeast Asia. Can. J. Earth Sci. 2006, 43, 509-532. [CrossRef]

21. Mitchell, A.; Chung, S.L.; Oo, T.; Lin, T.H.; Hung, C.H. Zircon U-Pb ages in Myanmar: Magmatic-metamorphic events and the closure of a neo-Tethys ocean? J. Asian Earth Sci. 2012, 56, 1-23. [CrossRef]

22. Sutherland, F.L.; Duroc-Danner, J.M.; Meffre, S. Age and origin of gem corundum and zircon megacrysts from the Mercaderes-Rio Mayo area, South-west Colombia, South America. Ore Geol. Rev. 2008, 34, 155-168. [CrossRef]

23. Sorokina, E.S.; Rösel, D.; Häger, T.; Mertz-Kraus, R.; Saul, J.M. LA-ICP-MS U-Pb dating of rutile inclusions within corundum (ruby and sapphire): New constraints on the formation of corundum deposits along the Mozambique belt. Miner. Depos. 2017, 52, 641-649. [CrossRef]

24. Link, K. New age data for blue sapphire from Mogok, Myanmar. J. Gemmol. 2016, 35, 107-109.

25. Balmer, W.A.; Hauzenberger, C.A.; Fritz, H.; Sutthirat, C. Marble-hosted ruby deposits of the Morogoro Region, Tanzania. J. Afr. Earth Sci. 2017, 134, 626-643. [CrossRef]

26. Gardiner, N.J.; Robb, L.J.; Morley, C.K.; Searle, M.P.; Cawood, P.A.; Whitehouse, M.J.; Kirkland, C.L.; Roberts, N.M.W.; Myint, T.A. The tectonic and metallogenic framework of Myanmar: A Tethyan mineral system. Ore Geol. Rev. 2016, 79, 26-45. [CrossRef]

27. Chhibber, H.L. The Geology of Burma; Macmillan and Co. Limited: London, UK, 1934.

28. Iyer, L.A.N. The Geology and Gem-Stones of the Mogok Stone Tract, Burma. Memoirs of the Geological Survey of India; Calcutta: Delhi, India, 1953; Volume 82.

29. Mitchell, A.H.G.; Htay, M.T.; Htun, K.M.; Win, M.N.; Oo, T.; Hlaing, T. Rock relationships in the Mogok metamorphic belt, Tatkon to Mandalay, central Myanmar. J. Asian Earth Sci. 2007, 29, 891-910. [CrossRef]

30. Bertrand, G.; Rangin, C.; Maluski, H.; Han, T.A.; Thein, M.; Myint, O.; Maw, W.; Lwin, S. Cenozoic metamorphism along the Shan scarp (Myanmar): Evidences for ductile shear along the Sagaing fault or the northward migration of the eastern Himalayan syntaxis? Geophys. Res. Lett. 1999, 26, 915-918. [CrossRef]

31. Bender, F. Geology of Burma; Schweizerbart Science Publishers: Stuttgart, Germany, 1983.

32. Zaw, K. Geological, petrological and geochemical characteristics of granitoid rocks in Burma: With special reference to the associated W-Sn mineralization and their tectonic setting. J. Southeast Asian Earth Sci. 1990, 4, 293-335. [CrossRef]

33. Gardiner, N.J.; Searle, M.P.; Morley, C.K.; Whitehouse, M.P.; Spencer, C.J.; Robb, L.J. The closure of Palaeo-Tethys in Eastern Myanmar and Northern Thailand: New insights from zircon $\mathrm{U}-\mathrm{Pb}$ and Hf isotope data. Gondwana Res. 2016, 39, 401-422. [CrossRef]

34. Lee, H.Y.; Chung, S.L.; Yang, H.M. Late Cenozoic volcanism in central Myanmar: Geochemical characteristics and geodynamic significance. Lithos 2016, 245, 174-190. [CrossRef]

35. Thu, Y.K.; Win, M.M.; Enami, M.; Tsuboi, M. Ti-rich biotite in spinel and quartz-bearing paragneiss and related rocks from the Mogok metamorphic belt, central Myanmar. J. Mineral. Petrol. Sci. 2016, 111, 270-282.

36. La Touche, T.H.D. Geology of the Northern Shan State; Office of the Geological Survey of India: Calcutta, India, 1913.

37. Thein, M. Modes of occurrence and origin of precious gemstone deposits of the Mogok Stone Tract. J. Myanmar Geosci. Soc. 2008, 1, 75-84.

38. Brook, M.; Snelling, N.J. K/Ar and Rb/Sr age determinations on rocks and minerals from Burma. In Report of the Isotope Geology Unit 76/12; Institute of Geological Science: Keyworth, Nottingham, UK, 1976. 
39. Barley, M.E.; Pickard, A.L.; Zaw, K.; Rak, P.; Doyle, M.G. Jurassic to Miocene magmatism and metamorphism in the Mogok metamorphic belt and the India-Eurasia collision in Myanmar. Tectonics 2003, 22, 1-11. [CrossRef]

40. Searle, M.P.; Waters, D.J.; Morley, C.K.; Gardiner, N.J.; Htun, U.K.; Nu, T.T.; Robb, L.J. Chapter 12 Tectonic evolution of the Mogok metamorphic and Jade mines belts and ophiolitic terranes of Burma (Myanmar). In Myanmar: Geology, Resources and Tectonics; Barber, A.J., Zaw, K., Crow, M.J., Eds.; Geological Society: London, UK, 2017; Volume 48, pp. 261-293.

41. Searle, D.L.; Haq, B.T. The Mogok belt of Burma and its relationship to the Himalayan orogeny. In Proceedings of the 22nd International Geological Congress, New Delhi, India, 14-22 December 1964; Volume 22, pp. 132-161.

42. Clegg, E.L.G. The Cretaceous and associated rocks of Burma. Mem. Geol. Surv. India 1941, 74, 1-102.

43. Sone, M.; Metcalfe, I. Parallel Tethian sutures in mainland Sout-East Asia: New insights for Palaeo-Tethys closure and implications for the Indosinian Orogeny. C. R. Geosci. 2008, 340, 166-179. [CrossRef]

44. Zaw, K.; Swe, K.; Barber, A.J.; Crow, M.J.; Nwe, Y.Y. Chapter 1 Introduction to the geology of Myanmar. In Myanmar: Geology, Resources and Tectonics; Barber, A.J., Zaw, K., Crow, M.J., Eds.; Geological Society: London, UK, 2017; Volume 48.

45. Damon, P.E. Granities from the Kabaing Batholithic Complex, Mogok Area, Burma; Correlation and Chronology of ore Deposits and Volcanic Rocks; Annual Progress Report No. C00-689-60; United States Atomic Energy Commission: Washington, DC, USA, 1966.

46. Phyo, M.M.; Franz, L.; De Capatini, C.; Balmer, A.W.; Krzemnicki, M.S. Petrology and PT-conditions of quartz- and nepheline-bearing gneisses from Mogok Stone Tract, Myanmar. In Proceedings of the 15th Swiss Geoscience Meeting, Davos, Switzerland, 17-18 November 2017.

47. Bayliss, P.; Mazzi, F.; Munno, R.; White, T.J. Mineral nomenclature: Zirconolite. Mineral. Mag. 1989, 53, 565-569. [CrossRef]

48. Hughes, R.W. Ruby \& Sapphire; RWH Publishing: Bangkok, Thailand, 1997.

49. Schaltegger, U.; Schmitt, A.K.; Horstwood, M.S.A. U-Th-Pb zircon geochronology by ID-TIMS, SIMS, and laser ablation ICP-MS: Recipes, interpretations, and opportunities. Chem. Geol. 2015, 402, 89-110. [CrossRef]

50. Hoskin, P.W.O.; Schaltegger, U. The Composition of Zircon and Igneous and Metamorphic Petrogenesis. Rev. Mineral. Geochem. 2003, 53, 27-62. [CrossRef]

51. Hendriks, L.; Gundlach-Graham, A.; Hattendorf, B.; Günther, D. Characterization of a new ICP-TOFMS instrument with continuous and discrete introduction of solutions. J. Anal. At. Spectrom. 2017, 32, 548-561. [CrossRef]

52. Wang, H.A.O.; Krzemncki, M.S. Multi-Element Analysis of Minerals using Laser Ablation Inductively Coupled Plasma Time Of Flight Mass Spectrometry. Manuscript near submission.

53. Jackson, S.E.; Pearson, N.J.; Griffin, W.L.; Belousova, E.A. The application of laser ablation-inductively coupled plasma-mass spectrometry to in situ U-Pb zircon geochronology. Chem. Geol. 2004, 211, 47-69. [CrossRef]

54. Horstwood, M.S.A.; Košler, J.; Gehrels, G.; Jackson, S.E.; McLean, N.M.; Paton, C.; Pearson, N.J.; Sircombe, K.; Sylvester, P.; Vermeesch, P.; et al. Community-Derived Standards for LA-ICP-MS U-(Th-)Pb Geochronology-Uncertainty Propagation, Age Interpretation and Data Reporting. Geostand. Geoanal. Res. 2016, 40, 311-332. [CrossRef]

55. Sláma, J.; Košler, J.; Condon, D.J.; Crowley, J.L.; Gerdes, A.; Hanchar, J.M.; Horstwood, M.S.A.; Morris, G.A.; Nasdala, L.; Norberg, N.; et al. Plešovice zircon-A new natural reference material for U-Pb and Hf isotopic microanalysis. Chem. Geol. 2008, 249, 1-35. [CrossRef]

56. Black, L.P.; Kamo, S.L.; Allen, C.M.; Aleinikoff, J.N.; Davis, D.W.; Korsch, R.J.; Foudoulis, C. TEMORA 1: A new zircon standard for phanerozoic U-Pb geochronology. Chem. Geol. 2003, 200, 155-170. [CrossRef]

57. Wiedenbeck, M.; Alle, P.; Corfu, F.; Griffin, W.L.; Meier, M.F.O.; von Quadt, A.; Roddick, J.C.; Spiegel, W. Three natural zircon standards for U-Th-Pb, Lu-Hf, trace element and REE analyses. Geostand. Newsl. 1995, 19, 1-23. [CrossRef]

58. Paton, C.; Hellstrom, J.; Paul, B.; Woodhead, J.; Hergt, J. Iolite: Freeware for the visualisation and processing of mass spectrometric data. J. Anal. At. Spectrom. 2011, 26, 2508-2518. [CrossRef]

59. Petrus, J.A.; Kamber, B.S. VizualAge: A Novel Approach to Laser Ablation ICP-MS U-Pb Geochronology Data Reduction. Geostand. Geoanal. Res. 2012, 36, 247-270. [CrossRef] 
60. Ulianov, A.; Müntener, O.; Schaltegger, U.; Bussy, F. The data treatment dependent variability of U-Pb zircon ages obtained using mono-collector, sector field, laser ablation ICPMS. J. Anal. At. Spectrom. 2012, 27, 663-676. [CrossRef]

61. Vermeesch, P. IsoplotR: A free and open toolbox for geochronology. Geosci. Front. 2018, 9, 1479-1493. [CrossRef]

62. Spencer, C.J.; Kirkland, C.L.; Taylor, R.J.M. Strategies towards statistically robust interpretations of in situ $\mathrm{U}-\mathrm{Pb}$ zircon geochronology. Geosci. Front. 2016, 7, 581-589. [CrossRef]

63. Guillong, M.; Hametner, K.; Reusser, E.; Wilson, S.A.; Günther, D. Preliminary Characterisation of New Glass Reference Materials (GSA-1G, GSC-1G, GSD-1G and GSE-1G) by Laser Ablation-Inductively Coupled Plasma-Mass Spectrometry Using 193 nm, 213 nm and 266 nm Wavelengths. Geostand. Geoanal. Res. 2005, 29, 315-331. [CrossRef]

64. Sylvester, P.J.; Ghaderi, M. Trace element analysis of scheelite by excimer laser ablation-inductively coupled plasma-mass spectrometry (ELA-ICP-MS) using a synthetic silicate glass standard. Chem. Geol. 1997, 141, 49-65. [CrossRef]

65. McDonougha, W.F.; Sun, S.-S. The composition of the Earth. Chem. Geol. 1995, 120, 223-253. [CrossRef]

66. Thu, Y.K.; Enami, M.; Kato, T.; Tsuboi, M. Granulite facies paragneisses from the middle segment of the Mogok metamorphic belt, central Myanmar. J. Mineral. Petrol. Sci. 2017, 112, 1-19.

67. Win, M.M.; Enami, M.; Kato, T. Metamorphic conditions and CHIME monazite ages of Late Eocene to Late Oligocene high-temperature Mogok metamorphic rocks in central Myanmar. J. Asian Earth Sci. 2016, 117, 304-316. [CrossRef]

68. Bertrand, G.; Rangin, C.; Maluski, H.; Bellon, H. Diachronous cooling along the Mogok Metamorphic Belt (Shan scarp, Myanmar): The trace of the northward migration of the Indian syntaxis. J. Asian Earth Sci. 2001, 19, 649-659. [CrossRef]

69. Mitchell, A.H.G. Cretaceous-Cenozoic tectonic events in the western Myanmar (Burma)-Assam region. J. Geol. Soc. Lond. 1993, 150, 1089-1102. [CrossRef]

70. Searle, M.P.; Noble, S.R.; Cottle, J.M.; Waters, D.J.; Mitchell, A.H.G.; Hlaing, T.; Horstwood, M.S.A. Tectonic evolution of the Mogok metamorphic belt, Burma (Myanmar) constrained by U-Th-Pb dating of metamorphic and magmatic rocks. Tectonics 2007, 26. [CrossRef]

71. Min, M. Thermochronology Applied to Strike-Slip Zones Central America and Myanmar. Ph.D. Thesis, Technische Universität Bergakademie Freiberg, Freiberg, Germany, 2007.

72. Crow, M.J.; Zaw, K. Appendix Geochronology in Myanmar (1964-2017). In Myanmar: Geology, Resources and Tectonics; Barber, A.J., Zaw, K., Crow, M.J., Eds.; Geological Society: London, UK, 2017; Volume 48, pp. 713-759.

73. Dewey, J.F.; Cande, S.; Pitman, W.C. Tectonic evolution of the India-Eurasia collision zone. Eclogae Geol. Helv. $1989,82,717-734$.

74. Jiang, H.; Li, W.Q.; Jiang, S.Y.; Wang, H.; Wei, X.P. Geochronological, geochemical and Sr-Nd-Hf isotopic constraints on the petrogenesis of Late Cretaceous A-type granites from the Sibumasu Block, Southern Myanmar, SE Asia. Lithos 2017, 268-271, 32-47. [CrossRef]

75. Hoskin, P.W.O.; Ireland, T.R. Rare earth element chemistry of zircon and its use as a provenance indicator. Geology 2000, 28, 627-630. [CrossRef]

76. Gieré, R. Zirconolite, allanite and hoegbomite in a marble skarn from the Bergell contact aureole: Implications for mobility of Ti, Zr and REE. Contrib. Mineral. Petrol. 1986, 93, 459-470. [CrossRef]

77. Trail, D.; Bruce Watson, E.; Tailby, N.D. Ce and Eu anomalies in zircon as proxies for the oxidation state of magmas. Geochim. Cosmochim. Acta 2012, 97, 70-87. [CrossRef]

78. Bieri, W.; Grobety, B.; Peretti, A.; Hametner, K.; Günther, D. Chemical composition of apatite inclusions in corundum and spinel determined by LA-ICP-MS and its potential for authentication and provenance determination. In Proceedings of the Goldschmidt 2010: Earth, Energy, and the Environment, Knoxville, TN, USA, 13-18 June 2010; p. 89.

(C) 2020 by the authors. Licensee MDPI, Basel, Switzerland. This article is an open access article distributed under the terms and conditions of the Creative Commons Attribution (CC BY) license (http://creativecommons.org/licenses/by/4.0/). 
Article

\title{
An Evaluation of the Potential for Determination of the Geographic Origin of Ruby and Sapphire Using an Expanded Trace Element Suite Plus $\mathrm{Sr}-\mathrm{Pb}$ Isotope Compositions
}

\author{
Mandy Y. Krebs ${ }^{1,2}, *$, Matthew F. Hardman ${ }^{1}$, David G. Pearson ${ }^{1}$, Yan Luo ${ }^{1}$, Andrew J. Fagan ${ }^{3}$ \\ and Chiranjeeb Sarkar ${ }^{1}$ \\ 1 Earth and Atmospheric Sciences Department, University of Alberta, 1-26 Earth Sciences Building, Edmonton, \\ AB T6G 2E3, Canada; mhardman@ualberta.ca (M.F.H.); gdpearso@ualberta.ca (D.G.P.); \\ yluo4@ualberta.ca (Y.L.); chiranjeeb.sarkar@ualberta.ca (C.S.) \\ 2 Gemological Institute of America, 5355 Armada Drive, Carlsbad, CA 92008, USA \\ 3 Hummingbird Geological Services, Vancouver, BC V5Z 1R9, Canada; ajf.geoconsulting@gmail.com \\ * Correspondence: mandy.krebs@nau.edu
}

Received: 17 April 2020; Accepted: 13 May 2020; Published: 16 May 2020

\begin{abstract}
The geographic origin of gem corundum has emerged as one of its major value factors. Combined with gemological observations, trace element analysis is a powerful tool for the determination of corundum provenance. However, owing to similar properties and features of gem corundum from different localities, but similar geological settings, and very low levels of many trace elements in gem corundum, the determination of geographic origin remains challenging. In this study, we present trace elements compositions determined by laser ablation inductively coupled plasma mass spectrometry (LA-ICP-MS) for rubies and blue sapphires from several different localities of geologically similar deposits: high-Fe amphibolite-type rubies, low-Fe marble-type rubies, and metamorphic blue sapphires. In addition, we determined $\mathrm{Sr}$ and $\mathrm{Pb}$ isotopic ratios by offline laser ablation sampling followed by thermal ionization mass spectroscopy (TIMS). By applying new and existing elemental discrimination schemes and the multivariate statistical method linear discriminant analysis (LDA), we show that, in addition to the commonly used discriminators $\mathrm{Mg}$, $\mathrm{Fe}$, $\mathrm{V}, \mathrm{Ti}$, and $\mathrm{Ga}$, the elements $\mathrm{Ni}, \mathrm{Zr}, \mathrm{Cr}$, and $\mathrm{Zn}$ show potential for geographic origin determination. Amphibolite-type rubies from different localities can be discriminated using $\mathrm{Sr}$ and $\mathrm{Pb}$ isotope ratios, whereas the discrimination of marble-type ruby and metamorphic blue sapphires is limited. Our results re-emphasize the challenge of geographic origin determination and the need for a more powerful discriminatory tool.
\end{abstract}

Keywords: geographic origin determination; ruby; sapphire; trace elements; radiogenic isotopes; linear discriminant analysis

\section{Introduction}

Gem corundum, especially the red ruby and blue sapphire varieties, are among the most valuable gemstones. The commercial value of a gem primarily depends on its size, its color, and its clarity, however, the geographic origin has recently emerged as a major factor affecting their valuation on the market [1]. This is in large part owing to the prestige attributed to certain regions (e.g., rubies from Myanmar, formerly Burma, sapphires from Kashmir), but also because of political, environmental, and ethical considerations [2,3]. Therefore, trying to identify the geographic origin of gem corundum has developed into one of the main tasks for gem-testing laboratories, driving technological approaches to establishing accurate methods of identifying the geographic origin of gemstones. 
Trace element analysis is a particularly powerful tool for the determination of gemstone provenance. Most gemological laboratories today use trace elements combined with gemological observations (e.g., inclusion characteristics and growth features) and spectroscopic analysis (Raman, Fourier transform infrared (FTIR) spectroscopy, and ultraviolet-visible-near-infrared (UV/vis-NIR) spectroscopy) to determine the country of origin [4-6]. Another technique that has proven useful for determining gem corundum provenance is the application of oxygen isotopes [7]. These approaches have proven successful in distinguishing between rubies and blue sapphires of different geological origin, however, they are not yet able to reliably distinguish between gems from different geographic regions with a similar geological formation environment $[4,5,8-11]$. To date, no unique fingerprinting method exists, illustrating the need for a more powerful tool for provenance determination. Determining the provenance of marble-type rubies and metamorphic blue sapphires remains particularly challenging.

Only a small number of trace elements substitute for $\mathrm{Al}^{3+}$ into the crystal structure: $\mathrm{Cr}, \mathrm{Fe}, \mathrm{V}$, $\mathrm{Ti}, \mathrm{Mg}$, and $\mathrm{Ga}$. All other trace elements (including $\mathrm{Sr}$ and $\mathrm{Pb}$ ) in gem corundum (chemical formula $\mathrm{Al}_{2} \mathrm{O}_{3}$ ) are present at ultra-trace levels and are hosted in micron to sub-micron inclusions. These micron to sub-micron inclusions may be derived during the original formation of the corundum, or from later metasomatic re-crystallization, and are either protogenetic, syngenetic, or epigenetic. In either case, the micron to sub-micron inclusion assemblage is unique for each individual deposit and as such, ultra-trace element data may provide additional discriminatory power for geographic origin determination. A recent study [12] developed a novel laser ablation inductively coupled plasma mass spectrometry (LA-ICP-MS) method for the determination of a broader spectrum of trace element compositions at quantitative levels than has been published previously. In addition to expanding the narrow range on quantifiable trace elements in ruby, Krebs et al. [12] measured $\mathrm{Sr}$ and $\mathrm{Pb}$ radiogenic isotope compositions in ruby for the first time using an offline laser ablation sampling technique followed by thermal ionization mass spectrometry (TIMS). Radiogenic isotope tracers are an attractive approach to the determination of geographic provenance because they remain largely unaffected by crystal fractionation [13].

Corundum forms in mafic and siliceous geological environments, always associated with rocks depleted in silica and enriched in alumina, because in the presence of silica, Al will be preferentially incorporated into aluminosilicate minerals such as feldspars and micas [14]. Gem corundum is rare because it also requires the presence of $\mathrm{Cr}, \mathrm{Fe}$, and $\mathrm{Ti}$ to substitute for $\mathrm{Al}$ in the structure $[9,15]$, and thermobarometric conditions favorable for its crystallization and stability [16,17]. Two major geological environments have been found to be favorable for the generation of gem-quality corundum; amphibolite- to medium pressure granulite-facies metamorphic belts and alkaline basaltic volcanism in continental rifting environments. The global distribution of corundum deposits is closely linked to collision, rift, and subduction geodynamics, and three main periods of corundum formation are recognized worldwide [11,18,19]: (1) The Pan-African orogeny (750-450 Ma), (2) The Cenozoic Himalayan orogeny (45 Ma-Quaternary), and (3) The Cenozoic alkali basalt extrusions (65 Ma-Quaternary). Gem corundum deposits formed during these periods are often referred to as classic sources and include (1) most deposits in Southeast and Central Asia (e.g., Myanmar, Vietnam, and Afghanistan) formed during the Himalayan orogeny for marble-hosted ruby deposits; (2) Mozambique and Madagascar, among others, for metamorphic or metasomatic rubies; (3) Sri Lanka, Myanmar, and Kashmir, as well as the more modern source of Madagascar, for the metamorphic blue sapphire group; and (4) Australia, Thailand, and Cambodia for basalt-related rubies and sapphires $[4,5,20]$. Gem corundum deposits that formed unrelated to these periods, such as the Yogo sapphire deposit in Montana, USA (360 to $325 \mathrm{Ma}$, Ar-Ar phlogopite [21]), are referred to as "non-classical" [4]. For these types of deposits, geographic origin determination is often easier, as they can be characterized by distinct geochemical characteristics that distinguish them from other localities. Corundum deposits can be classified into primary, where the corundum is either hosted in the rock where it crystallized, or in the rock that carried it from the zone of crystallization in the crust or mantle to the Earth's surface, and secondary, where the corundum is of detrital origin, that is, it formed in 
a different petrogenetic setting as where it is deposited [17]. Many of the classical gem corundum deposits are of the second type, which adds a further layer of difficulty to origin determination efforts.

In this study, we analyzed rubies and blue sapphires from several different localities of three geologically similar deposit types, amphibolite-type and marble-type rubies and metamorphic blue sapphires, using the LA-ICP-MS method of [12], to identify previously unquantifiable trace elements that show potential for geographic origin determination. In addition, $\mathrm{Sr}$ and $\mathrm{Pb}$ isotope compositions were measured for a subset of samples, and the potential usefulness of radiogenic isotopes for geographic origin determination is explored. While both LA-ICP-MS and isotope measurement approaches are currently too "destructive", that is, visible damage and measurable weight loss are incurred, to be used on high-value client stones, our results provide further insight into gem corundum geochemistry as well as directions of focus for future method development for gemological laboratories.

\section{Materials and Methods}

\subsection{Materials}

A total of 135 gem corundum grains from 11 different locations are analyzed in this study (Figure 1, Table 1). The quality of origin determination studies heavily depends on the completeness and reliability of the reference samples used. Ideally, the samples should be collected in the deposits or mines, however, this is not always feasible because some mines are no longer active, while others are inaccessible or off limits to foreigners [22]. In this study, the samples were classified using a classification scheme developed by the Gemological Institute of America (GIA), which reflects the degree of confidence for origin determination (Table S1; the classification codes can be found in Supplementary Material S6).

The samples are divided into three groups according to their variety and known or suspected geological origin.

\subsubsection{Amphibolite-Type Ruby}

This group comprises samples from four different localities, including the Namahaca deposit at Montepuez in Mozambique [23], the Winza deposit in Tanzania [24,25], and a deposit in the Zahamena National Park located on the Eastern coast of Madagascar [26,27]. For conventional LA-ICP-MS, a sample set provided by the American Museum of Natural History - thought to represent a deposit near Ampanihy, Toliara Province in southwestern Madagascar (George Harlow, pers. communication)—was also analyzed. However, the exact origin of this sample set could not be confirmed, and it was thus excluded from radiogenic isotope analysis. Previously published data from the Aappaluttoq deposit in SW Greenland [12] are included in the discussion, adding a fifth locality to this group. 


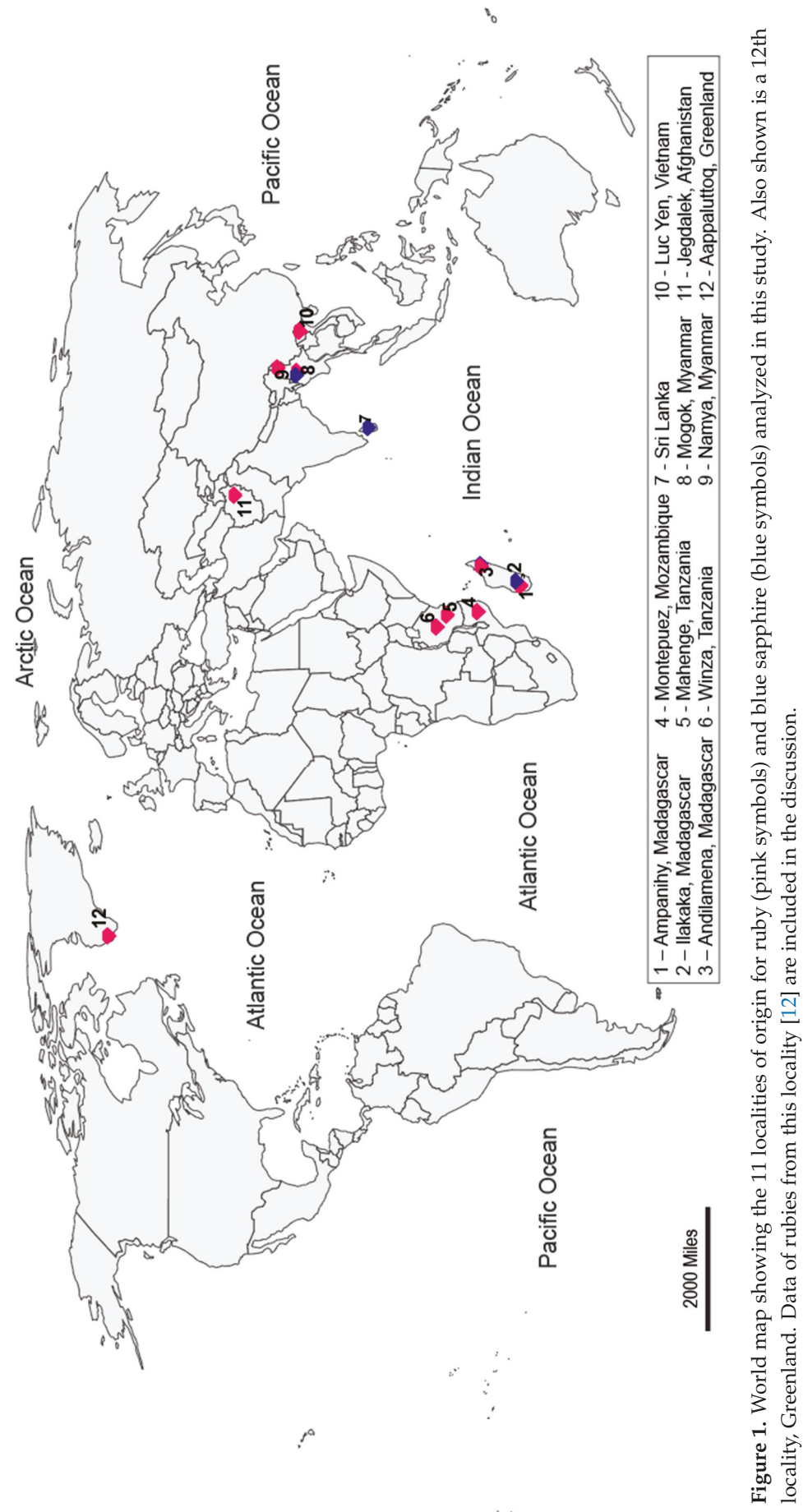


The localities were selected based on shared features commonly found in rubies from these sources as detailed in the literature: (1) Moderate (as defined by [20]) Fe contents (in this study, between 500 to $5000 \mathrm{ppm}$ ); (2) Common inclusions are amphibole, mica, rutile (crystals and needles), and zircon. One exception is Winza rubies, which contain mainly amphibole, garnet, and spinel inclusions [23,25-28]; (3) The oxygen isotope $\left(\delta^{18} \mathrm{O}\right)$ values overlap the mantle value, falling into the range determined for rubies formed in mafic-ultramafic rocks $\left(0.25<\delta^{18} \mathrm{O}<6.8 \%\right.$ o [20]) $[18,25,29,30]$. Information on the geology of ruby host rocks remains sparse for some deposits, but, where reported, primary deposits at the localities of the amphibolite-type group were found to be associated with mafic or ultramafic rocks $[25,27,30,31]$; rubies in this group are thought to have formed in a desilicified host with abundant metamorphic fluids, at high pressure and temperature (at least amphibolite facies). The scope of this study is the evaluation of the usefulness of trace element and radiogenic isotope characteristics for geographic origin determination, and thus the geology and formation of amphibolite-type ruby deposits will not be discussed further. Details on current knowledge of these deposits can be found elsewhere [20,27,30,31].

Table 1. Samples analyzed in this study. MozX_X samples were provided by A. Fagan, Hummingbird consulting, Vancouver. All ADXXX and four-digit samples are part of Gemological Institute of America's (GIA) research collection. All samples named A_XXX, V_XXX and M_XXX were provided by George Harlow from the American Museum of Natural History, New York.

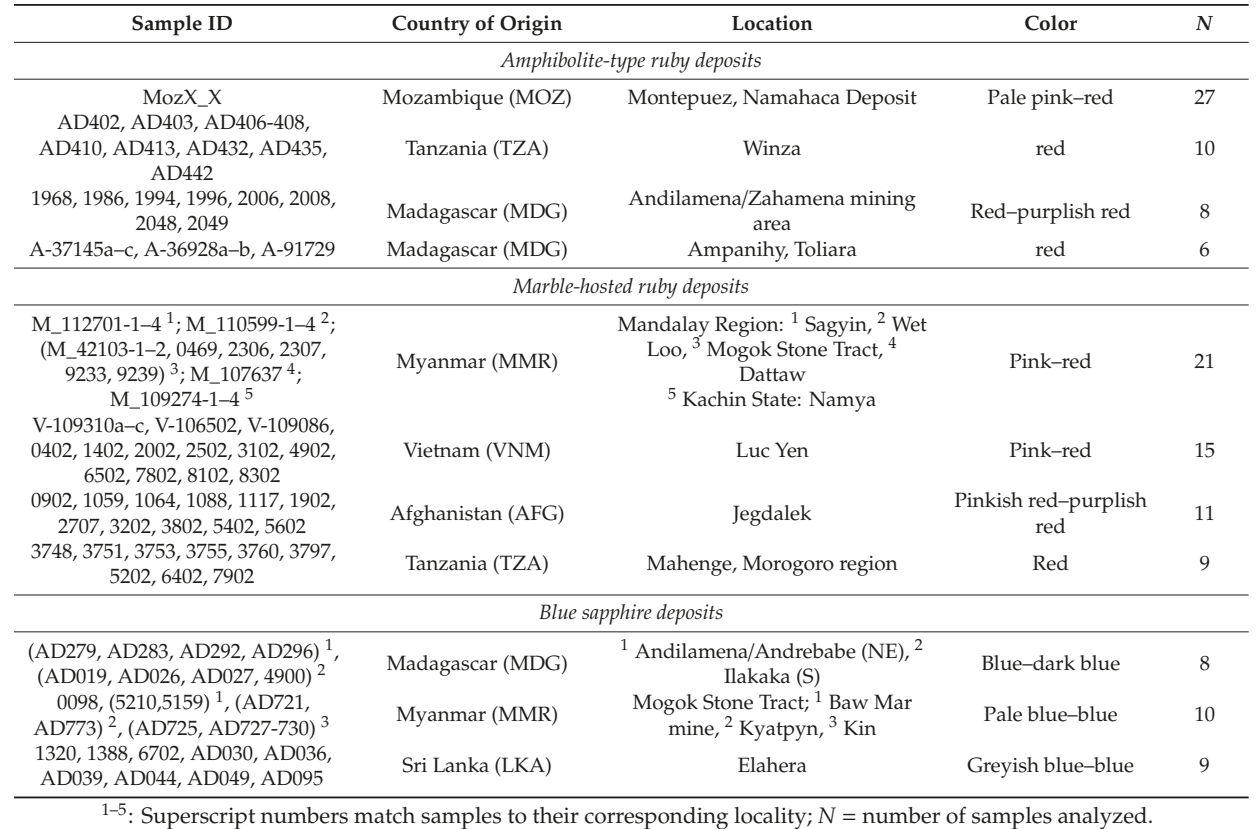

\subsubsection{Marble-Hosted Ruby}

Marble-hosted rubies from four different localities, Myanmar (Mandalay Region and Namya), Vietnam (Luc Yen), Afghanistan (Jegdalek), and Tanzania (Mahenge Mountains, Morogoro Region), were selected for this study. Three of the localities, Myanmar (Mandalay Region and Namya), Vietnam (Luc Yen), and Afghanistan (Jegdalek), are from deposits where the corundum crystallized in marble as a result of retrograde isochemical reactions mainly in a closed system. Several hypotheses on the genesis of these ruby deposits have been advanced and are summarized in [20]. Rubies from Myanmar in this study are from several different areas, most of which are in the Mandalay region and include the famous Mogok Stone 
Tract, Sagyin, Wet Loo, where rubies are found coating painite crystals, and Dattaw. Four samples originate from the Namya mines, located in the Kachin state, approximately $300 \mathrm{~km}$ north of Mogok (Figure 2).

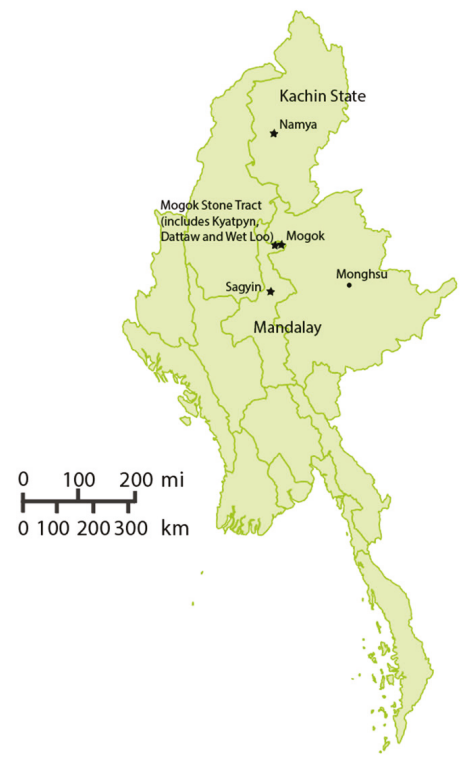

Figure 2. A political map showing Myanmar. Regions of origin for rubies analyzed in this study are marked by stars. Copyright (C) Free Vector Maps.com.

In the course of this study, no systematic differences between the different localities were found and the samples were thus grouped together. The localities were chosen because rubies from these deposits share the following common features: (1) Low Fe contents (in this study, between 20 and $800 \mathrm{ppm}$ ); (2) The most common inclusions include silk (rutile needles; to a varying degree), calcite, dolomite, apatite, spinel, zircon, and mica. In addition, salts are found as solid inclusions [20,32-35]; (3) The oxygen isotope $\left(\delta^{18} \mathrm{O}\right)$ values for rubies from these localities are high, consistent with previously published values for marble-hosted ruby $\left(16.3 \%\right.$ o $<\delta^{18} \mathrm{O}<23 \%$ o [7] $[35,36]$.

The marble-hosted ruby deposit in the Mahenge Mountains, Morogoro Region, Tanzania, is of a different type of ruby deposit associated with marble, where rubies form at the peak of prograde metamorphism in impure marble containing gneiss and silicate layers [20]. Rubies from Morogoro share similar features with those found in rubies from other marble-type deposits (e.g., Myanmar), including low Fe contents and rutile silk, spinel, zircon, and apatite inclusions [37,38]. Details on the geology and formation of marble-hosted ruby deposits have been described previously [20,38].

\subsubsection{Metamorphic Blue Sapphires}

Blue sapphires are broadly separated into two groups - "metamorphic" and "magmatic"—based on their geological origin $[4,10]$. Magmatic sapphires are primarily sapphires found as xenocrysts in alkali basalts, while metamorphic sapphires are primarily found in amphibolite- to medium pressure granulite-facies metamorphic belts. The majority of gem-quality metamorphic blue sapphire is found in secondary deposits, where it is of detrital origin, however, some primary deposits have been identified and are generally associated with desilicated pegmatites; skarn-related granites; marbles; gneisses; aluminous shale; and, in the case of Myanmar, syenite-like rocks associated with high-grade metamorphic rocks $[5,17,20]$. Metamorphic and magmatic sapphires can be separated using UV/vis-NIR spectroscopy. The spectra of the respective groups show many similarities; a major difference, however, is the presence 
of a broad band around $880 \mathrm{~nm}$ in magmatic basalt-type sapphires, which is always more intense than the $580 \mathrm{~nm}$ absorption band [4]. Blue sapphires from the Baw Mar mine in Myanmar have slightly different UV/vis spectra than those from other Mogok mines; however, they are also lacking the $880 \mathrm{~nm}$ band visible in basalt-type sapphires [39]. This classification is not always straight-forward, however, because a recent study on blue sapphires from Madagascar has shown that heat treatment-heating the sapphires to $800-1100{ }^{\circ} \mathrm{C}$ to improve the color-may shift the spectrum from primarily having peaks between 550 and $600 \mathrm{~nm}$ before heating, to having a strong peak at $880 \mathrm{~nm}$ after heating [40].

The blue sapphire samples analyzed in this study were classified as metamorphic based on UV/vis-NIR spectroscopy and inclusion features and are from three different countries: Sri Lanka, Myanmar, and Madagascar. Samples from Sri Lanka originate from the Elahera gem field in Central Sri Lanka [41]; sapphires from Myanmar from the Mogok Stone Tract [42,43]; and sapphires from Madagascar originate from two different areas, including the secondary Ilakaka deposit in the south [44] and Andrebabe in the northeast [45].

The localities for metamorphic blue sapphires in this study were chosen because they share several common features as published in previous studies: (1) lower Fe and Ga and higher $\mathrm{Mg}$ than magmatic blue sapphires, that is, sapphire xenocrysts within basalts [10]; (2) common inclusions are mica (phlogopite, muscovite, biotite), rutile crystals and needles, zircon, apatite, and spinel $[27,41,42,44,46-48]$; and (3) high $\delta^{18}$ O values (>7.7\%o) [7].

Details on the geology and formation of metamorphic blue sapphire deposits can be found elsewhere $[7,11,17]$.

\subsection{Methods}

\subsubsection{Trace Element Analysis}

Trace element and radiogenic isotope compositions were determined using novel methods developed for analysis of low abundance elements in ruby at the Arctic Resources Geochemistry Laboratory, University of Alberta (Edmonton, AB, Canada) [12]. Individual grains were mounted on one inch epoxy grain mounts and polished with diamond to obtain a flat surface.

Trace element compositions were determined via LA-ICP-MS using a RESOlution M-50-LR (Resonetics-Australian Scientific Instruments, Canberra, Australia) $193 \mathrm{~nm}$ ArF Excimer laser (CompexPro 102, Coherent, Santa Clara, CA, USA) coupled to a sector-field Thermo Scientific Element XR2 mass spectrometer (Thermo Fisher Scientific, Waltham, MA, USA) operated in low mass resolution mode $(M / \Delta M=$ ca. 300$)$. NIST612 was used as the primary standard. For quality control, NIST614 and NIST616 were measured every 8-10 samples (Table S2) and used as secondary standards to monitor overall instrument drift. Because the primary and secondary glass standards ablate differently from corundum, that is, they are not matrix-matched, repeat measurements were performed on corundum standard 02-1032 [49] to determine precision and, for some elements, accuracy (Table S2). We note that, at this stage, this reference material (RM) is not an internationally recognised reference material, but it is currently the only matrix-matched RM. We chose not to use it as a primary standard owing to the very limited number of elements for which it is characterised. Samples and standards were ablated with a laser spot size of $285 \mu \mathrm{m}$, at a repetition rate of $20 \mathrm{~Hz}$ and with a fluence of $\sim 6.6 \mathrm{~J} / \mathrm{cm}^{2}$. These parameters result in clean, circular ablation pits with precise geometry, conducive to low levels of inter-element fractionation, as shown in Figure 2 of [12]. Helium served as the carrier gas. Each analysis consisted of 60 $\mathrm{s}$ gas blank acquisition, followed by $60 \mathrm{~s}$ ablation time and a $40 \mathrm{~s}$ delay for washout. Data were acquired for ${ }^{25} \mathrm{Mg},{ }^{29} \mathrm{Si},{ }^{39} \mathrm{~K},{ }^{43} \mathrm{Ca},{ }^{49} \mathrm{Ti},{ }^{51} \mathrm{~V},{ }^{52} \mathrm{Cr},{ }^{57} \mathrm{Fe},{ }^{60} \mathrm{Ni},{ }^{64} \mathrm{Zn},{ }^{65} \mathrm{Cu},{ }^{71} \mathrm{Ga},{ }^{88} \mathrm{Sr},{ }^{90} \mathrm{Zr},{ }^{93} \mathrm{Nb},{ }^{120} \mathrm{Sn},{ }^{139} \mathrm{La},{ }^{140} \mathrm{Ce}$, ${ }^{141} \mathrm{Pr},{ }^{146} \mathrm{Nd},{ }^{165} \mathrm{Ho},{ }^{178} \mathrm{Hf},{ }^{181} \mathrm{Ta},{ }^{184} \mathrm{~W},{ }^{208} \mathrm{~Pb},{ }^{232} \mathrm{Th}$, and ${ }^{238} \mathrm{U}$, with a dwell time of $10 \mathrm{~ms}$ for $\mathrm{Mg}, \mathrm{Si}, \mathrm{K}, \mathrm{Ca}$, $\mathrm{Ti}, \mathrm{V}, \mathrm{Cr}, \mathrm{Fe}, \mathrm{Zn}, \mathrm{Ga}$, and $\mathrm{W}$; a dwell time of $20 \mathrm{~ms}$ for $\mathrm{Ni}, \mathrm{Cu}, \mathrm{Zr}, \mathrm{Nb}, \mathrm{La}, \mathrm{Ce}, \mathrm{Pr}, \mathrm{Nd}, \mathrm{Ho}, \mathrm{Hf}, \mathrm{Ta}$, Th, and U; and a dwell time of $30 \mathrm{~ms}$ for $\mathrm{Sr}, \mathrm{Sn}$, and $\mathrm{Pb}$. Two spots were measured on each grain. The analyzed areas were selected randomly, the only selection criterion was the absence of visible solid inclusions, other impurities, and fractures at the $10 \mu \mathrm{m}$ scale. Data reduction and processing was conducted offline 
using Iolite v. 3.3.2 [50] with ${ }^{27} \mathrm{Al}(52.92 \mathrm{wt} \%)$ as the internal standard element. Careful screening of the time-resolved display and segment-picking for data integration in Iolite permits the identification of signal spikes from prominent inclusions, and were thus excluded during data reduction, resulting in only a single analytical run for some samples. Limits of quantification (LOQ) for all analysed elements are calculated as $3 \times$ LOD and are listed in Table 2. Typical precision of the analyses ranges from $1 \%$ to

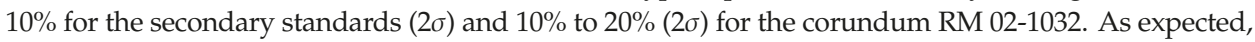
elements close to the LOQ have lower precision. The accuracy for corundum, using NIST 612 as the primary standard, could be determined for the elements $\mathrm{Mg}, \mathrm{Ti}, \mathrm{V}, \mathrm{Cr}, \mathrm{Fe}$, and $\mathrm{Ga}$, and is between $5 \%$ and $20 \%$ for the elements $\mathrm{Ti}, \mathrm{V}, \mathrm{Cr}$, and $\mathrm{Ga}$. For Mg and Fe, however, the accuracy is less satisfactory, with $\sim 75 \%$ and $\sim 35 \%$, respectively, and illustrates the importance of using matrix-matched standards for LA-ICP-MS where possible. It is important to note that the isotopes ${ }^{43} \mathrm{Ca}$ and ${ }^{29} \mathrm{Si}$ have isobaric interferences, ${ }^{27} \mathrm{Al}^{16} \mathrm{O}$ and ${ }^{28} \mathrm{SiH}$, respectively, which are not reflected in the LOQ calculation and make accurate quantification of low abundances difficult. This is also reflected by the low precision of these elements for corundum RM 02-1032 (Table S2); therefore, the reported concentrations should be viewed as quantitative and are used here in a strictly comparative manner. The interference of ${ }^{64} \mathrm{Ni}$ on ${ }^{64} \mathrm{Zn}$ was determined to be negligible and was not corrected for.

Table 2. Median limits of quantification ( $\mathrm{LOQ}-3 \times \mathrm{LOD}$ ) obtained for 26 elements in ppb.

\begin{tabular}{cccccc}
\hline Element & LOQ & Element & LOQ & Element & LOQ \\
\hline${ }^{25} \mathrm{Mg}$ & 378 & ${ }^{64} \mathrm{Zn}$ & 136 & ${ }^{141} \mathrm{Pr}$ & 0.59 \\
${ }^{29} \mathrm{Si}$ & 16266 & ${ }^{65} \mathrm{Cu}$ & 78 & ${ }^{146} \mathrm{Nd}$ & 2.55 \\
${ }^{39} \mathrm{~K}$ & 322 & ${ }^{71} \mathrm{Ga}$ & 20 & ${ }^{165} \mathrm{Ho}$ & 0.37 \\
${ }^{43} \mathrm{Ca}$ & 34500 & ${ }^{88} \mathrm{Sr}$ & 5.5 & ${ }^{178} \mathrm{Hf}$ & 1.4 \\
${ }^{49} \mathrm{Ti}$ & 253 & ${ }^{90} \mathrm{Zr}$ & 5.1 & ${ }^{181} \mathrm{Ta}$ & 0.95 \\
${ }^{51} \mathrm{~V}$ & 14 & ${ }^{93} \mathrm{Nb}$ & 1.37 & ${ }^{184} \mathrm{~W}$ & 1.04 \\
${ }^{52} \mathrm{Cr}$ & 299 & ${ }^{120} \mathrm{Sn}$ & 9.9 & ${ }^{208} \mathrm{~Pb}$ & 3.9 \\
${ }^{57} \mathrm{Fe}$ & 2530 & ${ }^{139} \mathrm{La}$ & 0.81 & ${ }^{232} \mathrm{Th}$ & 0.4 \\
${ }^{60} \mathrm{Ni}$ & 112 & ${ }^{140} \mathrm{Ce}$ & 0.56 & ${ }^{238} \mathrm{U}$ & 0.18 \\
\hline
\end{tabular}

\subsubsection{Radiogenic Isotope Analysis}

Of each corundum group, the cleanest samples were selected for isotope analysis-64 grains in total. Radiogenic isotope analyses were carried out using an offline laser ablation sampling technique, originally developed for the ablation of diamond [51,52], followed by thermal ionization mass spectrometry (TIMS). The technique utilizes a closed-system, custom-designed teflon laser ablation cell in which a sample is ablated, and the products are trapped, allowing the accumulation of higher volumes of analyte needed for isotope analysis. Within corundum, only few elements substitute into the crystal lattice, and $\mathrm{Sr}, \mathrm{Rb}, \mathrm{Pb}, \mathrm{Th}$, or $\mathrm{U}$ are hosted in micron to sub-micron mineral and fluid inclusions trapped within the corundum lattice instead. This technique allows us to bulk sample the micron to sub-micron mineral assemblages, and thus obtain representative isotopic ratios. Offline ablation and TIMS measurements were carried out following the protocols outlined in $[12,53]$ and briefly summarized here.

The corundum samples were leached in $16 \mathrm{~N}$ Seastar ultra purity acid (UPA)-grade $\mathrm{HNO}_{3}$ on a hotplate at $100^{\circ} \mathrm{C}$ for $24 \mathrm{~h}$ and then rinsed in $18.2 \Omega \mathrm{MQ} \mathrm{H}_{2} \mathrm{O}$. Subsequently, samples were leached in $6 \mathrm{~N} \mathrm{HCl}$ for another $24 \mathrm{~h}$ at $100{ }^{\circ} \mathrm{C}$ followed by another rinse in $\mathrm{MQ} \mathrm{H}_{2} \mathrm{O}$, and finally dried at $100{ }^{\circ} \mathrm{C}$ for at least $1 \mathrm{~h}$. All samples were weighed prior to the ablation. Ablations were performed using a RESOlution M-50HR (Resonetics) $193 \mathrm{~nm}$ ArF Excimer (CompexPro 110, Coherent, Santa Clara, CA, USA) laser ablation system, in a raster pattern with the following ablation conditions: spot size $90 \mu \mathrm{m}$, repetition rate $100 \mathrm{~Hz}$, and fluence $4-7 \mathrm{~J} / \mathrm{cm}^{2}$. Areas selected for ablation are free of visible inclusions and fractures, however, depending on the clarity of the samples, fractures are occasionally difficult to avoid, and larger solid inclusions may not be visible beneath the surface. Ablation times varied from 3 to $6 \mathrm{~h}$. 
Following ablation, $2 \mathrm{~mL}$ of $6 \mathrm{~N} \mathrm{HCl}$ ultra purity acid (UPA) was added to the sample beaker and a Teflon cap replaced the laser window. The sealed cell was then placed in an ultrasonic bath for $40 \mathrm{~min}$ to loosen the material from the sample. The fluid was then transferred using a pipette from the ablation cell to a $7 \mathrm{~mL}$ Teflon beaker and dried on a hotplate at $100{ }^{\circ} \mathrm{C}$. To determine the average size of the blank contribution, two to four total procedural blanks (TPBs) were collected for each batch of samples processed, using the same ablation cells and reagents used for the samples. The only step omitted was the step of ablating a solid because including an ablation step would require a solid that is essentially devoid of all trace elements or has trace element concentrations below the LOD of our method. Such a matrix has not yet been found, though we have evaluated Si-wafers for this purpose. Samples were rinsed in $\mathrm{MQ} \mathrm{H}_{2} \mathrm{O}$ and dried before being reweighed, and the weight loss (0.02-0.42 mg) resulting from the ablation was then calculated. The dried ablation products were dissolved in $200 \mu \mathrm{L}$ of $3 \mathrm{~N} \mathrm{HNO}_{3}$ and placed on a hot plate for approximately $2 \mathrm{~h}$ to homogenize. After cooling, a $20 \%$ aliquot by volume was transferred into a pre-leached $7 \mathrm{~mL}$ Teflon beaker for trace element analysis and the remaining sample was processed for isotopic analysis.

Strontium was separated using Sr spec resin following procedures after [54,55]. For the Mozambique sample suite, $\mathrm{Pb}$ was eluted after $\mathrm{Sr}$ in the same column. However, semi-transparent, sticky jam-like residues in the $\mathrm{Pb}$ fraction lead to loading difficulties, resulting in low intensities of $\mathrm{Pb}$ for TIMS analysis. Therefore, for all other samples, the $\mathrm{Pb}$ fraction was separated in separate columns using BioRad AG1-X8 anion exchange resin (100-200 $\mu \mathrm{m}$ mesh) [12].

Total procedural blanks (TPBs) and aliquot sample solutions were analyzed for trace elements using a Thermo Scientific Element XR2 magnetic sector ICPMS (Thermo Fisher Scientific, Waltham, MA, USA) coupled with an APEX-Q high-efficiency sample introduction system (Elemental Scientific Inc., Omaha, NE, USA) fitted with a membrane desolvation module (ACM-actively cooled membrane). Each dried sample was taken up in $1 \mathrm{~mL} 3 \%$ UPA $\mathrm{HNO}_{3}$, with 500 ppt In added as internal standard. Instrumental conditions were similar to those described by [53]. The isotopes measured were as follows: ${ }^{55} \mathrm{Mn},{ }^{56} \mathrm{Fe},{ }^{59} \mathrm{Co},{ }^{63} \mathrm{Cu},{ }^{64} \mathrm{Zn},{ }^{69} \mathrm{Ga},{ }^{85} \mathrm{Rb},{ }^{88} \mathrm{Sr},{ }^{89} \mathrm{Y},{ }^{90} \mathrm{Zr},{ }^{93} \mathrm{Nb},{ }^{98} \mathrm{Mo},{ }^{133} \mathrm{Cs},{ }^{137} \mathrm{Ba},{ }^{139} \mathrm{La},{ }^{140} \mathrm{Ce}$, ${ }^{141} \mathrm{Pr},{ }^{143} \mathrm{Nd},{ }^{147} \mathrm{Sm},{ }^{151} \mathrm{Eu},{ }^{157} \mathrm{Gd},{ }^{159} \mathrm{~Tb},{ }^{161} \mathrm{Dy},{ }^{167} \mathrm{Er},{ }^{173} \mathrm{Yb},{ }^{175} \mathrm{Lu},{ }^{178} \mathrm{Hf},{ }^{181} \mathrm{Ta},{ }^{208} \mathrm{~Pb},{ }^{232} \mathrm{Th}$, and ${ }^{238} \mathrm{U}$. Solution concentrations were measured against a five-point calibration line derived from dilutions of a synthetic rock multi-element standard solution, MES-0314-01. The standard was diluted 50,000, 100,000, 250,000 , and 500,000 times, yielding concentrations in the range of $1 \mathrm{ppt}$ to $35 \mathrm{ppb}$ for different elements and different dilutions, thus providing an appropriate matrix-match for the samples so calibration lines did not require extrapolation into the region of sample analyte concentrations. All concentrations were normalized to the sample weight loss.

The LOQ for trace element analysis were calculated following the same procedures detailed in [53]. A total of 57 TPBs were performed for the corundum ablations, resulting in the following LOQs: the elements $\mathrm{Cs}, \mathrm{Pr}, \mathrm{Sm}, \mathrm{Eu}, \mathrm{Gd}, \mathrm{Tb}, \mathrm{Dy}, \mathrm{Ho}, \mathrm{Er}, \mathrm{Yb}$, Lu, and $\mathrm{U}$ are less than 1 pg; the elements $\mathrm{Rb}, \mathrm{Y}, \mathrm{Nb}$, $\mathrm{La}, \mathrm{Nd}$, and $\mathrm{Th}$ are less than $5 \mathrm{pg}$; the elements $\mathrm{Co}, \mathrm{Ce}, \mathrm{Hf}$, and $\mathrm{Pb}$ are less than $20 \mathrm{pg}$; the elements $\mathrm{Sr}$ and $\mathrm{Ba}$ are less than $70 \mathrm{pg}$; the elements $\mathrm{Mn}, \mathrm{Cu}, \mathrm{Zr}$, and Mo are less than $350 \mathrm{pg}$; and the elements $\mathrm{Fe}$ and $\mathrm{Zn}$ are less than $10.4 \mathrm{ng}$.

A purified $\mathrm{TaF}_{5}$ activator was used to load $\mathrm{Sr}$ samples to enhance $\mathrm{Sr}$ ionisation. Sr isotope ratios were measured on Thermo Scientific Triton Plus TIMS, equipped with nine movable Faraday cups, in static mode using $10^{11} \Omega$ and $10^{12} \Omega$ amplifiers. Multiple loads $(n=21)$ of NBS987 standards of 5 and $10 \mathrm{ng}$ size gave an average value of $0.710270 \pm 92(2 \sigma ; n=21)$ and compares well with long-term data published in other laboratories (Thirlwall, 1991), with data for similar sized loads, and with values measured in the Arctic Resources laboratory for similar sized standards. Eleven loads of dissolved BHVO-2 of $6 \mathrm{ng}$ in size gave an average value of $0.70352 \pm 17(2 \sigma ; n=11)$, slightly higher than, but within uncertainty of, the reported average value of $0.70348 \pm 7$ (GeoREM Database, version 27).

Lead samples were loaded with a mixture of $3.5 \mu \mathrm{L}$ of silicic acid activator and $0.5 \mu \mathrm{L} 0.1 \mathrm{~N} \mathrm{H}_{3} \mathrm{PO}_{4}$, following a similar procedure as for $\mathrm{Sr}$. Pb isotopic ratios were analyzed on a Triton Plus TIMS (Thermo Fisher Scientific, Waltham, MA, USA) using a single SEM in peak-hopping mode using the method 
described in [56]. The average ${ }^{206} \mathrm{~Pb} / 204 \mathrm{~Pb},{ }^{207} \mathrm{~Pb} /{ }^{204} \mathrm{~Pb}$, and ${ }^{208} \mathrm{~Pb} / 204 \mathrm{~Pb}$ values for NBS981 were $16.950 \pm$ $0.015,15.456 \pm 0.013$, and $36.856 \pm 0.027$, respectively, based on 21 analyses, which are within uncertainty of the values published for double spike analyses of the reference material by Todt et al. [57] of ${ }^{206} \mathrm{~Pb} /{ }^{204} \mathrm{~Pb}$ $=16.937 \pm 0.0022,{ }^{207} \mathrm{~Pb} / 204 \mathrm{~Pb}=15.492 \pm 0.0025$, and ${ }^{206} \mathrm{~Pb} /{ }^{204} \mathrm{~Pb}=36.701 \pm 0.011$, respectively.

\section{Results}

\subsection{Trace Elements}

\subsubsection{LA-ICP-MS}

The trace element results for spot analyses on polished grains are listed in Table S1. The most abundant trace elements are Fe; $\mathrm{Ti} ; \mathrm{Ca} ; \mathrm{Mg}$; $\mathrm{Ga}$; and, with the exception of blue sapphires, $\mathrm{Cr}$. Trace elements also mostly above the LOQ (defined here as 10 standard deviations $(\sigma)$ above the gas blank) are $\mathrm{V}, \mathrm{Zn}, \mathrm{Ni}$, and $\mathrm{Pb}$. Other elements that are habitually above the $\mathrm{LOQ}$ for at least one of the groups are $\mathrm{Si}, \mathrm{K}, \mathrm{Cu}, \mathrm{Sr}, \mathrm{Zr}$, $\mathrm{Sn}, \mathrm{La}, \mathrm{Ce}, \mathrm{Nd}, \mathrm{Pr}, \mathrm{Th}$, and $\mathrm{U}$. Among the three gem corundum groups analyzed, marble-hosted rubies are the purest, that is, the number of elements $>\mathrm{LOQ}$ is the most limited. In Table 3, the trace elements relevant or with the potential to be useful for origin determination are summarized.

Table 3. Trace element comparative ranges with medians in parentheses. All data are in ppm $(\mu \mathrm{g} / \mathrm{g})$.

\begin{tabular}{|c|c|c|c|c|c|c|c|c|}
\hline Sample & ${ }^{25} \mathrm{Mg}$ & ${ }^{49} \mathrm{Ti}$ & ${ }^{51} \mathrm{~V}$ & ${ }^{52} \mathrm{Cr}$ & ${ }^{57} \mathrm{Fe}$ & ${ }^{60} \mathrm{Ni}$ & ${ }^{64} \mathrm{Zn}$ & ${ }^{71} \mathrm{Ga}$ \\
\hline \multicolumn{9}{|c|}{ Amphibolite-type ruby deposits } \\
\hline $\begin{array}{l}\text { MOZ } \\
n=54\end{array}$ & $\begin{array}{c}18-67 \\
(38)\end{array}$ & $\begin{array}{c}21-104 \\
(42)\end{array}$ & $\begin{array}{c}2.9-8.5 \\
(4.1)\end{array}$ & $\begin{array}{c}1119-9190 \\
(1812)\end{array}$ & $\begin{array}{c}688-1522 \\
(1001)\end{array}$ & $\begin{array}{c}0.4-3.2 \\
(1)\end{array}$ & $\begin{array}{c}0.3-5.6 \\
(0.8)\end{array}$ & $17-36(22)$ \\
\hline $\begin{array}{c}\text { TZA, Winza } \\
n=19\end{array}$ & $\begin{array}{c}6.4-128 \\
(91)\end{array}$ & $\begin{array}{c}16-584 \\
(99)\end{array}$ & $\begin{array}{c}0.9-8 \\
(3.1)\end{array}$ & $\begin{array}{l}526-2850 \\
(991)\end{array}$ & $\begin{array}{c}1648-3937 \\
(3204)\end{array}$ & $\begin{array}{c}0.4-9.7 \\
(6.6)\end{array}$ & $\begin{array}{c}0.2-1 \\
(0.6)\end{array}$ & $16-44(34)$ \\
\hline $\begin{array}{c}\text { MDG, } \\
\text { Zahamena } \\
n=13\end{array}$ & $\begin{array}{c}48-103 \\
(78)\end{array}$ & $\begin{array}{c}73-149 \\
(109)\end{array}$ & $\begin{array}{c}29-59 \\
(37)\end{array}$ & $\begin{array}{c}1782-8770 \\
(2839)\end{array}$ & $\begin{array}{c}1878-3521 \\
(2940)\end{array}$ & $\begin{array}{c}0.3-3.5 \\
(0.8)\end{array}$ & $\begin{array}{l}0.3-1 \\
(0.4)\end{array}$ & 49-101 (64) \\
\hline $\begin{array}{c}\text { MDG, } \\
\text { Ampanihy } \\
n=12\end{array}$ & $\begin{array}{c}13-40 \\
(27)\end{array}$ & $\begin{array}{c}21-86 \\
(42)\end{array}$ & $\begin{array}{c}26-49 \\
(32)\end{array}$ & $\begin{array}{c}1704-2679 \\
(2189)\end{array}$ & $\begin{array}{c}2720-3560 \\
(3095)\end{array}$ & $\begin{array}{c}0.5-2.7 \\
(0.8)\end{array}$ & $\begin{array}{c}0.4-1.4 \\
(0.8)\end{array}$ & $84-112(97)$ \\
\hline \multicolumn{9}{|c|}{ Marble-hosted ruby deposits } \\
\hline $\begin{array}{l}\text { MMR } \\
n=40\end{array}$ & $\begin{array}{c}13-129 \\
(61)\end{array}$ & $\begin{array}{c}35-207 \\
(109)\end{array}$ & $\begin{array}{c}46-1074 \\
(310)\end{array}$ & $\begin{array}{c}772-6850 \\
(2352)\end{array}$ & $\begin{array}{c}23-267 \\
(101)\end{array}$ & $\begin{array}{c}0.2-2.6 \\
(0.6)\end{array}$ & $\begin{array}{c}0.2-1.8 \\
(0.5)\end{array}$ & 12-192 (131) \\
\hline $\begin{array}{l}\text { VNM } \\
n=39\end{array}$ & $\begin{array}{c}12-161 \\
(39)\end{array}$ & $\begin{array}{c}36-627 \\
(126)\end{array}$ & $\begin{array}{c}8-480 \\
(63)\end{array}$ & $\begin{array}{c}242-8190 \\
(875)\end{array}$ & $\begin{array}{c}20-718 \\
(122)\end{array}$ & $\begin{array}{c}0.1-3.9 \\
(0.4)\end{array}$ & $\begin{array}{c}0.2-1.3 \\
(0.4)\end{array}$ & $9.3-133(58)$ \\
\hline $\begin{array}{c}\text { AFG } \\
n=23\end{array}$ & $\begin{array}{c}26-144 \\
(59)\end{array}$ & $\begin{array}{c}47-367 \\
(111)\end{array}$ & $\begin{array}{c}16-210 \\
(82)\end{array}$ & $\begin{array}{c}1267-9507 \\
(3145)\end{array}$ & $41-679(81)$ & $\begin{array}{c}0.07-3.2 \\
(0.6)\end{array}$ & $\begin{array}{c}0.2-1.9 \\
(0.5)\end{array}$ & $33-92(48)$ \\
\hline $\begin{array}{c}\text { TZA, } \\
\text { Morogoro } \\
n=19\end{array}$ & $\begin{array}{c}42-162 \\
(71)\end{array}$ & $\begin{array}{c}84-360 \\
(126)\end{array}$ & $\begin{array}{c}15-212 \\
(34)\end{array}$ & $\begin{array}{c}462-2319 \\
(1207)\end{array}$ & $\begin{array}{c}128-1250 \\
(449)\end{array}$ & $\begin{array}{c}0.08-1.7 \\
(0.2)\end{array}$ & $\begin{array}{c}0.2-0.6 \\
(0.4)\end{array}$ & $42-117(60)$ \\
\hline \multicolumn{9}{|c|}{ Blue Sapphire deposits } \\
\hline $\begin{array}{c}\text { MDG, } \\
\text { Andrebabe } \\
n=7\end{array}$ & $\begin{array}{c}6.4-44 \\
(19)\end{array}$ & $\begin{array}{c}22-35 \\
(26)\end{array}$ & $\begin{array}{l}1.8-7 \\
(3.6)\end{array}$ & $2.7-11(5.4)$ & $\begin{array}{c}2218-4975 \\
(3460)\end{array}$ & $\begin{array}{c}0.2-4.2 \\
(1.9)\end{array}$ & $\begin{array}{c}0.3-3.1 \\
(1.3)\end{array}$ & $125-216(159)$ \\
\hline $\begin{array}{c}\text { MDG, } \\
\text { Ilakaka } \\
n=6\end{array}$ & $\begin{array}{c}21-133 \\
(63)\end{array}$ & $\begin{array}{c}41-841 \\
(164)\end{array}$ & $\begin{array}{c}12-34 \\
(23)\end{array}$ & $2.2-20(6)$ & $\begin{array}{c}804-2136 \\
(924)\end{array}$ & $\begin{array}{c}0.09-0.4 \\
(0.23)\end{array}$ & $\begin{array}{c}0.25-0.75 \\
\quad(0.5)\end{array}$ & $50-233(63)$ \\
\hline $\begin{array}{c}\text { LKA } \\
n=18\end{array}$ & $\begin{array}{c}28-146 \\
(63)\end{array}$ & $\begin{array}{c}50-283 \\
(138)\end{array}$ & $\begin{array}{c}3.8-62 \\
(9.4)\end{array}$ & $\begin{array}{c}0.9-4.9 \\
(1.8)\end{array}$ & $\begin{array}{c}497-2402 \\
(997)\end{array}$ & $\begin{array}{c}0.8-1.9 \\
(0.33)\end{array}$ & $\begin{array}{c}0.1-0.9 \\
(0.3)\end{array}$ & $46-131(97)$ \\
\hline $\begin{array}{l}\text { MMR } \\
n=20\end{array}$ & $\begin{array}{c}5.8-77 \\
(25)\end{array}$ & $\begin{array}{c}8.7-275 \\
(59)\end{array}$ & $\begin{array}{c}0.5-27 \\
(1.5)\end{array}$ & $\begin{array}{c}1.6-9.8 \\
(2.6)\end{array}$ & $\begin{array}{c}1186-5617 \\
(2040)\end{array}$ & $\begin{array}{c}0.4-3.2 \\
(1)\end{array}$ & $\begin{array}{c}0.1-1.3 \\
(0.5)\end{array}$ & $51-193(89)$ \\
\hline
\end{tabular}

The trace element characteristics of the two ruby groups are consistent with those previously reported in the literature [20]: moderate contents of $\mathrm{Cr}(<1 \mathrm{wt} \%)$, low $\mathrm{Ga}(<130 \mathrm{ppm})$, and low $\mathrm{Ti}$ $(\sim 16-630 \mathrm{ppm})$ for all rubies, moderate contents of Fe for amphibolite-type rubies ( 700-4000 ppm), low Fe for marble-hosted rubies ( 20-1250 ppm), and low V for amphibolite-type rubies ( 1-60 ppm) compared with elevated V for marble-hosted rubies ( 8-1074 ppm). Among amphibolite-type rubies, 
some differences in trace element abundance are observed, including higher median V and Ga contents for rubies from Madagascar (medians of $\mathrm{V}=37$ and $\mathrm{Ga}=64 \mathrm{ppm}$ in the north, and $\mathrm{V}=32$ and $\mathrm{Ga}$ $=97 \mathrm{ppm}$ in the south) than for Mozambique (medians of $\mathrm{V}=4.1$ and $\mathrm{Ga}=22 \mathrm{ppm}$ ) and Tanzania (medians of $\mathrm{V}=3.1$ and $\mathrm{Ga}=34 \mathrm{ppm}$ ) rubies. Rubies from Tanzania and Zahamena, MDG have approximately twice as much $\mathrm{Mg}$ and $\mathrm{Ti}$ as those from Mozambique and Ampanihy, MDG. In addition, Mozambique rubies analyzed in this study have lower Fe (median $=1001 \mathrm{ppm}$ ) than rubies from the other amphibolite-type deposits (median $\sim 3000$ ppm), while Winza, TZA rubies are characterized by higher Ni contents (median $=6.6$ ppm vs. $\max \sim 1 \mathrm{ppm}$ for the other the deposits). Among the marble-hosted rubies, rubies from Myanmar have higher V (median $=310 \mathrm{ppm})$ and Ga $($ median $=$ $131 \mathrm{ppm}$ ) than rubies from the other localities, while rubies from Morogoro, TZA have the lowest V contents (median $=34 \mathrm{ppm}$ ), which overlap with the highest V values in the amphibolite-type deposits, and are also characterized by higher Fe contents (median $=449$ vs. median $=81-122$ ppm for the other deposits). Differences in trace elements of blue sapphires from different deposits are as follows: sapphires from Andrebabe, MDG, and Myanmar have lower $\mathrm{Mg}$, Ti, and $\mathrm{V}$, and higher Fe and $\mathrm{Ni}$ contents than Ilakaka, MDG and Sri Lanka sapphires. Both Madagascar sample suites have higher $\mathrm{Cr}$ contents than Sri Lanka and Myanmar samples. Blue sapphires from Andrebabe, MDG are further characterized by higher Ga contents. Overall, the trace element contents of the blue sapphire samples analyzed in this study exhibit trace element characteristics typical for metamorphic blue sapphires reported by [10], including low $\mathrm{Ga} / \mathrm{Mg}$ ratios $(<10)$.

\subsubsection{Solution ICP-MS}

For 64 rubies and sapphires, a fraction of the offline ablated material was analyzed for trace elements using solution ICP-MS. This comprised 17 amphibolite-type rubies (five from Zahamena, MDG; eight from Mozambique; and four from Winza, TZA), 24 marble-type rubies (10 from Myanmar; five from Vietnam; five from Afghanistan; and four from Morogoro, TZA) and 22 metamorphic blue sapphires (seven from Sri Lanka; eight from Myanmar; four from Ilakaka, MDG; and three from Andrebabe, MDG). For five samples, multiple offline ablations were performed to examine homogeneity and look for isotopic variations within single crystals.

The elemental abundances of all analyzed samples for rare earth elements (REEs), high field strength elements (HFSEs), and large ion lithophile elements (LILEs) range from low ppb levels up to 100s of ppm in some cases (Table S3). When normalized to primitive mantle values [58], most samples show enrichment of LILE and HFSE over LREE and $\mathrm{Nb}$, a positive $\mathrm{Pb}_{\mathrm{N}}$ anomaly (relative to $\mathrm{Ce}_{\mathrm{N}}$ and $\left.\operatorname{Pr}_{\mathrm{N}}\right)$ and LREE enrichment relative to $\operatorname{HREE}\left(\mathrm{La}_{\mathrm{N}} / \mathrm{Yb}_{\mathrm{N}} \sim 1.5-991\right)$ (Figure 3).

Except for the Mozambique and Zahamena, MDG suites, all $\mathrm{Y}_{\mathrm{N}}$ anomalies (relative to Dy and $\mathrm{Ho}_{\mathrm{N}}$ ) are not real, but are caused by single extremely high values in the Vietnam and Ilakaka, MDG datasets (Figure 3c,d). Eu anomalies $\left(E u / E u^{*}=2 \times \mathrm{Eu}_{\mathrm{N}} /(\mathrm{Sm}+\mathrm{Gd})_{\mathrm{N}}\right)$ are mostly negative, with only rubies from Mozambique showing $\mathrm{Eu} / \mathrm{Eu}^{*}>1$ (Figure 4a), while Ce anomalies are typically $\geq 1$ (Figure $4 \mathrm{~d}$ ). Sr anomalies for rubies are mostly positive-exceptions are the majority of the amphibolite-type Mozambique and some marble-type Myanmar rubies, while all blue sapphires have $\mathrm{Sr} / \mathrm{Sr}^{*}<1$ (Figure $4 \mathrm{c}$ ). It is also noteworthy that $\mathrm{Sr}$ is $<$ LOQ in all rubies from Zahamena, MDG. Ta/Nb ratios are predominantly $>1$ for all deposit groups (Figure $5 \mathrm{a}-\mathrm{c}$ ), while the $\mathrm{U} / \mathrm{Pb}$ ratios range are mostly $<1$ for amphibolite-type rubies, $>1$ for marble-type rubies, and range from $\mathrm{U} / \mathrm{Pb}_{\mathrm{N}}=0.01$ to 20 for metamorphic blue sapphires (Figure $5 \mathrm{~d}-\mathrm{f}$ ). Rubies mostly have $\mathrm{Th} / \mathrm{U}<1$, with the exception of amphibolite-type Mozambique rubies, most of which have Th/U < 1 (Figure $5 g-i$ ). 


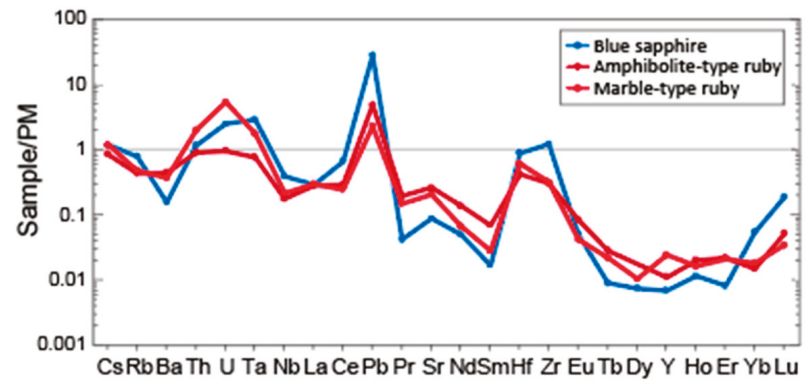

(a)

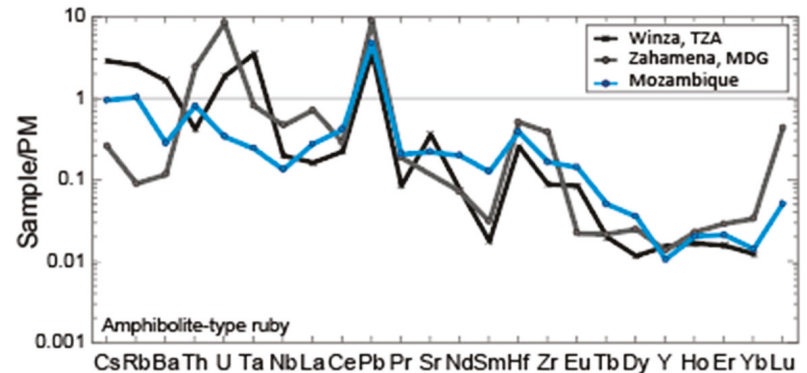

(b)

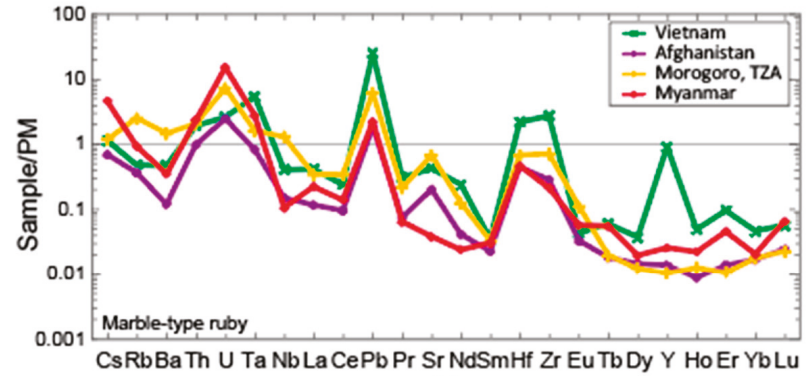

(c)

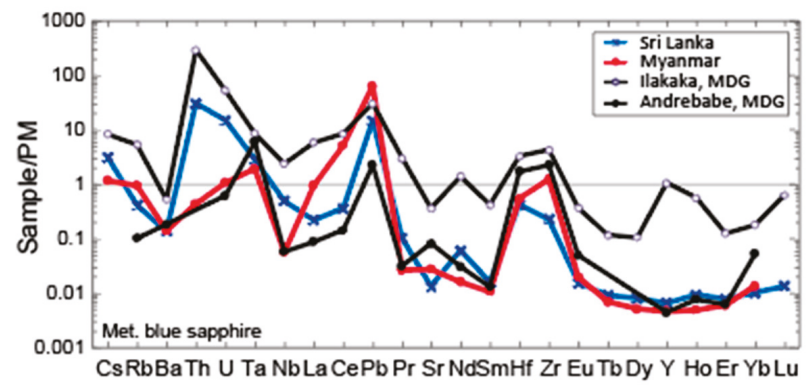

(d)

Figure 3. Primitive mantle (PM)-normalized [58] median trace element concentrations in (a) the three different deposit groups, (b) the amphibolite-type ruby localities, (c) the marble-type ruby localities, and (d) the localities of metamorphic blue sapphire analyzed by offline ablation followed by solution inductively coupled plasma mass spectrometry (ICPMS) in this study. All data plotted are >limit of quantification (LOQ). TZA, Tanzania; MDG, Madagascar. 
Most blue sapphires have Th $<\mathrm{LOQ}$, but where Th $>\mathrm{LOQ}, \mathrm{Th} / \mathrm{U}$ is predominantly $<1$. $\mathrm{Zr}$ and Hf, more often $>$ LOQ in ruby than in blue sapphire, are enriched with $\mathrm{Zr} / \mathrm{Hf}$ less than or greater than 1 (Figure 5j-1).

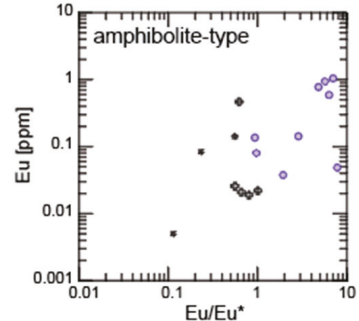

(a)

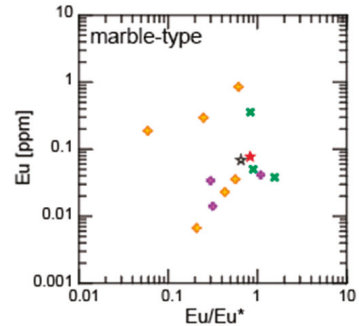

(d)

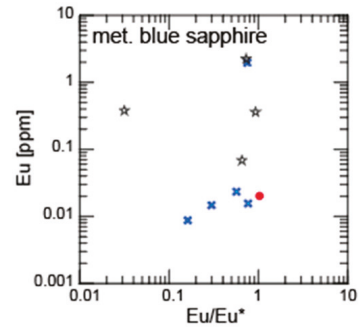

(g)

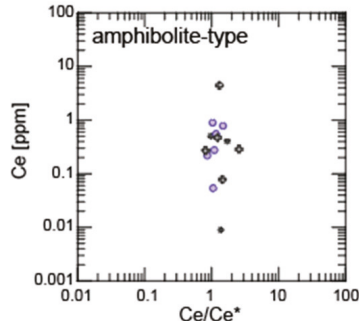

(b)

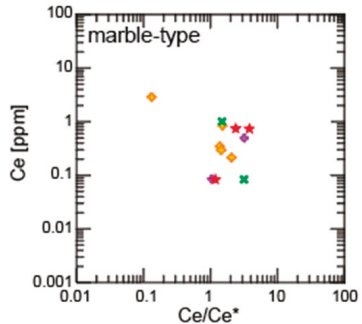

(e)

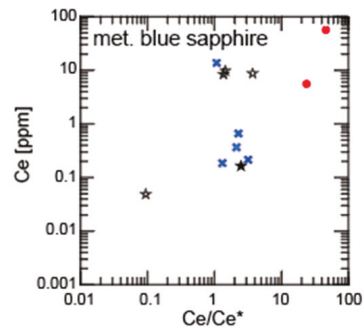

(h)

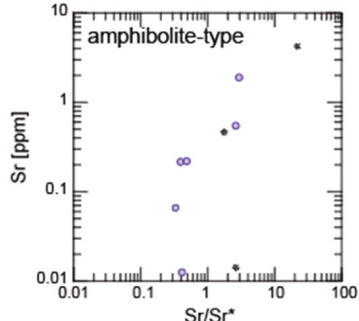

(c)

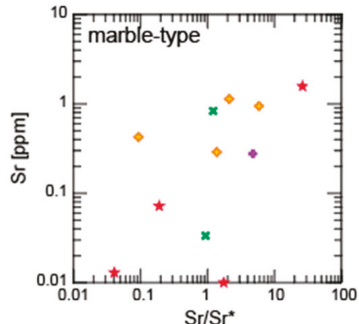

(f)

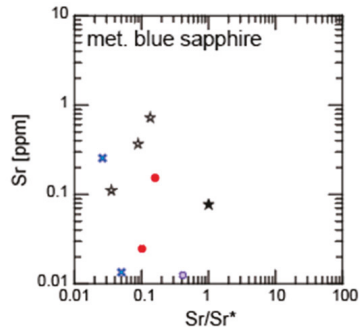

(i)

Met. blue sapphire

× Sri Lanka

- Myanmar

- Baw Mar \& Kyatpyn, MMR

मे llakaka, MDG

$\star$ Andrebabe, MDG

Figure 4. Primitive mantle-normalized [58] trace element compositions in gem corundum ablated offine in this study. Points represent individual analyses. (a-c) Eu versus $E u / E u^{*},(d-f)$ Ce versus $\mathrm{Ce} / \mathrm{Ce}^{*}$, and $(\mathrm{g}-\mathbf{i}) \mathrm{Sr}$ versus $\mathrm{Sr} / \mathrm{Sr}^{*}$. Anomalies were calculated using $\mathrm{Eu} / \mathrm{Eu}^{*}=2 \times \mathrm{Eu}_{\mathrm{N}} /(\mathrm{Sm}+\mathrm{Gd})_{\mathrm{N}}$, $\mathrm{Ce} / \mathrm{Ce}^{*}=\mathrm{Ce}_{\mathrm{N}} /\left(\left(\mathrm{La}_{\mathrm{N}}\right)^{0.667} \times\left(\mathrm{Nd}_{\mathrm{N}}\right)^{0.333}\right)$, and $\mathrm{Sr} / \mathrm{Sr}^{*}=2 \times \mathrm{Sr} /(\mathrm{Ce}+\mathrm{Nd})$, where $\mathrm{N}$ indicates normalization to average primitive mantle values of [58]. MNR, Myanmar.

Some differences between the different localities within each group are apparent. Among amphibolite-type ruby deposits, only the Mozambique suite is characterized by Eu/Eu* $>1$ (Figure 4a) and $\mathrm{Th} / \mathrm{U}$ ratios $>1$ (Figure 5g). In addition, $\mathrm{Zr}$ and $\mathrm{Hf}$ in Mozambique rubies are predominately $<$ LOQ - a characteristic also seen in the LA-ICP-MS data (Figure A2). Furthermore, rubies from Winza, TZA are characterized by positive Gd anomalies; rubies from Zahamena, MDG are characterized by the absence of Sr; and both the Zahamena, MDG and Mozambique suites show Lu enrichment (Figure 3b). 


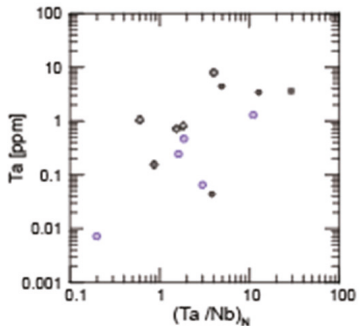

(a)

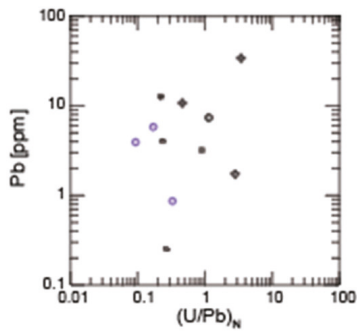

(d)

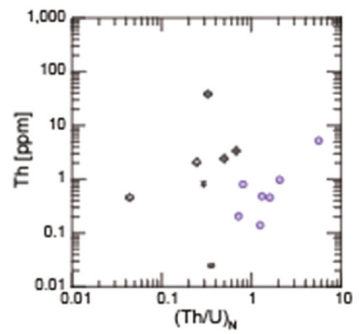

(g)

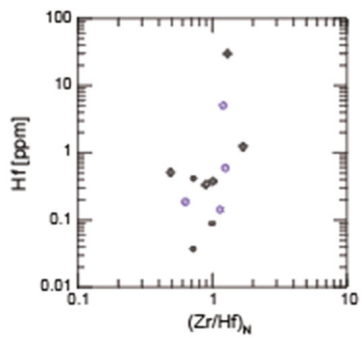

(j)

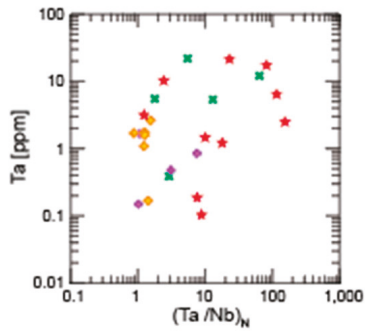

(b)

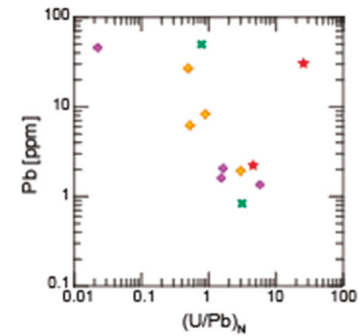

(e)

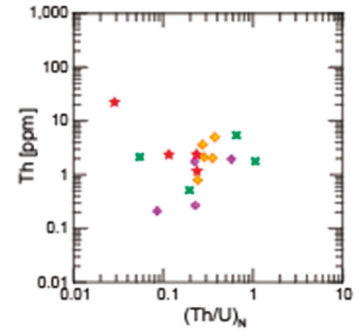

(h)

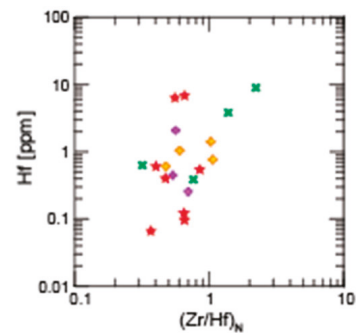

(k)

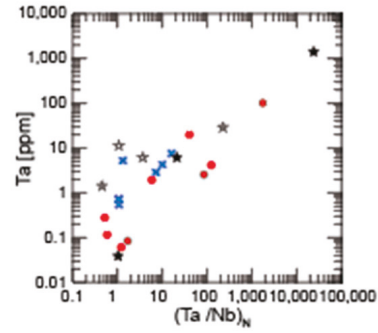

(c)

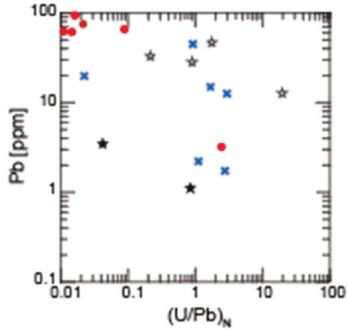

(f)

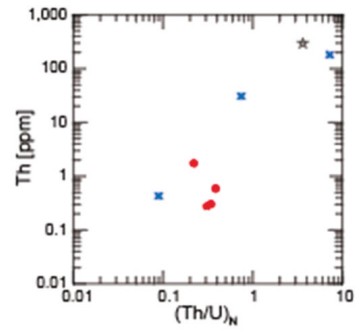

(i)

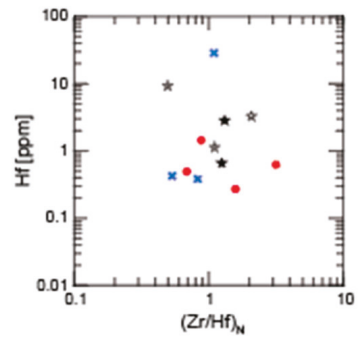

(I)

$\begin{array}{ll}\text { Amphibolite-type ruby } & \text { Marble-type ruby } \\ \star \text { Zahamena, MDG } & \star \text { Myanmar } \\ \text { - Mozambique } & \star \text { Vietnam } \\ * \text { Winza, TZA } & \star \text { Afghanistan } \\ & \diamond \text { Morogoro, TZA }\end{array}$

Met. blue sapphire

* Sri Lanka

- Myanmar

- Baw Mar \& Kyatpyn, MMR

s llakaka, MDG

$\star$ Andrebabe, MDG

Figure 5. Primitive mantle-normalized [58] trace element compositions in offline ablated gem corundum analyzed in this study. Points represent individual analyses. $(\mathbf{a}-\mathbf{c})$ Ta versus $(\mathrm{Ta} / \mathrm{Nb})_{\mathrm{N}} ;(\mathbf{d}-\mathbf{f}) \mathrm{Pb}$ versus $(\mathrm{U} / \mathrm{Pb})_{\mathrm{N}},(\mathrm{g}-\mathbf{i})$ Th versus $(\mathrm{Th} / \mathrm{U})_{\mathrm{N}}$, and $(\mathbf{j}-\mathbf{l})$ Hf versus $(\mathrm{Zr} / \mathrm{Hf})_{\mathrm{N}}$ for amphibole-type ruby, marble-type ruby, and met. blue sapphire, respectively. 
Trace element characteristics in offline-ablated marble-type rubies are mostly similar. However, different characteristics are apparent and include mostly very high $\mathrm{Ta} / \mathrm{Nb}$ for Myanmar and Vietnam rubies versus $\mathrm{Ta} / \mathrm{Nb} \sim 1$ for Morogoro, TZA rubies, and $\mathrm{Sr} / \mathrm{Sr}^{*}<1$ for Myanmar rubies (Figures 3, 4c and $5 b)$.

Among the different suites of metamorphic blue sapphires, several differences are observed. Blue sapphires from Sri Lanka and Ilakaka, MDG are very similar to each other, with $\mathrm{U} / \mathrm{Pb}$ mostly $>1$ and $\mathrm{U}$ (and Th where present) enrichment over Ta. Myanmar blue sapphires, on the other hand, show U/Pb $<$ 1 (Figure 5f). In addition, in Myanmar and Andrebabe, MDG sapphires, Cs is mostly <LOQ, whereas in sapphires from Sri Lanka and Ilakaka, MDG, Cs is >LOQ (Table S3).

Figure 6 shows the primitive mantle-normalized trace element patterns of the samples for which two separate offline ablations were performed to investigate the reproducibility of the data.

The trace element patterns of the two repeat analyses are remarkably similar for all samples, however, in some samples, variations for single elements are observed. For ruby moz2_2, for instance, Sr and Ba vary, while for blue sapphire 0098 from Myanmar, Sr and Ta of the two analyses are different, and one analysis of ruby moz1_4 shows a negative Tb anomaly. The observed variations in concentrations probably reflect different densities of inclusions, while differences in the trace element patterns of the replicates indicate that the composition of the micron to submicron inclusion assemblage varied in the ablated areas.

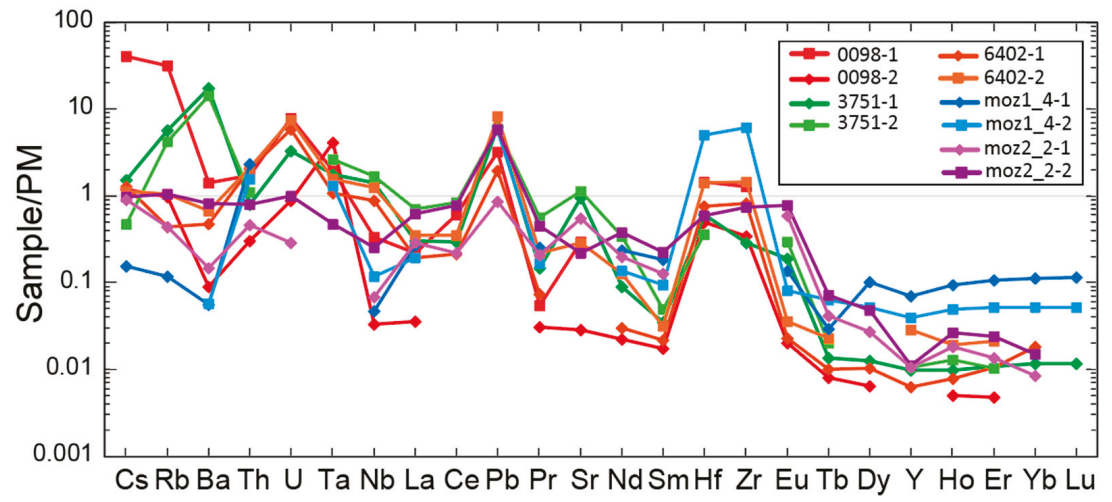

Figure 6. Primitive mantle-normalized [58] trace element concentrations of duplicate offline-ablations for five samples in this study. Lines of the same color denote replicate analyses of the same sample in a different area of the crystal. Sample 0098 is from the Mogok Stone Tract, Myanmar; samples 3751 and 6402 are from the Morogoro region in Tanzania; and samples moz1_4 and moz2_2 are from the Montepuez area in Mozambique.

\subsection{Radiogenic Isotopes}

\subsubsection{Sr Isotopic Composition}

Gem corundum from different locations and deposit types span a wide range of Sr isotopic compositions (Table 4 and Table S3). Sr isotopic ratios of the amphibolite-type rubies (21 analyses-three duplicate) span a range between ${ }^{87} \mathrm{Sr} /{ }^{86} \mathrm{Sr}=0.7071 \pm 0.0005$ and ${ }^{87} \mathrm{Sr} /{ }^{86} \mathrm{Sr}=0.7463 \pm 0.0042$. Within this group, rubies from Zahamena, MDG are the most radiogenic and have the widest range $\left({ }^{87} \mathrm{Sr} /{ }^{86} \mathrm{Sr}=\right.$ $0.7115 \pm 0.0035$ to $\left.{ }^{87} \mathrm{Sr} /{ }^{86} \mathrm{Sr}=0.7463 \pm 0.0042\right)$, while rubies from Winza, TZA are the most unradiogenic and define a narrow range between ${ }^{87} \mathrm{Sr} /{ }^{86} \mathrm{Sr}=0.7071 \pm 0.0006$ and ${ }^{87} \mathrm{Sr} /{ }^{86} \mathrm{Sr}=0.7101 \pm 0.0014$ with rubies from Mozambique falling in between (Figure 7b, Table 4). For three of the Mozambique rubies, two replicate analyses were conducted, with $\mathrm{Sr}$ isotopic compositions for moz2_2 of ${ }^{87} \mathrm{Sr} /{ }^{86} \mathrm{Sr}=0.7089$ \pm 0.0030 and ${ }^{87} \mathrm{Sr} /{ }^{86} \mathrm{Sr}=0.7075 \pm 0.0006$, for moz2 $\_6$ of ${ }^{87} \mathrm{Sr} /{ }^{86} \mathrm{Sr}=0.7148 \pm 0.0009$ and ${ }^{87} \mathrm{Sr} /{ }^{86} \mathrm{Sr}=0.7108$ \pm 0.0007 , and for moz2_8 of ${ }^{87} \mathrm{Sr} /{ }^{86} \mathrm{Sr}=0.7164 \pm 0.0005$ and ${ }^{87} \mathrm{Sr} /{ }^{86} \mathrm{Sr}=0.7112 \pm 0.0009$. For sample 
moz2 2 , the analyses are within error of one another. For samples moz2_6 and moz2_8, however, the ${ }^{87} \mathrm{Sr} /{ }^{86} \mathrm{Sr}$ ratios of the duplicate ablations are outside of their respective uncertainty intervals, indicating Sr isotopic heterogeneity that is likely controlled by the ablation of larger inclusions [12].

The range in ${ }^{87} \mathrm{Sr} /{ }^{86} \mathrm{Sr}$ isotope ratios for the marble-type rubies $\left({ }^{87} \mathrm{Sr} /{ }^{86} \mathrm{Sr}=0.7059 \pm 0.0007\right.$ to ${ }^{87} \mathrm{Sr} /{ }^{86} \mathrm{Sr}=0.7182 \pm 0.0021$, median $\left.{ }^{87} \mathrm{Sr} /{ }^{86} \mathrm{Sr} \sim 0.7082\right)$ is much narrower and more unradiogenic than that of both the amphibolite-type rubies (median ${ }^{87} \mathrm{Sr} /{ }^{86} \mathrm{Sr} \sim 0.7113$ ) and the metamorphic blue sapphires (median ${ }^{87} \mathrm{Sr} /{ }^{86} \mathrm{Sr} \sim 0.7156$ ) (Figure 7a). Among the different localities of marble-hosted ruby, rubies from Myanmar have a more radiogenic distribution (median ${ }^{87} \mathrm{Sr} /{ }^{86} \mathrm{Sr} \sim 0.7099$ ) and the widest range, while including both the most and least radiogenic marble-hosted ruby samples (Figure 7c). Rubies from Afghanistan; Morogoro, TZA; and Vietnam are less radiogenic, with median ${ }^{87} \mathrm{Sr} /{ }^{86} \mathrm{Sr}$ of $\sim 0.7083$, $\sim 0.7070$, and $\sim 0.7063$, respectively. For two rubies from Morogoro, TZA, two ablations and subsequent Sr isotope analyses were performed, with $\mathrm{Sr}$ isotopic ratios of ${ }^{87} \mathrm{Sr} /{ }^{86} \mathrm{Sr}=0.7081 \pm 0.0005$ and ${ }^{87} \mathrm{Sr} /{ }^{86} \mathrm{Sr}$ $=0.7063 \pm 0.0030$ for sample 3751 and ${ }^{87} \mathrm{Sr} /{ }^{86} \mathrm{Sr}=0.7072 \pm 0.0029$ and ${ }^{87} \mathrm{Sr} /{ }^{86} \mathrm{Sr}=0.7093 \pm 0.0047$ for sample 6402. For both samples, the duplicate analyses are within uncertainty of each other.

Table 4. Ranges in $\mathrm{Sr}$ and $\mathrm{Pb}$ isotopic ratios for the different localities analyzed in this study. Number of analyses in parentheses.

\begin{tabular}{|c|c|c|c|c|c|}
\hline Sample & ${ }^{87} \mathrm{Sr} /{ }^{86} \mathrm{Sr}$ & ${ }^{206} \mathrm{~Pb} /{ }^{204} \mathrm{~Pb}$ & ${ }^{207} \mathrm{~Pb} /{ }^{204} \mathrm{~Pb}$ & ${ }^{207} \mathrm{~Pb} /{ }^{206} \mathrm{~Pb}$ & ${ }^{208} \mathrm{~Pb} /{ }^{206} \mathrm{~Pb}$ \\
\hline \multicolumn{6}{|c|}{ Amphibolite-type deposits } \\
\hline MOZ & $\begin{array}{c}0.7075-0.72 \\
91(n=12)\end{array}$ & $\begin{array}{c}17.86-19.00 \\
(n=4)\end{array}$ & $\begin{array}{c}15.33-15.60 \\
(n=4)\end{array}$ & $\begin{array}{c}0.8305-0.8655 \\
(n=4)\end{array}$ & $\begin{array}{c}2.0292-2.0955 \\
(n=4)\end{array}$ \\
\hline TZA, Winza & $\begin{array}{c}0.7071-0.7101 \\
\quad(n=4)\end{array}$ & $\begin{array}{c}16.88-17.57 \\
(n=3)\end{array}$ & $\begin{array}{c}15.57-15.62 \\
(n=3)\end{array}$ & $\begin{array}{c}0.8880-0.9223 \\
(n=4)\end{array}$ & $\begin{array}{c}2.1290-2.1786 \\
(n=3)\end{array}$ \\
\hline $\begin{array}{c}\text { MDG, } \\
\text { Zahamena }\end{array}$ & $\begin{array}{c}0.7115-0.7463 \\
(n=4)\end{array}$ & $\begin{array}{c}15.92-24.64 \\
(n=4)\end{array}$ & $\begin{array}{c}15.21-15.99 \\
(n=4)\end{array}$ & $\begin{array}{c}0.6488-0.9539 \\
(n=4)\end{array}$ & $\begin{array}{c}1.5866-2.8679 \\
(n=4)\end{array}$ \\
\hline \multicolumn{6}{|c|}{ Marble-hosted deposits } \\
\hline MMR & $\begin{array}{c}0.7059-0.7182 \\
(n=8)\end{array}$ & $\begin{array}{c}18.02-19.75 \\
(n=9)\end{array}$ & $\begin{array}{c}15.55-15.72 \\
(n=9)\end{array}$ & $\begin{array}{c}0.7959-0.8636 \\
(n=9)\end{array}$ & $\begin{array}{c}1.9643-2.1037 \\
(n=9)\end{array}$ \\
\hline VNM & $\begin{array}{c}0.7062-0.7066 \\
(n=3)\end{array}$ & $\begin{array}{c}18.11-19.08 \\
(n=3)\end{array}$ & $\begin{array}{c}15.50-15.64 \\
(n=3)\end{array}$ & $\begin{array}{c}0.8177-0.8558 \\
\quad(n=3)\end{array}$ & $\begin{array}{c}2.0223-2.0819 \\
(n=3)\end{array}$ \\
\hline AFG & $\begin{array}{c}0.7059-0.7089 \\
(n=5)\end{array}$ & $\begin{array}{c}17.77-19.13 \\
(n=5)\end{array}$ & $\begin{array}{c}15.48-15.67 \\
(n=5)\end{array}$ & $\begin{array}{c}0.8196-0.9721 \\
(n=5)\end{array}$ & $\begin{array}{c}2.0090-2.1081 \\
(n=5)\end{array}$ \\
\hline $\begin{array}{c}\text { TZA, } \\
\text { Morogoro }\end{array}$ & $\begin{array}{c}0.7063-0.7093 \\
(n=5)\end{array}$ & $\begin{array}{c}17.38-35.86 \\
(n=4)\end{array}$ & $\begin{array}{c}15.39-16.57 \\
(n=4)\end{array}$ & $\begin{array}{c}0.4616-0.8858 \\
(n=4)\end{array}$ & $\begin{array}{c}1.0561-2.1320 \\
(n=4)\end{array}$ \\
\hline \multicolumn{6}{|c|}{ Blue sapphire deposits } \\
\hline $\begin{array}{c}\text { MDG, } \\
\text { Andrebabe }\end{array}$ & $\begin{array}{c}0.7066-0.7087 \\
(n=2)\end{array}$ & $\begin{array}{c}17.08-18.30 \\
(n=3)\end{array}$ & $\begin{array}{c}15.47-15.57 \\
(n=3)\end{array}$ & $\begin{array}{c}0.8505-0.9056 \\
(n=3)\end{array}$ & $\begin{array}{c}2.1113-2.1484 \\
(n=3)\end{array}$ \\
\hline MDG, Ilakaka & $\begin{array}{c}0.7156-0.7316 \\
(n=4)\end{array}$ & $\begin{array}{c}17.45-20.01 \\
(n=4)\end{array}$ & $\begin{array}{c}15.54-15.80 \\
(n=4)\end{array}$ & $\begin{array}{c}0.7895-0.8899 \\
(n=4)\end{array}$ & $\begin{array}{c}2.0243-2.5975 \\
(n=4)\end{array}$ \\
\hline LKA & $\begin{array}{c}0.7081-0.7316 \\
(n=7)\end{array}$ & $\begin{array}{c}17.24-20.69 \\
(n=7)\end{array}$ & $\begin{array}{c}15.49-15.95 \\
(n=7)\end{array}$ & $\begin{array}{c}0.7706-0.8974 \\
\quad(n=7)\end{array}$ & $\begin{array}{c}1.8330-3.2644 \\
(n=7)\end{array}$ \\
\hline MMR & $\begin{array}{c}0.7098-0.7152 \\
(n=7)\end{array}$ & $\begin{array}{c}17.86-18.65 \\
(n=3)\end{array}$ & $\begin{array}{c}15.40-15.65 \\
(n=3)\end{array}$ & $\begin{array}{c}0.8381-0.8634 \\
\quad(n=3)\end{array}$ & $\begin{array}{c}2.0629-2.0856 \\
(n=3)\end{array}$ \\
\hline
\end{tabular}

Metamorphic blue sapphires have $\mathrm{Sr}$ isotopic compositions ranging from ${ }^{87} \mathrm{Sr} /{ }^{86} \mathrm{Sr}=0.7066 \pm$ 0.0020 to ${ }^{87} \mathrm{Sr} /{ }^{86} \mathrm{Sr}=0.7316 \pm 0.0008$. Among the different localities, Ilakaka, MDG has blue sapphires with the most radiogenic Sr isotopic composition (median ${ }^{87} \mathrm{Sr} /{ }^{86} \mathrm{Sr} \sim 0.7206$ ), followed by Sri Lanka and Myanmar with median ${ }^{87} \mathrm{Sr} /{ }^{86} \mathrm{Sr} \sim 0.7141$ and ${ }^{87} \mathrm{Sr} /{ }^{86} \mathrm{Sr} \sim 0.7109$, respectively (Figure $7 \mathrm{~d}$, Table 4). Only two blue sapphires from Andrebabe, MDG were analyzed, and represent the most unradiogenic suite with Sr isotopic ratios of $0.7066 \pm 0.0020$ and $0.7087 \pm 0.0024$. For one blue sapphire from Myanmar (sample 0098), two $\mathrm{Sr}$ isotope analyses were carried out, giving two different ${ }^{87} \mathrm{Sr} /{ }^{86} \mathrm{Sr}$ ratios: ${ }^{87} \mathrm{Sr} /{ }^{86} \mathrm{Sr}$ $=0.7152 \pm 0.0008$ and ${ }^{87} \mathrm{Sr} /{ }^{86} \mathrm{Sr}=0.7130 \pm 0.0010$. 


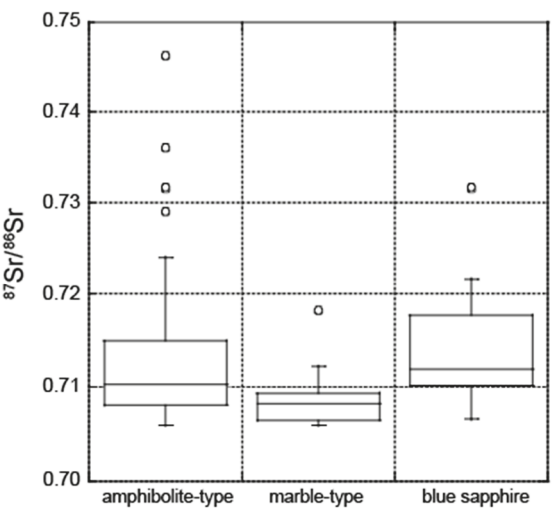

(a)

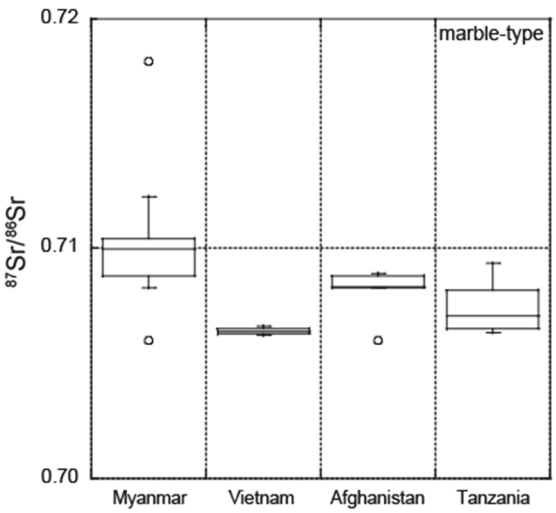

(c)

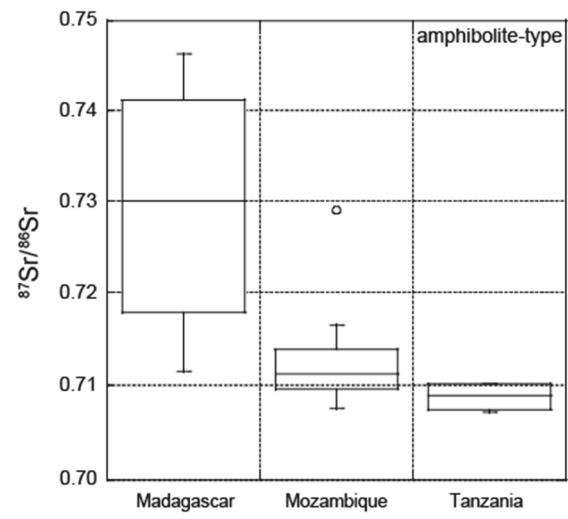

(b)

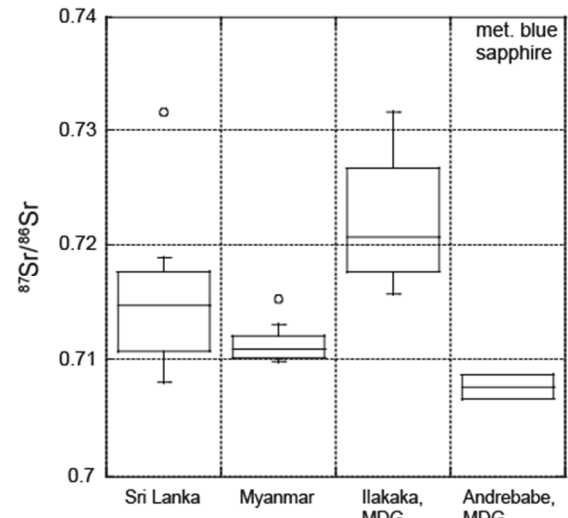

(d)

Figure 7. Box and whisker plots displaying ${ }^{87} \mathrm{Sr} /{ }^{86} \mathrm{Sr}$ isotopic compositions of gem corundum from (a) the three different deposit groups, (b) the amphibolite-type ruby localities, (c) the marble-type ruby localities, and (d) the localities of metamorphic blue sapphire measured in this study. Individual data points are outliers whose value is either greater than UQ $+1.5 \times$ IQD or less than LQ $-1.5 \times$ IQD (where $\mathrm{UQ}=$ upper quartile, $\mathrm{LQ}=$ lower quartile, and IQD = inter quartile distance).

\subsubsection{Pb Isotopic Composition}

The relative variations in $\mathrm{Pb}$ isotopic compositions in corundum of the different groups are minor (Table 4, Figure 8a-d); the amphibolite-type rubies have slightly more unradiogenic compositions (median ${ }^{206} \mathrm{~Pb} /{ }^{204} \mathrm{~Pb} \sim 17.93$, median ${ }^{207} \mathrm{~Pb} /{ }^{204} \mathrm{~Pb} \sim 15.58$, median ${ }^{207} \mathrm{~Pb} /{ }^{206} \mathrm{~Pb} \sim 0.8655$, and median ${ }^{208} \mathrm{~Pb} /{ }^{206} \mathrm{~Pb} \sim 2.1290$ ) than the marble-type rubies (median ${ }^{206} \mathrm{~Pb} /{ }^{204} \mathrm{~Pb} \sim 18.63$, median ${ }^{207} \mathrm{~Pb} /{ }^{204} \mathrm{~Pb} \sim 15.61$, median ${ }^{207} \mathrm{~Pb} / 206 \mathrm{~Pb} \sim 0.8308$, and median ${ }^{208} \mathrm{~Pb} /{ }^{206} \mathrm{~Pb} \sim 2.0483$ ) and the metamorphic blue sapphires (median ${ }^{206} \mathrm{~Pb} /{ }^{204} \mathrm{~Pb} \sim 18.50$, median ${ }^{207} \mathrm{~Pb} /{ }^{204} \mathrm{~Pb} \sim 15.58$, median ${ }^{207} \mathrm{~Pb} /{ }^{206} \mathrm{~Pb} \sim 0.8436$, and median ${ }^{208} \mathrm{~Pb} /{ }^{206} \mathrm{~Pb} \sim 2.0851$ ).

Among the different localities of amphibolite-type ruby, $\mathrm{Pb}$ isotopic ratios in samples from Zahamena, MDG span a wide range (e.g., ${ }^{207} \mathrm{~Pb} /{ }^{206} \mathrm{~Pb}=0.6488 \pm 0.0003$ to $0.9539 \pm 0.0005$, Figure 9a), while the ranges for samples from Mozambique and Winza, TZA are much more narrow, ${ }^{207} \mathrm{~Pb} /{ }^{206} \mathrm{~Pb}=$ $0.8305 \pm 0.0026$ to $0.8655 \pm 0.0016$ and ${ }^{207} \mathrm{~Pb} /{ }^{206} \mathrm{~Pb}=0.8880 \pm 0.0003$ to $0.9223 \pm 0.0002$, respectively. For one ruby (sample moz2_6), two Pb isotope analyses were carried out, giving two different ${ }^{207} \mathrm{~Pb} / 206 \mathrm{~Pb}$ ratios, $0.8655 \pm 0.0016$ and $0.8305 \pm 0.0026$. 
$\mathrm{Pb}$ isotopic ratios of rubies from different marble-type localities overlap significantly, with median ${ }^{207} \mathrm{~Pb} /{ }^{206} \mathrm{~Pb}$ values of $\sim 0.8280, \sim 0.8400, \sim 0.8489$, and $\sim 0.8328$ for rubies from Myanmar; Vietnam; Afghanistan; and Morogoro, TZA, respectively (Figure 9b). Sample 5202 from Morogoro, TZA is much more radiogenic $\left({ }^{207} \mathrm{~Pb} /{ }^{206} \mathrm{~Pb}=0.4615 \pm 0.0002\right)$ than any other sample in this group, resulting in a wide range of $\mathrm{Pb}$ isotopic compositions for this locality.

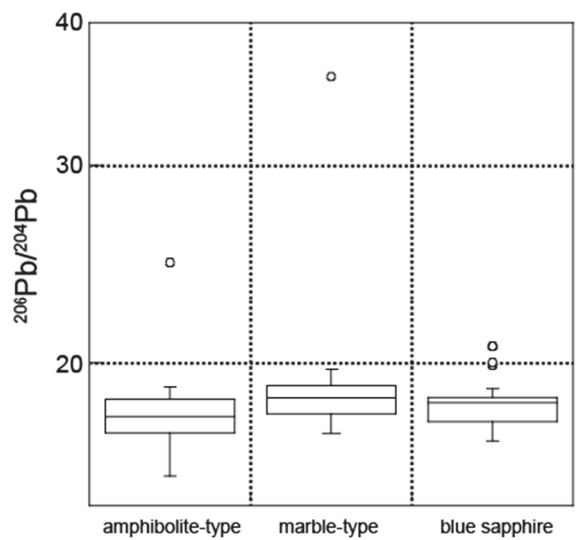

(a)

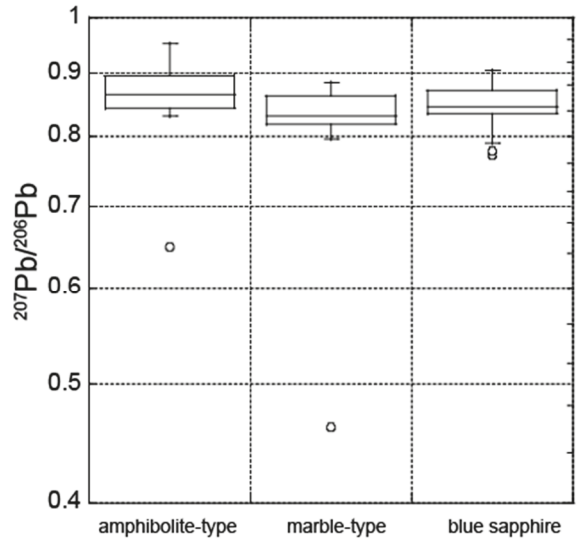

(c)

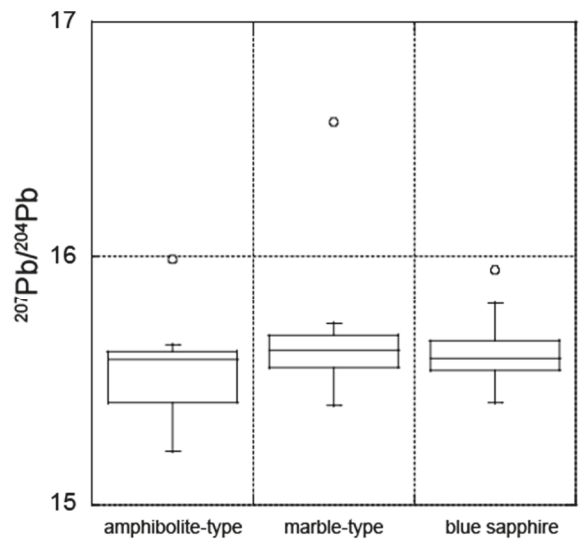

(b)

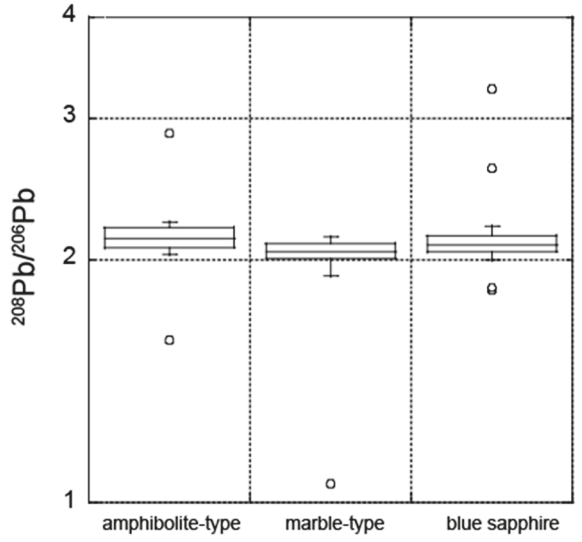

(d)

Figure 8. Box and whisker plots displaying (a) ${ }^{206} \mathrm{~Pb} /{ }^{204} \mathrm{~Pb}$, (b) ${ }^{207} \mathrm{~Pb} /{ }^{204} \mathrm{~Pb}$, (c) ${ }^{207} \mathrm{~Pb} /{ }^{206} \mathrm{~Pb}$, and (d) ${ }^{208} \mathrm{~Pb} /{ }^{206} \mathrm{~Pb}$ isotopic compositions of gem corundum from the three different deposit groups measured in this study. Individual data points are outliers whose value is either greater than UQ +1.5 $\times$ IQD or less than LQ $-1.5 \times$ IQD.

Similar to the amphibolite-type and marble-type rubies, $\mathrm{Pb}$ isotopic ratios of metamorphic blue sapphires from different localities overlap (Figure 9). Samples from Andrebabe, MDG have the most unradiogenic $\mathrm{Pb}$ isotope ratios (e.g., median ${ }^{207} \mathrm{~Pb} /{ }^{206} \mathrm{~Pb} \sim 0.8722$ ), followed by Myanmar with median ${ }^{207} \mathrm{~Pb} /{ }^{206} \mathrm{~Pb} \sim 0.8574$. Blue sapphires from Sri Lanka and Ilakaka, MDG are the most radiogenic with ${ }^{207} \mathrm{~Pb} /{ }^{206} \mathrm{~Pb}$ median values of $\sim 0.8384$ and $\sim 0.8436$, respectively. 


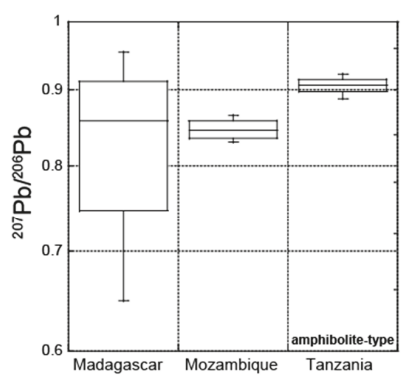

(a)

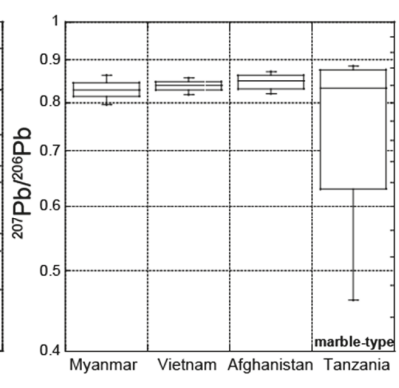

(b)

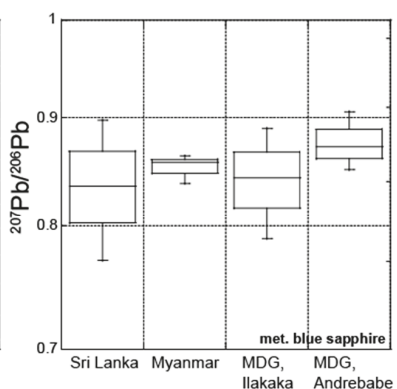

(c)

Figure 9. Box and whisker plots displaying ${ }^{207} \mathrm{~Pb} /{ }^{206} \mathrm{~Pb}$ isotopic compositions of gem corundum from (a) the amphibolite-type ruby localities, (b) the marble-type ruby localities, and (c) the localities of metamorphic blue sapphire measured in this study.

No correlations between $\mathrm{Sr}$ and $\mathrm{Pb}$ isotopic compositions are apparent for any of the sample suites analysed in this study (Figure 10).

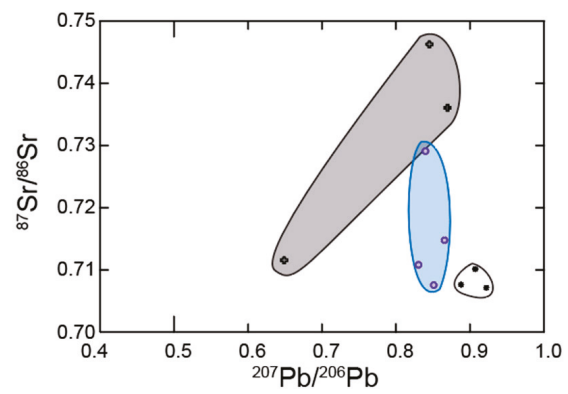

(a)

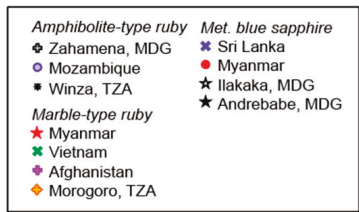

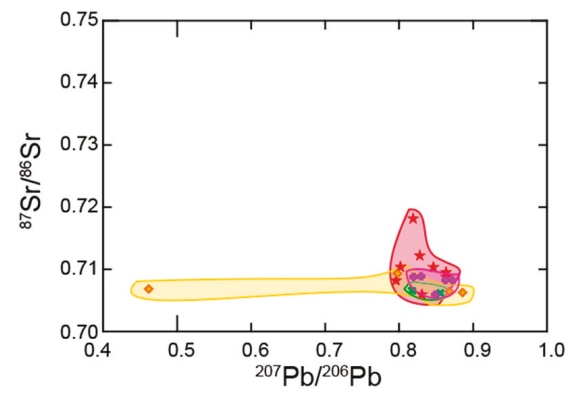

(b)

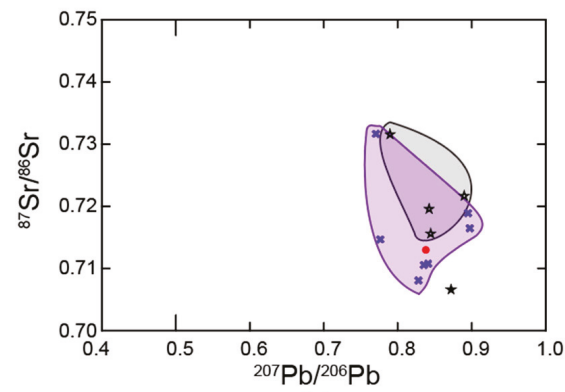

(c)

Figure 10. ${ }^{87} \mathrm{Sr} /{ }^{86} \mathrm{Sr}$ vs. ${ }^{207} \mathrm{~Pb} /{ }^{206} \mathrm{~Pb}$ ratios of (a) amphibolite-type rubies, (b) marble-type rubies, and (c) metamorphic blue sapphires measured in this study. Analytical uncertainties are less than the size of the plot symbols. Color of the fields correspond to the color of the symbols.

\section{Discussion}

\subsection{Trace Elements}

Quantitative data for the most commonly observed elements in ruby and sapphire- $\mathrm{Fe}, \mathrm{Cr}, \mathrm{Ti}$, V, and Ga-have been used by many authors (e.g., [8-10,15,33,59,60]) in attempts to determine gem 
corundum provenance. Figure 11 comprises a number of existing discrimination schemes, showing how our data compare with previously published data from the same localities. A number of classical and non-classical deposits are also plotted to place our data into worldwide context. A commonly used diagram is a logarithmic plot of wt $\%$ values $\mathrm{Cr}_{2} \mathrm{O}_{3} / \mathrm{Ga}_{2} \mathrm{O}_{3}$ versus $\mathrm{Fe}_{2} \mathrm{O}_{3} / \mathrm{TiO}_{2}$ (e.g., $[8,9,61]$ ).

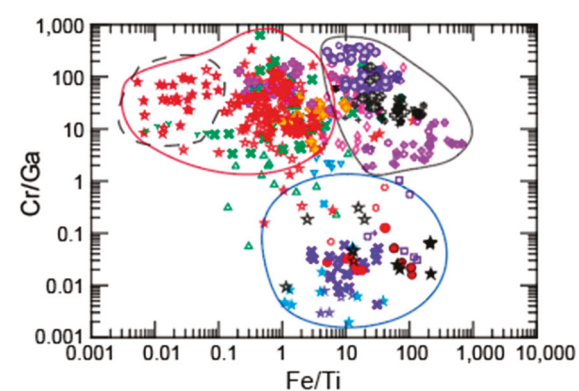

(a)

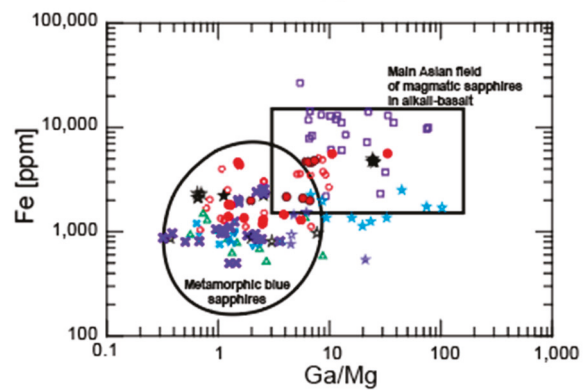

(b)

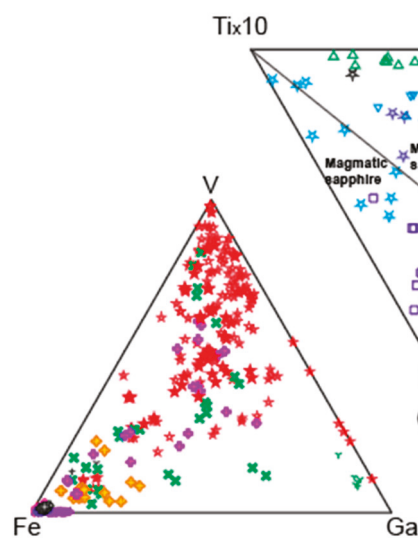

(d)
Amphibolite-type ruby

\& Zahamena, MDG

Ampanihy, MDG

- Namahaca, MOZ

* Winza, TZA

Marble-type ruby

$\star$ Various, MMR

* Luc Yen, Vietnam

- Jegdalek, AFG

$\diamond$ Morogoro, TZA

Met. blue sapphire

* Elahera, Sri Lanka

- Various, incl. Kin, MMR

- Baw Mar \& Kyatpyn, MMR

t llakaka, MDG

$\star$ Andrebabe, MDG

\section{Published data:}

Ruby

Metamorphic/Metasomatic

$Y$ John Saul, Kenya (skarn)

+ Umba River Valley, TZA

$r$ Tunduru, TZA

* Winza, TZA

- Andilamena, MDG

- Mozambique, Montepuez, various

$\checkmark$ Aappaluttoq, Greenland

Marble-type

\& Myanmar, various

Ł Mong Hsu, Myanmar

Basalt-type

- Australia, various

$\triangle$ Pailin, Cambodia

\& Bo Rai, Thailand

Blue sapphire

tr Andranondambo, MDG

tr Nigeria

+ Umba, TZA

- Mogok, Myanmar

* Ratnapura, LKA

口 Magmatic sapphires, various

$\triangle$ Argentina

$\nabla$ Russia

Figure 11. (a) Plot of $\mathrm{Cr} / \mathrm{Ga}$ (ppm) versus Fe/ Ti (ppm) (modified from [8]); fields are red = marble-type, black/dashed = Mong Hsu ruby [62], black = high Fe, and blue $=$ blue sapphires. (b) Fe (ppm) versus $\mathrm{Ga} / \mathrm{Mg}(\mathrm{ppm})($ after [10]); $(\mathrm{c}) \mathrm{Mg} \times 100-\mathrm{Fe}-\mathrm{Ti} \times 10$ ternary plot modified after [10]; and (d) Fe-V-Ga ternary plot (after [15]), and (e) Fe/20-V $\times 3-\mathrm{Ga} \times 3$ (after [28]) in gem corundum analyzed in this study. All data plotted are laser ablation inductively coupled plasma mass spectrometry (LA-ICP-MS) values. Additional data from $[10,23,25,33,42,43,59,60,62-69]$. 
Figure 11a is a plot of $\mathrm{Cr} / \mathrm{Ga}$ versus $\mathrm{Fe} / \mathrm{Ti}$ for the gem corundum suites analyzed in this study. Published datasets used for comparisons are exclusively LA-ICP-MS data, excluding electron microprobe (EMPA) data sets, because it has been shown that data derived from the different methods vary systematically for several elements [33]. In such a plot, marble-type rubies have $\mathrm{Cr} / \mathrm{Ga}>1$ and $\mathrm{Fe} / \mathrm{Ti}<6$, while high-Fe rubies, including amphibolite-type and basalt-type ruby, have $\mathrm{Cr} / \mathrm{Ga}>1$ and $\mathrm{Fe} / \mathrm{Ti}>6$. Blue sapphires, with measurable $\mathrm{Cr}$, have $\mathrm{Cr} / \mathrm{Ga}<1$ and $\mathrm{Fe} / \mathrm{Ti}>1$. Exceptions are two non-classical deposits, a suite of alluvial sapphires from Argentina [68], which have $\mathrm{Cr} / \mathrm{Ga}$ of up to $\sim 4$ and $\mathrm{Fe} / \mathrm{Ti}>0.1$, and a suite from the Ural mountains in Russia [67], with $\mathrm{Cr} / \mathrm{Ga} \sim 1-3$. High-Fe rubies, marble-type rubies, and blue sapphires thus fall into discrete fields with only minor overlap along the boundaries. However, different localities within the different deposit type groups overlap significantly. Blue sapphires, with the exception of the above-mentioned suites, overlap regardless of origin (metamorphic versus magmatic) and locality. Diagrams of Fe versus Ga/Mg and $\mathrm{Mg} \times 100-\mathrm{Fe}-\mathrm{Ti}$ $\times 10$, first introduced by [10], can be used to separate blue sapphires based on their geological origin. On such plots, the majority of our data of different metamorphic blue sapphire suites fall into the fields defined for metamorphic blue sapphires (Figure 11b,c). However, we note that several of our samples from Myanmar, specifically from the Baw Mar and Kyatpyn mines, and Andrebabe, MDG, fall into the "magmatic sapphire" field. In addition, a suite of blue sapphires from the northern part of the Baw Mar mine also plots as magmatic, despite the fact that these samples were classified as metamorphic based on standard gemological techniques, including inclusion studies and UV/vis spectroscopy [43]. On the basis of the geology at the mine site, these sapphires likely formed either directly in syenitic pegmatites or through the interaction of such pegmatites with surrounding marbles and/or gneisses [43]. In other words, trace element and gemological characteristics suggest that subgroups of sapphires classified as metamorphic formed in a metamorphic environment, but from magmatic rocks. As such, their trace elements reflect the magmatic nature of their host rock, while UV/vis spectroscopy and inclusions speak to their metamorphic origin. This illustrates that existing classification schemes for blue sapphire cannot account for the complex geological processes that form blue sapphires. However, both the Fe versus $\mathrm{Ga} / \mathrm{Mg}$ and $\mathrm{Mg} \times 100-\mathrm{Fe}-\mathrm{Ti} \times 10$ classification diagrams are useful in separating syenite-related metamorphic sapphire from Myanmar and Andrebabe, MDG, from those from Sri Lanka and Ilakaka, MDG. Within the respective fields, however, these populations overlap.

Among the marble-type rubies, only those from Mong Hsu, MMR [62], which is located about $250 \mathrm{~km}$ southeast of Mogok, are clearly distinguishable in Figure 11a, with much lower Fe/Ti values than those from the other localities. Rubies from Afghanistan analysed in this study have higher $\mathrm{Cr} / \mathrm{Ga}$ than those from Morogoro, TZA, however, both localities overlap with rubies from Myanmar and Vietnam. The overlap is somewhat less complete among the amphibolite-type rubies, with those from Winza, TZA, and Ampanihy, MDG, analyzed in this study plotting at slightly lower $\mathrm{Cr} / \mathrm{Ga}$ and higher Fe/Ti than those from Mozambique, the Andilamena area in Madagascar, Greenland, and basalt-type rubies from Cambodia and Thailand. However, only the basalt-type population from the New England Gem field, Australia, displaying relatively high $\mathrm{Fe} / \mathrm{Ti}$ and low $\mathrm{Cr} / \mathrm{Ga}$ indicative of igneous origin [8], does not overlap with other deposits. This deposit is thought to have experienced magmatic-metasomatic inputs in its genesis [66]. When plotting the same data on a ternary diagram depicting Fe-V-Ga concentrations (Figure 11d) after [15], high-Fe rubies all plot at the Fe-apex, while the low-Fe marble-type rubies show a wider distribution. Myanmar rubies plot at higher $\mathrm{V}$; those from Morogoro, TZA, plot close to the Fe-apex; and rubies from Afghanistan and Vietnam overlap both suites. While basalt-type rubies overlap with amphibolite-type ruby here, they are easily separated from other high-Fe rubies using $\mathrm{Mg}$ [5]. Smith et al. [28] modified the Fe-V-Ga ternary diagram to $\mathrm{Fe} / 20-\mathrm{V} \times 3-\mathrm{Ga} \times 3$ to provide more resolution in the Fe-apex area of the plot (Figure 11e). This approach allows the distinction of the basalt-hosted rubies from most rubies of metasomatic and metamorphic origin, but there is still significant overlap for the various localities. Only rubies from Winza, TZA, show minimal overlap. 
The overlap of samples from the different localities of both ruby groups examined here, as well as that among metamorphic blue sapphires, in commonly-used discrimination schemes, illustrates that, while they are useful in distinguishing rubies of different geological deposit types, they are not very effective in distinguishing between different localities of the same deposit type.

The broader spectrum of quantitative trace element data we were able to obtain using the ablation and measurement parameters detailed in Section 2.2.1 now makes it possible to evaluate the use of additional elements as provenance discriminators that have not been yet measured consistently. Amphibolite-type rubies in particular show a much broader spectrum of trace elements consistently $>$ LOQ, while such additional elements are fairly limited for the marble-type rubies. The main reason for this is very likely the (on average) higher clarity of the marble-hosted rubies analysed in this study (Figure A2). This suggests that the potential of using such low abundance elements is fairly limited, at least with the current sensitivity of the LA-ICP-MS method, because the main goal of developing a geochemical fingerprint is the determination of provenance for high-quality gemstones. However, the elements $\mathrm{Ni}, \mathrm{Zn}$, and $\mathrm{Pb}$ are consistently > LOQ for all corundum analysed in this study, regardless of geologic origin or clarity, and were thus included in the discrimination evaluation. Of these elements, $\mathrm{Pb}$ has proven to be ineffective as discriminator of geographic locality, at least for the deposit types and localities analysed in this study as contents between the analysed suites overlap significantly. Ni, however, shows good discriminatory power for the separation of different localities of amphibolite-type ruby (Figure 12a), and, in conjunction with Ti and V, defines discrete fields for rubies from Winza, TZA, Mozambique, Zahamena, MDG, and Amphanihy, MDG. Rubies from Greenland, however, have a wide range of $\mathrm{Ni}$, $\mathrm{Ti}$, and $\mathrm{V}$ contents, resulting in significant overlap on a $\mathrm{Ni} \times 100-\mathrm{Ti}-\mathrm{V} \times 10$ plot (Figure 12a). Some of this overlap can be resolved by further plotting the data on a binary Ga versus $\mathrm{V}$ plot (Figure 12b), thus effectively separating the Greenland rubies from those from Madagascar; minor overlap of Mozambique and Greenland persists, however.

\section{Amphibolite-type ruby \\ ¿ Zahamena, MDG \\ \& Ampanihy, MDG \\ - Namahaca, MOZ \\ * Winza, TZA \\ Published data: Metamorphic/Metasomatic \\ + Umba River Valley, TZA \\ Y Tunduru, TZA \\ Winza, TZA}

t5 Andilamena, MDG

- Mozambique, Montepuez, various

Aappaluttoq, Greenland

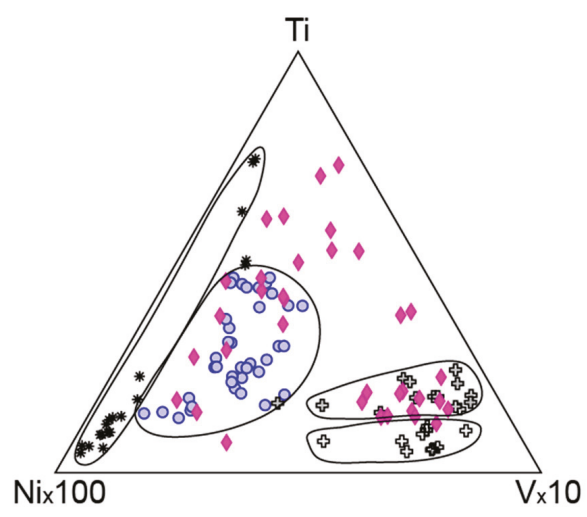

(a)

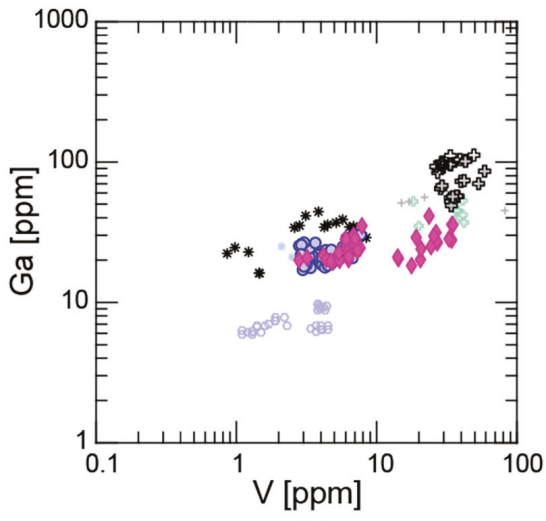

(b)

Figure 12. (a) Ternary diagram of $\mathrm{Ni} \times 100-\mathrm{Ti}-\mathrm{V} \times 10$ for amphibolite-type rubies analyzed using LA-ICP-MS in this study. Greenland data are taken from [12]. (b) Binary plot of Ga (ppm) versus V (ppm) abundances in amphibolite-type rubies analyzed in this study. Additional data from [23,25,59]. 
On the Ga versus V plot, rubies from the Andilamena region in Madagascar [59] plot at slightly lower Ga values than those analyzed in this study. More notably, rubies from Mozambique analyzed by [23] have significantly lower Ga contents than rubies from Mozambique in this study. Both these studies used matrix-matched synthetic corundum standards as calibration materials, while in this study, NIST612 was used, resulting in more accurate analyses for their data. These differences emphasize the importance of using matrix-matched standards for accurate LA-ICP-MS analyses, and also illustrate that, for effective comparative studies, the same LA-ICP-MS system and reference materials should be used.

For the discrimination of different localities among marble-type rubies, none of the additional trace elements obtained in this study add further discriminatory power. Instead, a combination of the most abundant trace elements in corundum delivers the best results (Figure 13). A binary plot of V versus $\mathrm{Cr}$ roughly divides rubies from Myanmar; Morogoro, TZA; and Afghanistan into separate fields with only minor overlap (Figure 13a), while a binary plot of Fe versus V clearly separates the Myanmar rubies analyzed in this study from those from Morogoro, TZA (Figure 13b). Ternary diagrams of $\mathrm{Fe} / \mathrm{Mg} \times 2-\mathrm{Cr} / \mathrm{Ti}-\mathrm{V} / 10$ and $\mathrm{V}-\mathrm{Cr} / 10-\mathrm{Ti}$ archive similarly passable separations of Myanmar; Morogoro, TZA; and Afghanistan rubies (Figure 13c,d). However, rubies from Vietnam have very variable trace element abundances and overlap with all other marble-type localities analysed in this study. Previously published data of Myanmar rubies [33,62] agree reasonably well with data from this study, however, the data presented here are more variable. 


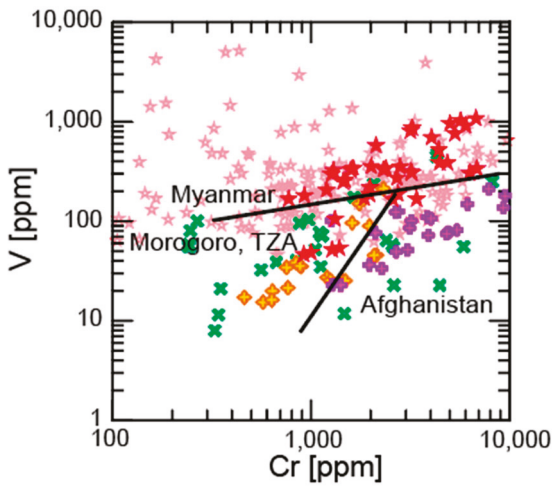

(a)

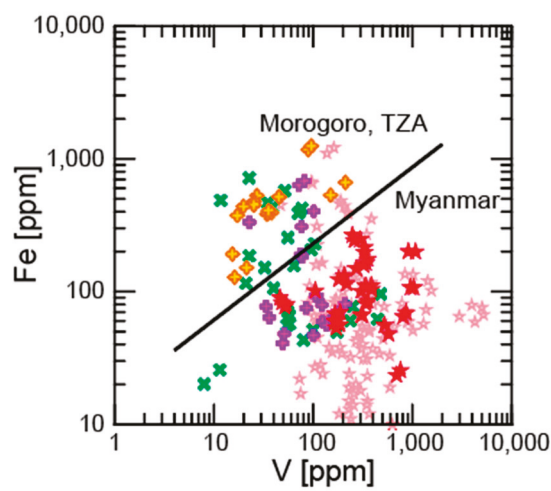

(b)

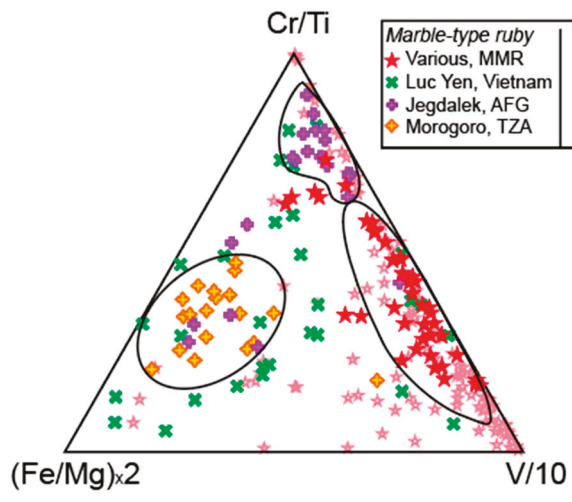

(c)

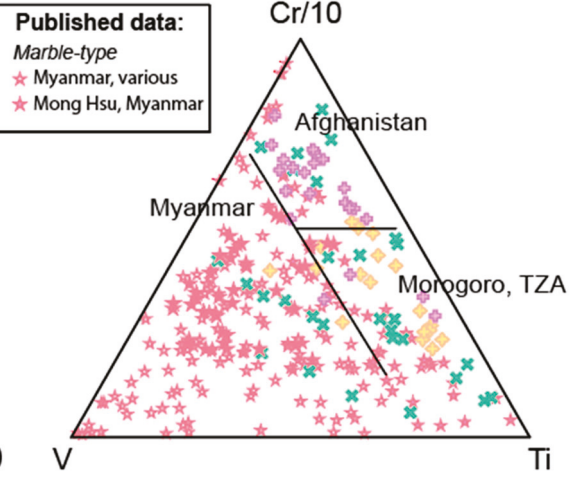

(d)

Figure 13. (a) Binary plot of $\mathrm{V}$ (ppm) versus $\mathrm{Cr}(\mathrm{ppm})$, (b) binary plot of Fe (ppm) versus $\mathrm{V}$ (ppm), (c) ternary diagram of $\mathrm{Fe} / \mathrm{Mg} \times 2-\mathrm{Cr} / \mathrm{Ti}-\mathrm{V} / 10$, and (d) ternary diagram of $\mathrm{V}-\mathrm{Cr} / 10-\mathrm{Ti}$ for marble-type rubies analyzed using LA-ICP-MS in this study. Fields are drawn by eye. Additional data from $[33,62]$.

As for marble-type ruby, none of the additional elements obtained in this study added obvious further discriminatory power for the separation of different localities of metamorphic blue sapphire. However, $\mathrm{Cr}$, which is often reported close to or below the LOD for samples from the localities studied here $[10,70]$, is consistently above LOQ and shows potential as an additional discriminatory element. A binary plot of Mg versus V separates sapphires from Myanmar and Andrebabe, MDG, from sapphires from Sri Lanka and Ilakaka, MDG. In addition, syenite-related metamorphic sapphires have lower Mg $(<20 \mathrm{ppm})$ and V $(<4 \mathrm{ppm})$. A bivariate plot of V versus $\mathrm{Cr} \times$ Ti separates Sri Lanka and Ilakaka, MDG, sapphires with only minor overlap (Figure 14). Myanmar and Andrebabe, MDG, with magmatic trace element signatures, have low $\mathrm{Cr} \times \mathrm{Ti}$. Using a bivariate diagram of $\mathrm{V}$ versus $\mathrm{Ga} / \mathrm{Ti}$, the Andrebabe, MDG sapphires can be separated from both the Myanmar and the overlapping Sri Lanka and Ilakaka, MDG sapphires (Figure 14c). Previously published data for sapphires from Andranondambo, MDG [59] show significant overlap with sapphires from Sri Lanka and Ilakaka, MDG. Trace element compositions previously published for Myanmar sapphires [42,43] are more variable than those analyzed in this study. Metamorphic sapphires from Russia [67] and Argentina [68] are easily distinguished from the other localities by their high $\mathrm{Cr} \times \mathrm{Ti}$ and low and high V contents, respectively (Figure 14b). 


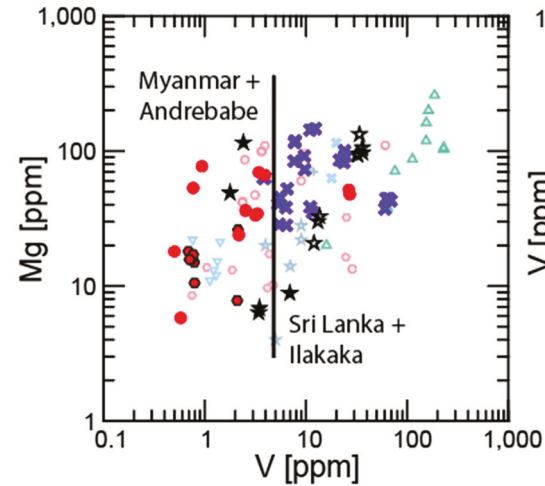

(a)

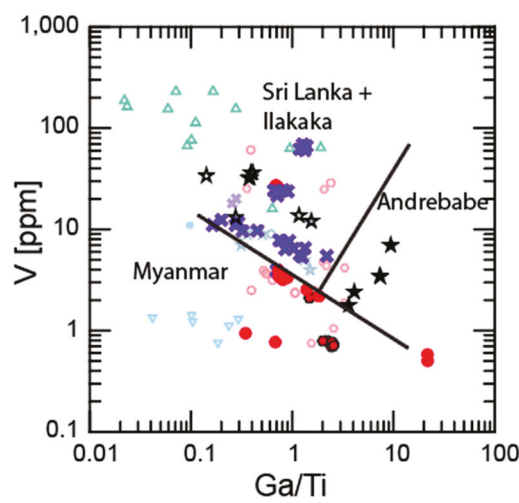

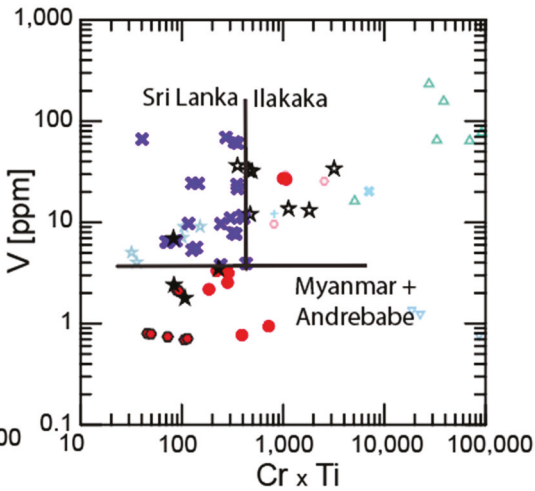

(b)

(c)

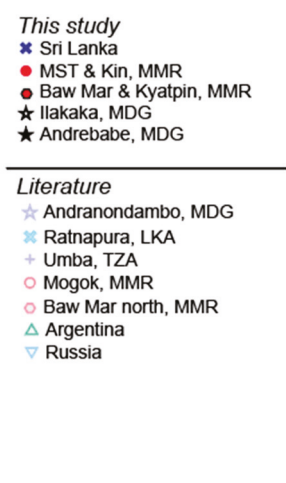

This study

Sri Lanka

MST \& Kin, MMR

Baw Mar \& Kyatpin, MMR

llakaka, MDG

iterature

Andranondambo, MDG

Ratnapura, LKA

Umba, TZA

Baw Mar north, MMR

Argentina

Russia

Figure 14. Binary plots of (a) Mg (ppm) versus V (ppm), (b) V (ppm) versus $\mathrm{Cr} \times \mathrm{Ti}(\mathrm{ppm})$, and (c) V versus $\mathrm{Ga} / \mathrm{Ti}$ for metamorphic blue sapphires analyzed using LA-ICP-MS in this study. Fields are drawn by eye. Additional data from $[10,42,43,59]$.

The results show that distinguishing between blue sapphires from Sri Lanka and Myanmar using trace elements is easily accomplished. Sapphires from Madagascar, however, show extensive chemical overlap with sapphires from other localities, which can be somewhat well-resolved for the small number of samples analyzed here. Madagascar has a vast number of ruby and sapphire deposits that are most often secondary deposits with stones that have formed in a variety of different geological settings [27]. As such, they are not only characterized by very variable trace element characteristics, but also a strong gemological diversity, and are known to overlap (sometimes significantly) with metamorphic sapphires from all other major sources [4].

Multivariate statistical analysis, including principal component analysis (PCA) and linear discriminant analysis (LDA), is a tool to identify patterns and relationships between multiple variables simultaneously and can, potentially, increase the reliability of origin determination as well as detect elements with potential discriminatory power. Both PCA [59,71] and LDA [59] have been successfully applied to rubies and sapphires of different geological deposit types; here, we apply both approaches to visualise the compositional differences for samples of the same geological type from different localities. Calculation of robust quantitative discriminants in this study is restricted by the modest 
population sizes, so we use PCA and LDA to qualitatively determine which elements might have discriminatory value.

To this end, we applied LDA to our online LA-ICP-MS dataset, using the software R (for details on $\mathrm{R}$ runstreams see Supplementary Material S4). LDA is a dimension reduction technique that defines linear discriminants that maximize the "distance" between the means of pre-defined classes. Data for rubies from Greenland [12] were included in the calculations for the amphibolite-type group, because they were collected on the same system using the same ablation and measurement conditions. LDA solutions are derived using the full dataset as calibration data, and the classification error (CE) of the method is determined by testing the calibration data on the method by the following formula:

$$
\mathrm{CE}=\text { number of incorrect classifications/total number of samples } \times 100 \%
$$

As the CE for the calibration data of the method it calibrated will result in an overly optimistic assessment of classification success or failure, solutions are assigned a method uncertainty by K-fold cross validation. This is conducted by subdividing the sample sets into five random folds with $80 \%$ of the data classified as "calibration" data, and the remaining 20\% as "validation" data. An LDA solution is derived using the calibration set of a single fold, and tested with its respective validation dataset. This is conducted upon all five folds, and the calculated error rates for the folds are then averaged and taken as the method uncertainty.

For the amphibolite-type deposits, LDA was applied iteratively to the datasets using combinations of chemical variables; through this process, we narrowed the number of most useful variables down to four $-\mathrm{V}, \mathrm{Fe}, \mathrm{Mg}$, and $\mathrm{Ni}$ - by excluding those elements that only reproduce existing discrimination power of others. This result confirms the potential of $\mathrm{Ni}$ as an element with discriminatory power for the amphibolite-type deposits evaluated in this study. To assess its influence, an LDA solution using only V, Fe, and Mg was applied (Figure 15a). This solution results in some overlap of rubies from Ampanihy, MDG; Winza, TZA; and Greenland, as well as some overlap of rubies from Greenland with rubies from Mozambique, similar to that observed using a ternary diagram of Ni $\times 100-\mathrm{Ti}-\mathrm{V} \times 10$ (Figure 12a). By adding Ni to the solution, only the overlap of Greenland with Mozambique remains (Figure $15 \mathrm{~b}$ ), and the CE is minimized at $\sim 13.7 \%$. The average K-fold ( $n=5$ folds) cross-validation error of $17.33 \pm 11.93(2 \sigma)$ is identical for both solutions (Supplementary Material S5).

For marble-type deposits, an LDA solution using seven elements-V, Fe, Ga, Mg, $\mathrm{Ti}, \mathrm{Cr}$, and $\mathrm{Zr}$-gives the best discrimination for the different localities studied here. While Zr shows no obvious discriminatory power in elemental plots, it influenced the LDA calculations positively. Bivariate plots of the linear discriminants (LDs) show a good separation of Morogoro, TZA and Myanmar (Figure 15c,d), similar to the discrimination achieved by plotting elemental abundances against each other (e.g., Figure 13b,c). In addition, the LDA solution results in a better discrimination of Vietnam rubies from Morogoro, TZA (Figure 15c) and from Afghanistan rubies (Figure 15d), which otherwise overlap significantly in the graphical bivariate discrimination schemes using elemental abundances (Figure 13). However, the chemical overlap is still significant with a CE of $\sim 21 \%$ and a similar average K-fold ( $n=5$ folds) cross-validation error of $19.09 \pm 11.85(2 \sigma)$. 


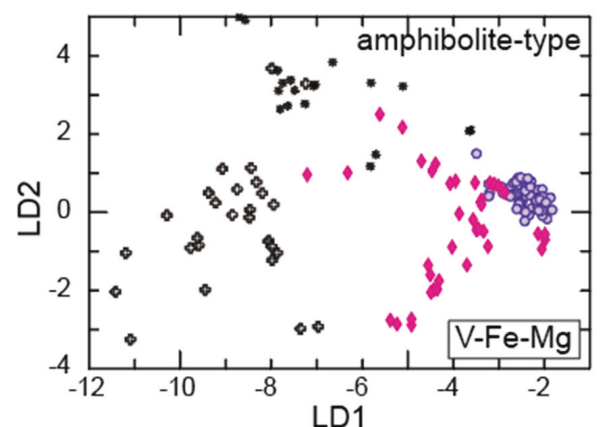

(a)

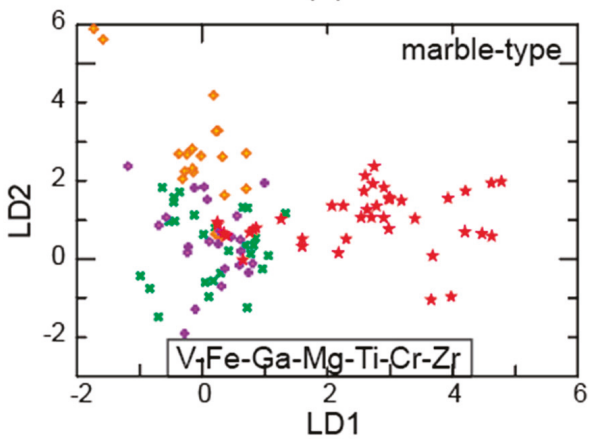

(c)

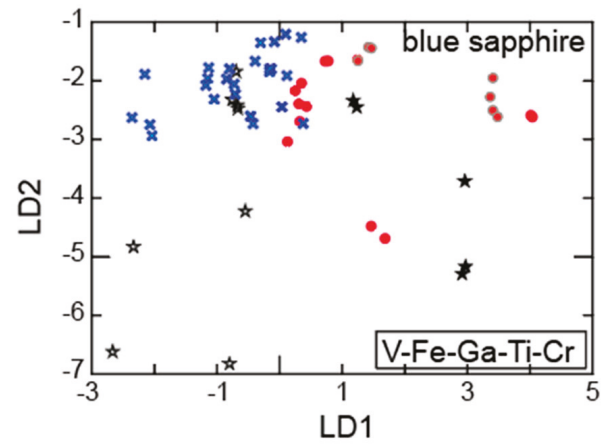

(e)

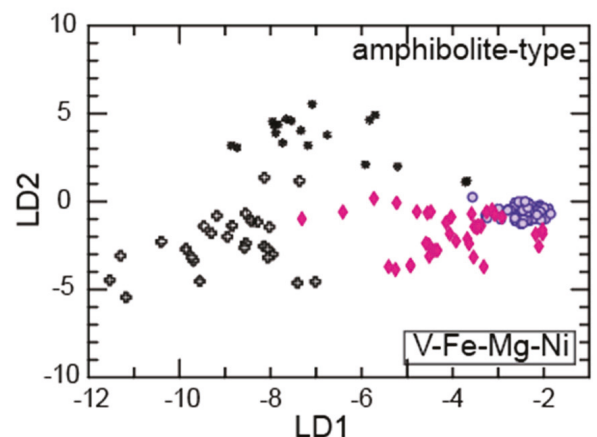

(b)

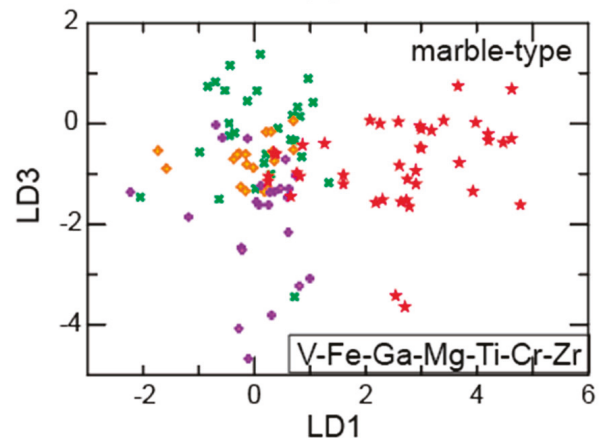

(d)

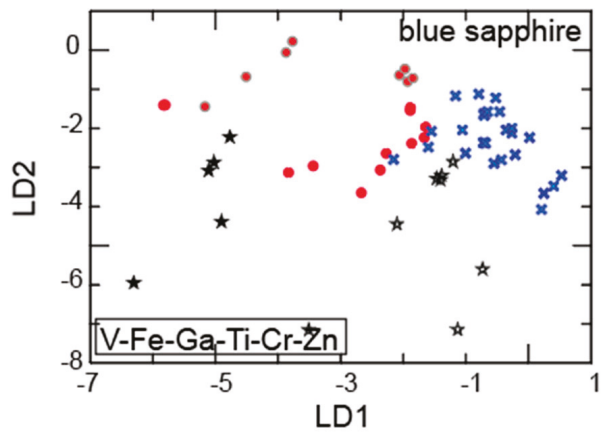

(f)

Figure 15. Linear discriminant analysis (LDA) solution for (a), (b) amphibolite-type rubies; (c), (d) marble-type rubies; and (e), (f) metamorphic blue sapphires. Elements used in method calibration are inset on each figure. Symbols as in Figure 11.

For application of LDA to the metamorphic blue sapphires, the Myanmar sapphires were separated into two groups based on the inference that they have discrete geological origins, resulting in five overall groups including the other locations. The best results were obtained using the six elements $\mathrm{V}, \mathrm{Fe}, \mathrm{Ga}, \mathrm{Ti}$, $\mathrm{Cr}$, and $\mathrm{Zn}$. Because $\mathrm{Zn}$ shows no obvious discriminatory power in elemental plots, an LDA solution using only $\mathrm{V}, \mathrm{Fe}, \mathrm{Ga}$, Ti, and $\mathrm{Cr}$ was also applied. The results show a clear improvement with the inclusion of $\mathrm{Zn}$, reducing the overlap between sapphires from Sri Lanka and Ilakaka, MDG (Figure 15e,f). The one obvious outlier of the Mogok Stone Tract (MST) \& Kin, MMR group behaves similar in the 
discrimination schemes using elemental abundances (Figure 14), reflecting a syenite-related origin. Whether this indicates that syenite-related samples are also found at the Kin mine or if the sample was mislabeled is unclear. The CE for the LDA solution calibrated on the elements $\mathrm{V}, \mathrm{Fe}, \mathrm{Ga}$, Ti, and $\mathrm{Cr}$ is $\sim 27 \%$, and $\sim 18.6 \%$ for the solution calibrated on the elements $\mathrm{V}, \mathrm{Fe}, \mathrm{Ga}, \mathrm{Ti}, \mathrm{Cr}$, and $\mathrm{Zn}$, showing a clear improvement of the classification through the addition of $\mathrm{Zn}$. No K-fold cross-validated error is calculated here owing to the small sample sets, which result in erratic calculated error rates, being prone to over- or underestimation of the true success or failures of the LDA methods. This is indicated by the large standard deviation of the average cross-validation error of the amphibolite-type group, which is the largest dataset in this study.

\section{Comparison of Online and Offline Laser Ablation Approaches}

Aside from a small number of elements that substitute for $\mathrm{Al}^{3+}$ in the crystal structure (e.g., $\mathrm{Mg}, \mathrm{Cr}$, $\mathrm{Fe}, \mathrm{V}, \mathrm{Ti}$, and $\mathrm{Ga}$ ), trace elements in gem corundum are present as mineral inclusions or as constituents in fractures, and their absolute trace element abundances are primarily a function of impurity density [12]. Therefore, the larger sampling volumes of the offline ablation approach result in more varied trace element characteristics that correspond to the presence of nano- to micrometer-sized mineral and fluid inclusions characteristic of the ruby or sapphire forming environment. Such variations are evident in the differences in $\mathrm{Ta} / \mathrm{Nb}_{\mathrm{N}}, \mathrm{U} / \mathrm{Pb}_{\mathrm{N}}, \mathrm{Th} / \mathrm{U}_{\mathrm{N}}$, and $\mathrm{Zr} / \mathrm{Hf}_{\mathrm{N}}$ ratios between online-and offline-ablated material, with the former showing variations for different localities and the latter showing complete overlap for all localities and deposit types (Figure A1a-l). Some of the trace element characteristics of the offline-ablated material show differences that could be utilized for geographic origin determination of different localities of similar deposit types, including, for example, the $\mathrm{Eu} / \mathrm{Eu}^{*}>1$ of Mozambique rubies (Figure $4 \mathrm{a}$ ), and the $\mathrm{Sr} / \mathrm{Sr}^{*}<1$ for Myanmar rubies. Some suites are also characterized by the absence or certain trace elements, $\mathrm{Sr}$, for example, is below $<$ LOQ in all rubies from Zahamena, MDG, and Cs in sapphires from Myanmar and Andrebabe, MDG. Most of these trace element characteristics, however, are specific to a certain deposit, and as such, cannot be applied universally. In addition, the number of samples ablated offline is small, and some characteristics observed may well be a result of low sample numbers. Owing to the small sample set sizes, we do not apply LDA to explore the data for useful chemical variables, as the derived discriminants may be skewed by the-potentially—non-representative datasets. Given the chemical variation within this modest sample set, outliers weighted more strongly on the solution than they would for a larger dataset. Instead, as a preliminary check, we applied PCA to the offline-ablated trace element datasets to identify possible chemical discriminants for provenance, associated with chemical variance. However, no clear discrimination is apparent in principal component space for the present datasets. Therefore, while some of the trace element characteristics observed may provide additional information valuable for provenance, at this time, they have little potential for the development of a robust geochemical fingerprint of provenance for gem corundum. As more data are acquired, the application of LDA and PCA to variable selection and class discrimination may be more appropriate.

\subsection{Radiogenic Isotopes}

As demonstrated in Section 4.1, geographic origin determination using trace elements is useful in distinguishing between deposits of different geological deposit types, however, to distinguish between deposits of similar geological type, but different locality is challenging. Similar challenges are faced when using classical gemological techniques [4]. In this study, we obtained $\mathrm{Sr}$ and $\mathrm{Pb}$ isotopic compositions for ruby and blue sapphire from a variety of different localities of three different geological groups to explore the potential of using isotopic tracers to constrain geographical origin. We evaluated the usefulness of all combinations of isotopic ratios and trace elements, and a selection of the most useful discriminatory plots is shown in Figure 16. 


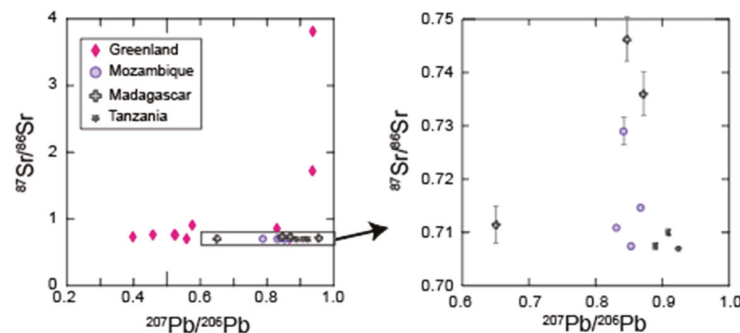

(a)

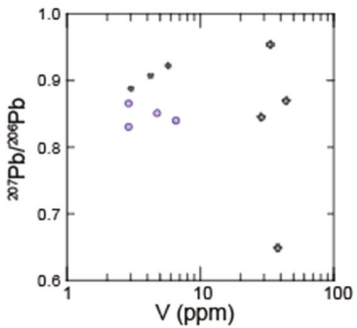

(c)

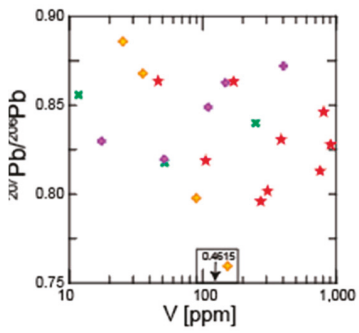

(f)

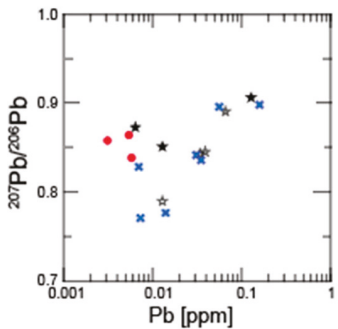

(i)

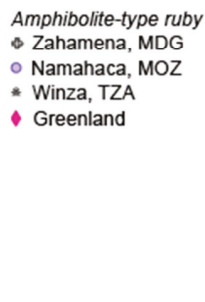

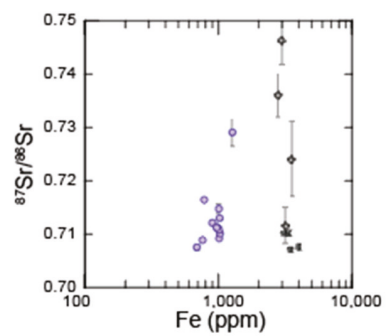

(b)

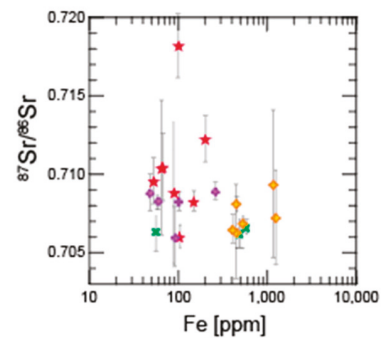

(e)

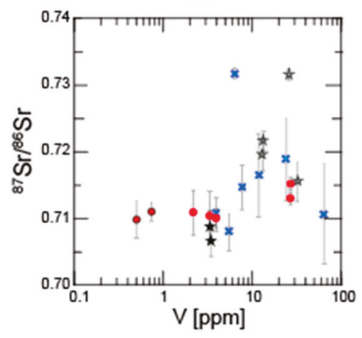

(h)

Met. blue sapphire * Elahera, Sri Lanka

- Various, incl. Kin, MMR

- Baw Mar \& Kyatpyn, MMR

\& llakaka, MDG

$\star$ Andrebabe, MDG

Marble-type ruby

$\star$ Various, MMR

* Jegdalek, AFG

$\diamond$ Morogoro, TZA

Figure 16. Radiogenic isotope characteristics of rubies and blue sapphires analyzed in this study. (a) ${ }^{87} \mathrm{Sr} /{ }^{86} \mathrm{Sr}$ versus ${ }^{207} \mathrm{~Pb} /{ }^{206} \mathrm{~Pb}$, (b) ${ }^{87} \mathrm{Sr} /{ }^{86} \mathrm{Sr}$ versus $\mathrm{Fe}(\mathrm{ppm})$, and (c) ${ }^{207} \mathrm{~Pb} /{ }^{206} \mathrm{~Pb}$ versus $\mathrm{V}$ (ppm) of amphibolite-type rubies. (d) ${ }^{87} \mathrm{Sr} /{ }^{86} \mathrm{Sr}$ versus ${ }^{207} \mathrm{~Pb} /{ }^{206} \mathrm{~Pb},(\mathbf{e}){ }^{87} \mathrm{Sr} /{ }^{86} \mathrm{Sr}$ versus $\mathrm{Fe}(\mathrm{ppm})$, and (f) ${ }^{207} \mathrm{~Pb} /{ }^{206} \mathrm{~Pb}$ versus $\mathrm{V}$ (ppm) of marble-type rubies. (g) ${ }^{87} \mathrm{Sr} /{ }^{86} \mathrm{Sr}$ versus ${ }^{207} \mathrm{~Pb} / 206 \mathrm{~Pb},(\mathbf{h}){ }^{87} \mathrm{Sr} /{ }^{86} \mathrm{Sr}$ versus $\mathrm{V}$ (ppm), and (i) ${ }^{207} \mathrm{~Pb} /{ }^{206} \mathrm{~Pb}$ versus $\mathrm{Pb}(\mathrm{ppm})$ of metamorphic blue sapphires. Where error bars are absent, uncertainties are smaller than the symbols.

The discrimination of rubies from different amphibolite-type deposits is fairly straight-forward using trace elements obtained via online LA-ICP-MS, however, some chemical overlap remains between rubies from Greenland with those from Mozambique (Figures 12 and 15a,b). This overlap can be resolved using both $\mathrm{Sr}$ and $\mathrm{Pb}$ isotopes, because Greenland rubies have been shown to be much more 
radiogenic than rubies from Mozambique, spanning a wide range of compositions ([12], Figure 16a). It is clear that these very distinct differences in isotopic compositions are largely because of the vast difference in formation age for the Greenland and Mozambique ruby deposits ( $\mathrm{Pb}-\mathrm{Pb}=\sim 2686 \mathrm{Ma}$ [12] and $\sim 550 \mathrm{Ma}$ [72], respectively).

Therefore, it is unsurprising that rubies from Zahamena, MDG and Winza, TZA that formed during the Pan-African orogeny (750-450 Ma) [20] have radiogenic isotope compositions more similar to those of Mozambique, with some minor overlap between the different localities (Figure 7b). Nevertheless, when plotting $\mathrm{Sr}$ and $\mathrm{Pb}$ isotopic compositions against each other or against trace elements, for example, Fe or V, the different localities fall into discrete fields (Figure 16a-c), demonstrating the usefulness of Sr and $\mathrm{Pb}$ isotope ratios for determining the geographic origin of different amphibolite-type deposits.

As shown in Section 3.2.2, the range in Sr isotopes of marble-hosted rubies is much narrower than those of the analysed suites of amphibolite-type ruby, and the overlap among the different localities of marble-type deposits is greater than that of amphibolite-type deposits (Figure 7c). While Myanmar and Afghanistan rubies tend to have more radiogenic Sr compositions than rubies from Vietnam or Morogoro, TZA, the overlap precludes any usefulness such trends might provide, even when combining Sr isotopic ratios with trace elements (e.g., ${ }^{87} \mathrm{Sr} /{ }^{86} \mathrm{Sr}$ versus Fe, Figure 16e). This overlap of the different localities is even more complete for the Pb isotopic compositions (Figures $9 \mathrm{~b}$ and $16 \mathrm{~b}$ ).

Similar to the marble-type rubies, metamorphic blue sapphires from different localities show significant overlap. Myanmar and Andrebabe, MDG sapphires generally show less radiogenic isotopic ratios than those from Sri Lanka and Ilakaka, MDG. This could be because of differences in the geological formation of the different deposits and differences in the age and lithology of their source components. In the MST, gem corundum of multiple geological origins was found and is thought to have formed either in connection with intrusions of granitoid rocks (leucogranites and hornblende syenites; between 35 and $23 \mathrm{Ma}$ [62,73]) or regional metamorphism (sillimanite-grade high-temperature metamorphism; from at least 43 to $29 \mathrm{Ma}$ [74]) [20]. The Elahera deposit in Sri Lanka, on the other hand, is an exoskarn deposit formed by the interaction of pegmatitic fluids with dolomitic marble [75]. The Ilakaka deposit in Madagascar is a secondary deposit and carries a wide variety of different sapphires, likely derived from several distinct geological formations. The sources are thought to be multiple and associated with granulite-facies metamorphism [20]. To date, nothing is known about the geology of the Andrebabe deposit in Madagascar, however, the trace element characteristics indicate an association with magmatic rocks. Another explanation could be different formation ages, because sapphires from Myanmar are thought to have formed during the Cenozoic Himalayan orogeny (e.g., zircon $\mathrm{U}-\mathrm{Pb} \sim 25 \mathrm{Ma}$ for foliated syenite associated with sapphire mineralization [76]), while the sapphires from Sri Lanka and Madagascar formed during the Pan-African orogeny $(750-450 \mathrm{Ma})[20,27]$. The observed overlap, complete for Sri Lanka and Ilakaka, MDG sapphires, can only partly be resolved when plotting $\mathrm{Sr}$ or $\mathrm{Pb}$ isotopic ratios against trace elements (Figure $16 \mathrm{~g}-\mathrm{i}$ ), and the use of $\mathrm{Sr}$ and $\mathrm{Pb}$ isotopic compositions for geographic origin determination has proven to be relatively ineffective. No PCA solution yielded positive results.

\section{Conclusions}

Using an LA-ICP-MS method that combines a large spot size $(285 \mu \mathrm{m})$ with a high repetition rate $(20 \mathrm{~Hz})$, we obtain a broader spectrum of quantitative trace element data than that obtained with more conventional approaches (spot size $\sim 50 \mu \mathrm{m}$, repletion rate of $5-10 \mathrm{~Hz}$; for example, [23,62]). This permits the determination of up to 26 elements at levels above the limit of quantification (LOQ) in some rubies and sapphires. Using elemental discrimination schemes and linear discriminant analysis (LDA), we have shown that elements other than the conventional Mg, Ti, V, Cr, Fe, and $\mathrm{Ga}$-which can substitute for $\mathrm{Al}^{3+}$ in the corundum crystal lattice-have the potential to be of use in geographic origin determination. The discrimination of the different localities of amphibolite-type ruby analyzed in this study is improved using Ni. For marble-type ruby, LDA results show that adding Zr positively influences the discrimination of the different marble-type localities. For metamorphic blue sapphire, 
the discrimination of corundum from the different localities analyzed in this study is improved by $\mathrm{Zn}$ concentrations. In addition, $\mathrm{Cr}$, which is often below the LOD for blue sapphires from the localities analyzed in this study using conventional methods [10], positively impacts the discrimination. While the discrimination of the different localities of the three different deposit groups is fairly good using LDA, some population overlap persists, particularly among the marble-type rubies and blue sapphires. This is not surprising owing to the very similar geological conditions of formation. The larger spot size of the LA-ICP-MS method used here precludes it from use in gemological laboratories on precious stones; however, our results indicate directions of focus for future method development. Trace element characteristics of the offline-ablated material show some differences that could be utilized for geographic origin determination of different localities of similar deposit types; however, the majority of these are specific to a certain deposit and, as such, may not be applied universally. Sr and $\mathrm{Pb}$ isotope compositions, obtained using offline laser ablation sampling followed by TIMS, have only limited potential for geographic origin determination at this time. Measured ${ }^{87} \mathrm{Sr} /{ }^{86} \mathrm{Sr}$ and $\mathrm{Pb}$ isotope ratios of rubies from different amphibolite-type deposits show distinct ranges and separate fields on bivariate plots that are positive indicators of discrimination. For marble-type rubies and metamorphic blue sapphires, however, different geographic origins overlap.

Overall, our results show that the discrimination of different geographic regions of similar geological deposit types using trace elements is fairly simple for amphibolite-type rubies, while it is much more challenging for marble-type rubies and metamorphic sapphires. As more data from these localities are acquired and analyzed, discriminants can be refined and developed further. However, adding additional localities might lead to more significant overlap. Similarly, radiogenic isotopes show discriminatory potential for amphibolite-type rubies, but not marble-type rubies or metamorphic blue sapphires, likely owing to significant isotopic variability in the different components that combine to form these gems. Our results re-emphasize both the promise of using combined isotopic and trace element fingerprints and the challenge of geographic origin determination, emphasizing the need for a more powerful discriminatory tool than can be formulated using current technology.

Supplementary Materials: The following are available online at http://www.mdpi.com/2075-163X/10/5/447/s1, Table S1: Elemental concentrations (ppm) of spot analyses of rubies and blue sapphires analyzed by LA-ICP-MS; Table S2: Trace element concentrations (ppm) in NIST SRM 614, NIST SRM 616, and corundum standard 02-1032-B analyzed by LA-ICP-MS; Table S3: Trace element abundances (ppm) and Sr and Pb isotopic ratios determined using offline LA followed by solution ICP-MS and TIMS for amphibolite- and marble-type ruby and metamorphic blue sapphires analyzed in this study. Quantification is achieved via normalization to the weight loss of the corundum crystals during ablation; Supplementary Material S4: LDA and PCA methodology and R runstreams, Supplementary Material S5: Summary of LDA results on LA-ICP-MS data, including error calculations, Supplementary Material S6: Sample classification codes.

Author Contributions: M.Y.K. performed the analyses, interpreted the results of the analyses, and wrote the manuscript. D.G.P. and M.Y.K. were responsible for the conception of this project. M.F.H. performed the statistical analyses and assisted with writing parts of the manuscript. Y.L. and C.S. provided technical input and assisted with the analyses. A.J.F. provided geology background and additional samples. All authors have read and agreed to the published version of the manuscript.

Funding: This research was primarily funded by a CERC award to Graham Pearson. The work was supported in part by the GIA R.T. Liddicoat Postdoctoral Fellowship.

Acknowledgments: The authors would like to thank Aaron Palke, of the Gemological Institute of America, for providing insight on sample gemology and fruitful discussions, and Sarah Woodland for assisting with measurements. In addition, the authors thank George Harlow, of the American Museum of Natural History, for providing samples from Myanmar, Vietnam, and Madagascar. Thank you to the three anonymous reviewers and the editors, Lin Sutherland and Khin Zaw, for providing constructive comments that improved this paper.

Conflicts of Interest: The authors declare no conflict of interest. 
Appendix A

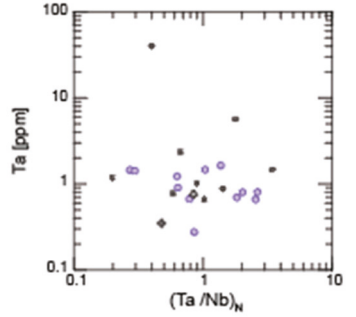

(a)

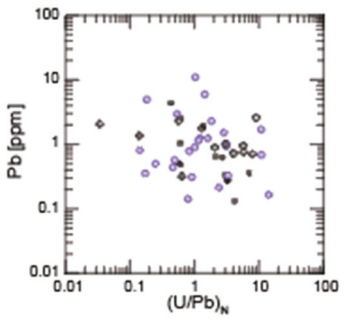

(d)

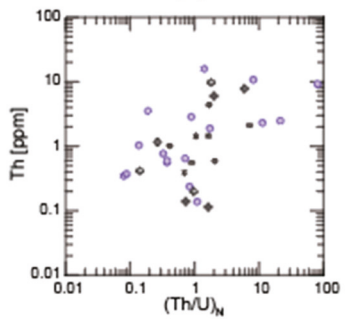

(g)

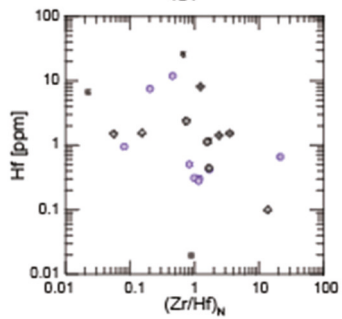

(j)

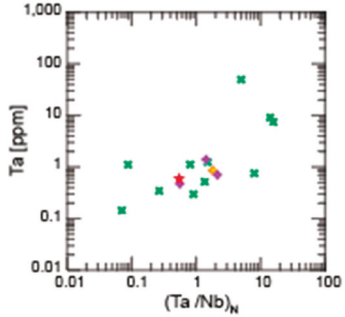

(b)

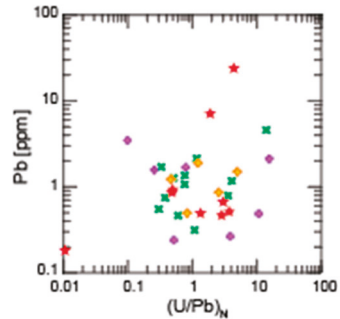

(e)

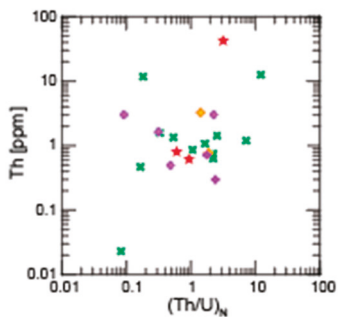

(h)

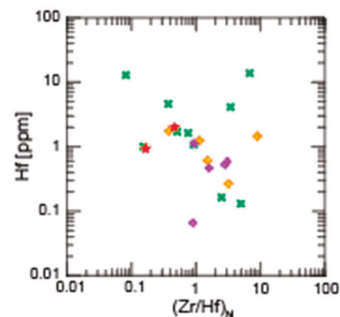

(k)

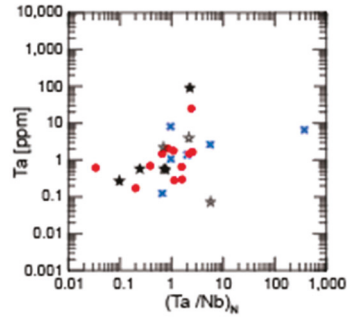

(c)

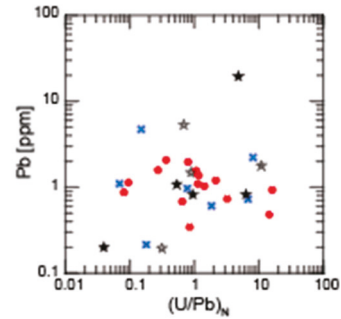

(f)

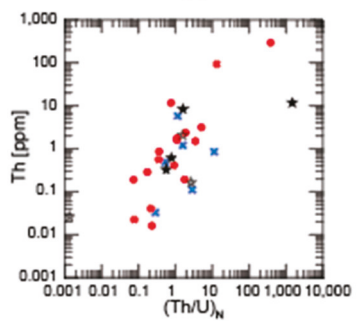

(i)

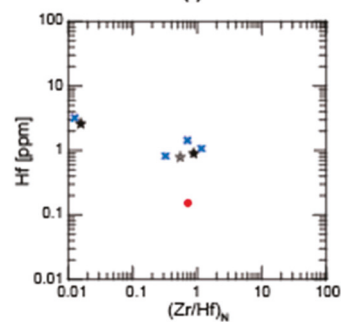

(I)

$\begin{array}{lll}\text { Amphibolite-type ruby } & \text { Marble-type ruby } & \text { Met. blue sapphire } \\ \text { ٪ Zahamena, MDG } & \star \text { Myanmar } & \star \text { Sri Lanka } \\ \text { Ampanihy, MDG } & \star \text { Vietnam } & \bullet \text { Myanmar } \\ \text { * Mozambique } & \star \text { Afghanistan } & \star \text { llakaka, MDG } \\ \text { * Winza, TZA } & \star \text { Morogoro, TZA } & \star \text { Andrebabe, MDG }\end{array}$

Figure A1. Primitive mantle-normalized [58] LA-ICP-MS data of gem corundum analyzed in this study. Points represent individual analyses. (a-c) Ta versus $(\mathrm{Ta} / \mathrm{Nb})_{\mathrm{N}} ;(\mathbf{d}-\mathbf{f}) \mathrm{Pb}$ versus $(\mathrm{U} / \mathrm{Pb})_{\mathrm{N}},(\mathrm{g}-\mathbf{i})$ Th versus $(\mathrm{Th} / \mathrm{U})_{\mathrm{N}}$, and $(\mathrm{j}-\mathrm{l}) \mathrm{Hf}$ versus $(\mathrm{Zr} / \mathrm{Hf})_{\mathrm{N}}$ for amphibole-type ruby, marble-type ruby, and met. blue sapphire, respectively. 

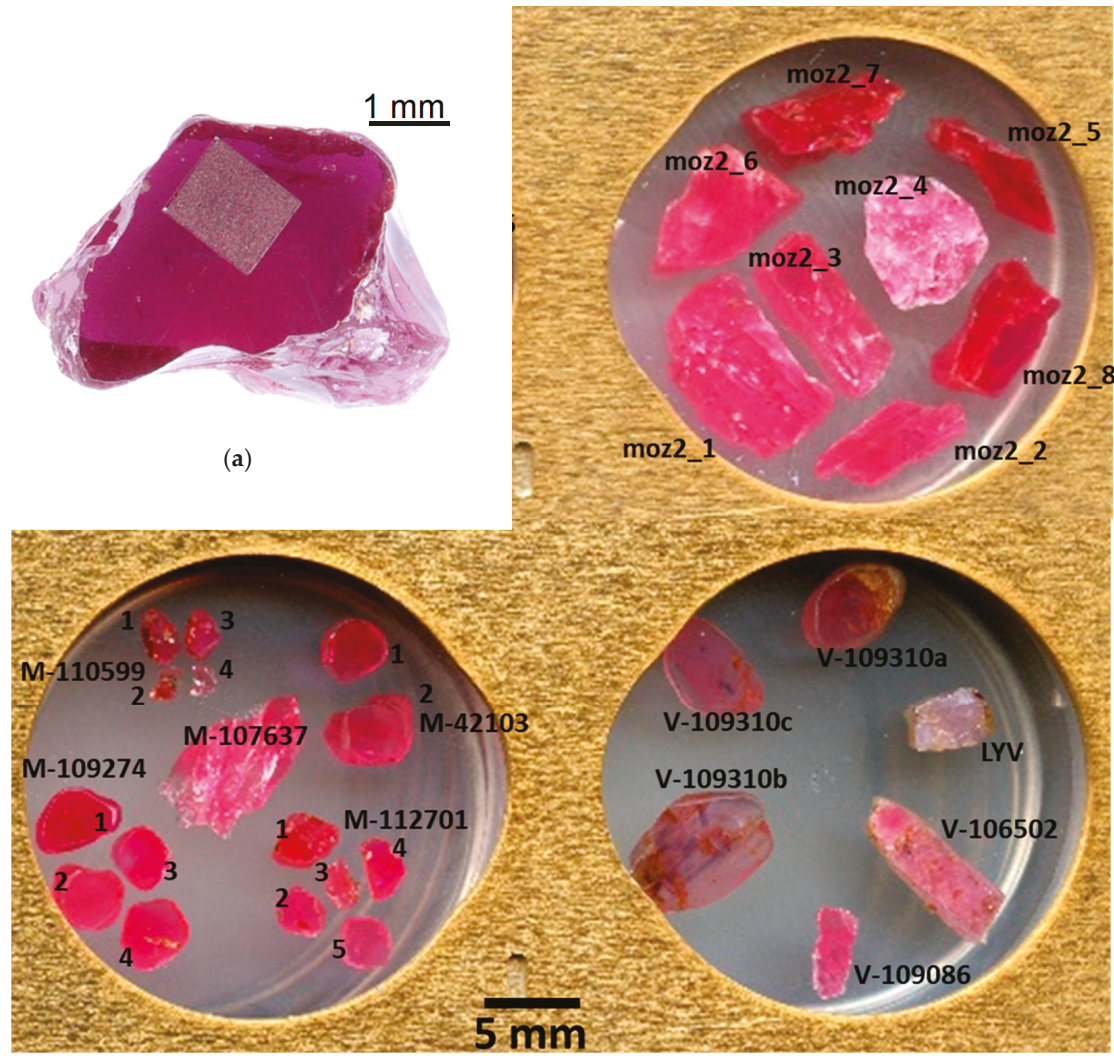

(b)

Figure A2. (a) Ruby from Zahamena, MDG after ablation clearly demonstrating the size of the offline ablation pit. (b) One inch resin sample mounts for LA-ICP-MS analysis showing rubies from Mozambique (moz), Myanmar (M-xxx), and Vietnam (V-xxx). A range of color and clarity is shown by these rubies.

\section{References}

1. McClure, S.F.; Moses, T.M.; Shigley, J.E. The geographic origin dilemma. Gems Gemol. 2019, 55, 457-462.

2. Bui, H.A.N.; Fritsch, E.; Rondeau, B. Geographical origin: Branding or science. InColor Mag. 2012, 19, 30-39.

3. Cartier, L. Environmental stewardship in gemstone mining: Quo vadis? InColor Mag. 2010, 15, 9.

4. Palke, A.C.; Saeseaw, S.; Renfro, N.D.; Sun, Z.; Mcclure, S.F. Geographic origin determination of blue sapphire. Gems Gemol. 2019, 55, 536-579. [CrossRef]

5. Palke, A.C.; Saeseaw, S.; Renfro, N.D.; Sun, Z.; Mcclure, S.F. Geographic origin determination of ruby. Gems Gemol. 2019, 55, 580-613. [CrossRef]

6. The Gübelin Gemological Laboratory. A Holistic Method to Determing Gem Origin. 2006. Available online: https://www.gubelingemlab.com/tl_files/content/03\%20Gemmology/Gem\%20Lab/ Documents/Origin_Article_Sep2006.pdf (accessed on 15 May 2020).

7. Giuliani, G.; Fallick, A.E.; Garnier, V.; France-Lanord, C.; Ohnenstetter, D.; Schwarz, D. Oxygen isotope composition as a tracer for the origins of rubies and sapphires. Geology 2005, 33, 249-252. [CrossRef]

8. Saminpaya, S.; Manning, D.A.C.; Droop, G.T.R.; Henderson, C.N.B. Trace elements in Thai gem corundums. J. Gemmol. 2003, 28, 399-416. [CrossRef] 
9. Abduriyim, A.; Kitawaki, H. Applications of Laser Ablation-Inductively Coupled Plasma-Mass Spectrometry (LA-ICP-MS) to gemology. Gems Gemol. 2006, 42, 98-118. [CrossRef]

10. Peucat, J.J.; Ruffault, P.; Fritsch, E.; Bouhnik-Le Coz, M.; Simonet, C.; Lasnier, B. Ga/Mg ratio as a new geochemical tool to differentiate magmatic from metamorphic blue sapphires. Lithos 2007, 98, 261-274. [CrossRef]

11. Graham, I.T.; Sutherland, L.; Zaw, K.; Nechaev, V.; Khanchuk, A. Advances in our understanding of the gem corundum deposits of the West Pacific continental margins intraplate basaltic fields. Ore Geol. Rev. 2008, 34, 200-215. [CrossRef]

12. Krebs, M.Y.; Pearson, D.G.; Fagan, A.J.; Bussweiler, Y.; Sarkar, C. The application of trace elements and Sr-Pb isotopes to dating and tracing ruby formation: The Aappaluttoq deposit, SW Greenland. Chem. Geol. 2019, 523, 42-58. [CrossRef]

13. Dickin, A.P. Radiogenic Isotope Geology, 2nd ed.; Cambridge University Press: New York, NY, USA, 2005; ISBN 9780521823166.

14. Garnier, V.; Giuliani, G.; Ohnenstetter, D.; Schwarz, D. Saphirs et rubis. Classification des gisements de corindon. Règne Minér. 2004, 55, 4-47.

15. Muhlmeister, S.; Fritsch, E.; Shigley, J.E.; Devouard, B.; Laurs, B.M. Separating natural and synthetic rubies on the basis of trace-element chemistry. Gems Gemol. 1998, 34, 80-101. [CrossRef]

16. Kievlenko, E.Y. Geology of Gems; Ocean Pictures Ltd.: Littleton, CO, USA, 2003.

17. Simonet, C.; Fritsch, E.; Lasnier, B. A classification of gem corundum deposits aimed towards gem exploration. Ore Geol. Rev. 2008, 34, 127-133. [CrossRef]

18. Giuliani, G.; Fallick, A.E.; Rakotondrazafy, M.; Ohnenstetter, D.; Andriamamonjy, A.; Ralantoarison, T.; Rakotosamizanany, S.; Razanatseheno, M.; Offant, Y.; Garnier, V.; et al. Oxygen isotope systematics of gem corundum deposits in Madagascar: Relevance for their geological origin. Miner. Depos. 2007, 42, 251-270. [CrossRef]

19. Stern, R.J.; Tsujimori, T.; Harlow, G.; Groat, L. Plate tectonic gemstones. Geology 2013, 41, 723-726. [CrossRef]

20. Giuliani, G.; Ohnenstetter, D.; Fallick, A.E.; Groat, L.A.; Fagan, A.J. The geology and genesis of gem corundum deposits. In Mineralogical Association of Canada Short Course; Mineralogical Association of Canada: Québec, QC, Canada, 2014; Volume 44, pp. 29-112.

21. Harlan, S.S. Timing of emplacement of the sapphire-bearing Yogo Dike, Little Belt Mountains, Montana. Econ. Geol. 1996, 91, 1159-1162. [CrossRef]

22. Vertriest, W.; Palke, A.C.; Renfro, N.D. Field gemology: Building a research collection and understanding the development of gem deposits. Gems Gemol. 2019, 55, 490-511. [CrossRef]

23. Pardieu, V.; Sangsawong, S.; Muyal, J.; Chauviré, B.; Massi, L.; Sturman, N. Rubies from the Montepuez area (Mozambique). GIA News; Bangkok, Thailand, 2013. Available online: https://www.gia.edu/doc/GIA_Ruby_ Montepuez_Mozambique.pdf (accessed on 10 May 2020).

24. Peretti, A.; Peretti, F.; Kanpraphai, A.; Bieri, W.P.; Mametner, K.; Guenther, D. Winza Rubies Identified, 2nd ed.; Peretti, A., Ed.; GRS Gem Research Swisslab: Lucerne, Switzerland, 2008; ISBN 9783952335970.

25. Schwarz, D.; Pardieu, V.; Saul, J.M.; Schmetzer, K.; Laurs, B.M.; Giuliani, G.; Klemm, L.; Malsy, A.; Erel, E.; Hauzenberger, C.; et al. Rubies and sapphires from Winza, Central Tanzania. Gems Gemol. 2008, 44, 322-347. [CrossRef]

26. Pardieu, V.; Sangsawong, S.; Detroyat, S. Rubies from a new deposit in zahamena national park, Madagascar. Gems Gemol. 2015, 51, 454-456.

27. Rakotondrazafy, A.F.M.; Giuliani, G.; Ohnenstetter, D.; Fallick, A.E.; Rakotosamizanany, S.; Andriamamonjy, A.; Ralantoarison, T.; Razanatseheno, M.; Offant, Y.; Garnier, V.; et al. Gem corundum deposits of Madagascar: A review. Ore Geol. Rev. 2008, 34, 134-154. [CrossRef]

28. Smith, C.P. Ruby and pink sapphire from Aappaluttoq, Greenland. J. Gemmol. 2016, 35, 294-306. [CrossRef]

29. Keulen, N.; Kalvig, P. Fingerprinting of corundum (ruby) from Fiskenaesset, West Greenland. Geol. Surv. Den. Greenl. Bull. 2013, 28, 53-56. [CrossRef]

30. Fagan, A.J. The Ruby and Pink Sapphire Deposits of SW Greenland: Geological Setting, Genesis, and Exploration Techniques. Ph.D. Thesis, The University of British Columbia, Vancouver, BC, Canada, 2018.

31. Fanka, A.; Sutthirat, C. Petrochemistry, mineral chemistry, and pressure-Temperature model of corundum-bearing amphibolite from Montepuez, Mozambique. Arab. J. Sci. Eng. 2018, 43, 3751-3767. [CrossRef] 
32. Bowersox, G.W.; Foord, E.E.; Laurs, B.M.; Shigley, J.E.; Smith, C.P. Ruby and sapphire from Jegdalek, Afghanistan. Gems Gemol. 2000, 36, 110-126. [CrossRef]

33. Harlow, G.E.; Bender, W. A study of ruby (corundum) compositions from the Mogok Belt, Myanmar: Searching for chemical fingerprints. Am. Miner. 2013, 98, 1120-1132. [CrossRef]

34. Van Long, P.; Giuliani, G.; Fallick, A.E.; Boyce, A.J.; Pardieu, V. Trace elements and oxygen isotopes of gem spinels in marble from the Luc Yen-An Phu areas, Yen Bai province, North Vietnam. Vietnam J. Earth Sci. 2018, 40, 166-179.

35. Van Long, P.; Vinh, H.Q.; Garnier, V.; Giuliani, G.; Ohnenstetter, D.; Lhomme, T.; Schwarz, D.; Fallick, A.E.; Dubessy, J.; Trinh, P.T.; et al. Gem corundum deposits in Vietnam. J. Gemmol. 2004, 29, 129-147. [CrossRef]

36. Garnier, V.; Giuliani, G.; Ohnenstetter, D.; Fallick, A.E.; Dubessy, J.; Banks, D.; Vinh, H.Q.; Lhomme, T.; Maluski, H.; Pêcher, A.; et al. Marble-hosted ruby deposits from Central and Southeast Asia: Towards a new genetic model. Ore Geol. Rev. 2008, 34, 169-191. [CrossRef]

37. Haenni, H.A.; Schmetzer, K. New rubies from the Morogoro area, Tanzania. Gems Gemol. 1991, 27, $156-167$. [CrossRef]

38. Balmer, W.A.; Hauzenberger, C.A.; Fritz, H.; Sutthirat, C. Marble-hosted ruby deposits of the Morogoro Region, Tanzania. J. Afr. Earth Sci. 2017, 134, 626-643. [CrossRef]

39. Kan-Nyunt, H.P.; Karampelas, S.; Link, K.; Thu, K.; Kiefert, L.; Hardy, P. Blue sapphires from the Baw Mar mine in Mogok. Gems Gemol. 2013, 49, 223-232. [CrossRef]

40. Hughes, E.B.; Perkins, R. Madagascar sapphire: Low-temperature heat treatment experiments. Gems Gemol. 2019, 55, 184-196. [CrossRef]

41. Guznawardenea, M.; Rupasinghe, M.S. The elahera gem field in Central Sri Lanka. Gems Gemol. 1986, 22, 80-95. [CrossRef]

42. Atikarnsakul, U.; Vertriest, W.; Soonthorntantikul, W. Characterization of Blue Sapphires from the Mogok Stone Tract, Mandalay Region, Burma (Myanmar). GIA News. 19 June 2018, pp. 1-56. Available online: https://www.gia.edu/doc/Characterization-of-blue-sapphires-from-the-Mogok-StoneTract-Mandalay-region-Burma-Myanmar.pdf (accessed on 10 May 2020).

43. Soonthorntantikul, W.; Vertriest, W.; Raynaud-flattot, V.L.; Sangsawong, S. An in-Depth Gemological Study of Blue Sapphires From the Baw Mar Mine (Mogok, Myanmar); GIA: Bangkok, Thailand, 2017.

44. Milisenda, C.C.; Henn, U.; Henn, J. New gemstone occurrences in the south-west of Madagascar. J. Gemmol. 2001, 27, 385-394. [CrossRef]

45. Pardieu, V.; Rakotosaona, N. Ruby and Sapphire Rush Near Didy, Madagascar (April-June 2012); GIA: Bangkok, Thailand, 2012.

46. Dissanayake, C.B.; Chandrajith, R.; Tobschall, H.J. The geology, mineralogy and rare element geochemistry of the gem deposits of Sri Lanka. Bull. Geol. Soc. Finl. 2000, 72, 5-20. [CrossRef]

47. Pardieu, V.; Sangsawong, S.; Vertriest, W.; Detroyat, S.; Raynaud, V.; Engniwat, S. Blue sapphires from a new deposit near Andranondambo, Madagascar. Gems Gemmol. 2016, 52, 96-97.

48. Schwarz, D.; Petsch, E.J.; Kanis, J. Sapphires from the Andranondambo Region, Madagascar. Gems Gemol. 1996, 32, 80-99. [CrossRef]

49. Stone-Sundberg, J.; Thomas, T.; Sun, Z.; Guan, Y.; Cole, Z.; Equall, R.; Emmett, J.L. Accurate reporting of key trace elements in ruby and sapphire using matrix-matched standards. Gems Gemol. 2017, 53, 438-451. [CrossRef]

50. Paton, C.; Hellstrom, J.; Paul, B.; Woodhead, J.; Hergt, J. Iolite: Freeware for the visualisation and processing of mass spectrometric data. J. Anal. At. Spectrom. 2011, 26, 2508. [CrossRef]

51. McNeill, J.; Pearson, D.G.; Klein-Bendavid, O.; Nowell, G.M.; Ottley, C.J.; Chinn, I. Quantitative analysis of trace element concentrations in some gem-quality diamonds. J. Phys. Condens. Matter 2009, 21, 364207. [CrossRef]

52. Klein-BenDavid, O.; Pearson, D.G.; Nowell, G.M.; Ottley, C.; McNeill, J.C.R.; Cartigny, P. Mixed fluid sources involved in diamond growth constrained by $\mathrm{Sr}-\mathrm{Nd}-\mathrm{Pb}-\mathrm{C}-\mathrm{N}$ isotopes and trace elements. Earth Planet. Sci. Lett. 2010, 289, 123-133. [CrossRef]

53. Krebs, M.Y.; Pearson, D.G.; Stachel, T.; Laiginhas, F.; Woodland, S.; Chinn, I.; Kong, J. A common parentage-low abundance trace element data of gem diamonds reveals similar fluids to fibrous diamonds. Lithos 2019, 324-325. [CrossRef] 
54. Charlier, B.L.A.; Ginibre, C.; Morgan, D.; Nowell, G.M.; Pearson, D.G.; Davidson, J.P.; Ottley, C.J. Methods for the microsampling and high-precision analysis of strontium and rubidium isotopes at single crystal scale for petrological and geochronological applications. Chem. Geol. 2006, 232, 114-133. [CrossRef]

55. Harlou, R.; Pearson, D.G.; Nowell, G.M.; Ottley, C.J.; Davidson, J.P. Combined Sr isotope and trace element analysis of melt inclusions at sub-ng levels using micro-milling, TIMS and ICPMS. Chem. Geol. 2009, 260, 254-268. [CrossRef]

56. Sarkar, C.; Pearson, D.G.; Heaman, L.M.; Woodland, S.J. Precise Pb isotope ratio determination of picogram-size samples: A comparison between multiple Faraday collectors equipped with $10^{12} \Omega$ amplifiers and multiple ion counters. Chem. Geol. 2015, 395, 27-40. [CrossRef]

57. Todt, W.; Cliff, R.A.; Hanser, A.; Hofmann, A.W. Evaluation of a $202 \mathrm{~Pb}-205 \mathrm{~Pb}$ double spike for high-precision lead isotope analysis. In Earth Processes: Reading the Isotopic Code; Basu, A., Hart, S.R., Eds.; American Geophysical Union Geophysical Monograph: Washington, DC, USA, 1996; pp. 429-437.

58. McDonough, W.F.; Sun, S.-S. The composition of the earth. Chem. Geol. 1995, 120, 223-253. [CrossRef]

59. Pornwilard, M.M.; Hansawek, R.; Shiowatana, J.; Siripinyanond, A. Geographical origin classification of gem corundum using elemental fingerprint analysis by laser ablation inductively coupled plasma mass spectrometry. Int. J. Mass Spectrom. 2011, 306, 57-62.

60. Sutherland, F.; Zaw, K.; Meffre, S.; Yui, T.-F.; Thu, K. Advances in trace element "Fingerprinting" of gem corundum, ruby and sapphire, Mogok Area, Myanmar. Minerals 2014, 5, 61-79. [CrossRef]

61. Sutherland, F.L.; Abduriyim, A. Geographic typing of gem corundum: A test case from Australia. J. Gemmol. 2009, 31, 203-210. [CrossRef]

62. Sutherland, F.; Zaw, K.; Meffre, S.; Thompson, J.; Goemann, K.; Thu, K.; Nu, T.; Zin, M.; Harris, S. Diversity in ruby geochemistry and its inclusions: Intra- and inter-continental comparisons from Myanmar and Eastern Australia. Minerals 2019, 9, 28. [CrossRef]

63. Sutherland, F.L.; Zaw, K.; Meffre, S.; Giuliani, G.; Fallick, A.E.; Graham, I.T.; Webb, G.B. Gem-corundum megacrysts from east Australian basalt fields: Trace elements, oxygen isotopes and origins. Aust. J. Earth Sci. 2009, 56, 1003-1022. [CrossRef]

64. Zaw, K.; Sutherland, L.; Yui, T.F.; Meffre, S.; Thu, K. Vanadium-rich ruby and sapphire within Mogok Gemfield, Myanmar: Implications for gem color and genesis. Miner. Depos. 2014, 50, 25-39. [CrossRef]

65. Sutherland, F.L.; Piilonen, P.C.; Zaw, K.; Meffre, S.; Thompson, J. Sapphire within zircon-rich gem deposits, Bo Loei, Ratanakiri Province, Cambodia: Trace elements, inclusions, U-Pb dating and genesis. Aust. J. Earth Sci. 2015, 62, 761-773.

66. Sutherland, F.L.; Graham, I.T.; Harris, S.J.; Coldham, T.; Powell, W.; Belousova, E.A.; Martin, L. Unusual ruby-sapphire transition in alluvial megacrysts, Cenozoic basaltic gem field, New England, New South Wales, Australia. Lithos 2017, 278-281, 347-360. [CrossRef]

67. Sorokina, E.S.; Rassomakhin, M.A.; Nikandrov, S.N.; Karampelas, S.; Kononkova, N.N.; Nikolaev, A.G.; Anosova, M.O.; Somsikova, A.V.; Kostitsyn, Y.A.; Kotlyarov, V.A.; et al. Origin of blue sapphire in newly discovered spinel-chlorite-muscovite rocks within meta-ultramafites of ilmen mountains, South Urals of Russia: Evidence from mineralogy, geochemistry, RB-SR and Sm-Nd isotopic data. Minerals 2019, 9, 36. [CrossRef]

68. Graham, I.T.; Harris, S.J.; Martin, L.; Lay, A.; Zappettini, E. Enigmatic alluvial sapphires from the Orosmayo Region, Jujuy Province, Northwest Argentina: Insights into their origin from in situ oxygen isotopes. Minerals 2019, 9, 390. [CrossRef]

69. Cartier, L.E. Ruby and sapphire from Marosely, Madagascar. J. Gemmol. 2009, 31, 171-180. [CrossRef]

70. Baldwin, L.C.; Ballhaus, F.T.C.; Fonseca, A.G.R.O.C. Petrogenesis of alkaline basalt-hosted sapphire megacrysts. Petrological and geochemical investigations of in situ sapphire occurrences from the Siebengebirge Volcanic Field, Germany. Contrib. Miner. Pet. 2017, 172, 1-27. [CrossRef]

71. Guillong, M.; Günther, D. Quasi "non-destructive" laser ablation-inductively coupled plasma-mass spectrometry fingerprinting of sapphires. Spectrochim. Acta-Part B At. Spectrosc. 2001, 56, 1219-1231. [CrossRef]

72. Boyd, R.; Nordgulen, O.; Thomas, R.J.; Bingen, B.; Bjerkgård, T.; Grenne, T.; Henderson, I.; Melezhik, V.A.; Often, M.; Sandstad, J.S.; et al. The geology and geochemistry of the East African orogen in northeastern Mozambique. S. Afr. J. Geol. 2010, 113, 87-129. [CrossRef] 
73. Barley, M.E.; Pickard, A.L.; Zaw, K.; Rak, P.; Doyle, M.G. Jurassic to Miocene magmatism and metamorphism in the Mogok metamorphic belt and the India-Eurasia collision in Myanmar. Tectonics 2003, 22, 22. [CrossRef]

74. Searle, M.P.; Noble, S.R.; Cottle, J.M.; Waters, D.J.; Mitchell, A.H.G.; Hlaing, T.; Horstwood, M.S.A. Tectonic evolution of the Mogok metamorphic belt, Burma (Myanmar) constrained by U-Th-Pb dating of metamorphic and magmatic rocks. Tectonics 2007, 26, 26. [CrossRef]

75. Silva, K.K.M.W.; Siriwardena, C.H.E.R. Geology and the origin of the corundum-bearing skarn at Bakamuna, Sri Lanka. Miner. Depos. 1988, 23, 186-190. [CrossRef]

76. Thu, K. The Igneous Rocks of the Mogok Stone Tract. Ph.D. Thesis, University of Yangon, Yangon, Myanmar, 2007.

(C) 2020 by the authors. Licensee MDPI, Basel, Switzerland. This article is an open access article distributed under the terms and conditions of the Creative Commons Attribution (CC BY) license (http://creativecommons.org/licenses/by/4.0/). 



\title{
Article \\ Coexisting Rubies and Blue Sapphires from Major World Deposits: A Brief Review of Their Mineralogical Properties
}

\author{
Aaron C. Palke \\ Gemological Institute of America, 5355 Armada Drive, Carlsbad, CA 92008, USA; apalke@gia.edu
}

Received: 3 March 2020; Accepted: 19 May 2020; Published: 22 May 2020

\begin{abstract}
Gem corundum deposits are typically divided into blue sapphire and ruby deposits. However, this classification often overlooks the fact that the precious stones produced are the same mineral with only an overall slight difference in their trace element profiles. It can take only a couple thousand ppm chromium to create the rich, red color expected of a ruby. This contribution deals specifically with economically important gem corundum mining regions that produce both blue sapphires and rubies either in comparable quantities (Mogok, Myanmar, and the basalt-related gem fields on the border between Thailand and Cambodia at Chanthaburi, Thailand, and Pailin, Cambodia) or predominantly blue sapphires with rare rubies (secondary Montana sapphire deposits and Yogo Gulch in Montana as well as the gem fields of Sri Lanka). Comparison of the trace element profiles and inclusions in the blue sapphire/ruby assemblages in these deposits shows that there are both monogenetic and polygenetic assemblages in which the blue sapphires and rubies have the same geological origin (monogenetic) or distinct geological origins (polygenetic). In the monogenetic assemblages, the rubies and blue sapphires have essentially indistinguishable inclusions and trace element chemistry profiles (with the exception of $\mathrm{Cr}$ contents). On the other hand, polygenetic assemblages are composed of rubies and blue sapphires with distinct inclusions and trace element chemistry profiles. Notably, in the monogenetic assemblages, chromium seems to vary independently from other trace elements. In these assemblages, $\mathrm{Cr}$ can vary by nearly four orders of magnitude with essentially no consistent relationship to other trace elements. The observations described herein are an attempt to address the question of what the geochemical and geological constraints are that turn gem corundum into a spectacular ruby.
\end{abstract}

Keywords: corundum; ruby; sapphire; gemology; geology of gem deposits

\section{Introduction}

In the gemological world we often speak of the "big three", the three high-value gems that dominate the colored stone market: ruby, sapphire, and emerald (at least in the western world, in much of Asia, jade is the most important gem). Two of the big three, ruby and sapphire, are the same mineral species, corundum, and this special issue is wholly devoted to ruby, the red variety of the mineral corundum. Although they are the same mineralogical species with essentially the same chemical makeup (generally $>98 \mathrm{wt} \% \mathrm{Al}_{2} \mathrm{O}_{3}$ ), rubies with a vivid, deep red saturated color can be far more desirable than almost any vividly colored blue sapphire.

In our silica-rich Earth, corundum $\left(\alpha-\mathrm{Al}_{2} \mathrm{O}_{3}\right)$ is not the easiest mineral to form as any excess alumina tends to react with silica and other components such as alkalis to form other alumina-rich minerals such as feldspars and micas. Corundum therefore forms in a limited range of P-T-x environments (including silica undersaturation), and the number of possible ways in which gem-quality corundum can form is even narrower [1,2]. The geological conditions of formation have imparted some gem corundum with a sufficient quantity of the red-coloring agent chromium to pass as a ruby, while some 
gem corundum is colored by iron and titanium, which impart the blue color seen in sapphires. In fact, considering the geology of the major ruby and sapphire deposits in the world, at first glance it seems to make sense. In metamorphic terranes, rubies often form in marbles derived from platform carbonates. While the exact mechanisms of formation may not be entirely understood, it has been suggested that molten evaporate salts enabled mobilization of chromium and aluminum that enabled crystallization of Cr-rich corundum [3,4]. In contrast, metamorphic blue sapphires typically form in settings where a deficiency in chromium is expected, such as from the interaction between syenitic pegmatites and high-grade metamorphic rocks (Mogok, Myanmar) or from amphibolite or granulite facies gneisses (Sri Lanka and Madagascar) [1,5].

This contribution will focus on specific gemstone deposits from major gem producing regions around the world which are known for producing both blue sapphires and rubies. This contribution focuses on gem deposits from major gem producing regions. The deposits included are Mogok, Myanmar; Chanthaburi, Thailand; Pailin, Cambodia; Montana, USA; and various gem deposits in Sri Lanka. The gemological properties of the blue sapphires and rubies from these deposits will be described, especially their inclusions and trace element chemistry, with the intent of determining the relationships (if any) between these two varieties of gem corundum and to help understand the possible controls on the geochemical behavior of chromium in the specific formation situation of gem corundum.

\section{Materials and Methods}

The samples dominantly were derived from the Gemological Institute of America's (GIA) Colored Stone Reference Collection, which was built up over more than 10 years through the GIA Field Gemology program [6]. This was supplemented, especially for the Montana sapphires, by samples provided by several trusted contacts who have worked extensively in the sapphire mining areas of Montana including Richard B. Berg from the Montana Bureau of Mines and Geology, John Emmett, a consultant with GIA, Jeff Hapeman, a gem dealer with Earth's Treasury, and Will Heierman, a gem dealer who has worked with many of the sapphire miners in Montana. The sample set is comprised of 17 Thai/Cambodian rubies, 28 Thai/Cambodian blue sapphires, 18 Sri Lankan rubies, 17 Sri Lankan pink sapphires, 61 Sri Lankan blue sapphires, 43 rubies from Mogok, Myanmar, 143 blue sapphires from Mogok, Myanmar, 16 secondary Montana rubies, 6 secondary Montana pink sapphires, 52 secondary Montana blue sapphires, 8 Yogo, Montana rubies, 9 Yogo, Montana violet sapphires, and 18 Yogo, Montana blue sapphires. Essentially all the samples in this reference collection were collected from secondary alluvial or elluvial deposits which were weathered from primary, hard rock deposits. The main exception is the Yogo sapphires and rubies, which are derived from a primary deposit.

Laser ablation inductively coupled plasma mass spectrometry (LA-ICP-MS) analyses were conducted using a Thermo Scientific iCap-Q ICP-MS (Thermo Fisher Scientific, Waltham, MA, USA) with plasma RF power of $1400 \mathrm{~W}$ coupled with a New Wave Research UP-213 laser ablation (New Wave Research, Inc, Bozeman, MT, USA) unit with a frequency-quintupled Nd:YAG laser (213 nm wavelength with $4 \mathrm{~ns}$ pulse width). Laser conditions consisted of a $55 \mu \mathrm{m}$ diameter spot size, a fluence of $10 \pm 1 \mathrm{~J} / \mathrm{cm}^{2}$, and a $15 \mathrm{~Hz}$ repetition rate using NIST 610 and 612 glasses as external standards and ${ }^{27} \mathrm{Al}$ as an internal standard with a defined value of 529,250 ppm Al. Accuracy of the measurements on the standard reference materials is generally within $5 \%$ to $20 \%$. On longer runs lasting more than $2 \mathrm{~h}$, one of the standards was run again as an unknown as a quality control measure to ensure instrument drift was kept at an acceptable level by ensuring that a standard reference material could be measured within $15 \%$ of its known values for the relevant elements. The analyses reported here were carried out over the course of several years in the lab at the GIA, and so the detection limits varied over the course of data collection. However, general ranges for detection limits are $0.1-0.3 \mathrm{ppm} \mathrm{Mg}, 1.2-4.7 \mathrm{ppm} \mathrm{Ti}$, 0.1-0.5 ppm V, 1.3-5.1 ppm Cr, 13.7-54.8 ppm Fe, and 0.1-0.2 ppm Ga. Detection limits were calculated according to the method of Longerich et al. [7]. Each stone was typically analyzed in three spots, but sometimes, up to 12 spots were obtained if there was significant color zoning or regions with 
clouds of microscopic inclusions that were targeted to get a statistically significant representation of chemical heterogeneity in these stones.

When possible, mineral inclusions were identified using Raman spectroscopy with a Renishaw inVia Raman microscope system. The Raman spectra of the inclusions were excited using a Stellar-REN Modu Ar-ion laser producing highly polarized light at $514 \mathrm{~nm}$ and collected at a nominal resolution of $3 \mathrm{~cm}^{-1}$ in the $2000-200 \mathrm{~cm}^{-1}$ range. Each spectrum was comprised of three accumulations at $20 \times$ or $50 \times$ magnification. In many cases, the confocal capabilities of the Raman system allowed inclusions beneath the surface to be analyzed. Several other stones were polished to expose the inclusion to the surface.

\section{Results}

\subsection{Thai/Cambodian Rubies and Sapphires}

Rubies and sapphires have been recovered from river gravels and secondary alluvial and elluvial deposits near the present-day Thai/Cambodian border near Chanthaburi, Thailand, and Pailin, Cambodia, for at least 200 years. During the mid to late 20th century, as ruby supplies from Mogok, Myanmar, started to dwindle due to political problems, Thai rubies and sapphires came to dominate the market and supplied much of the gem corundum bought and sold in the world at that time [8]. Currently, much of the deposit is exhausted, although some small operations are still producing gem corundum. While found in secondary gravels, the rubies and sapphires were derived from alkali basalt flows in the area in which the gem corundum was brought up as xenocrysts within the lavas [9-12]. Unfortunately, the specific geologic origin of the Thai/Cambodian rubies and sapphires is not yet precisely understood. Note, while there are several gem corundum deposits distributed throughout Thailand and Cambodia including Kanchanaburi, Thailand, and Ratanakiri, Cambodia, in this contribution we focus only on the gem fields of Chanthaburi, Thailand, and Pailin, Cambodia, which was the most important producer of gem corundum. Further, the gem fields where gem corundum is found straddle the border between these two countries and can effectively be considered one single deposit. This is corroborated by the similarities in the gemological properties of the stones found on both sides of the Thai/Cambodian border [8-15].

The Thai/Cambodian rubies are presumed to have been derived from some (ultra)mafic or basic host rocks, which is supported by the mineral inclusions in the rubies such as clinopyroxenes, $\mathrm{Mg}$-Fe-Ca-rich garnets, and rare sapphirine inclusions $[9,12,13]$. Often these results have been interpreted to support a model of ruby formation through high-temperature, high-pressure metamorphism of (ultra)mafic rocks and subsequent transport to the surface when the alkali basalts passed through these ruby-bearing formations. On the other hand, [14] studied melt inclusions in the Thai/Cambodian rubies and compared them to melt inclusions found in Yogo sapphires from Montana, USA. From their results they suggested the formation of the Thai/Cambodian rubies through a peritectic melting reaction when the alkali basaltic magma passed through mafic or basic igneous rocks and partially melted them, forming the corundum and simultaneously transporting it to the surface.

Blue sapphires from Chanthaburi, Thailand, and Pailin, Cambodia, share many properties with other blue-green-yellow (BGY) sapphires from alkali basalts as in Australia, China, Nigeria, and Ethiopia among others $[8,15]$. Their inclusions indicate a different geological source from the Thai/Cambodia rubies and include $\mathrm{Na} / \mathrm{K}$-rich feldspars, pyrochlores, ferrocolumbite, zircon, and uraninite $[15,16]$. Together with the dominantly $\mathrm{Na} / \mathrm{K}$-rich, moderately silica-rich melt inclusions found in these sapphires, this suggests their derivation from syenitic-type rocks possibly with some contribution from a carbonatite or $\mathrm{CO}_{2}$-rich component $[15,16]$. It should be noted that there are some general differences in some blue sapphires from Chanthaburi, Thailand, and Pailin, Cambodia, with hexagonal milky banding occurring more frequently in Pailin, Cambodia, stones. On the other hand, Chanthaburi, Thailand, sapphires do not generally exhibit this milky banding but tend to have denser, more coarse rutile silk. However, there are enough overall similarities in their trace element chemistry and solid inclusions to consider them as one general group here. 
The difference in the geologic source of the Thai/Cambodian rubies and sapphires is obvious when examining the range of their trace element profiles (Figure 1 and Table 1). While both the rubies and sapphires are characterized by relatively high iron contents (average of 4030.5 and $2505.5 \mathrm{ppm}$, respectively) and similar ranges of titanium (94.2 and $127.9 \mathrm{ppm}$, respectively) and vanadium (18.5 and $19.9 \mathrm{ppm}$, respectively), all the other trace elements are significantly different. $\mathrm{Mg}$ and $\mathrm{Cr}$ are enriched in the rubies while $\mathrm{Ga}$ is significantly enriched in the sapphires. The differences are still more obvious when observing plots of the trace element patterns for the Thai/Cambodian rubies and sapphires (Figure 2).

The relationships between the trace elements in Thai/Cambodian sapphires and rubies can be further elucidated by investigating the correlation matrices for the trace elements in these stones (Tables 2 and 3). The rubies and sapphires are considered separately in these correlation matrices given the obvious wide disparity in their trace element profiles. There is only weak positive correlation between any of the trace elements for the sapphires (Table 2). At most there is a slight positive correlation between some of the trivalent cations $\left(\mathrm{V}^{3+}, \mathrm{Cr}^{3+}\right.$ and $\left.\mathrm{Ga}^{3+}\right)$. However, these three elements show negative correlation with Fe which is especially pronounced for $\mathrm{V}^{3+}$. The Thai/Cambodian rubies show strong positive correlation between $\mathrm{Mg}$, Ti, and V (Table 3). Cr shows weak positive correlation with $\mathrm{Mg}$ and negative correlation with Ga but no other significant correlations.

Table 1. Summary of trace elements for Thai/Cambodian sapphires and rubies in ppm.

\begin{tabular}{|c|c|c|c|c|c|c|}
\hline \multicolumn{7}{|c|}{ Thai/Cambodian Blue Sapphires (28 Samples, 289 Analyses) } \\
\hline & $\mathrm{Mg}$ & $\mathrm{Ti}$ & $\mathbf{V}$ & $\mathrm{Cr}$ & $\mathrm{Fe}$ & Ga \\
\hline $\min$ & 2.0 & 20.1 & 3.2 & bdl & 1553.9 & 108.0 \\
\hline $\max$ & 39.7 & 372.9 & 58.6 & 88.1 & 6870.7 & 195.0 \\
\hline average & 8.9 & 94.2 & 18.5 & 6.0 & 4030.5 & 132.7 \\
\hline median & 8.1 & 78.0 & 13.0 & 3.9 & 4334.1 & 131.0 \\
\hline \multicolumn{7}{|c|}{ Thai/Cambodian Rubies (17 Samples, 54 Analyses) } \\
\hline & $\mathrm{Mg}$ & Ti & V & $\mathrm{Cr}$ & $\mathrm{Fe}$ & $\mathrm{Ga}$ \\
\hline $\min$ & 150.0 & 84.9 & 8.9 & 2189.9 & 1738.7 & 17.0 \\
\hline $\max$ & 216.0 & 208.9 & 34.7 & 4959.7 & 3317.7 & 34.8 \\
\hline average & 170.9 & 127.9 & 19.9 & 3302.7 & 2505.5 & 26.0 \\
\hline median & 165.0 & 120.5 & 18.2 & 3434.8 & 2721.4 & 25.6 \\
\hline
\end{tabular}

bdl = below the detection limit, see "Materials and Methods" section for details.

Table 2. Correlation table for trace elements of Thai/Cambodian Sapphires.

\begin{tabular}{ccccccc}
\hline & $\mathbf{M g}$ & $\mathbf{T i}$ & $\mathbf{V}$ & $\mathbf{C r}$ & $\mathbf{F e}$ & $\mathrm{Ga}$ \\
\hline $\mathbf{M g}$ & 1 & & & & & \\
$\mathbf{T i}$ & 0.015 & 1 & & & & \\
$\mathbf{V}$ & 0.175 & 0.051 & 1 & & & \\
$\mathbf{C r}$ & 0.073 & -0.287 & 0.360 & 1 & & \\
$\mathbf{F e}$ & -0.176 & 0.096 & -0.901 & -0.273 & 1 & \\
$\mathbf{G a}$ & 0.117 & 0.239 & 0.499 & 0.254 & -0.385 & 1 \\
\hline
\end{tabular}

Table 3. Correlation table for trace elements of Thai/Cambodian Rubies.

\begin{tabular}{ccccccc}
\hline & $\mathbf{M g}$ & $\mathbf{T i}$ & $\mathbf{V}$ & $\mathbf{C r}$ & $\mathbf{F e}$ & $\mathrm{Ga}$ \\
\hline $\mathbf{M g}$ & 1 & & & & & \\
$\mathbf{T i}$ & 0.817 & 1 & & & & \\
$\mathbf{V}$ & 0.814 & 0.911 & 1 & & & \\
$\mathbf{C r}$ & 0.282 & -0.028 & 0.135 & 1 & & \\
$\mathbf{F e}$ & 0.433 & 0.443 & 0.512 & -0.369 & 1 & \\
$\mathbf{G a}$ & 0.457 & 0.711 & 0.632 & 0.127 & -0.185 & 1 \\
\hline
\end{tabular}



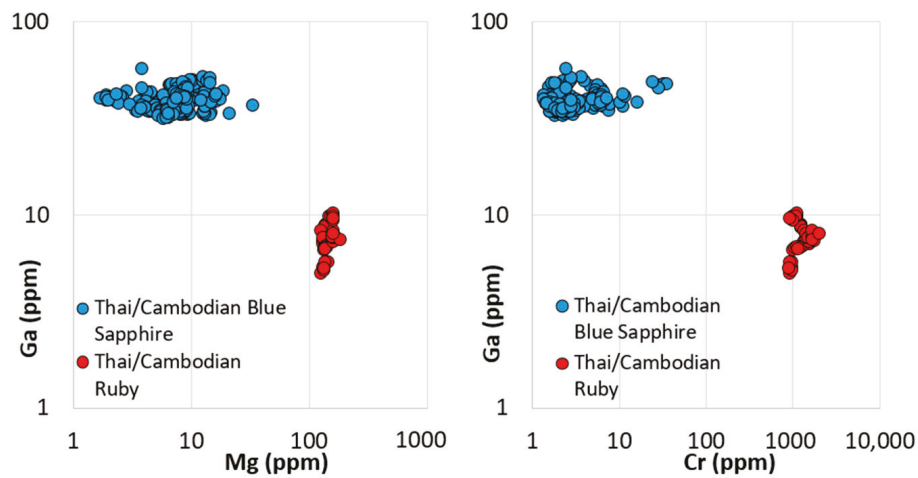

Figure 1. Trace element plots of Thai/Cambodian rubies and sapphires including Mg vs. Ga (left) and Cr vs. Ga (right) plots.
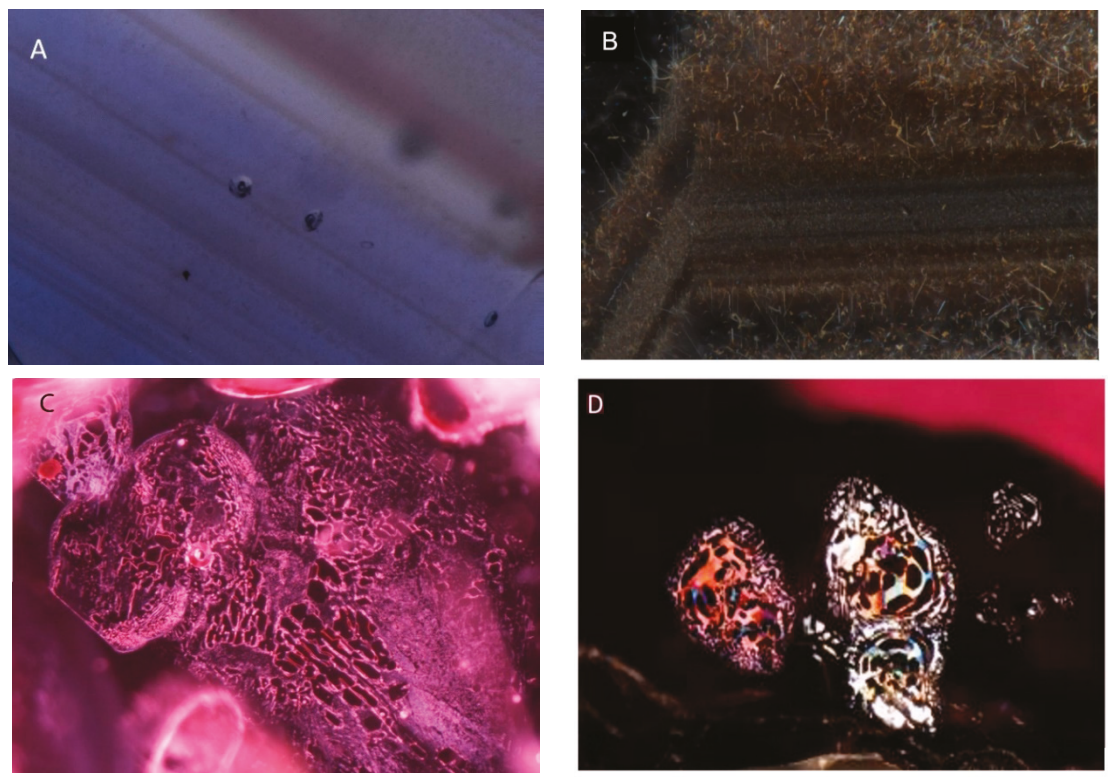

Figure 2. Photomicrographs of inclusions in Thai/Cambodian $(\mathbf{A}, \mathbf{B})$ blue sapphires representing (A) glassy melt inclusions and (B) oriented rutile inclusions in angular bands and (C,D) rubies representing (C) a glass melt inclusion which has burst out into the corundum host and (D) inclusions with geometric, partially healed decrepitation haloes. Thai/Cambodian rubies are characterized by melt-filled decrepitation haloes around melt inclusions, whereas the blue sapphires are characterized by melt inclusions and planar to hexagonally arranged bands of rutile silk. Photomicrographs by (A,B) Jonathan Muyal and (C,D) Aaron C. Palke. Fields of view: (A) $1.26 \mathrm{~mm}$ (B) $1.26 \mathrm{~mm}$, (C) $1.26 \mathrm{~mm}$, and (D) $1.58 \mathrm{~mm}$.

Additionally, Thai/Cambodian rubies and sapphires can easily be distinguished through microscopic observation of their inclusions (Figure 2A-D). While mineral inclusions of feldspars and pyrochlores may give an indication of the sapphires' geologic origin, they are actually quite uncommon in these gems. Generally, the most common inclusion in the blue sapphires is coarse rutile silk usually concentrated in hexagonal, angular bands but often with elongate rutile needles that 
can extend beyond individual growth zones (Figure 2A,B). In Cambodian sapphires, milky clouds are often seen, which are arranged in hexagonal growth zones. These milky clouds are composed of minute inclusions that cannot be individually identified microscopically but are presumed to be nano-sized inclusions of rutile or other oxides. In contrast, Thai/Cambodian rubies never have inclusions of rutile silk or milky clouds. These rubies often have few inclusions, however, the most common inclusions are melt inclusions or other crystalline inclusions with angular decrepitation haloes (Figure 2C,D). Sometimes, twinning planes with boehmite filling in the tubular intersections between adjacent twinned sectors also occur. While melt inclusions have been identified in both the rubies and sapphires, Electron Probe Microanalysis (EPMA) analyses of these inclusions (when polished to the surface) indicate the melts related to the formation of the rubies and sapphires are chemically distinct, with those occurring in the rubies being more Ca-rich and generally K-deficient, while those in the sapphires are generally Ca-poor and Na- and/or K-rich [14,17].

\subsection{Rubies and Sapphires from Myanmar, Mogok}

Mogok, or the fabled "Ruby Land", in Myanmar (formerly Burma) has been the world's preeminent source of fine rubies for at least 800 years. Mogok also produces significant quantities of fine blue sapphires as well. While production of fine rubies and sapphires has decreased in modern times, these gems still hold the allure and romance associated with the legendary gems from Myanmar. The gem deposits lie in the Mogok Metamorphic Belt, which was produced during the collision of the Indian plate with Eurasia. Mogok rubies are found in high-grade, relatively pure marbles and are interpreted to have formed from molten evaporite salt lenses that mobilized and crystallized alumina and chromium needed to form rubies [3,4]. The genesis of the sapphires is less well understood. However, the blue sapphires are known to be associated with intrusions of syenitic pegmatites into gneisses and other metamorphic rocks and are presumed to have formed through interaction between the alkaline igneous bodies and the metamorphic rocks into which they intruded.

Just as with the Thai/Cambodian stones, the difference in the geologic source formations for Mogok rubies and sapphires is well illustrated by studying their trace element patterns (Figure 3 and Table 4). However, the differences are not as dramatic as for the Thai/Cambodian stones. Generally, Mg and Ti have similar concentrations in the sapphires (average of $49.3 \mathrm{ppm}$ and $125.5 \mathrm{ppm}$, respectively) and rubies (average of $46.4 \mathrm{ppm}$ and $100.8 \mathrm{ppm}$, respectively), although the sapphires have wider extremes in their maximum and minimum values. However, the sapphires have much higher Fe concentrations (average of $2133.8 \mathrm{ppm}$ ) and slightly higher average Ga contents (average of $82.1 \mathrm{ppm}$ ) than the rubies (averages of 69.9 and $57.4 \mathrm{ppm}$ for Fe and $\mathrm{Ga}$, respectively). On the other hand, $\mathrm{V}$ and $\mathrm{Cr}$ are both much higher in the rubies (averages of $433.6 \mathrm{ppm}$ and $2962.5 \mathrm{ppm}$, respectively) than the sapphires (averages of $15.1 \mathrm{ppm}$ and $30.7 \mathrm{ppm}$, respectively). These different ranges in trace element chemistry are more easily seen graphically, where a Fe vs. Cr plot can clearly separate the rubies and sapphires, while plots involving $\mathrm{Cr}$, Fe, and/or Ga show their distinct ranges despite the small overlap in some cases (Figure 3). On the other hand, plots involving $\mathrm{Mg}$ or Ti generally show the two materials to be overlapping (Figure 3).

Some additional insights into the relationship between the various trace elements can be found by looking at correlation matrices for the trace elements in the Mogok blue sapphires and rubies (Tables 5 and 6). For Mogok blue sapphires, the strongest positive correlations are between Ti-Mg and Cr-V, and correlations between any other elements are weak. For Mogok rubies, $\mathrm{Ti}$ and $\mathrm{Mg}$ have very strong positive correlations, and there are weaker positive correlations between Fe and both $\mathrm{Ti}$ and $\mathrm{Mg}$ as well as with V and both Ti and Mg. For both the Mogok rubies and blue sapphires, Cr only shows significant positive correlation with $\mathrm{V}$ and weak correlation with all other elements. 

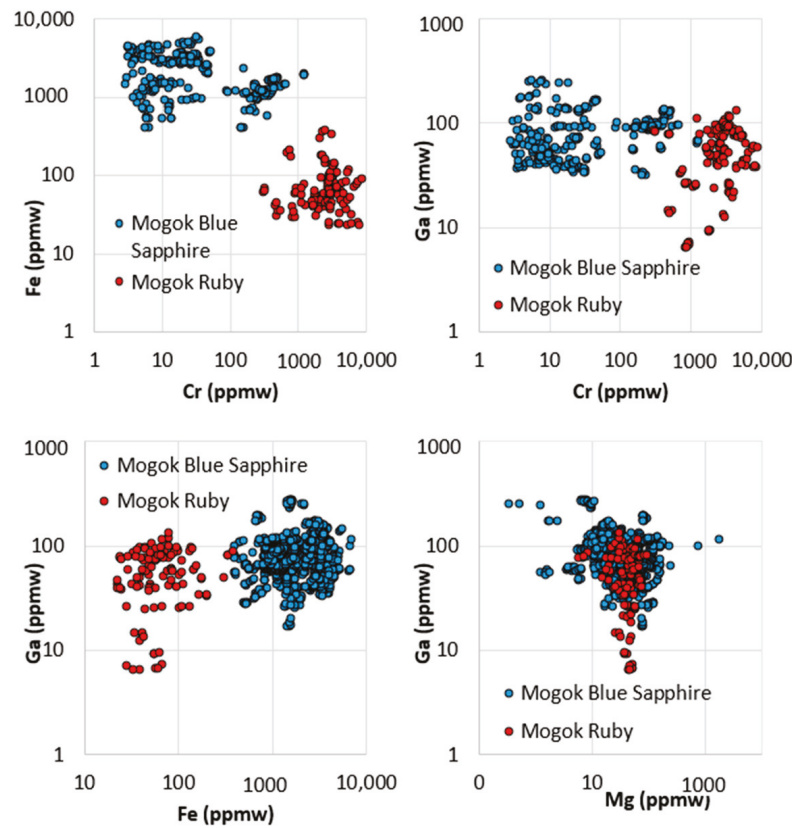

Figure 3. Trace element plots of rubies and blue sapphires from Mogok, Myanmar, showing their representative range of trace element profiles.

Table 4. Summary of trace elements for sapphires and rubies from Mogok, Myanmar, in ppm.

\begin{tabular}{|c|c|c|c|c|c|c|}
\hline \multicolumn{7}{|c|}{ Blue Sapphires from Mogok, Myanmar (143 Samples, 878 Analyses) } \\
\hline & Mg & $\mathrm{Ti}$ & V & $\mathrm{Cr}$ & Fe & Ga \\
\hline $\min$ & 0.3 & 14.6 & bdl & Bdl & 395.6 & 16.9 \\
\hline $\max$ & 1799.6 & 2389.4 & 182.0 & 1259.9 & 6996.6 & 280.0 \\
\hline average & 49.3 & 125.5 & 15.1 & 30.7 & 2133.8 & 82.1 \\
\hline median & 36.8 & 92.2 & 7.1 & 0.0 & 1755.5 & 70.5 \\
\hline \multicolumn{7}{|c|}{ Rubies from Mogok, Myanmar (43 Samples, 126 Analyses) } \\
\hline & $\mathrm{Mg}$ & $\mathrm{Ti}$ & V & $\mathrm{Cr}$ & Fe & Ga \\
\hline $\min$ & 6.1 & 15.5 & 119.0 & 303.0 & bdl & 6.6 \\
\hline $\max$ & 90.0 & 188.0 & 1620.1 & 8869.4 & 374.6 & 132.0 \\
\hline average & 46.4 & 100.8 & 433.6 & 2962.5 & 69.9 & 57.4 \\
\hline median & 46.2 & 99.6 & 373.5 & 2824.8 & 55.3 & 57.0 \\
\hline
\end{tabular}

$\mathrm{bdl}=$ below the detection limit, see "Materials and Methods" section for details.

Table 5. Correlation table for trace elements of blue sapphires from Mogok, Myanmar.

\begin{tabular}{ccccccc}
\hline & $\mathbf{M g}$ & $\mathbf{T i}$ & $\mathbf{V}$ & $\mathbf{C r}$ & $\mathbf{F e}$ & $\mathrm{Ga}$ \\
\hline $\mathbf{M g}$ & 1 & & & & & \\
$\mathbf{T i}$ & 0.581 & 1 & & & & \\
$\mathbf{V}$ & 0.036 & 0.065 & 1 & & & \\
$\mathbf{C r}$ & -0.032 & -0.021 & 0.685 & 1 & & \\
$\mathbf{F e}$ & 0.033 & -0.031 & -0.034 & -0.141 & 1 & \\
$\mathbf{G a}$ & -0.058 & -0.061 & -0.066 & 0.048 & -0.062 & 1 \\
\hline
\end{tabular}


Table 6. Correlation table for trace elements of rubies from Mogok, Myanmar.

\begin{tabular}{ccccccc}
\hline & $\mathbf{M g}$ & $\mathbf{T i}$ & $\mathbf{V}$ & $\mathbf{C r}$ & $\mathbf{F e}$ & $\mathbf{G a}$ \\
\hline $\mathbf{M g}$ & 1 & & & & & \\
$\mathbf{T i}$ & 0.965 & 1 & & & & \\
$\mathbf{V}$ & 0.168 & 0.203 & 1 & & & \\
$\mathbf{C r}$ & -0.035 & 0.010 & 0.252 & 1 & & \\
$\mathbf{F e}$ & 0.238 & 0.258 & -0.037 & -0.083 & 1 & \\
$\mathbf{G a}$ & -0.055 & 0.009 & 0.073 & 0.151 & 0.179 & 1 \\
\hline
\end{tabular}

Similarly to the case of Thai/Cambodian stones, the differences in geological origin between the Mogok rubies and sapphires can be discerned from their inclusions (Figure 4A-D). Rounded grains of carbonate minerals, apatite, and sulfide minerals are somewhat common in Mogok rubies, while feldspars and zircons and sometimes calcite are occasionally found in the blue sapphires. Mogok rubies are often distinguished by their short, reflective platelet rutile inclusions that can produce vivid interference colors when illuminated with an intense fiber optic light (Figure 4C). However, similar types of inclusions can be seen in the Mogok sapphires (Figure 4A). Longer, non-reflective rutile silk can be found in both types of stones, although it tends to occur in more of a "nested" intergrown arrangement in the rubies (Figure 4D) and is generally more dispersed or arranged in linear or angular bands in some cases in the sapphires. However, the sapphires are frequently characterized by the presence of polysynthetic twinning (Figure 4B).
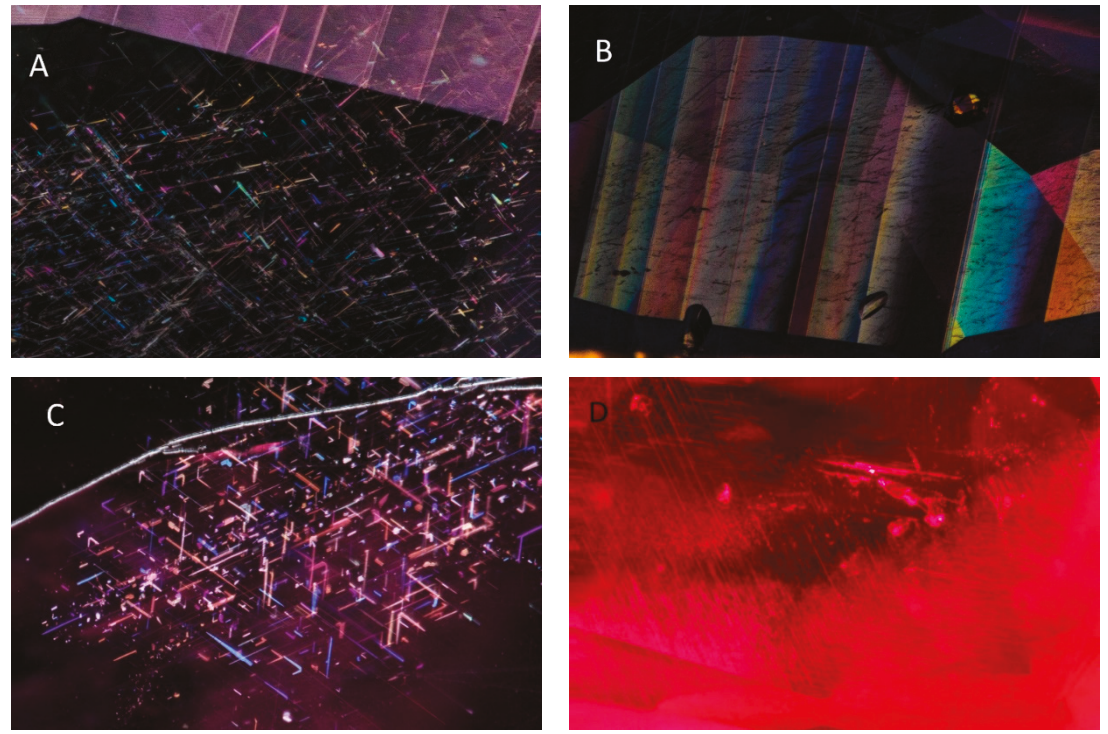

Figure 4. Photomicrographs of characteristic inclusions in Mogok, Myanmar, (A,B) blue sapphires showing reflective oriented rutile silk and polysynthetic twinning and (C,D) rubies including (C) reflective, oriented rutile silk and (D) nested elongate rutile silk surrounding mineral inclusions. Photomicrographs by (A,B,D) Aaron C. Palke and (C) Charuwan Khowpong. Fields of view: (A) $3.57 \mathrm{~mm}$, (B) $2.34 \mathrm{~mm}$, (C) $1.58 \mathrm{~mm}$, and (D) $4.48 \mathrm{~mm}$.

\subsection{Secondary Montana Blue Sapphires and Rubies}

Sapphires have been mined in Montana since the late 19th century when early prospectors found the dense gem-quality stones amongst the gravels they were working for gold. The two major deposits are at Rock Creek and a stretch of gravel bars along the Missouri River near the capital city of Helena. 
Note, the sapphires produced at the primary deposit in Yogo Gulch, Montana, are not considered along with the secondary Montana sapphires but will be discussed in the next section. Sapphires at both Rock Creek and the Missouri River are gemologically very similar in terms of their general color range, inclusions, and trace element chemistry. Geologically, the sapphires in both localities are understood to have been transported to the surface through volcanic eruptions that transported the sapphires from deep within the Earth's crust [18]. At Rock Creek, the volcanics are mostly rhyolitic in nature, while in the Missouri River deposit, sapphire-bearing basaltic trachyandesites have been identified as a potential source for the sapphires [18]. Chemically, the sapphires are classified as metamorphic based on their low $\mathrm{Ga}$ and $\mathrm{Mg} / \mathrm{Ga}$ contents [19,20]. In contrast, [21] studied melt inclusions in these sapphires and suggested their origin through peritectic melting reactions during partial melting of lower crustal anorthosites or other basic/mafic rocks, possibly during intrusion of the volcanic formations that eventually transported the sapphires to the surface.

Secondary Montana sapphires are predominantly pastel blue and green with accompanying pink, lavender, yellow, and orange stones. Even rare red rubies have been produced from these deposits, although it is possible that many of these exceptional stones were tragically lost to the tailings piles, as they may have been mistaken for ordinary garnets [22,23]. While the production is dominated by blue and green sapphires, there does seem to be a fairly continuous variation in color from blue and green to pink to lavender to true red. The similarity of the blue and pink sapphires and red rubies is corroborated by their trace element profiles. Except for $\mathrm{Cr}$ and $\mathrm{V}$, the ranges and averages of $\mathrm{Mg}$, $\mathrm{Ti}$, Fe and Ga concentrations are essentially the same across the entire color range from blue/green to pink to red (Table 7). Perhaps the most surprising aspect of this is that the trace elements Mg, Ti, Fe and Ga generally vary by one order of magnitude but always less than two orders of magnitude between the blue/green to pink sapphires to red rubies, while $\mathrm{Cr}$ varies by more than three orders of magnitude across the full color range. Examination of the trace element plots further explains these trends by showing that $\mathrm{Cr}$ concentrations vary continuously from the blue/green to pink sapphires to rubies with little to no variation in other trace elements (Figure 5), whereas trace element plots not involving $\mathrm{Cr}$ tend to show complete overlap among the entire range of colored gem corundum from these deposits (Figure 5).

Table 7. Summary of trace elements for secondary Montana sapphires and rubies in ppm.

\begin{tabular}{|c|c|c|c|c|c|c|}
\hline \multicolumn{7}{|c|}{ Secondary Montana Blue Sapphires (52 Samples, 246 Analyses) } \\
\hline & $\mathrm{Mg}$ & $\mathrm{Ti}$ & V & $\mathrm{Cr}$ & $\mathrm{Fe}$ & $\mathrm{Ga}$ \\
\hline $\min$ & 9.0 & 7.5 & 2.1 & bdl & 1402.8 & 24.0 \\
\hline $\max$ & 132.3 & 255.0 & 22.7 & 109.1 & 6326.2 & 59.8 \\
\hline average & 37.2 & 67.5 & 6.5 & 14.7 & 3681.0 & 45.7 \\
\hline median & 34.9 & 65.4 & 5.5 & 8.4 & 3703.7 & 46.5 \\
\hline \multicolumn{7}{|c|}{ Secondary Montana Pink Sapphires (6 Samples, 18 Analyses) } \\
\hline & Mg & $\mathrm{Ti}$ & V & $\mathrm{Cr}$ & $\mathrm{Fe}$ & Ga \\
\hline $\min$ & 13.2 & 22.2 & 6.0 & 81.5 & 1419.5 & 42.8 \\
\hline $\max$ & 58.9 & 76.6 & 13.6 & 854.9 & 4569.2 & 68.3 \\
\hline average & 31.5 & 53.6 & 9.0 & 287.8 & 3040.6 & 51.3 \\
\hline median & 32.0 & 60.1 & 8.5 & 189.0 & 2855.8 & 50.6 \\
\hline \multicolumn{7}{|c|}{ Secondary Montana Rubies (8 Samples, 48 Analyses) } \\
\hline & $\mathrm{Mg}$ & $\mathrm{Ti}$ & V & $\mathrm{Cr}$ & $\mathrm{Fe}$ & Ga \\
\hline $\min$ & 15.1 & 38.3 & 3.1 & 1040.0 & 2545.2 & 37.2 \\
\hline $\max$ & 45.8 & 189.0 & 68.1 & 6120.0 & 6804.0 & 67.8 \\
\hline average & 28.5 & 73.4 & 18.7 & 2495.0 & 4882.9 & 52.3 \\
\hline median & 28.1 & 64.1 & 11.8 & 2255.0 & 4947.6 & 52.3 \\
\hline
\end{tabular}

$\mathrm{bdl}=$ below the detection limit, see "Materials and Methods" section for details. 

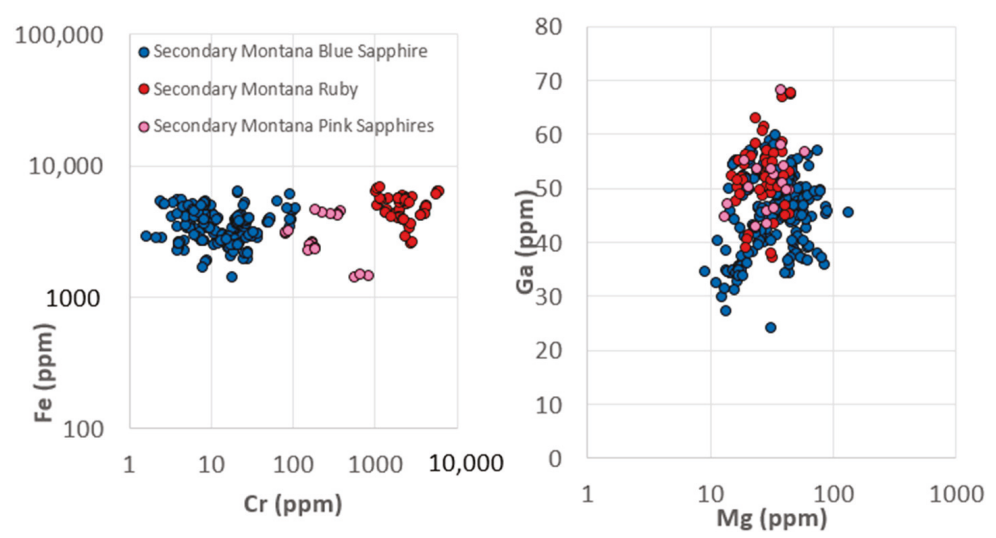

Figure 5. Trace element plots of secondary Montana blue and pink sapphires and rubies showing characteristic ranges of their trace elements.

Additional observations can be made about relationships between the various trace elements in the secondary Montana sapphires by investigating correlation matrices (Tables 8 and 9). Table 8 shows the correlation matrix for the full dataset including blue and pink sapphires and rubies. However, since the high-Cr sample set is composed of only a few samples, there is a possibility that these few samples could skew the $\mathrm{Cr}$ correlations, so another correlation matrix is presented in Table 9 for only the blue and pink sapphires. The strongest correlation in both cases is between $\mathrm{Ti}$ and $\mathrm{Mg}$. Iron appears to be positively correlated with $\mathrm{Ti}$ and $\mathrm{Mg}$ in both cases and with $\mathrm{V}$ and $\mathrm{Cr}$ with the full dataset, but the Fe- $\mathrm{V}$ and $\mathrm{Fe}-\mathrm{Cr}$ correlations weaken or disappear when only the blue and pink sapphires are compared. Further, Cr shows moderate positive correlation with V and Ga. Finally, Ga shows positive correlation with the trivalent cations $\mathrm{V}, \mathrm{Cr}$ and Fe and perhaps moderate correlation with Ti.

Table 8. Correlation table for trace elements of secondary Montana blue/green and pink sapphires and rubies.

\begin{tabular}{ccccccc}
\hline & $\mathbf{M g}$ & $\mathbf{T i}$ & $\mathbf{V}$ & $\mathbf{C r}$ & $\mathbf{F e}$ & $\mathrm{Ga}$ \\
\hline $\mathbf{M g}$ & 1 & & & & & \\
$\mathbf{T i}$ & 0.664 & 1 & & & & \\
$\mathbf{V}$ & -0.153 & -0.038 & 1 & & & \\
$\mathbf{C r}$ & -0.107 & 0.097 & 0.377 & 1 & & \\
$\mathbf{F e}$ & 0.117 & 0.252 & 0.303 & 0.360 & 1 & \\
$\mathbf{G a}$ & 0.074 & 0.217 & 0.312 & 0.361 & 0.405 & 1 \\
\hline
\end{tabular}

Table 9. Correlation table for trace elements of only blue/green and pink sapphires from the secondary Montana sapphire mines.

\begin{tabular}{ccccccc}
\hline & $\mathbf{M g}$ & $\mathbf{T i}$ & $\mathbf{V}$ & $\mathbf{C r}$ & $\mathbf{F e}$ & $\mathbf{G a}$ \\
\hline $\mathbf{M g}$ & 1 & & & & & \\
$\mathbf{T i}$ & 0.707 & 1 & & & & \\
$\mathbf{V}$ & -0.058 & -0.037 & 1 & & & \\
$\mathbf{C r}$ & -0.027 & -0.030 & 0.273 & 1 & & \\
$\mathbf{F e}$ & 0.270 & 0.309 & 0.150 & -0.187 & 1 & \\
$\mathbf{G a}$ & 0.138 & 0.206 & 0.467 & 0.269 & 0.319 & 1 \\
\hline
\end{tabular}

Observations of the inclusions in these stones suggest that there are no significant differences amongst the entire range of colors for these gem corundum (Figure 6A-D). Generally, inclusions in the secondary Montana sapphires include bands of coarse rutile silk involving short to long needles 
and reflective platelet-like inclusions (Figure 6B), inclusions of feldspar, rutile, garnet, apatite, zircon, and clinozoisite, as well as melt inclusions (Figure 6A). The same types of inclusions are seen in the pink sapphires and rubies. Melt inclusions have been analyzed only in the blue/green Montana sapphires so far, but their compositions have been interpreted to suggest the formation of these sapphires through partial melting of anorthosites or other calcic-feldspar-rich rocks [21].
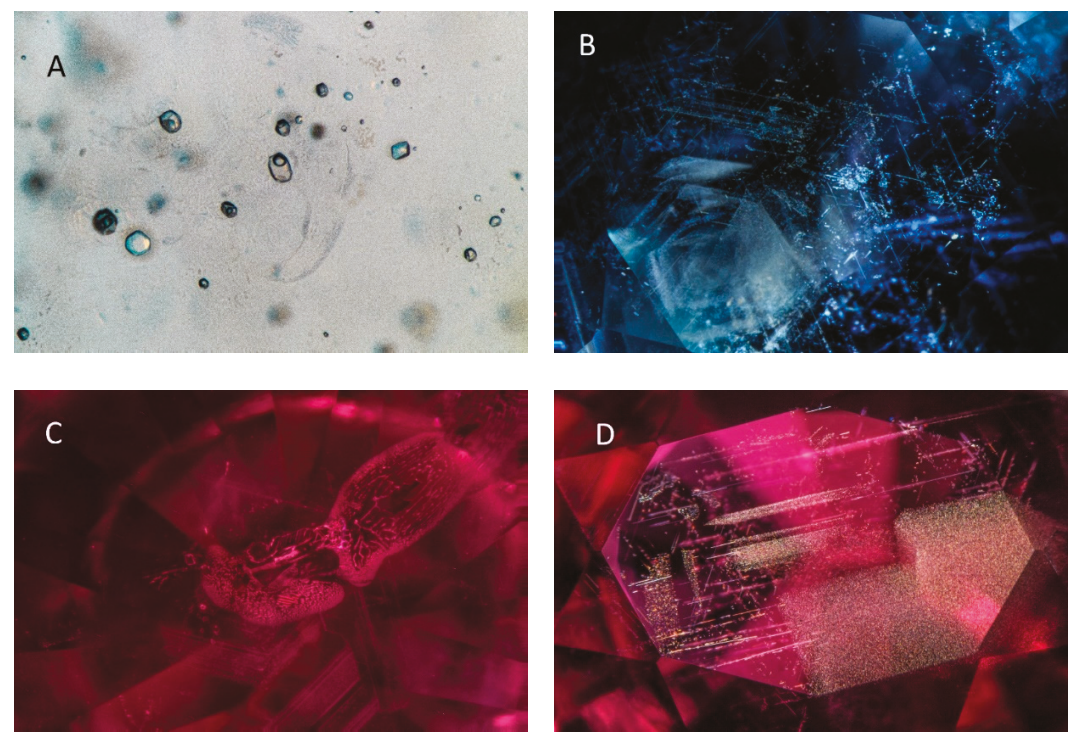

Figure 6. Photomicrographs of typical inclusions in secondary Montana (A,B) blue sapphires representing (A) melt inclusions and (B) hexangonally arranged rutile silk and (C,D) pink sapphires and rubies representing (C) melt inclusions and (D) hexagonally arranged bands of rutile silk. Photomicrographs by (A-C) Aaron C. Palke and (D) Tyler Smith. Fields of view: (A) $1.64 \mathrm{~mm}$, (B) $4.08 \mathrm{~mm}$, (C) $2.23 \mathrm{~mm}$, and (D) $3.57 \mathrm{~mm}$.

\subsection{Yogo Blue Sapphires and Rubies}

The sapphires produced from Yogo Gulch, Montana, have some geological similarities with those from the secondary deposits at Rock Creek and Missouri River, and yet, gemologically they are quite distinct. While all the Montana sapphires share a similar geological genesis story of being transported from deep within the Earth to the surface by volcanic activity in the Cenozoic, the Yogo sapphires were transported by a unique volcanic formation, a ouachitite, which is a member of the lamprophyre family [14]. Additionally, the Yogo sapphires are easily distinguishable from the secondary Montana sapphires by their trace elements and inclusions. Specifically, the dominant internal characteristic of Yogo sapphires is their distinct lack of any acicular rutile silk, which is a nearly ubiquitous feature in the secondary Montana sapphires. Additionally, Yogo sapphires and the secondary Montana sapphires have relatively high Fe and low Ga contents. Magnesium and titanium are generally more enriched in the Yogo sapphires, which allows them to be distinguished from nearly all of the secondary Montana sapphires.

In contrast, Yogo sapphires generally have a much more restricted color range than the secondary Montana sapphires. Yogo Gulch is known for producing predominantly cornflower blue sapphires, although there is a continuous gradation in color into purple and rare purplish-red rubies. The trace element patterns of the Yogo blue and violet sapphires and rubies are strikingly similar except for their $\mathrm{Cr}$ concentrations (Table 10). The ranges and averages of $\mathrm{Mg}, \mathrm{Ti}, \mathrm{Fe}$, and $\mathrm{Ga}$ are very similar, and even V has relatively little variation across the entire color range (Table 10). Graphically, this is seen 
more clearly by plotting essentially any of the trace elements against $\mathrm{Cr}$, which shows an unbroken continuity as $\mathrm{Cr}$ concentrations increase, with almost no variation in any of the other trace elements (Figure 7). However, plotting any of the other trace elements against each other shows the blue and violet sapphires and rubies are essentially completely overlapping (Figure 7).

Table 10. Summary of trace elements for Yogo sapphires and rubies in ppm.

\begin{tabular}{|c|c|c|c|c|c|c|}
\hline \multicolumn{7}{|c|}{ Yogo Blue Sapphires (18 Samples, 54 Analyses) } \\
\hline & $\mathrm{Mg}$ & $\mathrm{Ti}$ & $\mathbf{V}$ & $\mathrm{Cr}$ & Fe & $\mathrm{Ga}$ \\
\hline $\min$ & 89.4 & 136.0 & 3.5 & 2.4 & 1722.0 & 31.0 \\
\hline $\max$ & 142.0 & 239.0 & 24.3 & 208.0 & 3066.0 & 43.4 \\
\hline average & 115.9 & 192.5 & 13.1 & 52.1 & 2201.5 & 37.4 \\
\hline median & 116.0 & 193.5 & 12.6 & 33.8 & 2129.4 & 37.1 \\
\hline \multicolumn{7}{|c|}{ Yogo Violet Sapphires (9 Samples, 27 Analyses) } \\
\hline & $\mathrm{Mg}$ & $\mathrm{Ti}$ & $\mathrm{V}$ & $\mathrm{Cr}$ & $\mathrm{Fe}$ & $\mathrm{Ga}$ \\
\hline $\min$ & 120.0 & 209.0 & 28.2 & 312.0 & 1898.4 & 40.7 \\
\hline $\max$ & 170.0 & 266.0 & 61.0 & 2090.0 & 2570.4 & 57.4 \\
\hline average & 137.2 & 238.7 & 44.6 & 1049.9 & 2109.3 & 47.8 \\
\hline median & 137.0 & 242.0 & 45.2 & 1070.0 & 2049.6 & 46.9 \\
\hline \multicolumn{7}{|c|}{ Yogo Rubies (8 Samples, 24 Analyses) } \\
\hline & $\mathrm{Mg}$ & $\mathrm{Ti}$ & V & $\mathrm{Cr}$ & $\mathrm{Fe}$ & $\mathrm{Ga}$ \\
\hline $\min$ & 112.0 & 176.0 & 22.1 & 2110.0 & 1713.6 & 34.5 \\
\hline $\max$ & 164.0 & 306.0 & 68.5 & $1,2900.0$ & 2906.4 & 47.9 \\
\hline average & 135.3 & 233.5 & 43.6 & 5538.8 & 2308.3 & 41.2 \\
\hline median & 133.5 & 239.0 & 43.4 & 4685.0 & 2377.2 & 40.7 \\
\hline
\end{tabular}

bdl = below the detection limit, see "Materials and Methods" section for details.
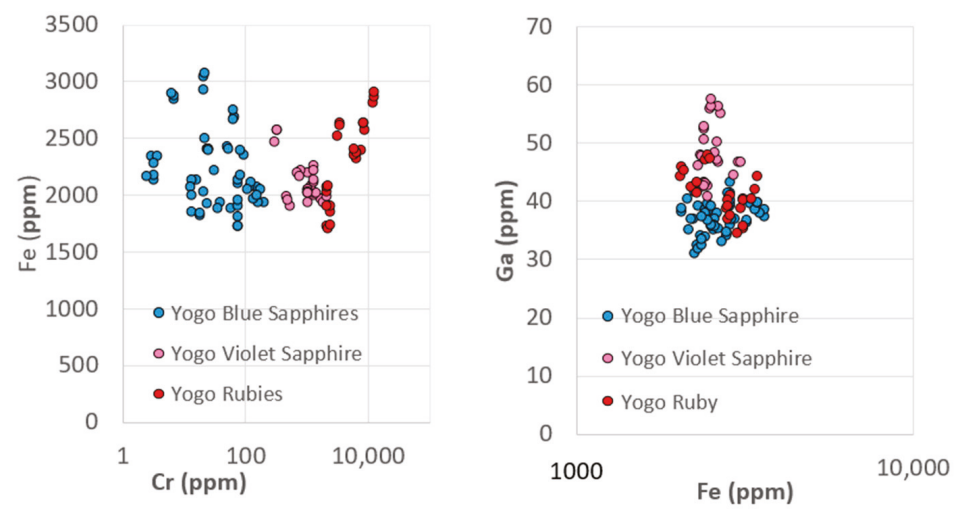

Figure 7. Plots of trace element chemistry of blue and pink sapphires and rubies from Yogo Gulch, Montana, showing their characteristic trace element ranges.

Further information about the relationships between the various trace elements in Yogo sapphires and rubies can be obtained by studying their correlation matrices (Tables 11 and 12). As with the secondary Montana sapphires, the very high $\mathrm{Cr}$ range for stones from Yogo is comprised of only a few samples. With this uneven distribution of samples across the $\mathrm{Cr}$ range, there is a chance that the correlations reported between $\mathrm{Cr}$ and other elements are skewed. For this reason, we report two correlation matrices for both the full range of samples including rubies (Table 11) and another reduced sample set including only blue and violet sapphires (Table 12). The strongest positive correlation is 
between $\mathrm{Mg}$ and $\mathrm{Ti}$, but there also appears to be strong positive correlation between $\mathrm{V}$ and both $\mathrm{Mg}$ and Ti. Chromium shows positive correlation with $\mathrm{V}$ in both datasets. When rubies are included, $\mathrm{Cr}$ shows positive correlation also with $\mathrm{Mg}$, Ti, Fe, and possibly $\mathrm{Ga}$; however, this disappears for Fe and $\mathrm{Ga}$ when rubies are removed, and it weakens for $\mathrm{Mg}$ and Ti. Additionally, Fe has weak correlation with $\mathrm{Mg}$, Ti and $\mathrm{V}$.

Table 11. Correlation table for trace elements of Yogo blue and violet sapphires and rubies.

\begin{tabular}{ccccccc}
\hline & $\mathbf{M g}$ & $\mathbf{T i}$ & $\mathbf{V}$ & $\mathbf{C r}$ & $\mathbf{F e}$ & $\mathbf{G a}$ \\
\hline $\mathbf{M g}$ & 1 & & & & & \\
$\mathbf{T i}$ & 0.956 & 1 & & & & \\
$\mathbf{V}$ & 0.665 & 0.748 & 1 & & & \\
$\mathbf{C r}$ & 0.551 & 0.496 & 0.520 & 1 & & \\
$\mathbf{F e}$ & -0.050 & -0.072 & -0.131 & 0.351 & 1 & \\
$\mathbf{G a}$ & 0.483 & 0.567 & 0.762 & 0.159 & -0.127 & 1 \\
\hline
\end{tabular}

Table 12. Correlation table for trace elements of only blue and violet sapphires from Yogo.

\begin{tabular}{ccccccc}
\hline & $\mathbf{M g}$ & $\mathbf{T i}$ & $\mathbf{V}$ & $\mathbf{C r}$ & $\mathbf{F e}$ & $\mathbf{G a}$ \\
\hline $\mathbf{M g}$ & 1 & & & & & \\
$\mathbf{T i}$ & 0.970 & 1 & & & & \\
$\mathbf{V}$ & 0.697 & 0.766 & 1 & & & \\
$\mathbf{C r}$ & 0.222 & 0.334 & 0.700 & 1 & & \\
$\mathbf{F e}$ & -0.151 & -0.162 & -0.347 & -0.340 & 1 & \\
$\mathbf{G a}$ & 0.407 & 0.400 & 0.376 & -0.018 & 0.208 & 1 \\
\hline
\end{tabular}

Generally speaking, gem corundum from Yogo tends to have very few inclusions, which makes it difficult to make microscopic observations on the inclusions within a statistically meaningful sample set for the rare red rubies. However, the small set of Yogo rubies we have been able to study appear to have similar inclusions to the purples and blues, including silicate and carbonatite melt inclusions, feldspars, and large, euhedral rutile inclusions. Melt inclusions have been analyzed in the Yogo sapphires and rubies and were found to be similar regardless of the color range [14].

\subsection{Sri Lankan Blue Sapphires and Rubies}

Sri Lanka was the ancient world's preeminent source of blue sapphires, and the culture of blue sapphire mining is still important to this gem island. While the mines are generally not as productive as they may have been in the past, there is still steady production of blue sapphires, especially in the Elahera, Ratnapura, and Kataragama areas. Today Sri Lankan sapphires also have to compete with the massive production of stones coming from the relatively new deposits in Madagascar, where the blue sapphires produced can be very similar in their gemological properties to Sri Lankan blue sapphires. In Sri Lanka (as well as in Madagascar), the sapphires are considered to belong to the metamorphic group and to have been formed during regional metamorphism during the collision of east and west Gondwana during the Mozambique Orogeny, which lasted from about 750 to $450 \mathrm{Ma}$ [1,2]. The host rock for the sapphires has not really been determined in most cases, but it is considered most likely that they formed from amphibolite or granulite facies metamorphic rocks [1].

The gem wealth of Sri Lanka does not stop at blue sapphires, and the color of gem corundum from Sri Lanka extends beyond just the blues. While blue sapphires are the most economically important, many other colors are produced including yellow and pink sapphires, orangy-pink or pinkish-orange so-called padparadscha sapphires, as well as uncommon rubies. In general, the blue and pink sapphires and rubies have similar averages and ranges for $\mathrm{Mg}$, $\mathrm{Ti}$, and $\mathrm{Ga}$, while Fe tends to be enriched in the blue sapphires relative to the pink sapphires and rubies, although there is overlap in the lower Fe concentration range (Table 13). As expected, $\mathrm{Cr}$ increases steadily from the blue sapphires (average of 
$4.2 \mathrm{ppm}$ ) to pink sapphires (average of $131 \mathrm{ppm}$ ) to rubies (average of $1217 \mathrm{ppm}$ ). Vanadium follows a similar trend increasing from blue sapphires (average of $19.8 \mathrm{ppm}$ ) to pink sapphires (average of $49.1 \mathrm{ppm}$ ) to rubies (average of $68.8 \mathrm{ppm}$ ) as well (Figure 8). One trend that is particularly notable is the continuous increase in $\mathrm{Cr}$ contents from blue to pink sapphires to rubies with little to no variation in the other trace elements. When these stones are displayed in plots not involving $\mathrm{Cr}$, there tends to be nearly complete overlap in their trace element ranges (except for the extension of the blue sapphires to the high Fe range).

Table 13. Summary of trace elements for Sri Lanka sapphires and rubies in ppm.

\begin{tabular}{|c|c|c|c|c|c|c|}
\hline \multicolumn{7}{|c|}{ Sri Lanka Blue Sapphires (61 Samples, 581 Analyses) } \\
\hline & $\mathrm{Mg}$ & $\mathrm{Ti}$ & $\mathbf{V}$ & $\mathrm{Cr}$ & Fe & Ga \\
\hline $\min$ & 20.3 & 20.9 & bdl & bdl & 57.1 & 21 \\
\hline $\max$ & 464.9 & 3309.1 & 122.0 & 74.4 & 2461.0 & 173.0 \\
\hline average & 50.3 & 311.6 & 19.8 & 4.2 & 760.0 & 66.8 \\
\hline median & 39.3 & 155.0 & 13.5 & bel & 601.4 & 65.9 \\
\hline \multicolumn{7}{|c|}{ Sri Lanka Pink Sapphires (18 Samples, 65 Analyses) } \\
\hline & Mg & $\mathrm{Ti}$ & V & $\mathrm{Cr}$ & $\mathrm{Fe}$ & $\mathrm{Ga}$ \\
\hline $\min$ & 25.0 & 32.1 & 9.9 & 28.4 & 53.7 & 8.2 \\
\hline $\max$ & 292.0 & 2500.0 & 309.0 & 248.0 & 819.8 & 113.3 \\
\hline average & 94.9 & 252.1 & 49.1 & 131.0 & 311.9 & 46.2 \\
\hline median & 75.3 & 156.0 & 30.8 & 123.0 & 302.4 & 47.0 \\
\hline \multicolumn{7}{|c|}{ Sri Lanka Rubies (17 Samples, 51 Analyses) } \\
\hline & $\mathrm{Mg}$ & $\mathrm{Ti}$ & V & $\mathrm{Cr}$ & $\mathrm{Fe}$ & $\mathrm{Ga}$ \\
\hline $\min$ & 11.5 & 36.0 & 15.1 & 207.0 & 26.9 & 32.5 \\
\hline $\max$ & 142.0 & 1429.6 & 210.0 & 4019.7 & 825.7 & 157.0 \\
\hline average & 66.6 & 276.2 & 68.8 & 1217.0 & 357.4 & 70.2 \\
\hline median & 66.7 & 232.9 & 51.9 & 834.9 & 377.1 & 59.2 \\
\hline
\end{tabular}

bdl = below the detection limit, see "Materials and Methods" section for details.
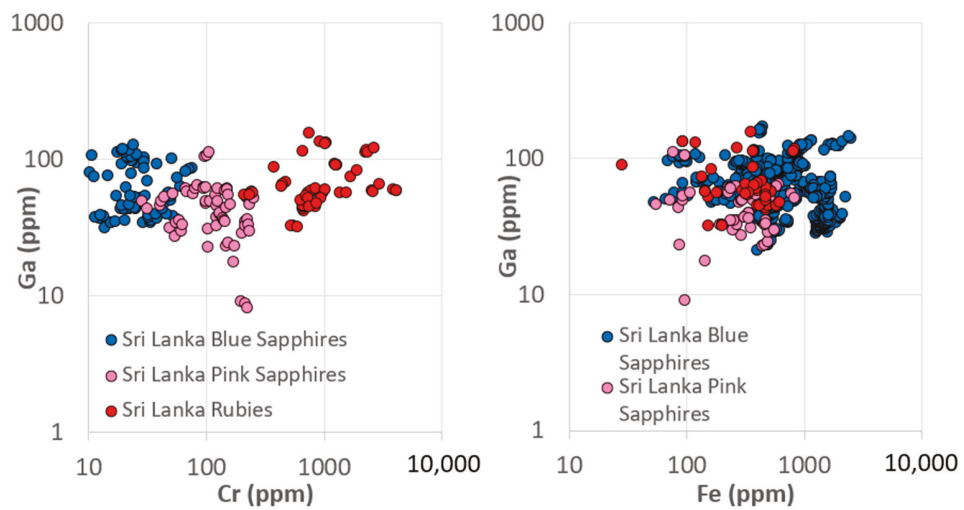

Figure 8. Trace element plots of blue and pink sapphires and rubies from Sri Lanka showing their characteristic trace element ranges.

Additional insight into the relationships between trace elements across the blue to pink sapphire to ruby range can be gained by studying correlation matrices between trace elements (Table 14). The strongest positive correlation is between $\mathrm{Mg}$ and $\mathrm{Ti}$, but there is also strong correlation between $\mathrm{V}$ and both $\mathrm{Mg}$ and $\mathrm{Ti}$. Chromium has a weak positive correlation with $\mathrm{Mg}$ but no correlations with any 
other elements. Both Fe and Ga show moderate positive correlation with $\mathrm{Mg}$, $\mathrm{Ti}$ and $\mathrm{V}$, but there is no correlation to a slightly negative correlation between Fe and Ga.

Table 14. Correlation table for trace elements of Sri Lankan blue and pink sapphires and rubies.

\begin{tabular}{ccccccc}
\hline & $\mathbf{M g}$ & $\mathrm{Ti}$ & $\mathbf{V}$ & $\mathbf{C r}$ & $\mathbf{F e}$ & $\mathrm{Ga}$ \\
\hline $\mathbf{M g}$ & 1 & & & & & \\
$\mathbf{T i}$ & 0.817 & 1 & & & & \\
$\mathbf{V}$ & 0.814 & 0.911 & 1 & & & \\
$\mathbf{C r}$ & 0.282 & -0.028 & 0.135 & 1 & & \\
$\mathbf{F e}$ & 0.433 & 0.443 & 0.512 & -0.369 & 1 & \\
$\mathbf{G a}$ & 0.457 & 0.711 & 0.632 & 0.127 & -0.185 & 1 \\
\hline
\end{tabular}

This similarity seen in trace element chemistry across the entire color range is also seen for these stones' inclusions. Typical inclusions within Sri Lankan blue sapphires are biotite, elongate, continuous rutile silk, $\mathrm{CO}_{2}$ inclusions, elongate negative crystals, and sometimes short, reflective platelet-like silk that can show iridescent colors using an intense fiber optic light (Figure 9C,D). The pink sapphires and rubies generally contain very similar inclusions with elongate silk, biotite, elongate negative crystals, and short, reflective platelet-like silk (Figure 9A,B).
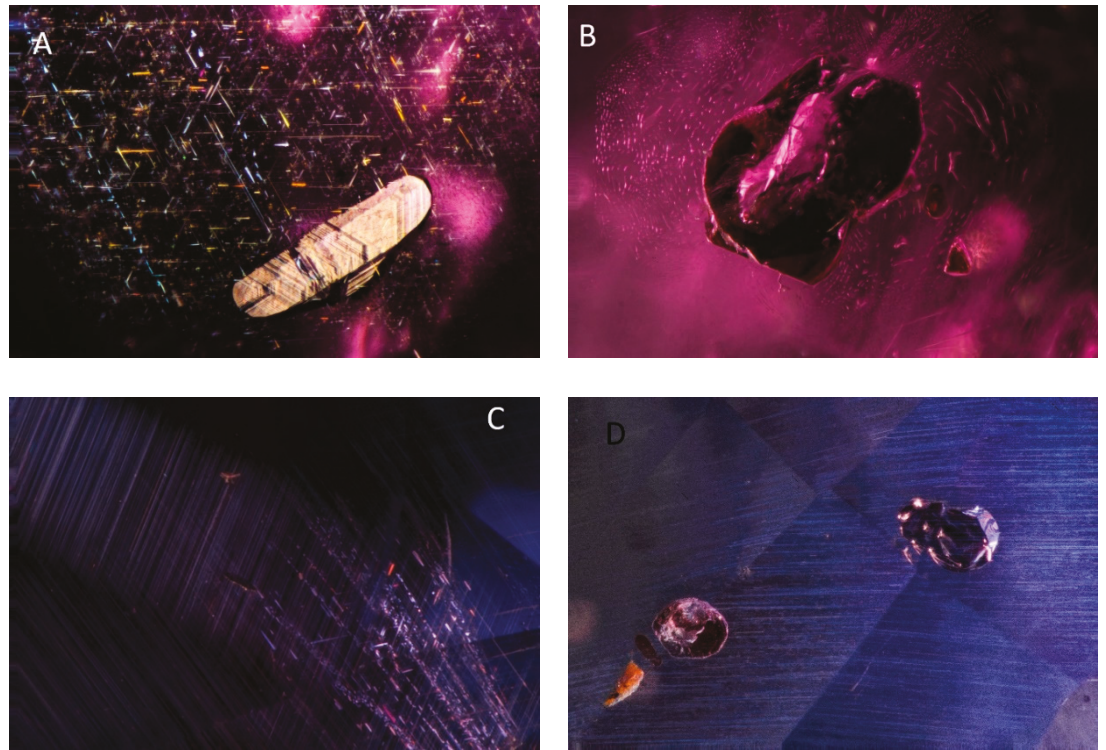

Figure 9. Photomicrographs of typical inclusions in Sri Lankan (A,B) rubies representing (A) elongate negative crystals and reflective rutile silk and (B) a biotite inclusion and (C,D) blue sapphire representing (C) elongate and reflective rutile silk and (D) biotite inclusions. Photomicrographs by Aaron C. Palke. Fields of view: (A) $1.26 \mathrm{~mm}$, (B) $1.76 \mathrm{~mm}$, (C) $1.47 \mathrm{~mm},($ D) $1.49 \mathrm{~mm}$.

\section{Discussion and Conclusions}

As this special issue can attest, the investigation of the geological genesis of important gemstone deposits has become a serious scientific pursuit. Unfortunately, in many cases traditional geological studies are inadequate to understand the formation of gem corundum deposits. This is because most gem corundum is found in secondary deposits formed through millions of years of weathering, and hence, much of the traditional geological context is lost. Therefore, in order to understand these 
precious stones' geological story, researchers must turn to clues taken from the stones' inclusions, trace elements, and isotopes. Inclusions have been especially helpful in many cases especially the study of melt and mineral inclusions [14,21,24-26]. It can be challenging to build a full geologic model from inclusions that may sparsely populate the gem corundum and which may or may not be fully representative of the initial mineral/fluid assemblage in which the stones formed. However, often inclusions are the only available piece of evidence that can directly link the sapphires and rubies to their geological origins. Inclusion analysis has been useful to study other gemstones as well such as the use of diamond inclusions, which has vastly improved our understanding of the deep Earth $[27,28]$.

In contrast, the path from trace element chemistry to geological origin is less well understood. Many previous studies have shown that trace element chemistry of gem corundum is controlled by geological origin $[19,29-31]$. However, there have been some documented cases where the trace element chemistry classification of stones from certain deposits does not agree with information of their geological origin from either their inclusions or geological field observations $[14,21,28,32,33]$. As described by these authors, while the existing chemical discrimination diagrams can be quite useful, in some cases, they do not always accurately predict geological origin. Even without these specific cases where the existing classification schemes break down, [15] suggested that even for the classical metamorphic and basalt-related blue sapphires, there is some degree of overlap in their trace element chemistry in the range of Fe and Ga concentrations, where the Fe and Ga are at the high end for metamorphic blue sapphires and at the low end for basalt-related blue sapphires.

When discussing the geological origins of gem corundum, rubies and blue sapphires are often considered separately [1], with the implication that the geological conditions for sufficient $\mathrm{Cr}$-enrichment to form rubies must be significantly different from the geological conditions that would form low-Cr blue sapphires. The Thai/Cambodian rubies are considered to have formed from rocks that could have been $\mathrm{Cr}$-enriched, while their blue sapphire counterparts likely formed from alkaline igneous rocks such as syenites that should not have been significantly enriched in $\mathrm{Cr}$ [11,15]. Some of the established trace element geological classification schemes utilize $\mathrm{Cr}$ as an essential discriminant between metamorphic and magmatic sapphires with the implication that $\mathrm{Cr}$ is expected to partition into corundum differently based on geological origin [34,35]. However, how far can this argument go before it breaks down? From the results presented above for gem corundum deposits that produce both rubies and blue sapphires within the same deposit, it is clear there are two types of coexisting blue sapphire/ruby assemblages: monogenetic and polygenetic assemblages.

The polygenetic assemblages are those in which rubies and blue sapphires clearly have different geological origins, and yet, the two geochemically and geologically distinct assemblages happen to occur in the same deposit. In the present work, this includes blue sapphires and rubies from Thailand/Cambodia as well as Mogok, Myanmar. It should be noted that this is not necessarily to say that the origin of the rubies and blue sapphires are completely unrelated. The rubies and blue sapphires in Chanthaburi, Thailand, and Pailin, Cambodia, were clearly transported to the surface by similar alkali basalts; however, the results above and work from other researchers indicate that these two varieties of gem corundum were derived from mineralogically and geochemically distinct environments $[14,16,17,24]$. Similarly, rubies and blue sapphires from Mogok, Myanmar, were both derived from regional metamorphism and/or igneous activity directly related to the Himalayan Orogeny, even if their specific modes of formation are distinct. Furthermore, while the rubies and sapphires from both the Thai/Cambodian and Mogok deposits are distinct in many of their properties, there are some similarities in their properties that tend to obscure the documented differences in their geological origins. For instance, although there are differences in their overall inclusions, the short reflective platelet-like silk, occasional long, slender rutile silk, and calcite mineral inclusions are common between the two types of stones. Additionally, for the sapphires and rubies from Mogok, Myanmar, while there are clear differences in their Fe contents, plots involving other elements such as $\mathrm{Mg}$, $\mathrm{Ti}$, and $\mathrm{Ga}$ tend to show nearly complete overlap in their compositions. 
In contrast, the monogenetic ruby/sapphire assemblages described here are those in which the inclusions and trace element chemistry point toward a single geological origin for rubies and blue sapphires within a single deposit. In this study this includes rubies and blue sapphires from Yogo Gulch, Montana, as well as the secondary Montana sapphires and rubies in addition to the rubies and blue sapphires from Sri Lanka. One notable aspect of the monogenetic assemblages is the continuous transition in $\mathrm{Cr}$ concentrations across the blue sapphire-pink sapphire-ruby spectrum. However, the most surprising feature of the trace element relationships in the monogenetic suites is that $\mathrm{Cr}$ does not show a correlation with most other trace elements. The main exception seems to be $\mathrm{V}$, which is positively correlated with $\mathrm{Cr}$ in most cases. Note, Zaw et al. also discussed the potential correlation between $\mathrm{V}$ and $\mathrm{Cr}$ in rubies and sapphires from Mogok, Myanmar [30]. Occasionally, the correlation matrices also show a weak positive correlation with trace elements like $\mathrm{Ga}$ and sometimes $\mathrm{Mg}$ or Ti. However, the other trace elements in the monogenetic assemblages tend to vary generally by less than two orders of magnitude, while $\mathrm{Cr}$ can vary by well over three to nearly four orders of magnitude. Even over this wide range in $\mathrm{Cr}$ concentrations, there is typically relatively little variation in the range of the other trace elements (except $\mathrm{V}$ as stated above). One surprising observation here is that $\mathrm{Cr}$ concentrations can vary between such extremes with little to no variations in the trace element chemistry and inclusions. This presumably indicates similar geological origins for the high- and low-Cr corundum. Apparently, in these environments, $\mathrm{Cr}$ behaves independently from the other trace elements commonly found in gem corundum, even when compared to trace elements that share the same valence state as $\mathrm{Al}^{3+}$ such as $\mathrm{Fe}^{3+}$ and $\mathrm{Ga}^{3+}$.

While this study focuses on a small number of deposits where reliably collected reference samples were available, there is ample room for expanding this work to other important deposits. Notably, the Australian sapphire fields, known as one of the most important producers of basalt-related sapphires, have also occasionally produced red rubies, although in significantly lower quantities [36-39]. In fact, Sutherland et al. [39] noted a very similar transition from purple and bluish sapphire to pink sapphire to rubies in the New England, New South Wales, gem fields which had higher Ga and Ga/Mg ratios than other basalt-related rubies such as those from Chanthaburi, Thailand, and Pailin, Cambodia. Additionally, while understudied, the gem corundum deposits of Colombia are known for producing small quantities of rubies in addition to blue and other fancy colored sapphire [40,41]. Rubies from many deposits in their natural, untreated state often have distinct blue color zoning either in the cores of the stones as in Mong Hsu stones from Myanmar [42,43], Vietnam [43-46], or Tajikistan [43,47,48]. While this blue/red zoned corundum may not fit the category of monogenetic ruby/blue sapphire assemblages, they are evidence of the complex geochemical controls on the trace element chemistry of gem corundum and the difficulty of neatly categorizing these stones based on their trace elements.

The reasons for the extreme diversity in $\mathrm{Cr}$ concentrations relative to other trace elements in the monogenetic ruby/blue sapphire assemblages are not obvious. One possible explanation is mineralogical heterogeneity in Cr-bearing minerals in the geological environment in which the gem corundum formed. Cr tends to be concentrated in a relatively small number of mineral phases compared to Fe and $\mathrm{Ga}$, and this extreme variance in $\mathrm{Cr}$ concentrations could be related to the fortuitous spatial relationship between the growing corundum crystal and nearby $\mathrm{Cr}$-bearing minerals. However, what would be the cause for such extreme heterogeneity in Cr-bearing minerals in the monogenetic assemblages relative to the polygenetic ruby/sapphire assemblages?

One conclusion from this study is that rubies and sapphires do not necessarily represent different tectonic environments or different geological conditions of formation. Whatever environments facilitate the formation of gem corundum in the Earth, they may not always discriminate between $\mathrm{Cr}$-enriched rubies and $\mathrm{Cr}$-poor blue sapphires. The observations and discussion presented here provide a basis for further investigations into the question posited above: what makes a ruby a ruby? With such huge differences in the value placed on these two varieties of gem corundum, we often still need to understand the geochemical constraints that can turn a sapphire into an extraordinary, richly colored red ruby. 
Funding: This research received no external funding.

Acknowledgments: I would like to express gratitude to my colleagues at the Gemological Institute of America who have helped inspire this work through conversations about the wide world of gemology and gemstone science including Nathan Renfro, Wim Vertriest, Sudarat Saeseaw, Ziyin Sun, Shane McClure, Dino DeGhionno, Karen Smit, Evan Smith, and Christopher M. Breeding. Four anonymous reviewers also provided many useful suggestions and comments that significantly strengthened this manuscript. Thanks as well to special editors Lin Sutherland and Khin Zaw for their editorial input and constructive suggestions and the invitation to submit this manuscript in this Special Issue of Minerals concerning the geology of ruby deposits.

Conflicts of Interest: The author declares no conflict of interest.

\section{References}

1. Giuliani, G.; Ohnenstetter, D.; Fallick, A.E.; Groat, L.A.; Fagan, A.J. The geology and genesis of gem corundum deposits. In Geology of Gem Deposits, 2nd ed.; Groat, L.A., Ed.; Short Course Series; Mineralogical Association of Canada: Quebec City, QC, Canada, 2014; Volume 44, pp. 29-112.

2. Giuliani, G.; Groat, L.A. Geology of corundum and emerald gem deposits: A review. Gems Gemol. 2019, 55, 464-489. [CrossRef]

3. Garnier, V.; Giuliani, G.; Ohnenstetter, D.; Fallick, A.E.; Dubessy, J.; Banks, D.; Vinh, H.Q.; Lhomme, T.; Maluski, H.; Pêcher, A.; et al. Marble-hosted ruby deposits from Central and Southeast Asia: Towards a new genetic model. Ore Geol. Rev. 2008, 34, 169-191. [CrossRef]

4. Giuliani, G.; Dubessy, J.; Ohnenstetter, D.; Banks, D.; Branquet, Y.; Feneyrol, J.; Fallick, A.E.; Martelat, J.-E. The role of evaporites in the formation of gems during metamorphism of carbonate platforms: A review. Miner. Depos. 2018, 53,1-20. [CrossRef]

5. Simonet, C.; Fritsch, E.; Lasnier, B.A. classification of gem corundum deposits aimed towards gem exploration. Ore Geol. Rev. 2008, 34, 127-133. [CrossRef]

6. Vertriest, W.; Palke, A.C.; Renfro, N.D. Field gemology: Building a research collection and understanding the development of gem deposits. Gems Gemol. 2019, 55, 490-511. [CrossRef]

7. Longerich, H.P.; Jackson, S.E.; Günther, D. Inter-laboratory note. Laser ablation inductively coupled plasma mass spectrometric transient signal data acquisition and analyte concentration calculation. J. Anal. At. Spctrm. 1996, 11, 899-904. [CrossRef]

8. Hughes, R.W.; Manorotkul, W.; Hughes, E.B. Ruby \& Sapphire: A Gemologist's Guide; RWH Publishing/Lotus Publishing: Bangkok, Thailand, 2017; p. 816.

9. Sutthirat, C.; Saminpanya, S.; Droop, G.T.R.; Henderson, C.M.B.; Manning, D.A.C. Clinopyroxene-corundum assemblages from alkali basalt and alluvium, eastern Thailand: Constraints on the origin of Thai rubies. Mineral. Mag. 2001, 65, 277-295. [CrossRef]

10. Khoi, N.N.; Sutthirat, C.; Tuan, D.A.; Van Nam, N.; Thuyet, N.T.M.; Nhung, N.T. Ruby and Sapphire from the Tan Huong-Truc Lau Area, Yen Bai Province, Northern Vietnam. Gems Gemol. 2011, 47, 182-195. [CrossRef]

11. Saminpanya, S.; Sutherland, F.L. Different origins of Thai area sapphire and ruby, derived from mineral inclusions and co-existing minerals. Eur. J. Mineral. 2011, 23, 683-694. [CrossRef]

12. Promwongnan, S.; Sutthirat, C. Mineral Inclusions in Ruby and Sapphire from the Bo Welu Gem Deposit in Chanthaburi, Thailand. Gems Gemol. 2019, 55, 354-369. [CrossRef]

13. Koivula, J.I.; Fryer, C.W. Sapphirine (not sapphire) in a ruby from Bo Rai, Thailand. J. Gemmol. 1987, $20,70$. [CrossRef]

14. Palke, A.C.; Wong, J.; Verdel, C.; Ávila, J.N. A common origin for Thai/Cambodian rubies and blue and violet sapphires from Yogo Gulch, Montana, USA? Am. Mineral. 2018, 103, 469-479. [CrossRef]

15. Palke, A.C.; Saeseaw, S.; Renfro, N.D.; Sun, Z.; McClure, S.F. Geographic origin determination of blue sapphire. Gems Gemol. 2019, 55, 354-369. [CrossRef]

16. Graham, I.; Sutherland, L.; Zaw, K.; Nechaev, V.; Khanchuk, A. Advances in our understanding of the gem corundum deposits of the West Pacific continental margins intraplate basaltic fields. Ore Geol. Rev. 2008, 34, 200-215. [CrossRef] 
17. Srithai, B.; Rankin, A. Geochemistry and genetic significance of melt inclusions in corundum from the Bo Ploi sapphire deposits, Thailand. In Proceedings of the Program with Abstracts of the First Meeting Asia Current Research on Fluid Inclusion, Nanjing, China, 26-28 May 2006.

18. Berg, R.B.; Palke, A.C. Sapphires from an Eocene sill near Helena, Montana. In Proceedings of the GSA Annual Meeting, Denver, CO, USA, 27 September 2016; p. 48.

19. Peucat, J.J.; Ruffault, P.; Fritsch, E.; Bouhnik-Le Coz, M.; Simonet, C.; Lasnier, B. Ga/Mg ratio as a new geochemical tool to differentiate magmatic from metamorphic blue sapphires. Lithos 2007, 98, 261-274. [CrossRef]

20. Zwaan, J.C.; Buter, E.; Mertz-Kraus, R.; Kane, R.E. Alluvial sapphires from Montana: Inclusions, geochemistry, and indications of a metasomatic origin. Gems Gemol. 2015, 51, 370-391. [CrossRef]

21. Palke, A.C.; Renfro, N.D.; Berg, R.B. Melt inclusions in alluvial sapphires from Montana, USA: Formation of sapphires as a restitic component of lower crustal melting? Lithos 2017, 278, 43-53. [CrossRef]

22. Malaquais, C. A rare ruby from Montana. Gems Gemol. 2018, 54, 434-435.

23. Palke, A.C.; Hapeman, J.R. Rubies from Rock Creek, Montana. Gems Gemol. 2019, 55, 286-288.

24. Limtrakun, P.; Zaw, K.; Ryan, C.G.; Mernagh, T.P. Formation of the Denchai gem sapphires, northern Thailand: Evidence from mineral chemistry and fluid/melt inclusion characteristics. Mineral. Mag. 2001, 65, 725-735. [CrossRef]

25. Pakhomova, V.A.; Zalishchak, B.L.; Odarichenko, E.G.; Lapina, M.I.; Karmanov, N.S. Study of melt inclusions in the Nezametnoye corundum deposit, Primorsky region of the Russian Far East: Petrogenetic consequences. J. Geochem. Explor. 2006, 89, 302-305. [CrossRef]

26. Palke, A.C.; Renfro, N.D.; Berg, R.B. Origin of sapphires from a lamprophyre dike at Yogo Gulch, Montana, USA: Clues from their melt inclusions. Lithos 2016, 260, 339-344. [CrossRef]

27. Smith, E.M.; Shirey, S.B.; Nestola, F.; Bullock, E.S.; Wang, J.; Richardson, S.H.; Wang, W. Large gem diamonds from metallic liquid in Earth's deep mantle. Science 2016, 354, 1403-1405. [CrossRef] [PubMed]

28. Smit, K.V.; Shirey, S.B.; Hauri, E.H.; Stern, R.A. Sulfur isotopes in diamonds reveal differences in continent construction. Science 2019, 364, 383-385. [CrossRef] [PubMed]

29. Sutherland, F.L.; Schwarz, D. Origin of gem corundums from basaltic fields. Aust. Gemmol. 2001, 21, 30-33.

30. Zaw, K.; Sutherland, L.; Yui, T.F.; Meffre, S.; Thu, K. Vanadium-rich ruby and sapphire within Mogok Gemfield, Myanmar: Implications for gem color and genesis. Miner. Depos. 2015, 50, 25-39. [CrossRef]

31. Sutherland, L.; Zaw, K.; Meffre, S.; Yui, T.-F.; Thu, K. Advances in trace element "Fingerprinting" of gem corundum, ruby and sapphire, Mogok Area, Myanmar. Minerals 2015, 5, 61-79. [CrossRef]

32. Sorokina, E.S.; Rassomakhin, M.A.; Nikandrov, S.N.; Karampelas, S.; Kononkova, N.N.; Nikolaev, A.G.; Anosova, M.O.; Somsikova, A.V.; Kostitsyn, Y.A.; Kotlyarov, V.A. Origin of blue sapphire in newly discovered spinel-chlorite-muscovite rocks within meta-ultramafites of Ilmen Mountains, South Urals of Russia: Evidence from mineralogy, geochemistry, Rb-Sr and Sm-Nd isotopic data. Minerals 2019, 9, 36. [CrossRef]

33. Darling, R.S.; Gordon, J.L.; Loew, E.R. Microscopic Blue Sapphire in Nelsonite from the Western Adirondack Mountains of New York State, USA. Minerals 2019, 9, 633. [CrossRef]

34. Sutherland, F.L.; Schwarz, D.; Jobbins, E.A.; Coenraads, R.R.; Webb, G. Distinctive gem corundum suites from discrete basalt fields; a comparative study of Barrington, Australia, and West Pailin, Cambodia, gemfields. J. Gemmol. 1998, 26, 65-85. [CrossRef]

35. Giuliani, G.; Pivin, M.; Fallick, A.E.; Ohnenstetter, D.; Song, Y. Demaiffe Geochemical and oxygen isotope signatures of mantle corundum megacrysts from Mbujui-Mayi kimberlite, Democratic Republic of Congo, and the Changle alkali basalt, China. Comptes Rend. Geosc. 2015, 347, 24-34. [CrossRef]

36. Sutherland, F.L.; Coenraads, R.R. An unusual ruby-sapphire-sapphirine-spinel assemblage from the Tertiary Barrington volcanic province, New South Wales, Australia. Mineral. Mag. 1996, 60, 623-638. [CrossRef]

37. Sutherland, F.L.; Graham, I.T.; Pogson, R.E.; Schwarz, D.; Webb, G.B.; Coenraads, R.R.; Fanning, C.M.; Hollis, J.D.; Allen, T.C. The Tumbarumba basaltic gem field, New South Wales: In relation to sapphire-ruby deposits of eastern Australia. Rec. -Aust. Mus. 2002, 54, 215-248.

38. Sutherland, F.L.; Coenraads, R.R.; Schwarz, D.; Raynor, L.R.; Barron, B.J.; Webb, G.B. Al-rich diopside in alluvial ruby and corundum-bearing xenoliths, Australian and SE Asian basalt fields. Mineral. Mag. 2003, 67, 717-732. [CrossRef] 
39. Sutherland, F.L.; Graham, I.T.; Harris, S.J.; Coldham, T.; Powell, W.; Belousova, E.A.; Martin, L. Unusual ruby-sapphire transition in alluvial megacrysts, Cenozoic basaltic gem field, New England, New South Wales, Australia. Lithos 2017, 278, 347-360. [CrossRef]

40. Keller, P.C.; Koivula, J.I.; Jara, G. Sapphire from the Mercaderes-Rio Mayo Area, Cauca, Colombia. Gems Gemol. 1985, 21, 20-25. [CrossRef]

41. Sutherland, F.L.; Duroc-Danner, J.M.; Meffre, S. Age and origin of gem corundum and zircon megacrysts from the Mercaderes-Rio Mayo area, South-west Colombia, South America. Ore Geol. Rev. 2008, 34, 155-168. [CrossRef]

42. Peretti, A.; Schmetzer, K.; Bernhardt, H.J.; Mouawad, F. Rubies from Mong Hsu. Gems Gemol. 1995, 31, $2-26$. [CrossRef]

43. Palke, A.C.; Saeseaw, S.; Renfro, N.D.; Sun, Z.; McClure, S.F. Geographic origin determination of ruby. Gems Gemol. 2019, 55. [CrossRef]

44. Kane, R.E.; McClure, S.F.; Kammerling, R.C.; Khoa, N.D.; Mora, C.; Repetto, S.; Khai, N.D.; Koivula, J.I. Rubies and fancy sapphires from Vietnam. Gems Gemol. 1991, 27, 136-155. [CrossRef]

45. Brown, G. Vietnamese ruby: A discriminatory problem for gemmologists. Aust. Gemmol. 1992, 18, 43-46.

46. Long, P.V.; Vinh, H.Q.; Garnier, V.; Giuliani, G.; Ohnenstetter, D. Marble-hosted ruby from Vietnam. Can. Gemmol. 2004, 25, 83-95.

47. Smith, C.P. Rubies and pink sapphires from the Pamir Range in Tajikistan, former USSR. J. Gemmol. 1998, 26, 103-109. [CrossRef]

48. Sorokina, E.S.; Litvinenko, A.K.; Hofmeister, W.; Häger, T.; Jacob, D.E.; Nasriddinov, Z.Z. Rubies and sapphires from Snezhnoe, Tajikistan. Gems Gemol. 2015, 51, 160-175. [CrossRef]

(C) 2020 by the author. Licensee MDPI, Basel, Switzerland. This article is an open access article distributed under the terms and conditions of the Creative Commons Attribution (CC BY) license (http://creativecommons.org/licenses/by/4.0/). 


\title{
Article \\ Petrogenesis of the Snezhnoe Ruby Deposit, Central Pamir
}

\author{
Andrey K. Litvinenko ${ }^{1}$, Elena S. Sorokina ${ }^{2,3}$, Tobias Häger ${ }^{2, *}$, Yuri A. Kostitsyn ${ }^{3}$, \\ Roman E. Botcharnikov ${ }^{2}$, Alina V. Somsikova ${ }^{3}$, Thomas Ludwig ${ }^{4}$, Tatiana V. Romashova ${ }^{3}$ \\ and Wolfgang Hofmeister ${ }^{2}$ \\ 1 Department of Mineralogy and Gemology, Russian State Geological Prospecting University (MGRI), \\ Miklukho-Maklai str. 23, 117485 Moscow, Russia; litvinenkoak@mgri.ru \\ 2 Institut für Geowissenschaften, Johannes Gutenberg-Universität Mainz (JGU), J.-J.-Becher-Weg 21, \\ 55128 Mainz, Germany; esorokin@uni-mainz.de (E.S.S.); rbotchar@uni-mainz.de (R.E.B.); \\ hofmeister@uni-mainz.de (W.H.) \\ 3 Vernadsky Institute of Geochemistry and Analytical Chemistry, Russian Academy of Sciences (GEOKHI \\ RAS), Kosygin str. 19, 119991 Moscow, Russia; kostitsyn@geokhi.ru (Y.A.K.); somsikova@geokhi.ru (A.V.S.); \\ romashova@geokhi.ru (T.V.R.) \\ 4 Institut für Geowissenschaften, Universität Heidelberg, Im Neuenheimer Feld 234-236, 69120 Heidelberg, \\ Germany; thomas.ludwig@geow.uni-heidelberg.de \\ * Correspondence: haeger@uni-mainz.de
}

Received: 1 April 2020; Accepted: 22 May 2020; Published: 24 May 2020

\begin{abstract}
The Snezhnoe ruby deposit is located in the Muzkol-Rangkul anticlinorium within the Cimmerian zone of the Central Pamir. On the local scale, the deposit occurs on discrete relict bedding planes of calcitic marbles belonging to the Sarydzhilgin suite. Four ruby-bearing mineral assemblages are present within the main parts of the deposit: (1) scapolite + phlogopite + muscovite + margarite; (2) plagioclase + muscovite + margarite; (3) muscovite + phlogopite + margarite; (4) calcite. The ruby + calcite association is the most economically important, whereas the association of plagioclase + scapolite + phlogopite + muscovite is typical for the ruby-free parts of the deposit. Mica group minerals with a distinctive green color due to enhanced $\mathrm{Cr}$ and $\mathrm{V}$ concentrations are the main prospecting indicators for the ruby mineralization. The oxygen isotopic composition of the rubies is $+15.3 \%$, a common value for crustal metamorphic and sedimentary rocks. The ratios of indicative trace elements in the rubies are $\mathrm{Ga} / \mathrm{Mg}<8.2, \mathrm{Fe} / \mathrm{Mg}<51.2, \mathrm{Cr} / \mathrm{Ga}>6.9$ and $\mathrm{Fe} / \mathrm{Ti}<31.6$. These values are characteristic for metamorphic corundum. The bulk ruby-bearing rocks have an initial ${ }^{87} \mathrm{Sr} /{ }^{86} \mathrm{Sr}$ ratio of $\sim 0.70791$ and $\varepsilon \mathrm{Nd}$ of $\sim-9.6$, also pointing to the crustal origin of the deposit in agreement with the geological data. Ancient Al-enriched sediments are suggested to be a possible protolith for the ruby-bearing rocks. The temperature of the metamorphic processes was estimated at $760 \pm 30^{\circ} \mathrm{C}$ using Zr-in-rutile geothermometry. Raman mapping of rutile inclusions trapped within the ruby crystal indicates that the minimum pressure of mineralization was about one kilobar. The age determined by the $\mathrm{Rb}-\mathrm{Sr}$ thermal ionization mass spectrometry of phlogopite, plagioclase and bulk rock is $23 \pm 1.6 \mathrm{Ma}$, corresponding to the timing of relaxation after peak metamorphism during the Alpine-Himalayan Orogeny.
\end{abstract}

Keywords: ruby; mineralogical association; geochemistry; Snezhnoe deposit; Tajikistan; Central Pamir; Muzkol-Rangkul anticlinorium; in situ U-Pb LA-ICP-MS rutile dating; oxygen isotopes; $\mathrm{Rb}-\mathrm{Sr}$ and $\mathrm{Sm}-\mathrm{Nd}$ isotopes

\section{Introduction}

Corundum $\left(\alpha-\mathrm{Al}_{2} \mathrm{O}_{3}\right)$ is the aluminum end-member of the hematite group of minerals and contains a limited number of transitional elements acting as its chromophores. Thus, ruby is assigned to the 
red-colored corundum variety that is due to the isomorphic substitution of $\mathrm{Al}^{3+}$ by $\mathrm{Cr}^{3+}$. Gem-quality ruby and sapphire (the blue-green-yellow-colored gem varieties of corundum) deposits are rare resulting in their high economic value with annual worldwide production exceeding several billion dollars [1]. The occasional discovery of large-scale commercial ruby deposits is related to the rarity of geological processes that produce them. Ruby mineralization commonly occurs as a result of moderate to high temperature metamorphic and magmatic processes in continent-continent collision zones ([2-6], etc.), less frequently in subduction areas [7]. Hence, their formation can be caused by several different processes over various timescales. This makes the reconstruction of the genesis and evolution of ruby mineralization challenging.

The Snezhnoe marble-hosted ruby deposit is located in the Tajik eastern part of the Central Pamir region within the Alpine-Himalayan Belt and is linked to Cenozoic Indo-Asia collision [4]. Due to being part of this collision, it shares many mineralogical and geochemical features common for metamorphic ruby sites formed along this mobile belt and related syn-tectonic structures including Mogok in Myanmar, Jegdalek in Afghanistan, the Hunza Valley in Pakistan, Luc Yen in Vietnam, etc. [4]. However, despite numerous studies ([8-12], etc.), the thermodynamic conditions during the mineralization process and the formation age of the ruby-bearing rocks of the Snezhnoe deposit remain poorly understood. New mineralogical and petrochemical features of the ruby-bearing rocks, along with data on the oxygen and radiogenic isotope signatures are presented in this study. This new dataset is then applied for a better understanding the geological processes responsible for the formation of the Snezhnoe ruby deposit as well as for the establishment of exploration criteria for discovering future gem corundum mineralization and deposits.

\section{Geological Setting}

On the regional scale, the Snezhnoe deposit is located within the Muzkol-Rangkul anticlinorium belonging to the eastern part of the Tajik Central Pamir region (Figure 1). The western part of the area is adjacent to the Vanch-Yazguliem anticlinorium. Both anticlinoria are linked to the exposed Precambrian crystalline basement which was tectonically re-worked during the Cimmerian Orogeny [13].

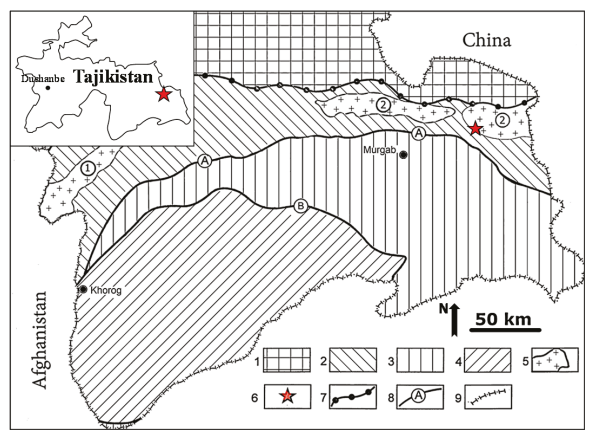

Figure 1. A location of the Snezhnoe deposit in relation to the main regional structures of the Pamir Mountains. Numbers 1-4 are folded regions: 1-northern Pamir (Hercynides); 2 to 4 -southern Pamir (Cimmerian Plate). The southern Pamir is subdivided into zone 2-central Pamir, 3-south-eastern Pamir and 4-southwestern Pamir; 5-Early Proterozoic blocks, 6- Snezhnoe deposit; 7 and 8-major faults: 7-between folded regions (Vanch-Akbaytal) and 8-between tectonic zones: A-Rushan-Pshart and B-Gunt-Alichur; 9-border of Tajikistan; 1 (in circle) -Vanch-Yazgulem anticlinorium, 2 (in circle) -Muzkol-Rangkul anticlinorium. The map is modified after [13].

The Muskol-Rangkul anticlinorium consists of two tectonic blocks, the Sarymulin anticline in the west and the Shatput anticline in the east. In the central part, it is covered by Paleozoic-Mesozoic volcanic-sedimentary rocks. The Snezhnoe deposit is located on the southwestern flank of the Shatput 
block $[14,15]$. This block represents a steeply dipping monocline with the main foliation trending from $200^{\circ}$ to $230^{\circ}$ and a dip angle varying from $45^{\circ}$ to $70^{\circ}$. Its length is $\sim 15 \mathrm{~km}$ and the thickness is $\sim 1.5 \mathrm{~km}$. The monocline structure is adjacent to the Permian-Triassic system of the southeastern Pamir and the steeply dipping Muzkol fault (Figure 2).

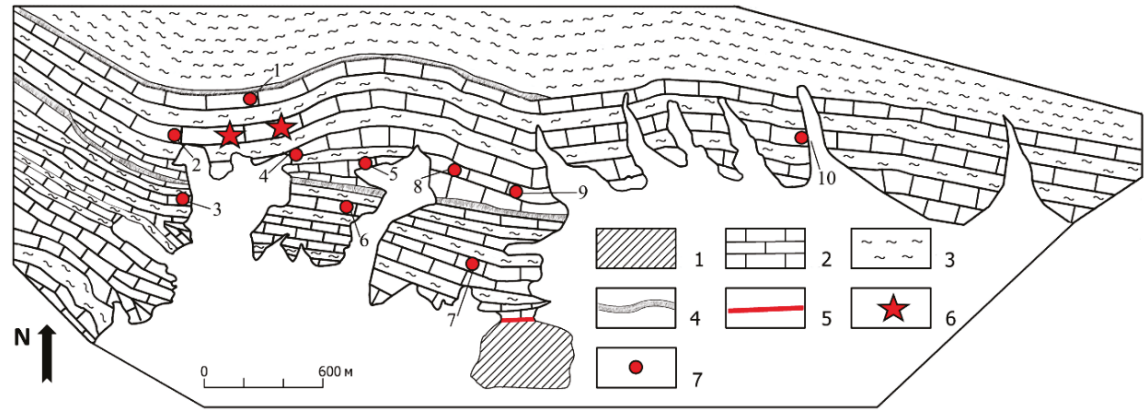

Figure 2. Geological map of the southwestern limb of the Shatput anticline modified after [8]. Geomorphologically, this is the southern slope of the Tura-Kuloma ridge. 1-Triassic system (lines indicate the strike of rocks; azimuth of dip is to the southeast). 2-4-Sarydzhilgin suite (sub-latitudinal strike): 2-marbles, 3-crystalline schists, 4-diopside-scapolite rocks, 5-deep fault, 6-ruby deposits: in the west-Nadezhda, in the east-Snezhnoye. 7-ruby occurrences close to red circles: 1-Timosha, 2-Corundum-4, 3-Corundum-7, 4-Lagernoye, 5-Alyonushka, 6-Corundum-2, 7-Corundum-1, 8-Corundum-8, 9-Corundum-6, 10-Trika. White area is the Quaternary sediments.

The thickness of the Muzkol metamorphic series within the Muzkol-Rangkul anticlinorium is about $6 \mathrm{~km}$. It consists of four suites [16], with the calcitic marbles of the Sarydzhilgin suite present as layers intercalated with amphibole-pyroxene and scapolite calciphyres, gneisses, crystalline schists and quartzites (Figure 3). These calcitic marbles host the Snezhnoe deposit, with the magnesium content of the marbles varying from $1.2 \% \mathrm{MgO}$ at the top to $2.7 \mathrm{wt} \% \mathrm{MgO}$ at the base. In the Snezhnoe deposit, micaceous ruby-bearing lenses are arranged as discrete en echelon lenses along the marble bedding surface and can be traced along strike for more than $200 \mathrm{~m}$ with the maximum thickness of individual lenses being $1 \mathrm{~m}$ [15]. These ruby-bearing lenses are cross-cut by numerous much smaller veins up to $5 \mathrm{~cm}$ thick and filled by later scapolite and mica group minerals, most likely linked to later hydrothermal processes [14]. The veins are zonal with the rim (up to $0.5 \mathrm{~cm}$ thick) composed of Cr-bearing muscovite and margarite and the core mainly comprising scapolite, which forms distinctive concentric aggregates.

The Muzkol series underwent multi-cyclic metamorphism from high-temperature amphibolite to epidote-amphibolite facies and then to retrogressive greenschist facies [16]. The first metamorphic cycle occurred at 1.9-1.6 Ga under the high-temperature conditions of amphibolite facies at $\mathrm{T}=700-750{ }^{\circ} \mathrm{C}$ and $\mathrm{P}=8-9 \mathrm{kbar}[16,17]$. The second cycle occurred between 100 to $20 \mathrm{Ma}$ and had a peak metamorphic temperature of about $800^{\circ} \mathrm{C}$ at a pressure close to $9 \mathrm{kbar}$ (with partial melting of protolith rocks) in the central part of the anticlinorium. The metamorphic facies evolved from high-temperature and high-pressure ones in the central part through medium T-P epidote-amphibolite to greenschist facies at $350{ }^{\circ} \mathrm{C}$ and 4 kbar towards the periphery $[18,19]$. 


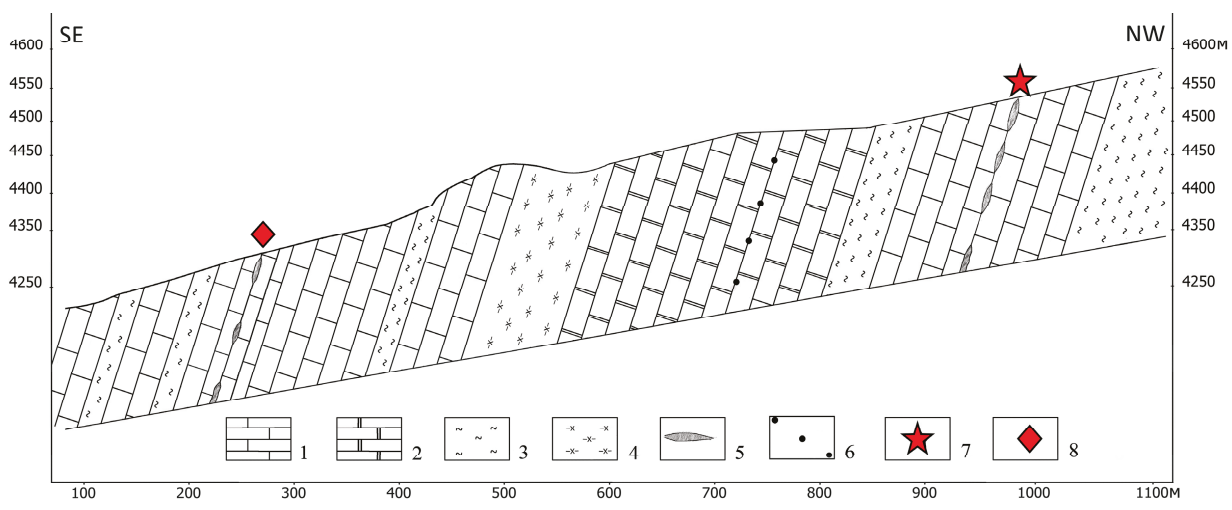

Figure 3. A geological cross-section of the upper part of the Sarydzhilgin suite through the Snezhnoe deposit and the ruby occurrences of Lagernoye and Alenushka: 1-calcitic marble and 2-dolomitic marble (dip angle is $60-70^{\circ}$ ), 3-high alumina crystalline schists, 4-diopside-scapolite rocks, 5-ruby deposits-micaceous lenses, 6-monomineralic ruby mineralization. 7-Snezhnoe deposit. 8 -Alyonushka ruby occurrence. The cross-section is modified after [20]. The area above of the upper curve represents the modern topographic surface, whereas the white area below is the cutoff of the geological cross-section.

Since the last century, different types of prospecting, evaluation and exploration activity was carried out at the Snezhnoe deposit. Currently, mining activity is conducted from the surface and by underground methods.

\section{Materials and Methods}

During field trips in 2010-2017, the Snezhnoe deposit was traced along its strike in order to examine a complete profile along the ruby-bearing rocks (Table S1). The concentrations of major and trace elements in the ruby-bearing rocks were analyzed using X-ray fluorescence spectrometry. The paragenetic mineral associations with ruby were determined by petrographic studies. Minerals were studied in petrographic thin-sections and by X-ray diffraction (XRD), while their composition was measured using electron microprobe analysis (EMPA) and laser-ablation inductively coupled plasma-mass spectrometry (LA-ICP-MS). In situ U-Pb LA-ICP-MS analyses of rutile grains, syn-genetically associated with the ruby, were applied for geochronological reconstructions. Age determinations of bulk corundum-bearing rocks and mineral separates were conducted using thermo-ionization mass-spectrometry (TIMS). Oxygen isotope analyses of rubies using secondary ionization mass-spectrometry (SIMS) were done for identification of the possible protolith of the corundum-bearing rocks.

The whole-rock chemistry of the studied samples was determined using an AXIOS Advanced $X$-ray fluorescence spectrometer at the Vernadsky Institute of Geochemistry and Analytical Chemistry, Russian Academy of Sciences (GEOKHI RAS) with an X-ray tube equipped with a Rh anode, $3 \mathrm{~kW}$ power, a Soller scanning channel with the analyzing crystals and a detonating device.

The selected minerals extracted from the ruby-bearing rocks were identified by X-ray diffraction analysis using the DRON-3 M facility at the Russian State Geological Prospecting University. The X-ray source is a Co-anode using a Fe-filter with $30 \mathrm{kV}$ voltage, current of $30 \mathrm{~mA}$ and $2 \theta$ scanning angle from $5^{\circ}$ to $60^{\circ}$.

The mineral composition was determined by EMPA using a Cameca SX 100 in the wavelength-dispersive detection mode at the GEOKHI RAS with an electron beam of $15 \mathrm{kV}, 30 \mathrm{nA}$ and a beam size of $5 \mu \mathrm{m}$. A set of natural and synthetic reference materials was used for calibration. 
The detection limit for almost all elements was less than $0.01 \mathrm{wt} \%$. Elemental concentrations were calculated using the PAP correction (atomic number, fluorescence and absorption correction).

The LA-ICP-MS analysis was performed to determine the trace element concentrations within discrete zones of ruby grains from the Snezhnoe deposit using an ESI NWR193 ArF Excimer Laser combined with an Agilent 7500 ce quadrupole-ICP-MS at the Institut für Geowissenschaften, Johannes Gutenberg-Universität Mainz (JGU), Germany. The samples were ablated using a spot size of $70 \mu \mathrm{m}$, a repetition rate of $10 \mathrm{~Hz}$ and an energy density of approximately $3.0 \mathrm{~J} / \mathrm{cm}^{2}$. Warmup/background time was $15 \mathrm{~s}$, dwell time $30 \mathrm{~s}$ and wash out time $20 \mathrm{~s}$. Trace elements of interest within the ruby structure were analyzed using the following isotopes: ${ }^{24} \mathrm{Mg},{ }^{47} \mathrm{Ti},{ }^{51} \mathrm{~V},{ }^{53} \mathrm{Cr},{ }^{56} \mathrm{Fe}$ and ${ }^{69} \mathrm{Ga}$. The isotopes of additional elements ${ }^{6} \mathrm{Li},{ }^{9} \mathrm{Be},{ }^{23} \mathrm{Na},{ }^{24} \mathrm{Mg},{ }^{29} \mathrm{Si},{ }^{39} \mathrm{~K},{ }^{43} \mathrm{Ca},{ }^{47} \mathrm{Ti},{ }^{55} \mathrm{Mn},{ }^{86} \mathrm{Sr},{ }^{90} \mathrm{Zr},{ }^{93} \mathrm{Nb},{ }^{137} \mathrm{Ba}$, ${ }^{179} \mathrm{Hf},{ }^{181} \mathrm{Ta}$ and ${ }^{208} \mathrm{~Pb}$ were analyzed as well to exclude the areas with possible contamination from solid inclusions in time-resolved spectra. NIST (National Institute of Standards and Technology) SRM (standard reference material) 612 was used as primary reference material. NIST SRM 610 and basaltic USGS (United States Geological Survey) BCR-2G basalt glass were used as quality control materials. Reference and quality control materials were measured after every 30 corundum unknowns to monitor the accuracy and precision of the analyses and calibration. The time-resolved signal spectra were processed in GLITTER 4.4.1 software (www.glitter-gemoc.com, Macquarie University, Sydney, Australia) using ${ }^{27} \mathrm{Al}$ as the internal standard applying a theoretical value of $\mathrm{Al}_{2} \mathrm{O}_{3}$ as $100 \mathrm{wt} \%$ for the corundum samples and the values given in GeoReM database for the reference material [21,22]. The measured concentrations for most elements in both QCM agree within 18\% with the preferred values provided in the GeoReM database.

Trace-elements and $\mathrm{U}-\mathrm{Pb}$ isotopic composition of rutile grains and rutile inclusions within ruby were determined using the Element2 ICP-MS (ThermoFisher) coupled with an Analyte G2 $193 \mathrm{~nm}$ excimer laser (PhotonMachines) at the Westfälische Wilhelms-Universität Münster. Twenty-three rutile grains from the Snezhnoe deposit were chosen for in situ LA-ICP-MS trace element measurements and $\mathrm{U}-\mathrm{Pb}$ dating. Prior to analysis, backscattered electron images (BSE) were obtained at the Institut für Geowissenschaften, Johannes Gutenberg-Universität Mainz (JGU), Germany using a Zeiss DSM 962 SEM coupled with an Oxford energy-dispersive spectrometer. For LA-ICP-MS measurements, gas flow rates were about $1.1 \mathrm{~L} / \mathrm{min}$ for $\mathrm{He}, 0.9 \mathrm{~L} / \mathrm{min}$ and $1.1 \mathrm{~L} / \mathrm{min}$ for the Ar-auxiliary and sample gas. The cooling gas flow rate was set to $16 \mathrm{l} / \mathrm{min}$. Trace element concentrations within the rutile grains were determined by measuring the following isotopes: ${ }^{51} \mathrm{~V},{ }^{53} \mathrm{Cr},{ }^{90} \mathrm{Zr}{ }^{93} \mathrm{Nb},{ }^{95} \mathrm{Mo},{ }^{118} \mathrm{Sn},{ }^{121} \mathrm{Sb},{ }^{178} \mathrm{Hf}$, ${ }^{181} \mathrm{Ta},{ }^{182} \mathrm{~W},{ }^{208} \mathrm{~Pb},{ }^{232} \mathrm{Th}$ and ${ }^{238} \mathrm{U}$. The analysis of ${ }^{29} \mathrm{Si},{ }^{43} \mathrm{Ca},{ }^{49} \mathrm{Ti},{ }^{89} \mathrm{Y},{ }^{139} \mathrm{La}$ and ${ }^{140} \mathrm{Ce}$ was applied to control any possible contamination with intergrown minerals. The spot-size during the analyses was $70 \mu \mathrm{m}$ at a repetition rate of $10 \mathrm{~Hz}$ and an energy density of $3-4 \mathrm{~J} / \mathrm{cm}^{2}$. The background time was $15 \mathrm{~s}$, dwell time was $40 \mathrm{~s}$ and wash out time was $20 \mathrm{~s}$. The NIST SRM 612 was used as the reference material, while R10 [23] and R632 [24] were applied for quality control (QCM). The time-resolved spectra were processed in GLITTER 4.4.1 software using Ti as the internal standard applying the stoichiometric value of $\mathrm{TiO}_{2}$ as $100 \mathrm{wt} . \%$ in pure crystalline rutile for analyzing the rutile unknowns.

For U-Pb rutile dating, ${ }^{206} \mathrm{~Pb},{ }^{207} \mathrm{~Pb},{ }^{208} \mathrm{~Pb},{ }^{232} \mathrm{Th}$ and ${ }^{238} \mathrm{U}$ isotopes were measured. The repetition rate was $10 \mathrm{~Hz}$ using an energy of about $3 \mathrm{~J} / \mathrm{cm}^{2}$. The spots size of $70 \mu \mathrm{m}$ were ablated in close vicinity to the spots used for trace element measurements. Five unknowns were bracketed with three measurements on the R10 calibration material to correct for instrumental mass bias. The data reduction was performed using an in-house Excel spreadsheet [25]. The rutile reference material SP-1 (Adirondack

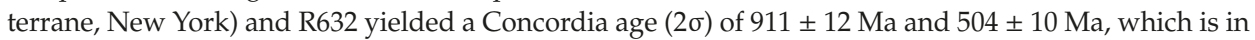
agreement with the ID-TIMS age of $911 \pm 2 \mathrm{Ma}$ and $496 \pm 2 \mathrm{Ma}$, respectively [24,26]. The Concordia diagrams and the age calculations were made using Isoplot v. 4.13 (Berkeley Geochronology Center, USA) [27].

Minimum entrapment pressures of rutile inclusions in the ruby host was estimated from the luminescence shift of the $\mathrm{Cr}^{3+} \mathrm{R}$-lines in the ruby host in close vicinity to the inclusions [28]. A Confocal Raman Spectrometer Horiba Jobin Yvon HR800 (HORIBA France SAS, Longjumeau, France) coupled 
with an Olympus BX41 microscope (Olympus Optical Co., Ltd., Tokyo, Japan) and automatic XYZ-stage were used for this technique. A red helium-neon laser with $\lambda=632.816 \mathrm{~nm}$ (polarized during the measurements) was used with a grating of 1800 grooves $/ \mathrm{mm}$. The confocal hole of $400 \mathrm{~mm}$ and the entrance slit of $100 \mathrm{~mm}$ produced a resolution of 0.7 (blue) to 0.5 (red) $\mathrm{cm}^{-1}$ for an exposition time of 0.5 $\mathrm{s}$ with measured steps of $100 \mathrm{~mm}$. Magnification of $\times 50$ was used for a measured range of 690.0-700.0 $\mathrm{nm}$. The spectrometer was calibrated at $520.7 \mathrm{~cm}^{-1}$ using $\mathrm{Si}$ as a reference.

The oxygen isotope composition of the ruby grains from Snezhnoe was determined by using the Cameca IMS1280-HR ion microprobe at Heidelberg University (HIP), Germany. Before the SIMS measurements, BSE images were taken using a LEO 440 scanning electron microscope coupled with an Oxford Instruments X-Max energy dispersive spectrometer in order to avoid the areas with inclusions. A $2 \mathrm{nA}$ and $20 \mathrm{keV} \mathrm{Cs}^{+}$primary ion beam with a raster size of $10 \mu \mathrm{m}$ (12 $\mu \mathrm{m}$ during pre-sputtering) was used for measurements targeting rim-to-rim areas of the ruby samples. Negative secondary ions were accelerated to $10 \mathrm{keV}$. The secondary ion image was limited to $\sim 23 \mu \mathrm{m}$, the dynamic transfer optical system (DTOS) was activated and sample charging was compensated with the electron gun (NEG). The ${ }^{16} \mathrm{O}$ and ${ }^{18} \mathrm{O}$ isotopes were detected simultaneously in two Faraday Cups. The mass resolving power was $\sim 2300$. Prior to each analysis, the secondary beam was centered automatically in the field aperture $(X$ and $Y$ ) and the entrance slit ( $X$ only). Including the time for beam centering, the analyses started after a total pre-sputtering time of $90 \mathrm{~s}$ and each analysis had 20 cycles with $4 \mathrm{~s}$ integration time per cycle. The internal precision reported is the standard deviation (SD) of the mean value of the isotope ratios. The baseline of the FC amplifiers was determined with an integration time of $200 \mathrm{~s}$. The instrumental mass fractionation was determined using a laser ruby reference material $\left(\delta^{18} \mathrm{O}=\right.$ $15.7 \%$ o $\pm 0.2 \%$, [29]) embedded within the same amount as the samples. The reproducibility of the IMF was $0.09 \%$ o (1 SD) for the session with this sample.

Powders of bulk ruby-bearing rocks were produced for $\mathrm{Rb}-\mathrm{Sr}$ and $\mathrm{Sm}-\mathrm{Nd}$ isotope analyses. Additionally, single mineral fractions of plagioclase and phlogopite were selected for $\mathrm{Rb}-\mathrm{Sr}$ geochronology. Some $0.02-0.03 \mathrm{~g}$ of powder from a larger portion of 200-300 $\mathrm{g}$ was dissolved in a mixture of hydrofluoric and nitric acids with a 5:1 ratio on a shaker under incandescent lamps within three days. The obtained solutions were evaporated on a heating plate and, after evaporation, $1 \mathrm{~mL}$ of concentrated $\mathrm{HCl}$ acid was added three times to the dry residue. Rubidium, $\mathrm{Sr}$ and $\mathrm{Sm}+$ $\mathrm{Nd}$ mixtures were extracted from the solutions using fluoroplastic chromatographic columns with a DowexW $50 \times 8$ synthetic ion-exchange resin. The extraction was done by stepwise elution with 2.2 acid normality $(\mathrm{N})$ of $\mathrm{HCl}$ (for $\mathrm{Rb}$ and $\mathrm{Sr}$ ) and 4.0-N HCl (for the $\mathrm{Sm}+\mathrm{Nd}$ mixture). From the $\mathrm{Sm}+\mathrm{Nd}$ mixture, $\mathrm{Sm}$ and $\mathrm{Nd}$ were extracted by stepwise elution with $0.15-\mathrm{N} \mathrm{HCl}, 0.3-\mathrm{N} \mathrm{HCl}$ and $0.7-\mathrm{N} \mathrm{HCl}$ using polyethylene columns with synthetic ion-exchange Ln-spec resin. Measurements were done using a Finnigan ${ }^{\mathrm{TM}}$ Triton multi-collector thermal ionization mass spectrometer (TIMS) by Thermo Scientific at GEOKHI RAS using a two-tape (Re-Re) ion source for Rb, Sm and Nd and a single-tape (Re) ion source for Sr. Measurements were performed in a static mode with simultaneous recordings of ion currents for different isotopes. Normalization was carried-out according to the exponential law for ${ }^{86} \mathrm{Sr} /{ }^{88} \mathrm{Sr}=0.1194$ and ${ }^{148} \mathrm{Nd} /{ }^{144} \mathrm{Nd}=0.241572$ to eliminate mass-discrimination. The analyses of the international standards Sr-SRM- 987 and JNdi-1 monitored the reproducibility and accuracy of isotope measurements for $\mathrm{Sr}$ and $\mathrm{Nd}$. The measured ratios in reference material are ${ }^{87} \mathrm{Sr} /{ }^{86} \mathrm{Sr}=0.710233 \pm 0.000010$ and ${ }^{143} \mathrm{Nd} /{ }^{144} \mathrm{Nd}=0.512093 \pm 0.000009$. Concentrations of $\mathrm{Rb}$, $\mathrm{Sr}, \mathrm{Sm}$ and $\mathrm{Nd}$ were determined by isotopic dilution using ${ }^{85} \mathrm{Rb}^{-}{ }^{84} \mathrm{Sr}$ and ${ }^{149} \mathrm{Sm}-{ }^{150} \mathrm{Nd}$ tracers. The data-reduction was performed using an in-house Excel spreadsheet.

\section{Results}

\subsection{Petrology of the ruby-bearing rocks}

The ruby-bearing rocks vary significantly in terms of their mineral composition changing along both strike and depth. Their structure is characterized by a wide range of crystal sizes and shapes. 
There are four groups of mineral associations with ruby forming isolated areas in the deposit with one, three and four-mineral parageneses (Table 1): (1) scapolite (marialite) + phlogopite + muscovite + margarite; (2) plagioclase (albite-andesine) + muscovite + margarite (Figure 4A); (3) muscovite + phlogopite + margarite; (4) calcite (Figure 4B). Ruby-free areas of the deposit are characterized by plagioclase + scapolite + phlogopite + muscovite mineral paragenesis.

Table 1. List of major, minor and accessory minerals from the Snezhnoe deposit.

\begin{tabular}{|c|c|c|}
\hline Minerals/Mineral Class & Major and Minor Minerals (Methods Applied *) & Accessory Minerals (Methods Applied) \\
\hline Oxides & $\begin{array}{l}\text { Corundum (LA-ICP-MS geochemistry, SIMS oxygen } \\
\text { isotopy) }\end{array}$ & $\begin{array}{c}\text { Rutile (U-Pb LA-ICP-MS dating, } \\
\text { Raman mapping) } \\
\text { Ilmenite + Nb-rich rutile } \\
\text { Magnetite }\end{array}$ \\
\hline Alumino-silicates & $\begin{array}{c}\text { Plagioclase (TIMS Rb-Sr/Sm-Nd isotopy) } \\
\text { Phlogopite (TIMS Rb-Sr/Sm-Nd isotopy) } \\
\text { Muscovite } \\
\text { Margarite }\end{array}$ & Corundophillite \\
\hline Silicates & Scapolite & $\begin{array}{c}\text { Zircon } \\
\text { Titanite } \\
\text { Tourmaline } \\
\text { Thorite } \\
\text { Dissakisite-(Ce) }\end{array}$ \\
\hline Phosphates & & $\begin{array}{l}\text { Xenotime- }(\mathrm{Y}) \\
\text { Monazite-(Ce) } \\
\text { Fluorapatite }\end{array}$ \\
\hline Native element & & Graphite \\
\hline
\end{tabular}

* EMPA was applied to all minerals listed.

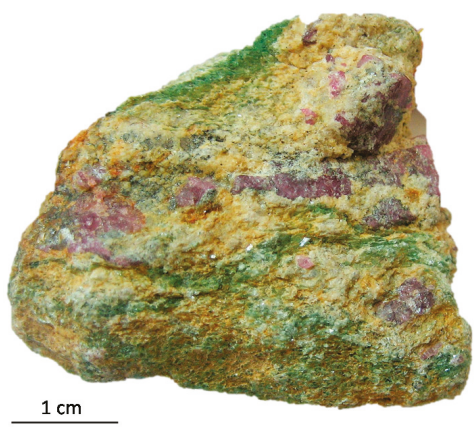

(A)

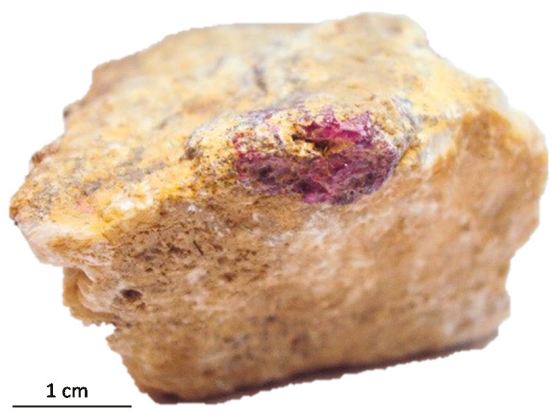

(B)

Figure 4. Images of hand specimens of Snezhnoe ruby-bearing rocks with: (A) ruby + plagioclase (albite-andesine) + muscovite (variety fuchsite) mineral paragenesis; (B) ruby + calcite mineral paragenesis. The images were modified from [11].

Gem-quality ruby is restricted in occurrence to Cr-bearing mica lenses or graphite-free areas within the host marbles. The gem quality of ruby (i.e., degrees of transparency and color intensity) increases with decreasing number of associated paragenetic minerals. Therefore, the calcite mono-mineralic assemblage is the most economically valuable. 


\subsection{Mineralogy of Ruby-Bearing Rocks}

\subsubsection{Major and Minor Minerals}

Mica group minerals were found in most ruby associations. Micas often contain traces of $\mathrm{Cr}$ and V (Table 1, Tables S2-S4) resulting in their characteristic green color (Figure 4A). These green-colored mica group minerals serve as the main prospecting indicator for the ruby mineralization.

Muscovite forms small- to medium-sized flaky aggregates ranging from $\sim 1$ to $4 \mathrm{~mm}$. It is also found as inclusions in plagioclase and scapolite group minerals and in ruby (Figure 5, Table S2). It is rarely replaced by the chlorite group minerals, likely clinochlore containing up to $25.35 \mathrm{wt} \% \mathrm{SiO}_{2}$, $22.52 \mathrm{wt} \% \mathrm{Al}_{2} \mathrm{O}_{3}, 22.45 \mathrm{wt} \% \mathrm{FeO}, 13.98 \mathrm{wt} \% \mathrm{MgO}, 1.35 \mathrm{wt} \% \mathrm{Cr}_{2} \mathrm{O}_{3}$ [11] and forming thin films on the surface of muscovite or infilling fractures in corundum.

Fuchsite (the chromium-enriched variety of muscovite) is found in the form of a fine-medium flaky aggregates or individual flakes with size to $1-3 \mathrm{~mm}$. These aggregates form micaceous ruby-bearing lenses as well as rare impregnations in calcitic marbles. The fuchsites are characterized by high concentrations of $\mathrm{TiO}_{2}$ up to $4.78 \mathrm{wt} \%, \mathrm{MgO}$ up to $5.5 \mathrm{wt} \%, \mathrm{Na}_{2} \mathrm{O}$ up to $2.07 \mathrm{wt} \%, \mathrm{Cr}_{2} \mathrm{O}_{3}$ up to $2.5 \mathrm{wt} \%$, $\mathrm{V}_{2} \mathrm{O}_{3}$ up to $0.89 \mathrm{wt} \%$ and $\mathrm{F}$ from $0.03 \mathrm{wt} \%$ to $0.89 \mathrm{wt} \%$ (Table S2). Fuchsite crystals were also detected in cross-cutting veins, which were considered as hydrothermal in origin [14]. These minerals form concentrically zoned crystals with a diameter up to $6 \mathrm{~mm}$ and they are found in paragenetic association with later margarite flakes, concentric scapolite crystals and likely clinochlore. Rarely, the hydrothermal veins contain later tourmaline and quartz (never observed in the original ruby-bearing association).

Margarite (the Ca-end member of the brittle mica group) was detected as a syngenetic rock-forming mineral within the Snezhnoe deposit [11,14]. Margarite forms coarse- and finely flaked mineral grains. It is localized in occurrence mainly among calcite porphyroblasts and included within host corundum. The margarite contains $\mathrm{Na}_{2} \mathrm{O}$ from $1.24 \mathrm{wt} \%$ to $4.37 \mathrm{wt} \%, \mathrm{Cr}_{2} \mathrm{O}_{3}$ up to $1.27 \mathrm{wt} \%, \mathrm{~V}_{2} \mathrm{O}_{3}$ up to $0.1 \mathrm{wt} \%$ and $\mathrm{F}$ up to $0.32 \mathrm{wt} \%$ (Figure 5; Table S3).

Phlogopite forms lustrous brown-colored well-formed crystals some $2-5$ to $10 \mathrm{~mm}$ in size. It is enriched in $\mathrm{Cr}_{2} \mathrm{O}_{3}$ up to $3.20 \mathrm{wt} \%$ and $\mathrm{F}$ up to $1.87 \mathrm{wt} \%$ (Table S4). As in the case of muscovite, it is only rarely found to be replaced by chlorite group minerals.

Plagioclase forms white to black (due to the abundance of mineral inclusions including graphite, rutile, mica, zircon and rarely, ruby) prismatic crystals up to $10 \mathrm{~mm}$ in size. The composition is albite-andesine $\left(\mathrm{An}_{6-41}\right)$ (Table S5). Dufour et al. [9] noted anorthite in the paragenesis with phlogopite and muscovite, however, albite occurs within rims around the ruby grains.

Scapolite forms two generations: the early one is metamorphic in origin and syngenetic with ruby and associated minerals. For this generation, the meionite component ranges from $23 \mathrm{wt} \%$ to $74 \mathrm{wt} \%$, while chlorine varies from $0.01 \mathrm{wt} \%$ to $2.29 \mathrm{wt} \%$, sulfur content was up to $0.5 \mathrm{wt} \%$ and fluorine values were up to $0.25 \mathrm{wt} \%$ (Table S6). The later generation is hydrothermal in origin and occurs in veins cross-cutting the ruby-bearing rocks.

Calcite occurs within the micaceous lenses as irregular-shaped grains up to $0.4 \mathrm{~mm}$ and locally replaced by scapolite [11]. In the host marbles, it comprises the porphyroblastic rock matrix with crystal size varying from 1 to $6 \mathrm{~mm}$. 

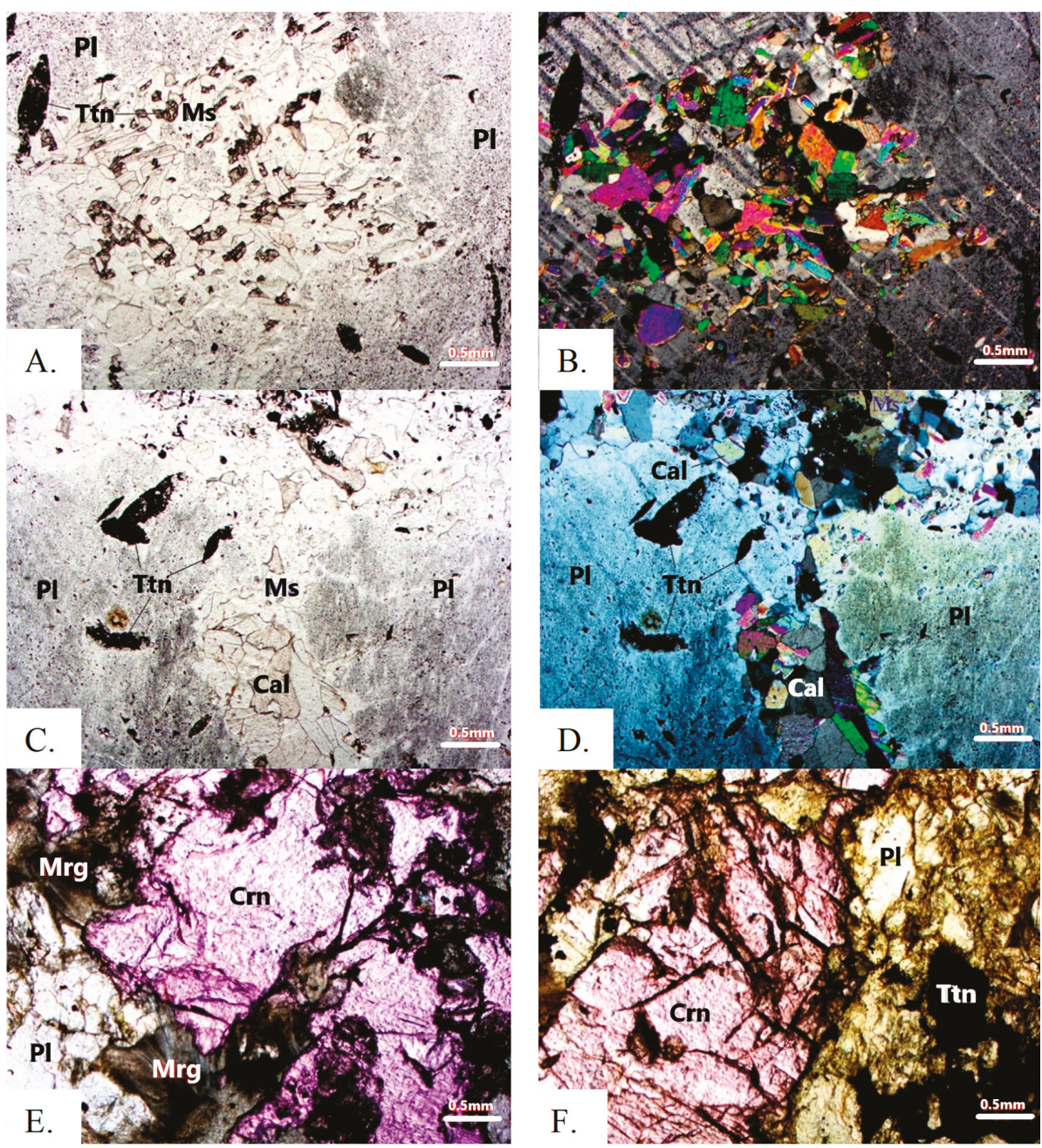

Figure 5. Petrographic thin-sections of titanite (Ttn), muscovite (Ms) and calcite (Cal) grains intergrown with larger plagioclase $(\mathrm{Pl})$ crystals in plane-polarized light $(\mathbf{A}, \mathbf{C})$ and under crossed-polarized light (B,D); corundum (Crn) intergrowths with margarite (Mrg) and plagioclase crystals (E,F), plane-polarized light.

\subsubsection{Accessory Minerals}

The accessory minerals identified in the studied ruby-bearing rocks are divided into two groups based on their typical size: (1) the large, up to millimeter size minerals, relatively easily distinguishable by eye and (2) those reaching only a few hundred micrometers in size and visible only under high magnification (Table 1). Currently, 20 accessory minerals were detected within the Snezhnoe deposit.

The first group includes graphite forming thin films around ruby grains, corundophyllite replacing muscovite, calcite with a minor $\mathrm{Mg}$ content, titanite (in 2 generations, with one replacing rutile and the other forming moderately rounded discrete crystals, Table S7), rutile (in 2 types with the earlier grains forming prisms and rounded grains linked to ruby and mica group minerals, while the later crystals replace titanite), tourmaline of the dravite-elbaite series (Table S9) and rare pyrite. 
The second group of accessory minerals was only detected at high magnification and includes ilmenite and $\mathrm{Nb}$-rich rutile, fluorapatite, pyrite, pyrrhotite, magnetite, chalcopyrite, thorite, dissakisite-(Ce) (allanite group), REE-rich carbonates, dolomite, xenotime-(Y), monazite-(Ce) and zircon containing up to $2 \mathrm{wt} \% \mathrm{HfO}_{2}$.

\subsubsection{Mineralogy, Geochemistry and Oxygen Isotopes of Ruby}

For the ruby-bearing assemblage, ruby is the largest mineral in these rocks with crystals reaching some $10 \times 20 \mathrm{~cm}$. Different ruby generations were observed during petrographic studies. The earlier crystals were found in the form of poikiloblastic grains in association with scapolite, plagioclase and micas. While the later generation of ruby was only observed in the calcitic marbles [30].

The ruby crystals are characterized by regular, distorted and combined forms. Regular crystal shapes are found in the form of hexagonal prisms combined with hexagonal pyramids, however, flattened by a pinacoid and rhombohedral faces (Figure 6). The crystal faces are often smooth and covered by fine-grained graphite, mica group minerals and calcite. Distorted crystals form sinuous and skeletal forms or nodules with a large number of faces poorly visible under the microscope. Combined crystals are formed by prisms complicated by skeletal surfaces. The surfaces of these crystals along with smooth ones, are tuberous, perforated (embossed) with noticeable resorption features. Margarite flakes of sometimes spherical shape, wedge-shaped titanite and calcite crystals are intergrown with the rubies.

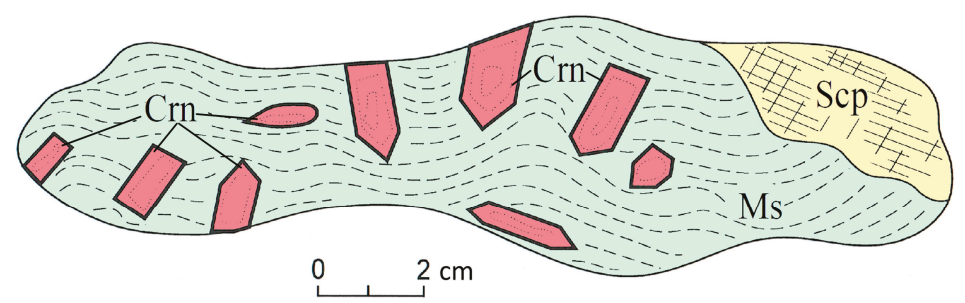

Figure 6. The sketch of a fragment of a ruby-bearing rock showing the apparent random orientation of ruby crystals. Crn—ruby crystals, Ms—muscovite (dashed lines), Scp—scapolite.

Using EMPA, the content of $\mathrm{Cr}_{2} \mathrm{O}_{3}$ within the pink corundum crystals varies from below detection limit ( $\mathrm{bdl} ;<0.01 \mathrm{wt} \%$ ) to $0.24 \mathrm{wt} \%$. In the red grains, it reaches $1.5 \mathrm{wt} \%$ with a mean value of $0.3-0.6 \mathrm{wt} \%$. In fact, the variations in $\mathrm{Cr}^{3+}$ concentration within the ruby lattice are linked to the variety of ruby tones and shades at the Snezhnoe deposit [15], frequently expressed as oscillatory color zonation within some crystals. Moreover, the rubies also contain significant concentrations of other trace elements including $\mathrm{FeO}_{\mathrm{t}}$ up to $0.41 \mathrm{wt} \%$ and $\mathrm{V}_{2} \mathrm{O}_{3}$ up to $0.13 \mathrm{wt} \%$. The dark pink to red ruby crystals are characterized by $\mathrm{Cr}_{2} \mathrm{O}_{3}$ ranging from $0.01 \mathrm{wt} \%$ to $0.55 \mathrm{wt} \%, \mathrm{FeO}_{\mathrm{t}}$ ranging from $0.03 \mathrm{wt} \%$ to $0.19 \mathrm{wt} \%$, $\mathrm{TiO}_{2}$ values from $0.01 \mathrm{wt} \%$ to $0.17 \mathrm{wt} \%, \mathrm{MgO}$ from bdl ( $\left.<0.01 \mathrm{wt} \%\right)$ to $0.04 \mathrm{wt} \%$ and $\mathrm{V}_{2} \mathrm{O}_{3}$ from 0.01 $\mathrm{wt} \%$ to $0.07 \mathrm{wt} \%$ (Table S10).

Three gem-quality rubies with bright red color and purple hue from the Snezhnoe deposit were analyzed using LA-ICP-MS to determine their concentrations of $\mathrm{Cr}, \mathrm{Fe}, \mathrm{V}, \mathrm{Mg}$, Ti and Ga (Table S11). The obtained values are in good agreement with the EMPA analyses for similar colored ruby crystals. Chromium (512 to $4720 \mu \mathrm{g} / \mathrm{g}), \mathrm{Fe}(371-623 \mu \mathrm{g} / \mathrm{g})$ and Ga (65.9-98.1 $\mu \mathrm{g} / \mathrm{g})$ all showed a heterogeneous distribution. However, these trace elements demonstrated a positive correlation between each other on different binary plots ( $\mathrm{Cr}+\mathrm{V}$ vs. Fe+ Ga, Fe vs. Ga, Cr vs. Ga, Figure 7). Such a correlation is linked presumably to the mechanism of $\mathrm{Al}^{3+}$ ion substitution within the corundum structure along the pinacoid faces in the direction perpendicular to the $c$-axis. It is frequently observed in other ruby locations [31]. The titanium content also shows a heterogeneous distribution ranging from 13.9 to $177 \mu \mathrm{g} / \mathrm{g}$ due to minor fluctuations, however, without any correlation with the $\mathrm{Cr}$, Ga or Fe values. 
Magnesium shows a mostly homogeneous distribution within the studied ruby grains (from 9.07 to $26.9 \mu \mathrm{g} / \mathrm{g})$.
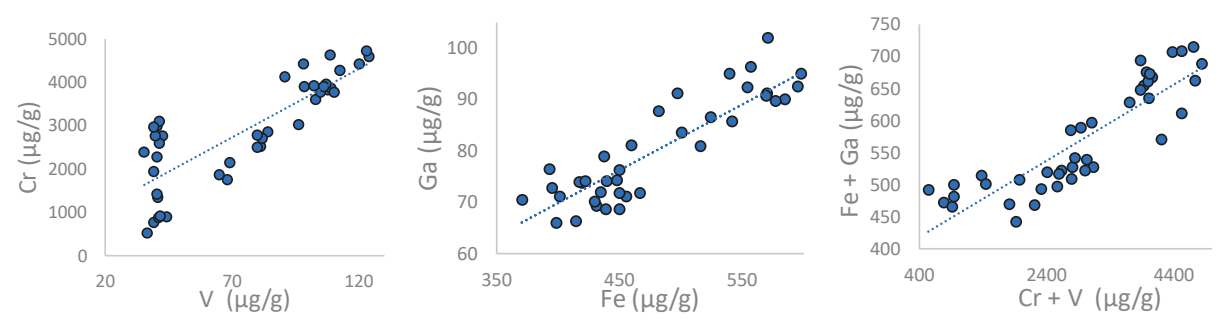

Figure 7. Trace element distribution within ruby grains oriented perpendicular to the $c$-axis on $\mathrm{Cr}$ vs. V (left panel), Ga vs. Fe (middle panel) and Fe+Ga vs. Cr + V (right panel) binary plots.

The trace element ratios of $\mathrm{Ga} / \mathrm{Mg}<8.2, \mathrm{Fe} / \mathrm{Mg}<51.2, \mathrm{Cr} / \mathrm{Ga}>6.9$ and $\mathrm{Fe} / \mathrm{Ti}<31.6$ are all in the range common for metamorphic corundum [32,33]. On the $\mathrm{FeO}-\mathrm{Cr}_{2} \mathrm{O}_{3}-\mathrm{MgO}-\mathrm{V}_{2} \mathrm{O}_{3} \mathrm{vs} . \mathrm{FeO}+\mathrm{TiO}_{2}+$ $\mathrm{Ga}_{2} \mathrm{O}_{3}$ plot [34], Snezhnoe rubies overlap the "John Saul ruby mine" area in the "ruby in marble" field in close proximity to the "metasomatic" corundum field (Figure 8).

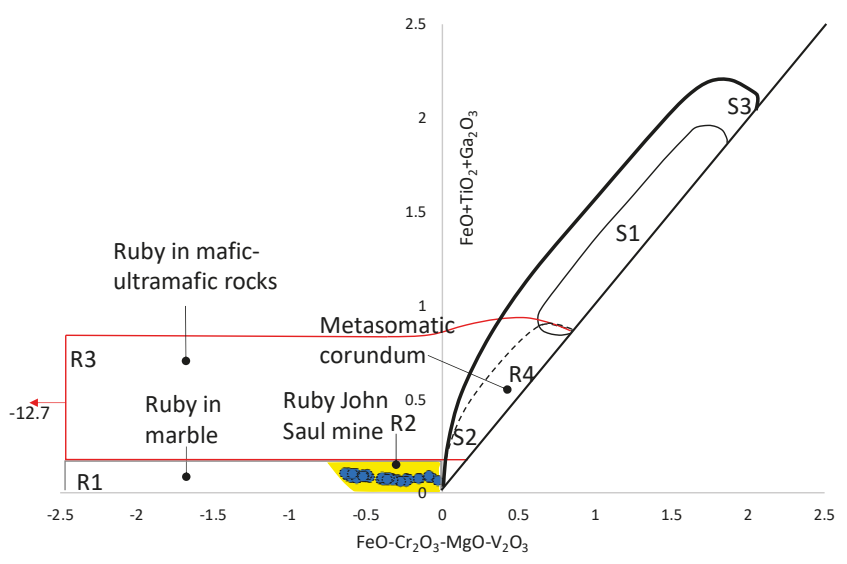

Figure 8. A FeO- $\mathrm{Cr}_{2} \mathrm{O}_{3}-\mathrm{MgO}-\mathrm{V}_{2} \mathrm{O}_{3}$ vs. $\mathrm{FeO}-\mathrm{TiO}_{2}-\mathrm{Ga}_{2} \mathrm{O}_{3}$ diagram (in wt $\%$ ) for rubies from the Snezhnoe deposit, modified after [34].

On the $\mathrm{Cr} / \mathrm{Ga}$ vs. Fe/Ti discrimination diagram of [33], the Snezhnoe rubies clearly plot within the "metamorphic" field (Figure 9A). On the other hand, they are in the "transitional" and, partly, in the "magmatic" field on the Fe $(\mu \mathrm{g} / \mathrm{g})$ vs. Fe/Ti plot of [32,33] (Figure 9B). 


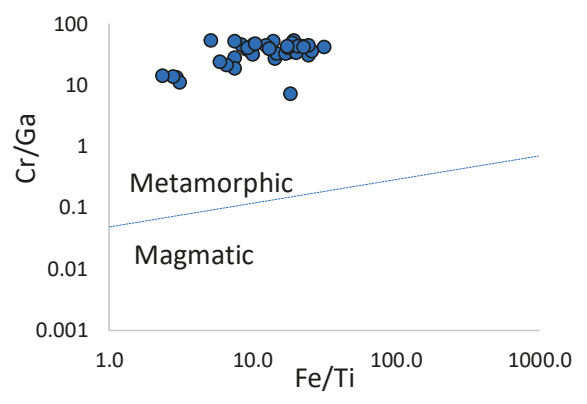

(A)

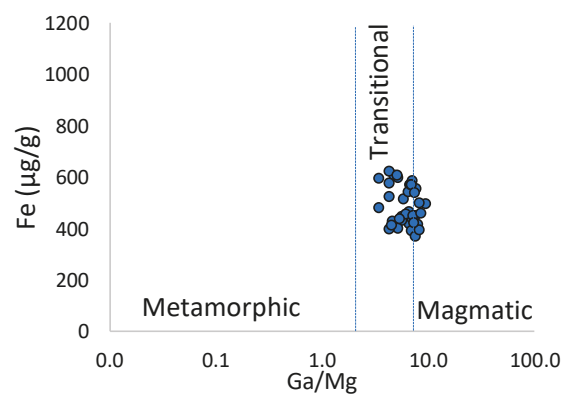

(B)

Figure 9. Cr/Ga vs. Fe/Ti plot of Snezhnoe ruby modified after [33] (A); Fe( $\mu \mathrm{g} / \mathrm{g})$ vs. Fe/Ti plot of Snezhnoe ruby modified after [32,33] (B).

The $\delta^{18} \mathrm{O}$ isotopic composition is used as a proxy in corundum provenance determination distinguishing corundum of different genetic origins [35]. Two ruby grains previously analyzed using LA-ICP-MS for their trace element composition were chosen for rim-to-rim oxygen isotope analysis using SIMS. In total, eight spots were measured within these samples. The $\delta^{18} \mathrm{O}$ rim-to-rim analyses show mostly a homogeneous distribution within the grains forming a narrow range from $+15.1 \%$ o to $+15.3 \%$ o with the standard deviation from $0.06 \%$ o to $0.12 \%$ o and the mean value of about $+15.25 \%$ o $\pm 0.07 \%$ o $(\mathrm{n}=8)$.

\subsection{Petrochemical Features of the Ruby-Bearing Rocks}

The whole-rock chemical composition of the ruby-bearing rocks varies considerably for all petrogenic elements (Table S12). These bulk-rock chemical variations correlate with changes in the mineral associations along strike.

Contents of the main petrogenic elements within the ruby-bearing rocks varied from $35 \mathrm{wt} \%$ to $98 \mathrm{wt} \%$ for $\mathrm{Al}_{2} \mathrm{O}_{3}$ (the most enriched in the Pamirs), up to $12 \mathrm{wt} \%$ for the sum of alkalis $\left(\mathrm{Na}_{2} \mathrm{O}+\right.$ $\mathrm{K}_{2} \mathrm{O}$ ) and from $3 \mathrm{wt} \%$ to $10 \mathrm{wt} \%$ for $\mathrm{CaO}$. In the crustal normalized spectra, the ruby-bearing rocks are mostly enriched in three+ and four+-charged, and, in less extend, one+, two+ and five+-charged lithophile ions (Figure 10). However, they are slightly depleted in Si and Mg. The ruby-bearing rocks are also characterized by the joint presence of oxides and sulfides of iron, along with traces of nickel up to $2 \mathrm{wt} \%$. All minerals found at the deposit contain $\mathrm{Cr}_{2} \mathrm{O}_{3}$ and $\mathrm{V}_{2} \mathrm{O}_{3}$ from hundredths to tenths parts of a percent, rarely, up to several percent. Cobalt and nickel were found in many minerals to hundredth parts of a percent. Minor elements within the ruby-bearing rocks exceed their average enrichment in the Earth's crust [36] by the orders of magnitude as follows: Ce (248), La (8.8), Ga (3.1), Sr (1.9), S (1.7), $\mathrm{Cl}(1.3)$ and $\mathrm{Zn}(1.3)$. The fluorine content is up to $4.6 \mathrm{wt} \%$ and this has played a significant role in increasing the mineral-forming activity of fluids. 


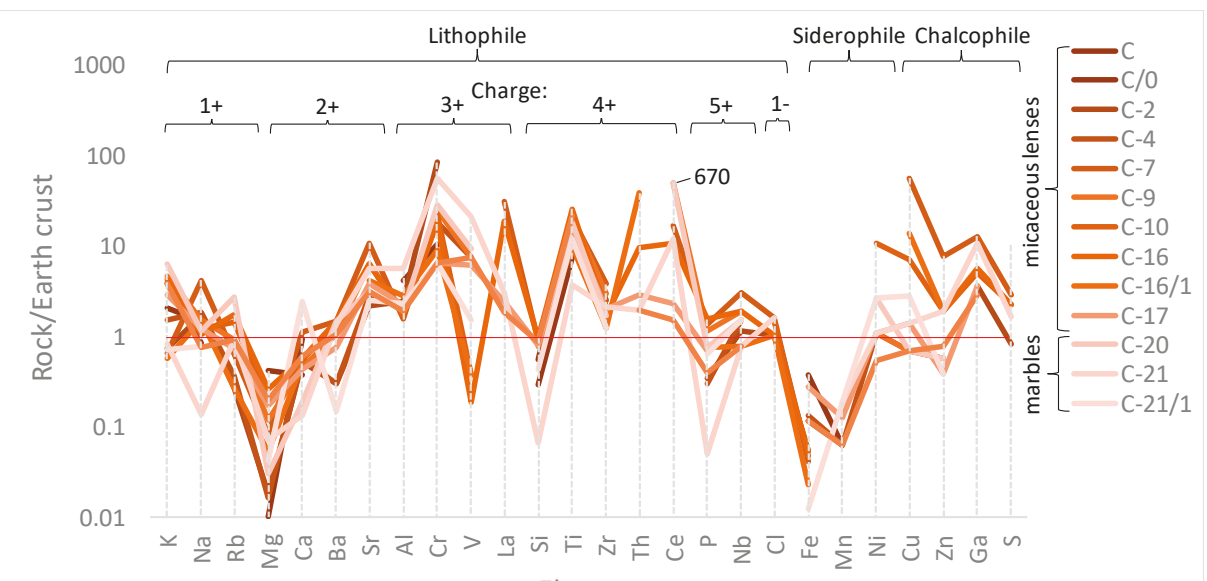

Element

Figure 10. Crustal-normalized concentrations of lithophile (arranged by cation/anion charge), siderophile and chalcophile elements in the Snezhnoe deposit. The cerium ratio at 670 was cutoff. The values for the Earth's crust are from [36].

4.4. In Situ U-Pb LA-ICP-MS Rutile Dating, Zr-in-rutile Temperature and Raman Mapping of Rutile Inclusions

Rutile grains from the Sneznoe deposit varied from $200 \times 200 \mu \mathrm{m}$ to $600 \times 600 \mu \mathrm{m}$ in size with most showing a homogeneous composition. However, inclusions of apatite, $\mathrm{Cr}$-bearing muscovite, margarite, zircon and calcite were found within rutile grains during SEM analyses. The following trace elements were detected in measured rutile grains (Table S13): V (1600-5000 $\mu \mathrm{g} / \mathrm{g}), \mathrm{Cr}(1360-5400$

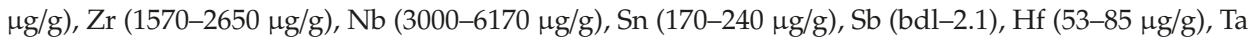

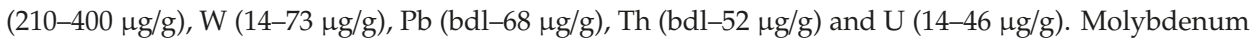
was measured but found to be below the detection limit (bdl varied from 0.3 to $0.9 \mu \mathrm{g} / \mathrm{g}$ ).

The in situ LA-ICP-MS U-Pb analyses of the rutile grains (21 spots) were plotted on Concordia diagram in Figure 11. All the rutiles analyzed yielded discordant ages with lower intercepts on the Concordia at about $12 \pm 1.5 \mathrm{Ma}(2 \sigma)$; MSWD (mean squared weighted deviation) is 9.7. The upper intercepts show an unreliable age at around 4.8-4.9 Ga likely due to contamination with common $\mathrm{Pb}$; the point with ${ }^{207} \mathrm{~Pb} /{ }^{208} \mathrm{~Pb}$ ratio is about 0.8 on the Tera-Wasserburg diagram (Figure 11, [37]). However, the ages obtained may be applied with caution due to the re-opening of the U-Pb system in rutile. 


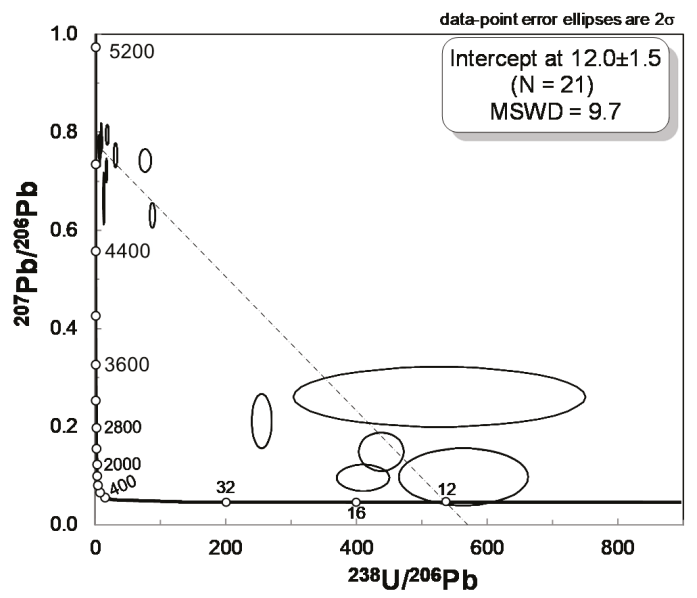

Figure 11. Tera-Wasserburg Concordia diagram based on the U-Pb LA-ICP-MS data for rutiles associated with ruby. The lower intercept age is shown in the legend.

Rutile grains were frequently found intergrown with zircon at the Snezhnoe deposit, and therefore could be used to calculate the apparent $\mathrm{Zr}$-in-rutile temperature [38]. The calculations were performed using the following formula: $\mathrm{T}\left({ }^{\circ} \mathrm{C}\right)=\frac{4470 \pm 120}{(7.36 \pm 0.10)-\log \left(Z r, \frac{\mu g}{8}\right)}-273$ [39]. The obtained temperatures were in the range from $830 \pm 60^{\circ} \mathrm{C}$ (Table S13).

Laser-induced luminescence measurements were applied for two rutile inclusions trapped within ruby grains; the same sample containing other rutile inclusions was used for $\mathrm{U}-\mathrm{Pb}$ rutile dating. The rutile grains varied from about $10 \times 20 \mu \mathrm{m}$ to $10 \times 70 \mu \mathrm{m}$ in size. The Raman shift of $\mathrm{Cr}^{3+} \mathrm{R}$-lines in ruby photoluminescence spectra around rutile inclusions provided their minimum entrapment pressure at about 1-1.2 kbar (Figure 12) according to the calibration of [28].

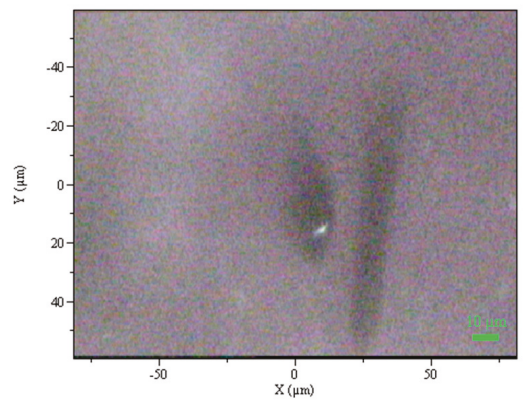

(A)

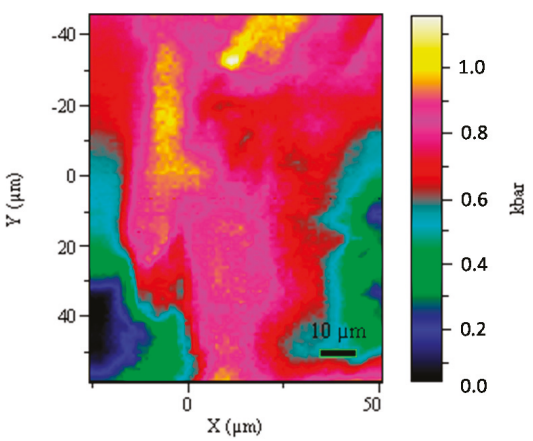

(B)

Figure 12. Photomicrograph of measured rutile inclusions within the ruby host (A); Raman map showing the shift of R-lines in laser-induced photoluminescence spectra expressed in pressure (in kbar) around rutile inclusions within the ruby host $(\mathbf{B})$.

\section{5. $\mathrm{R} b-\mathrm{Sr}$ and $\mathrm{Sm}-\mathrm{Nd}$ Isotope Measurements}

The ruby-bearing schists from Snezhnoe were studied by TIMS in order to obtain their Rb-Sr and $\mathrm{Sm}-\mathrm{Nd}$ isotope systematics. For the analyses, single minerals fractions of plagioclase and phlogopite were extracted from the rock matrix. The plagioclase and phlogopite contained no visual secondary 
alteration, however, some of the phlogopite could be possibly partially replaced by microscopic chlorite group minerals (most likely clinochlore). The results for the ruby-bearing schists within marble host rocks (single mineral fraction of mica and feldspar along with bulk rock analyzes) provided one errorchron (the large scatter in Rb-Sr signatures defining significant \pm errors and MSWD) with an age at $23.0 \pm 1.6 \mathrm{Ma}\left(\mathrm{MSWD}=37\right.$; Figure 13) and an initial ${ }^{87} \mathrm{Sr} /{ }^{86} \mathrm{Sr}$ ratio of 0.70791 . The high MSWD value is likely linked to re-opening of the $\mathrm{Rb}-\mathrm{Sr}$ system in phlogopite. Thus, 3 phlogopite samples provided one errorchron with a younger age of $12 \pm 27 \mathrm{Ma}(\mathrm{MSWD}=14)$ and an initial ${ }^{87} \mathrm{Sr} /{ }^{86} \mathrm{Sr}$ ratio of 0.7085 .

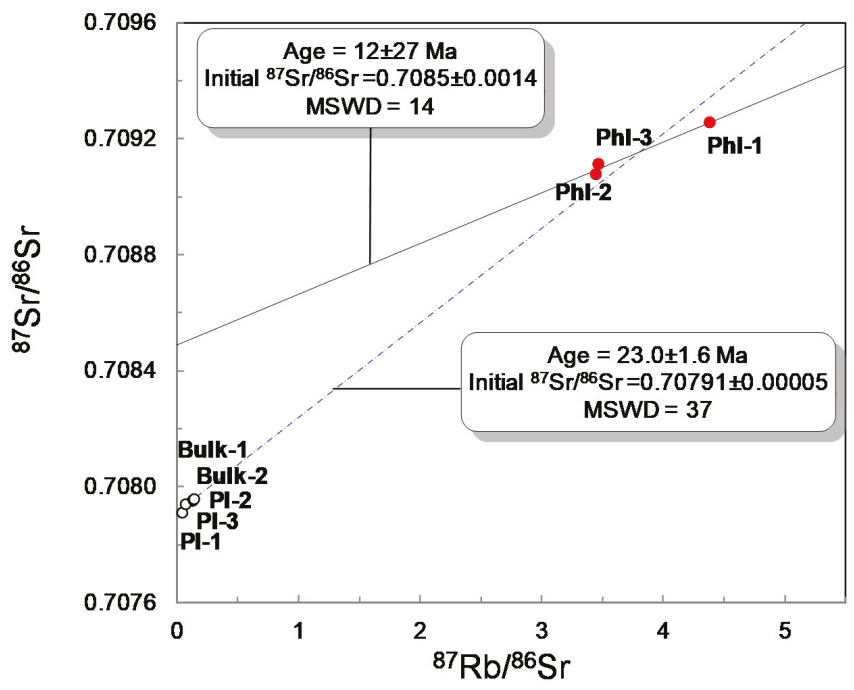

Figure 13. Two Rb-Sr errorchrons showing the ages of ruby-bearing rock at Snezhnoe (blue dotted line), with a likely alteration process affecting the Rb-Sr system in phlogopite (black solid line).

The epsilon notation value $\varepsilon_{\mathrm{Nd}}(20 \mathrm{Ma})$ for the bulk ruby-bearing rock was about -9.6 (Table S14).

\section{Discussion}

\subsection{Hypotheses of Origin of the Snezhnoe Ruby-Bearing Rocks}

Different hypotheses were proposed regarding the possible source for ruby-bearing rocks including metasomatic, hydrothermal or sedimentary-metamorphic scenarios. However, most of them remain controversial.

In the first scenario, Dufour et al. [9] proposed the formation of the ruby-bearing rocks through the metasomatic re-working of marbles intercalated with sandy-clay rocks, with the metasomatism induced likely by highly alkaline fluids. The desilication of sandy-clay rocks by fluids was followed by rapid enrichment in $\mathrm{Al}$ following the formation of biotite group minerals (according to our data, phlogopite) and muscovite. The $\mathrm{Al}_{2} \mathrm{O}_{3}$ excess resulted in the crystallization of corundum. This crystallization occurred during the final stage of regional metamorphism under the epidote-amphiboliteand greenschist facies with $\mathrm{T}=600-650{ }^{\circ} \mathrm{C}, \mathrm{P}=4-6 \mathrm{kbar}$ and $\mathrm{X}_{\mathrm{CO} 2}$ (mole fraction of $\left.\mathrm{CO}_{2}\right)=0.2-0.4$ (Figure 14). The timing of metamorphism, and, hence, ruby formation, corresponded to the Miocene (N1) during which the last recorded regional metamorphic process in the area occurred. Kievlenko [40] also referred to the ruby-bearing rocks in the Snezhnoe deposit to being of metasomatic origin and formed as endo-skarns due to the desilication of Al-Si rocks by hydrothermal solutions. The crystallization temperature of rubies was estimated at $450-500{ }^{\circ} \mathrm{C}$ by measuring the homogenization temperature of fluid inclusions inside the rubies. 
According to the second scenario [41], corundum mineralization formed by transport of $\mathrm{Si}, \mathrm{Al}, \mathrm{Ti}$, $\mathrm{Na}, \mathrm{Cl}$ and $\mathrm{B}$ in aqueous solutions migrated along fractures and layers in the marbles. Calcium and $\mathrm{CO}_{2}$ were removed by the fluid-marble interaction. Terekhov et al. [42] shared a similar opinion on ruby formation. These authors pointed out that the source of aluminum, required for ruby formation, may be linked to the endogenous fluids formed in an alkaline magmatic chamber of unknown location.

In the third scenario [43,44], ruby and associated minerals within the marble host rocks were formed during metamorphic reworking of primary sedimentary rocks without significant involvement of any external material. This hypothesis was further developed by Litvinenko [45,46], Barnov [10] and Nasreddinov [12]. According to this scenario, ruby was formed during iso-chemical metamorphism of Proterozoic bauxite-like sediments hosted by limestone during amphibolite facies metamorphism. This scenario was further developed by Garnier et. al. [2], who pointed-out the significant role of evaporates hosted by marbles in the formation of ruby mineralization in several deposits located along the Alpine-Himalayan Belt. The source of elements required for their crystallization may be linked to the clay minerals. These clay minerals, hosted by the limestones, underwent the amphibolite facies metamorphism at $\mathrm{T}$ from 610 to $790^{\circ} \mathrm{C}$ and $\mathrm{P} \sim 6 \mathrm{kbar}$. Ruby mineralization occurred during the retrograde stage at $\mathrm{T}=620-670^{\circ} \mathrm{C}$ and $\mathrm{P}=2.6-3.3 \mathrm{kbar}$.

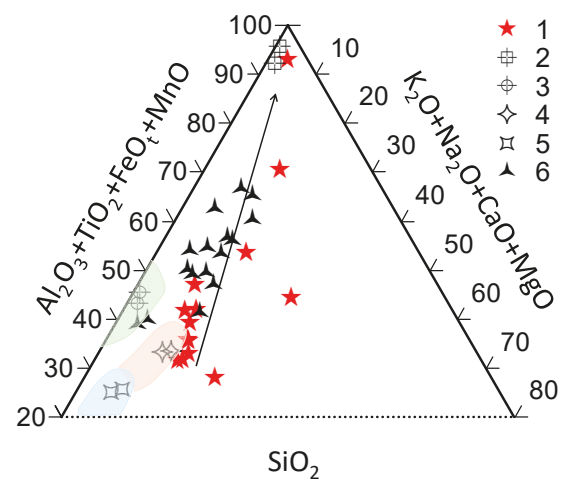

(A)

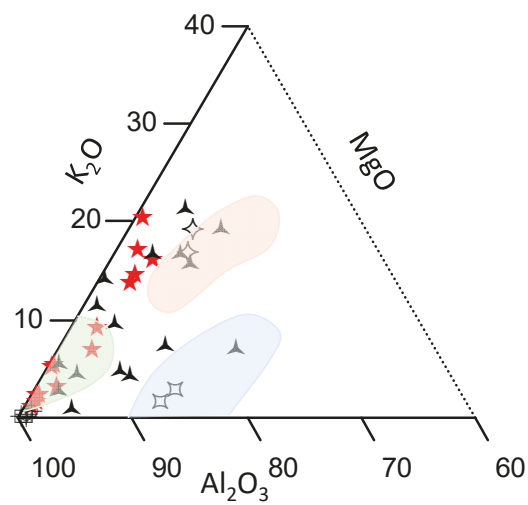

(B)

Figure 14. The $\mathrm{Al}_{2} \mathrm{O}_{3}+\mathrm{TiO}_{2}+\mathrm{FeOt}+\mathrm{MnO}-\mathrm{K}_{2} \mathrm{O}+\mathrm{Na}_{2} \mathrm{O}+\mathrm{CaO}+\mathrm{MgO}-\mathrm{SiO}_{2}(\mathrm{~A})$ and $\mathrm{K}_{2} \mathrm{O}-\mathrm{MgO}-\mathrm{Al}_{2} \mathrm{O}_{3}(\mathbf{B})$ ternary diagrams with the data of Snezhnoe ruby-bearing rocks from this study-1; Precambrian pelitic sediments: bauxite ores-2, kaolinitic clays -3 and green field, illitic clays -4 and orange field, montmorillonite clays -5 and blue field (numbers $2-5$ are the mean values of sediments after [47], the pelitic rock fields are after [48]); Al-enriched metamorphic rocks of Muzkol series-6 are after [49]. The rocks under numbers 2 and 3 overlap in the panel B.

\subsection{Origin of the Snezhnoe Ruby-Bearing Rocks}

The following geological characteristics indicate the sedimentary origin of the protolith considering the interlayered occurrence of carbonate and ruby-bearing rocks tracing along the strike on several kilometers. The petrochemical data reveal very high $\mathrm{Al}_{2} \mathrm{O}_{3}$ content ranging from $35 \mathrm{wt} \%$ to $98 \mathrm{wt} \%$ coupled with high alkali concentrations (about $12 \mathrm{wt} \%$ ) and a high proportion of CaO varying from 3 $w t \%$ to $10 \mathrm{wt} \%$. The admixture of lithophile $(\mathrm{Cr}, \mathrm{V}, \mathrm{Ti}, \mathrm{U}$, etc.) and siderophile ( $\mathrm{Sn}, \mathrm{Ni}$, etc.) elements coupled with Ga contents to $180 \mu \mathrm{g} / \mathrm{g}$ and REE elements up to several thousand $\mu \mathrm{g} / \mathrm{g}$ common for sedimentary rocks (Table S8). On the $\mathrm{Al}_{2} \mathrm{O}_{3}+\mathrm{TiO}_{2}+\mathrm{FeOt}+\mathrm{MnO}-\mathrm{K}_{2} \mathrm{O}+\mathrm{Na}_{2} \mathrm{O}+\mathrm{CaO}+\mathrm{MgO}-\mathrm{SiO}_{2}$ ternary plot, the Shenzhoe ruby-bearing rocks overlap the fields of Precambrian illitic clays and bauxite ores with a distinct trend from the pelites toward the Al-enriched sediments (Figure 14). However, they are falling to illitic and kaolinitic clay fields in close proximity to lateritic bauxite values on $\mathrm{K}_{2} \mathrm{O}-\mathrm{MgO}-\mathrm{Al}_{2} \mathrm{O}_{3}$ diagram (Figure 14). 
The ruby geochemistry indicates a metamorphic origin with trace element ratios of $\mathrm{Ga} / \mathrm{Mg}<$ 8.2, $\mathrm{Fe} / \mathrm{Mg}<51.2, \mathrm{Cr} / \mathrm{Ga}>6.9$ and $\mathrm{Fe} / \mathrm{Ti}<31.6$ [32,33]. On the $\mathrm{FeO}-\mathrm{Cr}_{2} \mathrm{O}_{3}-\mathrm{MgO}-\mathrm{V}_{2} \mathrm{O}_{3}$ vs. FeO + $\mathrm{TiO}_{2}+\mathrm{Ga}_{2} \mathrm{O}_{3}$ plot of [34], Snezhnoe rubies overlap the area of "John Saul ruby mine" (Kenia) in the "ruby in marble" field in close proximity to the "metasomatic" corundum field. Meanwhile, the John Saul mine rubies can clearly be separated in terms of their mineral inclusions (exsolved rutile needles, etc.), geochemistry (Ga values varies from 160 up to $480 \mu \mathrm{g} / \mathrm{g}$ [5]) and formation time (533 \pm 11 Ma by LA-ICP-MS U-Pb rutile dating [31]) from those of the Snezhnoe deposit. On the $\mathrm{Cr} / \mathrm{Ga}$ vs. Fe/Ti discriminant diagram of [33], the Snezhnoe rubies plot in the "metamorphic" field (Figure 9a). However, they are in the "transitional" and partly "magmatic" fields on the Fe( $\mu \mathrm{g} / \mathrm{g}) \mathrm{vs.}$ $\mathrm{Fe} / \mathrm{Ti}$ plot of [32,33] (Figure 9b), which is unlikely due to the geological data and mineral assemblage of the ruby-bearing rocks. The ruby-oxygen isotope composition varied in the narrow range of $+15.25 \% \pm 0.07 \%$ o. In a closed system at a temperature of around $800{ }^{\circ} \mathrm{C}$ the resulting corundum oxygen isotopic composition is controlled mainly by the protolith $\delta^{18} \mathrm{O}$ values, however, it can also be buffered by the marble host rocks [50]. The obtained oxygen isotopic composition at $\sim+15.3 \%$ o is slightly lower than that found in metamorphic marble-hosted corundums (from $+16.3 \%$ o to $+23.0 \%$; [4]). However, this is within the range detected for pelitic and bauxite-like sediments with $\delta^{18} \mathrm{O}$ values varying from about $+15 \%$ o to $+20 \%$ o $[4,50]$. Therefore, the obtained results confirm the third hypothesis indicating that the ruby-bearing rocks were formed from a sedimentary Al-enriched protolith re-worked during iso-chemical metamorphism.

According to the results of the $\mathrm{Zr}$-in-rutile thermometer, the apparent crystallization temperatures were in the range of $830 \pm 60^{\circ} \mathrm{C}$. However, the application of this thermometer for rutiles crystallizing in the quartz-free environment with an unconstrained silicon activity ( $\mathrm{a}_{\mathrm{SiO} 2}$ ) may lead to significant temperature overestimation (up to $70^{\circ} \mathrm{C}$ at $750^{\circ} \mathrm{C}$ [51]). Therefore, the apparent $\mathrm{Zr}$-in-rutile temperature should be recalculated to lower temperature of about $760 \pm 30^{\circ} \mathrm{C}$. This temperature estimation agrees with the range from 700 to $750{ }^{\circ} \mathrm{C}$ obtained in earlier studies [45] (Figure 15). Furthermore, this is close to the upper boundary of $600-650{ }^{\circ} \mathrm{C}$ detected previously by thermodynamic modeling of mineral equilibria in the system $\mathrm{CaO}-\mathrm{SiO} 2-\mathrm{Al} 2 \mathrm{O} 3-\mathrm{Na} 2 \mathrm{O}-\mathrm{K} 2 \mathrm{O}$ [9], but well above the micro-thermometric estimates of $450-500{ }^{\circ} \mathrm{C}$ using fluid inclusions [40] (Figure 15). The Raman shift in the $\mathrm{Cr}^{3+} \mathrm{R}$-lines in ruby photoluminescence spectra targeted to areas around rutile inclusions resulted in estimates for the minimum pressure for rutile entrapment at about 1-1.2 kbar. Previous studies have suggested 4-6 kbar [9] and 8-9 kbar [45] required for the formation of ruby-bearing rocks (Figure 15). The lower pressures recorded by rutile entrapment in ruby could be caused by: (1) analysis of already decompressed areas due to the development of microscopic fractures in the ruby crystal or (2) measurement of the secondary rutile in such fractures formed by a replacement of the titanite inclusions originally trapped within the ruby host. 


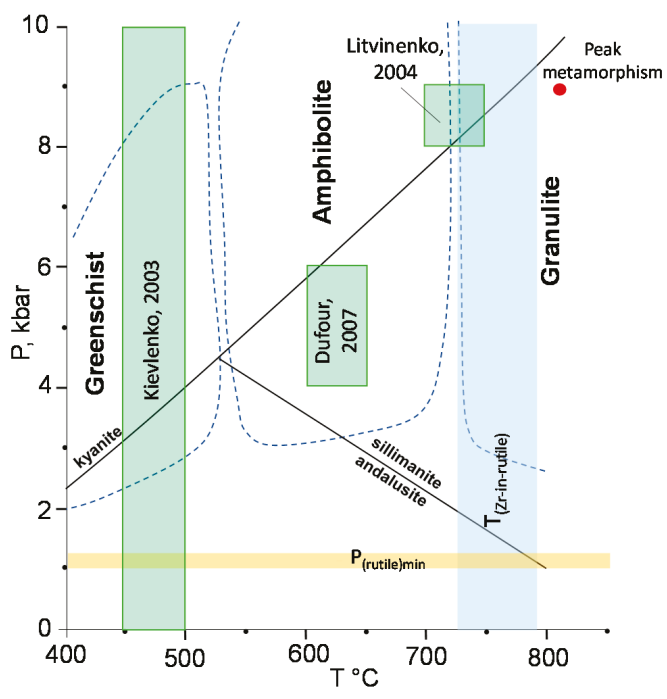

Figure 15. Temperature vs. pressure binary plot showing formation conditions of Snezhnoe ruby deposit recorded in rutiles: Zr-in-rutile thermometer $\mathrm{T}_{(\mathrm{Zr} \text {-in-rutile) }}$ (blue vertical field) and Raman mapping

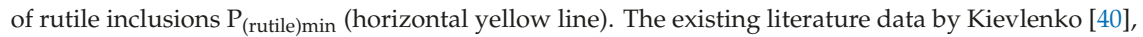
Dufour [9] and Litvinenko [44,45] are shown as green fields. The peak metamorphism conditions are shown as red point after [18,19]. The stability fields of aluminosilicates (divided by black lines) are after [52]. Schematic fields of Greenschist, Amphibolite and Granulite metamorphic facies are shown for clarity.

The $\mathrm{Rb}-\mathrm{Sr}$ isotopic measurements showed one errorchron with an age of $23 \pm 1.6 \mathrm{Ma}$. However, these data should be used with caution due to the upper values in samples of phlogopite with different degrees of alteration to clinochlore. The phlogopite errorchron (Figure 13) as in the case for the lower intercept on the $\mathrm{U}-\mathrm{Pb}$ Concordia (U-Pb rutile analyses in Figure 11) showed younger ages at about ca. $12 \mathrm{Ma}$ falling well within the range of 7-17 Ma obtained previously during K/Ar muscovite dating [41]. This phenomenon suggests the re-opening of the $\mathrm{Rb}-\mathrm{Sr}$ and $\mathrm{K} / \mathrm{Ar}$ systems in mica group minerals along with $\mathrm{U}-\mathrm{Pb}$ systematics in rutile linked likely to later hydrothermal process occurring at the deposit. This hydrothermal process led to the formation of several centimeter-thick veins filled with scapolite and mica group minerals clearly cross-cutting the ruby-bearing rocks. Meanwhile, these obtained $\mathrm{Rb}-\mathrm{Sr}$ and $\mathrm{U}-\mathrm{Pb}$ rutile ages are close to the Dufour et al. [9] estimations, while nowhere near the Budanova [19] observations suggesting a Precambrian age. These Rb-Sr ages are likely linked to the cooling stage and the period of relaxation after peak metamorphism during the Alpine-Himalayan Orogeny. However, they also fall in the time range for the other marble-hosted corundum deposits within this major tectonic structure [2,53] (Figure 16). The modeled age of the protolith $\mathrm{T}(\mathrm{DM})$ - model age-was estimated at about $1.3 \mathrm{Ga}$, later than the timing of the first metamorphic cycle in the area of the Snezhnoe deposit (1.9-1.6 Ga). However, this still confirms the hypothesis of a Proterozoic protolith for the ruby-bearing rocks. 


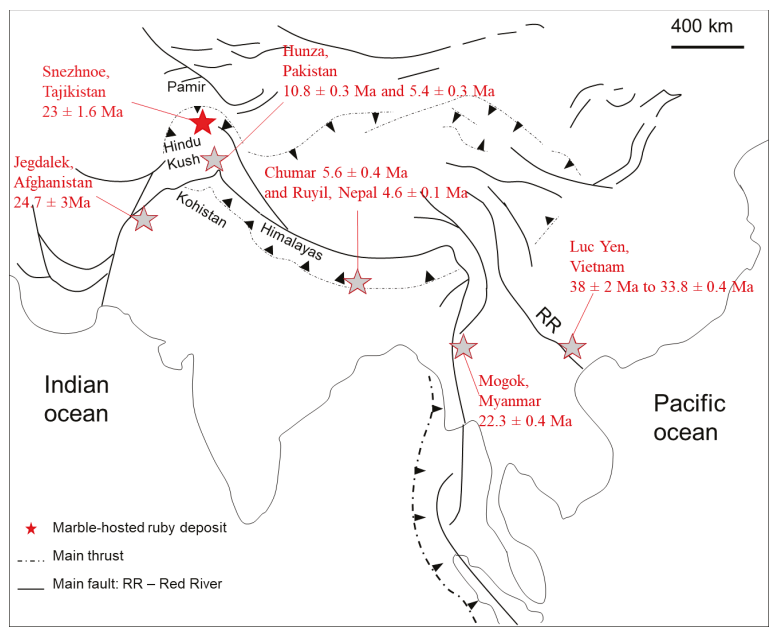

Figure 16. Tectonic map of Central and South East Asia with location of marble-hosted gem corundum deposits shown as gray stars (modified after [54]). Red star indicates the Snezhnoe ruby deposit with $\mathrm{Rb}-\mathrm{Sr}$ age obtained in this study. The ages of ruby deposits are from $[2,53]$.

\section{Conclusions}

1. The regional position of the Snezhnoe deposit is localized by the Muzkol-Rangkul anticlinorium within the Cimmerian zone of the Central Pamir. This tectonic structure comprises Precambrian metamorphic and igneous rocks that have undergone multi-stage metamorphism (1) under high-temperature amphibolite facies conditions (Precambrian) and, then, (2) from the melting zone in the central part of the anticlinorium through epidote-amphibolite to greenschist facies in the periphery (Mesozoic-Cenozoic). Ruby and associated minerals from the Snezhnoe deposit most likely formed at temperatures of $760 \pm 30^{\circ} \mathrm{C}$. The minimum pressure for rutile entrapment was estimated at $~ 1-1.2$ kbar. The Rb-Sr errorchron age (phlogopite-plagioclase-bulk rock) yielded $23 \pm 1.6 \mathrm{Ma}$. However, the Rb-Sr systematics of the phlogopite was likely affected by later hydrothermal processes at Snezhnoe. Therefore, the $\mathrm{Rb}-\mathrm{Sr}$ errorchron age for the ruby-bearing rocks should be used with caution.

2. The ratios of chromophore trace elements within Snezhnoe ruby are $\mathrm{Ga} / \mathrm{Mg}<8.2, \mathrm{Fe} / \mathrm{Mg}$ $<51.2, \mathrm{Cr} / \mathrm{Ga}>6.9$ and $\mathrm{Fe} / \mathrm{Ti}<31.6$, all within the range for metamorphic corundum. On the $\mathrm{FeO}-\mathrm{Cr}_{2} \mathrm{O}_{3}-\mathrm{MgO}-\mathrm{V}_{2} \mathrm{O}_{3}$ vs. $\mathrm{FeO}+\mathrm{TiO}_{2}+\mathrm{Ga}_{2} \mathrm{O}_{3}$ plot, the Snezhnoe rubies overlap those of the "John Saul ruby mine" in the "ruby in marble" field. On the $\mathrm{Cr} / \mathrm{Ga}$ vs. Fe/Ti discriminant diagram, the Snezhnoe rubies plot within the "metamorphic" field. The ruby-oxygen isotope composition is consistently around $+15.25 \% \pm 0.07 \%$ o well within the field for metamorphic and sedimentary rocks. The initial ${ }^{87} \mathrm{Sr} /{ }^{86} \mathrm{Sr}$ ratio is about 0.70791 and $\varepsilon \mathrm{Nd}$ is about -9.6 for bulk corundum-bearing rocks, confirming the geological data on the crustal origin of the ruby-bearing rocks at Snezhnoe. The possible protolith for these rocks was Proterozoic pelitic or bauxite-like sediments intercalated with carbonates.

3. The chemical composition of the ruby-bearing rocks varies considerably in terms of petrogenetic elements and is linked to the varying mineral associations along strike. Four mineral associations are distinguished: (1) ruby + scapolite (marialite) + muscovite + margarite + phlogopite; (2) ruby + plagioclase (albite-andesine) + muscovite + margarite; (3) ruby + muscovite + phlogopite + margarite; (4) ruby + calcite. The fourth mineral association is the most economically valuable. Meanwhile, the association of plagioclase + scapolite + phlogopite + muscovite is characteristic of the ruby-free zones. Mica group minerals were found in most ruby associations. Their specific features are traces of $\mathrm{Cr}$ and $\mathrm{V}$ linked to their green color being the main prospecting indicator for the ruby mineralization. 
Supplementary Materials: The following are available online at http://www.mdpi.com/2075-163X/10/5/478/s1, Table S1: Description of the ruby-bearing samples used in this study; Table S2: Chemistry of muscovite (no. 1-4) chromium-bearing muscovite (no. 5-20) and fuchsite (no. 21-23); Table S3: Chemistry of margarite; Table S4: Chemistry of phlogopite; Table S5: Chemistry of plagioclase group minerals; Table S6: Chemistry of scapolite group minerals; Table S7: Chemistry of titanite; Table S8: Chemistry of rutile; Table S9: Chemistry of tourmaline group minerals; Table S10: Chemistry of corundum using EMPA (in wt.\%); Table S11: Chemistry of corundum obtained by LA-ICP-MS (in $\mu \mathrm{g} / \mathrm{g}$ ); Table S12: Chemistry of ruby-bearing samples (wt.\%); Table S13: Geochemistry of rutile grains used for in situ U-Pb LA-ICP-MS geochronology; Table S14: Rb-Sr and Sm-Nd isotope measurements of phlogopite, plagioclase and ruby-bearing rock from the Snezhnoe deposit.

Author Contributions: Conceptualization, A.K.L. and E.S.S.; methodology, T.H., E.S.S., Y.A.K. and T.L.; formal analysis, A.K.L., E.S.S., T.H., A.V.S., T.L. and T.V.R.; investigation, A.K.L. and E.S.S.; writing-original draft preparation, A.K.L. and E.S.S.; writing-review and editing, E.S.S., T.H., R.E.B., Y.A.K., A.V.S. and W.H.; supervision, R.E.B. and W.H.; funding acquisition, E.S.S. All authors have read and agreed to the published version of the manuscript.

Funding: This research was supported by an Alexander von Humboldt Postdoctoral Fellowship to one author (E.S.S.). The U-Pb isotopic measurements were funded by the German Academic Exchange Service (DAAD, No 57378441) and Stiftung zur Förderung der Edelsteinforschung of Johannes Gutenberg-Universität Mainz (2018). EDXRF analyses, $\mathrm{Rb}-\mathrm{Sr}$ and $\mathrm{Sm}-\mathrm{Nd}$ isotopic measurements were supported by the Vernadsky Institute of Geochemistry and Analytical Chemistry (State Assignment no. 0137-2019-0014).

Acknowledgments: We are grateful to our colleagues from MGRI (Mikhail Yu. Gurvitch), GEOKHI RAS (Lia N. Kogarko, Natalia N. Kononkova, Tatiana G. Kuzmina, Victor A. Turkov), Stefan Buhre (JGU Mainz), colleagues from Heidelberg University (Axel Schmitt, Mario Trieloff and Sonja Storm), Jasper Berndt (Westfälische Wilhelms-Universität Münster), Delia Rösel (TU Bergakademie Freiberg and University of Gothenburg), Natalia P. Gorbunova (Institute of Geology, Academy of Science of Tajikistan) for their help in sample preparations, assistance in analytical measurements and discussions on the topic of research. The authors thank the Editor of Minerals and Guest Editors Frederick Lin Sutherland and Khin Zaw for invitation to submit the manuscript for consideration and possible contribution in a special issue on "Mineralogy and geochemistry of ruby". We are also thankful to Ian Graham (University of New South Wales, Australia) and two anonymous reviewers for improving the text of an earlier version of this article.

Conflicts of Interest: The authors declare no conflict of interest.

\section{References}

1. Graham, I.; Sutherland, F.L.; Zaw, K.; Nechaev, V.; Khanchuk, A. Advances in our understanding of the gem corundum deposits of the West Pacific continental margins intraplate basaltic fields. Ore Geol. Rev. 2008, 34, 200-215. [CrossRef]

2. Garnier, V.; Giuliani, G.; Ohnenstetter, D.; Fallick, A.E.; Dubessy, J.; Banks, D.; Hoàng Quang, V.; Lhomme, T.; Maluski, H.; Pêcher, A.; et al. Marble-hosted ruby deposits from Central and Southeast Asia: Towards a new genetic model. Ore Geol. Rev. 2008, 34, 169-191. [CrossRef]

3. Stern, R.G.; Tsujimori, T.; Harlow, G.; Groat, L.A. Plate tectonic gemstones. Geology 2013, 41, 723-726. [CrossRef]

4. Giuliani, G.; Ohnenstetter, D.; Fallick, A.E.; Groat, L.; Fagan, A.G. The geology and genesis of gem corundum deposits. In Geology of Gem Deposits, 2nd ed.; Groat, L.A., Ed.; Mineralogical Association of Canada: Tucson, AZ, USA, 2014; pp. 29-112.

5. Sorokina, E.S.; Rösel, D.; Häger, T.; Mertz-Kraus, R.; Saul, J.M. LA-ICP-MS U-Pb dating of rutile inclusions within corundum (ruby and sapphire): New constraints on the formation of corundum deposits along the Mozambique belt. Miner. Depos. 2017, 52, 641-649. [CrossRef]

6. Saul, J.M. Transparent gemstones and the most recent supercontinent cycle. Int. Geol. Rev. 2017, 60, 889-910. [CrossRef]

7. Meng, F.; Shmelev, V.R.; Kulikova, K.V.; Ren, Y. A red-corundum-bearing vein in the Rai-Iz ultramafic rocks, Polar Urals, Russia: The product of fluid activity in a subduction zone. Lithos 2018, 320, 302-314. [CrossRef]

8. Dmitriev, E.A. Types of corundum mineralization in the Precambrian marbles of the Muzkol-Rangkulsky anticlinorium. In Proceedings on Geology and Prospecting of the Gemstone Deposits of Tajikistan; Klimkin, A.V., Ed.; Donish: Dushanbe, Tajikistan, 1987; pp. 34-36. (In Russian)

9. Dufour, M.S.; Kol'tsov, A.B.; Zolotarev, A.A.; Kuznetsov, A.B. Corundum-bearing metasomatic rocks in the Central Pamirs. Petrology 2007, 15, 151-167. [CrossRef] 
10. Barnov, N.G. Geological Conditions of Localization and Prerequisites for Industrial Mineralization of Ruby in Marbles Using the Example of the Snezhnoye Deposit (Central Pamir). Unpublished Ph.D. Thesis, MGRI, Moscow, Russia, 2010. (In Russian).

11. Sorokina, E.S. Ontogeny and Quality of Gem Ruby from the Deposits of Central and South-East Asia. Unpublished Ph.D. Thesis, Fedorovsky All-Russian Research Institute of Mineral Resources, Moscow, Russia, 2011. (In Russian).

12. Nasriddinov, Z.Z. Geological and Mineralogical Features, Determining Quality of Rough from Snezhnoe Deposit. Unpublished Ph.D. Thesis, Russian State Geological Prospecting University, Moscow, Russia, 2013. (In Russian).

13. Barkhatov, B.P. Tectonics of the Pamirs; Leningrad University: Leningrad, USSR, 1963; 240p. (In Russian)

14. Litvinenko, A.K.; Nasreddinov, Z.Z.; Sorokina, E.S. Margarite-Rock-forming mineral from Snezhnoe ruby deposit, Central Pamir. Proc. High. Educ. Establ. Geol. Explor. 2015, 4, 80-82. (In Russian)

15. Sorokina, E.S.; Litvinenko, A.K.; Hofmeister, W.; Häger, T.; Jacob, D.E.; Nasriddinov, Z.Z. Rubies and Sapphires from Snezhnoe, Tajikistan. Gems Gemmol. 2015, 51, 160-175. [CrossRef]

16. Baratov, R.B. Dismemberment of Stratified and Intrusive Rocks of Tajikistan; Donish: Dushanbe, Tajikistan, 1976; 268p. (In Russian)

17. Budanov, V.I.; Budanova, K.T. Geological and petrological characteristics of the exposed crystalline basement. In The Earth's Crust and the Upper Mantle of Tajikistan; Donish: Dushanbe, Tajikistan, 1993; 275p. (In Russian)

18. Dufour, M.S.; Popova, V.A.; Krivets, T.N. Alpine Metamorphic Complex of the Eastern Part of the Central Pamirs; Leningrad University: Saint Petersburg, Russia, 1970; 126p.

19. Budanova, K.T. Metamorphic Formations of Tajikistan; Donish: Dushanbe, Tajikistan, 1991; 336p. (In Russian)

20. Litvinenko, A.K. Geology of Snezhnoe Ruby Deposit, Central Pamirs; Gornaya kniga: Moscow, Russia, 2020; 103p. (In Russian)

21. Jochum, K.P.; Nohl, U.; Herwig, K.; Lammel, E.; Stoll, B.; Hofmann, A.W. GeoReM: A new geochemical database for reference materials and isotopic standards. Geostand. Geoanal. Res. 2005, 29, 333-338. [CrossRef]

22. Jochum, K.P.; Weis, U.; Stoll, B.; Kuzmin, D.; Yang, Q.; Raczek, I.; Jacob, D.E.; Stracke, A.; Birbaum, K.; Frick, D.A.; et al. Determination of reference values for NIST SRM 610-617 glasses following ISO Guidelines. Geostand. Geoanal. Res. 2011, 35, 397-429. [CrossRef]

23. Luvizotto, G.; Zack, T.; Meyer, H.P.; Ludwig, T.; Triebold, S.; Kronz, A.; Münker, C.; Stockli, D.; Prowatke, S.; Klemme, S.; et al. Rutile crystals as potential trace element and isotope mineral standards for microanalysis. Chem. Geol. 2009, 261, 346-369. [CrossRef]

24. Axelsson, E.; Pape, J.; Berndt, J.; Corfu, F.; Mezger, K.; Raith, M.M. Rutile R632-A new natural reference material for U-Pb and $\mathrm{Zr}$ determination. Geostand. Geoanal. Res. 2018, 42, 319-338. [CrossRef]

25. Kooijman, E.; Berndt, J.; Mezger, K. U-Pb dating of zircon by laser ablation ICP-MS: Recent improvements and new insights. Eur. J. Miner. 2012, 24, 5-21. [CrossRef]

26. Mezger, K.; Hanson, G.N.; Bohlen, S.R. High-precision U-Pb ages of metamorphic rutile: Application to the cooling history of high-grade terranes. Earth Planet. Sci. Lett. 1989, 96, 106-118. [CrossRef]

27. Ludwig, K.R. A User's Manual; Berkeley Geochronology Center: Berkeley, CA, USA, 2009; p. 100.

28. Wanthanachaisaeng, B.; Häger, T.; Hofmeister, W.; Nasdala, L. Raman-und fluoreszenz-spektroskopische Eigenschaften von Zirkon-Einschlüssen in chrom-haltigen Korunden aus Ilakaka und deren Veränderung durch Hitzebehandlung. Z Dt. Gemmol. Ges. 2006, 55, 119-131. (In German)

29. Mariga, J.; Ripley, E.M.; Li, C.; McKeegan, K.D.; Schmidt, A.; Groove, M. Oxygen isotopic disequilibrium in plagioclase-corundum-hercynite xenoliths from the Voisey's Bay Intrusion, Labrador, Canada. Earth Planet. Sci. Lett. 2006, 248, 263-275. [CrossRef]

30. Sorokina, E.S.; Ozhogina, E.G.; Jacob, D.E.; Hofmeister, W. Some features of corundum ontogeny and the quality of ruby from Snezhnoe deposit, Tajikistan (the Eastern Pamirs). Zapiski RMO (Proc. Russ. Mineral. Soc.) 2012, 141, 100-108. (In Russian)

31. Sorokina, E.S.; Hofmeister, W.; Häger, T.; Mertz-Kraus, R.; Buhre, S.; Saul, J.M. Morphological and chemical evolution of corundum (ruby and sapphire): Crystal ontogeny reconstructed by EMPA, LA-ICP-MS, and Cr3+ Raman mapping. Am. Mineral. 2016, 101, 2716-2722. [CrossRef]

32. Peucat, J.J.; Ruffault, P.; Fritch, E.; Bouhnik-Le-Coz, M.; Simonet, C.; Lasnier, B. Ga/Mg ratio as a new geochemical tool to differentiate magmatic from metamorphic blue sapphires. Lithos 2007, 98, 261-274. [CrossRef] 
33. Sutherland, F.L.; Abduriyim, A. Geographic typing of gem corundum: A test case from Australia. J. Gemmol. 2009, 31, 203-210. [CrossRef]

34. Giuliani, G.; Caumon, G.; Rakotosamizanany, S.; Ohnenstetter, D.; Rakototondrazafy, M. Classification chimique des corindons par analyse factorielle discriminante: Application à la typologie des gisements de rubis et saphirs. Rev. Gemmol. 2014, 188, 14-22.

35. Giuliani, G.; Fallick, A.E.; Garnier, V.; France-Lanord, C.; Ohnenstetter, D.; Schwarz, D. Oxygen isotope composition as a tracer for the origins of rubies and sapphires. Geology 2005, 33, 249-252. [CrossRef]

36. Yaroshevsky, A.A. Abundances of chemical elements in the Earth's crust. Geochem. Int. 2006, 44, 48-55. [CrossRef]

37. Kostitsyn, Y.A.; Belousova, E.A.; Silant'ev, S.A.; Bortnikov, N.S.; Anosova, M.O. Modern problems of geochemical and U-Pb geochronological studies of zircon in oceanic rocks. Geochem. Int. 2005, 53, 759-785. [CrossRef]

38. Zack, T.; Moraes, R.; Kronz, A. Temperature dependence of Zr in rutile: Empirical calibration of a rutile thermometer. Contrib. Mineral. Petrol. 2004, 148, 471-488. [CrossRef]

39. Watson, E.B.; Wark, D.A.; Thomas, J.B. Crystallization thermometers for zircon and rutile. Contrib. Mineral. Petrol. 2006, 151, 413-433. [CrossRef]

40. Kievlenko, E.Y. Geology of Gems; Soregaroli, A., Ed.; Ocean Pictures Ltd.: Littleton, CO, USA, 2003; 432p.

41. Dmitriev, E.A.; Ishan-Sho, G.A. Chromium-bearing muscovites in metamorphic and hydrothermal formations of the Pamirs. Zapiski VMO (Proc. All-Union Mineral. Soc.) 1987, 116, 690-697. (In Russian)

42. Terekhov, E.N.; Akimov, A.P. Tectonic setting and genesis of the gem corundum deposits of High Azia. Lithosphere 2013, 5, 122-140. (In Russian)

43. Rossovskiy, L.N.; Konovalenko, S.I.; Ananjev, S.A. Conditions of ruby formation in marbles. Geol. Rudn. Mestorozhd. 1982, 24, 57-66. (In Russian)

44. Rossovsky, L.N. Ruby and sapphire deposits of the Alpine-Himalayan fold belt and their formation conditions. In Proceedings on Geology and Prospecting of Gemstone Deposits in Tajikistan; Klimkin, A.V., Ed.; Donish: Dushanbe, Tajikistan, 1987; pp. 36-38. (In Russian)

45. Litvinenko, A.K. Nuristan-South Pamir province of Precambrian gems. Geol. Ore Deposit. 2004, 46, $263-268$.

46. Litvinenko, A.K. The reconstruction of bauxite-like sediments in the Early Proterozoic metamorphites of the Central Pamir. In Proceedings of the Materials of the 5th All-Russian Lithologic Conference "the Types of Sedimentogenesis and Lithogenesis and Their Evolution in the History of the Earth", Ekaterinburg, Russia, 14-16 October 2008; pp. 428-430. (In Russian).

47. Predovsky, A.A. Reconstruction of Conditions of Sedimentogenesis and Volcanism of Early Precambrian; Nauka: Leningrad, USSR, 1980; 152p. (In Russian)

48. Golovenok, V.K. High-Alumina Precambrian Formations; Nedra: Leningrad, USSR, 1977; 267p. (In Russian)

49. Budanova, K.T. Mineralogical and petrochemical characteristics of high-alumina rocks in the eastern part of Central Pamir. Proc. AS Repub. Tajikistan (Zap. AN Resp. Tadjikistan). 1993, 1, 26-33. (In Russian)

50. Giuliani, G.; Fallick, A.E.; Rakotondrazafy, A.F.M.; Ohnenstetter, D.; Andriamamonjy, A.; Rakotosamizanany, S.; Ralantoarison, T.; Razanatseheno, M.M.; Dunaigre, C.; Schwarz, D. Oxygen isotope systematics of gem corundum deposits in Madagascar: Relevance for their geological origin. Miner. Deposita 2007, 42, 251. [CrossRef]

51. Ferry, J.M.; Watson, E.B. New thermodynamic models and revised calibrations for the Ti-in-zircon and Zr-in-rutile thermometers. Contrib. Mineral. Petrol. 2007, 154, 429-437. [CrossRef]

52. Bohlen, S.; Montana, A.; Kerrick, D.M. Precise determination of the equilibria kyanite=sillimanite and kyanite $=$ andalusite and a revised triple point for $\mathrm{Al}_{2} \mathrm{SiO}_{5}$ polymorphs. Am. Mineral. 1991, 76, 677-680.

53. Phyo, M.M.; Wang, H.A.; Guillong, M.; Berger, A.; Franz, L.; Balmer, W.A.; Krzemnicki, M.S. U-Pb Dating of Zircon and Zirconolite Inclusions in Marble-Hosted Gem-Quality Ruby and Spinel from Mogok, Myanmar. Minerals 2020, 10, 195. [CrossRef]

54. Mattauer, M.; Matte, P.; Jolivet, J.L. A 3D model of the India-Asia collision at late scale. Comptes Rendus 1999, 328, 499-508.

(C) 2020 by the authors. Licensee MDPI, Basel, Switzerland. This article is an open access article distributed under the terms and conditions of the Creative Commons Attribution (CC BY) license (http://creativecommons.org/licenses/by/4.0/). 


\title{
nane \\ Identification of Opaque Sulfide Inclusions in Rubies from Mogok, Myanmar and Montepuez, Mozambique
}

\author{
Wim Vertriest * and Aaron Palke \\ Gemological Institute of America, 5355 Armada Drive, Carlsbad, CA 92008, USA; apalke@gia.edu \\ * Correspondence: wvertrie@gia.edu
}

Received: 20 March 2020; Accepted: 21 May 2020; Published: 27 May 2020

\begin{abstract}
The red variety of corundum owes its color and strong fluorescence to the presence of $\mathrm{Cr}$, as well as traces of Fe. The latter can reduce the fluorescence and thus impact the appearance of the final gem. Gem quality rubies are rarely available for scientific study and even less common in their rough form. Opaque inclusions in rubies are often removed during faceting and remain unidentified. This study aims to identify opaque inclusions in rubies from the two most common origins seen in the high end market today: Mogok, Myanmar and Montepuez, Mozambique. Using electron probe microanalaysis (EPMA) the inclusions were identified as sphalerite and pyrrhotite in Mogok rubies. The paragenesis of Myanmar, marble-related rubies is fairly well understood and no Fe-rich minerals apart from sulfides have been identified. Opaque inclusions in Mozambican rubies are a complex mix of Fe-Cu-Ni sulfides with exsolution textures. These inclusions are interpreted to be small amounts of sulfide melt trapped during corundum formation. The different sulfide phases crystallized from this entrapped melt and some phases experienced later exsolution during cooling. The formation of amphibole-related, Mozambican rubies is not well understood, but it is obvious that very different processes are at work compared to the marble-related Myanmar ruby deposits.
\end{abstract}

Keywords: ruby; sulfides; Mogok; Montepuez; gemology; corundum

\section{Introduction}

Ruby has always been one of the most desired gemstones. Historically, the finest rubies were found in deposits throughout Central and South-East Asia [1]. In the last decades, many ruby deposits have been found in East Africa, introducing a slightly different type of ruby to the market that originated from geologically different deposits [2-14].

Marble-related rubies, such as the Myanmar stones, are famous for being extremely fluorescent and having very low Fe concentrations [15]. Amphibole-related rubies, like the Mozambican stones, show more variable fluorescence, ranging from almost none to intensities that nearly match marble-related stones [7]. The red gem variety of corundum owes its color and fluorescence to trace amounts of $\mathrm{Cr}$. Some rubies from Mogok have a considerable V content that can modify the color to be more purple [16]. The presence of Fe lowers the fluorescence of the ruby.

Inclusion studies are a critical part of gemological research, because included crystals are easy to observe and describe in transparent minerals. The only required equipment to see them is a gemological microscope and adequate lighting tools. Gemologists rely heavily on inclusions to determine treatments and geographic origin of gem quality corundum [17-19]. However, in most cases their studies are limited to visual observation. Since most gemstones have a high value, destructive analysis is rarely an option. This means that the chemical analysis of inclusions is only possible when they reach the polished surface of the gem. Spectroscopic techniques such as FTIR and Raman spectroscopy offer a solution, with Raman spectroscopy being the most ideal candidate to identify crystal inclusions [20]. For most common inclusions in finished gemstones, this is sufficient. In many cases, these crystals are transparent/translucent carbonate, phosphate, oxide or silicate minerals [1,21]. 
In the case of rough rubies, an additional type of inclusion can be frequently seen. These are dark, opaque, inclusions with a metallic luster. These dark colored inclusions are rarely retained in the facetted gems, because their high contrast with the transparent red bodycolor creates eye visible distractions that lower the value significantly.

On top of that, they react poorly to heat treatment $[2,17,18]$. Heating rubies is a standard practice in the gem trade to improve the color or clarity of the gemstone. These metallic inclusions often expand during this process. Expansion fractures commonly surround the crystal, often filled with black opaque residue, making the inclusion even more visible and distracting. Thus, facetters aim to remove these inclusions before polishing the gem.

The goals of this study are to identify these opaque inclusions and assess how their presence may explain the differences in trace element chromophores and visual appearance between the Myanmar and Mozambique rubies. Given the affinity for $\mathrm{S}$ to bind with Fe and create sulfides, the presence of $S$ during corundum formation may potentially be an important factor for the final fluorescence and appearance of the gem. The formation of amphibole related rubies is not fully understood. An analysis of the opaque sulfide inclusion could provide additional insight in the environment that allowed the formation of amphibole-related rubies.

\section{Materials and Methods}

\subsection{Materials}

For this study, rubies from Mogok, Myanmar and Montepuez, Mozambique were used (Table 1). These sources were chosen because they represent the majority of high-end rubies seen in the gem trade nowadays. Mogok, Myanmar is the most coveted ruby source in the world, due to its long history and the fabled gemstones that were sourced from its mines [1]. Montepuez Mozambique on the other hand is a very new source where rubies were only discovered in 2009, but its large volumes and high quality quickly made it the dominant supplier for the global ruby trade [2].

All samples are part of GIA's (Gemological Institute of America) Colored Stone Reference Collection (GIA CSRC) which consists of samples collected during GIA Field expeditions to gemstone mining locations around the world [22]. The selected samples were prepared and documented at GIA's laboratory in Bangkok, Thailand.

Every ruby selected contained opaque, mineral inclusions with metallic luster. In one case, the opaque mineral is not present as an inclusion. This sample (A6), from the Baw Lon Gyi mining area in Mogok, Myanmar, has an opaque mineral in the matrix attached to the ruby, rather than as an inclusion. 
Table 1. Samples used during this study.

\begin{tabular}{|c|c|c|c|c|c|}
\hline $\begin{array}{c}\text { GIA CSRC Sample } \\
\text { Number }\end{array}$ & Number & $\begin{array}{l}\text { Country of } \\
\text { Origin }\end{array}$ & Area & Mining Area & \\
\hline & & & & & 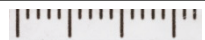 \\
\hline \multirow[t]{2}{*}{100321364740} & A1 & Myanmar & Mogok & Baw Lon Gyi & \\
\hline & & & & & 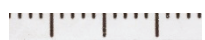 \\
\hline \multirow[t]{2}{*}{100315602328} & A2 & Myanmar & Mogok & Baw Lon Gyi & \\
\hline & & & & & י"ן'יי"ן'י" \\
\hline \multirow[t]{2}{*}{100322689933} & A3 & Myanmar & Mogok & Baw Lon Gyi & \\
\hline & & & & & 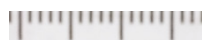 \\
\hline \multirow[t]{2}{*}{100318470512} & A4 & Myanmar & Mogok & Sin Kwa & \\
\hline & & & & & יין'ייין'יי \\
\hline \multirow[t]{2}{*}{100309935280} & A5 & Myanmar & Mogok & Sin Kwa & \\
\hline & & & & & 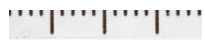 \\
\hline \multirow[t]{2}{*}{100327146806} & A6 & Myanmar & Mogok & Baw Lon Gyi & \\
\hline & & & & & י'י"י'י"'י"'י" \\
\hline \multirow[t]{2}{*}{100319160887} & B1 & Mozambique & Montepuez & Mugloto & \\
\hline & & & & & 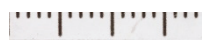 \\
\hline \multirow[t]{2}{*}{100327146596} & B2 & Mozambique & Montepuez & Mugloto & \\
\hline & & & & & 'י \\
\hline \multirow[t]{2}{*}{100319160890} & B3 & Mozambique & Montepuez & Mugloto & \\
\hline & & & & & 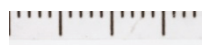 \\
\hline 100319160927 & B4 & Mozambique & Montepuez & Mugloto & \\
\hline
\end{tabular}

\subsection{Methods}

\subsubsection{Photomicrography}

Photomicrographs of internal features were captured at different magnifications with Nikon SMZ 18 and Nikon SMZ 1500 systems (Nikon, Tokyo, Japan), using darkfield, brightfield, diffused, and oblique illumination, together with a fiber-optic light source when necessary. It should be noted that the microscope magnification power was taken into consideration when calculating the field of view (FOV) information in the captions. 


\subsubsection{Inclusion Analysis}

Backscattered electron (BSE) images were obtained using a ZEISS 1550VP field emission SEM (ZEISS, Oberkochen, Germany) and a JEOL 8200 electron microprobe (JEOL, Tokyo, Japan) with AsB (angle selective backscatter) and solid-state BSE detectors, respectively. Quantitative elemental microanalyses were carried out using the JEOL 8200 electron microprobe, operated at $10 \mathrm{kV}$ (for smaller interaction volume) and $5 \mathrm{nA}$ in focused beam mode. Analyses were processed with the CITZAF correction procedure [23] using the Probe for electron probe microanalaysis (EPMA) software from Probe Software, Inc. (Eugene, OR, USA).

The EPMA analysis was set up to measure 8 selected elements: $\mathrm{S}, \mathrm{As}, \mathrm{Cu}, \mathrm{Fe}, \mathrm{Ni}, \mathrm{Zn}, \mathrm{Pb}$ and $\mathrm{Co}$. Analysis was calibrated using the following standards (Table 2).

Table 2. Details of the standards used during electron probe microanalaysis (EPMA) analysis.

\begin{tabular}{cccc}
\hline Elements & Standard Number & Mineral & Mineral Code \\
\hline $\mathrm{Cu}$ & St 129 & Copper & P-1012 \\
$\mathrm{S}$ & St 1830 & MnS syn & P-698 \\
$\mathrm{Ni}, \mathrm{S}$ & $\mathrm{St} 1831$ & $\mathrm{NiS}$ syn & $\mathrm{P}-699$ \\
$\mathrm{Zn}, \mathrm{S}$ & $\mathrm{St} 1832$ & $\mathrm{ZnS}$ syn & $\mathrm{P}-700$ \\
$\mathrm{~Pb}, \mathrm{~S}$ & $\mathrm{St} 1833$ & $\mathrm{PbS}$ syn & $\mathrm{P}-701$ \\
$\mathrm{As}, \mathrm{S}$ & $\mathrm{St} 1835$ & $\mathrm{As}_{2} \mathrm{~S}_{3}$ syn & $\mathrm{P}-703$ \\
$\mathrm{Co}, \mathrm{S}$ & $\mathrm{St} 1838$ & $\mathrm{Co}_{9} \mathrm{~S}_{8}$ syn & $\mathrm{P}-706$ \\
$\mathrm{Fe}, \mathrm{S}$ & $\mathrm{St} 1853$ & $\mathrm{FeS}_{2} \mathrm{mac}$ & $\mathrm{P}-1004$ \\
\hline
\end{tabular}

EPMA and BSE analysis were performed at the Geological and Planetary Science Division Analytical Facility at Caltech in Pasadena, California.

\section{Geological Setting}

Corundum only forms in natural environments that are depleted in Si. At high concentrations of silicon, Al will preferentially be incorporated in other minerals such as micas or feldspars. Consequently, corundum is often associated with $\mathrm{Si}$-free carbonates or silicate minerals, with a relatively high $\mathrm{Al} / \mathrm{Si}$ ratio such as plagioclase, amphibole or pyroxene [24]. For the formation of the ruby, it is necessary to incorporate trace amounts of $\mathrm{Cr}$ to act as a chromophore, as well as the right thermobarometric conditions to allow the growth of large crystals.

\subsection{Geologogical Setting and Formation of Mogok Rubies}

The Mogok Stone Tract, the source of many fine gems, is located in the northern part of the Mogok Metamorphic Belt. This metamorphic belt crosses Myanmar from north to south and forms the western margin of the Shan-Thai block [25-27]. The Mogok area is dominated by amphibolite to granulite facies marbles and paragneisses, as well as a variety of intrusive rocks and derived orthogneisses $[28,29]$. Recent data show a spatial relation between the gem corundum formation and intrusions, although the exact timing and the impact of the intrusive rocks on gem formation are not yet fully understood. It is suggested that Jurassic intrusions and associated alterations of the host rock were affected by regional granulite facies metamorphism related to the Himalayan Orogeny, lasting from 68-21 Ma. During this metamorphism, rubies and sapphires were formed in the marbles and metaskarns [30].

The rubies formed in metamorphosed carbonate platforms that contained some contamination of clays, organic material and evaporites (e.g., anhydrite and salts). The clays provided the necessary elements to build ruby ( $\mathrm{Al}$ and $\mathrm{Cr}$ ), while the molten salts allow these usually immobile elements to migrate through the marble. The molten salts and fluids associated with ruby formation are derived from the protolith and are also enriched in carbonate, sulfur and $\mathrm{Al}$ [31,32].

This results in layers of fairly pure marble with large, well-crystallized calcite interlayered, with silicate layers often containing amphiboles and micas [33]. Ruby crystals occur disseminated in the 
marble and are associated with accessory phlogopite, muscovite, scapolite, spinel, titanite, pyrite and graphite [34].

Throughout Central and Southeast Asia, several marble related deposits are found that are related to the Cenozoic Indo-Asian collision and share a similar formation history [35]. This includes Luc Yen, Vietnam; Murghab, Tajikistan; Hunza, Pakistan; Mong Hsu, Myanmar; Jegdalek, Afghanistan; etc. [32].

The Myanmar rubies from the Mogok valley are mined from hard rock deposits in the marbles, or from secondary mines inside karst features or alluvial deposits.

\subsection{Geological Setting and Formation of Mozambican Rubies}

Mozambican rubies are found in the Southern part of the Neoproterozoic Mozambique belt, which is closely linked with the Pan African orogeny $[6-8,36]$. This suture zone represents the collision between east and West Gondwana [37,38].

The geology of Mozambican rubies is not well understood. The deposit was only discovered in 2009 and most of the rubies come from secondary deposits. The primary deposits in the area are so weathered that they are barely recognizable.

The ruby-bearing rocks are amphibolites hosted in the Montepuez nappe of the Cabo Delgado complex [39]. The Montepuez complex is made up of orthogneiss (granitic to amphibolitic composition) and paragneiss (quartzite, meta-arkose, biotite gneiss and amphibole gneiss,) [40].

There is some evidence of intrusions seen in the Montepuez area in the form of pegmatites and granitic intrusions $[7,40]$.

The rubies are closely related to the bodies with an amphibolite-rich composition, although they are extremely weathered [8]. To date, there is only one study published that describes the petrography of Mozambican ruby host rocks. They contain significant amounts of plagioclase and calcic amphibole next to spinel and corundum, although the silicates are often weathered to clays and micas [41]. Whole-rock geochemical analysis shows that the rocks have a composition similar to picrobasalt in the TAS diagram [41,42]. While this classification is traditionally used for magmatic rocks, it is not yet proven that the protolith of the Mozambican ruby host rock is of magmatic origin. However, the geochemical analysis is at least suggestive that it is derived from a basaltic magma [41].

At the moment, the genesis of Mozambican ruby and amphibole-related ruby is not fully understood. The current model states that amphibole and corundum formed during peak metamorphism, which reacted to plagioclase and spinel during retrograde metamorphism. According to P-T calculation based on a combination of mineral isopleths, pseudosections and geothermometers, the rubies formed at temperatures around $550-600{ }^{\circ} \mathrm{C}$ and pressures around $10.5-11 \mathrm{kbar}$ [41]. These conditions place ruby formation in the amphibolite facies at high pressure and lower temperature. Terrain observations and geological surveys have shown the presence of migmatites and other features that partial melting took place in the amphibolites and gneisses [40,41].

\section{Inclusion Analysis}

\subsection{Literature Studies}

The most commonly used reference works for gemological inclusion studies describe nearly all opaque inclusions in marble-related ruby as pyrrhotite and pyrite [21,43]. The first main study on Mozambican rubies identifies them as chalcopyrite [7]. Nowadays, they are often described based on appearance as pyrite or chalcopyrite, for Myanmar and Mozambique respectively. Inclusions in gemstones are usually well described in the gemological literature. Characteristics such as color, transparency and shape are easy to observe and often allow for preliminary identification. Raman spectroscopy is often used to further identify the crystal inclusions, but this is not always conclusive. More advanced techniques are rarely employed by gemologists. Most of the gemstone inclusion knowledge stems from the three volume Photo-Atlas series, which documents and describes the 
internal world of gemstones [21]. The following is a list of crystal inclusions documented in rubies from Mogok, Myanmar.

1. Zircon, spinel, rutile prisms, mica, garnet, corundum [44]

2. Sphene (titanite), calcite [45]

3. Apatite, olivine, pargasite, sphalerite [46]

4. Dolomite, pyrrhotite, pyrite [21]

5. Sulfur [47]

6. Scapolite, graphite [48]

7. Vesuvianite [49]

The deposits around Montepuez, Mozambique were only recently discovered and there is not as much information is available [6,7]. In literature, the following inclusions have been described.

8. Amphibole and muscovite $[7,39,50]$

9. Chalcopyrite $[2,7]$

10. Orange, irregular masses identified as chromite [7]

However, based on the authors' experience, several additional, less common inclusions like tourmaline, feldspar, zicorn and anhydrite also occur in rubies from this deposit.

This study focusses on the black opaque inclusions that are found in many rough rubies, which are typically described as pyrrhotite/pyrite and chalcopyrite, for Myanmar and Mozambique respectively.

\subsection{Analytical Results}

\subsubsection{Imaging and Description}

All studied inclusions are opaque and have a metallic luster. The apparent color of the inclusions varies from black to red, which are colors not typically associated with most common crystallized metallic minerals. This is because they are found as inclusions within a bright red ruby matrix, where the color of the host mineral obscures the color of the actual inclusion.

Most of the crystals in the Myanmar rubies have sharp angles and well-formed surfaces (A1, A2, A4, A5), while sample A2 shows a very clear step pattern on its surface (Figure 1). Sample A4 has a clear (pseudo?-) hexagonal outline. None of these samples are associated with fractures or show any evidence that they could be secondary.

The inclusions in Mozambican rubies are very similar in color and luster to the Myanmar ones (Figure 2). Their outlines are more spherical but still exhibit flat crystal faces, indicating that all of these crystals are primary inclusions. Sample B1 is associated with a fracture, but this does not extend to the exterior of the stone. 

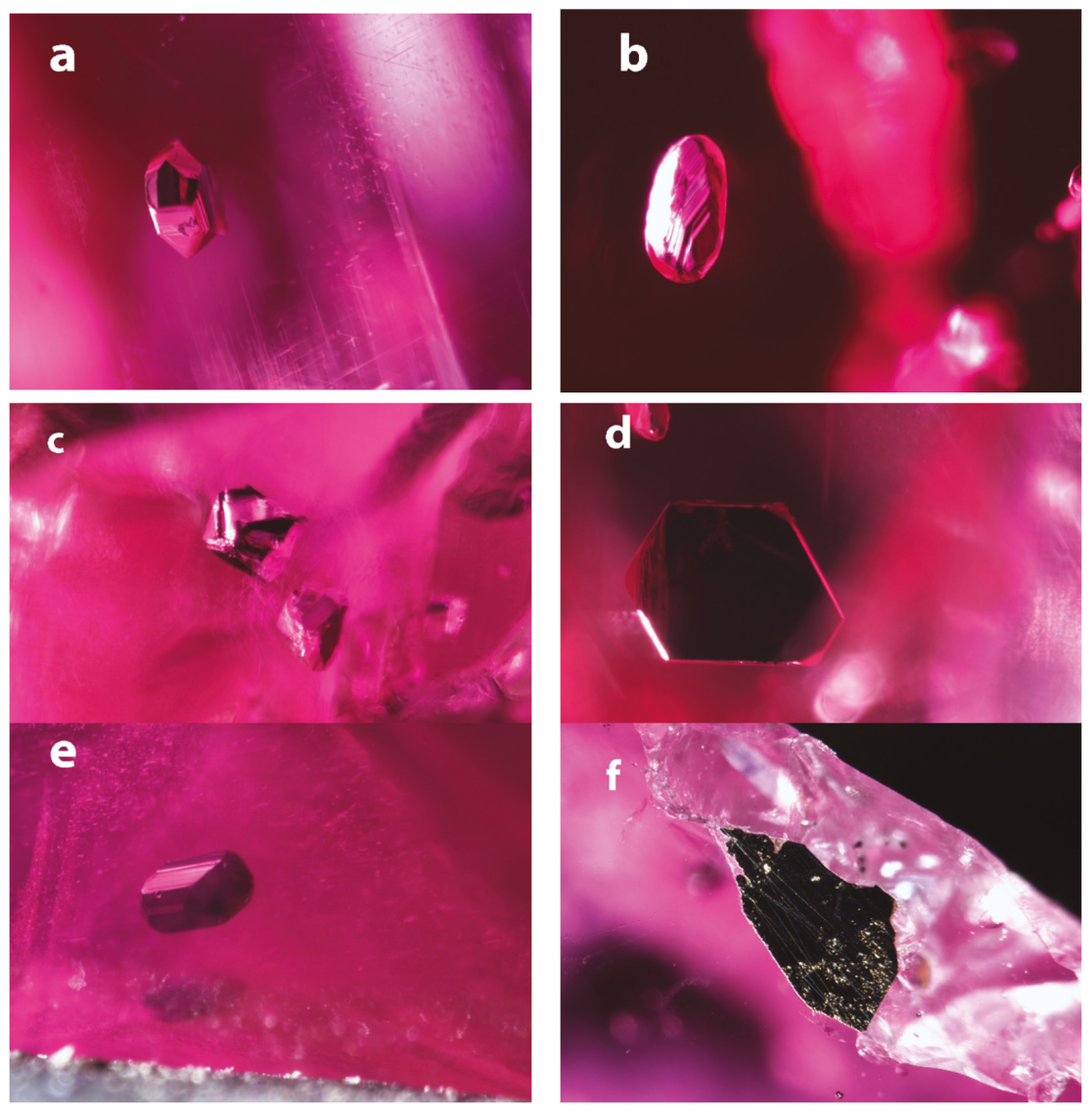

Figure 1. Images of the inclusions in the Mogok rubies. (a) Opaque inclusion in A1, showing well-formed crystal faces. FOV: $1.2 \mathrm{~mm}$; (b) Opaque inclusion in A2 has more rounded appearance due to the terraced angular features. FOV: $1.01 \mathrm{~mm}$; (c) Opaque inclusions in A3 exhibit almost a bipyramidal shape reminiscent of a cubic crystal structure. FOV: $1.2 \mathrm{~mm}$; (d) Opaque inclusion in A3 has a very flat, (pseudo?) hexagonal outline. FOV: $0.85 \mathrm{~mm}$; (e) Opaque inclusion in A5 shows well developed crystal faces and a slightly elongated blocky crystal shape. FOV: $0.85 \mathrm{~mm}$; (f) The opaque minerals associated with sample A6 are an irregular mass, attached to the ruby and surrounded by carbonates. FOV: $1.44 \mathrm{~mm}$.

We also checked a number of samples from GIA's CSRC, to see how abundant those inclusions are. In 54 rough samples from Mogok, we found 46 samples that contained at least one metallic opaque inclusion. In Mozambican rubies, metallic inclusions are much less common, with only 37 out of 109 Mozambican rubies showing this type of inclusion. 

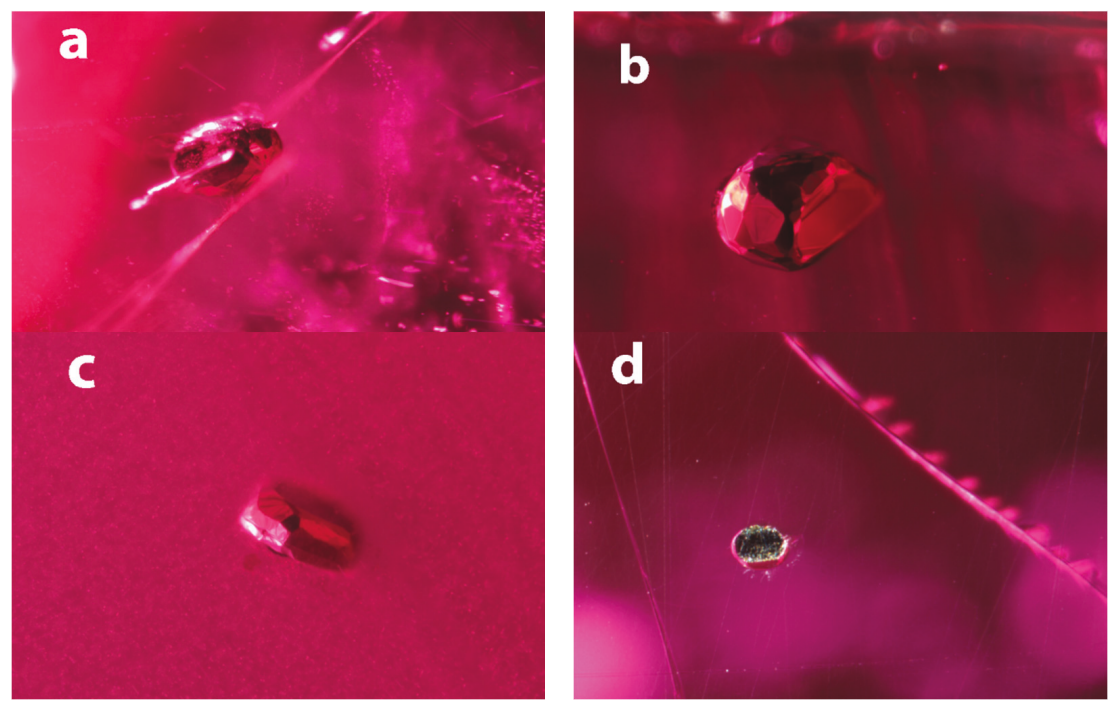

Figure 2. Inclusions in Mozambican rubies. (a) The inclusion in sample B1 is more egg shaped, but shows many small flat crystal faces. It is surrounded by a fracture that is reminiscent of an expansion fracture, which might be an indication of a temperature increase during its geological history after the corundum formed. FOV: $1.50 \mathrm{~mm}$; ( b) The opaque inclusion in sample B2 show many larger crystal faces that do not seem regularly distributed. The overall appearance is rather spherical. FOV: $0.78 \mathrm{~mm}$; (c) The inclusions in sample B3 are similar to B2 but appears flatter. FOV: $1.2 \mathrm{~mm}$; (d) The inclusion in sample B4 was cut through during sample fabrication and shows the brassy color around the edges. FOV: $0.72 \mathrm{~mm}$.

\subsubsection{BSE Imaging}

Back-scattered electron imaging shows that the inclusions in Mogok rubies are mainly single phases (Figure 3). Polish lines and pits were caused by the sample preparation process. Some samples show fractures that were already present, but might have been enlarged during polishing. In some cases, the inclusion is not entirely preserved and some parts were removed during the fabrication process. One sample (A4) shows some obvious zoning with a darker area, showing a herringbone texture. The sample with the sulfide located in the attached matrix (Figure $3 \mathrm{f}$ ) shows a subtle transition between phases.

The Mozambican ruby inclusions show much more complex features (Figure 4). All samples have clearly separated phases. Sample B1 shows three clearly separated phases based on the intensity in BSE images. They are sometimes separated by fractures at the phase contact. In samples B1 and B2, the darkest phase also shows clear exsolution textures. The exsolution pattern in sample B2 is more expressed than it is in sample B1. The homogenous phases without exsolution patterns are also smaller and confined to the fringes of the inclusion. Samples B3 and B4 lack any obvious exsolution patterns, but still show very clear phase separations. 


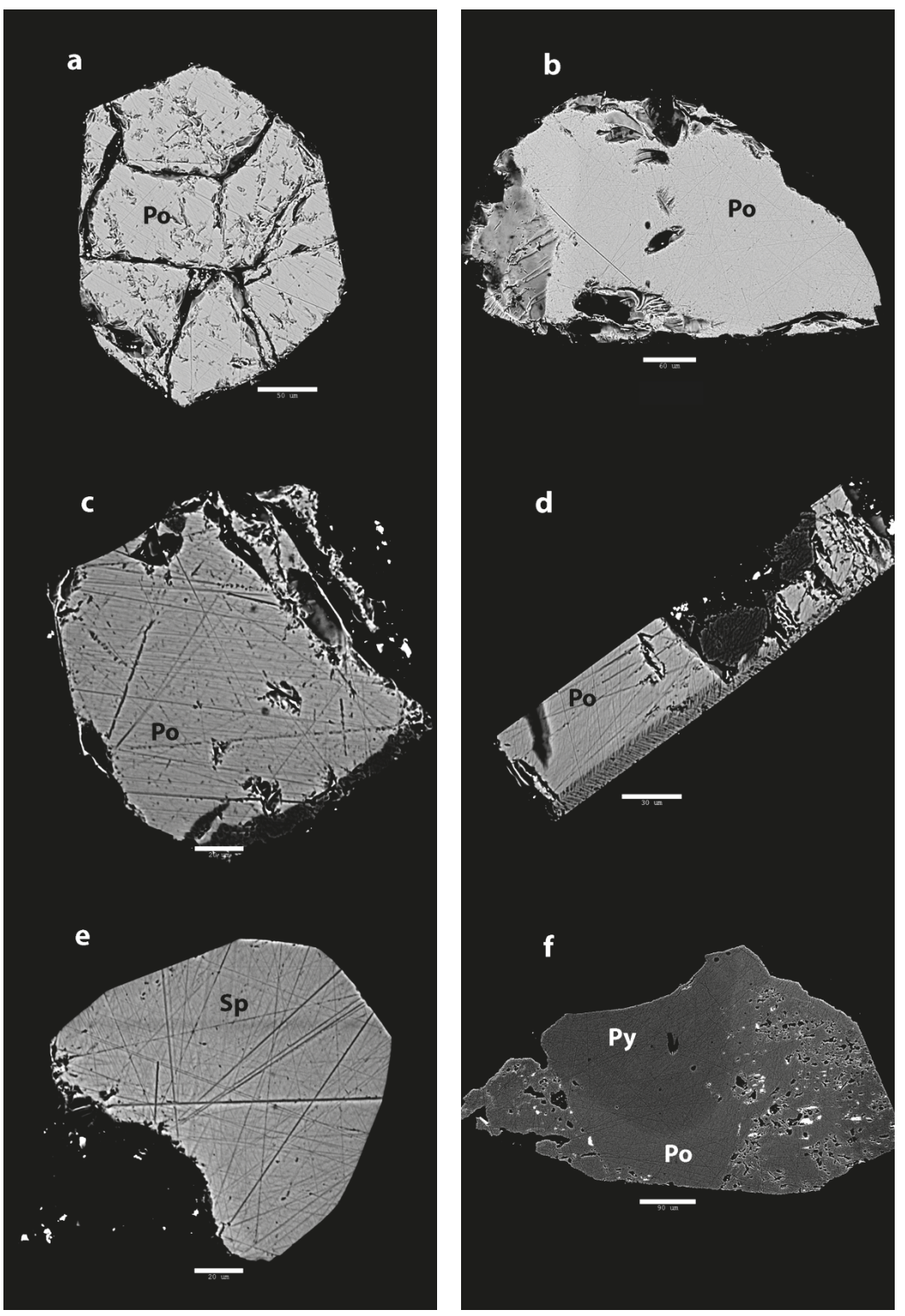

Figure 3. BSE images of Mogok rubies. (a) Inside sample A1, the inclusion shows hexagonal outline and large internal cracks. Scale bar: $50 \mu \mathrm{m}$; (b) The inclusion in sample A2 shows an irregular outline with a homogenous interior. Scale bar: $60 \mu \mathrm{m}$; (c) The inclusion in sample A3 shows straight outline with numerous polish lines. Scale bar: $20 \mu \mathrm{m}$; (d) Sample A4 also shows a lot of polish lines, but most notable is the herringbone texture on the side. Scale bar: $30 \mu \mathrm{m}$; (e) The inclusion in sample A5 has a well-defined outline on the top right. The bottom left has been removed during polishing. Apart from polishing lines, this inclusion appears very homogenous. Scale bar: $20 \mu \mathrm{m}$; (f) The opaque minerals attached to sample A6 show many pits but most important is the subtle zoning in the central part. The ruby is attached to the lower part. Scale bar: $90 \mu \mathrm{m}$. 

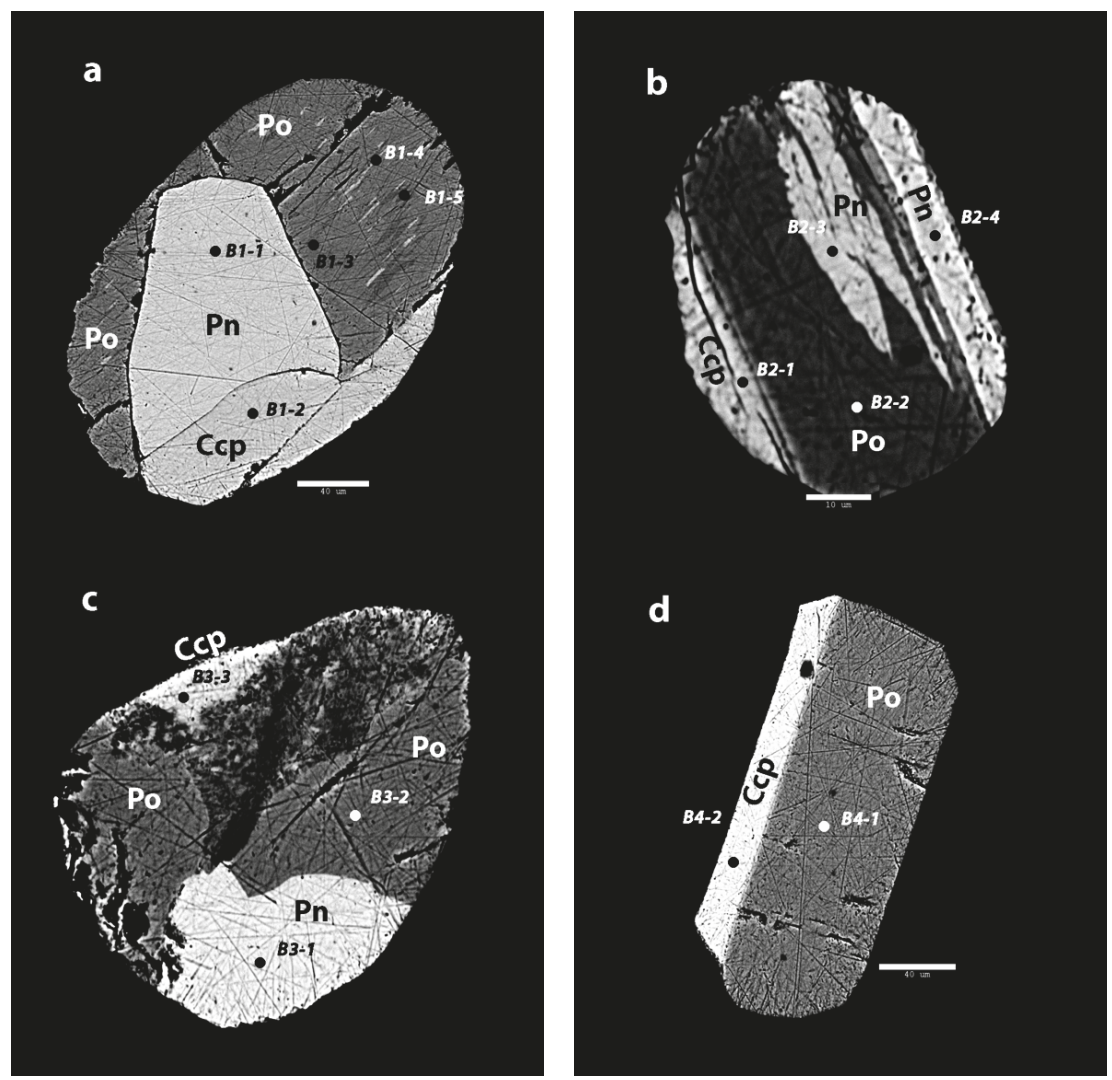

Figure 4. Back scattered electron images of the sulfide inclusions in Mozambican ruby. (a) The inclusion in sample B1 shows three main phases, of which one has various exsolutions. Scale bar: $40 \mu \mathrm{m}$; (b) In sample B2, there are three phases with two phases that show exsolution patterns. Scale bar: $10 \mu \mathrm{m}$; (c) In sample B3, there are three distinct phases. The darker phase shows deeper polish lines and large pits, which might indicate a more unstable mineral. Scale bar: $20 \mu \mathrm{m}$; (d) B4 shows two clearly separated phases without any exsolution textures. Scale bar: $40 \mu \mathrm{m}$.

\subsubsection{EPMA Analysis}

During the EPMA analysis, eight selected elements were quantified (Tables 3 and 4). All of the inclusions turned out to be sulfides, which is consistent with the previous work [7,21]. Most of the analyses resulted in an elemental total of $97-98 \%$ for the inclusions in Mogok rubies. The missing percentages are most likely explained by surface oxidation of the samples. However, it cannot be excluded that an element was not measured during our analysis, which was limited to eight elements. Notably, in sample A4, the elemental total measured in the section with the herringbone pattern was significantly lower. 
Table 3. EPMA results: Elemental percentages and the elemental totals.

\begin{tabular}{cccccccccc}
\hline Mogok & S & Fe & Cu & As & Co & Ni & Zn & Pb & Elemental Totals \\
\hline A1 & 38.66 & 59.14 & 0.00 & 0.00 & 0.13 & 0.03 & 0.01 & 0.20 & 98.19 \\
A2 & 38.58 & 59.28 & 0.00 & 0.00 & 0.14 & 0.06 & 0.10 & 0.16 & 98.31 \\
A3 & 38.68 & 59.51 & 0.01 & 0.00 & 0.12 & 0.15 & 0.10 & 0.18 & 98.75 \\
A4 & 38.72 & 58.91 & 0.00 & 0.00 & 0.11 & 0.15 & 0.06 & 0.20 & 98.14 \\
A4-herringbone & 41.96 & 43.18 & 0.00 & 0.00 & 0.09 & 0.58 & 0.03 & 0.18 & 86.01 \\
A5 & 33.21 & 10.70 & 0.00 & 0.00 & 0.02 & 0.00 & 53.95 & 0.06 & 97.94 \\
A6-dark phase & 53.34 & 46.76 & 0.00 & 0.00 & 0.07 & 0.00 & 0.03 & 0.24 & 100.45 \\
A6-light phase & 38.75 & 59.49 & 0.00 & 0.00 & 0.12 & 0.22 & 0.04 & 0.18 & 98.80 \\
Mozambique & & & & & & & & & \\
B1-1 & 32.82 & 28.74 & 0.05 & 0.00 & 1.22 & 34.43 & 0.05 & 0.16 & 97.46 \\
B1-2 & 34.77 & 29.27 & 32.55 & 0.00 & 0.05 & 0.00 & 0.02 & 0.17 & 96.85 \\
B1-3 & 36.22 & 60.97 & 0.01 & 0.00 & 0.14 & 0.02 & 0.08 & 0.19 & 97.63 \\
B1-4 & 34.22 & 40.43 & 0.04 & 0.00 & 0.17 & 22.52 & 0.09 & 0.15 & 97.62 \\
B1-5 & 35.95 & 61.78 & 0.01 & 0.00 & 0.13 & 0.00 & 0.08 & 0.15 & 98.11 \\
B2-1 & 34.02 & 28.89 & 32.33 & 0.00 & 0.06 & 0.00 & 0.09 & 0.16 & 95.56 \\
B2-2 & 39.14 & 58.43 & 0.13 & 0.00 & 0.12 & 0.16 & 0.14 & 0.16 & 98.27 \\
B2-3 & 33.19 & 30.28 & 0.07 & 0.00 & 1.22 & 32.51 & 0.21 & 0.14 & 97.61 \\
B2-4 & 32.72 & 29.16 & 0.11 & 0.00 & 1.27 & 34.54 & 0.00 & 0.16 & 97.96 \\
B3-1 & 32.65 & 29.02 & 0.00 & 0.00 & 1.14 & 34.75 & 0.02 & 0.18 & 97.75 \\
B3-2 & 38.11 & 58.95 & 0.07 & 0.00 & 0.12 & 0.40 & 0.18 & 0.15 & 97.99 \\
B3-3 & 33.47 & 29.49 & 32.07 & 0.00 & 0.07 & 0.00 & 0.10 & 0.13 & 95.31 \\
B4-1 & 38.63 & 58.50 & 0.00 & 0.00 & 0.13 & 0.93 & 0.11 & 0.19 & 98.49 \\
B4-2 & 34.02 & 29.84 & 32.18 & 0.00 & 0.07 & 0.00 & 0.03 & 0.18 & 96.31 \\
\hline
\end{tabular}

In the case of the Mozambican ruby inclusions, there was a larger spread in elemental totals. The minerals that are dominated by Fe-Ni-S have elemental totals between $97 \%$ and $98 \%$, which is comparable to the numbers seen for the Mogok rubies. Samples with significant $\mathrm{Cu}$ content have lower elemental totals (95-97\%), which could be explained by a more intense alteration or a minor element that is missing.

From the eight elements that were quantified, only five were found to be major elements in the minerals. In every sample, the $\mathrm{Co}$ and $\mathrm{Pb}$ content is low enough to consider them trace elements. Arsenic was not detected in any of the samples.

The analysis shows the presence of pyrrhotite $\mathrm{Fe}_{(0.88)} \mathrm{S}$ and sphalerite $\left(\mathrm{Zn}_{0.8}, \mathrm{Fe}_{0.18}\right) \mathrm{S}$ in the Mogok rubies (Table 4). Additionally, in the matrix sample, pyrrhotite $\mathrm{Fe}_{(0.88)} \mathrm{S}$ and pyrite $\mathrm{FeS}_{2}$ are found together.

The inclusions in Mozambican samples are more complex. They show three main mineral components: chalcopyrite, pentlandite and pyrrhotite. These are well separated and do not show any mixing. The darker pyrrhotite phase often shows different flame-like exsolution patterns. The exsolved minerals consist of Fe-Ni sulfides and pyrrhotite, with slightly elevated Fe contents. 
Table 4. Molar percentages normalized to sulfur.

\begin{tabular}{|c|c|c|c|c|c|c|c|c|}
\hline Mogok & $\mathrm{S}$ & $\mathrm{Fe}$ & $\mathrm{Cu}$ & Co & $\mathrm{Ni}$ & $\mathrm{Zn}$ & Mineral Name & Mineral Formula \\
\hline A1 & 1.00 & 0.88 & 0.00 & 0.00 & 0.00 & 0.00 & pyrrhotite & $\mathrm{Fe}_{0.88} \mathrm{~S}$ \\
\hline $\mathrm{A} 2$ & 1.00 & 0.88 & 0.00 & 0.00 & 0.00 & 0.00 & pyrrhotite & $\mathrm{Fe}_{0.88} \mathrm{~S}$ \\
\hline A3 & 1.00 & 0.88 & 0.00 & 0.00 & 0.00 & 0.00 & pyrrhotite & $\mathrm{Fe}_{0.88} \mathrm{~S}$ \\
\hline A4 & 1.00 & 0.87 & 0.00 & 0.00 & 0.00 & 0.00 & pyrrhotite & $\mathrm{Fe}_{0.87} \mathrm{~S}$ \\
\hline A5 & 1.00 & 0.18 & 0.00 & 0.00 & 0.00 & 0.80 & sphalerite & $\left(\mathrm{Fe}_{0.18}, \mathrm{Zn}_{0.80}\right) \mathrm{S}$ \\
\hline A6-dark phase & 1.00 & 0.50 & 0.00 & 0.00 & 0.00 & 0.00 & pyrite & $\mathrm{FeS}_{2}$ \\
\hline $\begin{array}{l}\text { A6-light phase } \\
\text { Mozambique }\end{array}$ & 1.00 & 0.88 & 0.00 & 0.00 & 0.00 & 0.00 & pyrrhotite & $\mathrm{Fe}_{0.88} \mathrm{~S}$ \\
\hline B1-1 & 1.00 & 0.50 & 0.00 & 0.02 & 0.57 & 0.00 & pentlandite & $\begin{array}{c}\left(\mathrm{Fe}_{4}, \mathrm{Ni}_{4.56}\right. \\
\left.\mathrm{Co}_{0.16}\right) \mathrm{S}_{8}\end{array}$ \\
\hline B1-2 & 1.00 & 0.48 & 0.47 & 0.00 & 0.00 & 0.00 & chalcopyrite & $\mathrm{Cu}_{0.47} \mathrm{Fe}_{0.48} \mathrm{~S}$ \\
\hline B1-3 & 1.00 & 0.97 & 0.00 & 0.00 & 0.00 & 0.00 & pyrrhotite & $\mathrm{Fe}_{0.97} \mathrm{~S}$ \\
\hline B1-4 & 1.00 & 0.68 & 0.00 & 0.00 & 0.36 & 0.00 & $\begin{array}{c}\text { ?Fe-rich } \\
\text { pentlandite? }\end{array}$ & \\
\hline B1-5 & 1.00 & 0.99 & 0.00 & 0.00 & 0.00 & 0.00 & pyrrhotite & $\mathrm{Fe}_{0.99} \mathrm{~S}$ \\
\hline B2-1 & 1.00 & 0.49 & 0.48 & 0.00 & 0.00 & 0.00 & chalcopyrite & $\mathrm{Cu}_{0.48} \mathrm{Fe}_{0.49} \mathrm{~S}$ \\
\hline B2-2 & 1.00 & 0.86 & 0.00 & 0.00 & 0.00 & 0.00 & pyrrhotite & $\mathrm{Fe}_{0.86} \mathrm{~S}$ \\
\hline B2-3 & 1.00 & 0.52 & 0.00 & 0.02 & 0.53 & 0.00 & pentlandite & $\begin{array}{c}\left(\mathrm{Fe}_{4.16}, \mathrm{Ni}_{4.24}\right. \\
\left.\mathrm{Co}_{0.16}\right) \mathrm{S}_{8}\end{array}$ \\
\hline B2-4 & 1.00 & 0.51 & 0.00 & 0.02 & 0.58 & 0.00 & pentlandite & $\begin{array}{c}\left(\mathrm{Fe}_{4.04}, \mathrm{Ni}_{4.64}\right. \\
\left.\mathrm{Co}_{0.16}\right) \mathrm{S}_{8}\end{array}$ \\
\hline B3-1 & 1.00 & 0.51 & 0.00 & 0.02 & 0.58 & 0.00 & pentlandite & $\begin{array}{c}\left(\mathrm{Fe}_{4.04}, \mathrm{Ni}_{4.64}\right. \\
\left.\mathrm{Co}_{0.16}\right) \mathrm{S}_{8}\end{array}$ \\
\hline B3-2 & 1.00 & 0.89 & 0.00 & 0.00 & 0.01 & 0.00 & pyrrhotite & $\mathrm{Fe}_{0.89} \mathrm{~S}$ \\
\hline B3-3 & 1.00 & 0.51 & 0.48 & 0.00 & 0.00 & 0.00 & chalcopyrite & $\mathrm{Cu}_{0.48} \mathrm{Fe}_{0.51} \mathrm{~S}$ \\
\hline B4-1 & 1.00 & 0.87 & 0.00 & 0.00 & 0.01 & 0.00 & pyrrhotite & $\mathrm{Fe}_{0.87} \mathrm{~S}$ \\
\hline B4-2 & 1.00 & 0.50 & 0.48 & 0.00 & 0.00 & 0.00 & chalcopyrite & $\mathrm{Cu}_{0.48} \mathrm{Fe}_{0.50} \mathrm{~S}$ \\
\hline
\end{tabular}

\section{Discussion}

Based on the EPMA analyses, it is clear that the inclusions in Mozambican rubies have not been correctly identified by previous methods. Originally described as pyrite and chalcopyrite in Mogok and Mozambican rubies respectively, they were now identified as pyrrhotite and $\mathrm{Fe}-\mathrm{Ni}$-Cu-sulfides.

Pyrrhotite has a very narrow stability field at surface conditions, but is the most stable iron-sulfide at higher temperatures $\left(>743^{\circ} \mathrm{C}\right)$. Fluid inclusion studies of marble-related ruby deposits in Central Asia and northern Vietnam provide formation temperatures between 620 and $670{ }^{\circ} \mathrm{C}$, with pressures between 2.6 and 3.3 kbar [32].

Various studies have been done to determine P-T conditions of gneisses in the Mogok Metamorphic Belt, which stretches more than $1000 \mathrm{~km}$ and has shown a range of temperatures from 625 to $950{ }^{\circ} \mathrm{C}[51,52]$. For the Mogok deposit, there are no temperature estimates available for the marbles. However, various studies have determined the formation temperatures of the gneisses in the Mogok stone tract and these yielded significantly higher temperatures. Formation temperatures of quartz-dominated gneisses are reported to be $750-790^{\circ} \mathrm{C}$ [53]. However, it is important to note that the prevalent genetic model for marble-hosted rubies places the ruby formation in the retrograde path [32]. These temperatures are significantly higher than the formation conditions of other marble related deposits and most likely represent peak conditions of the host rock, which was reached before ruby formation. Under the higher peak conditions, pyrrhotite is stable, making it the most likely Fe-S mineral that would later be incorporated as a protogenetic inclusion in the ruby [32].

The presence of sphalerite has been previously documented, but it is described as a more transparent phase [46]. It is a common mineral and frequently encountered during low grade metamorphism of sedimentary rocks. The observed sphalerite inclusion most likely formed during metamorphism of the platform carbonates and their associated clay sediments, although it cannot be excluded that it formed from external hydrothermal fluids. 
The EPMA analysis of the herringbone structure in sample A4 only totals $86.01 \%$. The most likely explanation is that this patterned zone consists of a different mineral or an intergrowth of different minerals. Our analysis was set up to quantify eight elements that are commonly found in sulfides, but it is possible that this zone incorporates elements that we did not analyze. Although a different mineral is the most likely explanation, alteration due to the fabrication process cannot be excluded until this inclusion is further analyzed.

The paragenesis of Mogok rubies is pretty well understood and it is interesting to note that the only mineral that incorporates $\mathrm{Fe}$, are these sulfides. Thus, the presence of sulfur might be an important factor for the formation of low-Fe, and thus, more fluorescent rubies. Marble-related ruby forming systems have a significant amount of evaporites, including sulfates. During increasing metamorphism, these sulfates will reduce, due to reactions with organic matter [54]. This reaction provides an ample supply of reduced, reactive sulfur to react with all Fe and form Fe-sulfides before corundum forms. The presence of S-rich fluid inclusions and native sulfur found in marble related ruby inclusions supports this model $[31,55,56]$. The same model could also explain the extreme fluorescence witnessed in red/pink spinel from marble related deposits. Gem spinel shares a very similar formation model with ruby in marbles, apart from the fact that it has a significant $\mathrm{Mg}$ component and most likely formed at slightly different P-T conditions [34,57,58]. A similar mechanism where sulfur is responsible for Fe removal during formation of high quality gemstones has been proposed for the Colombian emeralds [59]. It seems that, in both situations, the reaction of sulfates with organic matter provided sufficient reduced sulfur to trap much of the Fe present in the system in sulfide phases [59]. This results in Fe-poor, Cr-rich emeralds and rubies, creating a strong color and fluorescence. While this mechanism is similar between these deposits, the rest of the geological conditions are very different.

Although the inclusions in Mozambican amphibole-related rubies are visually very similar to the ones from Mogok's marble-related rubies, they are chemically very different. This was expected, given that their geological history and host rocks are very different.

The composition of the inclusions in Mozambican rubies strongly resembles a sulfide melt trapped during formation. The texture of these inclusions is suggestive of phases crystallizing from a melt individually, rather than exsolving from one originally homogeneous inclusion [60]. For instance, certain crystallized phases in these inclusions do show very obvious exsolution textures (Figure 4a,b), which are distinctly different from the overall textural relationships observed between the main sulfide phases. Such sulfide melts can form at higher temperatures, precipitating multiple sulfide phases upon cooling [61,62]. The overall consistency of these inclusions between the different samples indicates that they formed as a separate and homogeneous phase, possibly a partial sulfide melt, and were later incorporated in the ruby. The rounded shape of the inclusions is also more suggestive of a molten phase. Conversely, in Mogok rubies, the more regular, almost euhedral, outlines suggest that these inclusions were trapped as solid crystals.

During cooling, the individual components in such a sulfide melt would have separated and crystallized into the different phases (chalcopyrite, pentlandite, pyrrhotite). The creation of sulfide melts through partial melting has been documented at temperatures as low as $300^{\circ} \mathrm{C}$, but this applies only to a limited amount of sulfide minerals, often with considerable amounts of As [62]. The most common Fe-Ni-Cu sulfide system in nature consists of chalcopyrite and monosulfide solid-solution (FeS-NiS). Early experimental work suggested that significant quantities of melt are produced only at around $850^{\circ} \mathrm{C}$ [63]. However, some experiments have shown that first melting may initiate at about $760^{\circ} \mathrm{C}$ in this system $[64,65]$. The mineralogy of sulfide crystallization in these references is consistent with that seen in the Mozambican ruby inclusions with chalcopyrite and $\mathrm{Fe}-\mathrm{Ni}$ sulfides, that have completely separated from what could have been a single homogeneous partial melt at high temperature. The flame-like patterns observed also suggests exsolution of the Fe-Ni sulfide phase during cooling, that formed the patterns seen now. The main potential concern with this hypothesis is that the melting temperatures of this system are significantly higher than the $550-650^{\circ} \mathrm{C}$ reported for the ruby host rock in previous studies $[41,66]$. However, these pressure-temperature calculations should be approached with 
some caution. These PT estimates are based on models that assume equilibrium between various phases found associated with corundum in the Mozambique deposit. However, the Mozambican ruby host rock is extensively weathered and in most cases completely reduced to clay and sedimentary detritus. It is often hard to say if the minerals that are seen in thin sections, and used in geothermobarometry, are actually related to the ruby formation. For instance, it is possible (if not likely) that the kyanite and Fe-carbonate used to determine a temperature of $650{ }^{\circ} \mathrm{C}$ and pressure of $9.5 \mathrm{kbar}$, are alteration products formed during retrograde metamorphism and/or interaction with fluids rich in $\mathrm{Si}$ and carbonates [66]. The same applies to the stability field used to estimate a temperature estimate of $550-600{ }^{\circ} \mathrm{C}$, based on a plagioclase-garnet-diopside-pargasite-clinochlore-quartz-corundum assemblage [41], especially as clinochlore is a common alteration product when amphibole weathers. It would be highly unlikely that these minerals all formed together, especially quartz and corundum, which cannot coexist under ordinary geological conditions. The presence of an inclusion derived from partial sulfide melt rich in $\mathrm{Ni}-\mathrm{Cu}-\mathrm{S}$, as we have proposed here, would suggest that reported formation temperatures of around $550-600{ }^{\circ} \mathrm{C}$ are underestimated.

Given that the data on Mozambican ruby is limited, the data on other amphibole related deposits in East-Africa can provide limited insight. The ruby deposit in Winza, Tanzania has reported P-T conditoons of $750-850^{\circ} \mathrm{C}$ and 9.5-12 kbar [67]. Similar conditions are reported for Vohibory, Madagascar, although the temperature range is narrower at $750-800^{\circ} \mathrm{C}$, with pressure of $9-11.5 \mathrm{kbar}$ [68]. While these conditions are not directly related to the Mozambican ruby deposit, they can provide an indication for the formation of amphibole-related rubies in East Africa. These temperatures are more in line with the likely temperatures for the formation of a partial sulfide melt. The effect of various parameters, such as water content, oxygen fugacity, sulfur fugacity, the involvement of other minerals and the potential for lowering the initial melting temperature of a free sulfide melt by addition of other sulfide components, are not well understood and could potentially have a significant impact on formation conditions of these potential sulfide melt inclusions [62]. It has to be noted that these conditions are unknown in most ruby forming systems.

In Mogok, the presence of abundant sulfur allows for the formation of low-Fe ruby, because much of the Fe is locked in pyrrhotite. The sulfide inclusions in Mozambican rubies are more complex, as is their associated mineral assemblage. Although it is not well studied, many of the observed minerals contain a significant Fe component, which indicates that the Fe-balance in the amphibole-related ruby forming system has more controlling factors than those in marble-related systems. In the Mozambican rubies, with $\mathrm{Fe}-\mathrm{Cu}-\mathrm{Ni}$ sulfides, it is clear that simply an availability of abundant sulfur is not the controlling factor for the Fe concentration in rubies.

This is reflected in the wider variety of iron contents seen in rubies from Montepuez, which ranges from 414 to 4000 ppmw [2,6]. This variability in Fe concentrations obviously results in much more variable fluorescence in Mozambican rubies compared to Mogok rubies.

\section{Conclusions}

Opaque inclusions are common in many rubies forming in different geological environments. The identification of these crystals is usually based on their visual characteristics, which are sometimes misleading. Chemical analysis has shown that the inclusions in Mogok rubies are dominantly homogenous pyrrhotite and with one inclusion identified as sphalerite. Pyrite is found in the marble that hosts these rubies, but was not found as an inclusion. The presence of these sulfides and the presence of abundant sulfur in the marble could be an important geological indicator for strong fluorescent rubies. Fluorescence is deemed an important quality factor in ruby valuation and is quenched by the presence of Fe. In marble hosted ruby deposits, there is abundant sulfur present to trap all iron in sulfide minerals, allowing the formation of low-Fe rubies.

The opaque inclusions in Mozambican rubies from Montepuez look very similar to the ones found in Mogok in the microscope, but they are very different compositionally and mineralogically. Analysis of these stones shows a complex mix of Fe-Cu-Ni-sulfides with clearly separated phases, 
as well as exsolution patterns. Their compositions and textures are reminiscent of melt inclusions forming from a sulfide partial melt. To form such inclusions, the temperatures should be higher than the reported P-T conditions, meaning that the temperatures reported in literature might be too low. More studies are required to better understand the genesis of these inclusions and its ruby host.

Author Contributions: Conceptualization and methodology, W.V. and A.P.; writing-original draft preparation, W.V.; writing - review and editing, W.V. and A.P. All authors have read and agreed to the published version of the manuscript.

Funding: This research received no external funding.

Acknowledgments: The authors would like to thank Charuwan Khowpong, Sasithorn Engniwat and Suwasan Wongchacree for sample analysis and inclusion photography. We thank Mike Breeding (GIA) for helpful comments on the manuscript. We also thank two anonymous peer reviewers for their help in improving this manuscript. We would also like to thank Lin Sutherland and Khin Zaw for extending the invitation to submit a manuscript to this Special Issue on ruby geology and geochemistry, as well as their editorial input. Chi Ma, director of the GPS analytical facility at Caltech, Pasadena, CA was of great assistance during the setting up of the EPMA analysis.

Conflicts of Interest: The authors declare no conflict of interest.

\section{References}

1. Hughes, R.W.; Manorotkul, W.; Hughes, E.B. Ruby and Sapphire: A Gemologist's Guide; Lotus Publishing: Chichester, UK; London, UK, 2017.

2. Vertriest, W.; Saeseaw, S. A decade of Ruby from Mozambique: A review. Gems Gemol. 2019, 55. [CrossRef]

3. Pardieu, V. Update on Mozambique ruby mining and trading. Gems Gemol. 2017, 53, 3.

4. Vertriest, W.; Pardieu, V. Update on gemstone mining in Northern Mozambique. Gems Gemol. 2016, 52, 4. [CrossRef]

5. Hughes, R.W. Red Rain: Mozambique Ruby Pours into the Market. Available online: http://www. lotusgemology.com/index.php/library/articles/316-red-rain-mozambique-ruby-pours-into-the-market (accessed on 10 February 2020).

6. Hsu, T.; Lucas, A.; Pardieu, V. Mozambique: A Ruby Discovery for the 21st Century; GIA: Carlsbad, CA, USA, 2014.

7. Pardieu, V.; Sangsawong, S.; Muyal, J.; Chauviré, B.; Massi, L.; Sturman, N. Rubies from the Montepuez Area (Mozambique); GIA: Carlsbad, CA, USA, 2013.

8. Pardieu, V.; Jacquat, S.; Bryl, L.P.; Senoble, J.B. Rubies from northern Mozambique. InColor 2009, 12, 32-36.

9. Vincent, P.; Rakotosona, N. Ruby and Sapphire Rush Near Didy, Madagascar. Available online: http://www.giathai.net/pdf/Didy_Madagascar_US.pdf (accessed on 22 February 2020).

10. Rakontondrazafy, A.F.M.; Giuliani, G.; Ohnenstetter, D.; Fallick, A.E.; Rakotosamizanay, S.; Andriamamonjy, A.; Ralantoarison, T.; Razanatseheno, M.; Offant, Y.; Garnier, V.; et al. Gem corundum deposits of Madagascar: A review. Ore Geol. Rev. 2008, 34, 135-154.

11. Pardieu, V.; Wise, R.W. Ruby boom town. Colored Stone 2006, 19, 30-33.

12. Hughes, R.W.; Pardieu, V.; Schorr, D. Sorcerers \& Sapphires: A Vsit to Madagascar. Available online: https://lotusgemology.com/index.php/library/articles/161-sorcerers-sapphires-a-visit-to-madagascar (accessed on 22 February 2020).

13. Schwarz, D.; Schmetzer, K. Rubies from the Vatomandry area, eastern Madagascar. J. Gemmol. 2001, 27, 409-416. [CrossRef]

14. Abduriyim, A.; Kitawaki, H. New geological origin: Ruby from Winza of Tanzania. Gemmology 2008, 8, 4-7.

15. Keller, P.C. The rubies of Burma: A review of the Mogok Stone Tract. Gems Gemol. 1983, 19, 209-219. [CrossRef]

16. Zaw, K.; Sutherland, L.; Yui, T.-F.; Meffre, S.; Thu, K. Vanadium-rich ruby and sapphire within Mogok Gemfield, Myanmar: Implications for gem color and genesis. Miner. Depos. 2015, 50, 25-39. [CrossRef]

17. Saeseaw, S.; Kongsomart, B.; Atikarnsakul, U.; Khowpong, C.; Vertriest, W.; Soonthorntantikul, W. Update on "Low-Temperature" Heat Treatment of Mozambican Ruby: A Focus on Inclusions and FTIR Spectroscopy; GIA: Carlsbad, CA, USA, 2018.

18. Pardieu, V.; Saeseaw, S.; Detroyat, S.; Raynaud, V.; Sangsawong, S.; Bhurisom, T.; Engniwat, S.; Muyal, J. "Low Temperature" Heat Treatment of Mozambique Ruby; GIA: Carlsbad, CA, USA, 2015.

19. Palke, A.C.; Saeseaw, S.; Renfro, N.D.; Sun, Z.; McClure, S.F. Geographic origin determination of ruby. Gems Gemol. 2019, 55, 580-613. [CrossRef] 
20. Kiefert, L.; Karampelas, S. Use of the Raman spectrometer in gemmological laboratories: Review. Spectrochim. Acta A 2011, 80, 119-124. [CrossRef] [PubMed]

21. Gübelin, E.J.; Koivula, J.I. Photoatlas of Inclusions in Gemstones; ABC Edition: Zürich, Switzerland, 1986; p. 532.

22. Vertriest, W.; Palke, A.C.; Renfro, N.D. Field gemology: Building a research collection and understanding the development of gem deposits. Gems Gemol. 2019, 55, 580. [CrossRef]

23. Armstrong, J.T. CITZAF-A package of correction programs for the quantitative electron microbeam X-ray-analysis of thick polished materials, thin-films and particles. Microbeam Anal. 1995, 4, 177-200.

24. Garnier, V.; Giuliani, G.; Ohnenstetter, D.; Schwarz, D. Les gisements de corindon: Classification et genèse. Règne Miner. 2004, 55, 7-47.

25. Iyer, L.A.N. The geology and gem-stones of the Mogok stone tract, Burma. Geol. Surv. India-Mem. 1953, 82, 8-100.

26. Themelis, T. Gems and Mines of Mogok; Self-published: Bangkok, Thailand, 2008.

27. Chhibber, H.L. The Geology of Burma; MacMillan and Co.: London, UK, 1934; p. 538.

28. Thu, Y.K.; Win, M.M.; Enami, M.; Tsuboi, M. Ti-rich biotite in spinel and quartz-bearing paragneiss and related rocks from the Mogok metamorphic belt, central Myanmar. J. Miner. Petrol. Sci. 2016, 111, $270-282$.

29. Thu, K. The Igneous Rocks of the Mogok Stone Tract: Their Distributions, Petrography, Petrochemistry, Sequence, Geochronology and Economic Geology; University of Yangon: Yangon, Myanmar, 2007.

30. Searle, M.; Garber, J.; Hacker, B.; Htun, K.; Gardiner, N.; Waters, D.; Robb, L. Timing of syenite-charnockite magmatism and ruby and sapphire metamorphism in the mogok valley region, Myanmar. Tectonics 2020, 39, 39. [CrossRef]

31. Giuliani, G.; Dubessy, J.; Ohnenstetter, D.; Banks, D.; Branquet, Y.; Feneyrol, J.; Fallick, A.E.; Martelat, J.-E. The role of evaporites in the formation of gems during metamorphism of carbonate platforms: A review. Miner. Depos. 2017, 53,1-20. [CrossRef]

32. Garnier, V.; Giuliani, G.; Ohnenstetter, D.; Fallick, A.E.; Dubessy, J.; Banks, D.; Hoang, V.Q.; Lhomme, T.; Maluski, H.; Pecher, A.; et al. Marble-hosted ruby deposits from Central and Southeast Asia: Towards a new genetic model. Ore Geol. Rev. 2008, 34, 169-191. [CrossRef]

33. Kievlenko, E.Y. Geology of Gems; Ocean Pictures Ltd.: Littleton, CO, USA, 2003.

34. Giuliani, G.; Ohnenstetter, D.; Fallick, A.; Groat, L.; Fagan, A.J. Chapter 2: The geology and genesis of gem corundum deposits. In Geology of Gem Deposits, 2nd ed.; Groat, L., Ed.; Mineralogical Association of Canada: Tucson, AZ, USA, 2014.

35. Garnier, V.; Maluski, H.; Giuliani, G.; Ohnenstetter, D.; Schwarz, D. Ar-Ar and U-Pb ages of marble-hosted ruby deposits from central and southeast Asia. Can. J. Earth Sci. 2006, 43, 509-532. [CrossRef]

36. Bingen, B.; Jacobs, J.; Viola, G.; Henderson, I.H.C.; Skar, O.; Boyd, R.; Thomas, R.J.; Solli, A.; Key, R.M.; Daudi, E.X.F. Geochronology of the Precambrian crust in the Mozambique Belt in NE Mozambique, and implications for Gondwana assembly. Precambrian Res. 2009, 170, 231-255. [CrossRef]

37. Meert, J.G. A synopsis of events related to the assembly of eastern Gondwana. Tectonophysics 2003, 362, 1-40. [CrossRef]

38. Muhongo, S. Anatomy of the Mozambique Belt of eastern and southern Africa: Evidence from Tanzania. Gondwana Res. 1999, 2, 369-375. [CrossRef]

39. Pardieu, V.; Thanachakaphad, J.; Jacquat, S.; Senoble, J.B.; Bryl, L.P. Rubies from the Niassa and Cabo Delgado Regions of Northern Mozambique; GIA Laboratory: Carlsbad, CA, USA, 2009; pp. 5-16.

40. Boyd, R.; Nordgulen, O.; Thomas, B.; Bingen, B.; Bjerkgård, T.; Grenne, T.; Henderson, I.; Melezhik, V.; Sandstad, J.; Solli, A.; et al. The geology and geochemistry of the East African orogen in northeastern Mozambique. S. Afr. J. Geol. 2010, 113, 87-129. [CrossRef]

41. Fanka, A.; Sutthirat, C. Petrochemistry, mineral chemistry, and pressure-temperature model of corundum-bearing amphibolite from Montepuez, Mozambique. Arab. J. Sci. Eng. 2018, 43, 3751-3767. [CrossRef]

42. Lebas, M.J.; Lemaitre, R.W.; Streckeisen, A.; Zanettin, B. A chemical classification of volcanic-rocks based on the total alkali silica diagram. J. Petrol. 1986, 27, 745-750.

43. Gübelin, E.J. On the nature of mineral inclusions in gemstones-Parts 1 and 2. Gems Gemol. 1969, 13, 42-56.

44. Gübelin, E.J. Inclusions as a Means of Gemstone Identification; GIA: Los Angeles, CA, USA, 1953; p. 220.

45. Gübelin, E.J. On the nature of mineral inclusions in gemstones. J. Gemmol. 1969, 11, 149-192. [CrossRef]

46. Gübelin, E.J. Internal World of Gemstones; reprinted 1983 ed.; ABC Verlag: Zürich, Switzerland, 1973; p. 234.

47. Fritsch, E.; Rossman, G.R. New technologies of the 1980s: Their impact on gemology. Gems Gemol. 1990, 26, 64-75. [CrossRef] 
48. Kammerling, R.C.; Scarratt, K.; Bosshart, G.; Jobbins, E.A.; Kane, R.E.; Gubelin, E.J.; Levinson, A.A. Myanmar and its gems-An update. J. Gemmol. 1994, 24, 3-40. [CrossRef]

49. Renfro, N.; Koivula, J. Vesuvianite in burmese ruby. Gems Gemol. 2017, 51, 469.

50. Leelawathanasuk, T.; Pisutha-Arnond, V.; Atichat, W.; Sutthirat, C.; Wathanakul, P.; Sriprasert, B. Some characteristics of "Mozambique ruby". In 31st International Gemmological Congress-Abstracts; IGC: Arusha, Tanzania, 2009; pp. 33-34.

51. Searle, M.P.; Noble, S.R.; Cottle, J.M.; Waters, D.J.; Mitchell, A.H.G.; Hlaing, T.; Horstwood, M.S.A. Tectonic evolution of the Mogok metamorphic belt, Burma (Myanmar) constrained by U-Th-Pb dating of metamorphic and magmatic rocks. Tectonics 2007, 26, 26. [CrossRef]

52. Yonemura, K.; Osanai, Y.; Nakano, N.; Adachi, T.; Charusiri, P.; Zaw, T. EPMA U-Th-Pb monazite dating of metamorphic rocks from the Mogok Metamorphic Belt, central Myanmar. J. Mineral. Petrol. Sci. 2013, 108, 184-188. [CrossRef]

53. Myat Phyo, M.; Franz, L.; Capitani, C.; Balmer, W.; Krzemnicki, M.; Christian, C. Petrology and PT-conditions of quartz- and nepheline-bearing gneisses from Mogok Stone Tract, Myanmar. In Proceedings of the 15th Swiss Geoscience Meeting, Davos, Switzerland, 17-18 November 2017. [CrossRef]

54. Goldstein, T.; Aizenshtat, Z. Thermochemical sulfate reduction a review. J. Therm. Anal. Calorim. 1994, 42, 241-290. [CrossRef]

55. Giuliani, G.; Dubessy, J.; Banks, D.; Hoang, V.Q.; Lhomme, T.; Pironon, J.; Garnier, V.; Phan, T.T.; Pham, L.V.; Ohnenstetter, D.; et al. $\mathrm{CO}_{2}-\mathrm{H}_{2} \mathrm{~S}-\mathrm{S}_{8}-\mathrm{AlO}(\mathrm{OH})$-bearing fluid inclusions in ruby from marble-hosted deposits in Luc Yen area, North Vietnam. Chem. Geol. 2003, 194, 167-185. [CrossRef]

56. Hoang, V.Q.; Giuliani, G.; Phan, T.T.; Pham, L.V. Fluid inclusion on ruby from the Yen Bai Province. In Geo- and Material-Science on Gem Minerals of Vietnam; GIA: Carlsbad, CA, USA, 2003; pp. 136-144.

57. Phyo, M.M.; Bieler, E.; Franz, L.; Balmer, W.; Krzemnicki, M.S. Spinel from mogok, myanmar-A detailed inclusion study by raman microspectroscopyand scanning electron microscopy. J. Gemmol. 2019, 36, 418-435. [CrossRef]

58. Malsy, A.; Klemm, L. Distinction of gem spinels from the Himalayan mountain belt. Chimia 2010, 64, 741-746. [CrossRef]

59. Ottaway, T.; Wicks, F.; Bryndzia, L.; Spooner, E. Formation of the Muzo hydrothermal emerald deposit in Colombia. Nature 1994, 369, 552-554. [CrossRef]

60. Bard, J.P. Microtextures of Igneous and Metamorphic Rocks; Springer Netherlands: Dordrecht, The Netherlands, 1986.

61. Tomkins, A.G.; Pattison, D.R.M.; Frost, B.R. On the initiation of metamorphic sulfide anatexis. J. Petrol. 2006, 48, 511-535. [CrossRef]

62. Frost, B.; Mavrogenes, J.; Tomkins, A. Partial melting of sulfide ore deposits during medium- and high-grade metamorphism. Can. Mineral. 2002, 40,1-18. [CrossRef]

63. Craig, J.R.; Kullerud, G. The Cu-Fe-Ni-S system. Carnegie Inst. Wash. Yearb. 1968, 66, 413-417.

64. Peregoedova, A.; Ohnenstetter, M. Collectors of Pt, Pd and Rh in a S-poor Fe-Ni-Cu sulfide system at $760{ }^{\circ} \mathrm{C}$ : Experimental data and application to ore deposits. Can. Mineral. 2002, 40, 527-561. [CrossRef]

65. Sugaki, A.; Kitakaze, A. High form of pentlandite and its thermal stability. Am. Mineral. 1998, 83, $133-140$. [CrossRef]

66. Institute, S.S.G. New Rubies from Montepuez, Mozambique; GIA: Carlsbad, CA, USA, 2010; p. 17.

67. Schwarz, D.; Pardieu, V.; Saul, J.M.; Schmetzer, K.; Laurs, B.M.; Giuliani, G.; Klemm, L.; Malsy, A.K.; Erel, E.; Hauzenberger, C.; et al. Rubies and sapphires from Winza, central Tanzania. Gems Gemol. 2008, 44, 322-347. [CrossRef]

68. Nicollet, C. Saphirine et staurotide riche en magnésium et chrome dans les amphibolites et anorthosites à corindon du Vohibory Sud, Madagascar. Bull. Mineral. 1986, 109, 599-612. [CrossRef] 

MDPI

St. Alban-Anlage 66

4052 Basel

Switzerland

Tel. +41 616837734

Fax +41 613028918

www.mdpi.com

Minerals Editorial Office

E-mail: minerals@mdpi.com www.mdpi.com/journal/minerals

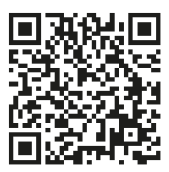



MDPI

St. Alban-Anlage 66

4052 Basel

Switzerland

Tel: +41 616837734

Fax: +41 613028918

www.mdpi.com 